\title{
Fuel Summary Report: Shippingport Light Water Breeder Reactor
}

\author{
G. L. Olson \\ R. K. McCardell \\ D. B. Illum
}

September 2002

Idaho National Engineering and Environmental Laboratory Bechtel BWXT Idaho, LLC 


\section{NOTICE}

This document has been prepared using the best available source of information. Every reasonable attempt has been made to ensure that the data have been correctly extracted and summarized from source documents. However, this document may contain incomplete and inaccurate information for reasons that include, without limitation:

1. The original source documents contained errors

2. Source documents could not be located that contained appropriate data and information

3. Source documents contained conflicting information, and engineering judgment has been used to select the data and information presented in this document

4. Additional data may exist but are yet to be located.

Document users need to ensure that this information is adequate for its intended use. Bechtel BWXT Idaho, LLC makes no representation or warranty, expressed or implied, as to the completeness, accuracy, or usability of the data or information contained in this report. 


\title{
Fuel Summary Report: Shippingport Light Water Breeder Reactor
}

\author{
G. L. Olson \\ R. K. McCardell \\ D. B. Illum \\ September 2002 \\ Idaho National Engineering and Environmental Laboratory \\ Idaho Falls, Idaho 83415 \\ Prepared for the \\ U.S. Department of Energy \\ Assistant Secretary for Environmental Management \\ Under DOE Idaho Operations Office \\ Contract DE-AC07-99ID13727
}




\begin{abstract}
The Shippingport Light Water Breeder Reactor (LWBR) was developed by Bettis Atomic Power Laboratory to demonstrate the potential of a water-cooled, thorium oxide fuel cycle breeder reactor. The LWBR core operated from 1977-82 without major incident. The fuel and fuel components suffered minimal damage during operation, and the reactor testing was deemed successful. Extensive destructive and nondestructive postirradiation examinations confirmed that the fuel was in good condition with minimal amounts of cladding deformities and fuel pellet cracks. Fuel was placed in wet storage upon arrival at the Expended Core Facility, then dried and sent to the Idaho Nuclear Technology and Engineering Center for underground dry storage. It is likely that the fuel remains in good condition at its current underground dry storage location at the Idaho Nuclear Technology and Engineering Center. Reports show no indication of damage to the core associated with shipping, loading, or storage.
\end{abstract}




\section{SUMMARY}

The Shippingport Light Water Breeder Reactor (LWBR) was developed by Pittsburgh Naval Reactors Office and operated at Shippingport Atomic Power Station in Pennsylvania from 1977 to 1982 . This test reactor was developed to prove the concept of a pressurized water breeder reactor. The reactor core consisted of 12 hexagonal seed modules, each of which was surrounded by a stationary blanket module. The 12 seed-blanket clusters ( 24 modules combined) were surrounded by 15 reflector modules, which contained rods with thoria pellets. Instead of using poison control rods, the core was designed with a movable seed, which was raised and lowered to control neutron absorption. The fuel consisted of binary ceramic pellets with 1 to $5 \%$ uranium in a thoria matrix. The uranium was more than $98 \%$ enriched with U-233, which was the only uranium isotope believed to be a feasible breeder in a light water reactor. To minimize neutron poisoning associated with hafnium and other impurities, the fuel rod cladding and some of the key structural components were made of a high-purity, high-performance zircaloy alloy.

Over the course of 5 years, the LWBR operated for about 29,000 effective full power hours. After the reactor was shut down, the modules were removed from the core, partially disassembled, and shipped to the Expended Core Facility (ECF) at the Naval Reactor Facility at the Idaho National Engineering and Environmental Laboratory (INEEL). At ECF, the modules were placed in containers (liners), and the liners were submerged into positions within storage racks in the ECF water pits. Twelve of the 39 modules were remotely disassembled underwater to free the core components and fuel rods to facilitate postirradiation testing. Two of the 12 modules had their shells removed, and all 12 had their baseplates cut off. A sample of about 1000 rods were removed from the 12 modules for nondestructive and destructive evaluation. All of these rods were examined with a specially designed fuel assay gauge to obtain total fissile content, and 17 of the rods were dissolved and assayed to obtain the isotopic contents. At the conclusion of the testing, the intact loose rods were loaded into liners that were designed to hold seed, blanket, and reflector rods. The disassembled modules were clamped before being placed back into their liners.

In all, there are 47 liners of LWBR fuel addressed in this report: 12 liners contain seed modules, 12 contain blanket modules, 15 contain reflector modules, 7 contain the loose rods, and 1 contains leftover rods and rod sections from the LWBR research and development program. There is also an unirradiated LWBR seed module, not addressed in this report. The 47 liners were shipped from ECF to the Idaho Nuclear and Technology Engineering Center at the INEEL, where they were placed in dry underground storage. 


\section{ACKNOWLEDGMENTS}

Special appreciation goes to Dr. Don Graczyk at Argonne National Laboratory-East, who made the destructive evaluation data available for our use, and to Steve McKinney formerly at LMITCO, who evaluated and summarized that data. 


\section{CONTENTS}

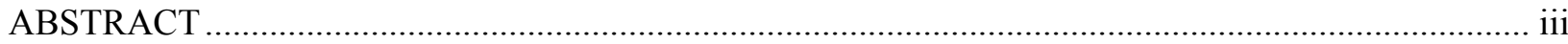

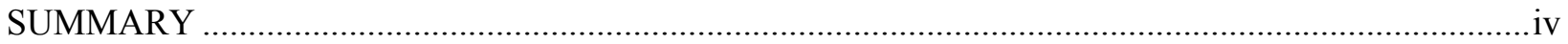

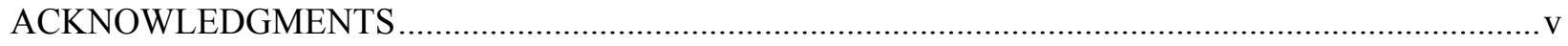

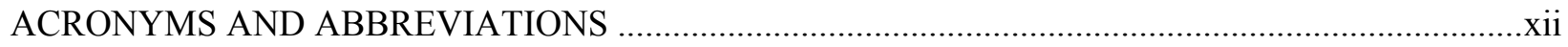

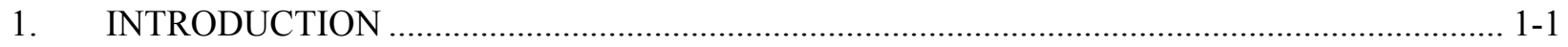

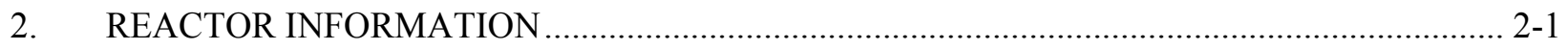

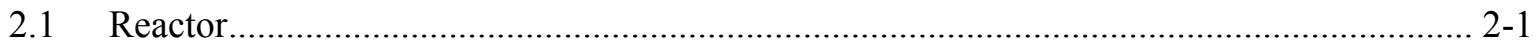

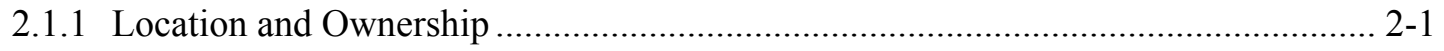

2.1.2 Reactor Type/Design.................................................................................. 2-1

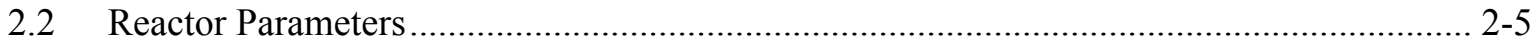

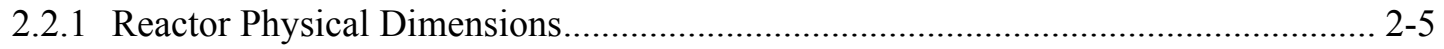

2.2.2 Core Grid Locations ..................................................................................... 2-5

2.2.3 Maximum Design Parameters ......................................................................... 2-5

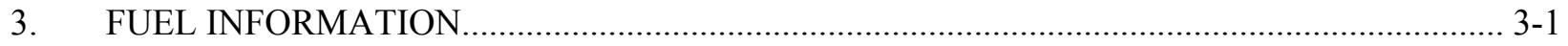

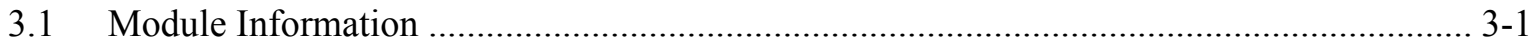

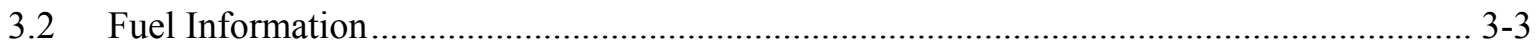

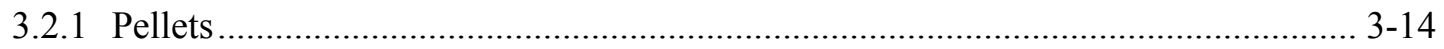

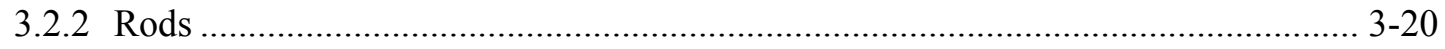

3.2.3 Beginning-of-Life Fissile Loading............................................................... 3-25

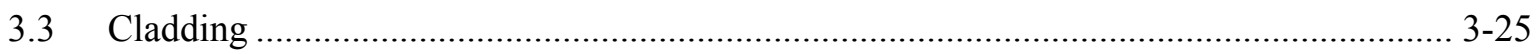

3.3.1 General Description of Cladding Types....................................................... 3-25

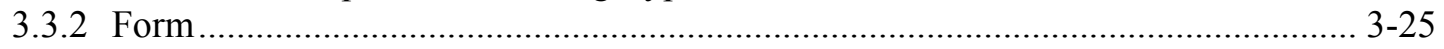

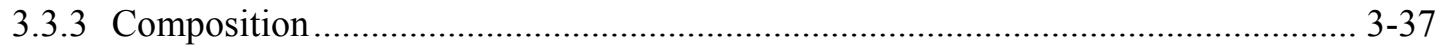

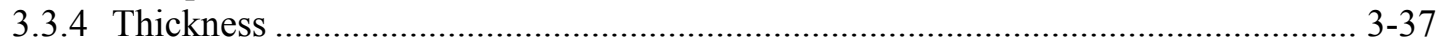

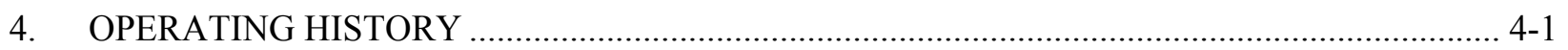

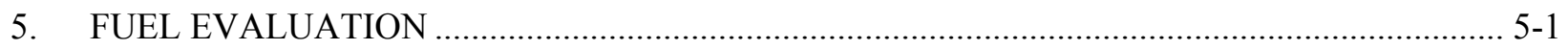

5.1 End-of-Life Nondestructive and Destructive Examinations............................................ 5-1

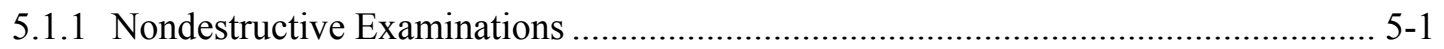

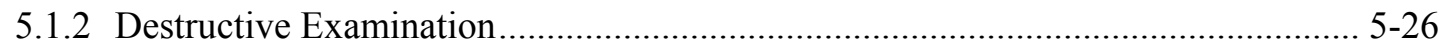

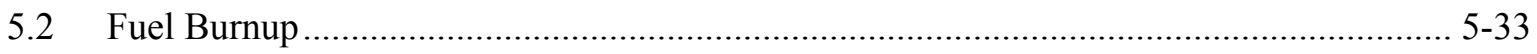


5.3 Iodine and Cesium Analysis of the Fuel Cladding.....

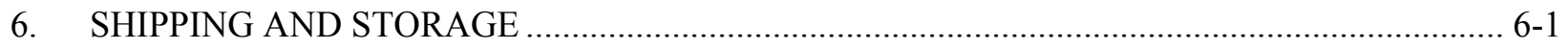

6.1 Shipment from Shippingport to Expended Core Facility ............................................. 6-1

6.2 Handling, Disassembly of Selected Modules, and Storage at Expended Core Facility ..... 6-10

6.2.1 Water Removal at Expended Core Facility......................................................... 6-13

6.2.2 Shipment from Expended Core Facility to INTEC ............................................. 6-13

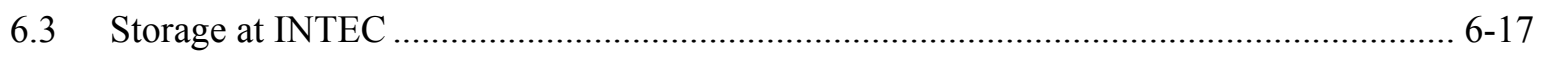

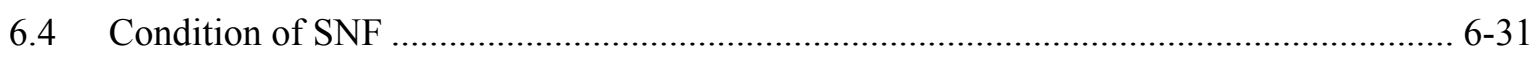

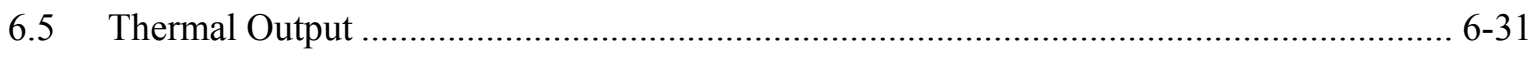

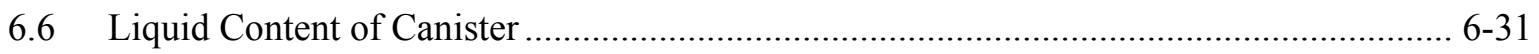

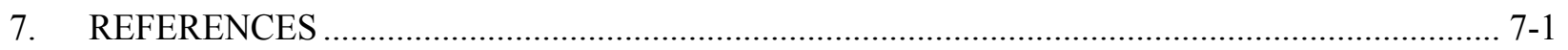

Appendix A—End-of-Life Fissile Data from the Production Irradiated Fuel Assay Gauge ....................A-1

Appendix B—Results from ANL-E Destructive Examinations.............................................................

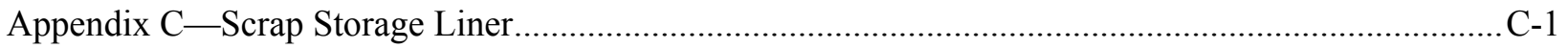

Appendix D—Rods in the Type C Storage Liners ...........................................................................

\section{FIGURES}

2-1. Conversion of Thorium-232 to uranium by neutron absorption and radioactive decay in a Light Water Breeder Reactor....

2-2. Light Water Breeder Reactor core in Shippingport Reactor Vessel ......................................... 2-3

2-3. Light Water Breeder Reactor cross-section module identification ........................................ 2-4

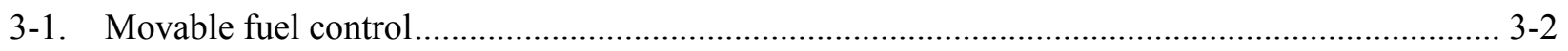

3-2. Light Water Breeder Reactor Type IV Reflector Module rod and cell identification ................... 3-4

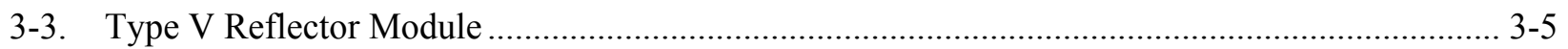

3-4. Cross-sectional dimensions of the Light Water Breeder Reactor modules.................................. 3-6

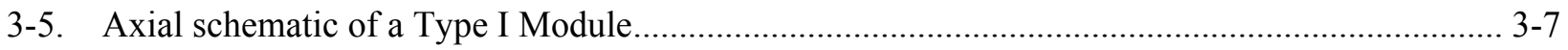

3-6. Light Water Breeder Reactor movable seed module rod arrangement and cell identification ....... 3-8

3-7. Light Water Breeder Reactor Type I blanket module rod configuration and cell identification .... 3-9 
3-8. Axial schematic of the seed surrounded by a power-flattening blanket module

3-9. Type II blanket module rod and cell identification............................................................. 3-11

3-10. Type III blanket module rod and cell identification .......................................................... 3-12

3-11. Light Water Breeder Reactor seed fuel rods ................................................................ 3-22

3-12. Light Water Breeder Reactor blanket fuel rods ............................................................... 3-24

3-13. Light Water Breeder Reactor reflector fuel rods ............................................................. 3-26

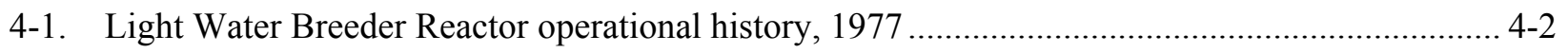

5-1. Diagram of Light Water Breeder Reactor core, showing locations of Proof-of-Breeding modules and boundaries of Sixth-Core Sectors .................................................................. 5-2

5-2. Location of proof-of-breeding rods in Seed Module I-1 ..................................................... 5-12

5-3. Location of proof-of-breeding rods in Seed Module II-3 .................................................... 5-13

5-4. Location of proof-of-breeding rods in Seed Module III-1 .................................................... 5-14

5-5. Location of proof-of-breeding rods in Seed Module III-2 ................................................... 5-15

5-6. Location of proof-of-breeding rods in Blanket Module I-3 ….............................................. 5-16

5-7. Location of proof-of-breeding rods in Blanket Module II-2 ................................................ 5-17

5-8. Location of proof-of-breeding rods in Blanket Module III-2 ….......................................... 5-18

5-9. Location of proof-of-breeding rods in Blanket Module III-6 ................................................ 5-19

5-10. Location of proof-of-breeding rods in Reflector Module IV-4 .............................................. 5-20

5-11. Location of proof-of-breeding (POB) rods in Reflector Module IV-9 ................................... 5-21

5-12. Location of proof-of-breeding rods in Reflector Module IV-3 ............................................. 5-22

5-13. Location of proof-of-breeding rods in Reflector Module V-4 .............................................. 5-23

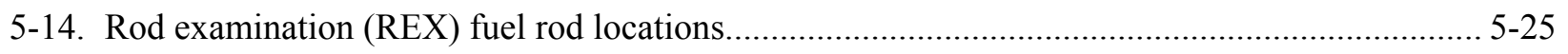

6-1. Light Water Breeder Reactor seed module as received at the Expended Core Facility................. 6-2

6-2. Light Water Breeder Reactor blanket module as received at Expended Core Facility .................. 6-3

6-3. Light Water Breeder Reactor reflector module as received at Expended Core Facility ................ 6-4

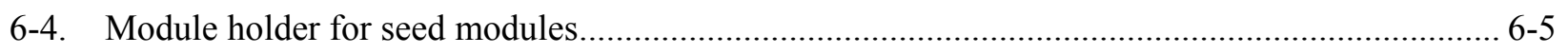

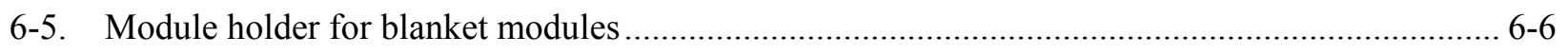


6-6. Module holder for reflector modules

6-7. M-130 shipping container as modified for Light Water Breeder Reactor fuel shipments .............. 6-8

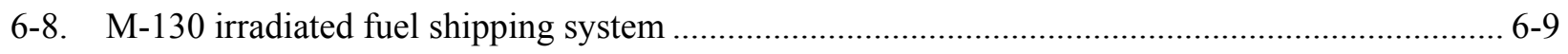

6-9. Light Water Breeder Reactor fuel module grapple shown with seed module ............................ 6-11

6-10. Area of the Expended Core Facility water pits used for Light Water Breeder Reactor

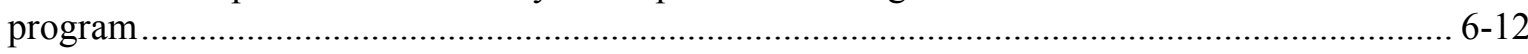

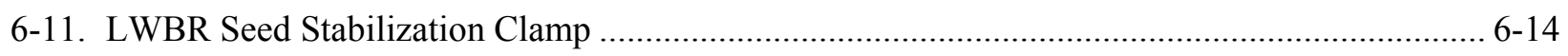

6-12. Light Water Breeder Reactor storage liner blowdown schematic ......................................... 6-15

6-13. Light Water Breeder Reactor storage liner air circulation schematic ...................................... 6-16

6-14. Typical Light Water Breeder Reactor fuel module storage liner ............................................. 6-18

6-15. Section views of the dry well design for both unirradiated and irradiated Light Water Breeder Reactor fuel storage dry wells

6-16. Plat plan of the Light Water Breeder Reactor fuel storage facility ......................................... 6-20

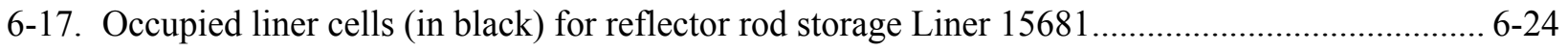

6-18. Occupied liner cells (in black) for blanket rod storage Liner 15682 ..................................... 6-25

6-19. Occupied liner cells (in black) for reflector rod storage Liner 15683.................................... 6-26

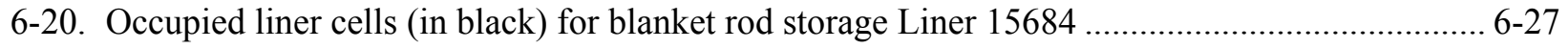

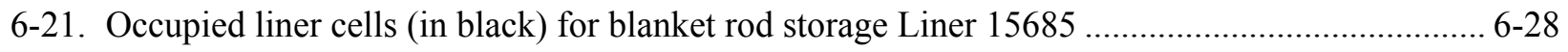

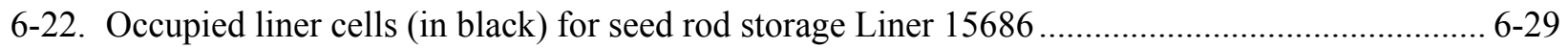

6-23. Occupied liner cells (in black) for blanket rod storage Liner 15687 ...................................... 6-30

6-24. Decay heat as a function of cooling time for the hottest fully rodded seed, blanket, and reflector modules

\section{TABLES}

2-1. Average as-built Light Water Breeder Reactor fuel lattice characteristics

2-2. Peak local linear power rating burnup and fluence for each of Light Water Breeder Reactor fuel regions.

3-1. Number of fuel rods by module and total number of fuel rods in Light Water Breeder Reactor core 
3-2. Masses of uranium isotopes in the seed modules and in the power flattening and standard portions of the blanket modules at beginning of life

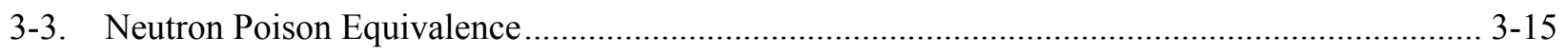

3-4. Average as-built Light Water Breeder Reactor pellet characteristics .................................... 3-16

3-5. Light Water Breeder Reactor fuel pellet dimension ....................................................... 3-17

3-6. Average as-built pellet density and void fraction ....................................................... 3-18

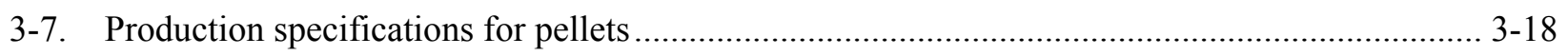

3-8. Grain size of Light Water Breeder Reactor fuel at end-of-life ............................................. 3-19

3-9. Light Water Breeder Reactor fuel rod dimensions ........................................................... 3-21

3-10. Average as-built Light Water Breeder Reactor loading by module type ................................. 3-27

3-11. Seed and blanket module initial thorium and uranium loadings........................................... 3-28

3-12. Light Water Breeder Reactor fuel rod cladding material properties....................................... 3-29

3-13. Requirements for Light Water Breeder Reactor tubing ................................................... 3-30

3-14. Ingot requirements for Light Water Breeder Reactor Zircaloy-4 tubing ................................ 3-38

4-1. Summary of Light Water Breeder Reactor station performance .............................................. 4-8

4-2. Summary of Light Water Breeder Reactor operating conditions.............................................. 4-9

4-3. Timeline of events for the Light Water Breeder Reactor...................................................... 4-10

5-1. Modeled and measured end-of-life (EOL) isotopic content of Light Water Breeder Reactor

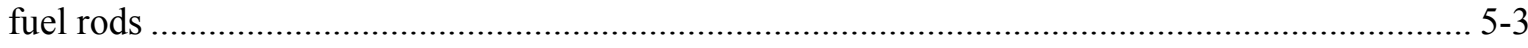

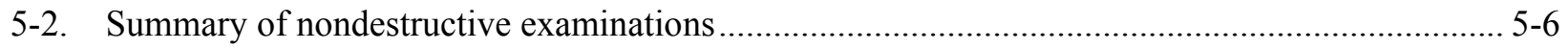

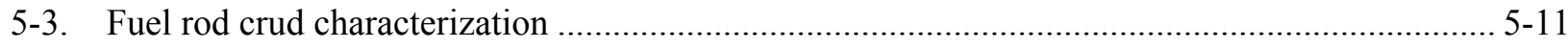

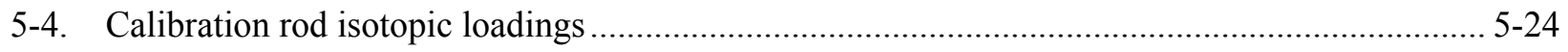

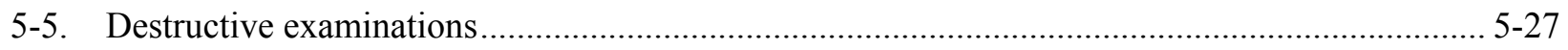

5-6. Operating characteristics of the 12 Light Water Breeder Reactor destructive examination fuel rods at end-of-life

5-7. Light Water Breeder Reactor fuel rod fission gas release at end-of-life................................... 5-30

5-8. Fission gases $(\mathrm{Kr}+\mathrm{Xe})$ released during processing of Light Water Breeder Reactor rods ......... 5-31 
5-9. Isotopic results from Argonne National Laboratory-East destructive examination of 17 Light Water Breeder Reactor rods.

5-10. Comparison of measured and calculated fuel depletion and burnup

5-11. Concentration of I-129 in Light Water Breeder Reactor fuel rod cladding and fuel pellets......

5-12. Concentration of Cs-137 in Light Water Breeder Reactor fuel rod cladding and fuel pellets ...... 5-35

6-1. Types and contents of Light Water Breeder Reactor storage liners....................................... 6-21

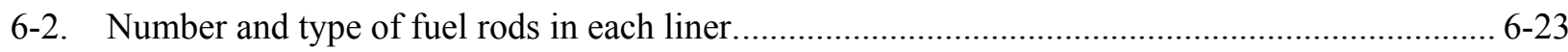

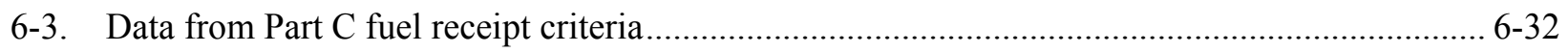

6-4. Estimated decay heat values for Light Water Breeder Reactor core modules in the year 2005 ... 6-35 


\section{ACRONYMS AND ABBREVIATIONS}

ANL-E Argonne National Laboratory-East

ANL-W Argonne National Laboratory-West

APS Atomic Power Station

AWBA Advanced Water Breeder Applications

DOE U.S. Department of Energy

ECF Expended Core Facility

EFPH effective full power hours

EOL end-of-life

INEEL Idaho National Engineering and Environmental Laboratory

INTEC Idaho Nuclear Technology and Engineering Center

LWBR Light Water Breeder Reactor

NPE neutron poison equivalence

NRF Naval Reactor Facility

PIFAG Production Irradiated Fuel Assay Gauge

REX Rod Examination 


\section{Fuel Summary Report: Shippingport Light Water Breeder Reactor}

\section{INTRODUCTION}

The Shippingport Light Water Breeder Reactor (LWBR) was a water-cooled, U-233/Th-232 cycle breeder reactor developed by the Pittsburgh Naval Reactors to improve use of the nation's nuclear fuel resources in light water reactors. The LWBR was operated at Shippingport Atomic Power Station (APS), which was a U.S. Department of Energy (DOE) (formerly Atomic Energy Commission)-owned reactor plant. Shippingport APS was the first large-scale, central-station nuclear power plant in the United States and the first plant of such size in the world operated solely to produce electric power.

This report compiles and summarizes information about the LWBR core and its present configuration. Information presented here was derived or extracted from technical reports, shipping documentation, laboratory results, letters, and other documentation. This report is intended to provide an overview of the existing data and point to reference sources to obtain additional detail. The report is not intended for direct use in design applications. For design applications, the original source documentation must be used.

Shippingport's program was started in 1953 to confirm the practical application of nuclear power for large-scale electric power generation. Subsequent to development and successful operation of the pressurized water reactor, the Atomic Energy Commission in 1965 undertook a research and development program to design and build an LWBR core for operation in the Shippingport Station. In 1976, with fabrication of the Shippingport LWBR core nearing completion, the Energy Research and Development Administration, now DOE, established the Advanced Water Breeder Applications (AWBA) program to develop and disseminate technical information that would assist the U.S. industry in evaluating the LWBR concept for commercial-scale applications. The AWBA program was conducted under the technical direction of the Office of the Deputy Assistant Secretary for Naval Reactors of DOE (Beaudoin 1987, WAPD-TM-1315, p. iii).

The Shippingport LWBR operated from 1977 to 1982 at the APS. During the 5 years of operation, the LWBR generated more than 29,000 effective full power hours (EFPH) of energy.

After final shutdown, the 39 core modules of the LWBR were shipped to the Expended Core Facility (ECF) at the Naval Reactors Facility (NRF) at the Idaho National Engineering and Environmental Laboratory (INEEL). At ECF, 12 of the 39 modules were dismantled, and about 1000 rods were removed from the modules for proof-of-breeding and fuel performance testing. Some of the removed rods were kept at ECF, some were sent to Argonne National Laboratory-West (ANL-W) in Idaho and some to ANL-East (ANL-E) in Chicago for a variety of physical, chemical, and radiological examinations. All rods and rod sections remaining after the experiments were shipped back to the ECF, where modules and loose rods were repackaged in liners for dry storage. In a series of shipments, the liners were transported from ECF to the Idaho Nuclear Technology and Engineering Center (INTEC), formerly the Idaho Chemical Processing Plant. The 47 liners that contain the fully rodded and partially derodded core modules, the loose rods, and the rod scraps are now stored in underground dry wells at CPP-749. 


\section{REACTOR INFORMATION}

\subsection{Reactor}

\subsubsection{Location and Ownership}

The Shippingport LWBR was installed in the Shippingport APS on the south bank of the Ohio River in Shippingport Borough, Beaver County, Pennsylvania, about 30 miles northwest of Pittsburgh.

The LWBR was developed and designed by the Bettis Atomic Power Laboratory, which was operated by Westinghouse Electric Corporation. Design and development occurred under the technical direction of the Division of Naval Reactors of DOE (addendum to Sarber 1983, WAPD-TM-1455, p. 2). The Shippingport LWBR was operated by Duquesne Light Company (Sarber 1983, WAPD-TM-1455, p. 2).

Pressurized water reactors were originally operated at Shippingport; then the LWBR was designed and constructed to fit into the existing reactor core vessel. The LWBR is the only core to operate at Shippingport APS that used highly enriched U-233 oxides and was designed to breed, and is distinguished from the other cores from the same location on that basis.

\subsubsection{Reactor Type/Design}

The LWBR was designed as a pressurized, light-water moderated and cooled thermal reactor that used the thorium/uranium-233 fuel cycle. Figure 2-1 presents a schematic of the breeding decay series showing Th-232 conversion to uranium. The LWBR core was developed for reactor operation within the constraints of the existing Shippingport reactor. Nuclear design of the LWBR core used a seed-blanket concept similar to that successfully applied to the first two pressurized water reactor cores operated at Shippingport, but with reactivity control provided by core geometry changes (movable fuel) instead of poison rods (Campbell and Giovengo 1987, WAPD-TM-1387, p. 4). Figure 2-2 shows the arrangement of the core components in the Shippingport reactor vessel. Figure 2-3 shows a plan cross section of the LWBR core installed in the Shippingport pressurized water reactor vessel. The interior modules were designed so that they could be used directly in a large (1,000 MW(e)) LWBR core. The design simulated a large LWBR core's interior and permitted net breeding in the entire core (Atherton 1987, WAPD-TM-1600, pp. 15, 22).

The LWBR core was designed to minimize parasitic neutron absorption in core and structural materials. Some of the core design features that contributed to improved neutron economy in the LWBR were:

1. Use of movable fuel to control core reactivity, rather than conventional poison control rods, soluble poison, or burnable poison.

2. Use of peripheral radial and axial thoria reflector blanket regions to reduce neutron leakage from the core.

3. Use of zircaloy with a low hafnium content $(<40 \mathrm{ppm})$ for fuel rod cladding and for all structures in the active fuel region except the fuel rod support grids.

4. Use of stainless steel (AM-350) rather than Iconel for fuel rod support grids (Hecker 1979, WAPD-TM-1326). 


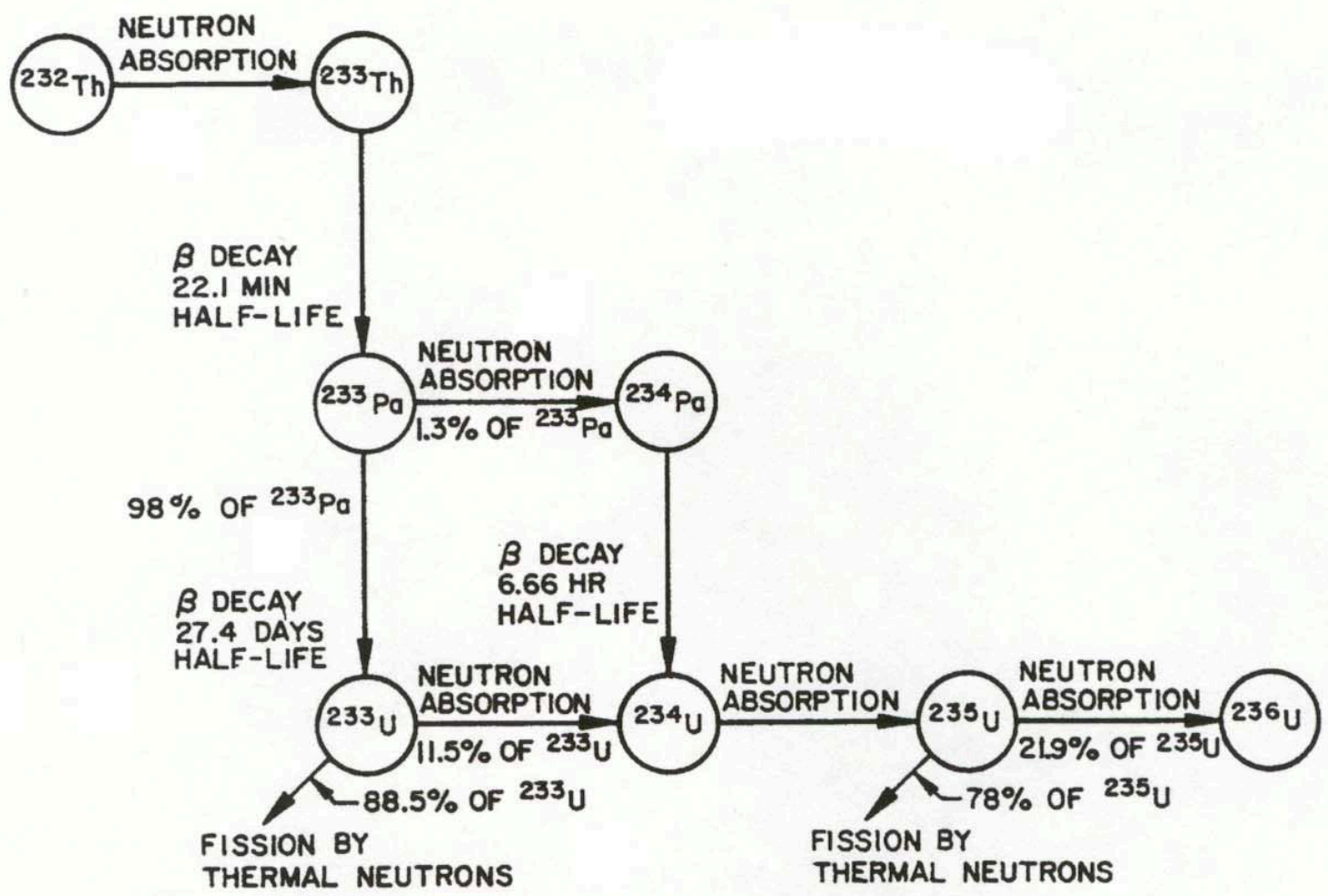

Figure 2-1. Conversion of Thorium-232 to uranium by neutron absorption and radioactive decay in a Light Water Breeder Reactor (Campbell and Giovengo 1987, WAPD-TM-1387). 


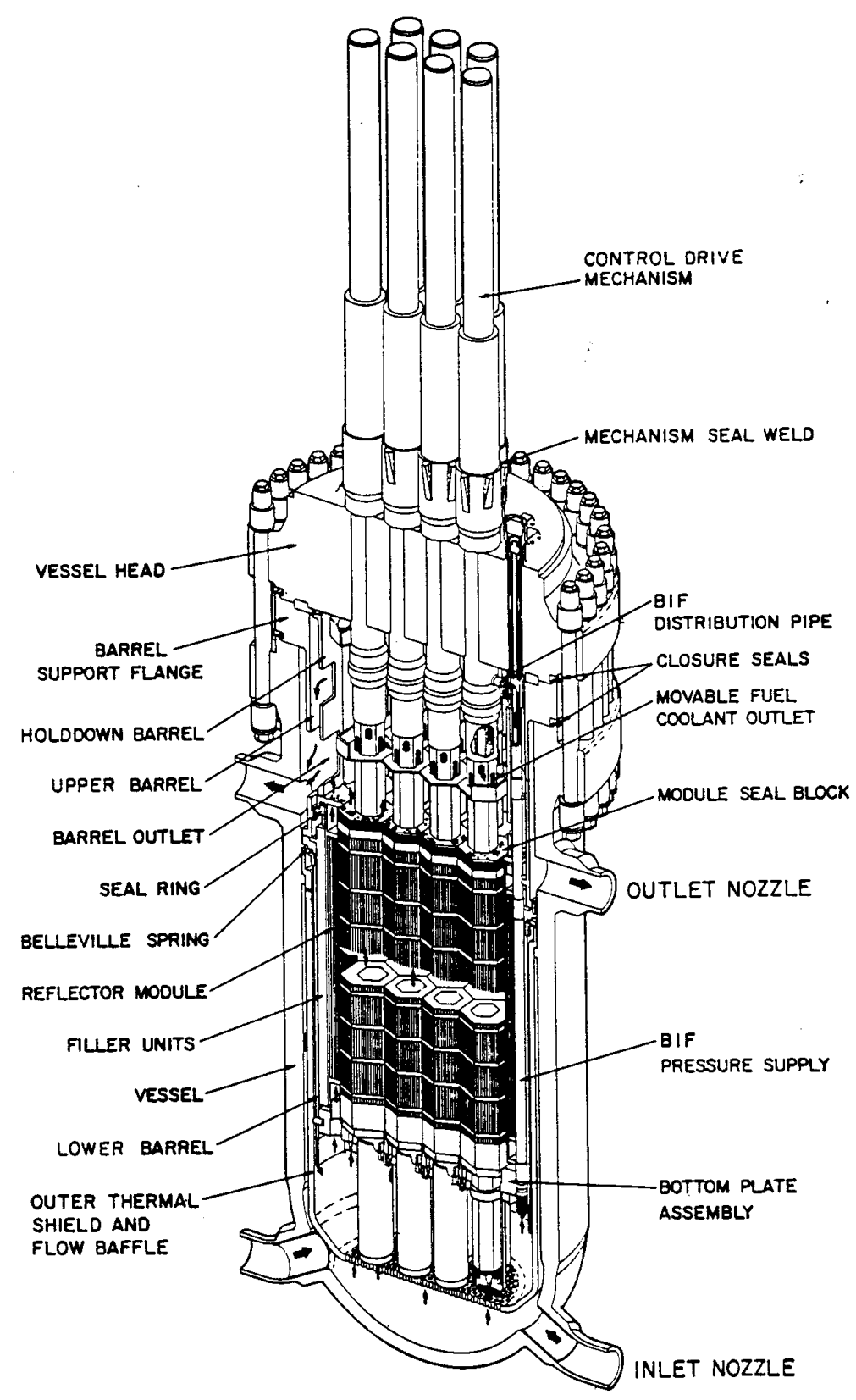

Figure 2-2. Light Water Breeder Reactor core in Shippingport Reactor Vessel (Connors et al. 1979, WAPD-TM-1208). 


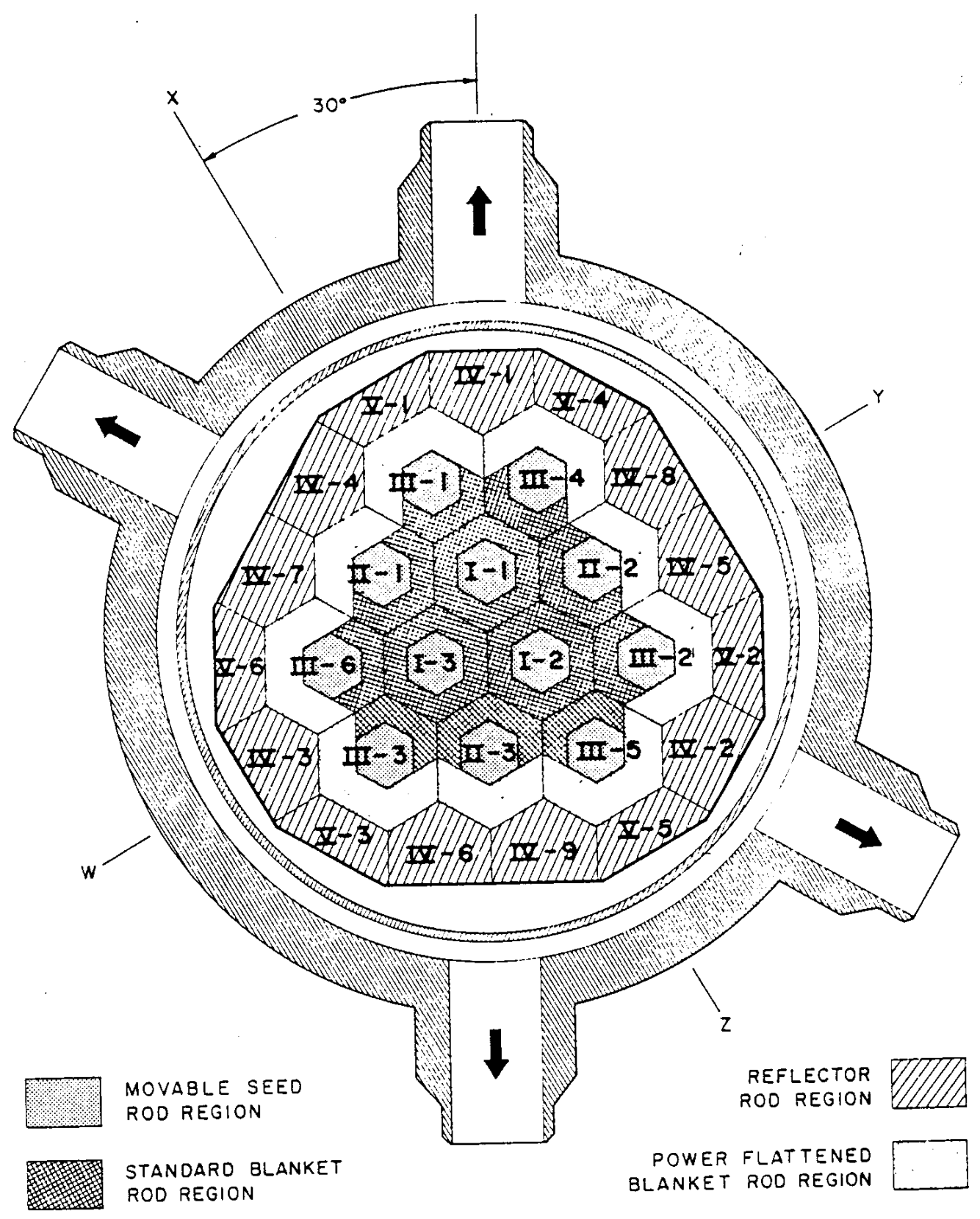

Figure 2-3. Light Water Breeder Reactor cross-section module identification (Sarber 1976, WAPD-TM-1336).

The four primary fuel regions (seed, standard blanket, power-flattening blanket, and reflector blanket) were each optimized to maximize neutron absorption in thorium and to minimize neutron loss (Campbell and Giovengo 1987, WAPD-TM-1387, p. 4). The three central fuel modules of the core are identical and symmetrical and were designed for use in a large central station reactor plant. The three Type I central seed and blanket modules were surrounded by nine Type II or Type III module groups, each consisting of a movable seed and a stationary blanket. The Type II and Type III blanket modules consisted of a standard and a power-flattening component. The power-flattening blankets were slightly thicker and contained slightly more U-233 than the standard blanket regions of the inner modules. Use of this more highly loaded power-flattening blanket region produced a relatively uniform power distribution 
within the interior of the core, and thereby better simulating the environment of a typical large core. The power flattening increased the U-233 loading required for the small core used in Shippingport (Freeman 1978, WAPD-TM-1314, p. 4).

The seed with highly enriched $\mathrm{UO}_{2}$ provided neutrons efficiently. The fertile fuel in the blanket absorbed excess neutrons efficiently and produced fissile fuel. Both the seed and blanket were optimized to maximize neutron production and minimize neutron loss (Hecker and Freeman 1981, WAPD-TM-1409). Reactivity in a seed-blanket reactor is dominated by the seed; thus changes in seed geometry caused reactivity variations. The central movable seed concept for fuel reactivity control eliminated the need for control poisons (Hecker 1979, WAPD-TM-1326, p. 3).

Water entered the vessel through four inlet nozzles at the bottom of the reactor vessel. The water was heated as it flowed upward through the modules, past the fuel elements, and exited the vessel through the outlet nozzles after a single pass through the core (Atherton 1987, WAPD-TM-1600, p.10).

\subsection{Reactor Parameters}

\subsubsection{Reactor Physical Dimensions}

The reactor vessel at Shippingport was approximately $33 \mathrm{ft}$ high with an inner diameter of $9 \mathrm{ft}$ and a nominal wall thickness of 8-7/8 in. (Massimino and Williams 1983, WAPD-TM-1342). Within the vessel was a core barrel, a long cylinder that locates fuel assemblies within the vessel. The core barrel was supported in the vessel by a large doughnut-shaped weldment called the support flange that rested on top of the vessel. The support flange also served as the entrance point of various types of core instrumentation and safety injection piping. The support flange was clamped in position by the 50 -inch-thick steel closure head using 6-inch diameter studs, which were installed in mating bolting flanges of the closure head and reactor vessel (Massimino and Williams 1983, WAPD-TM-1342, p. 2).

\subsubsection{Core Grid Locations}

The axial fuel rod support system for the LWBR fuel consisted of hexagonal grids made of precision-stamped AM-350 stainless steel sheet metal components (Atherton 1987, WAPD-TM-1600). The grids were designed to maintain the tight rod-to-rod spacing (about 0.06 in.) necessary to achieve a high fuel-to-water ratio, facilitate the production of neutrons, and achieve fuel economy. There were nine grids in the seed assembly and eight in the blanket assembly (Hecker 1979, WAPD-TM-1326). The grid volume per fuel rod data is given in Table 2-1, and accounts for only the number of grids present over the fuel height and only the fraction per level actually present in the fuel lattice. Remaining grid volumes are contained in metal-water regions exterior to the fuel lattice regions. Note: Table 2-1 lists 6, 6.5, or 7.5 for the number of grids in the fuel height. The table shows fewer grids in the fuel height because one grid is entirely above the fuel and half of a grid is below the fuel in each assembly (Hecker 1979, WAPD-TM-1326).

\subsubsection{Maximum Design Parameters}

Data for peak local linear power rating and fluence for each of the four LWBR fuel regions (seed, power-flattening and standard blanket, and reflector regions) are presented in Table 2-2. 


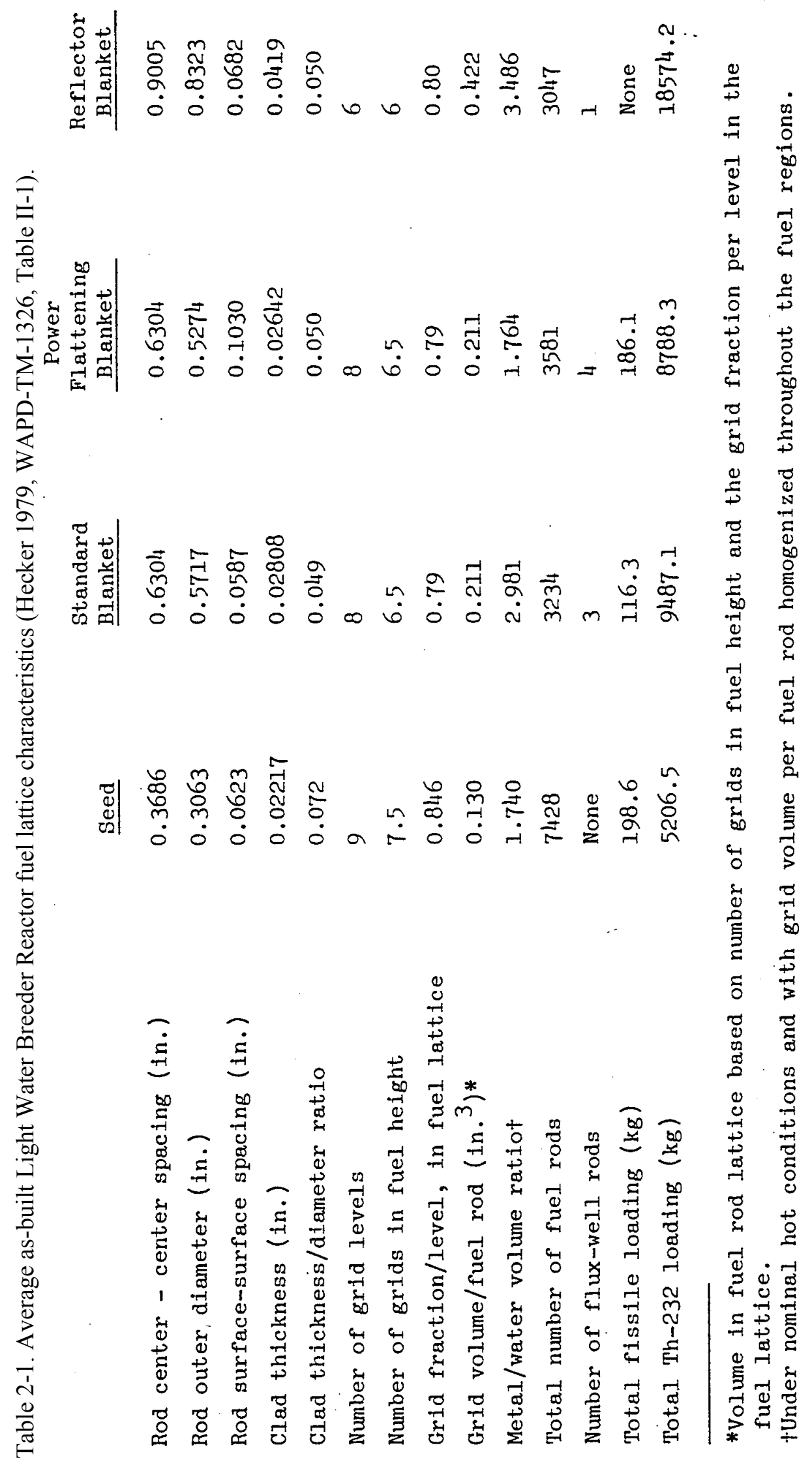


Table 2-2. Peak local linear power rating burnup and fluence for each of Light Water Breeder Reactor fuel regions (Campbell and Giovengo 1987, WAPD-TM-1387, Table 1).

\begin{tabular}{|c|c|c|c|c|}
\hline Parameter & Seed & $\begin{array}{l}\text { Standard } \\
\text { Blanket }\end{array}$ & $\begin{array}{l}\text { Region } \\
\text { Plater } \\
\text { Flatening } \\
\text { Blanket } \\
\end{array}$ & Ref lector \\
\hline \multicolumn{5}{|l|}{ Peak Linear Power $(k w / f t)$} \\
\hline $\begin{array}{l}\text { Best Estimate } \\
\text { Design }\end{array}$ & $\begin{array}{l}6.7 \\
8.8\end{array}$ & $\begin{array}{r}8.9 \\
11.7\end{array}$ & $\begin{array}{r}8.7 \\
11.5\end{array}$ & $\begin{array}{l}3.6 \\
4.7\end{array}$ \\
\hline \multicolumn{5}{|l|}{ Peak Depletion $\left(10^{20} \mathrm{f} / \mathrm{cc}\right)$} \\
\hline $\begin{array}{l}\text { Best Estimate at } 18,000 \text { EFPH } \\
\text { Best Estimate at } 29,047 \mathrm{EFPH} \\
\text { Oesign at } 18,000 \mathrm{EFPH} \\
\text { Design at } 29,047 \mathrm{EFPH}\end{array}$ & $\begin{array}{r}8.3 \\
11.4 \\
9.7 \\
13.4\end{array}$ & $\begin{array}{l}3.4 \\
5.3 \\
4.3 \\
6.7\end{array}$ & $\begin{array}{l}3.9 \\
5.7 \\
4.6 \\
7.0\end{array}$ & $\begin{array}{l}0.5 \\
1.0 \\
0.6 \\
1.3\end{array}$ \\
\hline \multicolumn{5}{|l|}{ Peak Burnup (MWD/MTM) } \\
\hline $\begin{array}{l}\text { Best Estimare at } 18,000 \text { EFPH } \\
\text { Best Estimate at } 29,047 \text { EFPH } \\
\text { Design at } 18,000 \text { EFPH } \\
\text { Design at } 29,047 \mathrm{EFPH}\end{array}$ & $\begin{array}{l}38,900 \\
53,400 \\
45,300 \\
62,500\end{array}$ & $\begin{array}{l}15,200 \\
23,200 \\
19,000 \\
29,600\end{array}$ & $\begin{array}{l}17,000 \\
25,200 \\
20,500 \\
30,800\end{array}$ & $\begin{array}{l}2,400 \\
4,500 \\
2,800 \\
5,600\end{array}$ \\
\hline \multicolumn{5}{|l|}{ Maximum Rod - Average } \\
\hline \multicolumn{5}{|l|}{ Depletion $\left(10^{20} \mathrm{f} / \mathrm{cc}\right)$} \\
\hline $\begin{array}{l}\text { Best Estimate at } 18,000 \text { EFPH } \\
\text { Best Estimate at } 29,047 \text { EFPH } \\
\text { Design at } 18,000 \text { EFPH } \\
\text { Design at } 29,047 \text { EFPH }\end{array}$ & $\begin{array}{l}4.4 \\
6.4 \\
4.7 \\
7.0\end{array}$ & $\begin{array}{l}2.0 \\
3.0 \\
2.2 \\
3.5\end{array}$ & $\begin{array}{l}2.2 \\
3.3 \\
2.5 \\
3.8\end{array}$ & $\begin{array}{l}0.3 \\
0.5 \\
0.3 \\
0.6\end{array}$ \\
\hline \multicolumn{5}{|l|}{$\begin{array}{l}\text { Maximum Rod - Average } \\
\text { Burnup (MHD/MTM) }\end{array}$} \\
\hline $\begin{array}{l}\text { Best Estimate at } 18,000 \text { EFPH } \\
\text { Best Estimate at } 29,047 \mathrm{EFPH} \\
\text { Design at } 18,000 \mathrm{EFPH} \\
\text { Design at } 29,047 \mathrm{EFPH}\end{array}$ & $\begin{array}{l}20,500 \\
29,800 \\
22,100 \\
32,900\end{array}$ & $\begin{array}{r}8,700 \\
13,200 \\
9,700 \\
15,500\end{array}$ & $\begin{array}{r}9,800 \\
14,700 \\
10,900 \\
16,800\end{array}$ & $\begin{array}{l}1,200 \\
2,200 \\
1,300 \\
2,700\end{array}$ \\
\hline \multicolumn{5}{|l|}{$\left.\overline{\left(10^{20} \mathrm{n} / \mathrm{cm}^{2}\right.},>1 \mathrm{Mev}\right)$} \\
\hline $\begin{array}{l}\text { Best Estimate at } 18,000 \text { EFPH } \\
\text { Best Estimate at } 29,047 \text { EFPH } \\
\text { Design at } 18,000 \text { EFPH } \\
\text { Design at } 29,047 \text { EFPH }\end{array}$ & $\begin{array}{r}66.3 \\
96.5 \\
70.3 \\
104.7\end{array}$ & $\begin{array}{l}48.4 \\
73.8 \\
53.8 \\
84.0\end{array}$ & $\begin{array}{l}38.5 \\
58.6 \\
44.0 \\
69.0\end{array}$ & $\begin{array}{l}17.7 \\
27.8 \\
20.0 \\
32.1\end{array}$ \\
\hline
\end{tabular}




\section{FUEL INFORMATION}

The nuclear parameter most important to breeding is the neutron regeneration factor $(\eta)$, which is the average number of neutrons produced in fission for each neutron absorbed in fissile fuel. To achieve breeding, this ratio must be greater than 2.0. Only three nuclear fuel materials are capable of fissioning on a practical basis for the production of electrical energy (U-235, Pu-239, and U-233). There was evidence from earlier work that the neutron regeneration factors for $\mathrm{U}-235$ and $\mathrm{Pu}-239$ were inadequate for light water reactors, but the $\eta$ for U-233 suggested U-233 had greater potential for breeding, particularly in a reactor with low water content (achieved by close fuel rod spacing) (Hecker 1989, WAPD-TM-1409, pp. 3-6). Thus, U-233 was used in the LWBR.

The LWBR core had a seed-blanket configuration consisting of 12 movable-fuel seed assemblies each surrounded by a stationary blanket assembly. The seed-blanket assemblies were designated as Types I, II, or III based on the nature of the blanket assemblies surrounding the seeds (see Figure 2-3), and the Type I, II and III assemblies were surrounded by Type IV and V reflector assemblies.

Fabrication was completed between 1976 and 1977, and the LWBR core began operating in the fall of 1977 (DeGeorge and Goldberg 1986, WAPD-TM-1278, p. iii). Approximately 24,000 fuel rods were manufactured from which 17,288 were assembled into the LWBR core (DeGeorge and Goldberg 1986, WAPD-TM-1278, p. I-1).

\subsection{Module Information}

The LWBR core consisted of an array of seed and blanket modules surrounded by an outer reflector region (see Figure 2-3). The three central (Type I) seed-blanket modules were designed insofar as practical to represent a configuration that could be used in a large central station reactor plant. Core reactivity control was achieved by moving the seed up and down within the stationary blanket assemblies using individual control drive mechanisms.

The seeds were symmetrical hexagons. Surrounding the three central seeds were symmetrical hexagonal Type I blanket modules. The rest of the seeds were surrounded by Type II and Type III blanket modules, which consisted of standard and power-flattening portions (see Figure 2-3).

Changing the axial position of the seed relative to the blankets changed the relative amounts of neutron absorptions in the fissile (U-233) and fertile (Th-232) fuel materials. To shut the reactor down, the seed assemblies were positioned $60 \mathrm{in}$. below the bottoms of the blanket assemblies as shown in Figure 3-1. To start up the reactor, the seed assemblies were raised, bringing the U-233 bearing parts of the fuel closer together. The control scheme was analogous in concept and operation to that of conventional poison rod control where negative reactivity addition and core shutdown are achieved by lowering the control elements, and positive reactivity addition is achieved by raising the control elements (Sarber 1976, WAPD-TM-1336, p. 6).

There were four regions of the core as shown in Figure 2-3: seed, standard blanket around the core center, power-flattening blanket around the outside of the central core, and the reflector region around the core perimeter. Each module was loaded with hundreds of rods.

Each standard blanket module (Type I) was a symmetrical hexagon with a movable seed module in its center. Each power-flattening blanket module was an asymmetrical hexagon with a movable seed in its center, a standard component toward the core interior, and a power-flattening component toward the outer core. The power-flattening blanket modules were referred to as either Type II or Type III depending on the shape. Type II modules contained hexagonal blankets that had two power-flattening sides; Type III blankets were hexagons with three power-flattening sides. Power-flattening sides were wider than the 


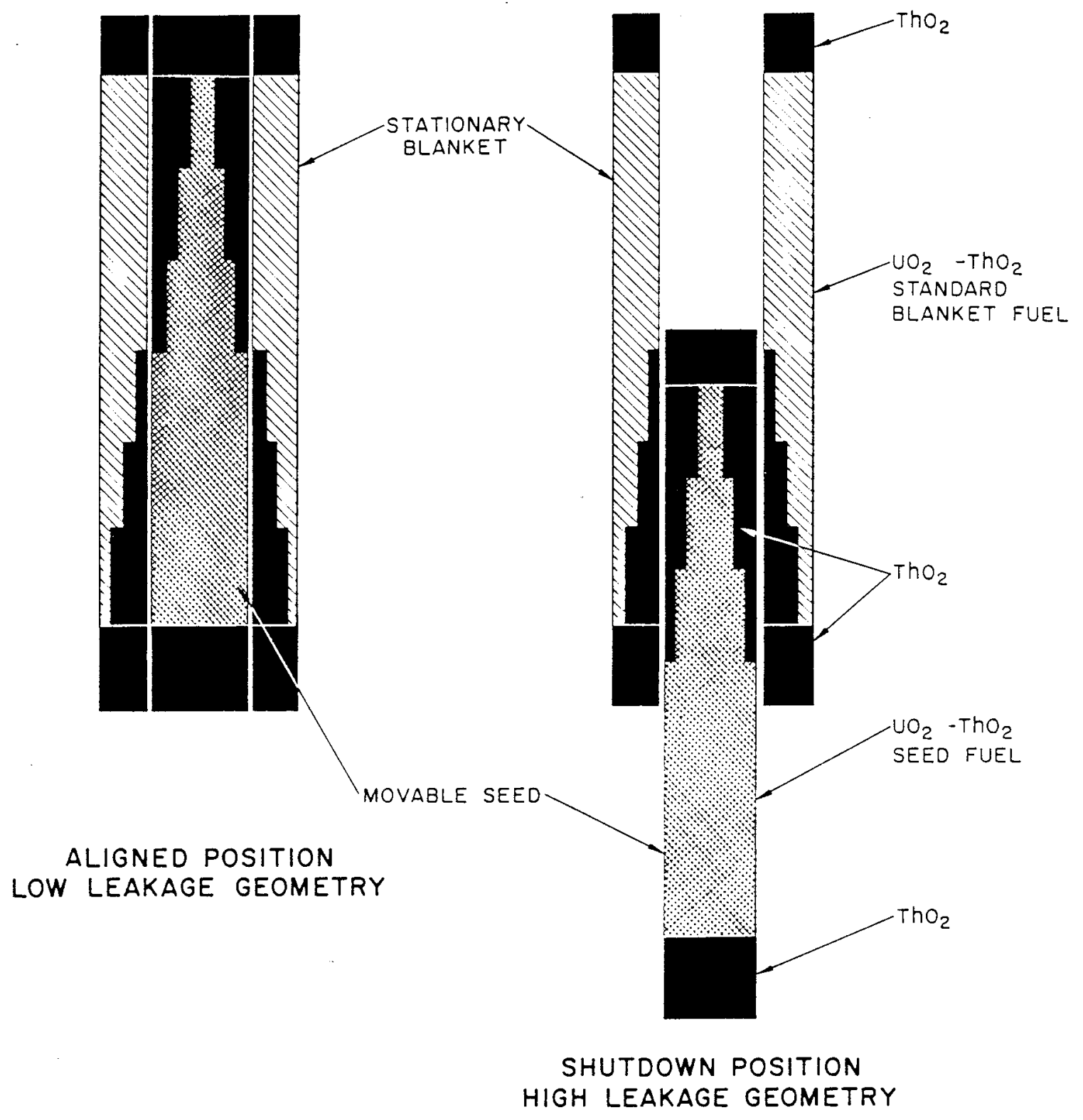

Figure 3-1. Movable fuel control (Sarber 1976, WAPD-TM-1336, Figure II-2). 
standard sides, but the rods in the power-flattening blankets were smaller in diameter and higher in U-233 than rods in the standard blankets (Hecker 1979, WAPD-TM-1326). The reflector modules were either five-sided Type IV reflectors (Figure 3-2) or four-sided Type V reflectors (Figure 3-3). Surrounding the reflector modules were 15 stainless steel, nonfuel filler units whose purpose was to limit core flow leakage by filling the space between the reflector modules and the core vessel (Hecker 1979, WAPD-TM-1326, p. 4). Cross-sectional dimensions of the modules are presented in Figure 3-4.

In all, there were 39 modules in the LWBR core (12 seeds, 3 Type I blankets, 3 Type II blankets, 6 Type III blankets, 9 Type IV reflectors, and 6 Type V reflectors), with a total of 17,288 rods. The number of rods in each fully rodded module is listed in Table 3-1. The seed and blanket rods contained stacked ceramic binary $\left(\mathrm{UO}_{2}-\mathrm{ThO}_{2}\right)$ fuel pellets. Binary stack lengths and urania concentrations varied axially and radially within seed and blanket regions to maximize efficiency. The reflector rods contained no binary fuel, only thoria pellets.

Each fuel module contained a lattice of fuel rods arranged on a triangular pitch. The fuel rods were supported vertically in the fuel modules by the module baseplates and laterally by the grid support system. Figure 3-5 is a schematic axial cross-section of a seed/standard blanket configuration showing the highly enriched fuel in the central seed surrounded by lower-enriched fuel of diminishing binary stack lengths outside. Figure 3-6 depicts how the rods are configured radially within the seed module, and Figure 3-7 depicts the radial configuration of the rods in the standard blanket module. Figure 3-8 is a schematic of the axial cross-section of a seed and power-flattening blanket regions. Figures 3-9 and 3-10 depict the rod arrangement for the Type II and III power-flattening blankets, respectively. The standard portions of the Type II and Type III blanket modules (i.e., the uncolored portions in Figures 3-9 and 3-10) were loaded like the Type I blankets. The tops and bottoms of the fuel rods in the seed and blanket modules were stacked with fertile material in the form of $\mathrm{ThO}_{2}$ fuel pellets.

To enhance breeding performance, the standard blanket region had a high metal-to-water ratio of 2.98. The power-flattening blanket fuel region had a lower metal-to-water ratio of about 1.76 (see Table 2-1) and a higher $\mathrm{UO}_{2}$ concentration than the standard blanket. The power-flattening blanket was located on the outer periphery of the nine seed-blanket assemblies surrounding the three center seedblanket assemblies. As a result, the overall radial core power distribution was flattened (Gorscak, Campbell, and Clayton 1987, WAPD-TM-1605, p. 5).

There were 9, 8, and 6 grid levels per each seed, blanket, and reflector module, respectively. Approximately half the fuel rods in each module were fixed to the top of the module, and the other half were fixed to the bottom of the module (Gorscak, Campbell, and Clayton 1987, WAPD-TM-1605, p. 8).

\subsection{Fuel Information}

The LWBR core was fueled with Th-232 and U-233, zoned axially and radially to maximize neutron economy (Hecker 1979, WAPD-TM-1326, p. 6+). The combination of radial and axial fuel zones served the dual purpose of achieving an acceptable peak-to-average power ratio and providing adequate movable fuel reactivity worths. Seed and blanket assemblies contained both fissile U-233 and fertile Th-232 at beginning of life, while the reflector fuel modules contained only thorium (as-built). The mass of each uranium isotope in the seed modules and the standard and power-flattening portions of the blanket modules is shown in Table 3-2.

The thoria-based fuel system had many operating advantages over the urania system with some fabrication disadvantages. Fabrication difficulties of importance to design included uranium homogeneity, which is difficult to obtain in a single fire process; attainment of high density because of thoria's high melting temperature; and reduced diffusion coefficients at normal sintering temperature. Attainment of 

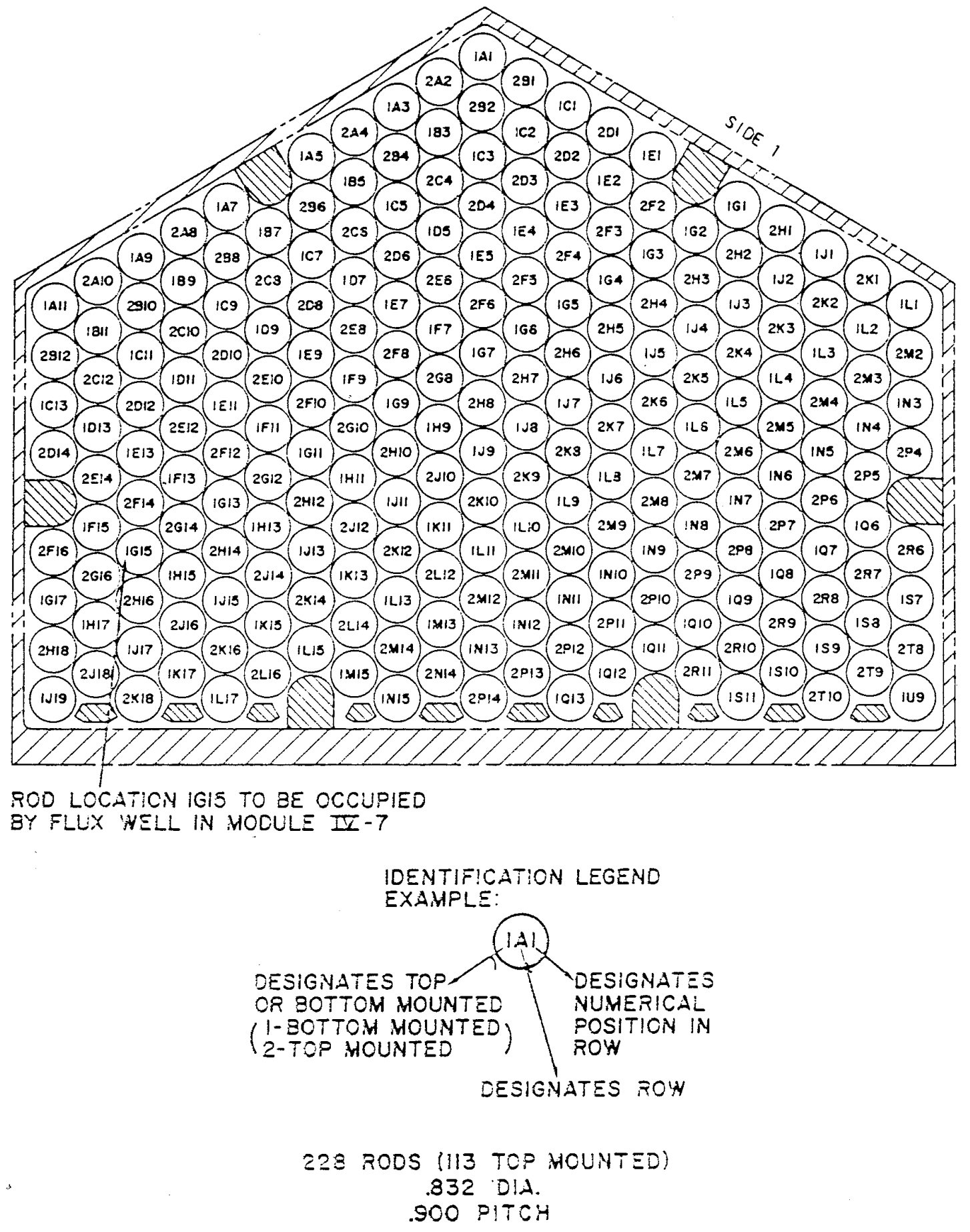

Figure 3-2. Light Water Breeder Reactor Type IV Reflector Module rod and cell identification (Gorscak, Campbell, and Clayton 1987, WAPD-TM-1605, Figure A1-5). 

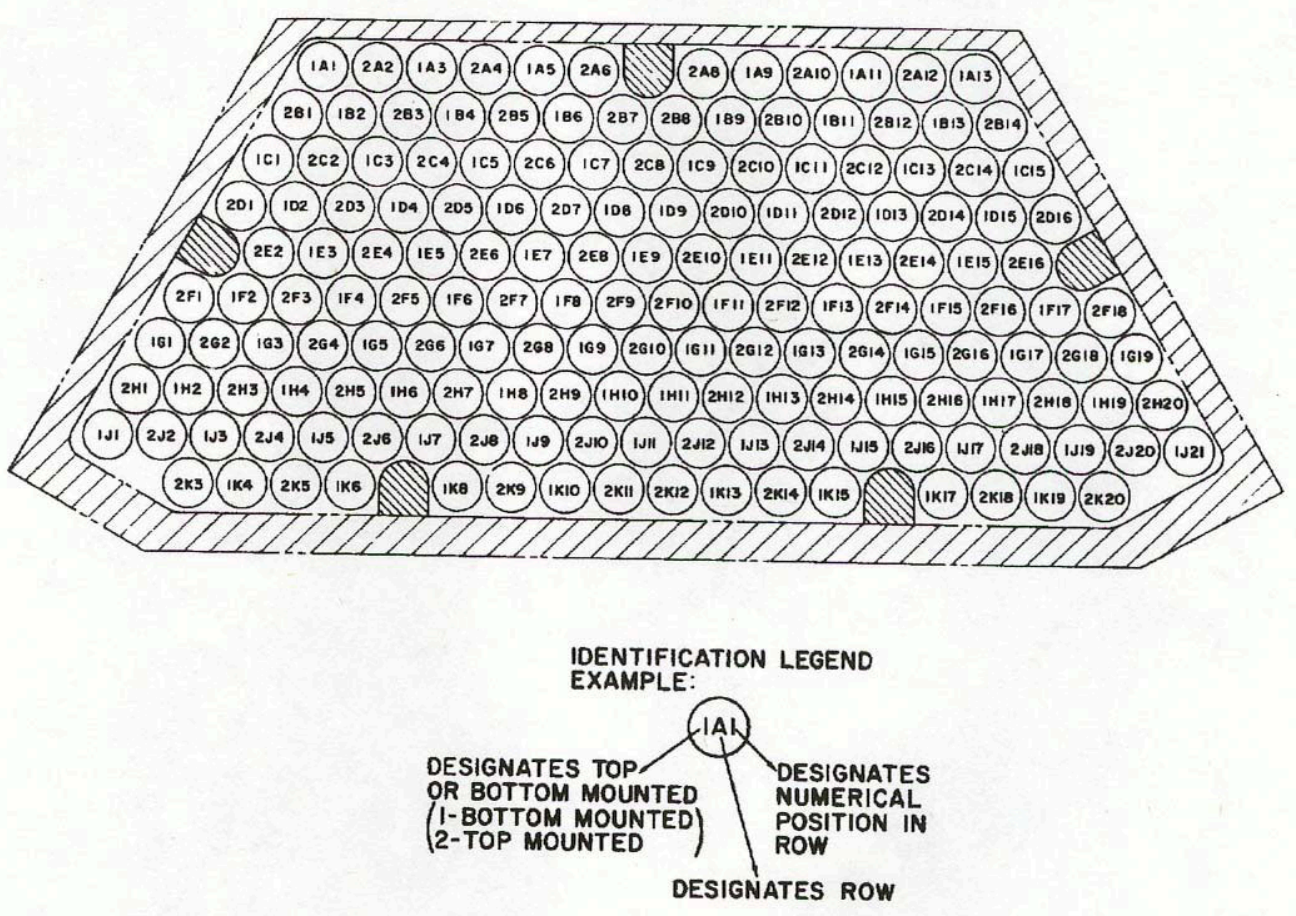

166 RODS (84 TOP MOUNTED)

.832 DIA.

$.900 \mathrm{PITCH}$

Figure 3-3. Type V Reflector Module (blackened dots represent the rods removed from RV-4 for proof-of-breeding tests, from Schick et al. 1987, WAPD-TM-1612, Figure V-13). 


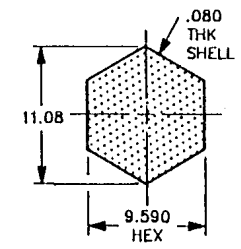

SEED

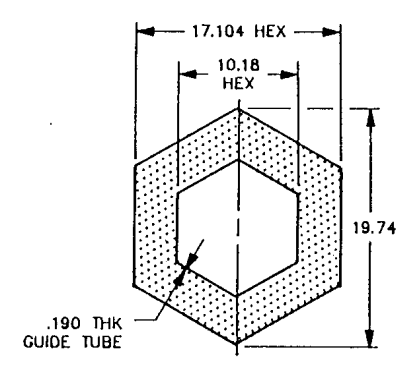

BLANKET
TYPE I

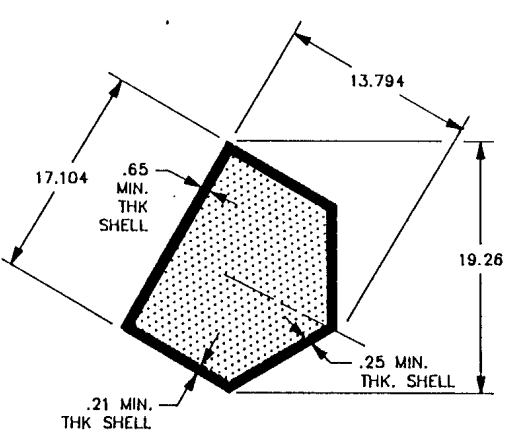

REFLECTOR

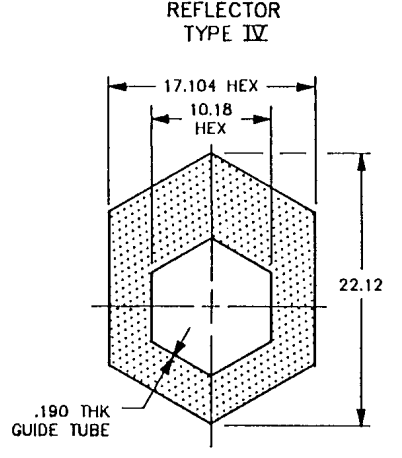

BLANKET
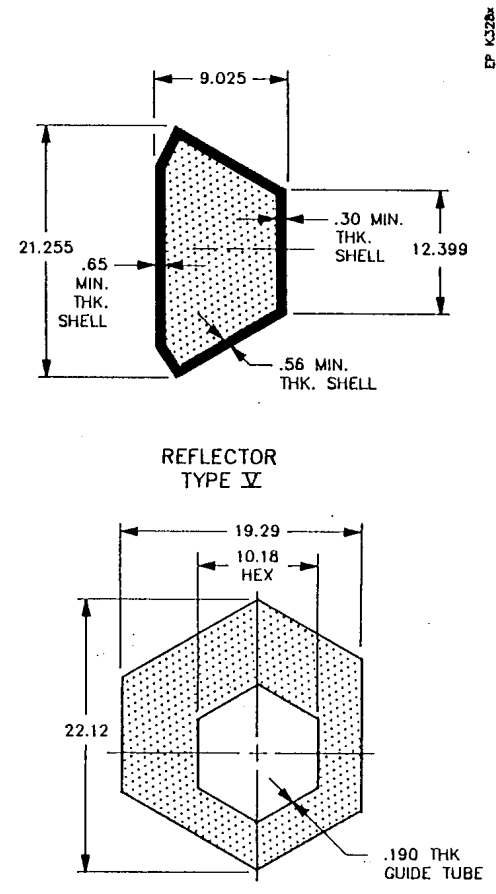

BLANKET

Figure 3-4. Cross-sectional dimensions of the Light Water Breeder Reactor modules (Greenberger and Miller 1987, WAPD-TM-1608, Figure 24).

Table 3-1. Number of fuel rods by module and total number of fuel rods in Light Water Breeder Reactor core.

\begin{tabular}{lccc}
\hline \multicolumn{1}{c}{ Module Type } & $\begin{array}{c}\text { Number of Rods } \\
\text { per Module }\end{array}$ & $\begin{array}{c}\text { Number of Modules } \\
\text { per Core }\end{array}$ & $\begin{array}{c}\text { Total Number of Rod } \\
\text { Locations per Core }\end{array}$ \\
\hline Seed & 619 & 12 & 7,428 \\
Type I blanket & 444 & 3 & 1,332 \\
$\begin{array}{l}\text { Type II standard blanket } \\
\text { Type II power-flattening }\end{array}$ & 261 & 3 & 783 \\
blanket & 303 & & 909 \\
$\begin{array}{l}\text { Type III standard blanket } \\
\text { Type III power-flattening }\end{array}$ & 187 & 6 & 1,122 \\
blanket & 446 & & 2,676 \\
Type IV reflector & 228 & 9 & 2,052 \\
Type V reflector & 166 & 6 & 996 \\
Total & & 39 & $17,304^{\text {a }}$ \\
\hline & & & \\
a. The actual core used 16 rod locations for flux wells, so the actual core was loaded with a total of 17,288 rods. \\
\hline
\end{tabular}




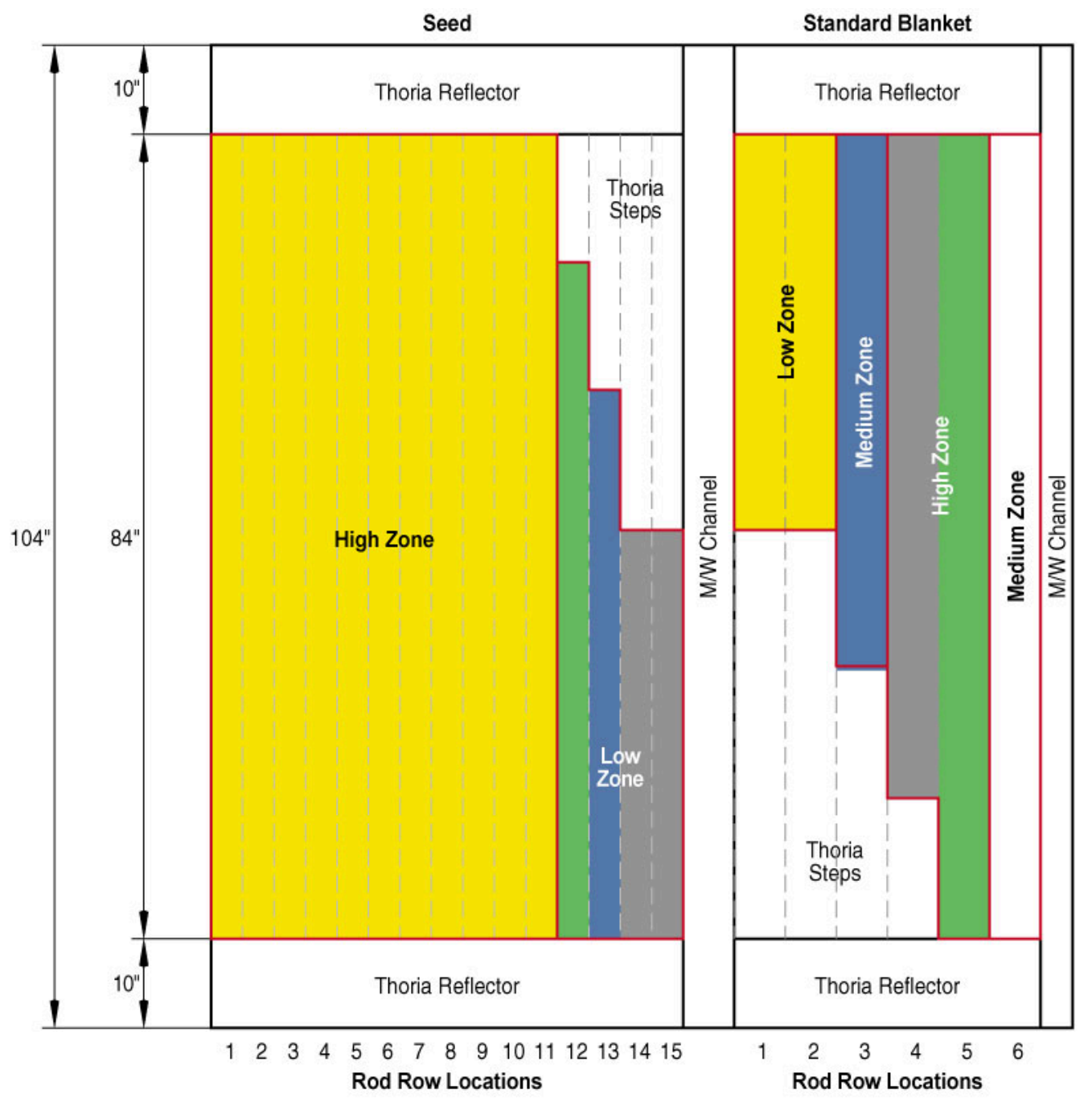

Y98 0400

Figure 3-5. Axial schematic of a Type I Module (modified from Hecker 1979, WAPD-TM-1326, Figure II-4). 


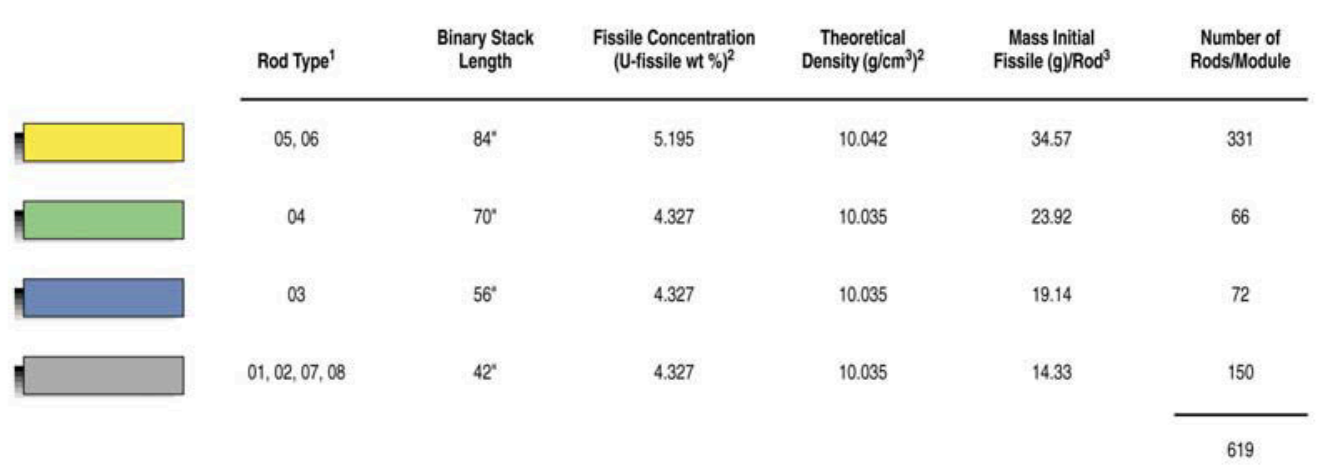

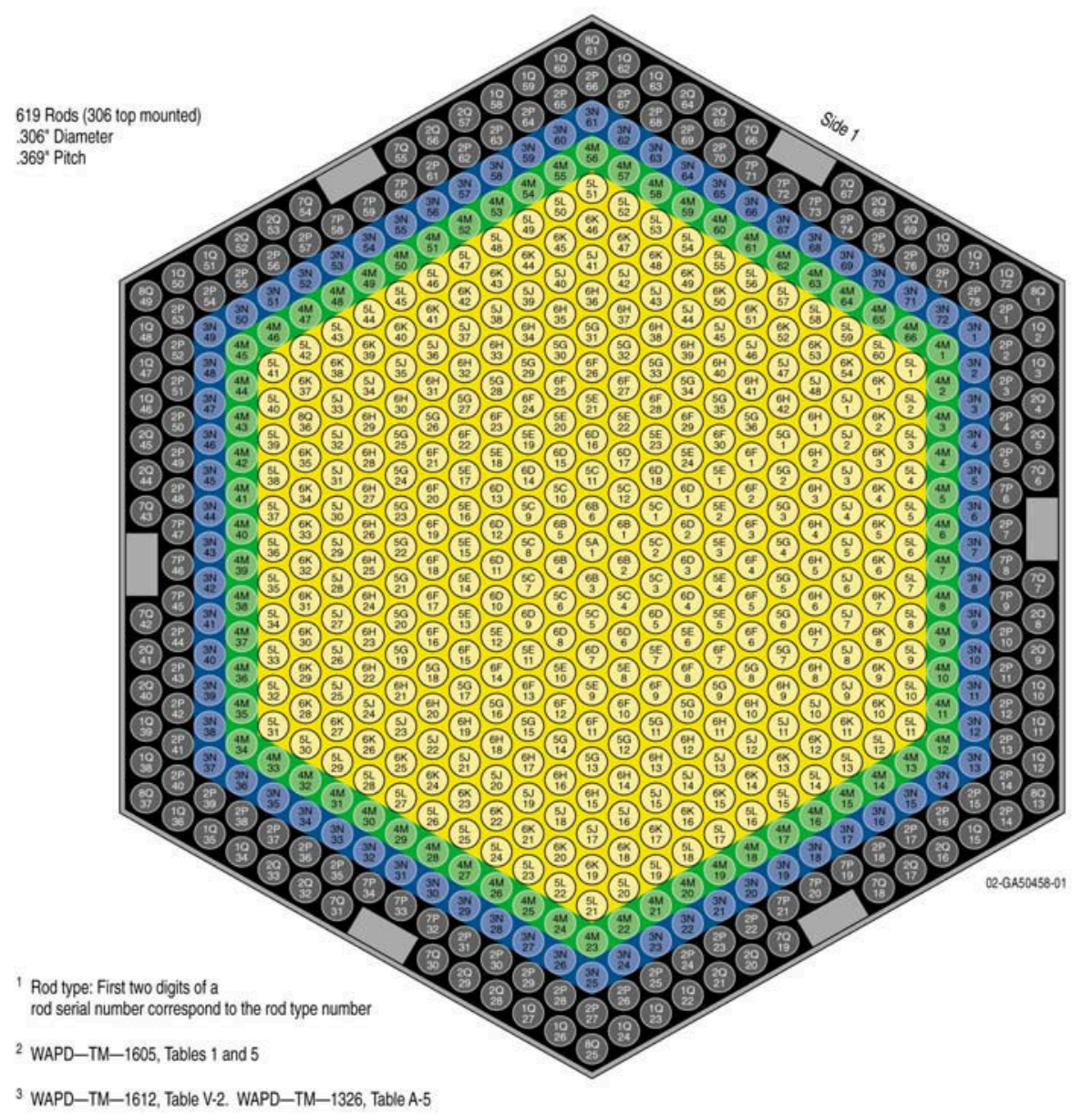

Figure 3-6. Light Water Breeder Reactor movable seed module rod arrangement and cell identification (modified from Figure A-1 of Gorscak, Campbell, and Clayton 1987, WAPD-TM-1605). 


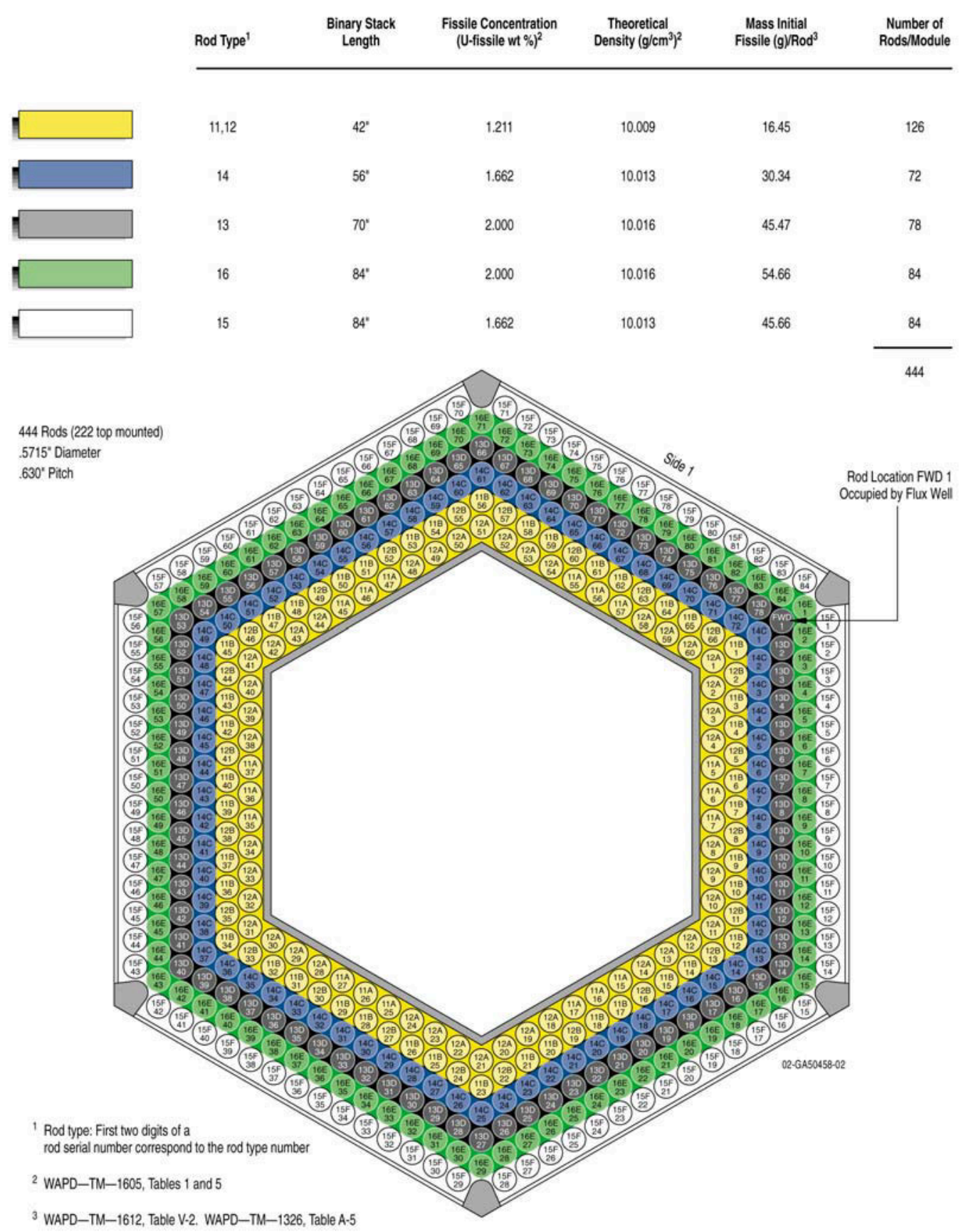

Figure 3-7. Light Water Breeder Reactor Type I blanket module rod configuration and cell identification (modified from Figure A1-2 of Gorscak, Campbell, and Clayton 1987, WAPD-TM-1605). 


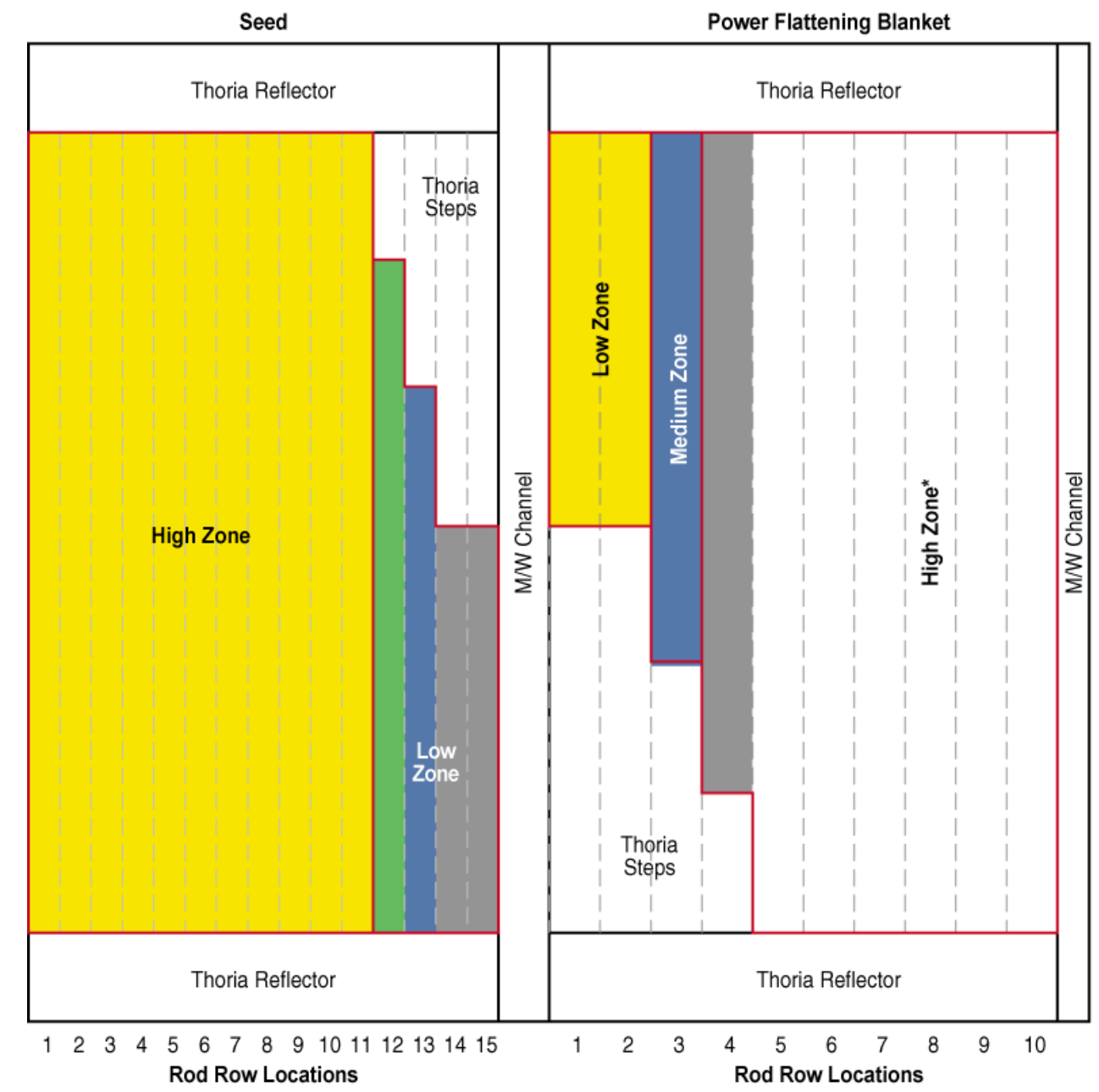

* Except for eight Medium zone rods per module in row six $\square$ (4 on each side, along interface between modules).

Y98 0399

Figure 3-8. Axial schematic of the seed surrounded by a power-flattening blanket module (modified from Hecker 1979, WAPD-TM-1326, p. 17). 
Region 2

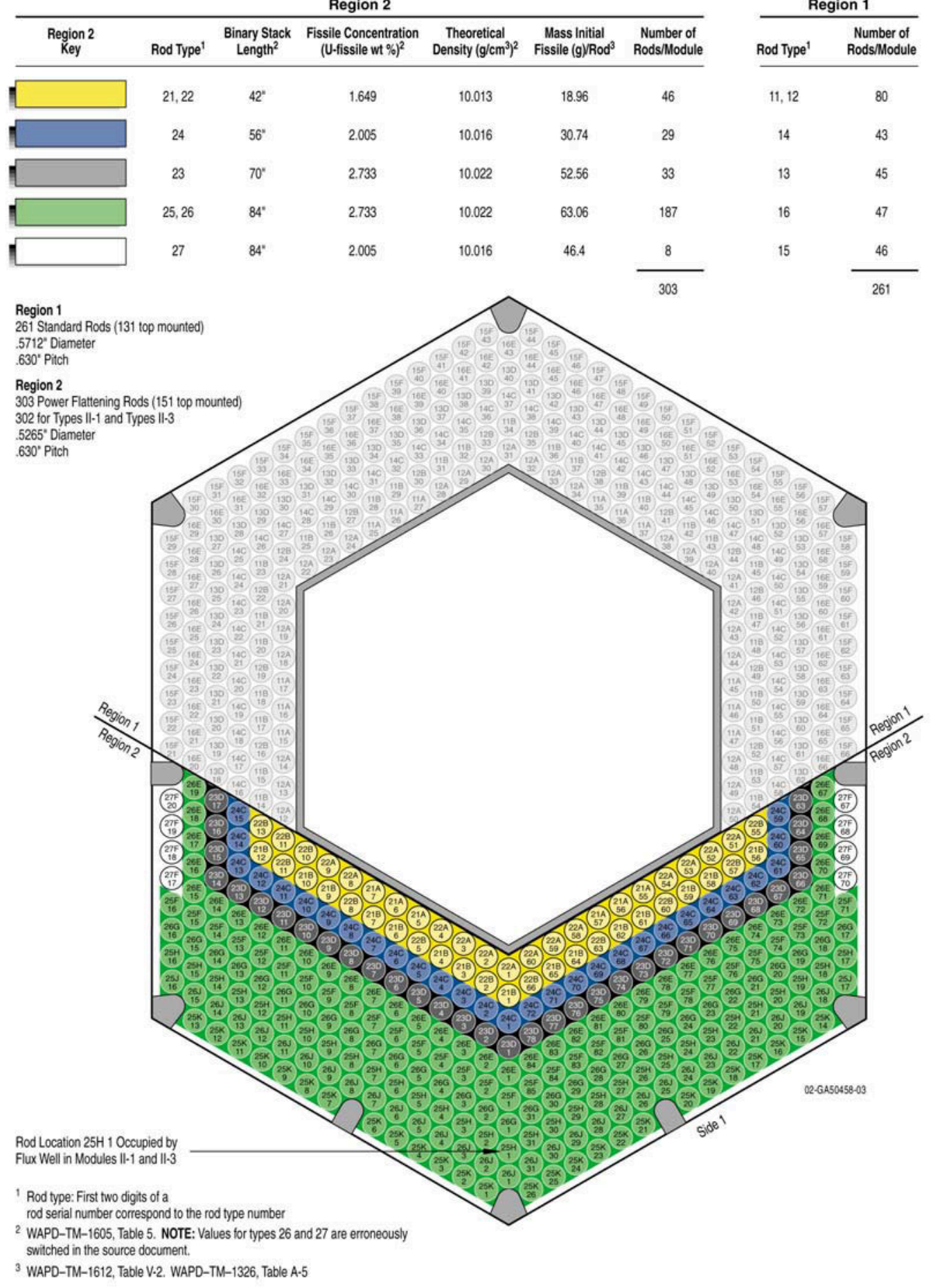

Figure 3-9. Type II blanket module rod and cell identification (modified from Figure A1-3 of Gorscak, Campbell, and Clayton 1987, WAPD-TM-1605). 
Region 2

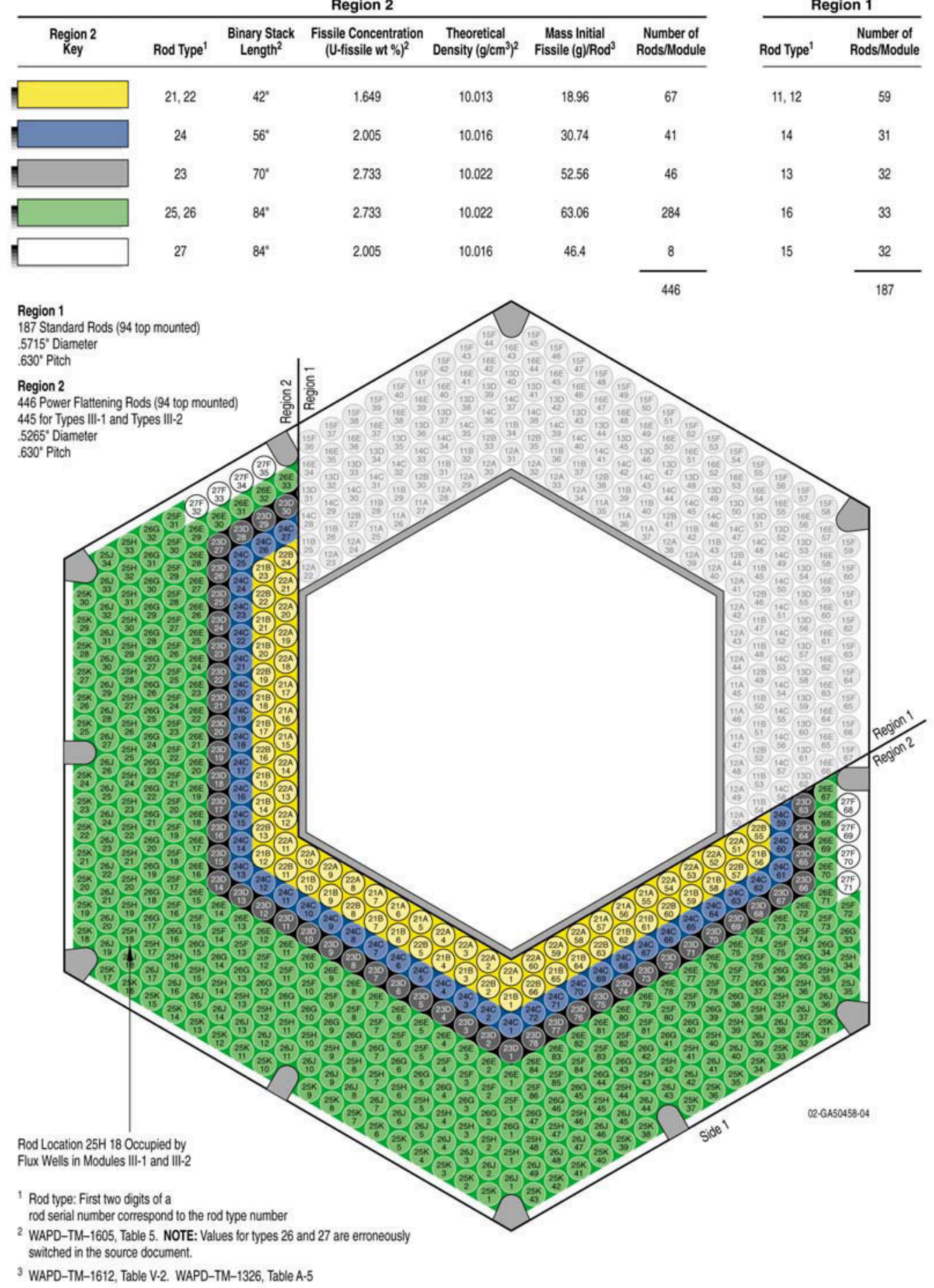

Figure 3-10. Type III blanket module rod and cell identification (modified from Figure A1-4 of Gorscak, Campbell, and Clayton 1987, WAPD-TM-1605). 


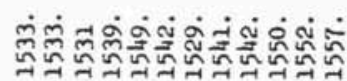

กี่

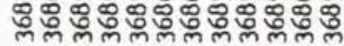

0.0000000000

चี

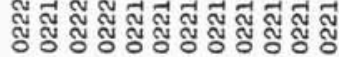

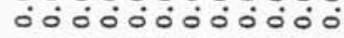

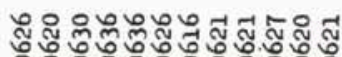

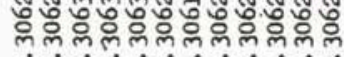

०0000000000

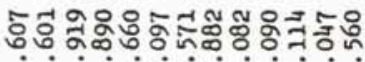

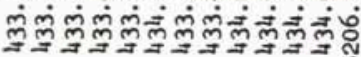

00 - य००० -

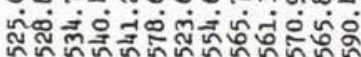

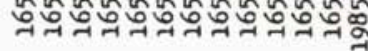

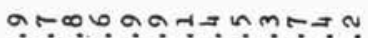

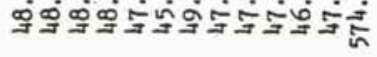

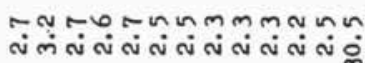

O O No in un o a anz N

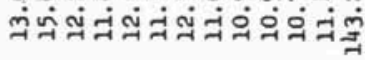

ฯ

สี่ ลี่ ลี่ สี่

은

สิ่

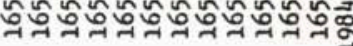

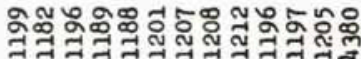

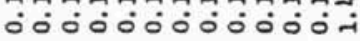

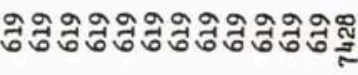

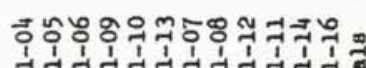

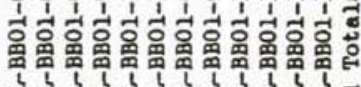

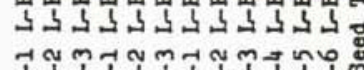

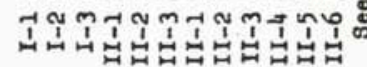

का ⿻上丨

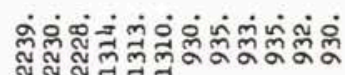

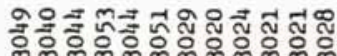

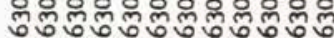
०००000000

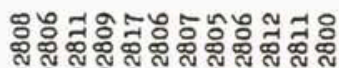

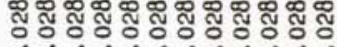

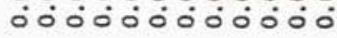

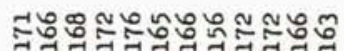

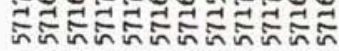
0.0000000000

น

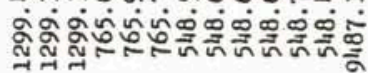

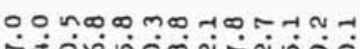

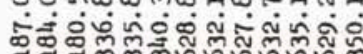

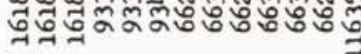

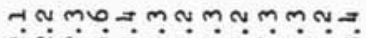

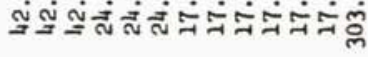

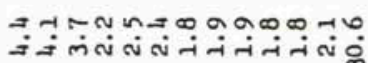

raOm ro=0 rnm

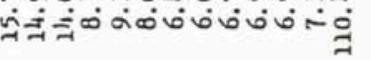

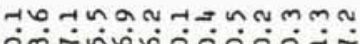

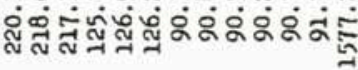

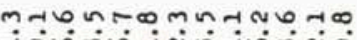

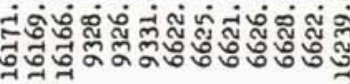

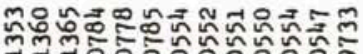

퀴귱ㅇํㅇํㅇํํํํํํํำ ०0000000000

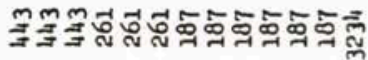

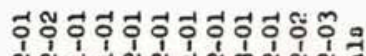

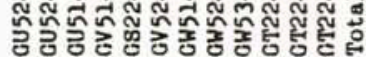

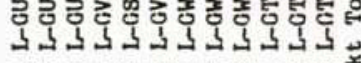

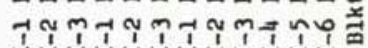

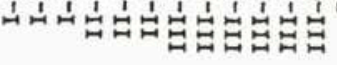

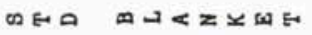

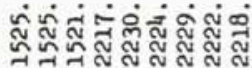

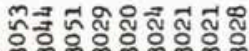

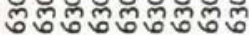
०००000000

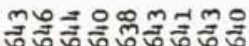

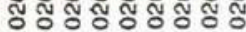
00000000

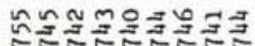

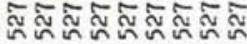
- 0005000

ผ ¡ं

-min w

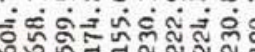

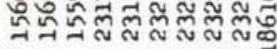

annu $\rightarrow m 00 \rightarrow 0$

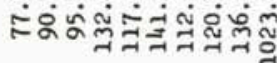

raztomaror

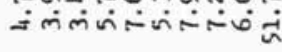

ल⿻上丨m

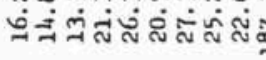

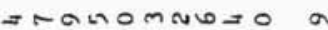

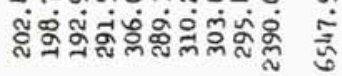

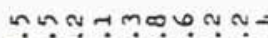
ฝึં

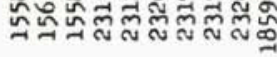

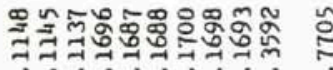

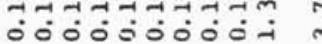

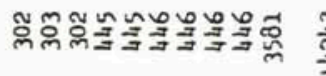

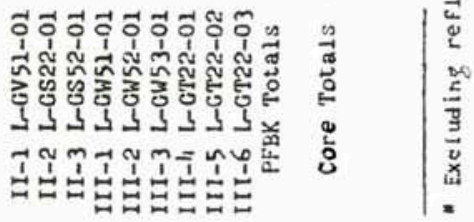


uranium homogeneity limits was achieved by comicronizing and by thoroughly mixing the binary compositions. High density was achieved by using micronized powder and a slightly higher than normal sintering temperature (Gorscak Campbell, and Clayton 1987, WAPD-TM-1605, p. 20-21).

Best estimate melting point is about $5950^{\circ} \mathrm{F}$ for $\mathrm{UO}_{2}-\mathrm{ThO}_{2}$ fuel systems containing 2 to $6 \mathrm{wt} \% \mathrm{UO}_{2}$ . Thermal conductivity and corrosion resistance of the thoria-based system was higher than the urania system (Gorscak, Campbell, and Clayton 1987, WAPD-TM-1605, p. 21).

Pellets were loaded into Zircaloy-4 cladding tubes, which were welded at both ends to solid end plugs (Atherton 1987, WAPD-TM-1600, Section 3-2). Within the tube and above the fuel stack, there was a plenum void to house the plenum spring, which allowed fuel stack expansion to accept fission gas released from the fuel. This design served to minimize internal gas pressure.

Because impurities interfered with the breeding performance of the fuel, there was a need to tightly quantify and control the amount of impurities allowed in the fuel. Neutron poison equivalence (NPE) was calculated on every tenth pellet blend. The NPE was an index that accounted for the amount and neutron absorption properties of each impurity. Elements with large neutron absorption cross sections could be tolerated at only low levels, whereas elements with moderate cross sections could be tolerated at higher levels. Impurities with extremely low cross sections might not need to be controlled at all from the point of view of breeding. The neutron absorption capability of one part cobalt per million parts of thorium was assigned a reference value of 1.0. Mass spectrometry was used to quantify fuel impurities. NPE is discussed in Hecker 1979, WAPD-TM-1326, Appendix B, and NPE data are presented in Table 3-3.

\subsubsection{Pellets}

The LWBR core contained about 3 million fuel pellets. Approximately 1.6 million of the pellets were binary (uranium oxide-thorium oxide), and the rest were thoria. There were several different sizes, shapes, and enrichments of pellets fabricated for the various rod types. All pellets were ceramic, more or less right circular cylinders, and either $\mathrm{ThO}_{2}$ or binary $\left(\mathrm{ThO}_{2}-{ }^{233} \mathrm{UO}_{2}\right)$. Binary pellets were used only in the seed and blanket modules of the reactor. There were eight sizes of binary pellets. Thoria pellets were fabricated in four different sizes; one for each type of rod (i.e., seed, standard blanket, power flattening blanket, and reflector rods). Table 3-4 lists the properties of the pellets used in the various zones of the core. Pellet dimensions with uncertainties are presented in Table 3-5.

The fuel pellets contained from 1-5 wt $\% \mathrm{UO}_{2}$ in a thoria matrix (Walter and Weinreich 1976, WAPD-TM-1244(L), p. I-2). Uranium in the $\mathrm{UO}_{2}$ was $98.23 \%$ enriched with fissile U-233 (Hecker 1979, WAPD-TM-1326, p. 11; Schick et al. 1987, WAPD-TM-1612, p. 5). The percentage of theoretical densities for the pellets ranged from 97.28 to $98.61 \%$. Table 3-6 lists the theoretical densities and void fractions for the various types of pellets.

Each powder blend, either binary or thoria, received a unique blend designation. A representative sample of pellets from a blend was taken and used to determine the characteristics of the blend. The pellet properties that were measured and needed for the computational model of the core were length, diameter, and weight for all pellets in the sample, and weight percent $(\mathrm{wt} \%)$ of total uranium and uranium isotopic weight percents for binary pellets. These properties for binary pellets were stored in a computer file for each binary blend manufactured and used to compute uranium and thorium loadings of binary fuel rods (Freeman 1978, WAPD-TM-1314, pp. 27-28). 
Table 3-3. Neutron Poison Equivalence (NPE) (Hecker 1979, WAPD-TM-1326, Table A-17).

\begin{tabular}{lcc} 
Composition & $\begin{array}{c}\text { Blends } \\
\text { Sampled }\end{array}$ & $\begin{array}{c}\text { Average } \\
\text { NPE }\end{array}$ \\
\hline Low seed & 13 & 14.3 \\
High seed & 23 & 14.2 \\
Low standard blanket & 3 & 17.1 \\
Medilm standard blanket & 21 & 13.2 \\
Higi standard blanket & 9 & 17.7 \\
Low power flattening blanket & 2 & 15.8 \\
Medium power flattening blanket & 2 & 14.3 \\
High power flattening blanket & 5 & 19.3 \\
All binary & 78 & 14.8 \\
Seed thoria & 5 & 15.2 \\
Standard blanket thoria & 18 & 14.7 \\
Power flattening blanket thoria & 4 & 6.8 \\
Reflector blanket thoria & 36 & 28.7 \\
All thoria & 63 & 22.2 \\
All binary and thoria & 141 & 18.2
\end{tabular}




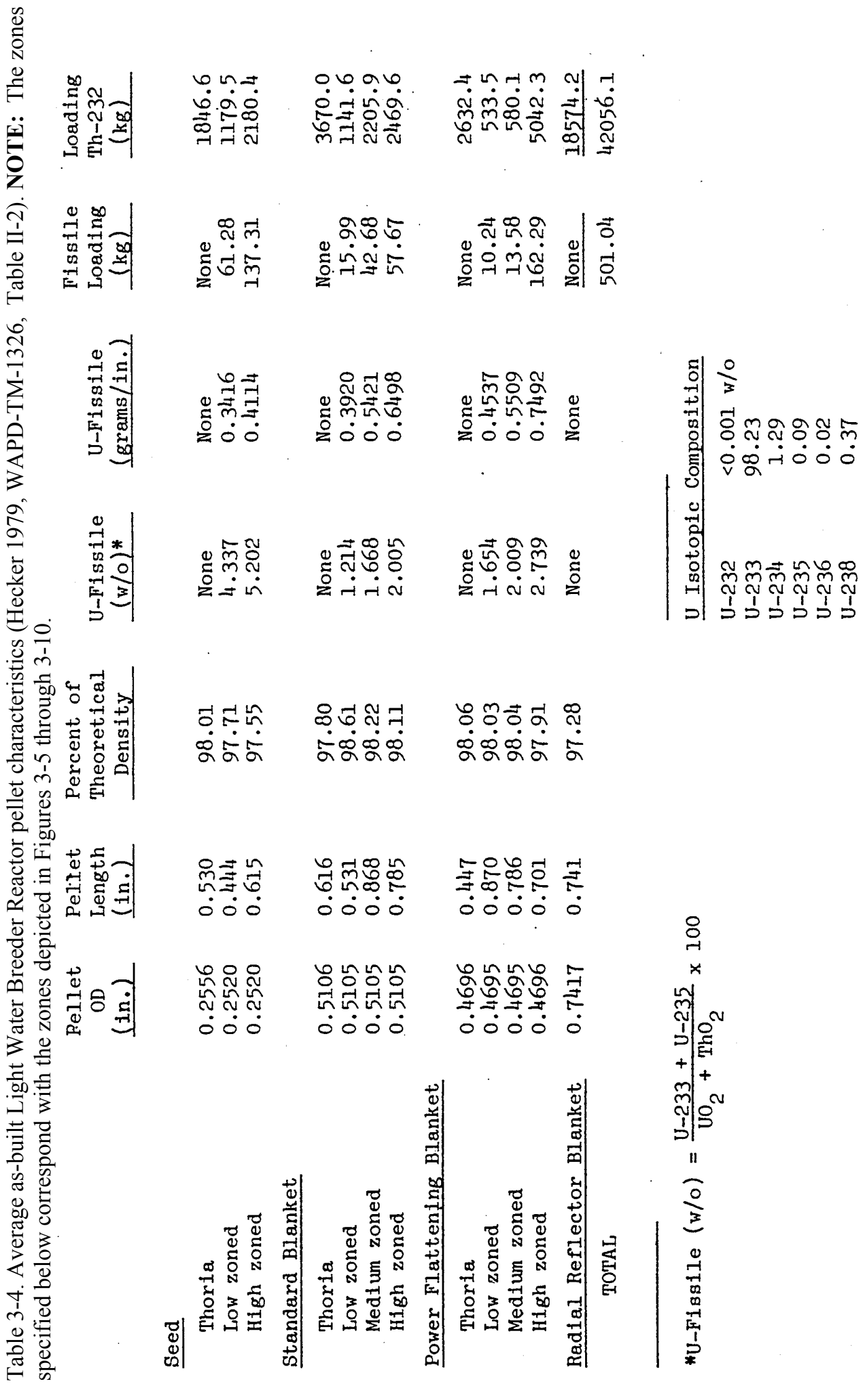


Table 3-5. Light Water Breeder Reactor fuel pellet dimensions (Campbell and Giovengo 1987, WAPD-TM-1387, Table 4).

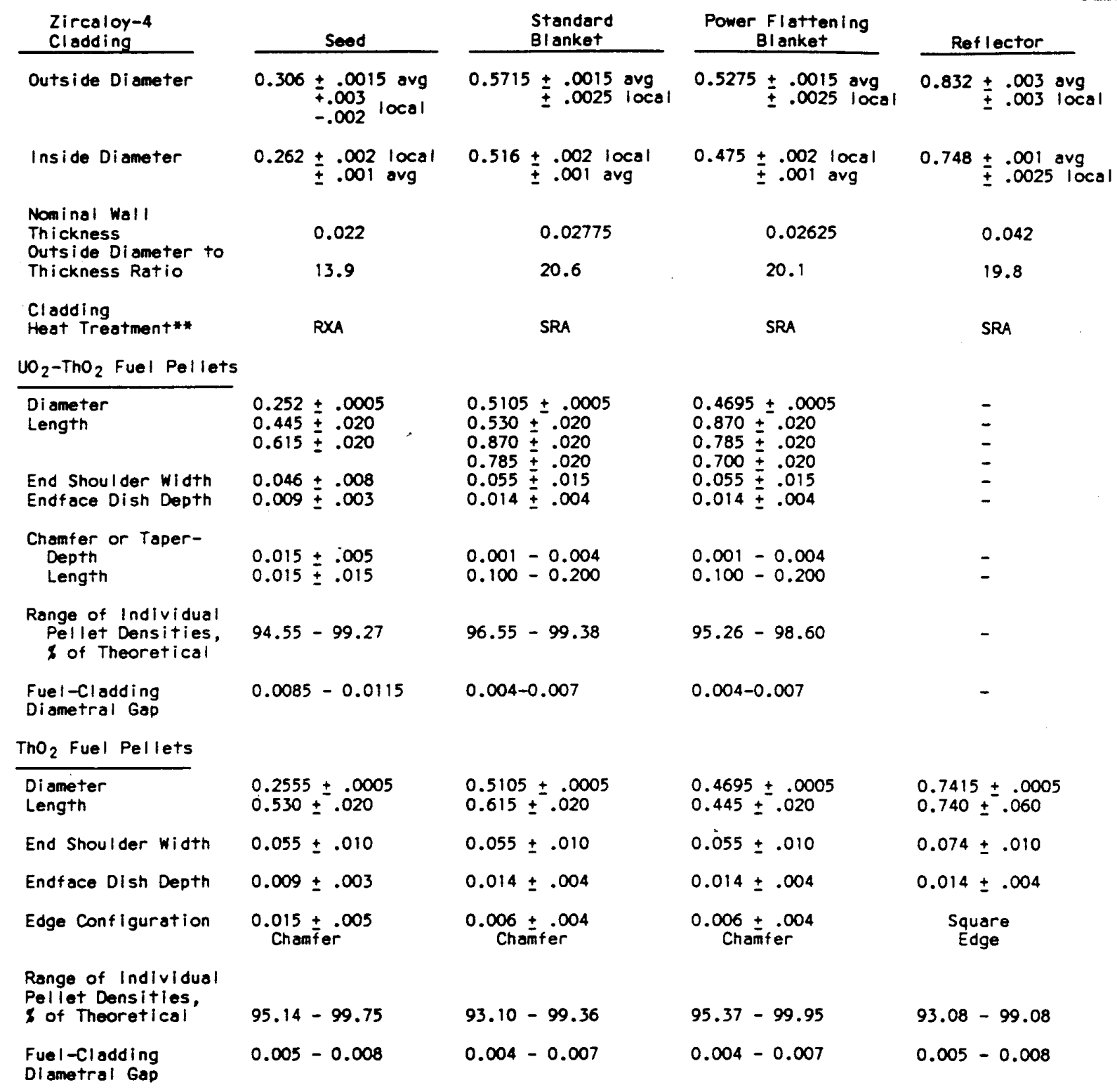

* All dimensions are in inches, except as noted.

* $R X A=$ Recrystallization Annealed

SRA = Stress Relief Annealed 
Table 3-6. Average as-built pellet density and void fraction (Hecker 1979, WAPD-TM-1326, Table A-10).

\begin{tabular}{|c|c|c|c|}
\hline & $\begin{array}{c}\text { Percent } \\
\text { Theoretical } \\
\text { Density } \\
\end{array}$ & $\begin{array}{c}\text { Theoretical } \\
\text { Density } \\
\text { (gm/cm } 3) \\
\end{array}$ & $\begin{array}{c}\text { Void } \\
\text { Fraction }\end{array}$ \\
\hline \multicolumn{4}{|l|}{ Seed } \\
\hline $\begin{array}{l}\text { Thoria } \\
\text { Low zoned } \\
\text { High zoned }\end{array}$ & $\begin{array}{l}98.013 \\
97.712 \\
97.554\end{array}$ & $\begin{array}{r}9.999 \\
10.035 \\
10.042\end{array}$ & $\begin{array}{l}0.01253 \\
0.01704 \\
0.01172\end{array}$ \\
\hline \multicolumn{4}{|l|}{ Standard Blanket } \\
\hline $\begin{array}{l}\text { Thoria } \\
\text { Low zoned } \\
\text { Medium zoned } \\
\text { High zoned }\end{array}$ & $\begin{array}{l}97.796 \\
98.608 \\
98.224 \\
98.115\end{array}$ & $\begin{array}{r}9.999 \\
10.009 \\
10.013 \\
10.016\end{array}$ & $\begin{array}{l}0.01399 \\
0.02494 \\
0.01335 \\
0.01600\end{array}$ \\
\hline \multicolumn{4}{|c|}{ Power Flattening Blanket } \\
\hline $\begin{array}{l}\text { Thoria } \\
\text { Low zoned } \\
\text { Medium zoned } \\
\text { High zoned }\end{array}$ & $\begin{array}{l}98.057 \\
98.034 \\
98.041 \\
97.906\end{array}$ & $\begin{array}{r}9.999 \\
10.013 \\
10.016 \\
10.022\end{array}$ & $\begin{array}{l}0.01966 \\
0.01998 \\
0.01753 \\
0.01578\end{array}$ \\
\hline Reflector Blanket & 97.282 & 9.999 & 0.01317 \\
\hline
\end{tabular}

Hundreds of pellets were loaded in each rod; hundreds of rods were loaded in each of the core's 39 modules. The uranium concentrations varied between types of pellets, but differing concentrations were not mixed in the same rod; all binary pellets in any given rod had the same $\mathrm{wt} \%$ of fissile uranium. More detail about pellets in the seed, blanket, and reflector rods is presented in Section 3.2.2.

Production specifications for the powder used in production of the fuel pellets are provided in Table 3-7. The surface area and particle size shown were necessary for the production of high density, high integrity thoria, and binary pellets. Surface areas were monitored using a gas absorption surface area analyzer, and statistical limits were imposed for postmicronized surface areas. Surface area measurement was an essential product control for micronized powders (Walter and Weinreich 1976, WAPD-TM-1244(L), p. V.C-2). Grain size of LWBR fuel at end-of-life (EOL) is shown in Table 3-8.

Table 3-7. Production specifications for pellets (Walter and Weinreich 1976, WAPD-TM-1244(L), Table V.C-1).

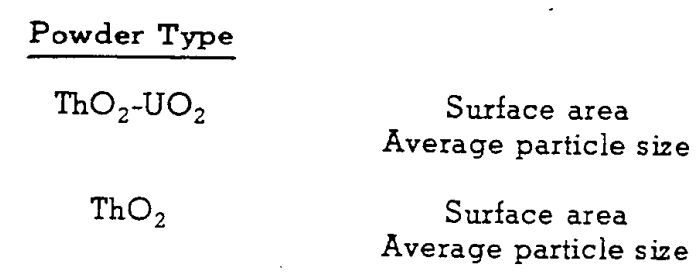

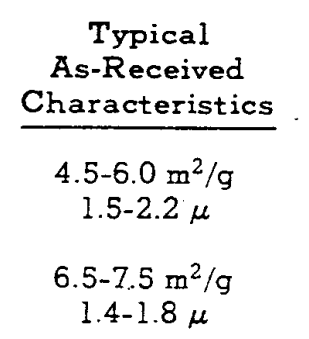

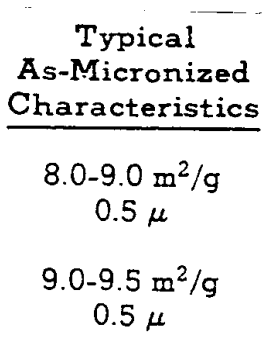




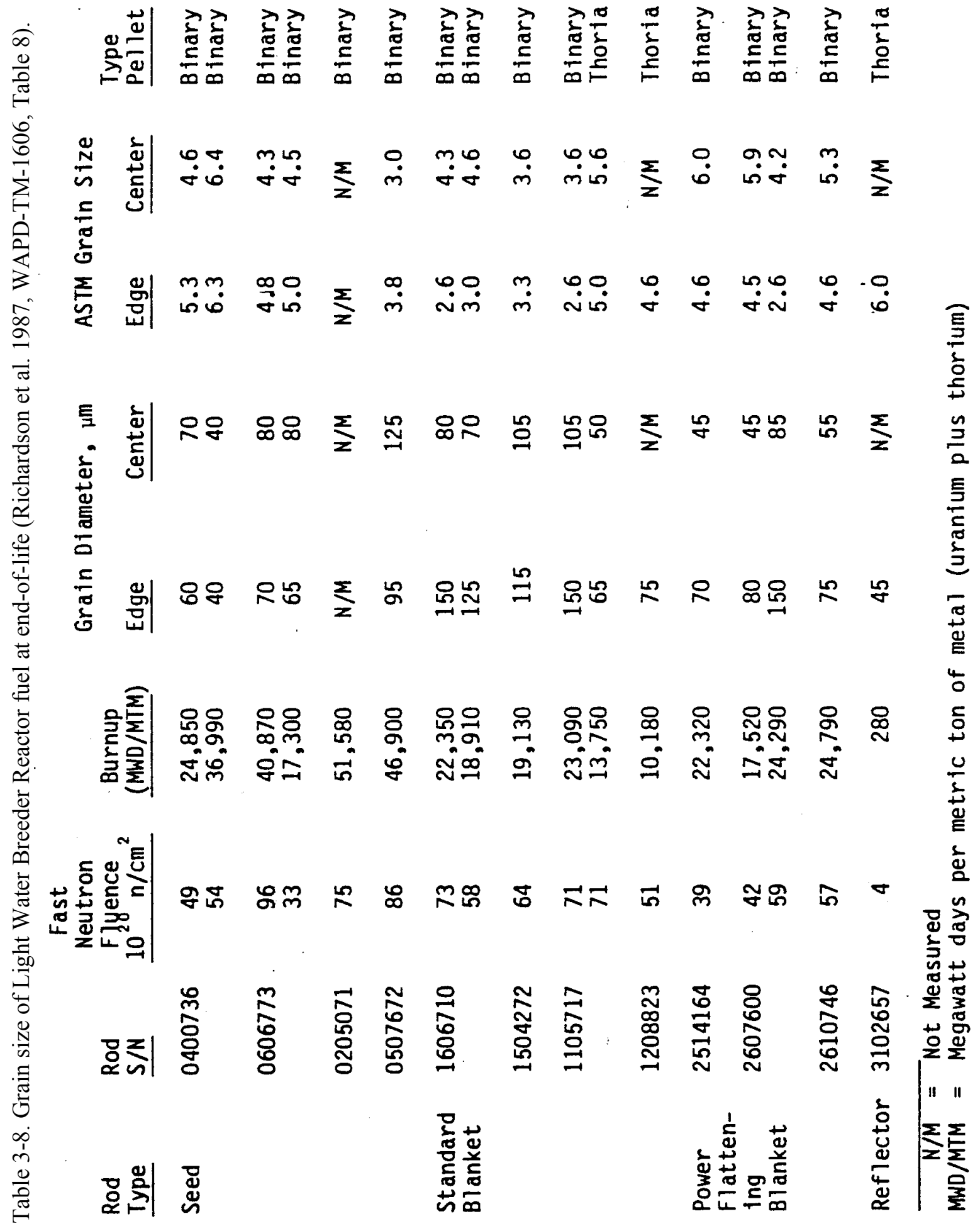




\subsubsection{Rods}

Fuel rods were fabricated with many features that had never been used in fuel elements of commercial reactors. Uranium-233 was selected for the fissile fuel, because it has the largest neutron regeneration factor $(\eta=2.3)$ in the thermal and epithermal region of any of the potential fissile fuels (Pu-239, Pu-241, U-235, and U-233) (see Section 3). In addition, U-233 has a much lower total fission gas release at typical operating heat flux conditions. Assuming iodine release is proportional to total fission gas release, less iodine is released using U-233 in thoria, resulting in less iodine stress corrosion cracking in the cladding (Campbell and Giovengo 1987, WAPD-TM-1387, p. 27).

There were 23 different rod types in the LWBR core, namely 8 seed rod types, 6 standard blanket rod types, 7 power-flattening blanket rod types, and 2 reflector rod types (DeGeorge and Goldberg 1986, WAPD-TM-1278, p. II-1). Each fuel rod was composed of a Zircaloy-4 seamless tube filled with fuel pellets. The fuel rods in each region of the core were of a different diameter, physical length, binary stack length (length of the rod occupied by binary pellets), and initial uranium loadings. Radial and axial variations of fuel loading were employed in every region of the core except the reflector modules. Rod lengths ranged from about 110 to 118 in., and diameters ranged from 0.3 to $0.8 \mathrm{in}$. (Table 3-9). Irradiation of the rods caused the rod diameters to shrink. Shrinkage measured in a sample of rod types were: (Gorscak, Campbell, and Clayton 1987, WAPD-TM-1605, Table 15)

$\begin{array}{ll}\text { Seed } & 1.2 \text { to } 2.5 \text { mils }(0.03 \text { to } 0.06 \mathrm{~mm}) \\ \text { Standard blanket } & 2.9 \text { to } 3.8 \text { mils }(0.07 \text { to } 0.10 \mathrm{~mm}) \\ \text { Power-flattening blanket } & 2.4 \text { to } 2.8 \text { mils }(0.06 \text { to } 0.07 \mathrm{~mm}) \\ \text { Reflector } & 2.9 \text { to } 5.5 \text { mils }(0.07 \text { to } 0.14 \mathrm{~mm})\end{array}$

A plenum region at the top of each rod provided void volume to accommodate released fission gas, and a helical coiled spring to exert pressure on the pellets to keep the stack together.

Tops and bottoms of the seed and blanket rods were packed with at least $10 \mathrm{in}$. of thoria pellets (see Figures 3-5 and 3-8) for the purpose of reducing axial neutron leakage from the core. Rods with shorter stack lengths had more thoria pellets. The overall pellet stack length in each rod, including the thoria pellets, was about 104 in. Beginning and end-of-life fissile loading is addressed in Section 5 and listed by rod type in Table 5-1.

Rods varied slightly in length, depending on their location and loading within the core. Seed rods were about 117 in., and blanket rods were about 118 in. Shim pellets of thoria fuel were used near the top and bottom of the fuel stack to make up the desired fuel stack length. A spring-bearing fuel pellet with only one dished end was used at the top of the fuel stack.

3.2.2.1 Seed Region. LWBR seed modules had eight types of seed fuel rods designated as 01,02 , 03, 04, 05, 06, 07, and 08 (Figure 3-6). Rod types with odd designations were fixed to a baseplate at the bottom of the seed module, and rod types with even designations were fixed to a baseplate at the top end of the module. Nominal rod dimensions are shown for the eight types of seed rods in Figure 3-11. Seed rods weighed about $2 \mathrm{lb}$ each (Gorscak, Campbell, and Clayton 1987, WAPD-TM-1605, p. 37) and had a 10 in. plenum at the top of the fuel stack to accommodate fission gas release. The plenum included an Inconel compression spring at the top of the stack to minimize formation of axial gaps in the stack during handling, normal reactor operation, and shock loading (e.g., from scrams, check value slams, earthquakes) (Gorscak, Campbell, and Clayton 1987, WAPD-TM-1605, p. 8-13). 


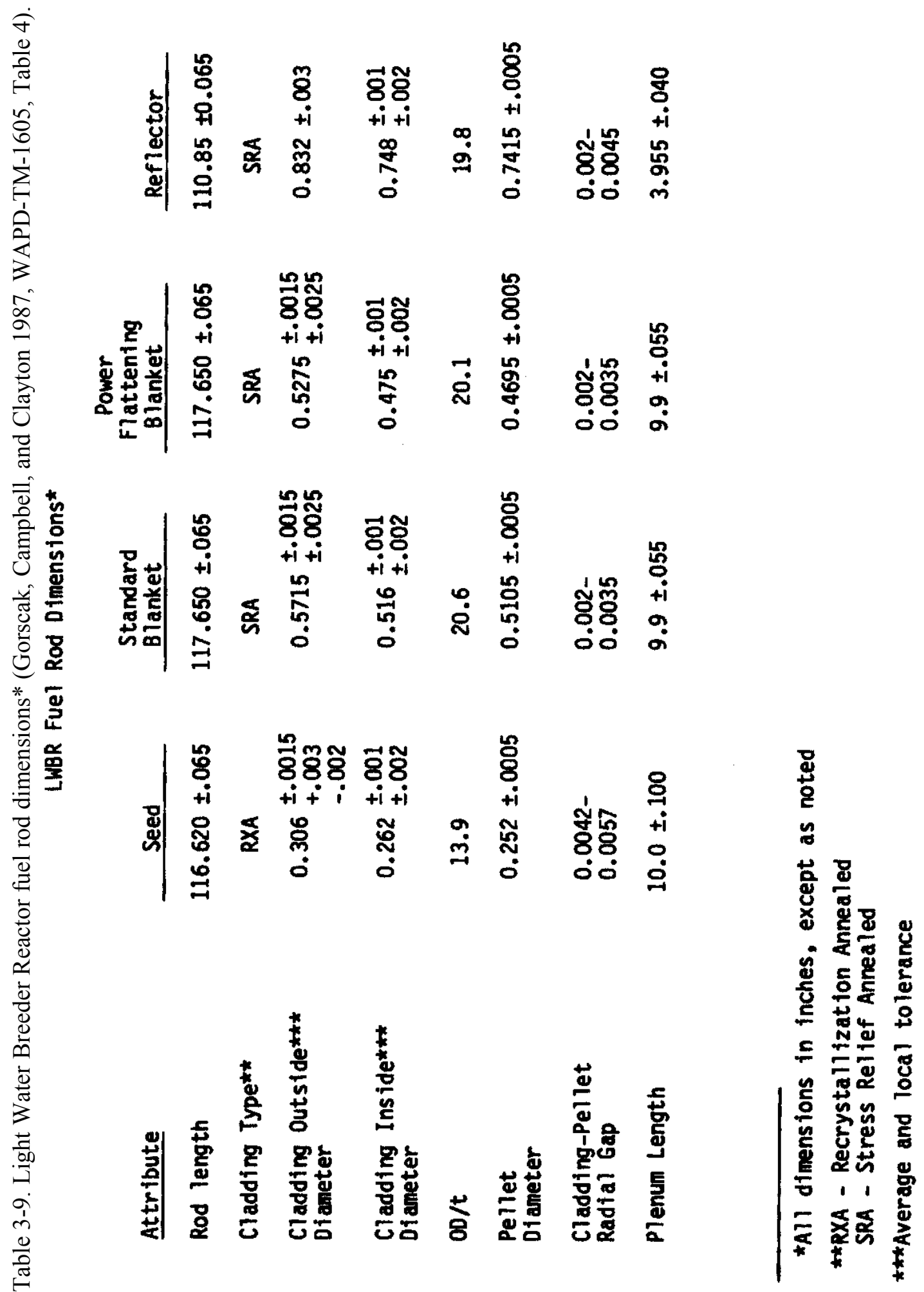




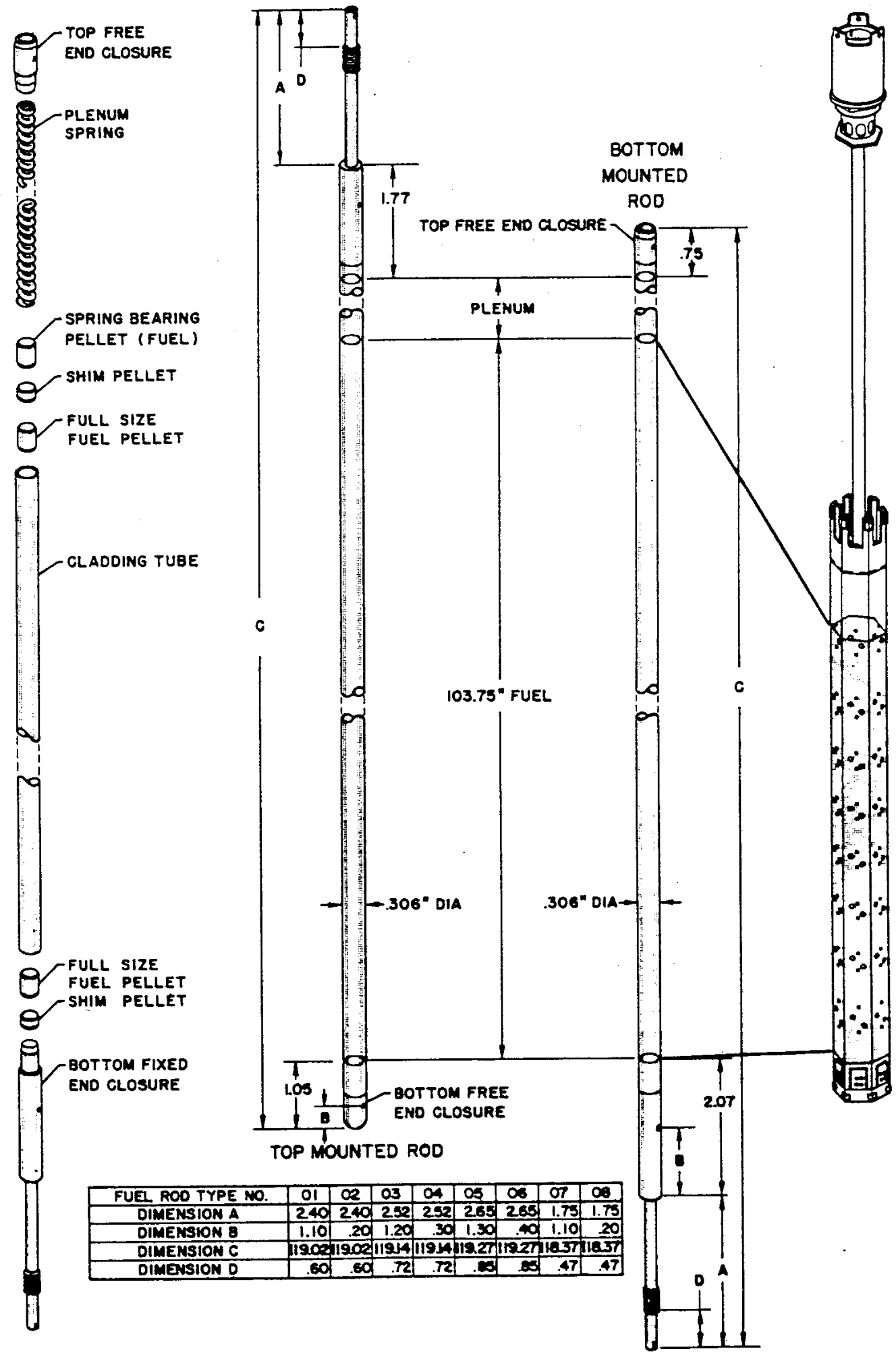

Figure 3-11. Light Water Breeder Reactor seed fuel rods (Gorscak, Campbell, and Clayton 1987, WAPD-TM-1605, Figure 3). 
The seed fuel rods had four different stack lengths (42, 56, 70, or 84 inches, Figure 3-6). Figure 3-11 shows a seed fuel rod and identifies the varying dimensions of the eight different types of seed rods (identified as $01-08$ in the imbedded table). The rod type identifiers correspond with the identifiers provided in Figure 3-6 and Table 5-1.

Seed pellets were right circular cylinders with chamfers on both ends to ease loading into tubing, facilitate movement of the pellet stack in the tubing during power operation, and reduce pellet chipping during fabrication, rod handling, and power operation. The seed pellets had dished ends to reduce axial expansion of the stack (Walter and Weinreich 1976, WAPD-TM-1244(L)).

Binary pellets used in the seed rods were 0.252 in. in diameter and either 0.445 or 0.615 in. long. The shorter pellets had enrichments of about $4.3 \mathrm{wt} \%$ U-fissile (Table $3-4)$. The longer (0.615 in.) pellets had identical diameters, but enrichments of $5.2 \mathrm{wt} \%$ U-fissile (Table 3-4). The pellets were sintered to 97 or $98 \%$ of their theoretical density of about $10 \mathrm{~g} / \mathrm{cm}^{3}$ to maximize pellet dimensional stability (Hecker 1979, WAPD-TM-1326). Dimensions for seed fuel pellets are presented in Tables 3-4 and 3-5.

3.2.2.2 Standard Blanket Region. The standard blanket region of the core included all of the Type I blankets and the interior portions of the Type II and Type III blankets (see Figure 2-3). Three types of binary pellets and various stack lengths were used in the standard blankets. The binary pellets used contained $1.211,1.662$, or $2.000 \mathrm{wt} \%$ urania. There were four binary stack lengths and three zones in the Standard Blanket Region of the core (see Figures 3-5 and 3-7).

There were three types of binary pellets manufactured for the standard blanket rods (see Tables 3-4 and 3-5). The binary pellets were right circular cylinders with tapers on both ends to minimize ridging of cladding due to pellet hourglassing and had dished ends to reduce fuel stack axial expansion (Campbell and Giovengo 1987, WAPD-TM-1387).

Figure 3-12 shows LWBR standard and power-flattening blanket fuel rods. There were six types of standard blanket fuel rods designated as $11,12,13,14,15$, and 16 (corresponding to identifiers in Figure 3-7 and Figure 3-12). Rod types with odd designations were fixed to the bottom of the modules. Rod types with even designations were fixed to the top of the module (Gorscak, Campbell, and Clayton 1987, WAPD-TM-1605, p. 13). Loading and binary stack lengths for standard blanket fuel rods are presented in Figure 3-7. Standard blanket rods weighed about $8 \mathrm{lb}$ each, (Gorscak, Campbell, and Clayton 1987, WAPD-TM-1605, p. 37).

3.2.2.3 Power-flattening Blanket Region. The power-flattening blanket region of the core was located inside the reflector region and consisted of Type II and Type III blanket modules. Two of the six sides of the Type II modules were power-flattening sides; three of the six sides of the Type III modules were power-flattening sides. The power-flattening regions were created using three types of pellets $(1.649,2.005$, and $2.773 \mathrm{wt} \%)$ with three zones and four binary stack lengths (see Figures 3-8 and 3-10). Average as-built characteristics for the pellets used in the power-flattening rods are presented in Table 3-4.

There were seven types of power-flattening blanket fuel rods, designated as 21, 22, 23, 24, 25, 26, and 27 (corresponding to identifiers in Figures 3-9 and 3-10). Figure 3-12 shows a power-flattening blanket rod. Each power-flattening rod weighed about $7 \mathrm{lb}$ (Gorscak, Campbell, and Clayton 1987, WAPD-TM-1605, p. 37).

3.2.2.4 Reflector. The reflector modules contained rods with only thoria pellets. Rod configurations for Type IV and V reflectors are shown in Figures 3-2 and 3-3. 


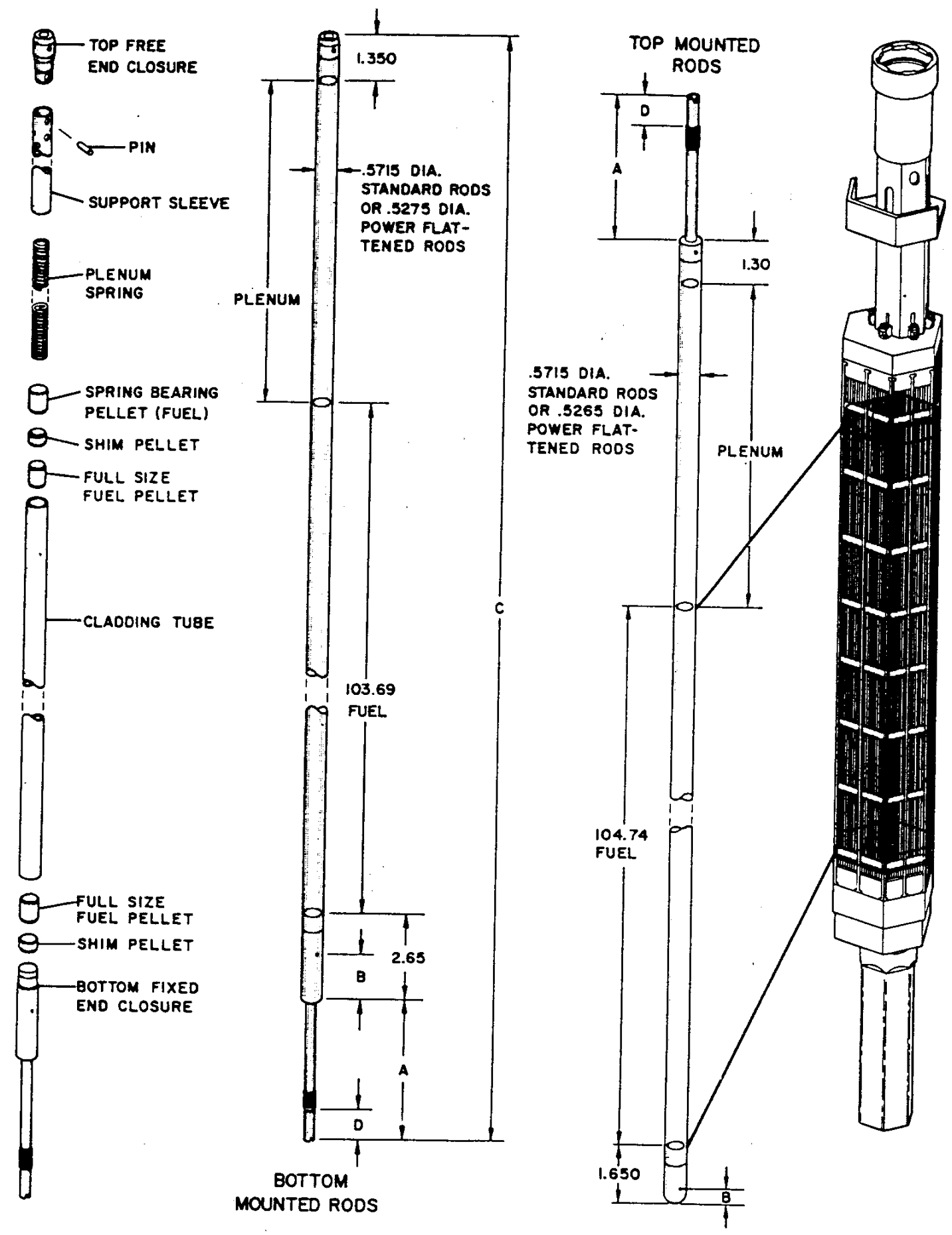

\begin{tabular}{|c|c|c|c|c|c|c|c|c|c|c|c|c|c|}
\hline FUE ROD TYPE NO & II & 12 & 13 & 14 & 15 & 16 & 21 & 22 & 23 & 24 & 25 & 26 & 27 \\
\hline DIMENSION-A & 4.23 & 4.23 & 4.35 & 435 & 447 & 4.47 & 4.23 & 4.23 & 4.35 & 4.35 & 4.47 & 4.47 & 4.60 \\
\hline DIMENSION-8 & 1.40 & .30 & 1.50 & .60 & 1.60 & .70 & 1.70 & .80 & 1.80 & .90 & 1.90 & 1.00 & 2.00 \\
\hline DIMENSION - Cะ.07 & 121.9 & 121.9 & 1220 & 1220 & 122.1 & 122.1 & 121.9 & 121.9 & 122.0 & 122.0 & 122.1 & 122.1 & 122.3 \\
\hline DIMENSION - D & 78 & .78 & .90 & .90 & 1.03 & 1.03 & .78 & .78 & .90 & .90 & 1.03 & 1.03 & 1.16 \\
\hline
\end{tabular}

Figure 3-12. Light Water Breeder Reactor blanket fuel rods (Gorscak, Campbell, and Clayton 1987, WAPD-TM-1605, Figure 4). Standard and power-flattening rods are depicted here. Standard rods have a rod type number $<20$. 
Figure 3-13 shows a reflector rod. Reflector rods had only two rod types: 31 and 32. Rod Type 31 was attached to the bottom of the module, and rod Type 32 was attached to the top of the fuel module. Both types contained only thoria pellets.

Reflector fuel rods had a 4-in. plenum with an Inconel support sleeve. The axial gap between the support sleeve and the top of its pellet stack was nominally 0.23 in. Each reflector rod had an Inconel compression spring at the top of the fuel stack to minimize the formation of in-stack pellet-to-pellet gaps. Each top-mounted reflector fuel rod had a hemispherical free end. Each bottom-mounted fuel rod had a square free end. The rods were backfilled with helium at $1 \mathrm{~atm}$ pressure during welding. Dimensions for reflector fuel rods are summarized in Figure 3-13 and Table 3-9. Reflector rods weighed about $16 \mathrm{lb}$ each (Gorscak, Campbell, and Clayton 1987, WAPD-TM-1605, p. 37).

Pellets were right circular cylinders with square edges and had dished ends to minimize axial expansion of the fuel stack (Campbell and Giovengo 1987, WAPD-TM-1387, p. 25, Figure 9). Dimensions of reflector pellets are presented in Tables 3-4 and 3-5.

\subsubsection{Beginning-of-Life Fissile Loading}

Average as-built LWBR fissile loading by module type is presented in Table 3-10. Thorium and uranium loadings for the seed modules and for the standard and power-flattening portions of the blanket modules are presented in Table 3-11. There was no fissile uranium (i.e., no binary fuel) in the reflectors at beginning of life.

\subsection{Cladding}

\subsubsection{General Description of Cladding Types}

All rods were clad with Zircaloy-4 tubing (Gorscak, Campbell, and Clayton 1987, WAPD-TM-1605, pp. 10 and 17). Data for the cladding are summarized in Tables 3-5 and 3-12. Dimensions and characteristics data for tubing are provided in Table 3-13.

Seed rod cladding: The seed cladding was freestanding (i.e., the cladding would not collapse onto the fuel pellets). Seed fuel rod cladding was recrystallization annealed Zircaloy-4 (Gorscak, Campbell, and Clayton 1987, WAPD-TM-1605, pp. 8 and 13).

Blanket fuel cladding: For LWBR operating pressure and temperatures, cladding for both standard and power-flattening fuel rods was nonfreestanding (i.e., the cladding would collapse onto the fuel pellets after exposure in the core). Blanket fuel rod cladding was highly cold worked and stress relief annealed Zircaloy-4 (Gorscak, Campbell, and Clayton 1987, WAPD-TM-1605).

Reflector fuel rod cladding: Reflector cladding was highly cold worked and stress relief annealed Zircaloy-4. Cladding was nonfreestanding for LWBR operating pressure and temperature (Gorscak, Campbell, and Clayton 1987, WAPD-TM-1605, p. 17).

\subsubsection{Form}

To improve neutron economy, blanket and reflector fuel rods were designed with nonfreestanding, thin-walled Zircaloy-4 tubing, highly cold worked and stress relief annealed. The seed fuel rods, because of their higher duty demands, were fabricated with freestanding recrystallization annealed Zircaloy-4 cladding. All cladding was fabricated from selected Zircaloy-4 ingots with less than $50 \mathrm{ppm}$ hafnium content, which is lower than normal, to reduce parasitic absorption of neutrons (Campbell and Giovengo 1987, WAPD-TM-1387, p. 10). 


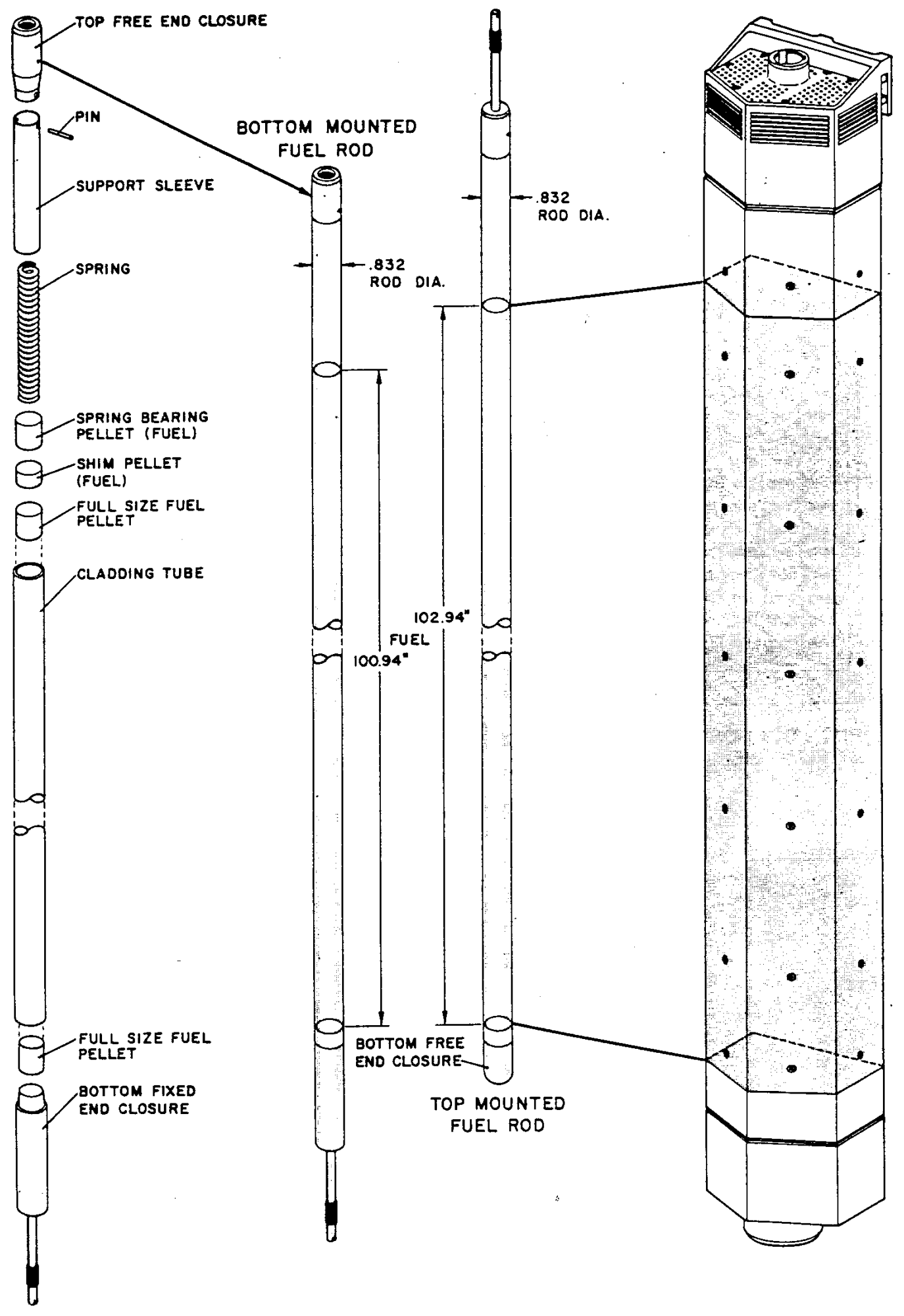

Figure 3-13. Light Water Breeder Reactor reflector fuel rods (Gorscak, Campbell, and Clayton 1987, WAPD-TM-1605, Figure 5). 
Table 3-10. Average as-built Light Water Breeder Reactor loading by module type (Hecker 1979, WAPD-TM-1326, Table II-3).

Module Regions

Seedt

Standard blanket

Power flattening blanket

Total blanket

Module total

\begin{tabular}{|c|c|c|}
\hline $\begin{array}{l}\text { Type I } \\
\text { Module } \\
\end{array}$ & $\begin{array}{l}\text { Type II } \\
\text { Module }\end{array}$ & $\begin{array}{l}\text { Type III } \\
\text { Module }\end{array}$ \\
\hline 16.53 & 16.55 & 16.56 \\
\hline 16.18 & 9.34 & 6.63 \\
\hline None & $15.66 *$ & $23.22^{*}$ \\
\hline 16.18 & $25.00 *$ & $29.85 *$ \\
\hline 32.71 & $41.55 *$ & $46.41 *$ \\
\hline
\end{tabular}

*Two Type II and two Type III modules have $0.06 \mathrm{~kg}$ less loading due to flux well locations.

tA I2-seed average of $16.55 \mathrm{~kg}$ was used for all seeds in the calculations. 
Table 3-11. Seed and blanket module initial thorium and uranium loadings (NOTE: Type II and III blanket modules consist of both a standard and power-flattening portion) (Schick et al. 1987, WAPD-TM-1612, Table III-1).

\begin{tabular}{|c|c|c|c|c|c|c|c|c|c|}
\hline Module & Rods & $\begin{array}{c}\text { Thorium } \\
\text { kgs }\end{array}$ & $\begin{array}{l}{ }^{232} \mathrm{U} \\
\text { Grams }\end{array}$ & $\begin{array}{l}{ }^{233} \mathrm{U} \\
\text { Grams }\end{array}$ & $\begin{array}{l}234 \mathrm{U} \\
\text { Gràms }\end{array}$ & $\begin{array}{l}235 \mathrm{U} \\
\text { Grams }\end{array}$ & $\begin{array}{l}236 \mathrm{U} \\
\text { Grams }\end{array}$ & $\begin{array}{l}{ }^{238} \mathrm{U} \\
\text { Grams }\end{array}$ & $\begin{array}{c}U_{\text {fissile }} \\
\text { Grams }\end{array}$ \\
\hline 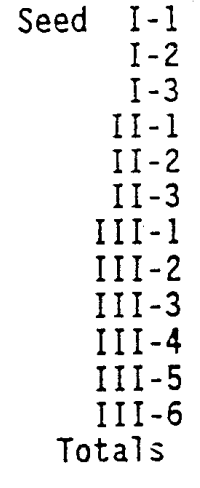 & $\begin{array}{l}619 \\
619 \\
619 \\
619 \\
619 \\
619 \\
619 \\
619 \\
619 \\
619 \\
619 \\
619 \\
7428\end{array}$ & $\begin{array}{r}433.61 \\
433.60 \\
433.91 \\
433.88 \\
433.66 \\
434.09 \\
433.57 \\
433.87 \\
434.07 \\
434.08 \\
434.11 \\
434.04 \\
5206.55\end{array}$ & $\begin{array}{l}0.12 \\
0.11 \\
0.10 \\
0.10 \\
0.10 \\
0.10 \\
0.11 \\
0.11 \\
0.11 \\
0.11 \\
0.10 \\
0.11 \\
1.34\end{array}$ & $\begin{array}{r}16505.1 \\
16506.9 \\
16522.9 \\
16529.4 \\
16528.4 \\
16568.7 \\
16505.3 \\
16545.4 \\
16557.8 \\
16552.1 \\
16562.0 \\
16557.2 \\
198441.2\end{array}$ & $\begin{array}{r}215.12 \\
218.02 \\
215.80 \\
215.21 \\
216.03 \\
215.20 \\
214.12 \\
214.16 \\
214.11 \\
214.04 \\
213.93 \\
214.96 \\
2580.75\end{array}$ & $\begin{array}{r}13.04 \\
14.95 \\
12.21 \\
11.79 \\
12.46 \\
11.49 \\
12.25 \\
11.01 \\
10.90 \\
10.85 \\
10.69 \\
11.40 \\
143.10\end{array}$ & $\begin{array}{r}2.68 \\
3.21 \\
2.70 \\
2.57 \\
2.74 \\
2.49 \\
2.47 \\
2.33 \\
2.32 \\
2.28 \\
2.24 \\
2.45 \\
30.53\end{array}$ & $\begin{array}{r}48.92 \\
48.66 \\
48.83 \\
48.55 \\
47.85 \\
45.85 \\
49.03 \\
47.44 \\
47.46 \\
47.34 \\
46.69 \\
47.39 \\
574.04\end{array}$ & $\begin{array}{l}16518.1 \\
16521.8 \\
16535.1 \\
16541.2 \\
16540.8 \\
16580.2 \\
16517.5 \\
16556.5 \\
16568.7 \\
16563.0 \\
16572.7 \\
16568.6 \\
198584.3\end{array}$ \\
\hline 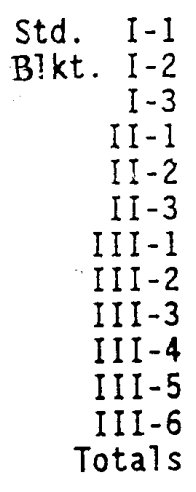 & $\begin{array}{l}443 \\
443 \\
443 \\
261 \\
261 \\
261 \\
187 \\
187 \\
187 \\
187 \\
187 \\
187 \\
3234\end{array}$ & $\begin{array}{r}1299.45 \\
1299.37 \\
1299.30 \\
765.65 \\
765.91 \\
765.71 \\
548.50 \\
548.69 \\
548.62 \\
548.69 \\
548.72 \\
548.46 \\
9487.14\end{array}$ & $\begin{array}{l}0.13 \\
0.13 \\
0.13 \\
0.07 \\
0.07 \\
0.07 \\
0.05 \\
0.05 \\
0.05 \\
0.05 \\
0.05 \\
0.05 \\
0.97\end{array}$ & $\begin{array}{r}16166.5 \\
16163.9 \\
16161.5 \\
9325.4 \\
9324.0 \\
9329.1 \\
6619.9 \\
6623.3 \\
6618.4 \\
6623.6 \\
6626.4 \\
6619.7 \\
116201.6\end{array}$ & $\begin{array}{r}220.01 \\
218.54 \\
217.06 \\
125.49 \\
126.84 \\
126.12 \\
90.10 \\
90.39 \\
90.50 \\
90.19 \\
90.26 \\
91.26 \\
1576.82\end{array}$ & $\begin{array}{r}15.69 \\
14.85 \\
13.97 \\
8.26 \\
9.05 \\
8.55 \\
6.42 \\
6.59 \\
6.67 \\
6.47 \\
6.49 \\
7.09 \\
110.17\end{array}$ & $\begin{array}{l}4.41 \\
4.07 \\
3.73 \\
2.22 \\
2.53 \\
2.35 \\
1.81 \\
1.86 \\
1.90 \\
1.82 \\
1.83 \\
2.06 \\
30.63\end{array}$ & $\begin{array}{l}42.11 \\
42.19 \\
42.24 \\
24.56 \\
24.39 \\
24.31 \\
17.20 \\
17.25 \\
17.18 \\
17.32 \\
17.28 \\
17.17 \\
303.26\end{array}$ & $\begin{array}{r}16182.2 \\
16178.7 \\
16175.4 \\
9333.6 \\
9333.0 \\
9337.6 \\
6626.4 \\
6629.9 \\
6625.1 \\
6630.1 \\
6632.9 \\
6626.7 \\
116311.7\end{array}$ \\
\hline $\begin{array}{r}\text { Pwr. II -1 } \\
\text { Flat. II -2 } \\
\text { BIkt. II -3 } \\
\text { III -1 } \\
\text { III -2 } \\
\text { IIII-3 } \\
\text { IIII-4 } \\
\text { III -5 } \\
\text { III-6 } \\
\text { Totals }\end{array}$ & $\begin{array}{r}302 \\
303 \\
302 \\
445 \\
445 \\
446 \\
446 \\
446 \\
446 \\
3581\end{array}$ & $\begin{array}{r}741.39 \\
743.51 \\
741.36 \\
1092.25 \\
1092.02 \\
1094.47 \\
1094.36 \\
1094.55 \\
1094.30 \\
8788.26\end{array}$ & $\begin{array}{l}0.11 \\
0.11 \\
0.11 \\
0.17 \\
0.17 \\
0.17 \\
0.17 \\
0.17 \\
0.17 \\
1.39\end{array}$ & $\begin{array}{r}15590.0 \\
15644.8 \\
15588.4 \\
23155.6 \\
23131.0 \\
23212.3 \\
23197.7 \\
23201.8 \\
23210.8 \\
185932.6\end{array}$ & $\begin{array}{r}202.42 \\
198.72 \\
192.90 \\
291.57 \\
305.97 \\
289.36 \\
310.19 \\
303.67 \\
295.43 \\
2390.28\end{array}$ & $\begin{array}{r}16.22 \\
14.85 \\
13.25 \\
21.14 \\
26.29 \\
20.53 \\
27.32 \\
25.16 \\
22.61 \\
187.41\end{array}$ & $\begin{array}{r}4.72 \\
3.92 \\
3.44 \\
5.68 \\
7.57 \\
5.33 \\
7.93 \\
7.16 \\
6.00 \\
51.80\end{array}$ & $\begin{array}{r}77.94 \\
90.47 \\
95.46 \\
132.64 \\
117.14 \\
141.33 \\
112.01 \\
120.02 \\
136.16 \\
1023.23\end{array}$ & $\begin{array}{r}15606.3 \\
15659.7 \\
15601.7 \\
23176.7 \\
23157.3 \\
23232.9 \\
23225.1 \\
23227.0 \\
23233.4 \\
186120.1\end{array}$ \\
\hline$t$ & & & & & & 440.69 & 112.9 & 1900.5 & 501016.1 \\
\hline
\end{tabular}


Table 3-12. Light Water Breeder Reactor fuel rod cladding material properties (Gorscak, Campbell, and Clayton 1987, WAPD-TM-1605, Table 3).

\begin{tabular}{|c|c|c|c|c|}
\hline Attribute & Seed & $\begin{array}{l}\text { Standard } \\
\text { Blanket }\end{array}$ & $\begin{array}{l}\text { Power } \\
\text { Flattening } \\
\text { Blanket } \\
\end{array}$ & Reflector \\
\hline $\begin{array}{l}\text { Final Heat Treatment } \\
\text { Temperature, degrees } F\end{array}$ & $1225 \pm 25$ & $925 \pm 25$ & $925 \pm 25$ & $925 \pm 25$ \\
\hline $\begin{array}{l}\text { Final Heat } \\
\text { Treatment Time (hrs) }\end{array}$ & $2-5$ & $2-5$ & $2-5$ & $2-5$ \\
\hline $\begin{array}{l}70 \mathrm{~F} \text { Yield } \\
\text { Strength (ksi)* }\end{array}$ & $\begin{array}{l}54.66 \\
49.74\end{array}$ & $\begin{array}{l}79.77 \\
73.55\end{array}$ & $\begin{array}{l}80.71 \\
76.13\end{array}$ & $\begin{array}{l}77.79 \\
72.36\end{array}$ \\
\hline $\begin{array}{l}700 \mathrm{~F} \text { Yield } \\
\text { Strength }(\mathrm{ksi})^{\star}\end{array}$ & $\begin{array}{l}18.57 \\
17.37\end{array}$ & $\begin{array}{l}51.14 \\
47.89\end{array}$ & $\begin{array}{l}53.13 \\
50.67\end{array}$ & $\begin{array}{l}49.49 \\
46.56\end{array}$ \\
\hline $\begin{array}{l}70 \mathrm{~F} \text { Yield/Uit. } \\
\text { Ratio* }\end{array}$ & $\begin{array}{l}1.472 \\
1.405\end{array}$ & $\begin{array}{l}1.363 \\
1.310\end{array}$ & $\begin{array}{l}1.359 \\
1.330\end{array}$ & $\begin{array}{l}1.367 \\
1.330\end{array}$ \\
\hline $\begin{array}{l}700 \mathrm{~F} \text { Yield/U1t. } \\
\text { Ratio* }\end{array}$ & $\begin{array}{l}1.951 \\
1.872\end{array}$ & $\begin{array}{l}1.259 \\
1.212\end{array}$ & $\begin{array}{l}1.254 \\
1.226\end{array}$ & $\begin{array}{l}1.288 \\
1.261\end{array}$ \\
\hline $\begin{array}{l}70 \mathrm{~F} \\
\text { Elongation }(\%) \star\end{array}$ & $\begin{array}{l}29.2 \\
27.04\end{array}$ & $\begin{array}{l}21.87 \\
20.41\end{array}$ & $\begin{array}{l}19.63 \\
18.49\end{array}$ & $\begin{array}{l}23.57 \\
22.16\end{array}$ \\
\hline $\begin{array}{l}700 \mathrm{~F} \\
\text { Elongation }(\%) *\end{array}$ & $\begin{array}{l}35.75 \\
32.19\end{array}$ & $\begin{array}{l}20.61 \\
18.83\end{array}$ & $\begin{array}{l}18.17 \\
16.90\end{array}$ & $\begin{array}{l}21.87 \\
20.33\end{array}$ \\
\hline
\end{tabular}

*Average and lower $95 / 95$ tolerance interval 
Table 3-13. As-built requirements for Light Water Breeder Reactor tubing (Eyler 1981, WAPD-TM-1289, Table A-2).

A. Nondestructive Inspections

1. Inside Diameter

a. Local

$\begin{array}{lll}\text { Type } & \text { Nominal* } & \text { Tolerance } \\ \text { Seed } & 0.262 & \\ \text { PFB } & 0.475 & \pm 0.0015 \\ \text { Std. B. } & 0.516 & \pm 0.0020 \\ \text { Refi. } & 0.748 & \pm 0.0020 \\ & & \pm 0.0025 \\ \text { (A11) } & \text { Nominal } & \pm 0.0010\end{array}$

2. Outside Diameter-Local

$\begin{array}{lll}\text { Type } & \text { Nominal* } & \text { Tolerance* } \\ \text { Seed } & 0.3105 & \\ \text { PFB } & 0.5310 & \pm 0.0020 \\ \text { Std. B. } & 0.5760 & \pm 0.0020 \\ \text { Refi. } & 0.8350 & \pm 0.0020 \\ & & \pm 0.0025\end{array}$

3. Wall Thickness

$\begin{array}{lll}\text { Type } & \text { Nominal* } & \text { Minimum* } \\ \text { Seed } & 0.0243 & 0.0225 \\ \text { PFB } & 0.0280 & 0.0260 \\ \text { Std.B. } & 0.0300 & 0.0280 \\ \text { Refi. } & 0.0435 & 0.0413\end{array}$

4. Wall Eccentricity-Maximum*

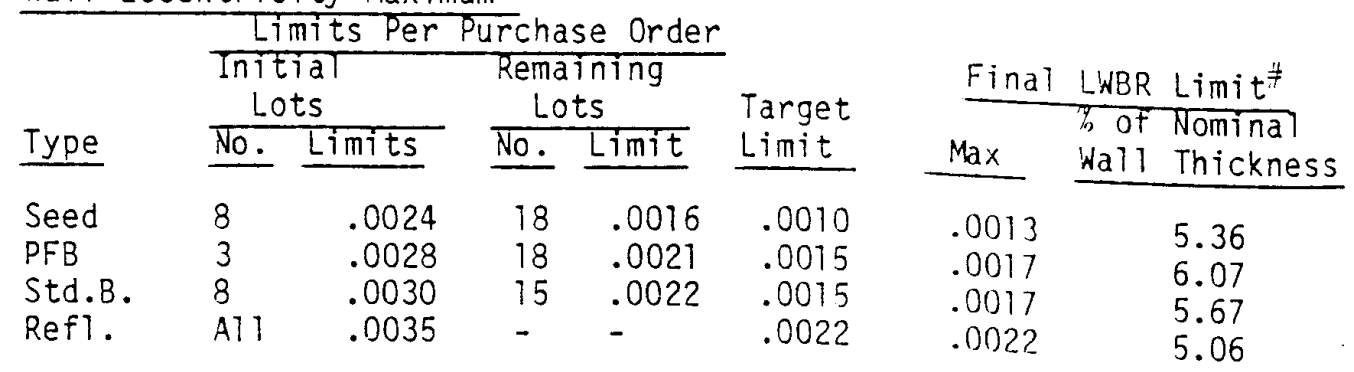

*Al dimensions are stated in inches.

\# Limits achieved by additional inspection and/or sorting performed at Bettis. 
Table 3-13. (continued).

5. Wavelength of Helical Wall Eccentricity

$\begin{array}{lc}\text { Type } & \text { Minimum } \\ \text { Seed } & 80 \\ \text { PFB } & \\ \text { Std. B. } & 70 \\ \text { Ref7. } & \end{array}$

6. Length

\begin{tabular}{lll} 
Type & Nominal* & Tolerance* \\
\cline { 2 - 3 } Seed & 119 & $+0.5,-0.0$ \\
PFB & 117 & $+0.5,-0.0$ \\
Std.B. & 117 & $+0.5,-0.0$ \\
Refl. & 110.5 & $+0.5,-0.0$ \\
At Bettis & Fuel Rod Nominal & \pm 0.015
\end{tabular}

7. Perpendicularity of End Face (at Bettis only)

A11 The deviation from perpendicularity to the OD surface of the end two inches shatl be 1 imited to $0.006 \mathrm{in} / \mathrm{in}$.

8. Edge Squareness (at Bettis only)

A11 The maximum deviation from square edges as chamfer or rounding of the $I D$ or $O D$ edge of the end face shall not reduce the local wall thickness at the end face by more than 0.003 inch.

9. Straightness

A11 0.010 inch maximum deflection (bow) of the tube from the center of a 15 inch chord (gage length).

A11 dimensions are stated in inches.

Limits achieved by additional inspection and/or sorting performed at

Bettis. 
Table 3-13. (continued).

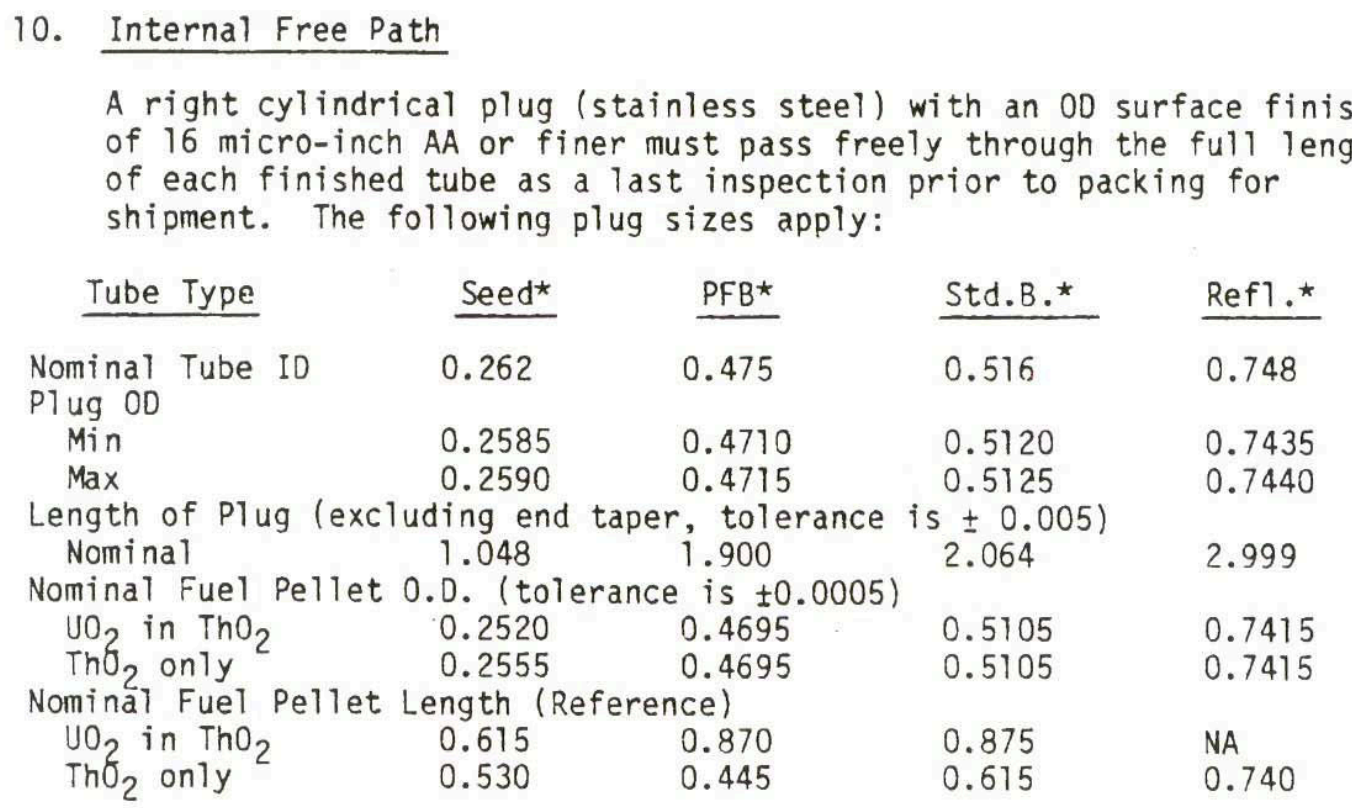

11. Visual Surface Inspection

The tubing $O D$ and ID surfaces must be free of unacceptable surface conditions as determined by visual inspection. These unacceptable conditions include, but are not limited to, scratches, abrasions, nicks, dents, pits, holes, foreign material, and material defects (cracks, laps, seams, lamination, etc.).

12. Surface Finish

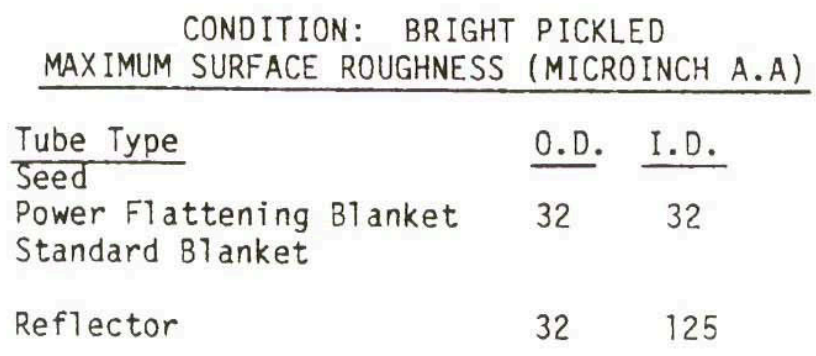

*AT dimensions are stated in inches. 
Table 3-13. (continued).

\section{Material Quality}

The tubing must be free of material and fabrication defects which exhibit a stronger response to the ultrasonic search beam than $80 \%$ of the response exhibited by the standard notches contained in the test calibration tube. The dimensions of the standard notch are shown below. Test sensitivity notches, half the depth of the standard notches must be reproducibly detected. All dimensions are in inches.

\begin{tabular}{|c|c|c|c|c|}
\hline \multirow[b]{2}{*}{ Tube Type } & \multirow[b]{2}{*}{ Nom. Wa11 } & \multicolumn{3}{|c|}{ Standard Defect Notch (Max) } \\
\hline & & Depth & Length & Width \\
\hline $\begin{array}{l}\text { Seed } \\
\text { PF Blanket } \\
\text { Standard Blanket } \\
\text { Reflector }\end{array}$ & $\begin{array}{l}0.0242 \\
0.0280 \\
0.0300 \\
0.0435\end{array}$ & $\begin{array}{l}0.0020 \\
0.0021 \\
0.0022 \\
0.0032\end{array}$ & $\begin{array}{l}0.0200 \\
0.0210 \\
0.0225 \\
0.0326\end{array}$ & $\begin{array}{l}0.003 \\
0.003 \\
0.003 \\
0.003\end{array}$ \\
\hline
\end{tabular}

B. Destructive Testing

1. Chemistry

Compliance with the requirement for ingot composition (Table A-1) satisfies the basic chemistry requirements of the finished tubing. Samples from each lot of finished tubing must meet the limits noted for the five elements 1 isted below.

El ements

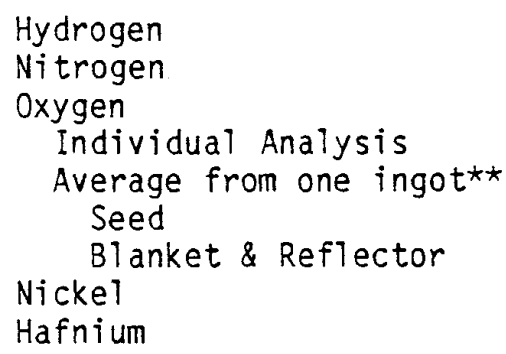

ppm Max. ppm Min.

$\begin{array}{rr}25 & 0 \\ 80 & 0 \\ 1800 & 900 \\ 1700 & 900 \\ 1600 & 900 \\ 70 & 0 \\ 45 & 0\end{array}$

2. Surface Chemistry

Fluorine on ID surface in micrograms per square decimeter

Target 30 to 40

Alert 65

**Average of all finish tubing analyses from one ingot. 
Table 3-13. (continued).

3. Corrosion Resistance

Test Condition

a. 14 days in $750^{\circ} \mathrm{F}$
steam at $1500 \mathrm{psig}$
b. 14 days in $680^{\circ} \mathrm{F}$
water at 2705 psig
Max. Weight Gain

$38 \mathrm{mg} / \mathrm{dm}^{2}$

$28 \mathrm{mg} / \mathrm{dm}^{2}$ (preproduction only)

The corrosion tested tubing must exhibit a continuous lustrous, black, adherent, corrosion film consistent with established visual standards.

4. Longitudinal Uniaxial Tensile Properties

Tube Type

(U/Y Ratjo)

$0.2 \%$ off set Yield Strength

$\%$ Total (psi) $\underline{(\operatorname{Min})^{(a)}}$ Min. Max. Elongation

a. Room Temperature

$\begin{array}{llll}\text { Seed } & 1.20 & 35,000 & -\end{array}$

PF Blanket

Standard Blanket $1.15 \quad 55,570 \quad-\quad 8.1$

Reflector

b. $700^{\circ} \mathrm{F}$
Seed
1.5
$15,500 \quad 30,000$
20.0

PF Blanket

Standard BTanket 1.15

$43,500 \quad 69,500$

8.1

Reflector

5. Circumferential Tensile Properties (Burst Test)

\begin{tabular}{lc} 
Tube Type & Minimum \% Ductility at $700^{\circ} \mathrm{F}(\mathrm{C})$ \\
\cline { 2 - 2 } Seed & 20 \\
PF Blanket & 5 \\
Standard BTanket & 5 \\
Reflector &
\end{tabular}

(a) Ratio of Utimate Tensile Strength to $0.2 \%$ Offset Yield Strength

(b) Minimum in 2 inch gage length

(c) Percent increase in circumference of metallic portion of the bulge measured from fracture edge to fracture edge around the maximum circumference of the ruptured specimen. 
Table 3-13. (continued).

6. Texture (Contractile Strain Ratio or CSR)

\begin{tabular}{lcc} 
Tube Type & Mi Limits & \\
\cline { 1 - 2 } $\begin{array}{l}\text { Seed } \\
\text { PF Blanket }\end{array}$ & Max. \\
$\begin{array}{l}\text { Std. Blanket } \\
\text { Reflector }\end{array}$ & 1.2 & 2.0 \\
& 1.2 & 2.3
\end{tabular}

7. Hydride Orientation

The orientation of the zirconium hydride platelets (needles) in the finished tubing must be such that no more than the specified percent of the classifiable hydride needles are aligned within $30^{\circ}$ of the radial direction (i.e., parallel to the tube radius).

Max. Individual Wal1 Segment

Reading O.D., Middle, or I.D. Max. Avg. of Three Segments Third of Wall Thickness For Each Sample

Seed $50 \%$

Blanket \& Reflector $30 \%$ $45 \%$ Not Applicable

8. Post-Anneal Cold Work

Seed (RXA) 3.0\% Maximum

Blanket \& Reflector (SRA) Not Applicable

9. Grain Size

Seed

Blanket \& Reflector

ASTM 9-12.5 (in the finished tubing) ASTM 8-12.0 (at completion of the alpha recrystallization anneal prior to the last reduction)

10. Metallographic Inspection for Equiaxed Grains

Seed (RXA) No distorted or non-equiaxed (nonrecrystallized) grains permitted.

Blanket \& Reflector (SRA) There must be no evidence of recrystallization; i.e., there must be no equiaxed grains. 
Table 3-13. (continued).

11. Metallographic Defects

Al1 Tube Types

A11 metallographic inspections for hydride orientation, post anneal cold work, grain size, and equiaxed grains shall include an inspection for the presence of any defects exceeding 0.0040 inch in any dimension. Defects in excess of 0.0040 inch are not permitted.

C. Cold Work in Final Reduction

The amount of cold work $(\mathrm{CW})^{(*)}$, or the reduction in cross-section area, in the last tube reduction shall be within the following ranges for the specified final heat treatment.

\begin{tabular}{lcc}
$\begin{array}{l}\text { Tube } \\
\text { Type }\end{array}$ & Final Reduction & $\begin{array}{l}\text { Final Heat } \\
\text { Treatment (d) }\end{array}$ \\
\cline { 2 - 3 } Seed & 50 to $70 \%$ & RXA \\
PFB & & \\
Std.B. & 60 to $80 \%$ & SRA \\
Ref1. & &
\end{tabular}

D. Final Heat Treatment

All tubes shall have a final heat treatment within the specified limits for the tube type. The size and placement of the load within the furnace, the mass in the furance, and the furnace operating characteristics must be balanced such that the inntermost (slowest heating) tube in the load receives the minimum heat treatment while the outermost (fastest heating) tube does not receive an excessive heat treatment. The prescribed heat treatment parameters for a 11 LWBR tubes are shown in the following table.

\begin{tabular}{|c|c|c|c|c|c|}
\hline $\begin{array}{l}\text { Final } \\
\text { Heat } \\
\text { Treatment }(d) \\
\end{array}$ & $\begin{array}{l}\text { Tube } \\
\text { Type }\end{array}$ & Temp & ure & $\begin{array}{l}\text { Hour } \\
\text { Min. }\end{array}$ & $\begin{array}{l}\text { ove } \\
\text { ip. }\end{array}$ \\
\hline & & Min & $\operatorname{Max}$. & Min. & Max. \\
\hline RXA & Seed & 1200 & 1250 & 2 & 4.5 \\
\hline SRA & $\begin{array}{l}\text { PF Blanket } \\
\text { Standard } 37 \text { anket } \\
\text { Reflector }\end{array}$ & 900 & 950 & 1 & 5.5 \\
\hline
\end{tabular}

(*) The calculation is

$$
\because C W=\frac{A-a}{A} \times 100 \text { where: } \quad \begin{aligned}
& A=\text { cross-section area before reduction } \\
& a=\text { cross-section area after reduction }
\end{aligned}
$$

(d) RXA is recrystallization anneal and SRA is stress relief anneat. 


\subsubsection{Composition}

Cladding consisted of Zircaloy-4 tubes with a low hafnium content (Hecker 1979, WAPD-TM-1326, p. 3). Neutron poisoning in zirconium was found to be attributed to the 2 to $3 \%$ of hafnium present in natural zirconium (Hecker and Freeman 1981, WAPD-TM-1409, p. 6). Zircaloy used for cladding and all other structures in the active fuel region except the fuel rod support grids had a low hafnium content ( $<50 \mathrm{ppm}$ ) (Campbell and Giovengo 1987, WAPD-TM-1387, p. 10$)$. Ingot requirements for LWBR low hafnium Zircaloy-4 tubing are presented in Table 3-14. Stress corrosion cracking in zircaloy tubing is caused by pressure as low as 20,000 psi in the presence of controlled amounts of iodine gas at typical fuel rod operating temperatures. Normal yield strength of irradiated zircaloy is 40,000 to 60,000 psi. (Campbell and Giovengo 1987, WAPD-TM-1387, p. 51). Cladding fabrication is discussed in Eyler 1981 (WAPD-TM-1289).

\subsubsection{Thickness}

Wall thickness of each tube was measured over a spiral pattern as the tube rotated and advanced under the transducer station, which used a high frequency ultrasonic puls-echo measuring technique. Cladding wall thicknesses ranged from a minimum of $0.023 \mathrm{in}$. for the seed rods to a nominal $0.0435 \mathrm{in}$. for reflector rods (Table 3-13). 
Table 3-14. Ingot requirements for Light Water Breeder Reactor Zircaloy-4 tubing (Eyler 1981, WAPDTM-1289, Table A-1).

$$
\text { Zircaloy-4 Tubing }
$$

I. Alloy Chemistry"

El ement
Tin
Iron
Chromium
Oxygen
Iron + Chromium
Zirconium

\begin{tabular}{|c|c|c|}
\hline Symbol & $\%$ Min. & $\% \operatorname{Max}$. \\
\hline Sn & 1.20 & 1.70 \\
\hline $\mathrm{Fe}$ & 0.18 & 0.24 \\
\hline $\mathrm{Cr}$ & 0.07 & 0.13 \\
\hline 0 & 0.09 & 0.15 \\
\hline - & 0.28 & 0.37 \\
\hline $\mathrm{Zr}$ & Remainder & \\
\hline
\end{tabular}

II. Group A Impurity Limits

ASTM

8-353-1977

\begin{tabular}{c} 
Symbol \\
\hline$A 7$ \\
$A$ \\
Cd \\
$C$ \\
Co \\
$\mathrm{Cu}$ \\
$\mathrm{Hf}$ \\
$\mathrm{H}$ \\
$\mathrm{Mg}$ \\
$\mathrm{Mn}$ \\
$\mathrm{Ni}$ \\
$\mathrm{Nb}$ \\
$\mathrm{N}$ \\
$\mathrm{Si}$ \\
$\mathrm{Ta}$ \\
$\mathrm{Ti}$ \\
$\mathrm{W}$ \\
$U$ \\
$\mathrm{U}-235$
\end{tabular}

ppm Max.

75

0.5

0.5

270

20

50

35

25

15

50

70

100

60

110

200

40

80

3

0.025
100

20

80

200

50

100

3.5 
Table 3-14. (continued).

III. Group B Impurity Limits

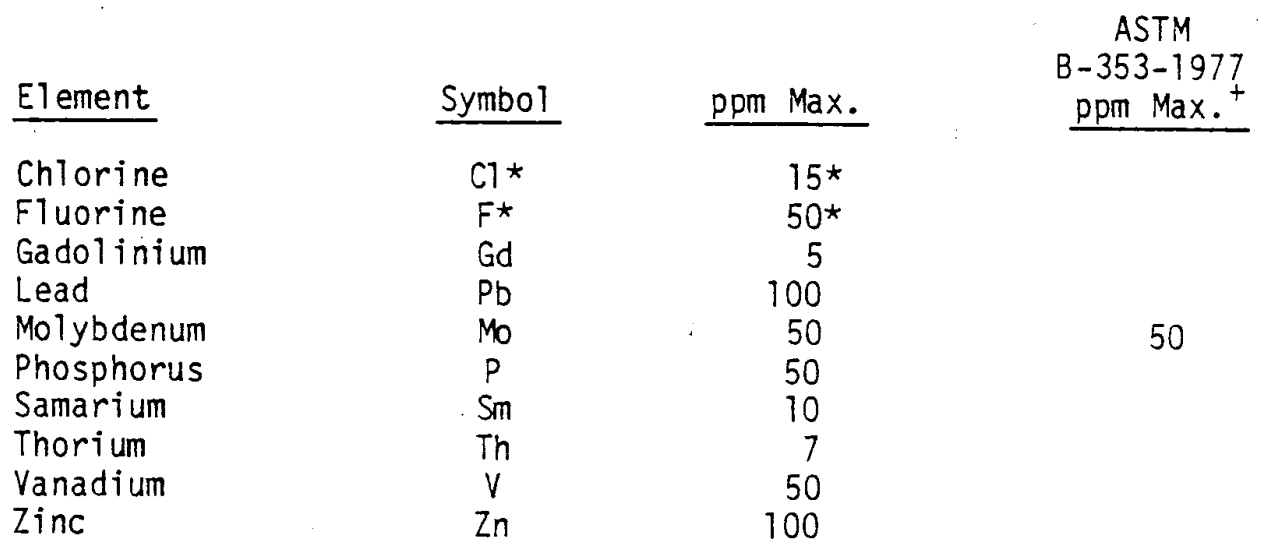

IV. Ingot Composition - Materials Source and Limits

\begin{tabular}{ll} 
Source & Limits \\
\cline { 2 - 2 } Sponge & $50 \% \min$. \\
Solid Scrap & $40 \% \max$. \\
Ingot Turnings & $15 \% \max$.
\end{tabular}

V. Ingot Hardness - Brinell Hardness Number (BHN)

$\begin{array}{ll}\text { Test } & 10 \mathrm{~mm} \text { ba } 1,3000 \mathrm{~kg} \text { load } \\ \text { Limits } & 200 \mathrm{BHN} \text { max. individual } \\ & 187 \mathrm{BHN} \text { max. average of } 10 \text { at room } \\ & \text { temperature }\end{array}$

VI. Miscellaneous Tests

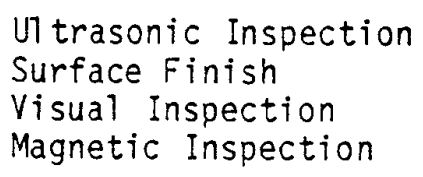

For information only.

Identical to ASTM B-353-1977 (Ref. (c)). except as noted.

$\dagger$ Only specified in ASTM B-353-1977 as noted. 


\section{OPERATING HISTORY}

Shippingport LWBR was operated for about 29,000 EFPH ${ }^{\mathrm{a}}$ from September 1977 until October 1, 1982 (Budd 1986, WAPD-TM-1542, p. 1-9, and ICPP Fuel Receipt Criteria attached to WAPD-NRF(L)C-104, p.3). Average daily generator output as net electrical megawatts and reactor coolant temperature are presented in Figure 4-1 (Budd 1986, WAPD-TM-1542, Figure 1-1). The EFPH, number of hours the reactor was critical, and gross electrical output (in MWhr) are presented for the LWBR by quarter from 1977 to 1982 in Table 4-1.

During most of core life, the LWBR was operated as a base load station (Richardson et al. 1987, WAPD-TM-1606, p. 35). During the first two years of operation, the core was subjected to 204 planned swingload cycles to demonstrate the core transient capability and generating system load follow to simulate operation of a large commercial nuclear reactor (Richardson et al. 1987, WAPD-TM-1606, p. 35). A swing load cycle is defined as power reduction from about $90 \%$ to $35-60 \%$ for 4 to $8 \mathrm{hr}$, then back to $90 \%$ or higher power. Despite shutdowns and swing, the reactor achieved a high capacity factor of $65 \%$ and high availability factor of $86 \%$ (Richardson et al. 1987, WAPD-TM-1606, p. 35).

For its initial 18,000 EFPH, the maximum allowable reactor power was established as $72 \mathrm{MW}$ gross (electric), and the average coolant temp was $531^{\circ} \mathrm{F}$. Pressure was eventually reduced to 1,615 psia (Budd et al. 1986, WAPD-TM-1542, pp. 127-128). Table 4-2 identifies the operating temperatures and pressures for the LWBR operating life (Budd et al. 1986, WAPD-TM-1542, Table 4-1).

In the LWBR irradiation test program, two cladding defects occurred during planned power ramps. Both were hairline cracks attributed to stress corrosion cracking. Stress corrosion cracking was shown in laboratory tests on unfueled tubing specimens to occur at stress levels as low as 20,000 psi in the presence of controlled amounts of iodine gas at typical fuel rod operating temperatures (Campbell and Giovengo 1987, WAPD-TM-1387, p. 51).

The timeline for the LWBR reactor is presented in Table 4-3.

a. $1 \mathrm{EFPH}$ is the equivalent of operating the core for one hour at rated power, namely, 236.6 MW (thermal). 


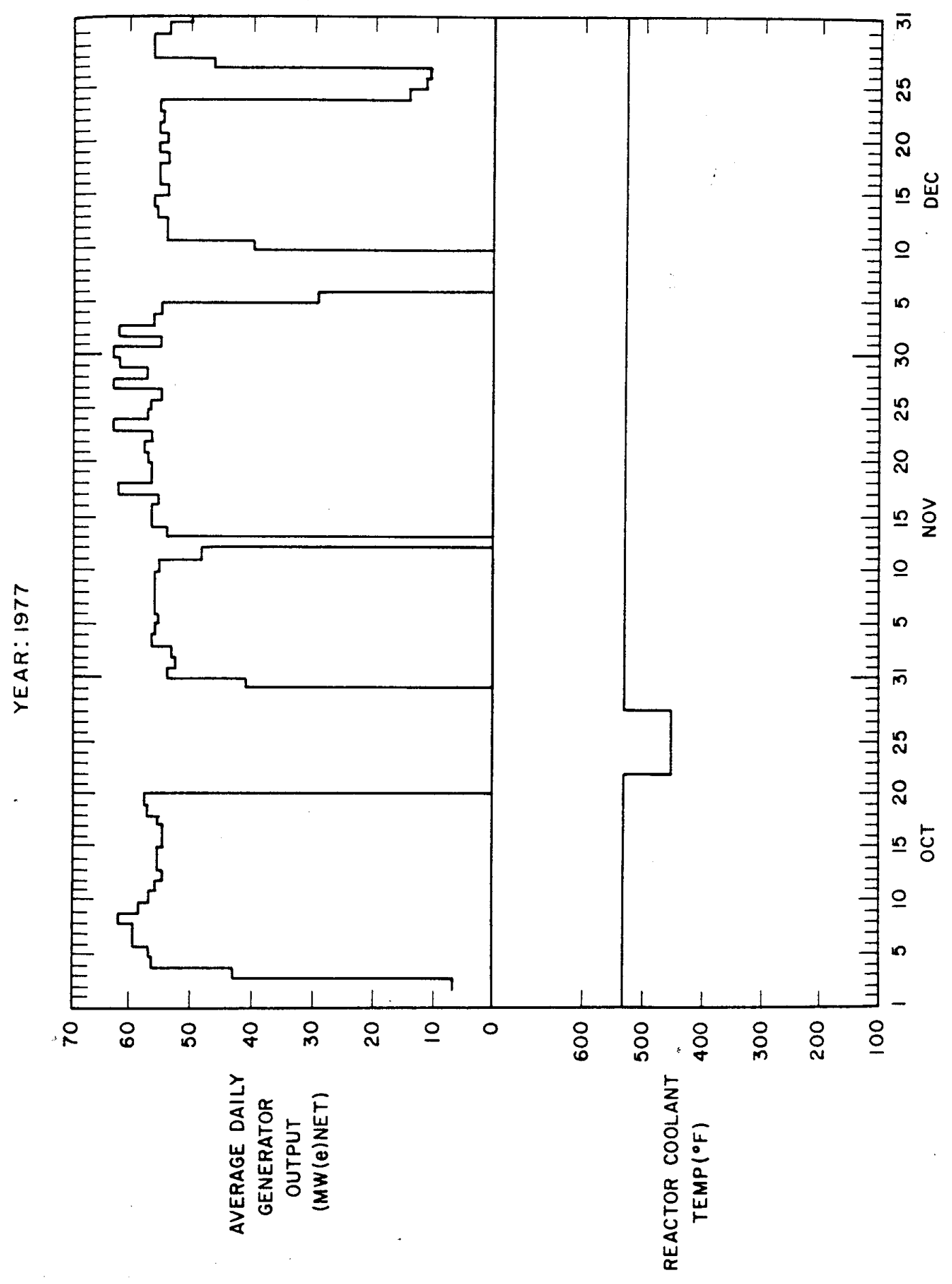

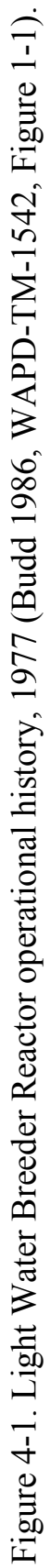




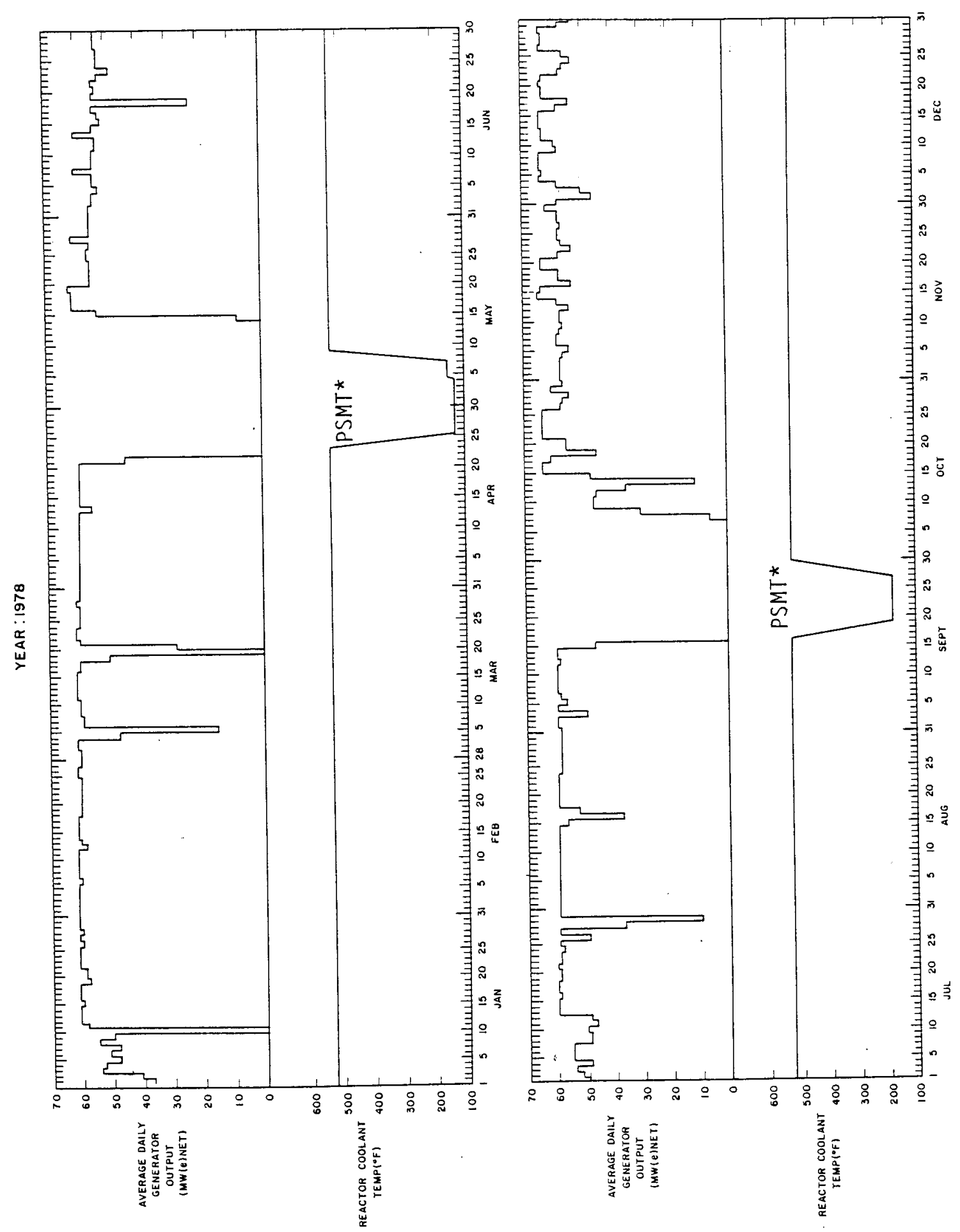

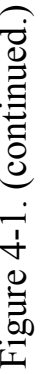



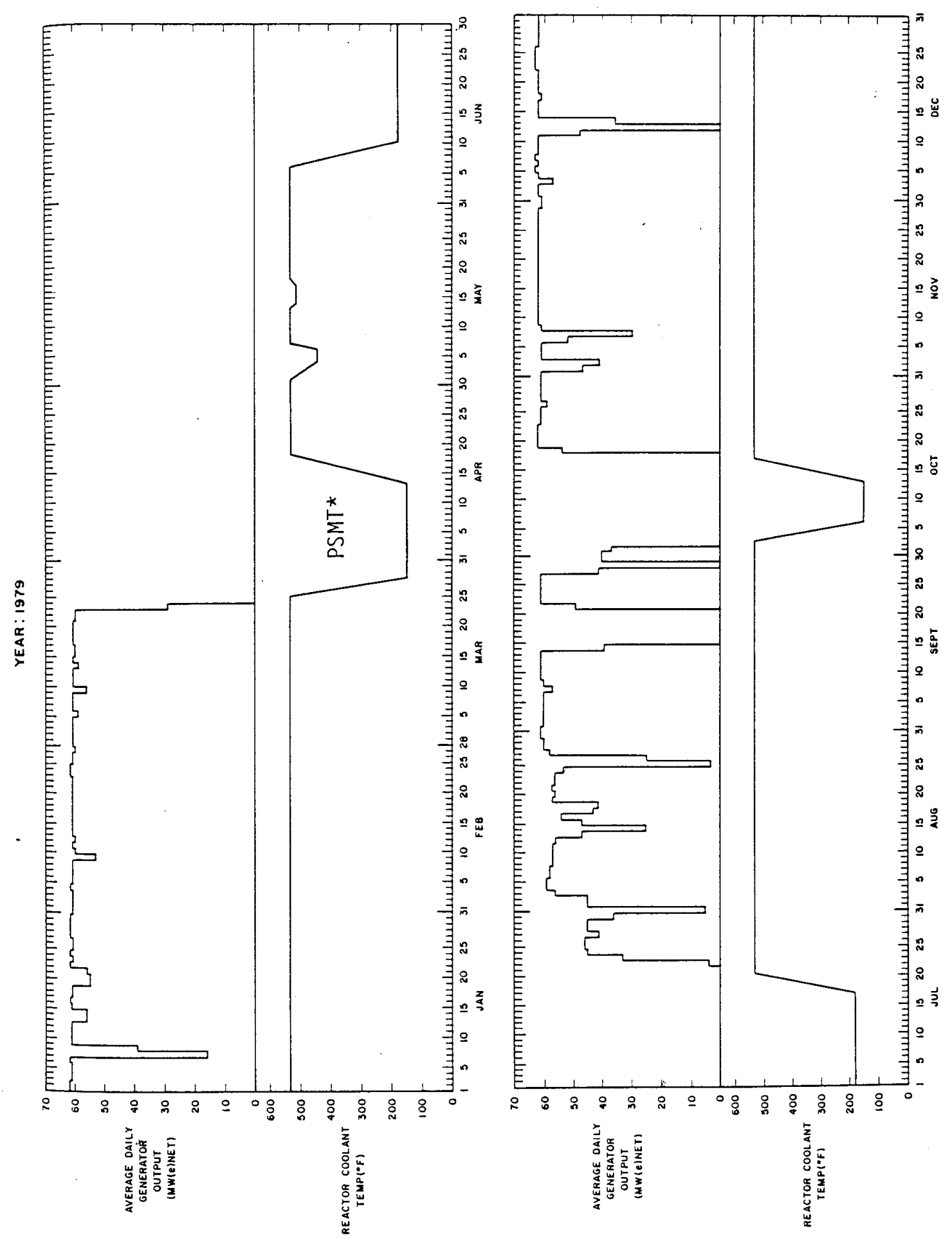

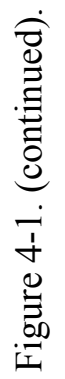



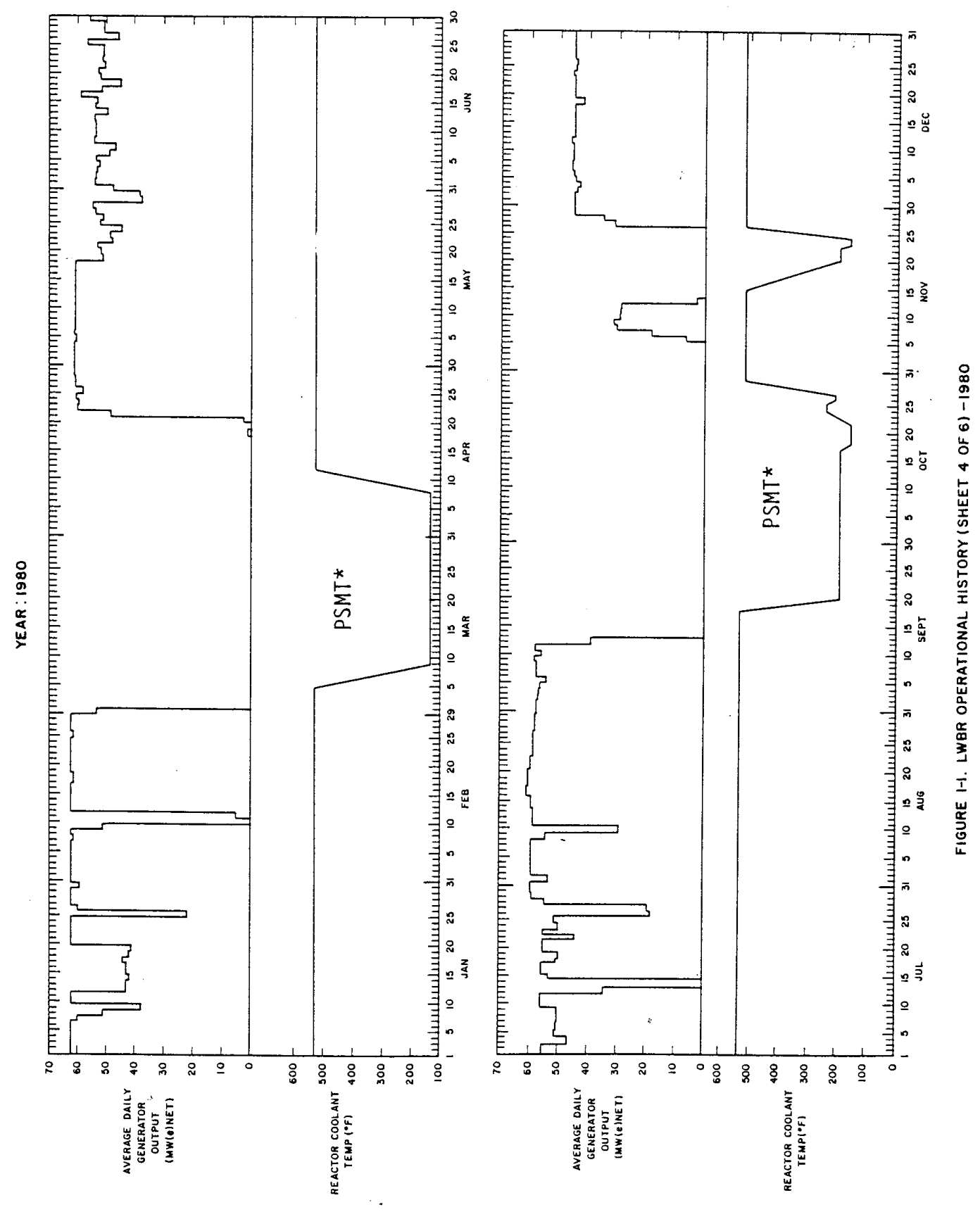

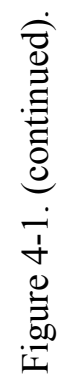




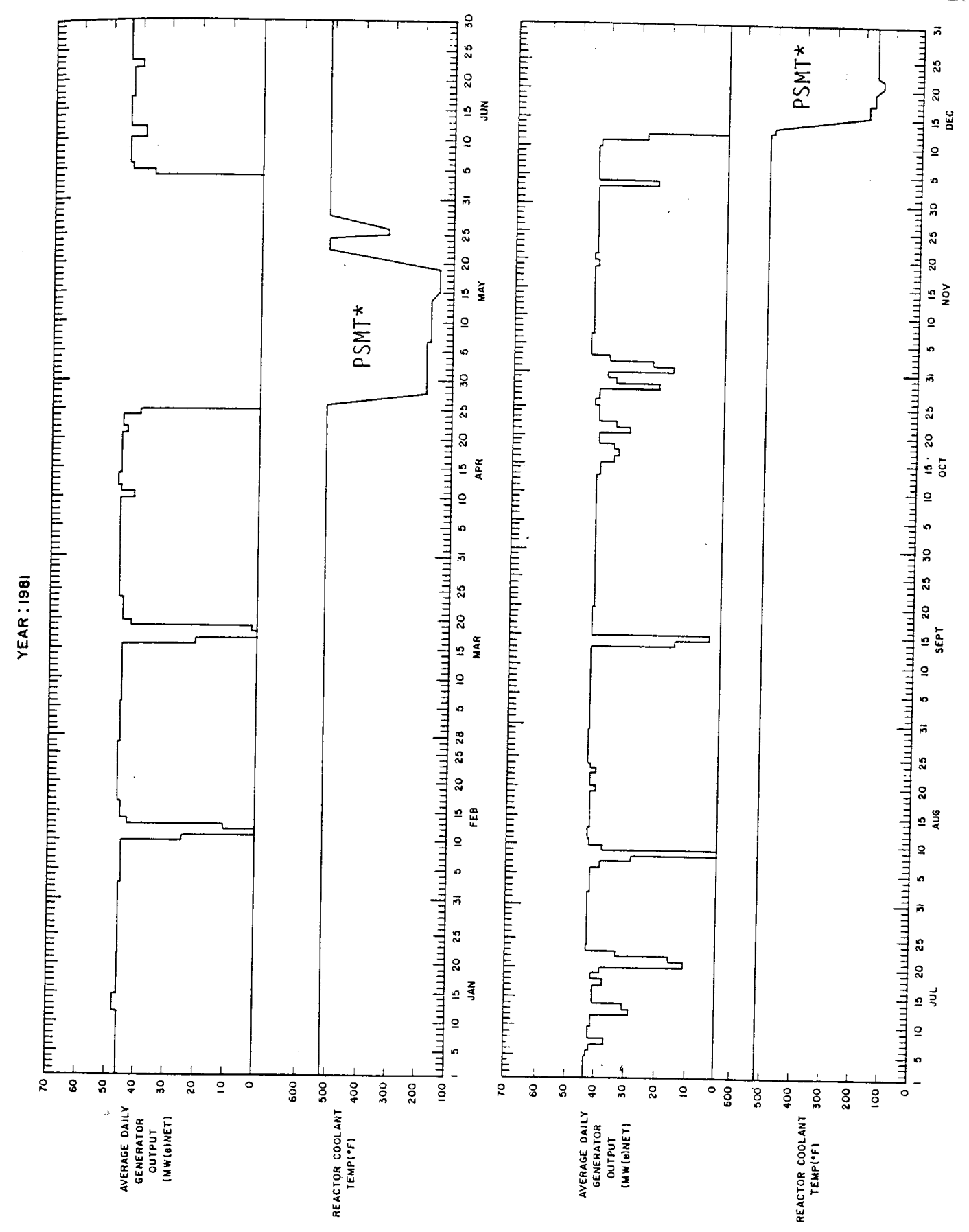

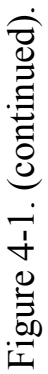



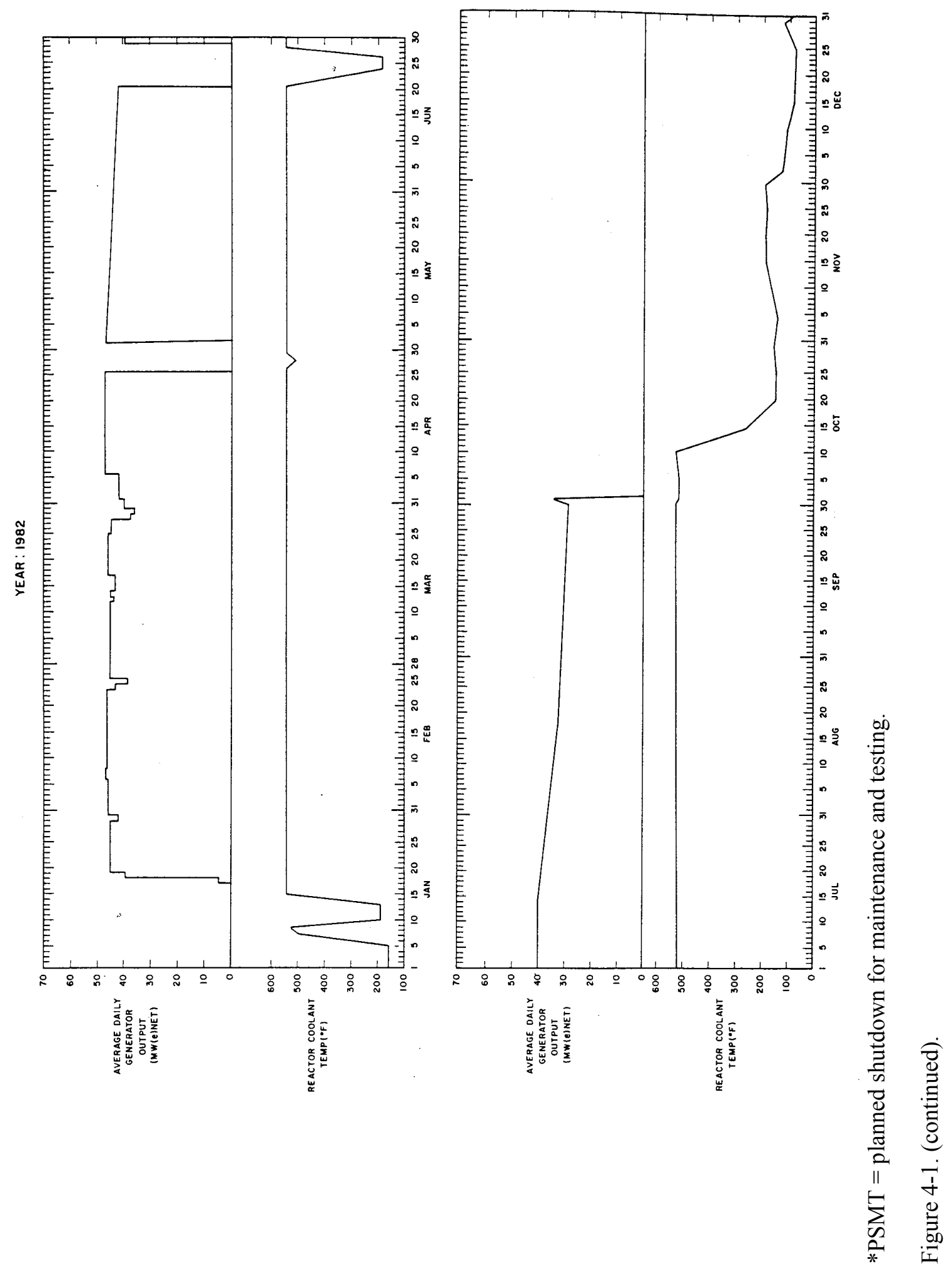
Table 4-1. Summary of Light Water Breeder Reactor station performance (Budd 1986, WAPD-TM-1542, Table 1-1).

\begin{tabular}{|c|c|c|c|c|c|c|}
\hline \multirow[b]{2}{*}{ Year } & \multirow[b]{2}{*}{ Quarter } & \multicolumn{2}{|c|}{ EFPH* } & \multicolumn{2}{|c|}{ Hrs Reactor Critical } & \multirow[t]{2}{*}{$\begin{array}{c}\text { Gross } \\
\text { Electrical Output } \\
\frac{\text { Mwhr }}{\text { To Date }}\end{array}$} \\
\hline & & This Quarter & To Date & This Quarter & To Date & \\
\hline 1977 & $\begin{array}{l}3 \\
4\end{array}$ & $\begin{array}{r}270.4 \\
1553.9\end{array}$ & $\begin{array}{r}270.4 \\
1824.3\end{array}$ & $\begin{array}{r}641.9 \\
1814.2\end{array}$ & $\begin{array}{r}641.9 \\
2456.1\end{array}$ & $\begin{array}{r}17899 \\
134232\end{array}$ \\
\hline 1978 & $\begin{array}{l}1 \\
2 \\
3 \\
4\end{array}$ & $\begin{array}{l}2010.4 \\
1536.6 \\
1761.0 \\
1878.1\end{array}$ & $\begin{array}{l}3834.7 \\
5371.3 \\
7132.3 \\
9010.4\end{array}$ & $\begin{array}{l}2137.9 \\
1695.6 \\
1859.3 \\
2111.6\end{array}$ & $\begin{array}{r}4594.0 \\
6289.6 \\
8148.9 \\
10260.5\end{array}$ & $\begin{array}{l}283947 \\
396929 \\
523279 \\
662675\end{array}$ \\
\hline 1979 & $\begin{array}{l}1 \\
2 \\
3 \\
4\end{array}$ & $\begin{array}{c}1921.9 \\
0 \\
1353.9 \\
1734.9\end{array}$ & $\begin{array}{l}10932.3 \\
10932.3 \\
12286.2 \\
14021.1\end{array}$ & $\begin{array}{r}1945.5 \\
346.9 \\
1574.7 \\
1802.3\end{array}$ & $\begin{array}{l}12206.0 \\
12552.9 \\
14127.6 \\
15929.9\end{array}$ & $\begin{array}{r}805655 \\
805655 \\
903425 \\
1034503\end{array}$ \\
\hline 1980 & $\begin{array}{l}1 \\
2 \\
3 \\
4\end{array}$ & $\begin{array}{r}1304.6 \\
1544.2 \\
1636.8 \\
757.7\end{array}$ & $\begin{array}{l}15325.7 \\
16869.9 \\
18506.7 \\
19264.4\end{array}$ & $\begin{array}{l}1415.4 \\
1815.4 \\
1782.1 \\
1213.3\end{array}$ & $\begin{array}{l}17345.3 \\
19160.7 \\
20942.8 \\
22156.1\end{array}$ & $\begin{array}{l}1133200 \\
1248104 \\
1366698 \\
1423380\end{array}$ \\
\hline 1981 & $\begin{array}{l}1 \\
2 \\
3 \\
4\end{array}$ & $\begin{array}{r}1617.6 \\
960.6 \\
1649.5 \\
1311.4\end{array}$ & $\begin{array}{l}20882.0 \\
21842.6 \\
23492.1 \\
24803.5\end{array}$ & $\begin{array}{l}2090.3 \\
1462.6 \\
2151.9 \\
1715.8\end{array}$ & $\begin{array}{l}24246.4 \\
25713.0 \\
27864.9 \\
29580.7\end{array}$ & $\begin{array}{l}1545038 \\
1615465 \\
1731032 \\
1824592\end{array}$ \\
\hline 1982 & $\begin{array}{l}1 \\
2 \\
3 \\
4\end{array}$ & $\begin{array}{r}1355.7 \\
1459.7 \\
1422.8 \\
5.7\end{array}$ & $\begin{array}{l}26159.2 \\
27618.9 \\
29041.7 \\
29047.4\end{array}$ & $\begin{array}{r}1807.6 \\
1911.7 \\
2208.0 \\
293.1\end{array}$ & $\begin{array}{l}31388.3 \\
33300.0 \\
35508.0 \\
35801.1\end{array}$ & $\begin{array}{l}1923224 \\
2029313 \\
2128542 \\
2128943\end{array}$ \\
\hline
\end{tabular}

$\star E F P H$ - Equivalent Ful] Power Hours [where full power is defined as 236.6 Megawatts therma 1, Mw( $t)$ ] 
Table 4-2. Summary of Light Water Breeder Reactor operating conditions (Budd 1986, WAPD-TM-1542, Table 4-1).

\section{LWBR POWER OPERATING CONDITIONS}

\begin{tabular}{|c|c|c|c|c|}
\hline Effective Date & $\begin{array}{l}\text { Reactor } \\
\text { Lifet Ime }\end{array}$ & $\begin{array}{l}\text { Reactor Power } \\
\text { Gross Electric }\end{array}$ & $\begin{array}{c}\text { System } \\
\text { Pressure } \\
\end{array}$ & $\begin{array}{l}\text { Average Coolant } \\
\text { Temperature } \\
\end{array}$ \\
\hline September 1977 & 0 & $72 \mathrm{MW}$ & 2000 psta & $531^{\circ} \mathrm{F}$ \\
\hline May 1978 & 4325 EFPH & $72 \mathrm{MW}$ & 1940 psta & $531^{\circ} \mathrm{F}$ \\
\hline October 1978 & 7132 EFPH & 72 MW & 1870 psia & $531^{\circ} \mathrm{F}$ \\
\hline July 1979 & 10932 EFPH & $72 \mathrm{MW}$ & 1815 psia & $531^{\circ} \mathrm{F}$ \\
\hline November 1980 & 18507 EFPH & $58 \mathrm{MW}$ & 1615 psia & $521^{\circ} \mathrm{F}$ \\
\hline $\begin{array}{l}\text { June to } \\
\text { October } 1982\end{array}$ & $\begin{array}{l}27419 \text { to } \\
29047 \text { EFPH }\end{array}$ & $\begin{array}{c}54 \text { to } 43 \mathrm{MW} \\
\text { (in } 12 \text { steps) }\end{array}$ & 1615 psia & $521^{\circ} \mathrm{F}$ \\
\hline
\end{tabular}


Table 4-3. Timeline of events for the Light Water Breeder Reactor.

Reactor loading

Initial criticality of core

Full power operation

Achieved depletion to $18,298 \mathrm{EFPH}$

Operated at $80 \%$ of maximum, reduced

temperature and pressure

Maintenance and testing

Reactor operation to 29,047 EFPH

Reactor disassembly

Shipping from Shippingport

(10 shipments)

Water pits S4-39 and N4-43 at Expended Core

Facility for the majority of fuel disposal operations

(Hodges 1987, WAPD-TM-1601, p. 1-4)

Dismantling at Expended Core Facility

17 rods to Argonne National Lab-East

12 rods to Argonne National Lab-West

Testing:

Production Irradiated Fuel Assay Gauge

Chronology of assay operations are provided in

Table 24 (Tessler et al. 1987, WAPD-TM-1614,

Table 4, p. 81)

Repackaging at Expended Core Facility

Shipping to Idaho Nuclear Technology and

Engineering Center

Dry Storage at Idaho Nuclear Technology and

Engineering Center
1977

Aug. 26, 1977 (Sarber 1983, WAPD-TM-1455 addendum, p. 3)

Sept. 21, 1977 (Sarber 1983, WAPD-TM-1455 addendum, p. 3)

Sept. 12, 1980 (Sarber 1983, WAPD-TM-1455 addendum, p. 3)

Sept. 12, 1980 through Dec. 11, 1981

(18,298-24,451 EFPH) (Sarber 1983, WAPD-TM-1455 addendum, p. 3)

21,094-24,541 EFPH

$1977-82$

Dec. 1982-Aug. 1984 (Selsley 1987c, WAPD-TM-1552, p. 7-9)

Sept. 1984 (Selsley 1987c, WAPD-TM-1552, p. 9)

1984

June 1984-May 1987 (Tessler et al. 1987, WAPD-TM-1614, p. 2).

1986-1987

Current 


\section{FUEL EVALUATION}

In order to verify both fuel and reactor performance, measured data were required to validate analytical models used to evaluate the LWBR burnup and breeding characteristics, as well as the reactor's physics parameters. A calculational model was developed to analyze the as-built core and predict the nuclear performance of the core prior to operation. The use of the U-233/Th fuel system led to the need for an extensive analysis of available cross section data and other basic nuclear data for U-233 and thorium, which had previously been given less attention than U-235 and U-238. The U-233 cross-section dependence on energy is particularly complex with broad resonances and strong multilevel effects. In addition, the U-233 cross section interferes with the thorium resonances and with the resonances of its own precursor Pa-233 (Freeman 1978, WAPD-TM-1314).

EOL destructive and nondestructive measurement data were used to compare with the calculational model results in order to verify and validate calculated breeding and burnup predictions.

\subsection{End-of-Life Nondestructive and Destructive Examinations}

The LWBR modules and rods were examined destructively and nondestructively to assess reactor and breeding performance. Examinations started in 1982 when the core was being removed from the reactor. At Shippingport, the modules were visually examined using an underwater closed circuit television camera, which verified that no indications of rough handling or other unusual conditions were present (WAPD-NRF(L)C-104 Fuel Receipt Criteria Part B 1987, p. 4). Following initial examination and loading, the modules were sent to ECF.

At ECF, 12 of the 39 core fuel modules were prepared for fuel rod removal: four seeds (SI-1, SII-3, SIII-1, and SIII-2), four blankets (BI-3, BII-2, BIII-2, and BIII-6) and four reflectors (RIV-3, RIV-4, RIV-9, and RV-4). Refer to Figure 5-1 for the locations of the removed modules in relation to the rest of the core. Both power-flattening and standard-type blanket rods were removed from the blanket modules. In all, more than 1000 rods were removed for testing and proof of breeding experiments. Of the $1,000+$ rods, 524 were nondestructively evaluated at ECF using the Production Irradiated Fuel Assay Gauge (PIFAG) to measure rod EOL fertile and fissile thorium and uranium isotopic mass. To corroborate PIFAG measurements and obtain accurate data for the proof of breeding, 17 of the 524 PIFAG-analyzed rods were completely dissolved and assayed by ANL-E (Graczyk et al. 1987, ANL-87-2). Uranium isotopic data for each rod type are presented in Table 5-1, including destructive examination data (shaded), nondestructive examination data from the PIFAG (maximum assay results) and modeled beginning of life fissile content data. Information about the calculational model used to obtain the modeled data is presented in Freeman (1978)(WAPD-TM-1314). Information about nondestructive and destructive testing follows. An additional 12 PIFAG rods were destructively examined at ANL-W for fission gases.

\subsubsection{Nondestructive Examinations}

Nondestructive examinations were performed to confirm breeding, assess support structure and fuel rod performance, and provide a database for evaluation of design procedures (Table 5-2). The EOL examination program included examinations of entire modules as well as individual components (rods, grids, bolts, etc.) and crud examination (Table 5-3).

PIFAG. The PIFAG, discussed in Tessler et al. 1987 (WAPD-TM-1614), was used to nondestructively measure the fissile fuel content of 524 spent fuel rods from the modules. Cell locations of the 524 rods are shown in Figures 5-2 through 5-13. The 524 rods were selected using a statistical 


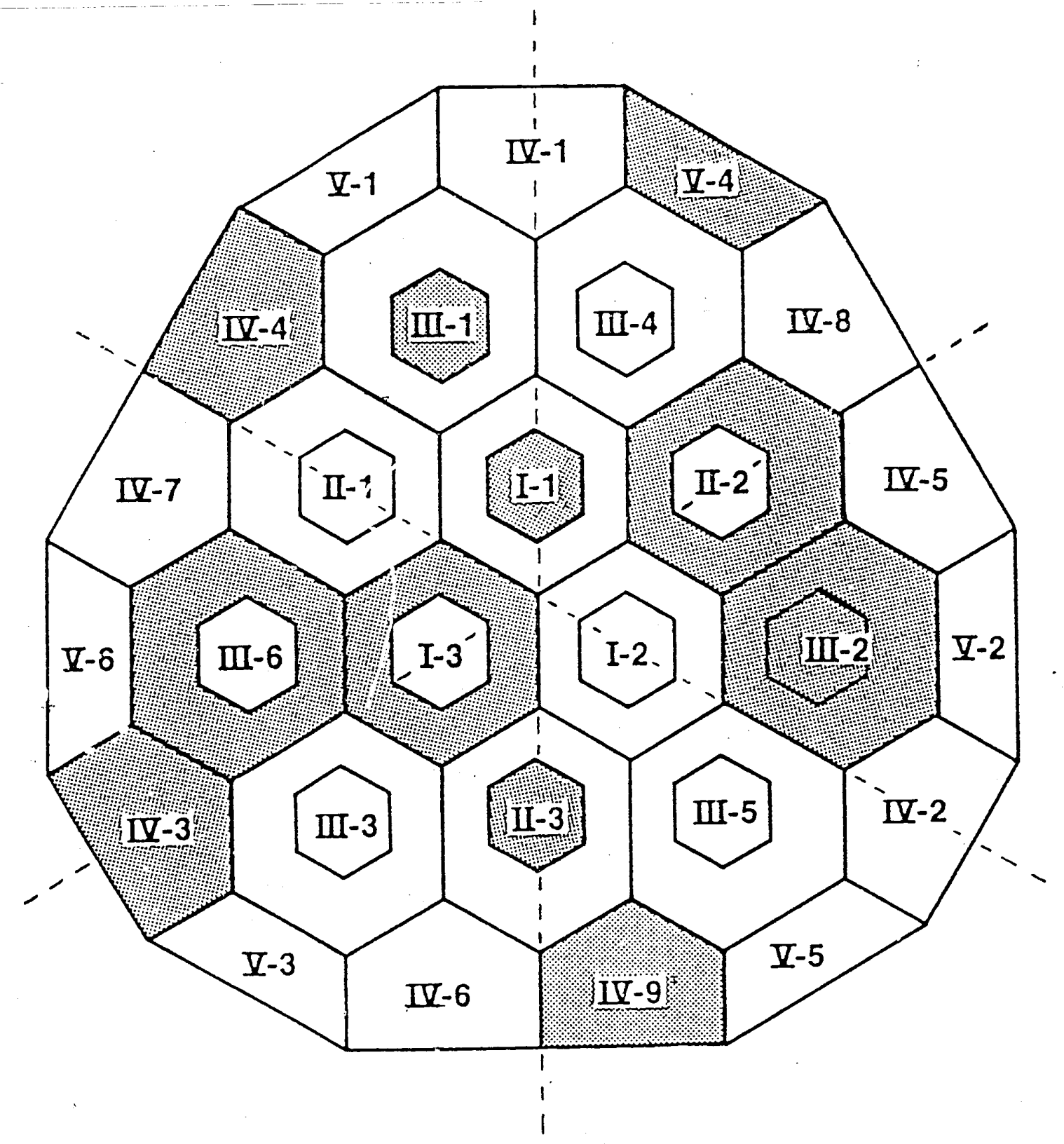

Figure 5-1. Diagram of Light Water Breeder Reactor core, showing locations of Proof-of-Breeding modules (shaded) and boundaries of Sixth-Core Sectors (dashed) (Schick et al. 1987, WAPD-TM-1612, Figure V-1). 
Table 5-1. Modeled and measured end-of-life (EOL) isotopic content of Light Water Breeder Reactor fuel rods (from Fuel Receipt Criteria Part B information and ANL-E unpublished data).

\begin{tabular}{|c|c|c|c|c|c|c|c|c|c|c|}
\hline $\begin{array}{l}\text { Rod } \\
\text { Type }\end{array}$ & $\begin{array}{c}\text { Module } \\
\text { Type } \\
\text { (cell) }\end{array}$ & $\begin{array}{c}\text { Th-232a } \\
\text { (g) }\end{array}$ & $\begin{array}{c}\mathrm{U}-232^{\mathrm{a}} \\
(\mathrm{g})\end{array}$ & $\begin{array}{c}\mathrm{U}-233^{\mathrm{a}} \\
(\mathrm{g})\end{array}$ & $\begin{array}{c}\mathrm{U}-234^{\mathrm{a}} \\
(\mathrm{g})\end{array}$ & $\begin{array}{c}\mathrm{U}-235^{\mathrm{a}} \\
(\mathrm{g})\end{array}$ & $\begin{array}{c}\mathrm{U}-236^{\mathrm{a}} \\
(\mathrm{g})\end{array}$ & $\begin{array}{c}\mathrm{U}-238^{\mathrm{a}} \\
(\mathrm{g})\end{array}$ & $\begin{array}{l}\text { Maximum } \\
\text { BOL } \\
\text { Fissile }^{\mathrm{b}} \\
\text { (Modeled) } \\
(\mathrm{g}) \\
\end{array}$ & $\begin{array}{c}\text { Maximum } \\
\text { EOL } \\
\text { Fissile } \\
\text { (Measured) }^{\mathrm{c}} \\
(\mathrm{g})\end{array}$ \\
\hline \multirow[t]{5}{*}{$1,2,7,8$} & SI-1 & 0.7 & 0.03 & 13.69 & 1.67 & 0.29 & 0.03 & 0.03 & 14.35 & 14.23 \\
\hline & SI-1 (P39) ${ }^{\mathrm{d}}$ & & 0.02 & 13.57 & 1.69 & 0.29 & 0.03 & 0.04 & 14.22 & 13.99 \\
\hline & SII-3 & 0.71 & 0.02 & 13.75 & 1.48 & 0.23 & 0.02 & 0.03 & 14.37 & 14.27 \\
\hline & SIII-1 & 0.71 & 0.02 & 13.82 & 1.32 & 0.19 & 0.02 & 0.03 & 14.33 & 14.32 \\
\hline & SIII-2 & 0.71 & 0.02 & 13.82 & 1.32 & 0.19 & 0.02 & 0.03 & 14.45 & 14.38 \\
\hline \multirow[t]{5}{*}{3} & SI-1 & 0.7 & 0.03 & 15.29 & 1.89 & 0.33 & 0.03 & 0.04 & 19.18 & 15.68 \\
\hline & SI-1 (N63) ${ }^{\mathrm{d}}$ & & 0.02 & 15.3 & 1.88 & 0.34 & 0.04 & 0.05 & 19.18 & 15.68 \\
\hline & SII-3 & 0.7 & 0.03 & 15.6 & 1.7 & 0.28 & 0.02 & 0.04 & 19.15 & 15.77 \\
\hline & SIII-1 & 0.7 & 0.02 & 15.88 & 1.53 & 0.23 & 0.02 & 0.04 & 19.14 & 15.98 \\
\hline & SIII-2 & 0.7 & 0.02 & 15.88 & 1.53 & 0.23 & 0.02 & 0.04 & 19.19 & 16.44 \\
\hline \multirow[t]{5}{*}{4} & SI-1 & 0.69 & 0.03 & 17.17 & 2.13 & 0.38 & 0.04 & 0.05 & 23.90 & 17.52 \\
\hline & SI-1 (M49) ${ }^{\mathrm{d}}$ & & 0.02 & 17.06 & 2.12 & 0.37 & 0.03 & 0.07 & 23.70 & 17.52 \\
\hline & SII-3 & 0.69 & 0.03 & 17.72 & 1.93 & 0.31 & 0.03 & 0.05 & 24.03 & 18.06 \\
\hline & SIII-1 & 0.69 & 0.02 & 18.24 & 1.76 & 0.26 & 0.02 & 0.05 & 23.90 & 18.77 \\
\hline & SIII-2 & 0.69 & 0.02 & 18.24 & 1.76 & 0.26 & 0.02 & 0.05 & 23.98 & 18.92 \\
\hline \multirow[t]{6}{*}{5,6} & SI-1 & 0.68 & 0.03 & 24.34 & 2.54 & 0.41 & 0.03 & 0.07 & 34.74 & 25.71 \\
\hline & SI-1 (L29) ${ }^{\mathrm{d}}$ & & 0.02 & 22.33 & 2.74 & 0.46 & 0.04 & 0.08 & 34.60 & 22.96 \\
\hline & SI-1 $(\mathrm{C} 10)^{\mathrm{d}}$ & & 0.02 & 25.15 & 2.51 & 0.4 & 0.03 & 0.08 & 34.68 & 25.67 \\
\hline & SII-3 & 0.68 & 0.03 & 25.37 & 2.31 & 0.35 & 0.03 & 0.07 & 34.87 & 26.88 \\
\hline & SIII-1 & 0.68 & 0.02 & 26.28 & 2.1 & 0.29 & 0.02 & 0.07 & 34.74 & 27.67 \\
\hline & SIII-2 & 0.68 & 0.02 & 26.28 & 2.1 & 0.29 & 0.02 & 0.07 & 34.84 & 27.58 \\
\hline \multirow[t]{5}{*}{11,12} & $\mathrm{BI}-3$ & 2.9 & 0.1 & 35.4 & 3.25 & 0.54 & 0.05 & 0.03 & 16.50 & 36.88 \\
\hline & BI-3 (A49) ${ }^{\mathrm{d}}$ & & 0.08 & 35.9 & 3.87 & 0.7 & 0.07 & 0.04 & 16.45 & 36.88 \\
\hline & BII-2 & 2.9 & 0.09 & 34.3 & 2.98 & 0.47 & 0.04 & 0.03 & 16.48 & 36.10 \\
\hline & BIII-2 & 2.91 & 0.08 & 33.3 & 2.73 & 0.41 & 0.03 & 0.03 & 16.48 & 34.11 \\
\hline & BIII-6 & 2.91 & 0.08 & 33.3 & 2.73 & 0.41 & 0.03 & 0.03 & 16.51 & 34.72 \\
\hline \multirow[t]{5}{*}{13} & $\mathrm{BI}-3$ & 2.87 & 0.1 & 47.2 & 4.42 & 0.74 & 0.06 & 0.08 & 45.53 & 47.75 \\
\hline & BI-3 (D24) ${ }^{\mathrm{d}}$ & & 0.06 & 46.43 & 4.35 & 0.73 & 0.07 & 0.1 & 45.46 & 47.38 \\
\hline & BII-2 & 2.87 & 0.09 & 46.87 & 4.22 & 0.68 & 0.06 & 0.08 & 45.52 & 47.68 \\
\hline & BIII-2 & 2.87 & 0.08 & 46.59 & 4.02 & 0.63 & 0.05 & 0.08 & 45.56 & 47.25 \\
\hline & BIII-6 & 2.87 & 0.08 & 46.59 & 4.02 & 0.63 & 0.05 & 0.08 & 45.58 & 47.07 \\
\hline
\end{tabular}


Table 5-1. (continued).

\begin{tabular}{|c|c|c|c|c|c|c|c|c|c|c|}
\hline $\begin{array}{l}\text { Rod } \\
\text { Type }\end{array}$ & $\begin{array}{c}\text { Module } \\
\text { Type } \\
\text { (cell) }\end{array}$ & $\begin{array}{c}\text { Th- } 232^{\mathrm{a}} \\
(\mathrm{g})\end{array}$ & $\begin{array}{c}\mathrm{U}-232^{\mathrm{a}} \\
(\mathrm{g})\end{array}$ & $\begin{array}{c}\mathrm{U}-233^{\mathrm{a}} \\
(\mathrm{g})\end{array}$ & $\begin{array}{c}\mathrm{U}-234^{\mathrm{a}} \\
(\mathrm{g})\end{array}$ & $\begin{array}{c}\mathrm{U}-235^{\mathrm{a}} \\
(\mathrm{g})\end{array}$ & $\begin{array}{c}\mathrm{U}-236^{\mathrm{a}} \\
(\mathrm{g})\end{array}$ & $\begin{array}{c}\mathrm{U}-238^{\mathrm{a}} \\
(\mathrm{g})\end{array}$ & $\begin{array}{l}\text { Maximum } \\
\text { BOL } \\
\text { Fissile }^{\mathrm{b}} \\
\text { (Modeled) } \\
(\mathrm{g})\end{array}$ & $\begin{array}{c}\text { Maximum } \\
\text { EOL } \\
\text { Fissile } \\
\text { (Measured) }^{\mathrm{c}} \\
(\mathrm{g})\end{array}$ \\
\hline \multirow[t]{5}{*}{14} & BI-3 & 2.92 & 0.09 & 40.74 & 3.63 & 0.61 & 0.05 & 0.06 & 30.67 & 41.35 \\
\hline & BI-3 $(C 3)^{d}$ & & 0.06 & 40.03 & 3.59 & 0.58 & 0.04 & 0.07 & 30.67 & 40.76 \\
\hline & BII-2 & 2.92 & 0.09 & 40.74 & 3.63 & 0.61 & 0.05 & 0.06 & 30.61 & 40.96 \\
\hline & BIII-2 & 2.92 & 0.08 & 39.4 & 3.21 & 0.5 & 0.04 & 0.06 & 30.64 & 39.89 \\
\hline & BIII-6 & 2.92 & 0.08 & 39.4 & 3.21 & 0.5 & 0.04 & 0.06 & 30.71 & 39.89 \\
\hline \multirow[t]{4}{*}{15} & BI-3 & 2.88 & 0.1 & 47.04 & 4.66 & 0.76 & 0.07 & 0.09 & 45.84 & 48.78 \\
\hline & BII-2 & 2.88 & 0.1 & 46.88 & 4.5 & 0.72 & 0.06 & 0.09 & 45.75 & 48.45 \\
\hline & BIII-2 & 2.88 & 0.09 & 46.71 & 4.29 & 0.67 & 0.06 & 0.09 & 45.74 & 48.23 \\
\hline & BIII-6 & 2.88 & 0.09 & 46.71 & 4.29 & 0.67 & 0.06 & 0.09 & 45.76 & 48.21 \\
\hline \multirow[t]{5}{*}{16} & BI-3 & 2.89 & 0.1 & 52.19 & 4.92 & 0.8 & 0.07 & 0.1 & 54.75 & 52.81 \\
\hline & BI-3 $(E 56)^{d}$ & & 0.07 & 51.41 & 5.23 & 0.88 & 0.08 & 0.12 & 54.55 & 52.51 \\
\hline & BII-2 & 2.89 & 0.09 & 52.1 & 4.74 & 0.75 & 0.07 & 0.1 & 54.86 & 52.88 \\
\hline & BIII-2 & 2.9 & 0.09 & 52.06 & 4.53 & 0.7 & 0.06 & 0.1 & 54.67 & 52.74 \\
\hline & BIII-6 & 2.9 & 0.09 & 52.06 & 4.53 & 0.7 & 0.06 & 0.1 & 54.70 & 52.64 \\
\hline \multirow[t]{4}{*}{21,22} & BII-2 & 2.45 & 0.06 & 30.09 & 2.67 & 0.4 & 0.03 & 0.04 & 19.00 & 31.14 \\
\hline & BIII-2 & 2.45 & 0.05 & 28.98 & 2.29 & 0.31 & 0.02 & 0.04 & 18.99 & 30.55 \\
\hline & BIII-6 & 2.45 & 0.05 & 28.98 & 2.29 & 0.31 & 0.02 & 0.04 & 19.00 & 30.39 \\
\hline & BIII-6 (B62) ${ }^{\mathrm{d}}$ & & 0.04 & 28.91 & 2.27 & 0.32 & 0.03 & 0.05 & 19.00 & 29.37 \\
\hline \multirow[t]{4}{*}{23} & BII-2 & 2.42 & 0.06 & 45.57 & 3.95 & 0.57 & 0.05 & 0.22 & 52.79 & 46.03 \\
\hline & BIII-2 & 2.42 & 0.05 & 46.13 & 3.53 & 0.47 & 0.04 & 0.22 & 52.77 & 46.86 \\
\hline & BIII-6 & 2.42 & 0.05 & 46.13 & 3.53 & 0.47 & 0.04 & 0.22 & 52.55 & 46.71 \\
\hline & BIII-6 (D29) ${ }^{\mathrm{d}}$ & & 0.05 & 44.45 & 4.4 & 0.71 & 0.08 & 0.12 & 52.51 & 45.36 \\
\hline \multirow[t]{4}{*}{24} & BII-2 & 2.46 & 0.06 & 34.68 & 2.98 & 0.45 & 0.04 & 0.06 & 30.77 & 35.29 \\
\hline & BIII-2 & 2.46 & 0.05 & 34.11 & 2.62 & 0.37 & 0.03 & 0.06 & 30.88 & 34.49 \\
\hline & BIII-6 & 2.46 & 0.05 & 34.11 & 2.62 & 0.37 & 0.03 & 0.06 & 30.80 & 34.89 \\
\hline & BIII-6 $(\mathrm{C} 13)^{\mathrm{d}}$ & & 0.02 & 33.61 & 2.21 & 0.28 & 0.02 & 0.08 & 30.78 & 34.02 \\
\hline \multirow[t]{6}{*}{25,26} & BII-2 & 2.43 & 0.05 & 53.87 & 3.78 & 0.47 & 0.04 & 0.26 & 63.39 & 56.60 \\
\hline & BIII-2 & 2.43 & 0.03 & 55.13 & 3.3 & 0.38 & 0.03 & 0.26 & 63.18 & 57.41 \\
\hline & BIII-6 & 2.43 & 0.03 & 55.13 & 3.3 & 0.38 & 0.03 & 0.26 & 63.45 & 57.53 \\
\hline & BIII-6 (F73) & & 0.04 & 53.07 & 4.27 & 0.62 & 0.07 & 0.15 & 63.27 & 53.75 \\
\hline & BIII-6 (H1) ${ }^{\mathrm{d}}$ & & 0.01 & 57.1 & 2.51 & 0.23 & 0.01 & 0.46 & 63.00 & 57.44 \\
\hline & BIII-6 (E31) ${ }^{\mathrm{d}}$ & & 0.05 & 50.7 & 4.94 & 0.78 & 0.09 & 0.15 & 63.12 & 51.62 \\
\hline
\end{tabular}




\begin{tabular}{|c|c|c|c|c|}
\hline & 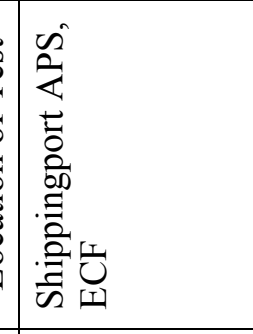 & 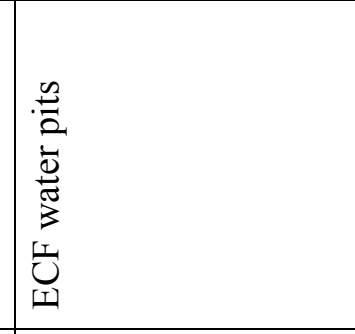 & 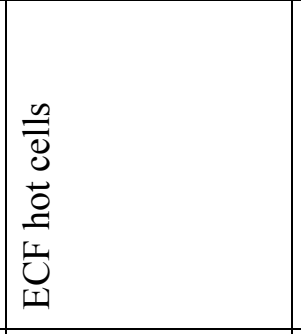 & 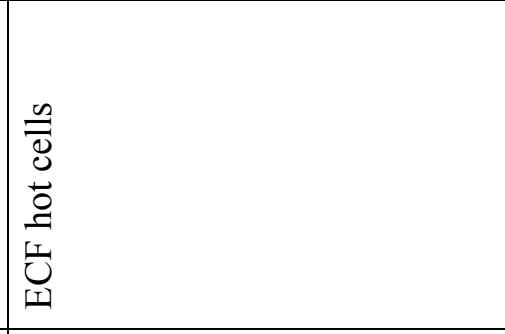 \\
\hline & 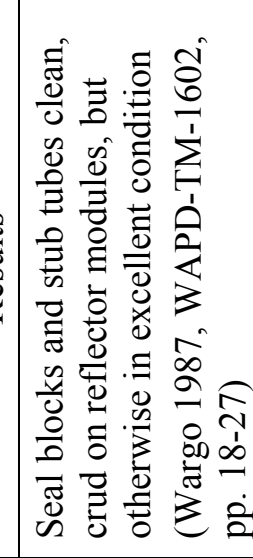 & 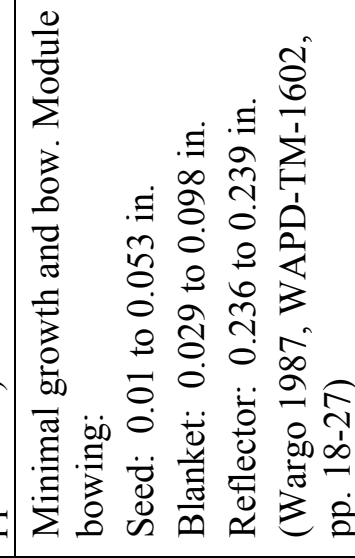 & 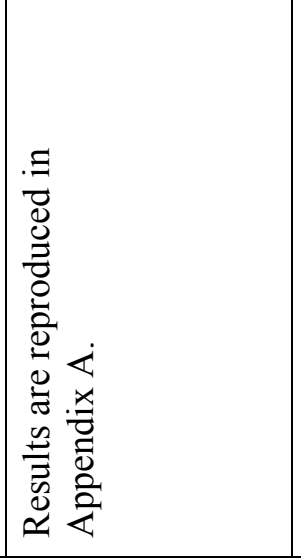 & 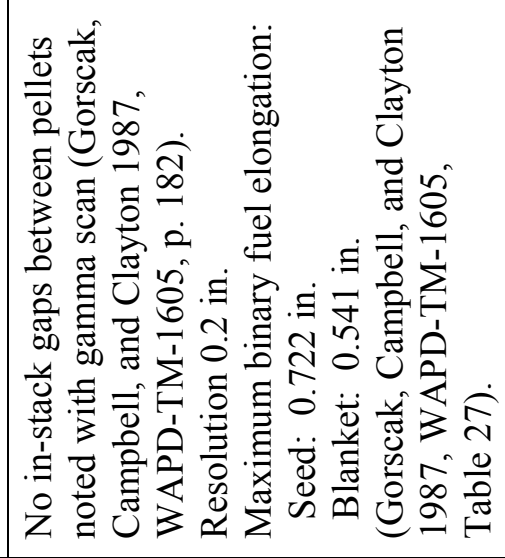 \\
\hline & 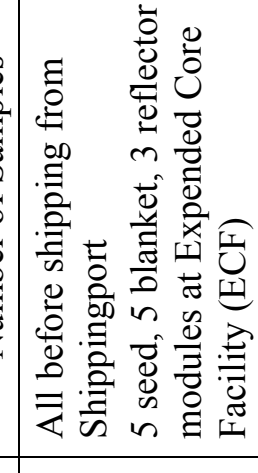 & 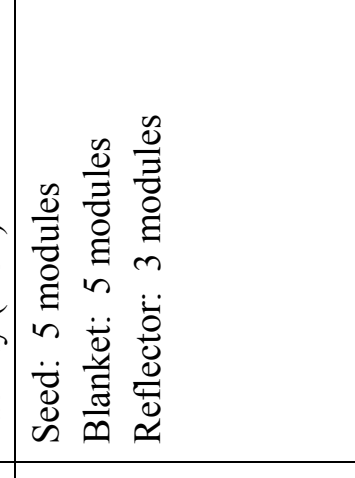 & 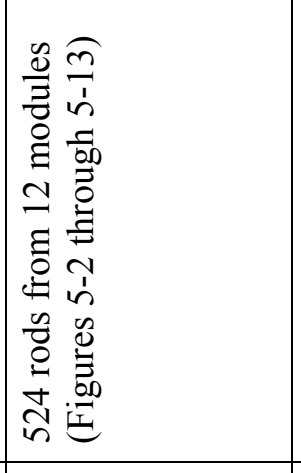 & 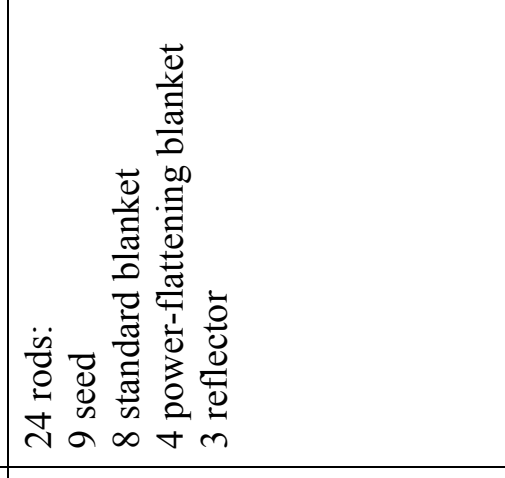 \\
\hline & 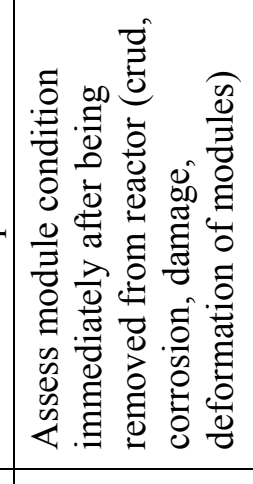 & 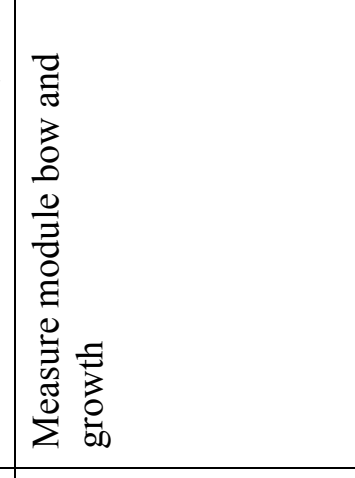 & 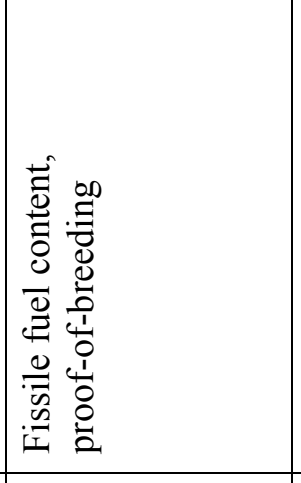 & 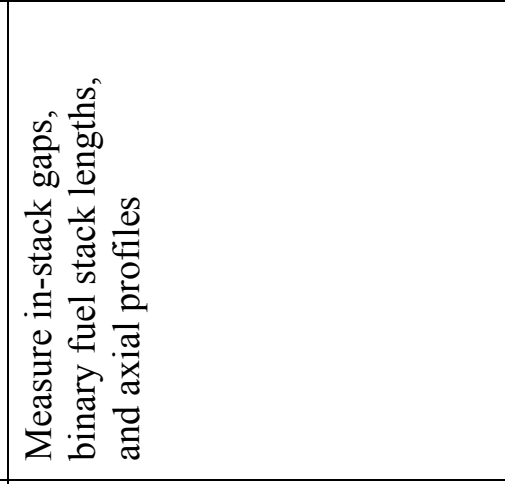 \\
\hline & 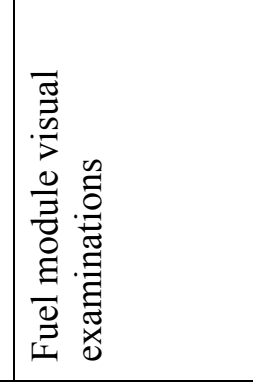 & 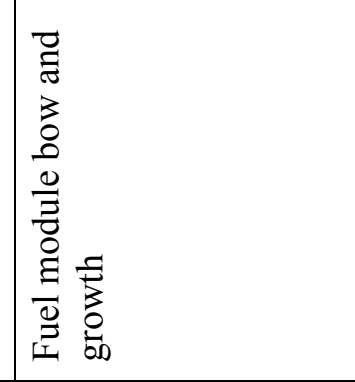 & 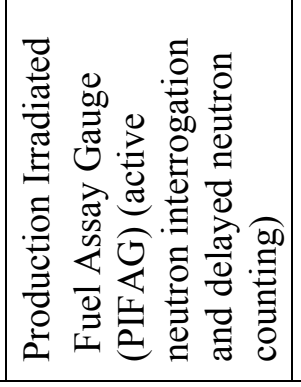 & 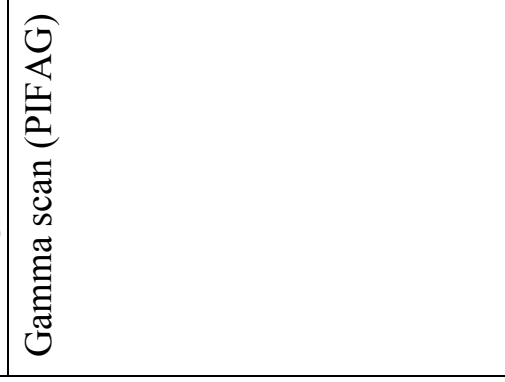 \\
\hline
\end{tabular}




\begin{tabular}{|c|c|c|c|c|}
\hline 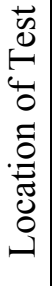 & $\underbrace{\underline{L}}_{\text {U }}$ & $\stackrel{\mathscr{E}}{0}_{\mathscr{D}}^{n}$ & $\underbrace{\text { II }}_{\text {III }}$ & $\underbrace{\text { II }}_{\text {II }}$ \\
\hline 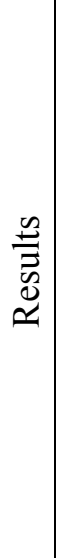 & 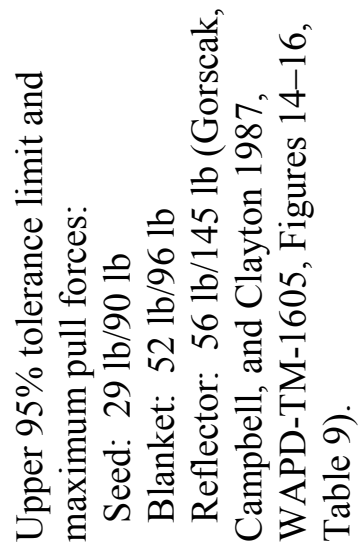 & 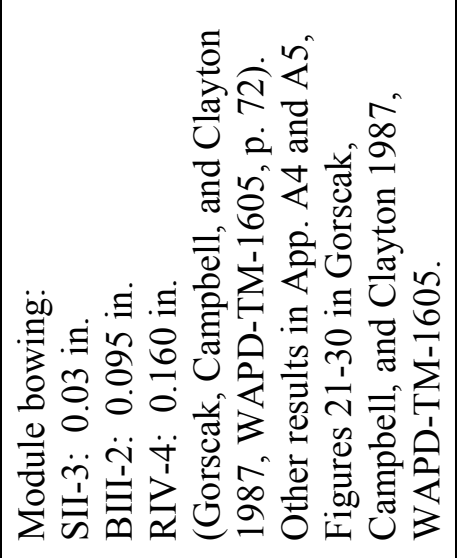 & 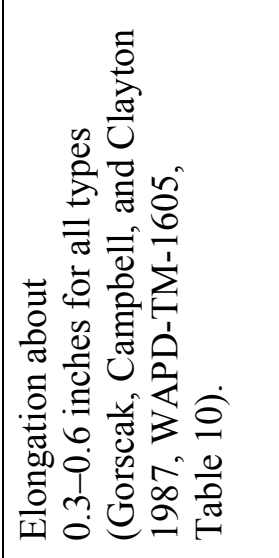 & 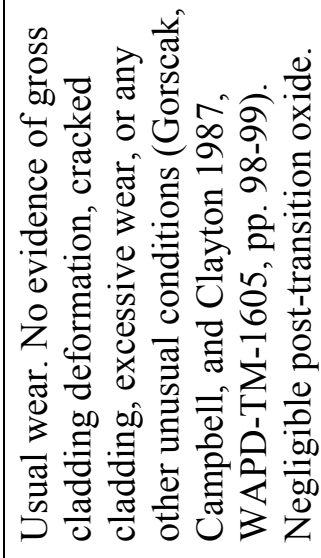 \\
\hline 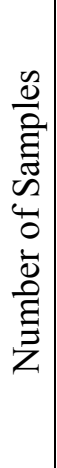 & 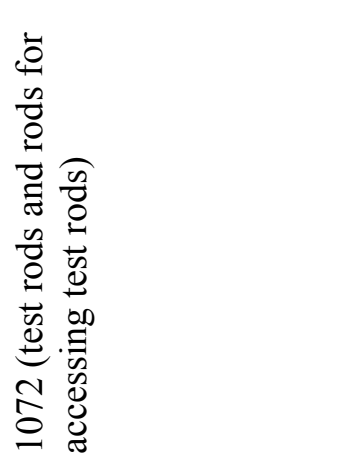 & 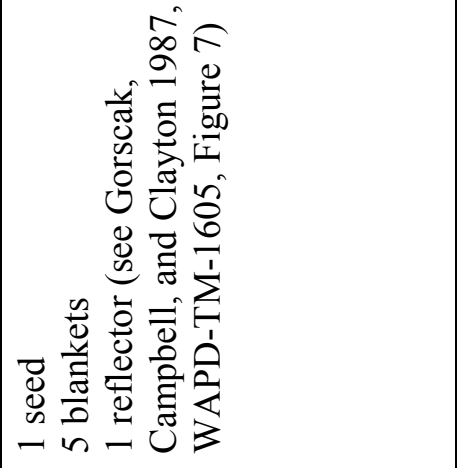 & 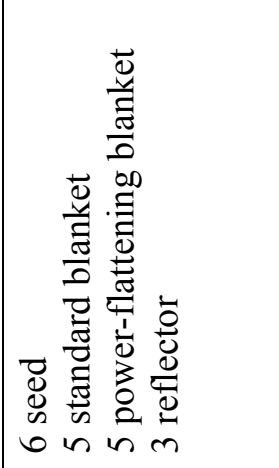 & 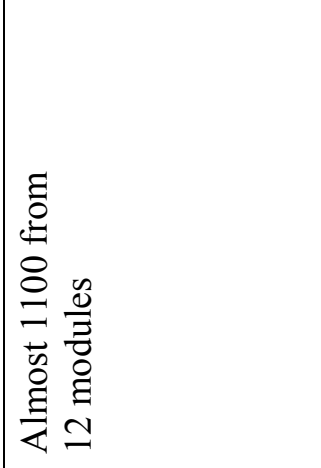 \\
\hline 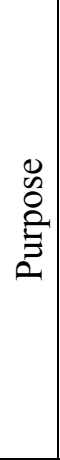 & 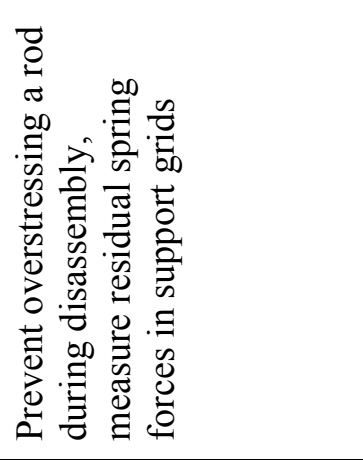 & 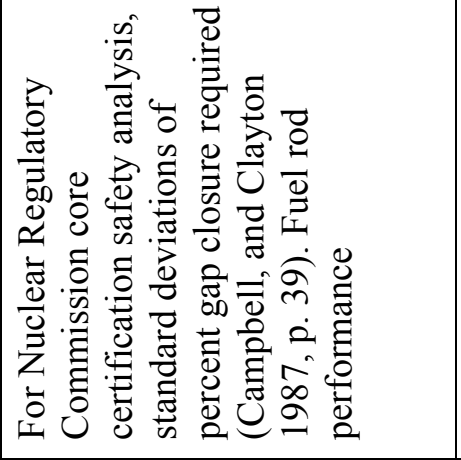 & 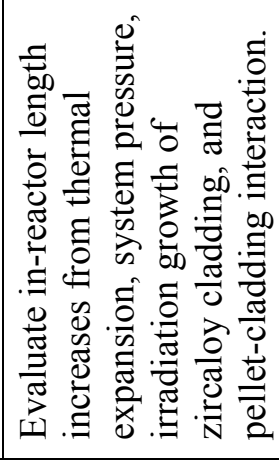 & 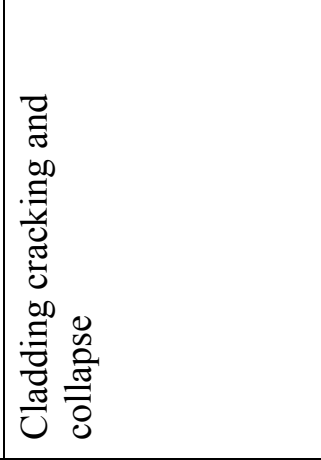 \\
\hline$\stackrel{\vec{v}}{\oplus}$ & 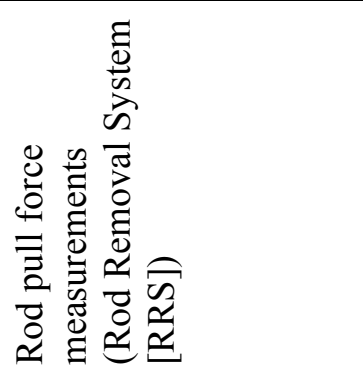 & 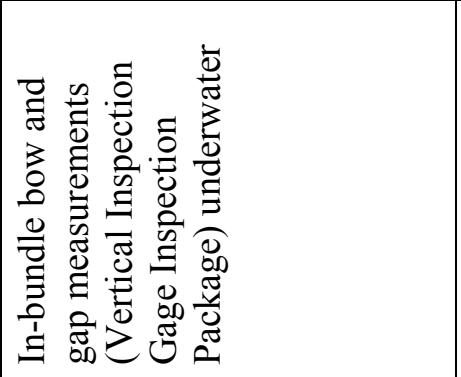 & 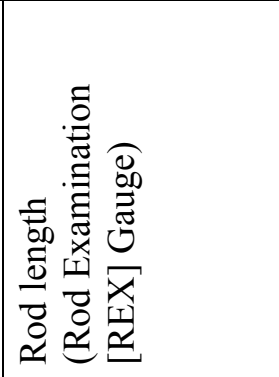 & 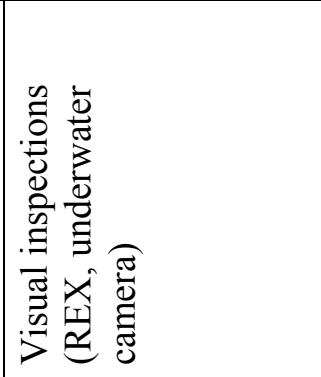 \\
\hline
\end{tabular}




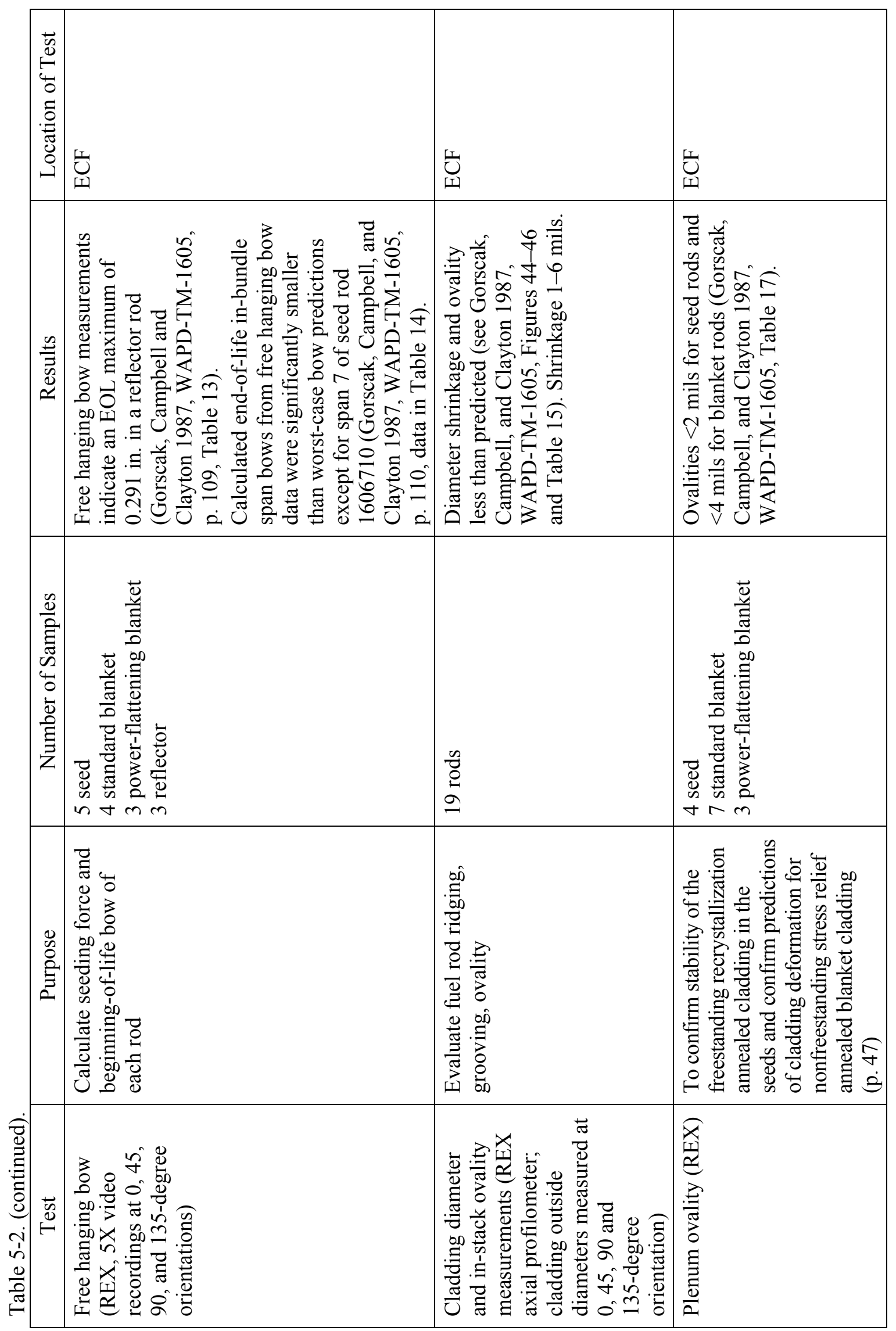




\begin{tabular}{|c|c|c|c|c|}
\hline 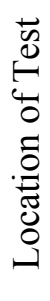 & $\underbrace{\mid L}_{\text {II }}$ & $\underbrace{\mathrm{I}}_{\text {U }}$ & $\underbrace{\mathrm{I}}_{\text {UI }}$ & 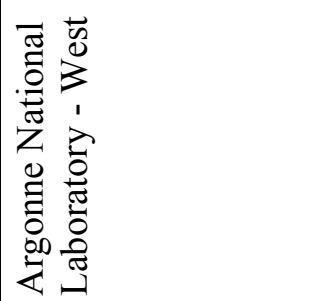 \\
\hline 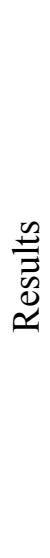 & 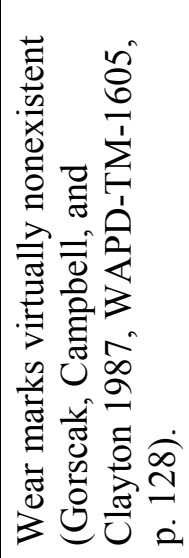 & 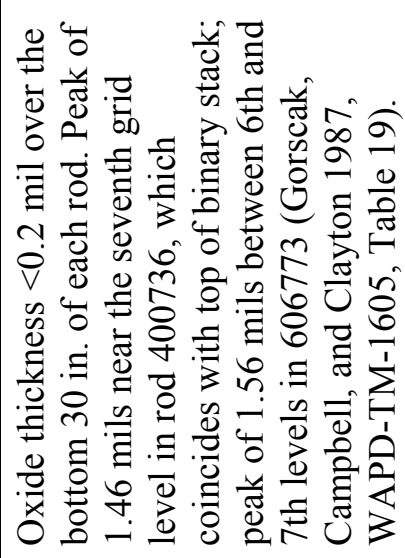 & 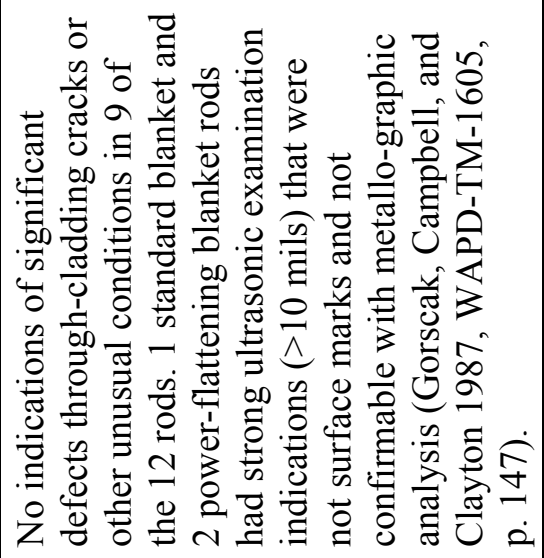 & 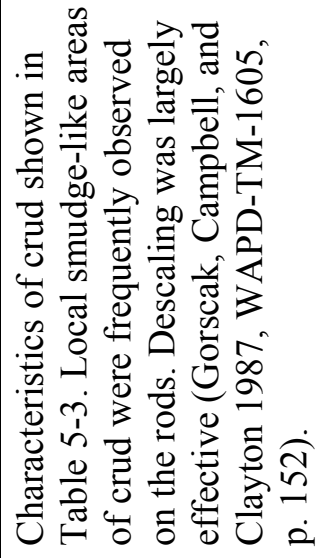 \\
\hline 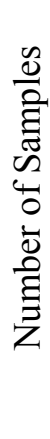 & 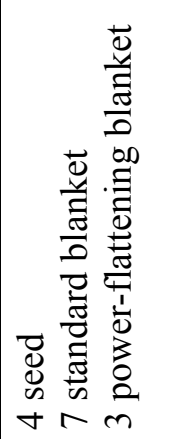 & 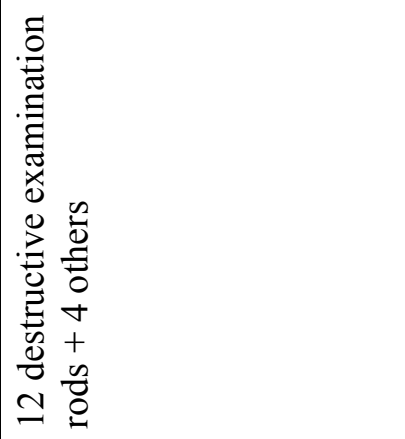 & 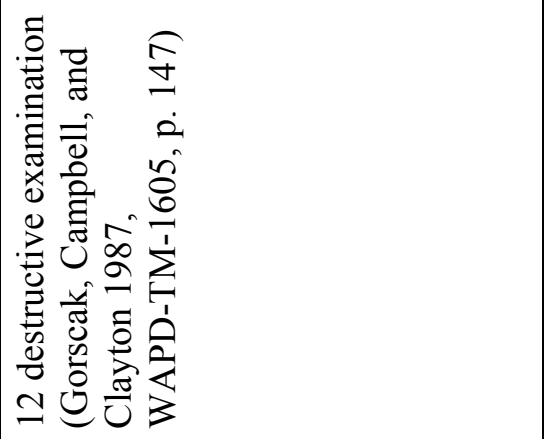 & 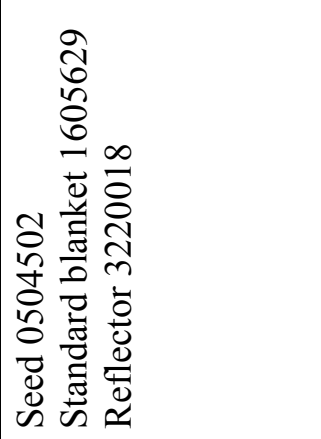 \\
\hline $\begin{array}{l}0 \\
\infty \\
0 \\
\vdots \\
\vdots \\
\vdots\end{array}$ & 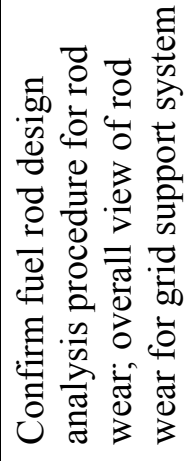 & 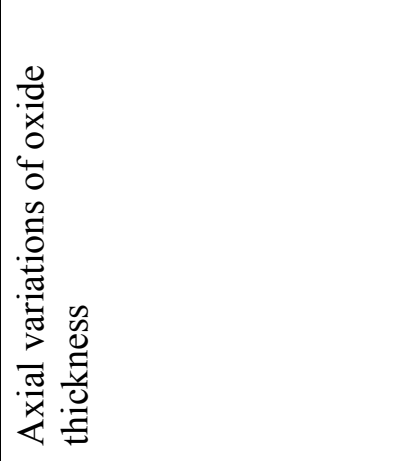 & 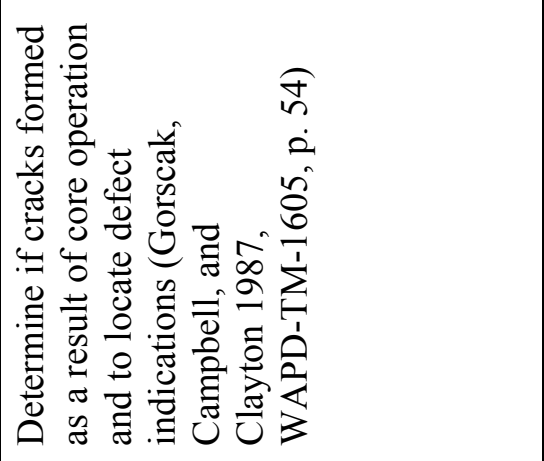 & 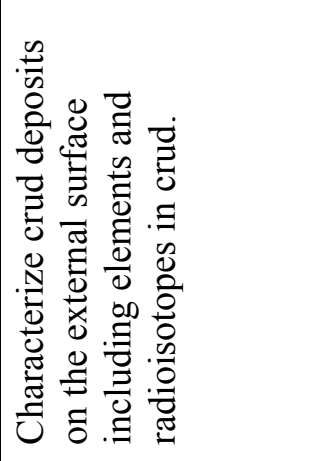 \\
\hline 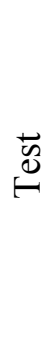 & 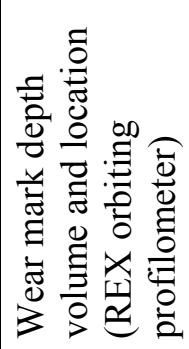 & 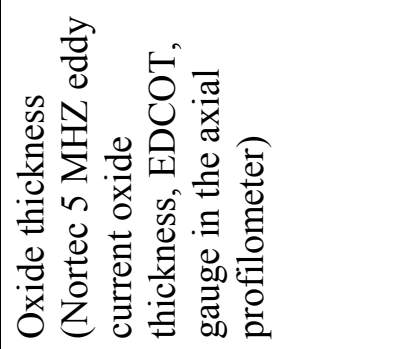 & 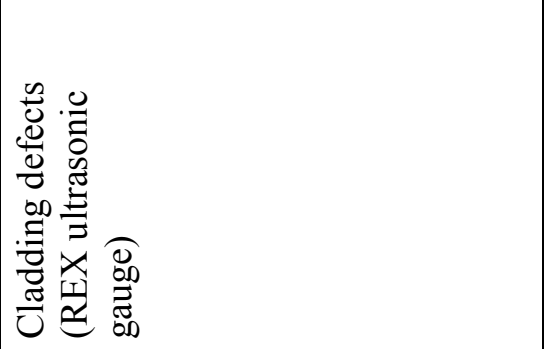 & 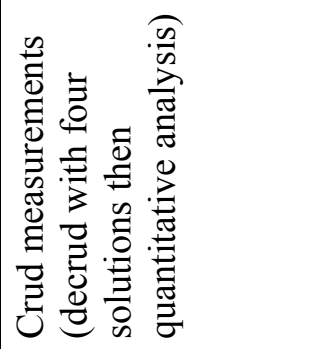 \\
\hline
\end{tabular}




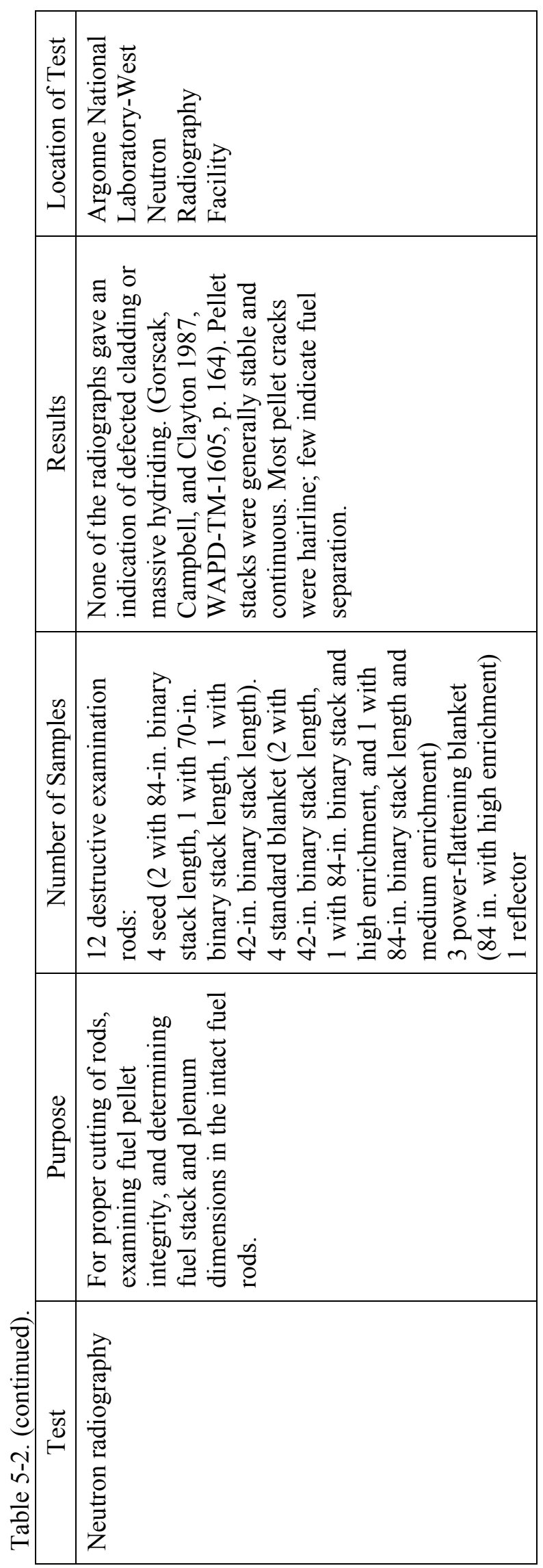


Table 5-3. Fuel rod crud characterization (Gorscak, Campbell, and Clayton 1987, WAPD-TM-1605, Table 21).

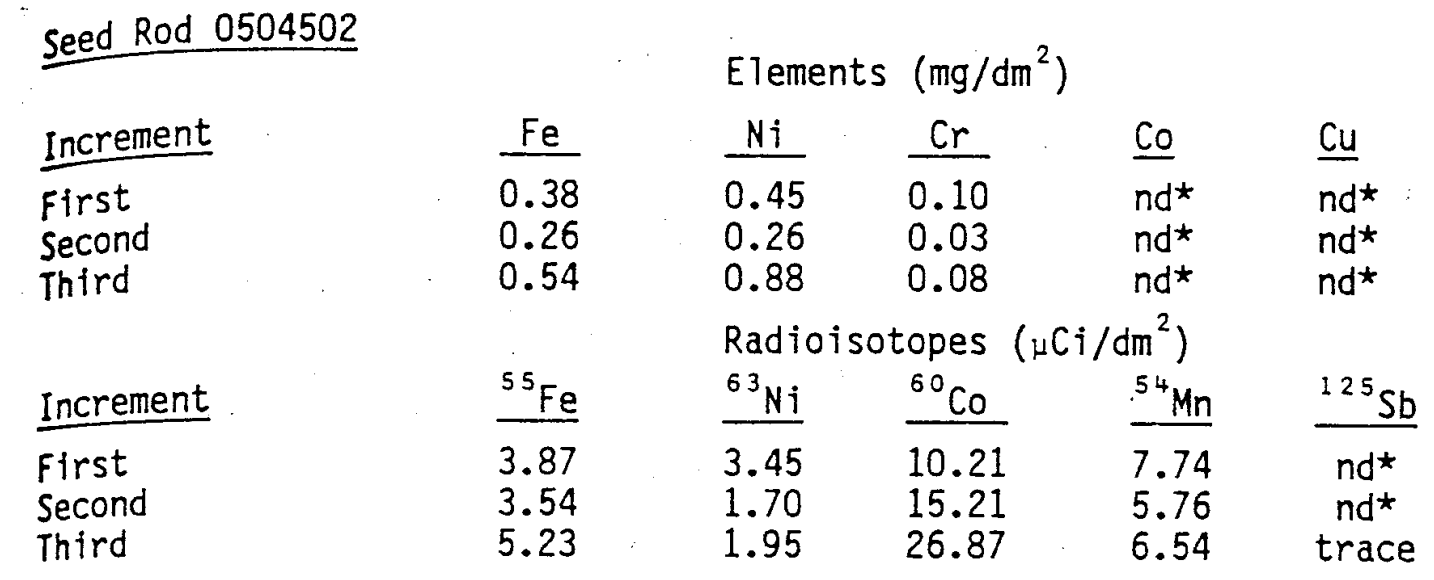

Blanket Rod 1605629

Increment
First
Second
Third

$\begin{array}{llllll}\frac{\mathrm{Fe}}{0.48} & \frac{\mathrm{Ni}}{\mathrm{N}} & \frac{\mathrm{Cr}}{0.39} & \frac{\mathrm{Co}}{\mathrm{Cu}} & \mathrm{Cu} \\ 0.73 & 0.56 & 0.04 & \mathrm{nd}^{\star} & \mathrm{nd} \\ 2.02 & 0.86 & 0.09 & \mathrm{nd}^{\star} & \mathrm{nd}^{\star} & \mathrm{nd}^{\star}\end{array}$

Increment

55 (6)

First

Second

Third

$\frac{{ }^{55 e}}{3.02}$

${ }^{63} \mathrm{Ni} \quad{ }_{1.91}^{60} \mathrm{Co}$

${ }^{54} \mathrm{Mn}$

1.91

12.68

5.57

42.61

8.52
13.83

4.18

62.76

3.30

7.10

5.81

$\frac{{ }^{25} \mathrm{Sb}}{\mathrm{nd}^{\star}}$

Reflector Rod 3220018

\begin{tabular}{|c|c|c|c|c|c|}
\hline \multirow[b]{2}{*}{ Increment } & & & & & \\
\hline & $\mathrm{Fe}$ & $\mathrm{Ni}$ & $\mathrm{Cr}$ & Co & $\underline{\mathrm{Cu}}$ \\
\hline $\begin{array}{l}\text { First } \\
\text { Second } \\
\text { Third }\end{array}$ & $\begin{array}{l}0.49 \\
0.34 \\
0.40\end{array}$ & $\begin{array}{l}0.47 \\
0.86 \\
0.04\end{array}$ & $\begin{array}{l}0.04 \\
0.04 \\
0.04\end{array}$ & $\begin{array}{l}\overline{n d^{*}} \\
\text { ndt }^{\star} \\
\text { nd }^{\star}\end{array}$ & $\begin{array}{l}\text { ndt } \\
\text { ndt } \\
\text { ndt }\end{array}$ \\
\hline & \multicolumn{5}{|c|}{ Radioisotopes $\left(\mu \mathrm{Ci} / \mathrm{dm}^{2}\right)$} \\
\hline Increment & ${ }^{55} \mathrm{Fe}$ & ${ }^{63} \mathrm{Ni}$ & ${ }^{60} \mathrm{Co}$ & ${ }^{54} \mathrm{Mn}$ & ${ }^{125} \mathrm{Sb}$ \\
\hline $\begin{array}{l}\text { First } \\
\text { Second } \\
\text { Third }\end{array}$ & $\begin{array}{l}2.03 \\
4.58 \\
2.16\end{array}$ & $\begin{array}{l}1.48 \\
5.08 \\
0.73\end{array}$ & $\begin{array}{l}2.61 \\
9.66 \\
5.13\end{array}$ & $\begin{array}{r}3.47 \\
2.69 \\
\text { nd* }\end{array}$ & $\begin{array}{l}\mathrm{nd}^{\star} \\
\text { nd* } \\
\text { ndt }\end{array}$ \\
\hline
\end{tabular}

*nd - not discernible 


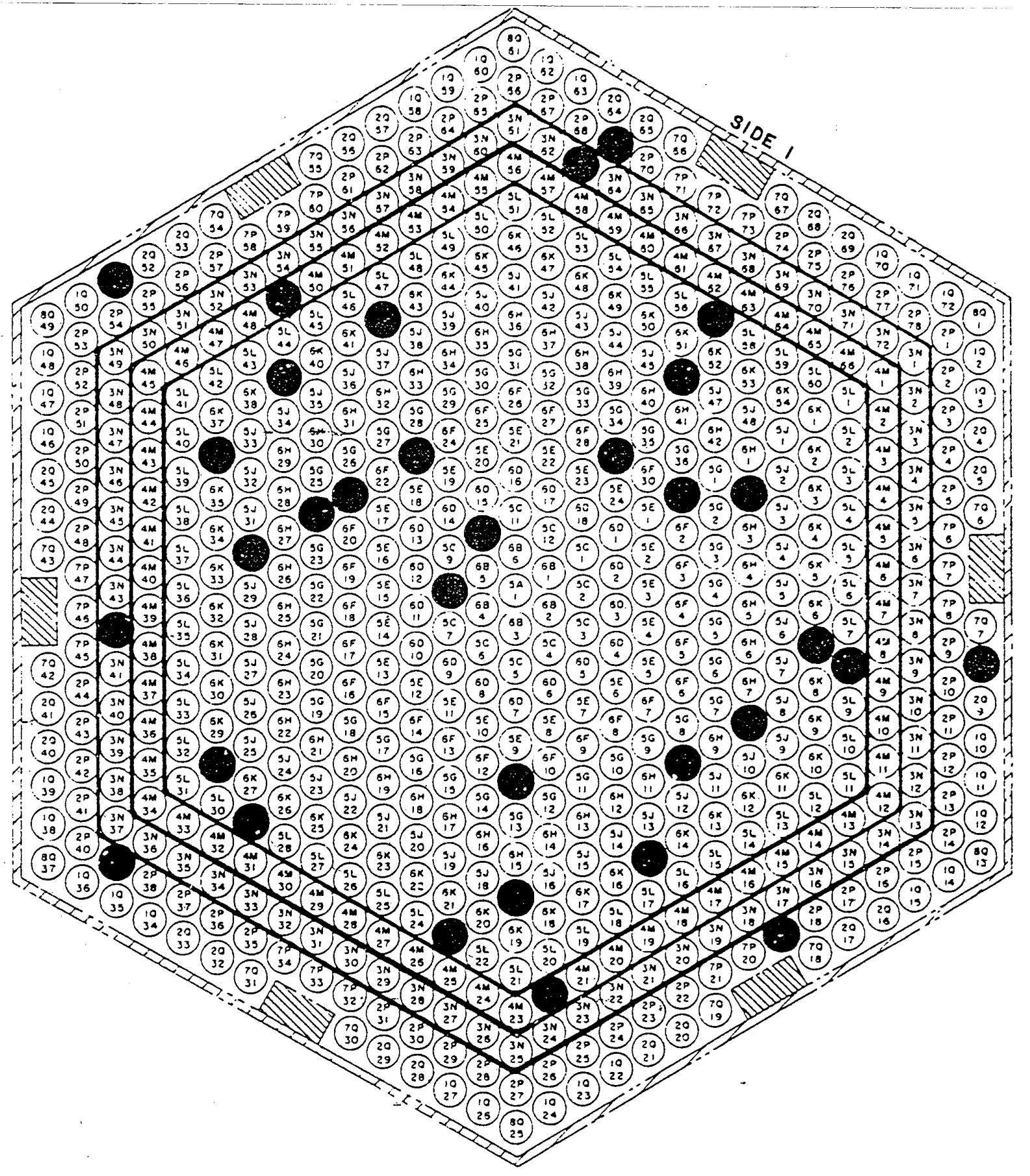

Figure 5-2. Location of proof-of-breeding rods in Seed Module I-1 (Schick et al. 1987, WAPD-TM-1612, Figure V-2). 


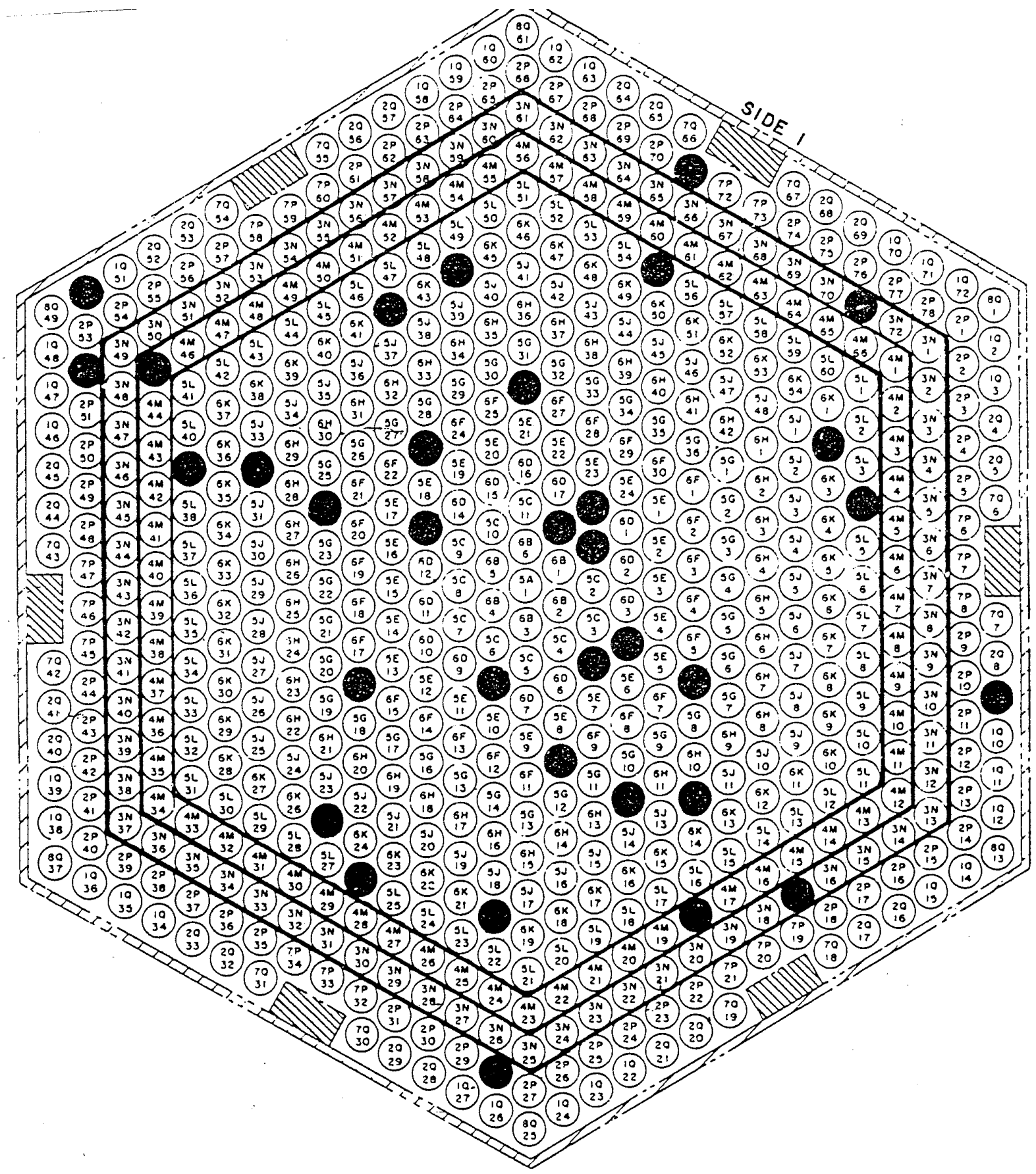

Figure 5-3. Location of proof-of-breeding rods in Seed Module II-3 (Schick et al. 1987, WAPD-TM-1612, Figure V-3). 


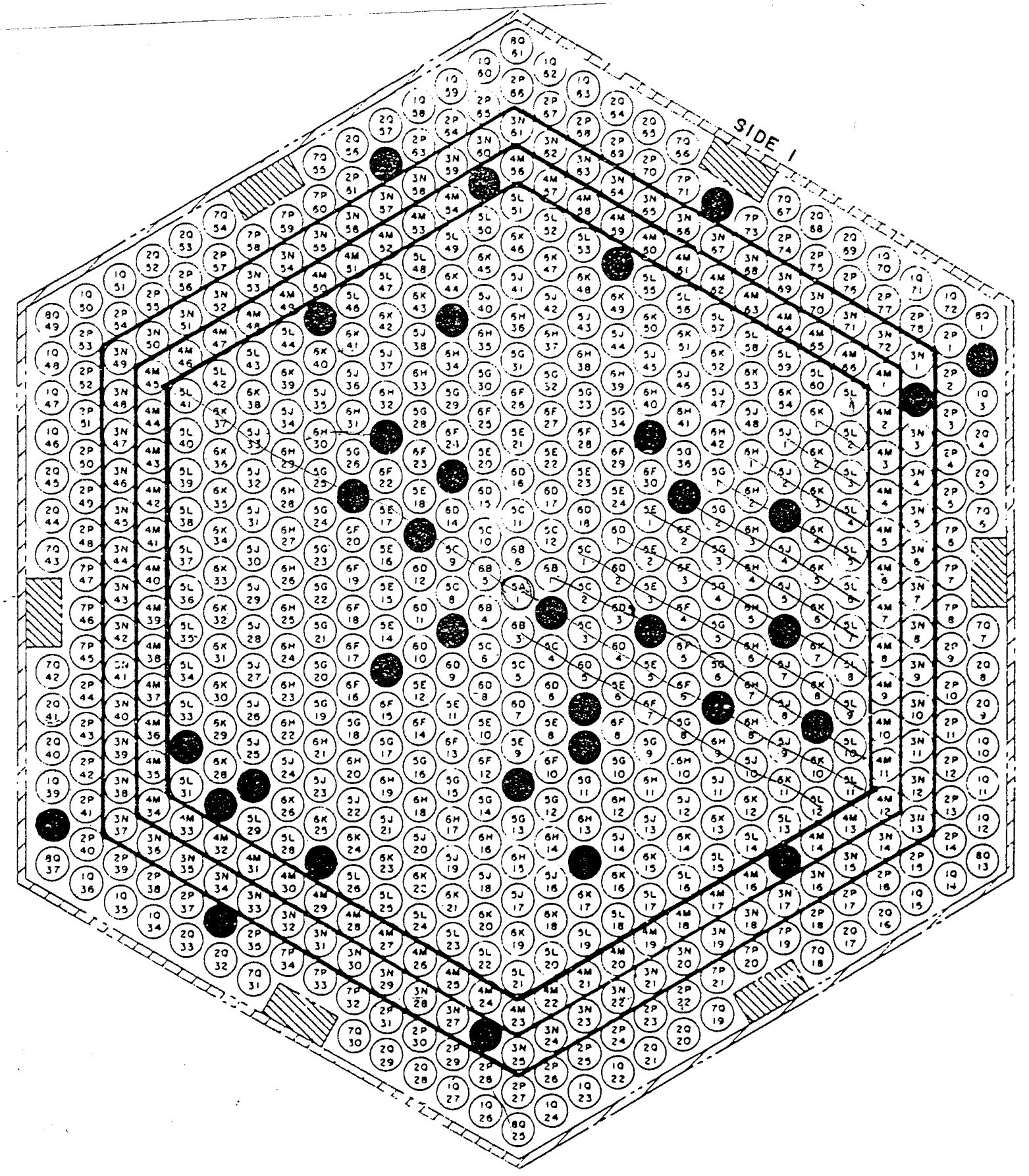

Figure 5-4. Location of proof-of-breeding rods in Seed Module III-1 (Schick et al. 1987, WAPD-TM-1612, Figure V-4). 


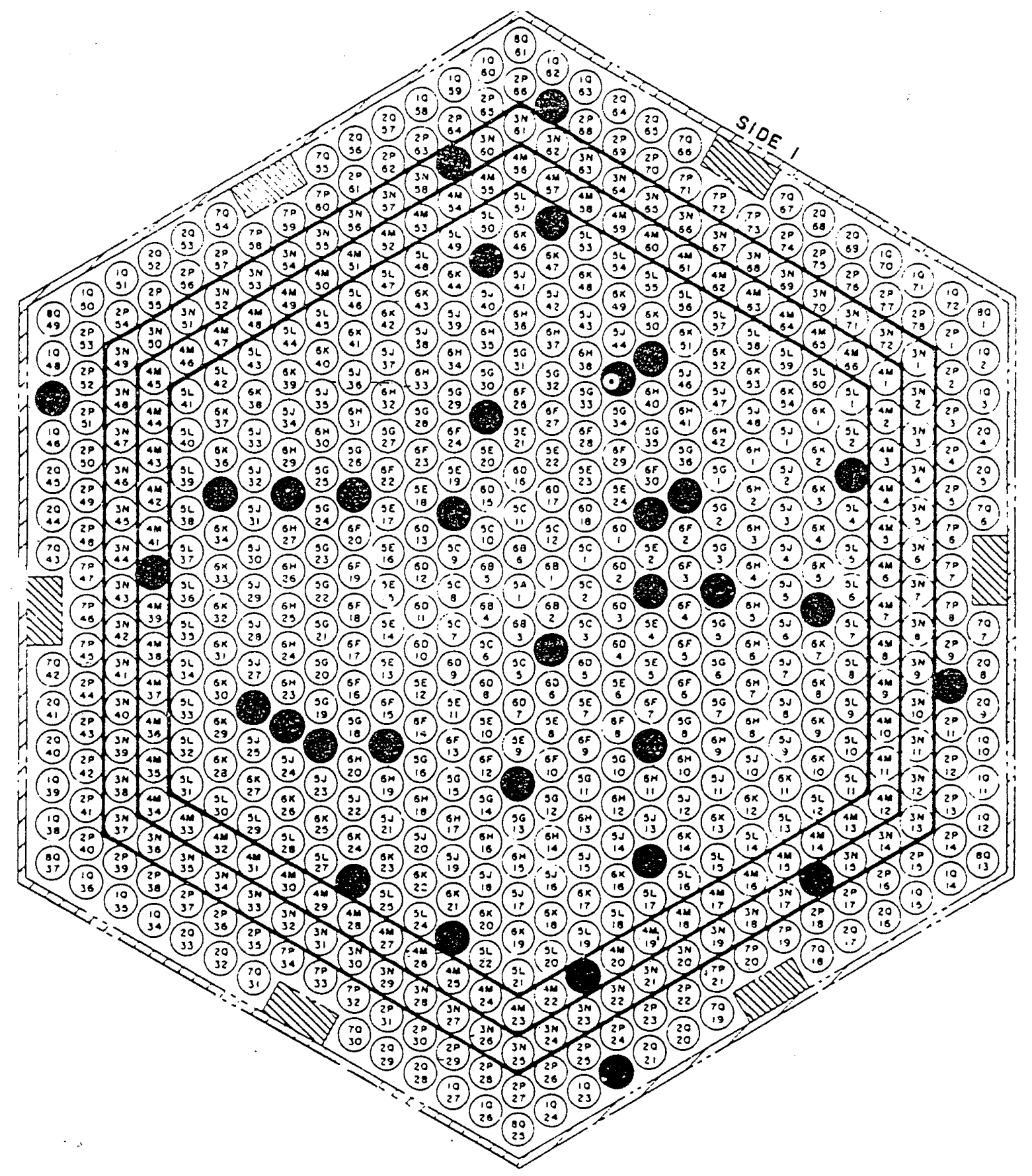

Figure 5-5. Location of proof-of-breeding rods in Seed Module III-2 (Schick et al. 1987, WAPD-TM-1612, Figure V-5). 


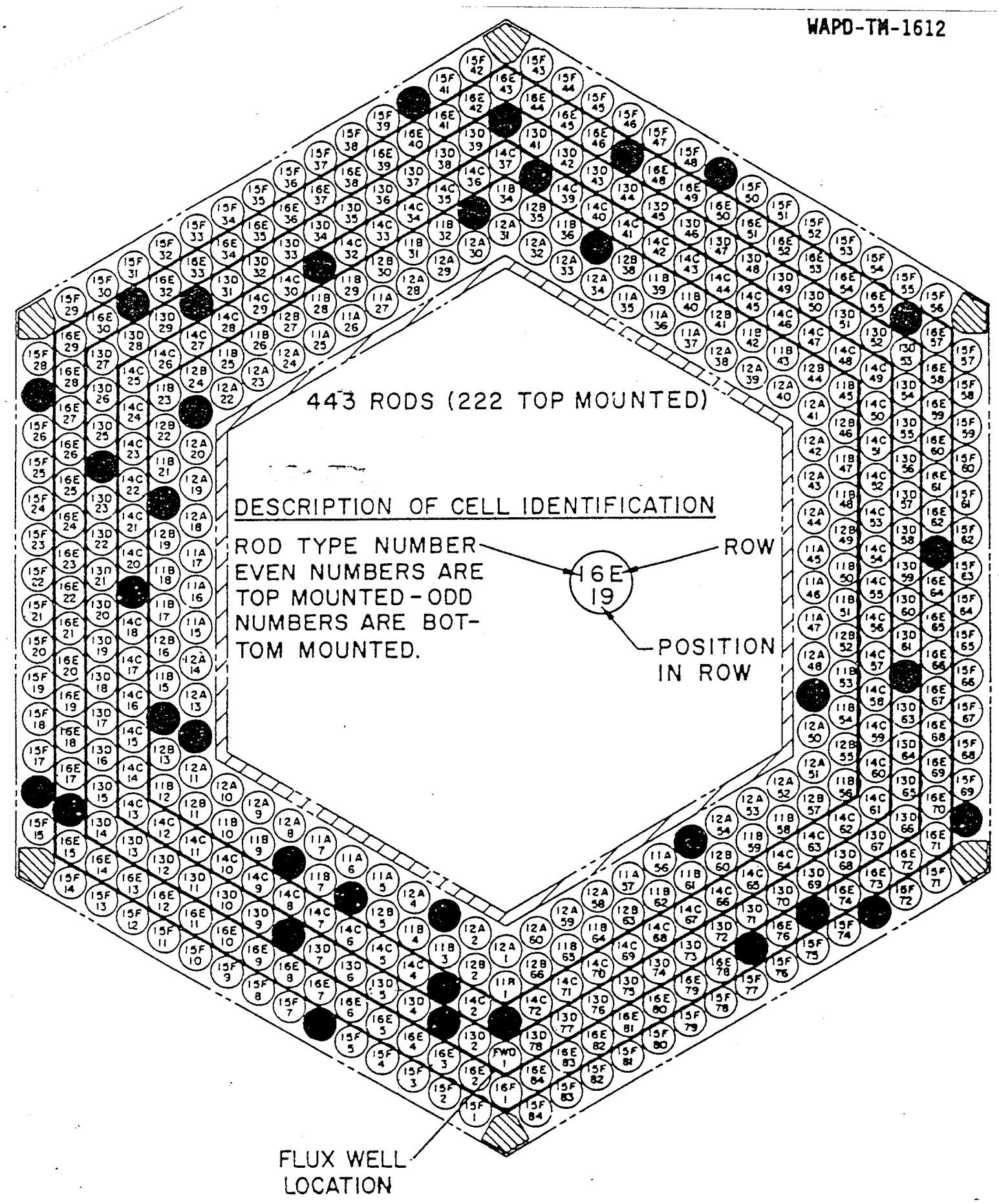

Figure 5-6. Location of proof-of-breeding rods in Blanket Module I-3 (Schick et al. 1987, WAPD-TM-1612, Figure V-6). 


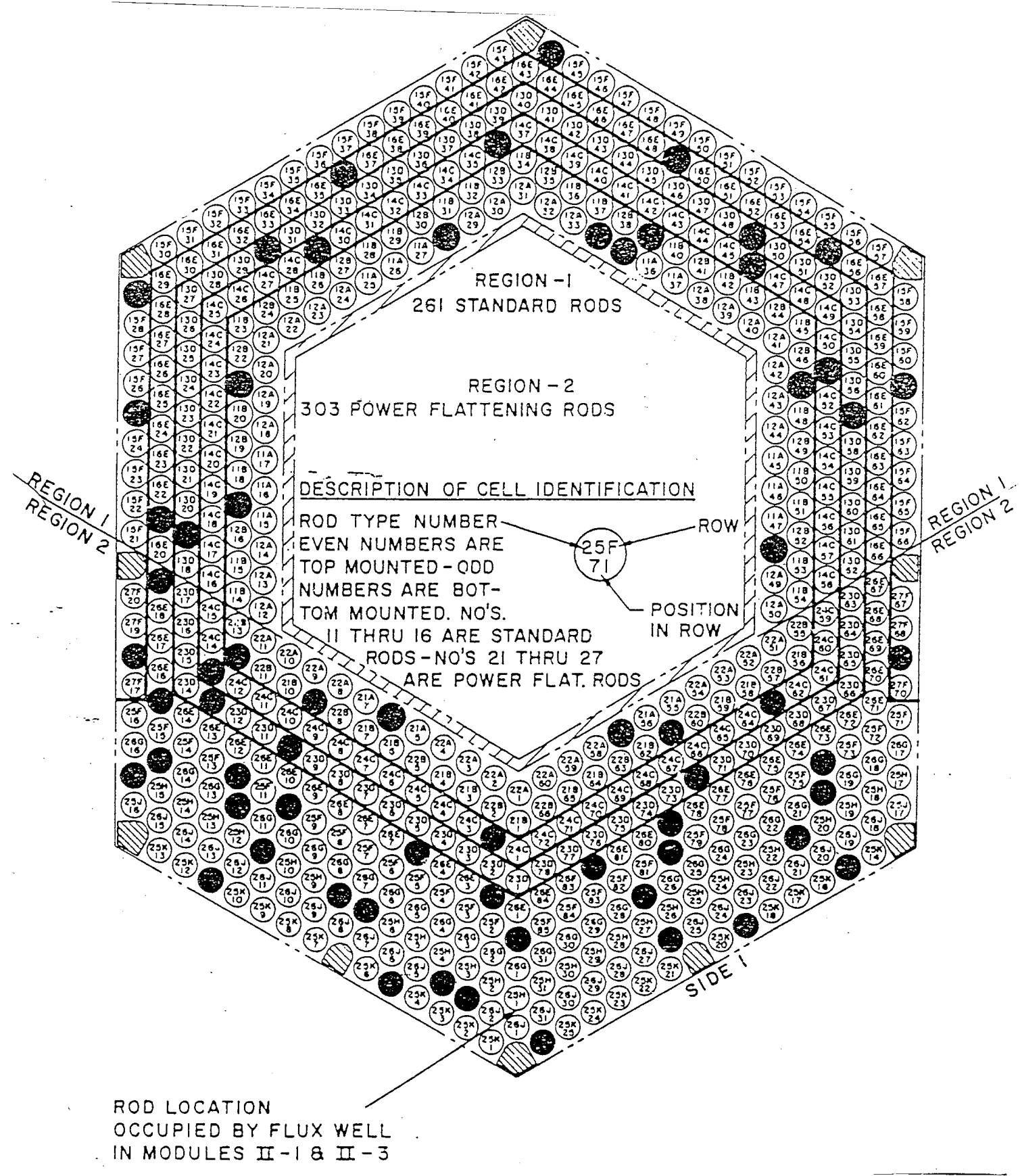

Figure 5-7. Location of proof-of-breeding rods in Blanket Module II-2 (Schick et al. 1987, WAPD-TM-1612, Figure V-7). 
WAPD-TM-1612

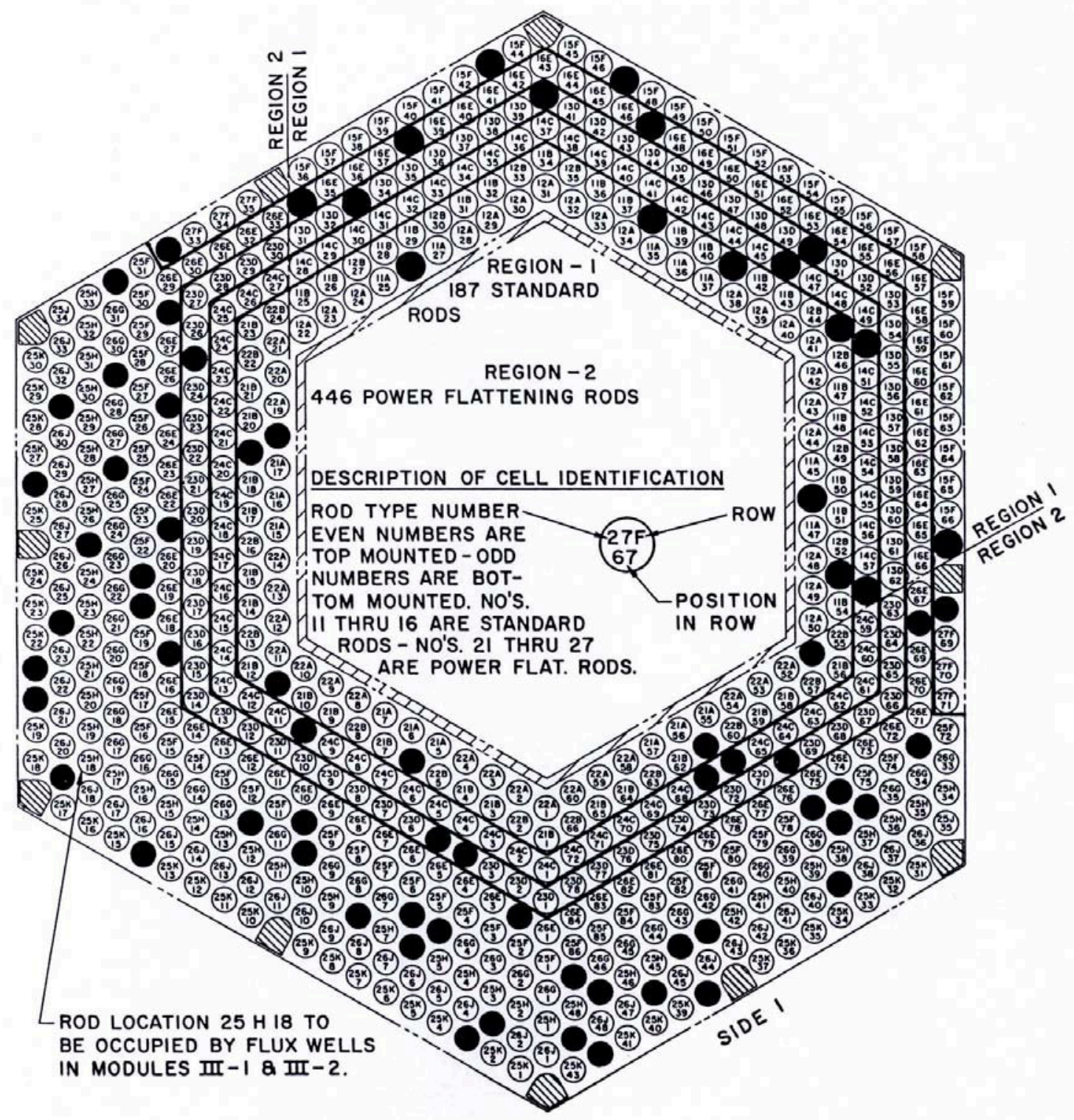

Figure 5-8. Location of proof-of-breeding rods in Blanket Module III-2 (Schick et al. 1987, WAPD-TM-1612, Figure V-8). 
HAPD-TM-1612

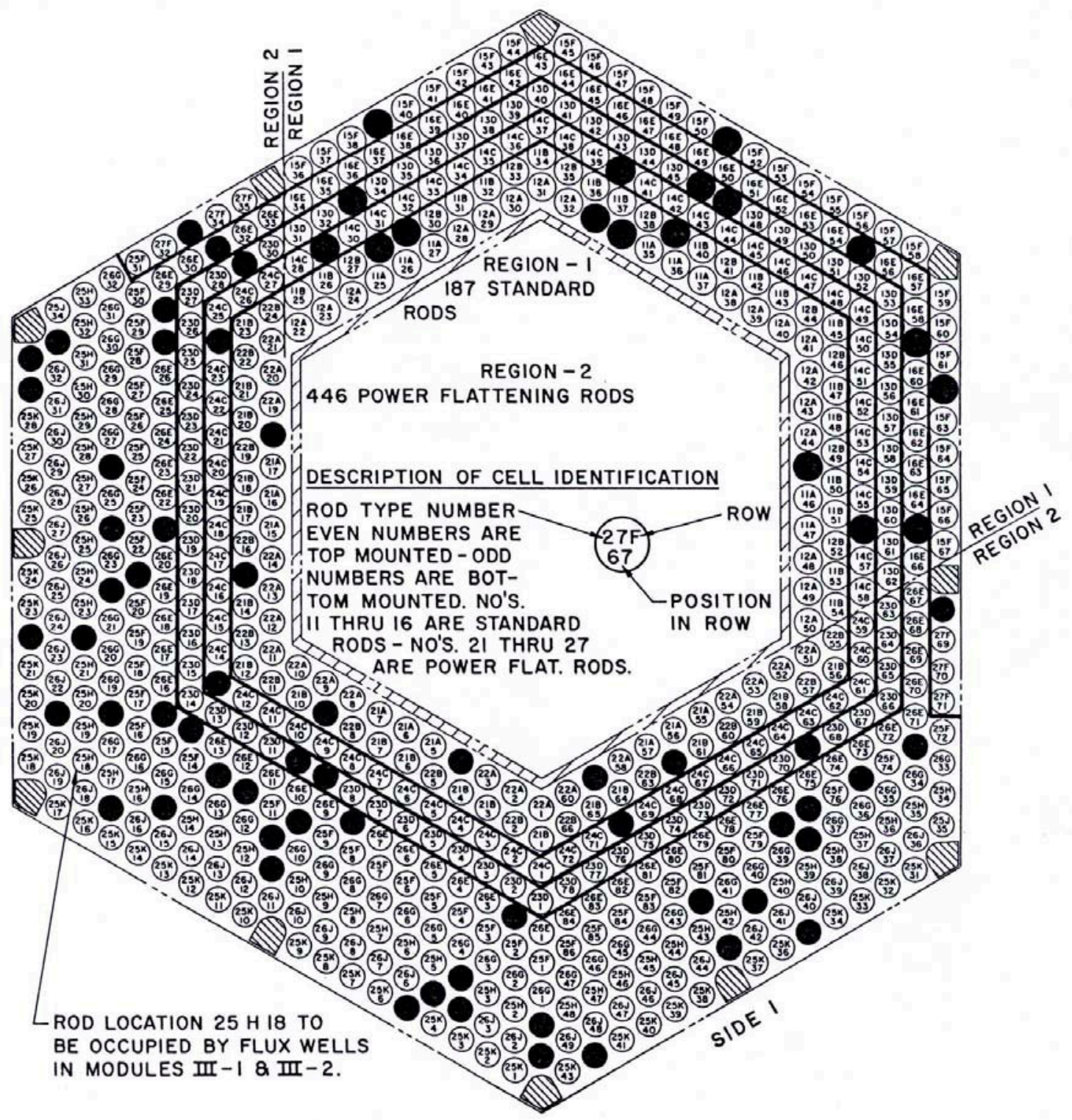

Figure 5-9. Location of proof-of-breeding rods in Blanket Module III-6 (Schick et al. 1987, WAPD-TM-1612, Figure V-9). 

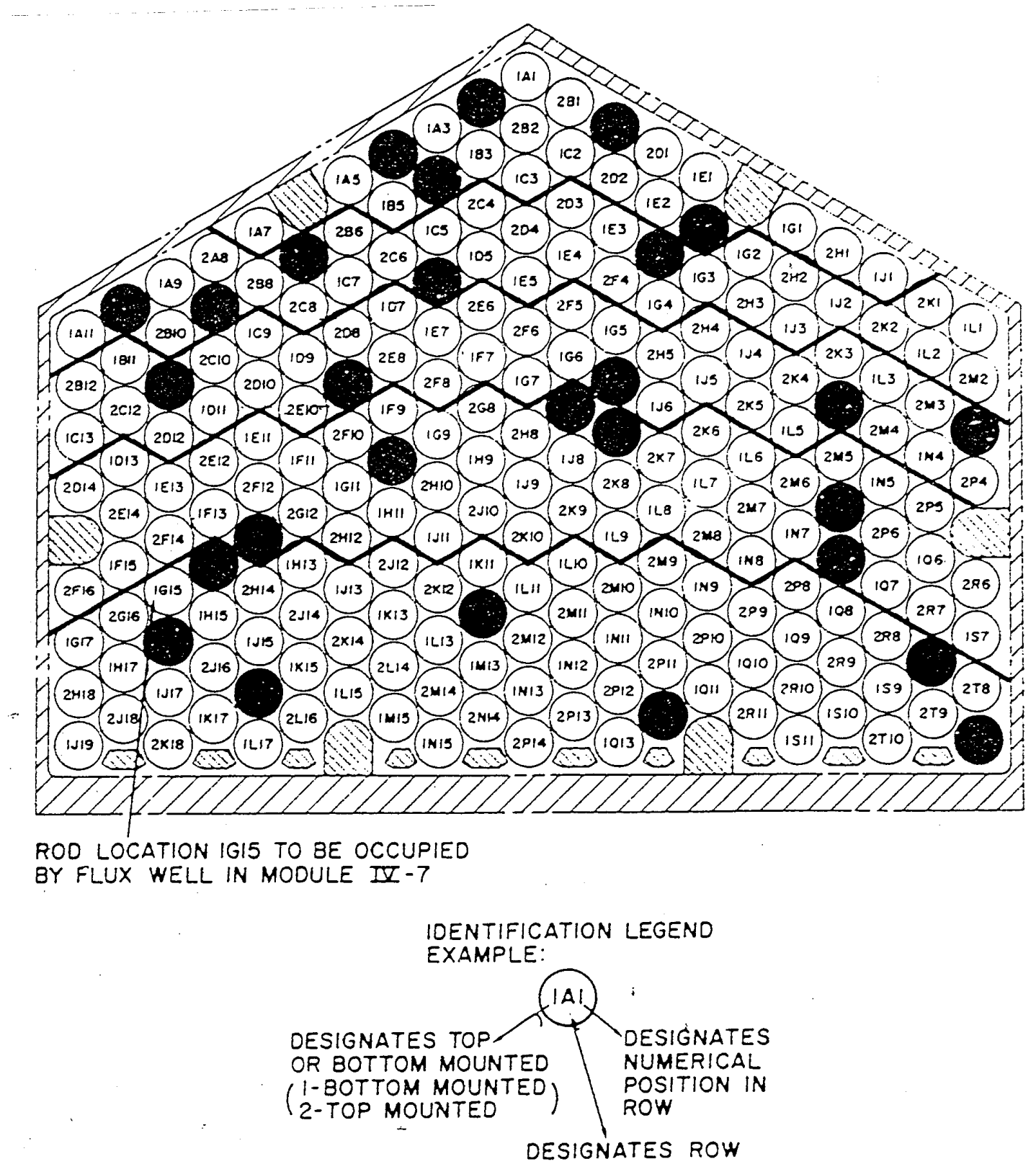

Figure 5-10. Location of proof-of-breeding rods in Reflector Module IV-4 (Schick et al. 1987, WAPD-TM-1612, Figure V-10). 

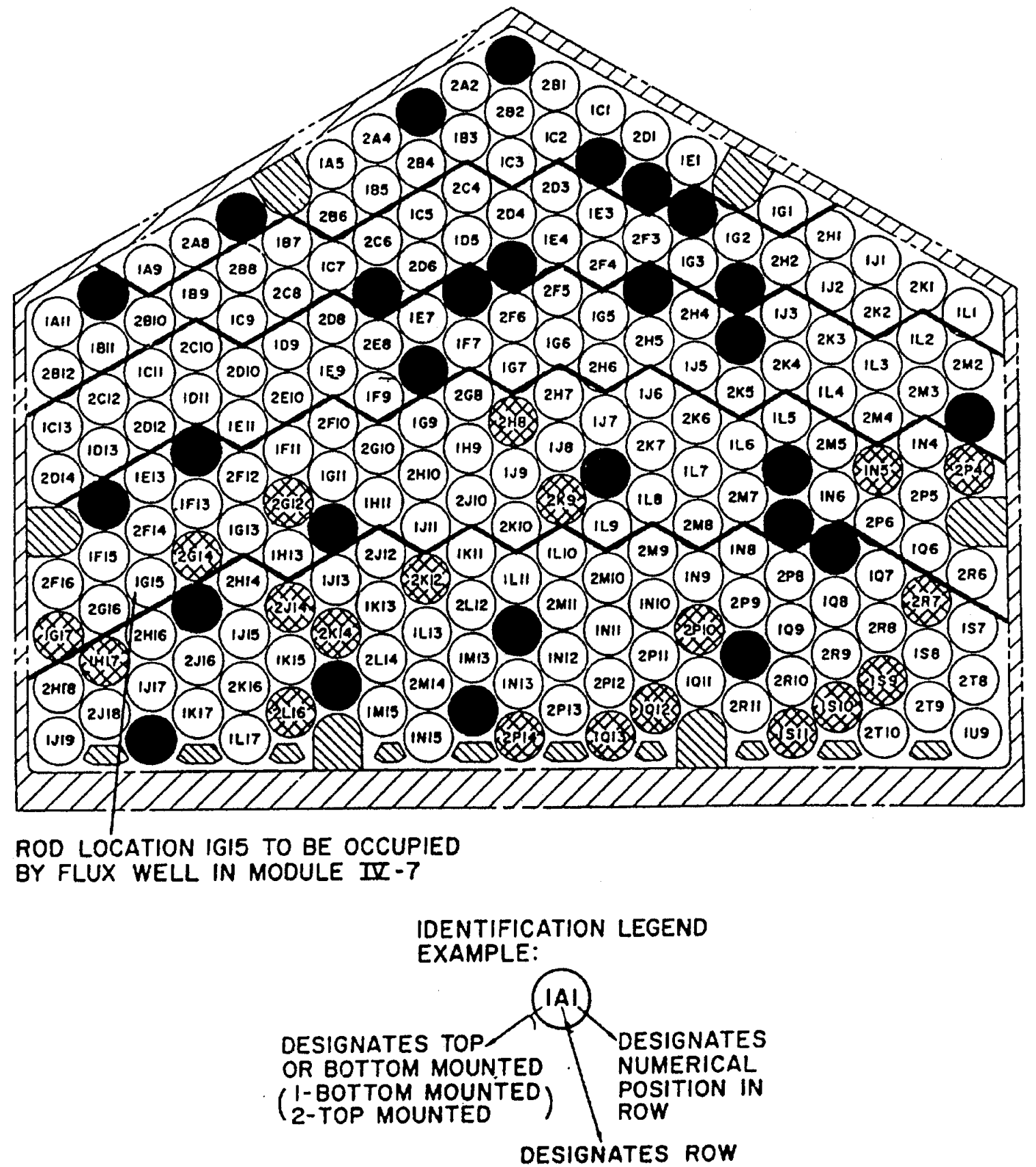

Figure 5-11. Location of proof-of-breeding (POB) rods in Reflector Module IV-9. Twenty additional rods that are not part of the original POB sample are indicated by cross hatching (Schick et al. 1987, WAPD-TM-1612, Figure V-11). 

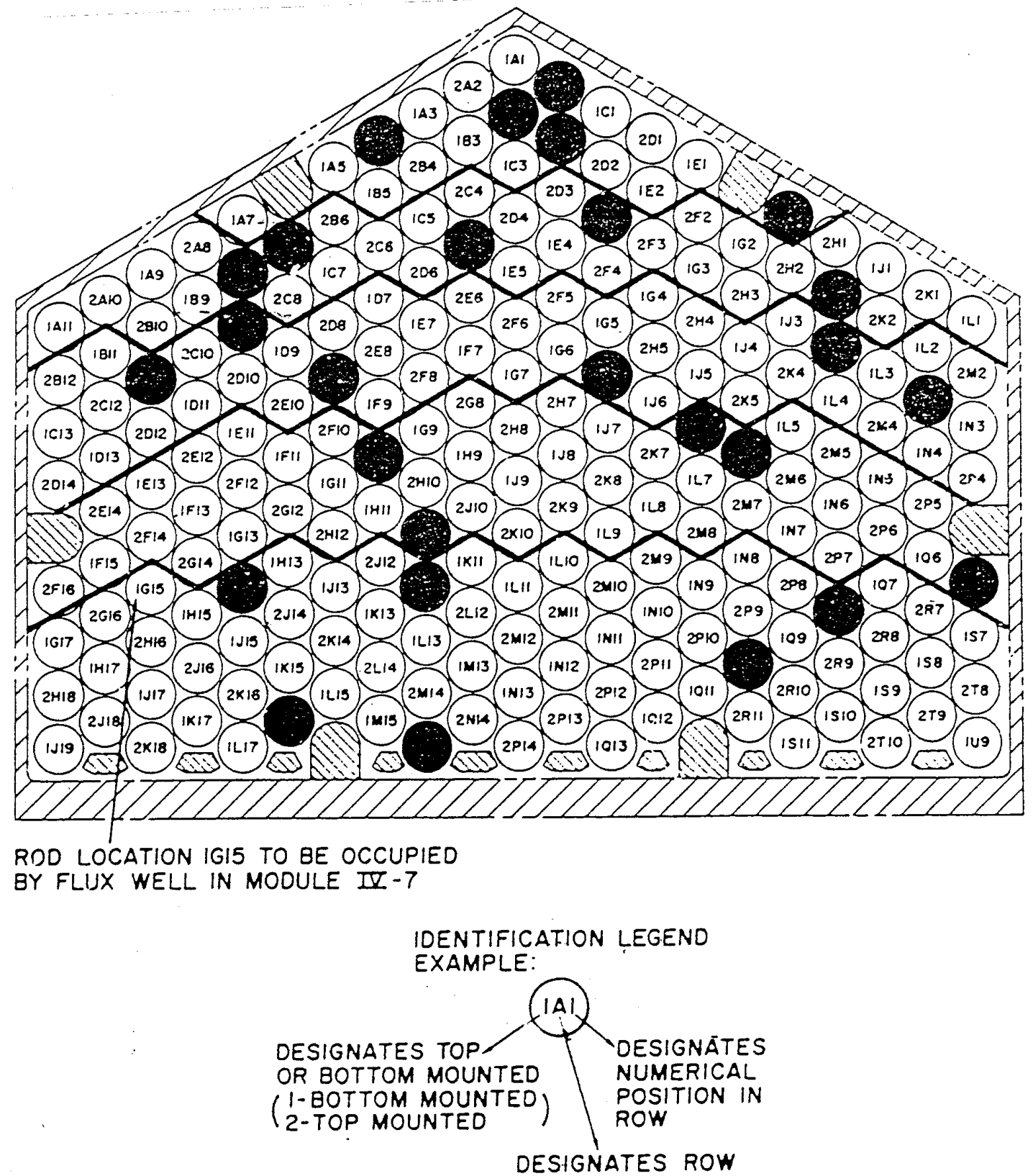

Figure 5-12. Location of proof-of-breeding rods in Reflector Module IV-3 (Schick et al. 1987, WAPD-TM-1612, Figure V-12). 

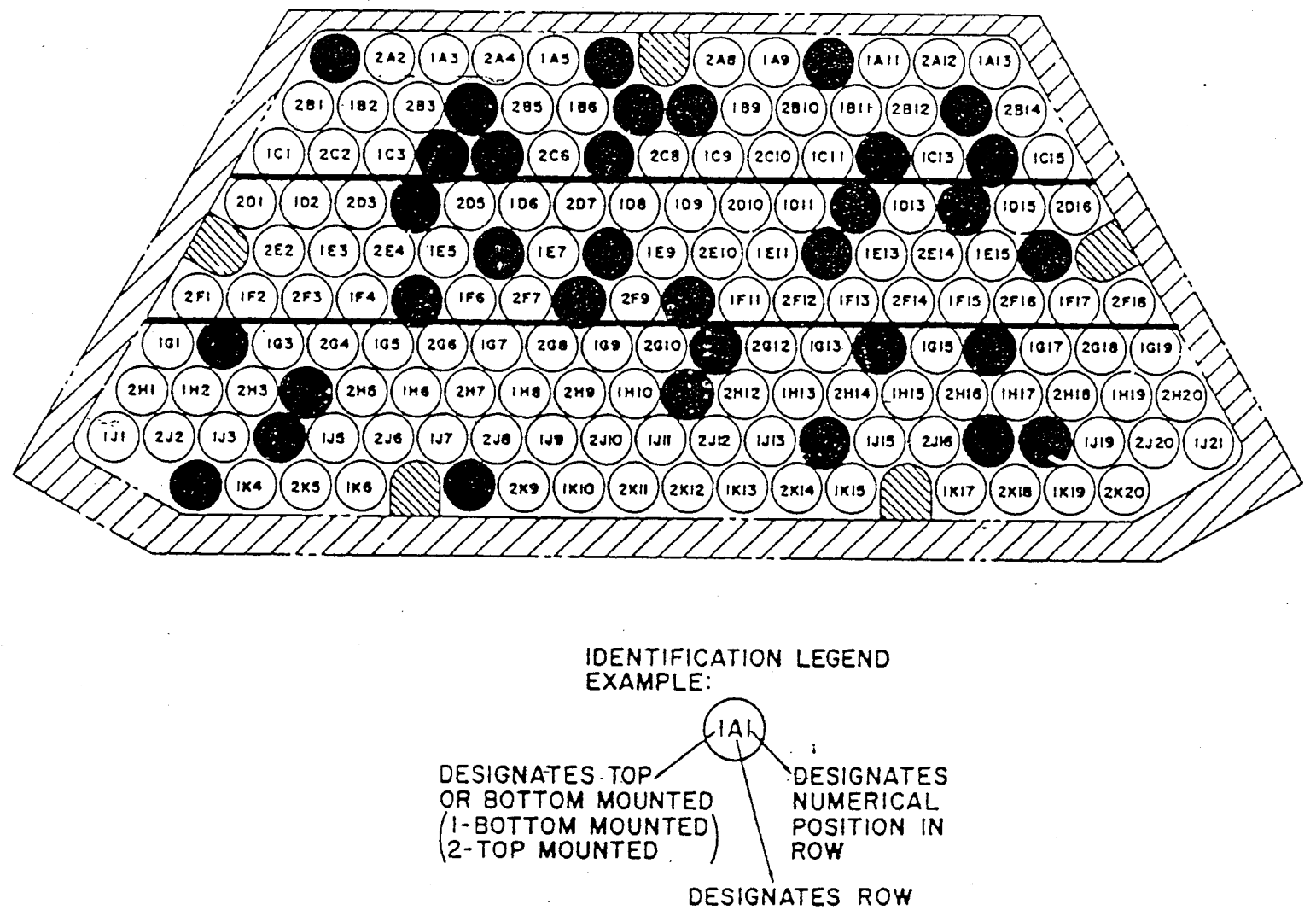

Figure 5-13. Location of proof-of-breeding rods in Reflector Module V-4 (Schick et al. 1987, WAPD-TM-1612, Figure V-13).

sampling plan, and the resulting data were used to estimate the EOL fissile inventory for the whole core. Data from the PIFAG are provided in Appendix A. EOL fissile data from PIFAG were compared with data from extensive destructive evaluations to assess the accuracy of the PIFAG. EOL and beginning-of-life data were compared to determine if breeding had occurred (Tessler et al. 1987, WAPD-TM-1614, p. 1).

The PIFAG used the method of active neutron interrogation and delayed neutron counting (see Tessler et al. 1987, WAPD-TM-1614) to determine the fissile uranium loading of each rod. The PIFAG was assembled in a hot cell at Naval Reactors ECF. As-fabricated (unirradiated) rods were used to calibrate the PIFAG. Isotopic loadings for individual unirradiated seed, standard blanket, power-flattening and reflector rods are presented in Table 5-4. Core rod testing was conducted from June 1984 to May 1987 (Tessler et al. 1987, WAPD-TM-1614).

Rods were irradiated by neutrons from four Cf-252 sources, then delayed neutrons resulting from the fissions occurring from the source were counted as the rod passed through the detector region. The indium-cadmium liner in the PIFAG could be positioned to provide thermal or epithermal neutron interrogation spectrum. After an epithermal mode foreground pass, the rods were gamma scanned, and a cumulative gamma ray spectrum was recorded (Tessler et al. 1987, WAPD-TM-1614, p. 25). The PIFAG performance was closely monitored. The accuracy of the PIFAG was determined by comparing PIFAG results with destructive analysis results for 17 of the rods (Tessler et al. 1987, WAPD-TM-1614, p.74). 
Table 5-4. Calibration rod isotopic loadings. All values are in grams (Tessler et al. 1987, WAPD-TM-1614, Table 24).

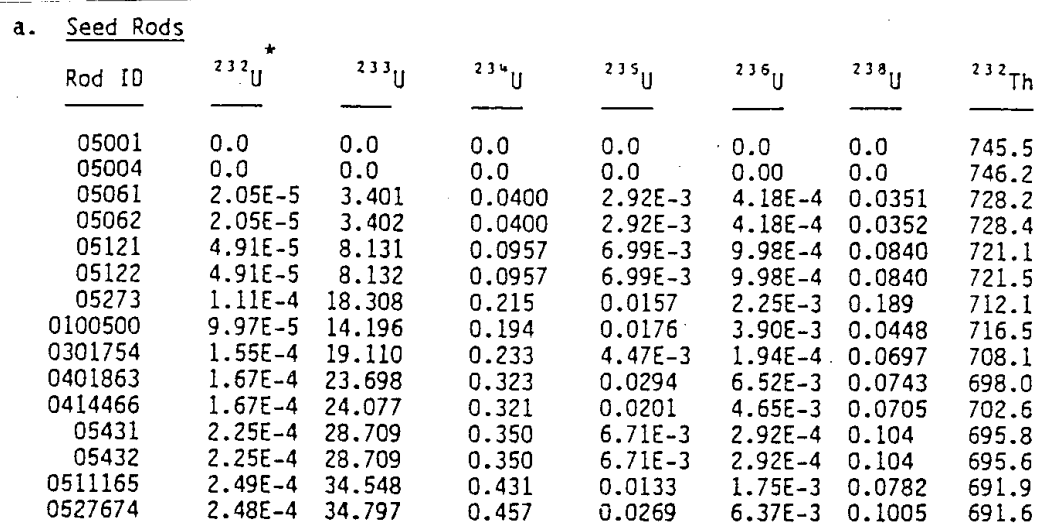

b. Regular BTanket Rods

\begin{tabular}{|c|c|c|c|c|c|c|c|c|}
\hline \multirow[b]{2}{*}{1} & Rod ID & $232 \mathrm{U}$ & ${ }^{233} \mathrm{U}$ & ${ }^{234} \mathrm{U}$ & ${ }^{235} \mathrm{U}$ & $236 \mathrm{U}$ & ${ }^{238} \mathrm{U}$ & ${ }^{232} \mathrm{Th}$ \\
\hline & $\begin{array}{r}15002 \\
15004 \\
15061 \\
15064 \\
1103425 \\
1104780 \\
15122 \\
15124 \\
1412359 \\
1501827 \\
1512019 \\
1300545 \\
1613659 \\
1613834\end{array}$ & $\begin{array}{l}0.0 \\
0.0 \\
8.35 E-5 \\
8.35 \mathrm{E}-5 \\
1.41 \mathrm{E}-4 \\
1.40 \mathrm{E}-4 \\
2.57 \mathrm{E}-4 \\
2.58 \mathrm{E}-4 \\
2.54 \mathrm{E}-4 \\
3.89 \mathrm{E}-4 \\
3.89 \mathrm{E}-4 \\
3.83 \mathrm{E}-4 \\
4.59 \mathrm{E}-4 \\
4.59 \mathrm{E}-4\end{array}$ & $\begin{array}{l}0.0 \\
0.0 \\
13.838 \\
13.829 \\
16.445 \\
16.431 \\
32.814 \\
32.829 \\
30.094 \\
45.577 \\
45.528 \\
45.399 \\
54.397 \\
54.380\end{array}$ & $\begin{array}{l}0.0 \\
0.0 \\
0.163 \\
0.163 \\
0.221 \\
0.221 \\
0.475 \\
0.475 \\
0.392 \\
0.612 \\
0.611 \\
0.604 \\
0.719 \\
0.719\end{array}$ & $\begin{array}{l}0.0 \\
0.0 \\
0.0119 \\
0.0119 \\
0.0135 \\
0.0135 \\
0.0478 \\
0.0478 \\
0.0190 \\
0.0380 \\
0.0380 \\
0.0362 \\
0.0431 \\
0.0431\end{array}$ & $\begin{array}{l}0.0 \\
0.0 \\
1.70 E-3 \\
1.70 E-3 \\
3.51 E-3 \\
3.51 E-3 \\
0.0154 \\
0.0154 \\
3.98 E-3 \\
9.74 E-3 \\
9.73 E-3 \\
9.15 E-3 \\
0.0111 \\
0.0111\end{array}$ & $\begin{array}{l}0.0 \\
0.0 \\
0.143 \\
0.143 \\
0.0452 \\
0.0451 \\
0.0823 \\
0.0823 \\
0.0826 \\
0.124 \\
0.124 \\
0.119 \\
0.143 \\
0.143\end{array}$ & $\begin{array}{l}2954.3 \\
2959.0 \\
2949.5 \\
2949.0 \\
2931.2 \\
2936.2 \\
2910.7 \\
2912.2 \\
2953.6 \\
2915.2 \\
2914.9 \\
2904.0 \\
2923.6 \\
2922.3\end{array}$ \\
\hline \multirow[t]{3}{*}{ c. } & \multicolumn{8}{|c|}{ Power Flattening Blanket Rods } \\
\hline & Rod ID & $232 \mathrm{U}$ & ${ }^{233} \mathrm{U}$ & ${ }^{234} \mathrm{U}$ & $235 \mathrm{U}$ & $236 u$ & ${ }^{238} \mathrm{U}$ & ${ }^{232} \mathrm{Th}$ \\
\hline & $\begin{array}{r}25001 \\
25004 \\
25063 \\
25064 \\
25122 \\
25123 \\
2100153 \\
2103140 \\
25161 \\
25163 \\
2402626 \\
2700468 \\
2701624 \\
2303222 \\
2500452 \\
2502616\end{array}$ & $\begin{array}{l}0.0 \\
0.0 \\
7.04 \mathrm{E}-5 \\
7.03 \mathrm{E}-5 \\
1.69 \mathrm{E}-4 \\
1.69 \mathrm{E}-4 \\
1.60 \mathrm{E}-4 \\
1.58 \mathrm{E}-4 \\
3.19 \mathrm{E}-4 \\
3.22 \mathrm{E}-4 \\
2.43 \mathrm{E}-4 \\
3.82 \mathrm{E}-4 \\
3.56 \mathrm{E}-4 \\
3.76 \mathrm{E}-4 \\
4.43 \mathrm{E}-4 \\
4.51 \mathrm{E}-4\end{array}$ & $\begin{array}{c}0.0 \\
0.0 \\
11.660 \\
11.646 \\
27.930 \\
27.940 \\
18.910 \\
18.972 \\
37.813 \\
38.168 \\
30.601 \\
46.313 \\
46.523 \\
52.579 \\
62.959 \\
63.139\end{array}$ & $\begin{array}{l}0.0 \\
0.0 \\
0.137 \\
0.137 \\
0.329 \\
0.329 \\
0.250 \\
0.257 \\
0.500 \\
0.505 \\
0.424 \\
0.636 \\
0.683 \\
0.639 \\
0.732 \\
0.747\end{array}$ & $\begin{array}{l}0.0 \\
0.0 \\
0.0100 \\
0.0100 \\
0.0240 \\
0.0240 \\
0.0144 \\
0.0180 \\
0.0292 \\
0.0295 \\
0.0343 \\
0.0519 \\
0.0749 \\
0.0440 \\
0.0398 \\
0.0464\end{array}$ & $\begin{array}{l}0.0 \\
0.0 \\
1.43 E-3 \\
1.43 E-3 \\
3.43 E-3 \\
3.43 E-3 \\
3.46 E-3 \\
4.83 E-3 \\
6.92 E-3 \\
6.99 E-3 \\
9.97 E-3 \\
0.0146 \\
0.0237 \\
8.59 E-3 \\
7.71 E-3 \\
0.0122\end{array}$ & $\begin{array}{l}0.0 \\
0.0 \\
0.120 \\
0.120 \\
0.289 \\
0.289 \\
0.0496 \\
0.0521 \\
0.0984 \\
0.0993 \\
0.0826 \\
0.126 \\
0.124 \\
0.415 \\
0.482 \\
0.439\end{array}$ & $\begin{array}{l}2488.9 \\
2493.2 \\
2489.8 \\
2486.5 \\
2473.8 \\
2474.7 \\
2477.8 \\
2471.2 \\
2459.3 \\
2459.2 \\
2472.6 \\
2452.6 \\
2455.7 \\
2433.6 \\
2427.1 \\
2431.0\end{array}$ \\
\hline \multicolumn{9}{|c|}{ d. } \\
\hline & Rod ID & ${ }^{232} \mathrm{U}$ & ${ }^{233} \mathrm{~V}$ & ${ }^{234} \mathrm{U}$ & ${ }^{235} \mathrm{U}$ & ${ }^{236} U$ & ${ }^{238} U$ & ${ }^{232} \mathrm{Th}$ \\
\hline & $\begin{array}{r}3106718 \\
3108707 \\
3102143 \\
31062 \\
31063 \\
31123 \\
31124\end{array}$ & $\begin{array}{l}0.0 \\
0.0 \\
0.0 \\
1.75 E-4 \\
1.75 E-4 \\
4.19 E-4 \\
4.19 E-4\end{array}$ & $\begin{array}{c}0.0 \\
0.0 \\
0.0 \\
29.048 \\
29.052 \\
69.363 \\
69.401\end{array}$ & $\begin{array}{l}0.0 \\
0.0 \\
0.0 \\
0.342 \\
0.342 \\
0.816 \\
0.817\end{array}$ & $\begin{array}{l}0.0 \\
0.0 \\
0.0 \\
0.0250 \\
0.0250 \\
0.0596 \\
0.0596\end{array}$ & $\begin{array}{l}0.0 \\
0.0 \\
0.0 \\
3.57 E-3 \\
3.57 E-3 \\
8.52 E-3 \\
8.52 E-3\end{array}$ & $\begin{array}{l}0.0 \\
0.0 \\
0.0 \\
0.300 \\
0.300 \\
0.717 \\
0.717\end{array}$ & $\begin{array}{l}6089.4 \\
6028.1 \\
6036.7 \\
6033.9 \\
6037.6 \\
5978.9 \\
5976.9\end{array}$ \\
\hline
\end{tabular}

* Notation n. nnE-n $\equiv n . n n \times 10^{-n}$ 
Paired t-test analysis of the differences in results by rod type indicates a small statistically insignificant bias at the 5\% significance levels (Tessler et al., WAPD-TM-1614, pp. 60-61). Table 5-1 shows the comparative results of the PIFAG and the destructively evaluated rods.

REX. The Rod Examination (REX) gauge measured fuel rod length, diameter, oxide thickness, ovality, wear mark depth, and volume and provided a $5 \mathrm{X}$ visual examination and video recording capabilities. The gauge also had the capability of ultrasonic screening of the fuel rod cladding for defects.

Nineteen rods were removed for nondestructive examinations in the REX gauge (12 of those were also destructively examined at ANL-W). The 19 were selected to evaluate the effects of a broad range of parameters on fuel rod performance and included: 6 seed rods, 7 standard blanket rods, 3 power-flattening rods, and 3 reflector rods. Their approximate locations are shown in Figure 5-14.

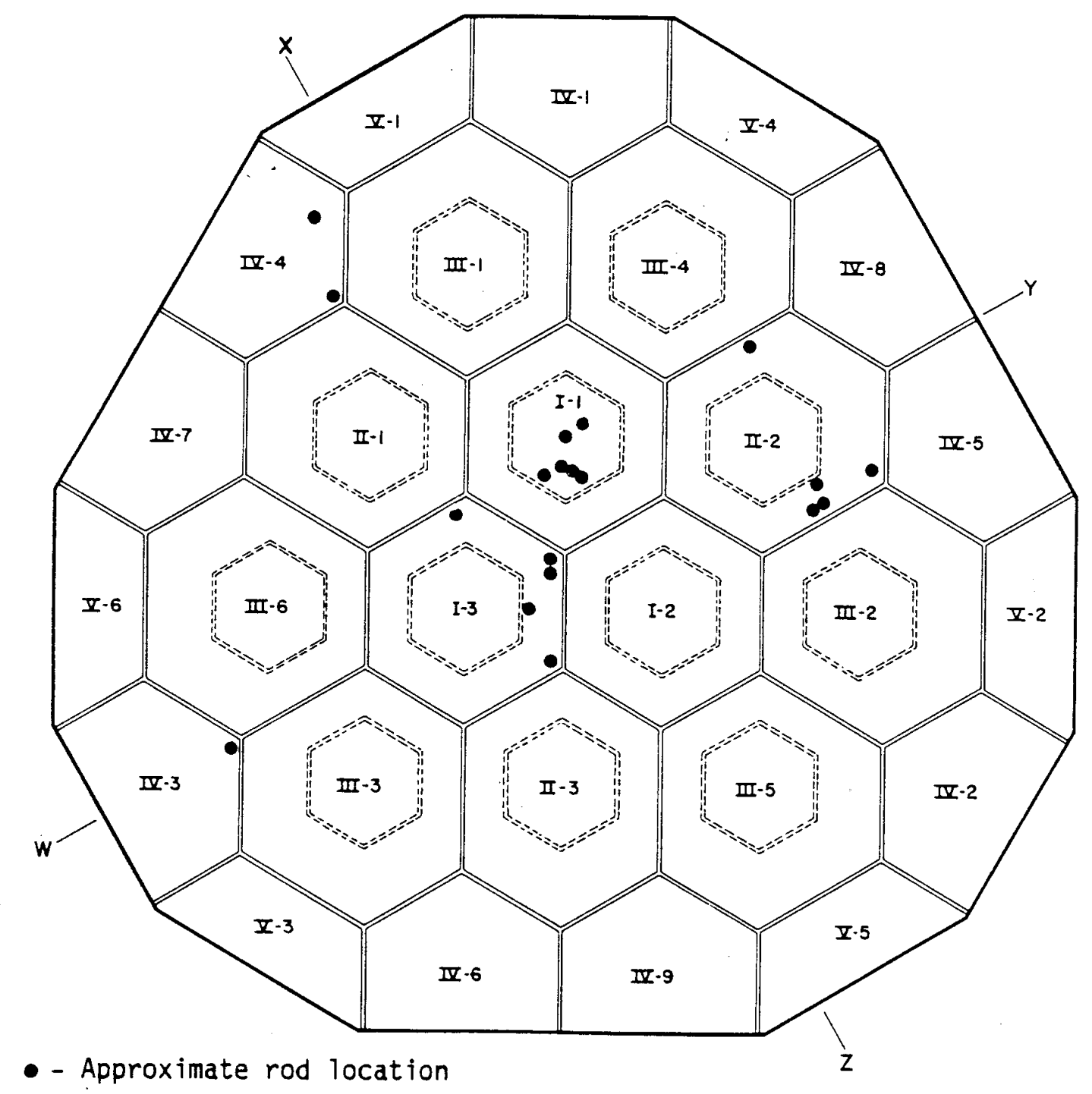

Figure 5-14. Rod examination (REX) fuel rod locations (Gorscak, Campbell, and Clayton 1987, WAPD-TM-1605, Figure 9). 


\subsubsection{Destructive Examination}

Twelve of the 19 rods examined using the REX gauge were shipped to ANL-W for nondestructive neutron radiography, then were punctured to obtain fission gases. Seventeen of the 524 rods examined for fissile content with the PIFAG were shipped to ANL-E for destructive examination for the isotopic content. Destructive examinations conducted on both the 12 rods and the 17 rods are summarized in Table 5-5 and discussed briefly below.

5.1.2.1 Fission Gas Release at End-of-Life. Twenty-nine rods were selected for fission gas (xenon and krypton) analysis, 12 were sent to ANL-W and 17 to ANL-E. Rods were chosen to represent a broad range of as-built and core operating characteristics and to cover a broad range of power density, fuel burnup, and rod neutron fluence. Operating characteristics of the 12 rods selected for analysis by ANL-W are presented in Table 5-6.

Only fission gas released from the plenum was measured at ANL-W. In contrast, ANL-E measured fission gas from the plenum as well as fission gas released during rod shearing and rod dissolution. The method for fission gas sampling of the plenum involved puncturing the rod cladding with a laser, collecting the released gases in a sample collection tube, and analyzing by mass spectrometry for xenon and krypton (Richardson et al.1987, WAPD-TM-1606, pp. 39-40). Results from the plenum tap from both sets of samples are presented in Table 5-7. Results from the plenum puncture, shearing, and dissolution samples for the 16 rods are presented in Table 5-8.

Plenum gas analyses were only obtained for 11 of the 12 sampled rods at ANL-W (the twelfth sample was lost during plenum tap) and from 16 of the 17 rods from ANL-E (one sample was contaminated with nitrogen and oxygen from the room). Results from the 11 ANL-W samples and all 17 ANL-E samples are presented in Table 5-7. ${ }^{b}$ Core locations of the 28 rods can be determined using the cell numbers presented in Table 5-7 along with the cell maps presented in Section 3. All rods were shown to have gas release levels below the low-temperature prediction line. Because fuel rods from peak temperature and peak depletion locations were included in the samples, all fuel was considered to have operated at temperatures below $2580^{\circ} \mathrm{F}$ (Richardson et al. 1987, WAPD-TM-1606, pp. 49-50).

5.1.2.2 Isotopic Results. The 17 rods shipped to ANL-E were analyzed for isotopic inventory. Total uranium and uranium isotopic (U-233, U-234, U-235, U-236, U-238) analyses were performed by thermal ionization mass spectrometry. Because of the interference of Th-232, U-232 was determined by alpha spectrometry (ANL-E data reports). Fission products Cs-137, Ce-144, and Nb-95 (Zr-95 daughter) were determined by gamma spectrometry (high purity germanium detector with associated automated multi-channel analyzer/data management system) on weighed aliquots of the samples. Cs-137 and Ce-144 were determined on a sample aliquot by direct counting. Zirconium-95 was obtained after processing the sample aliquot through a cleanup procedure to reduce interferences. The losses of Zr-95 were accounted for by using before and after values of the Ce-144. Error requirements for $\mathrm{Zr}-95$ measurements that were made after October 1984 were waived due to the short half-life (64.02 days).

Results from isotopic analyses were sent to Lockheed Martin Idaho Technologies Company by the former project manager (Don Graczyk, Analytical Chemistry Laboratory, Chemical Technology Division, ANL-E) of the destructive evaluation at ANL-E. These results are summarized in Table 5-9 and provided in detail in Appendix B.

b. According to the notes attached to the sample report for the contaminated sample (Rod "R" as referred to in Appendix B), ANL-E provided Bettis with sufficient data to calculate or compile fission data for Rod "R." 


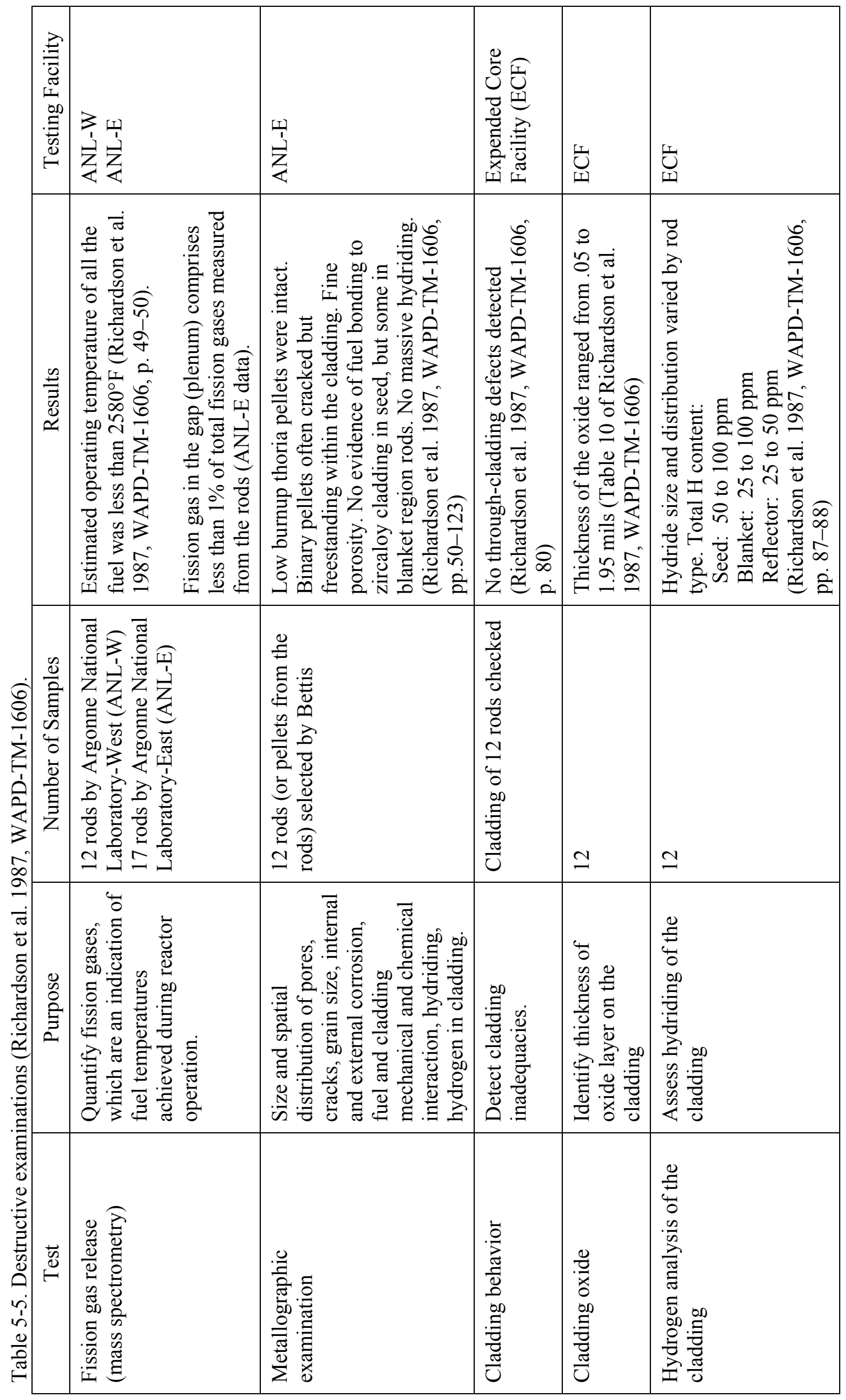




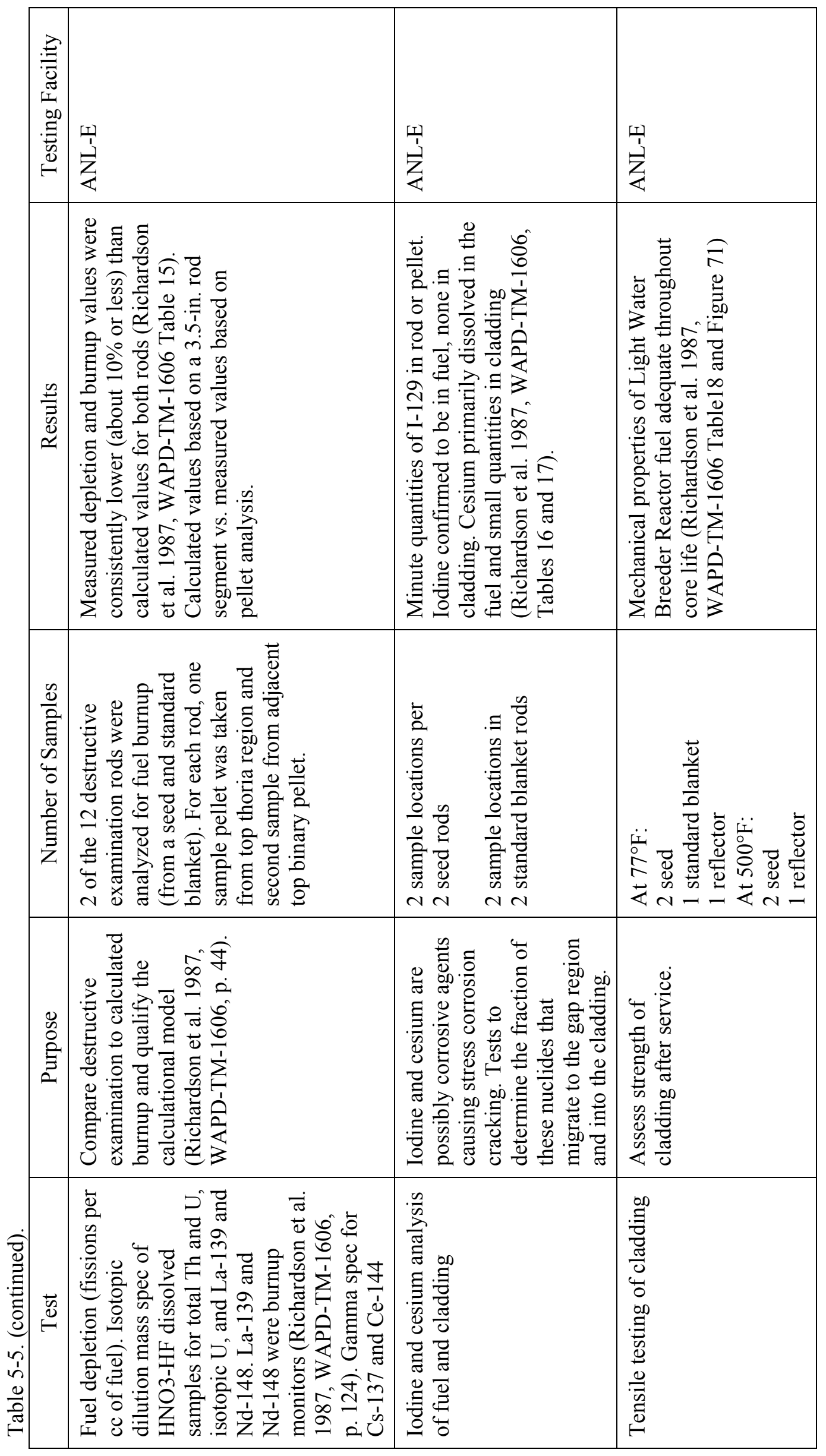


Table 5-6. Operating characteristics of the 12 Light Water Breeder Reactor destructive examination fuel rods at end-of-life (Richardson et al. 1987, WAPD-TM-1606, Table 6).

\begin{tabular}{|c|c|c|c|c|c|}
\hline $\begin{array}{l}\text { Modu le } \\
\text { Type }\end{array}$ & Rod $S / N$ & $\begin{array}{l}\text { Peak } \\
\text { Power } \\
\text { (Kw/ft) } \\
\end{array}$ & $\begin{array}{c}\text { Peak } \\
\text { Depletion } \\
\left(10^{2} \quad \mathrm{f} / \mathrm{cc}\right) \\
\end{array}$ & $\begin{array}{l}\text { Peak } \\
\text { Burnup } \\
\text { MWD/MTM* }\end{array}$ & $\begin{array}{l}\text { Peak Fast } \\
\text { Fluence } \\
\left(>1 \frac{1}{20} \mathrm{Mev}\right) \\
\left(10^{2} \mathrm{n} / \mathrm{cm}^{2}\right)\end{array}$ \\
\hline Seed I-1 & 0400736 & 6.7 & 9.52 & 44,500 & 85.0 \\
\hline Seed I-1 & 0606773 & 4.4 & 8.81 & 41,200 & 96.5 \\
\hline Seed I-1 & 0205071 & 5.5 & 11.43 & 53,400 & 75.5 \\
\hline Seed I-1 & 0507672 & 4.2 & 10.12 & 47,300 & 87.9 \\
\hline Blanket I-3 & 1606710 & 8.7 & 5.07 & 22,300 & 73.0 \\
\hline Blanket I-3 & 1105717 & 8.6 & 5.18 & 22,800 & 71.4 \\
\hline Blanket I-3 & 1504272 & $7 . .4$ & 4.37 & 19,200 & 64.2 \\
\hline Blanket II-2 & 1208823 & 6.9 & 4.25 & 18,700 & 55.4 \\
\hline Blanket II-2 & 2610746 & 8.7 & 5.70 & 25,200 & 57.7 \\
\hline Blanket II-2 & 2514164 & 8.3 & 5.05 & 22,300 & 38.6 \\
\hline Blanket II-2 & 2607600 & 8.4 & 5.53 & 24,400 & 58.6 \\
\hline Refiector IV-3 & 3102657 & 3.4 & 0.96 & 4,100 & 25.9 \\
\hline
\end{tabular}

* MWD/MTM $=$ Megawatt days per metric ton of metal (uranium plus thorium) 
Table 5-7. Light Water Breeder Reactor fuel rod fission gas release at end-of-life (Richardson et al. 1987, WAPD-TM-1606, Table 7).

\begin{tabular}{|c|c|c|c|c|c|c|c|}
\hline \multirow[b]{2}{*}{ Rod $S / N$} & \multirow[b]{2}{*}{ Cell } & \multirow[b]{2}{*}{ Module } & & \multicolumn{4}{|c|}{ Fission Gas } \\
\hline & & & $\begin{array}{c}\text { Rod-average } \\
\text { Depletion } \\
\left(10^{20} \mathrm{f} / \mathrm{cc}\right) \\
\end{array}$ & $\begin{array}{l}\text { Generated } \\
\text { in Fue } 1^{\star} \\
\text { (mol) } \\
\end{array}$ & $\begin{array}{l}\text { Measured in } \\
\text { Plenum Tap } \\
(10-5 \text { mol }) \\
\end{array}$ & $\begin{array}{l}\text { Recovered } \\
\text { Fraction } \star \star \\
\end{array}$ & $\begin{array}{l}\text { Re leased } \\
(\%)^{\star \star \star \star}\end{array}$ \\
\hline $\begin{array}{l}0606773 \\
0507672 \\
0504042 \\
0507057 \\
0400736 \\
0401744 \\
0307602 \\
0205071 \\
0201562\end{array}$ & $\begin{array}{l}6 B 4 \\
5 L 31 \\
5 L 29 \\
5 C 10 \\
4 M 33 \\
4 M 49 \\
3 N 63 \\
2 Q 41 \\
2 P 39\end{array}$ & $\begin{array}{l}\text { SI-1 } \\
\text { SI-1 } \\
\text { SI-1 } \\
\text { SI-1 } \\
\text { SI-1 } \\
\text { SI-1 } \\
\text { SI-1 } \\
\text { SI-1 } \\
\text { SI-1 }\end{array}$ & $\begin{array}{l}5.4 \\
6.4 \\
6.0 \\
5.1 \\
5.3 \\
4.8 \\
4.2 \\
4.5 \\
3.8\end{array}$ & $\begin{array}{l}0.02683 \\
0.03198 \\
0.03007 \\
0.02575 \\
0.02631 \\
0.02398 \\
0.02120 \\
0.02266 \\
0.01890\end{array}$ & $\begin{array}{l}1.22 \\
2.51 \\
2.37 \\
1.30 \\
1.51 \\
3.76 \\
1.36 \\
1.02 \\
1.06\end{array}$ & $\begin{array}{l}0.803 \\
0.725 \\
0.734 \\
0.744 \\
0.912 \\
0.849 \\
0.767 \\
0.782 \\
0.816\end{array}$ & $\begin{array}{l}0.06 \\
0.11 \\
0.11 \\
0.07 \\
0.06 \\
0.18 \\
0.08 \\
0.06 \\
0.07\end{array}$ \\
\hline $\begin{array}{l}1606710 \\
1605519 \\
1504272 \\
1400544 \\
1302864 \\
1200830 \\
1208823 \\
1105717\end{array}$ & $\begin{array}{l}16 \mathrm{E} 57 \\
16 \mathrm{E} 56 \\
15 \mathrm{~F} \cdot 11 \\
14 C \cdot 3 \\
13024 \\
12 \mathrm{~A} 49 \\
12 \mathrm{~A} 12 \\
11 \mathrm{~A} 46\end{array}$ & $\begin{array}{l}B I-3 \\
B I-3 \\
B I-3 \\
B I-3 \\
B I-3 \\
B I-3 \\
B I I-2 \\
B I-3\end{array}$ & $\begin{array}{l}2.9 \\
2.9 \\
2.5 \\
1.9 \\
2.4 \\
2.1 \\
1.8 \\
2.2\end{array}$ & $\begin{array}{l}0.05723 \\
0.05693 \\
0.04831 \\
0.03791 \\
0.04582 \\
0.04051 \\
0.03436 \\
0.04304\end{array}$ & $\begin{array}{l}3.10 \\
2.76 \\
1.90 \\
1.77 \\
1.49 \\
1.37 \\
0.89 \\
2.27\end{array}$ & $\begin{array}{l}0.662 \\
0.659 \\
0.726 \\
0.959 \\
0.675 \\
0.695 \\
0.788 \\
0.722\end{array}$ & $\begin{array}{l}0.08 \\
0.07 \\
0.05 \\
0.05 \\
0.05 \\
0.05 \\
0.03 \\
0.07\end{array}$ \\
\hline $\begin{array}{l}2610746 \\
2606481 \\
2514164 \\
2513854 \\
2502102 \\
2400408 \\
2300711 \\
2102187\end{array}$ & $\begin{array}{l}26 E 68 \\
26 E 31 \\
25 \mathrm{~K} 13 \\
25 \mathrm{~F} 73 \\
25 \mathrm{H} 1 \\
24 \mathrm{C} 13 \\
23 \mathrm{D} 29 \\
21 \mathrm{~B} 62\end{array}$ & $\begin{array}{l}\text { BII-2 } \\
\text { BIII-6 } \\
\text { BII-2 } \\
\text { BIII-6 } \\
\text { BII I-6 } \\
\text { BIII-6 } \\
\text { BIII-6 } \\
\text { BIII-6 }\end{array}$ & $\begin{array}{l}3.3 \\
3.1 \\
2.9 \\
2.6 \\
1.3 \\
1.4 \\
2.8 \\
1.5\end{array}$ & $\begin{array}{l}0.05531 \\
0.05424 \\
0.04741 \\
0.04345 \\
0.02209 \\
0.02319 \\
0.04622 \\
0.02380\end{array}$ & $\begin{array}{l}3.22 \\
3.43 \\
1.63 \\
1.46 \\
0.22 \\
0.38 \\
2.54 \\
0.44\end{array}$ & $\begin{array}{l}0.646 \\
0.743 \\
0.629 \\
0.655 \\
0.770 \\
0.725 \\
0.633 \\
0.729\end{array}$ & $\begin{array}{l}0.09 \\
0.09 \\
0.06 \\
0.05 \\
0.01 \\
0.02 \\
0.09 \\
0.03\end{array}$ \\
\hline $\begin{array}{l}3102657 \\
3211456 \\
3110505\end{array}$ & $\begin{array}{l}1 \mathrm{~A} 1 \\
2 \mathrm{~B} 1 \\
1 \mathrm{E3}\end{array}$ & $\begin{array}{l}\text { RIV }-3 \\
\text { RIV }-3 \\
\text { RIV }-3\end{array}$ & $\begin{array}{l}0.5 \\
0.4 \\
0.2\end{array}$ & $\begin{array}{l}0.01856 \\
0.01659 \\
0.00687\end{array}$ & $\begin{array}{l}0.17 \\
0.12 \\
0.04\end{array}$ & $\begin{array}{l}0.983 \\
0.788 \\
0.999\end{array}$ & $\begin{array}{l}0.01 \\
0.01 \\
0.01\end{array}$ \\
\hline
\end{tabular}

* Calculated from rod-average depletion

** Ratio of helium recovered to calculated amount present from initial fill and $\{n, y\}$ reaction

$\star \star \star$ Gas release $=$ (Amount measured in plenum tap) $/($ Amount generated $) /$ (Recovered fraction) 
Table 5-8. Fission gases $(\mathrm{Kr}+\mathrm{Xe})$ released during processing of Light Water Breeder Reactor rods. (Source: Data packages from ANL-E).

\begin{tabular}{cccccc}
\hline Rod ID & $\begin{array}{c}\text { Gas released in } \\
\text { Plenum Puncture } \\
(\mathrm{g})\end{array}$ & $\begin{array}{c}\text { Gas Released } \\
\text { in Shearing } \\
(\mathrm{g})\end{array}$ & $\begin{array}{c}\text { Gas Released } \\
\text { in Dissolution } \\
(\mathrm{g})\end{array}$ & $\begin{array}{c}\text { Total Gas } \\
\text { Released } \\
(\mathrm{g})\end{array}$ & $\begin{array}{c}\text { Percent } \\
\text { Plenum Gas } \\
\text { in Total }\end{array}$ \\
\hline 2606481 & 0.0037 & 0.0140 & 5.3379 & 5.3556 & 0.0691 \\
2513854 & 0.0017 & 0.0138 & 4.9268 & 4.9423 & 0.0344 \\
2502102 & 0.0003 & 0.0065 & 2.3256 & 2.3324 & 0.0129 \\
2102187 & 0.0005 & 0.0065 & 2.8505 & 2.8575 & 0.0175 \\
2400408 & 0.0005 & 0.0044 & 2.5041 & 2.5091 & 0.0199 \\
2300711 & 0.0030 & 0.0192 & 4.9428 & 4.9650 & 0.0604 \\
3211456 & 0.0001 & 0.0032 & 1.8676 & 1.8709 & 0.0053 \\
1605519 & 0.0033 & 0.0151 & 6.6098 & 6.6283 & 0.0498 \\
1200830 & 0.0016 & 0.0158 & 5.0025 & 5.0198 & 0.0319 \\
1302864 & 0.0018 & 0.0091 & 5.3405 & 5.3514 & 0.0336 \\
1400544 & 0.0022 & 0.0078 & 4.2974 & 4.3074 & 0.0511 \\
0504042 & 0.0029 & 0.0183 & 3.6756 & 3.6968 & 0.0784 \\
0507057 & 0.0016 & 0.0131 & 3.0711 & 3.0859 & 0.0518 \\
0201562 & 0.0013 & 0.0161 & 2.4877 & 2.5051 & 0.0519 \\
0307602 & 0.0012 & 0.0134 & 2.7539 & 2.7685 & 0.0433 \\
0401744 & 0.0046 & 0.0181 & 3.0852 & 3.1079 & 0.1480 \\
\hline
\end{tabular}




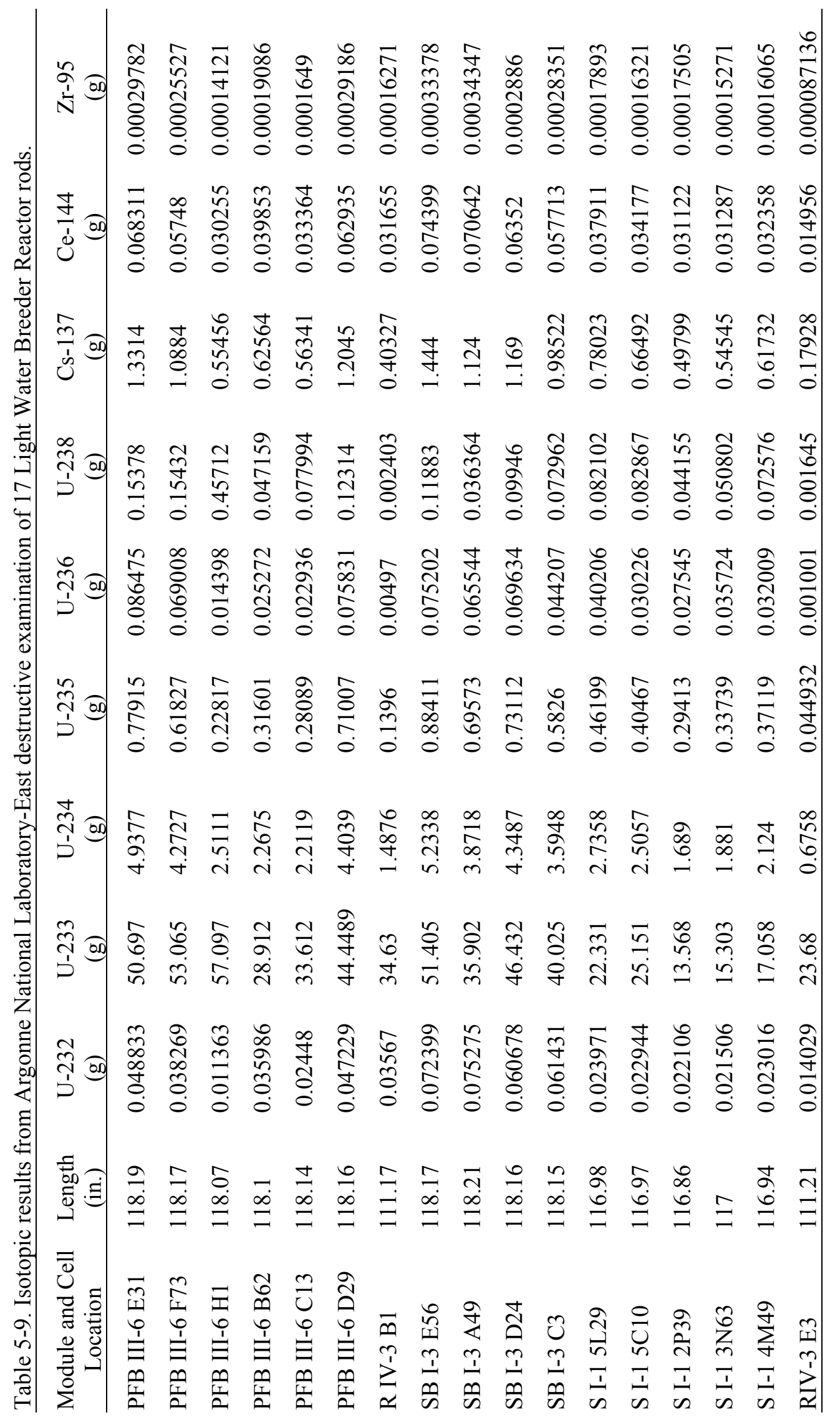


Data from the nondestructive (PIFAG) and destructive (ANL-E dissolution) examinations for fuel loading were compared to assess the accuracy of the PIFAG and to demonstrate breeding; results showed the Fissile Inventory Ratio (ratio of the fissile inventory at EOL versus beginning-of-life) was 1.01, which included fissile inventory gains in the reflector rods.

5.1.2.3 Isotopic and Heat Rate Validation Studies. Recent validation work has been performed in support of radionuclide inventory and heat rate predictions for the LWBR modules. One study (Sterbentz 1999) focused on the prediction of uranium, fission product, krypton, and xenon isotopic masses in a seed, a blanket and a reflector rod. A comparison of the results showed less than a 5\% difference between the calculated and measured mass concentrations in the three rods for the two major uranium isotopes (U-233, U-234). Further discussion on the comparisons for the other isotopes is given in the reference.

Heat rate predictions (Sterbentz and Wahnschaffe 2001) were calculated for a single seed (Type I), standard blanket (Type I), standard/power-flattening blanket (Type II), standard/power-flattening blanket (Type III), Reflector IV, and Reflector V module. Module heat rates are given as a function of decay date (2000-2030). These calculated module heat rates were also compared to heat rates reported in WAPD-NRF(L)C-104, which were calculated values verified against actual LWBR module decay heat measurements. The Sterbentz and Wahnschaffe (2001) calculated values were 33\% and 29\% higher than the WAPD-NRF(L)C-104 values for a single seed module and a single standard blanket/power-flattening blanket module, respectively. The Sterbentz and Wahnschaffe (2001) Reflector IV decay heat value was about $29 \%$ lower than the WAPD value.

\subsection{Fuel Burnup}

Fuel burnup is defined in terms of fissions per cubic centimeter of fuel, or more often, given in terms of megawatt days per metric ton of initial heavy metal (Richardson et al. 1987, WAPD-TM-1606, p. 44). In the case of LWBR, the initial heavy metal includes both uranium and thorium. Calculated burnup data are provided in several places in Richardson 1987 (WAPD-TM-1606, p. 37) for the 12 rod samples that were destructively examined at ECF.

Only 2 of the 12 rods destructively evaluated by ANL-W were selected for burnup evaluation and model verification; those two rods were seed rod 0205071 and standard blanket rod 1606710 (Richardson et al. 1987, WAPD-TM-1606, p. 44). Two fuel pellets from each of the two rods were analyzed and compared with calculated burnup values to qualify the calculational model. For each of the two fuel rods examined for burnup, one of the pellets was taken from the top thoria region, and the second pellet was taken from the adjacent top binary pellet.

Pellets were removed from the cladding and dissolved in acid solution $\left(\mathrm{HNO}_{3}-\mathrm{HF}\right)$ without comminution (pulverization). After decontamination of the analytes from interferences and radioactive fission products, total thorium and uranium, isotopic uranium, and stable fission products La-139 and Nd-148 were measured by isotopic dilution mass spectroscopy. (Note from Richardson et al. 1987, WAPD-TM-1606, p. 124: La-139 and Nd-148 were burnup monitors.) The mass spectrometer was calibrated with istopically pure $\mathrm{ThO}_{2}$ and a National Institute of Standards and Technology uranium standard.

Calculated and measured burnup data for the two seed pellets (Rod No. 0205071 from location Q41) and the two blanket pellets (Rod No. 1606710 from location E57) are presented in Table 5-10. Calculated burnups for a larger variety of rods are presented in Table 5-6. 
Table 5-10. Comparison of measured and calculated fuel depletion and burnup (Richardson et al. 1987, WAPD-TM-1606, Table 15).

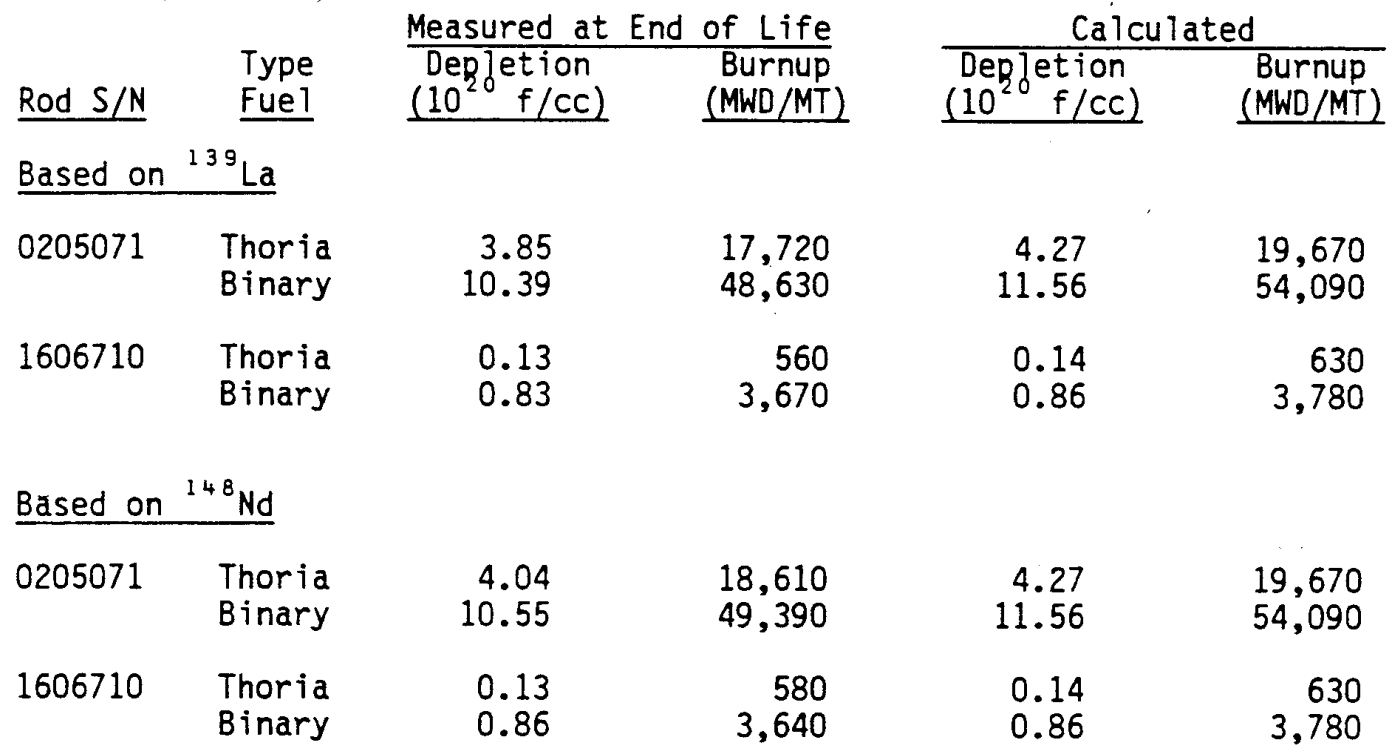

\section{3 lodine and Cesium Analysis of the Fuel Cladding}

Stress corrosion cracking of metallic components, such as the Zircaloy-4 cladding, has historically been a problem concerning reactor safety and fuel performance. Iodine and cesium have been identified as possible corrosive agents causing stress corrosion cracking. Under reactor conditions, fission product iodine can react with zircaloy. Measurement of fission product iodine and cesium inventories in the fuel rod samples was performed to determine the fraction of these nuclides that migrate to the gap region and into the cladding. (The gap region was defined as the fuel-cladding gap, fuel cracks, and the interconnected, open porosity in the fuel.) The quantity of fission products I-129 and Cs-137 in the fuel-cladding gap and, separately, dissolved in the fuel and cladding, were determined for two seed fuel rods and two standard blanket fuel rods (Richardson et al. 1987, WAPD-TM-1606).

Fission products I-129 and Cs-137 deposited in the gap were determined by immersing the fuel and cladding separately in $2 \mathrm{~N} \mathrm{HCl}$ for 30 minutes. Ultrasonic vibration was applied to aid in dissolving any iodine and cesium deposits from the cladding surface only. Fuel particles remaining in the cladding and fuel wash solution were analyzed for Cs-137 by gamma-ray spectroscopy. The I-129 was precipitated, and the precipitate was counted for I-129 with a calibrated lithium-drifted germanium detector (Richardson et al. 1987, WAPD-TM-1606, pp. 44-45).

The I-129 and Cs-137 inventory in fuel and cladding were determined using similar techniques described above. Results for the analyses are presented in Tables 5-11 and 5-12. All analyses demonstrate that almost all the I-129 and Cs-137 stayed in the fuel rather than migrating to the gap where they could have induced accelerated corrosion and cracking. These results agree with the nondestructive examination findings with the REX that no gross cladding defects resulted from reactor operations (see Table 5-2). 
Table 5-11. Concentration of I-129 in Light Water Breeder Reactor fuel rod cladding and fuel pellets $(\mu \mathrm{g} / \mathrm{g})$ (Richardson et al. 1987, WAPD-TM-1606, Table 16).

\begin{tabular}{|c|c|c|c|c|c|c|}
\hline Rod S/N & $\begin{array}{l}\text { Type } \\
\text { Fuel } \\
\end{array}$ & $\begin{array}{r}\text { Sample } \\
\text { No.* } \\
\end{array}$ & $\begin{array}{c}\text { Cladding } \\
\text { Wash } \\
\end{array}$ & $\begin{array}{l}\text { Fuel } \\
\text { Wash } \\
\end{array}$ & $\begin{array}{c}\text { In } \\
\text { Cladding }\end{array}$ & $\begin{array}{c}\text { In } \\
\text { Fue } 1 \\
\end{array}$ \\
\hline \multicolumn{7}{|c|}{ Seed Region Fuel } \\
\hline \multirow[t]{2}{*}{0205071} & Thoria & $\begin{array}{l}1 \mathrm{~A} \\
1 \mathrm{~B}\end{array}$ & $\begin{array}{l}\text { N.D. } \\
\text { N.D. }\end{array}$ & $\begin{array}{l}\text { N.D. } \\
\text { N.D. }\end{array}$ & $\begin{array}{l}\text { N.D. } \\
\text { N.D. }\end{array}$ & $\begin{array}{l}123.2 \\
135.7\end{array}$ \\
\hline & Binary & $\begin{array}{l}2 \mathrm{~A} \\
2 \mathrm{~B}\end{array}$ & $\begin{array}{l}\text { N.D. } \\
\text { N.D. }\end{array}$ & $\begin{array}{l}0.1 \\
0.2\end{array}$ & $\begin{array}{l}\text { N.D. } \\
\text { N.D. }\end{array}$ & $\begin{array}{l}309.3 \\
317.9\end{array}$ \\
\hline \multirow[t]{2}{*}{0507672} & Binary & 1 & N.D. & N.D. & N.D. & 261.9 \\
\hline & Binary & 2 & N.D. & N.D. & N.D. & 335.4 \\
\hline
\end{tabular}

Blanket Region Fuel

$\begin{array}{lllllll}1606710 & \text { Binary } & 1 A & 0.4 & 0.2 & \text { N.D. } & 130.4 \\ & & 1 B & \text { N.D. } & \text { N.D. } & \text { N.D. } & 153.3 \\ 1105717 & \text { Binary } & 2 & \text { N.D. } & \text { N.D. } & \text { N.D. } & 136.0 \\ & \text { Thoria } & 1 & \text { N.D. } & \text { N.D. } & \text { N.D. } & 112.8 \\ & \text { Binary } & 2 & \text { N.D. } & \text { N.D. } & \text { N.D. } & 149.3\end{array}$

* $A$ and $B$ samples were obtained from adjacent fue 1 rod sections.

N.D. = Not Detected

Table 5-12. Concentration of Cs-137 in Light Water Breeder Reactor fuel rod cladding and fuel pellets $(\mu \mathrm{g} / \mathrm{g})$ (Richardson et al. 1987, WAPD-TM-1606, Table 17).

\begin{tabular}{|c|c|c|c|c|c|}
\hline $\operatorname{lod} S / N$ & $\begin{array}{l}\text { Type } \\
\text { Fuel }\end{array}$ & $\begin{array}{l}\text { Sample } \\
\text { No.* }\end{array}$ & $\begin{array}{l}\text { Cladding } \\
\text { Wash }\end{array}$ & $\begin{array}{l}\text { Fue } 1 \\
\text { Wash }\end{array}$ & $\begin{array}{l}\text { In } \\
\text { Cladding }\end{array}$ \\
\hline
\end{tabular}

Seed Region Fuel

$\begin{array}{llllllr}0205071 & \text { Thoria } & \text { IA } & 0.1 & 1.8 & 2.8 & 1609.8 \\ & & \text { IB } & 0.1 & 3.0 & 3.1 & 527.8 \\ & \text { Binary } & \text { 2A } & 0.2 & 4.3 & 5.9 & 1261.5 \\ 0507672 & \text { 2B } & 0.2 & 4.4 & 6.5 & 294.0 \\ & \text { Binary } & 1 & 0.2 & 2.4 & 5.8 & 1355.2 \\ & \text { Binary } & 2 & \star \star & \star \star & 6.2 & 1317.0\end{array}$

Blanket Region Fuel

$\begin{array}{lllllll}1606710 & \text { Binary } & \text { 1A } & 0.6 & 0.4 & 2.8 & 622.1 \\ & & \text { 1B } & 0.1 & 0.6 & \text { N.M. } & 812.7 \\ 1105717 & \text { Binary } & 2 & 0.1 & 0.4 & 2.9 & 571.6 \\ & \text { Thoria } & 1 & 1.9 & 0.4 & 1.5 & 234.5 \\ & \text { Binary } & 2 & 0.1 & 0.7 & 1.8 & 622.0\end{array}$

* $A$ and $B$ samples were obtained from adjacent fuel rod sections.

$\star \star 0.2 \mu \mathrm{g} / \mathrm{g}$ was recorded for a combined cladding and fuel wash solution.

N.M. = Not Measured 


\section{SHIPPING AND STORAGE}

\subsection{Shipment from Shippingport to Expended Core Facility}

After the reactor was shut down, the reactor was defueled, and the fuel modules were partially disassembled then loaded into modified M-130 casks and shipped to ECF in 10 shipments (4 shipments of blanket modules, 2 of seed modules, and 4 of reflector modules) (Selsley 1987b, WAPD-TM-1553, p. 7). To ensure criticality control during defueling, potassium tetraborate was added to the reactor vessel and canal water to about 4,200 parts per million (ppm) by weight of natural boron (Selsley 1987a, WAPD-TM-1551, p. 111).

Disassembly of the modules at Shippingport APS was required to permit them to fit inside the M-130 shipping containers. The seed assemblies were modified by removing the support shaft, balance piston, and buffer cylinder. Lifting studs were installed, and a shipping plate was attached to them. The shipping plate was designed to accommodate a lift adapter used at ECF. The modified seed module received at ECF is shown in Figure 6-1 (Hodges 1987, WAPD-TM-1601).

To reduce the size of each blanket module, the support tube and seal block assembly at the top of the module and the guide tube extension and stub tube assembly at the bottom of the module were removed. For top end disassembly, the instrumentation tubes were cut, and the blanket support tube was unbolted. At the bottom end, the six guide tube extension bolts were severed, and the stub tube and guide tube extension were removed. A shipping plate was installed at the top of the module to provide structural support and to accommodate the lift adapter. The modified blanket module received at ECF is shown in Figure 6-2 (Hodges 1987, WAPD-TM-1601).

Reflector modules were modified by removing the top seal block assembly. As with the seed and blanket assemblies, a shipping plate was attached to the top of the reflector module to provide structural support and accommodate the lift adapter. The modified reflector module received at ECF is shown in Figure 6-3 (Hodges 1987, WAPD-TM-1601). Module holders for seed, blanket, and reflector modules are shown in Figures 6-4 through 6-6.

The modified M-130 container used to ship the assemblies is shown in Figure 6-7 (Williams 1987, WAPD-TM-1611). The M-130 is an upright, right circular cylinder, with outside dimensions of 84 in. in diameter by 158 in. high. Inside dimensions are 55 in. in diameter by 132 in. high (Selsley 1987b, WAPD-TM-1553, Appendix A). Each of the M-130 containers was fitted with module holders, which were designed to accommodate the largest of each module type within the respective containers. The M-130s modified for blankets used special inserts for the Type I and Type II blanket modules; the M-130s modified for reflectors used special inserts for the Type V reflectors (Selsley 1987b, WAPD-TM-1553, p. A1-4). A recessed head was used for LWBR shipping because of module length and the need for specified holddown devices required in the event of a container accident. M-130 container modifications were reviewed by the Nuclear Regulatory Commission, and a certificate of compliance was issued (Selsley 1987b, WAPD-TM-1553, p. 7).

An A-frame on the railcar served to suspend the M-130 slightly from the deck of the railcar and functioned as a shock absorber (Figure 6-8). Energy absorbers were also fastened to the top of each M-130 container (Selsley 1987b, WAPD-TM-1553). 


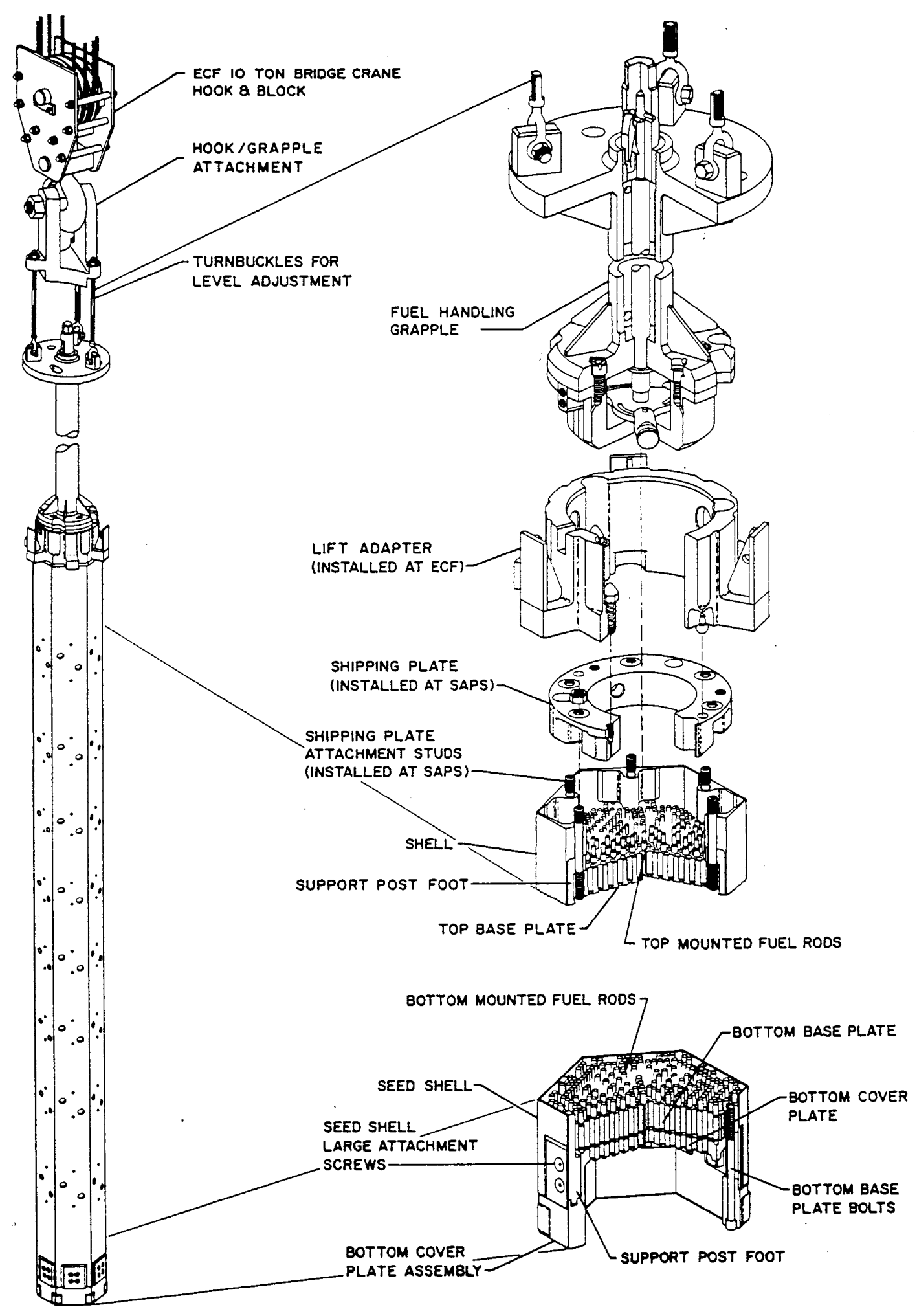

Figure 6-1. Light Water Breeder Reactor seed module as received at the Expended Core Facility (Hodges 1987, WAPD-TM-1601, Figure 1-1). 


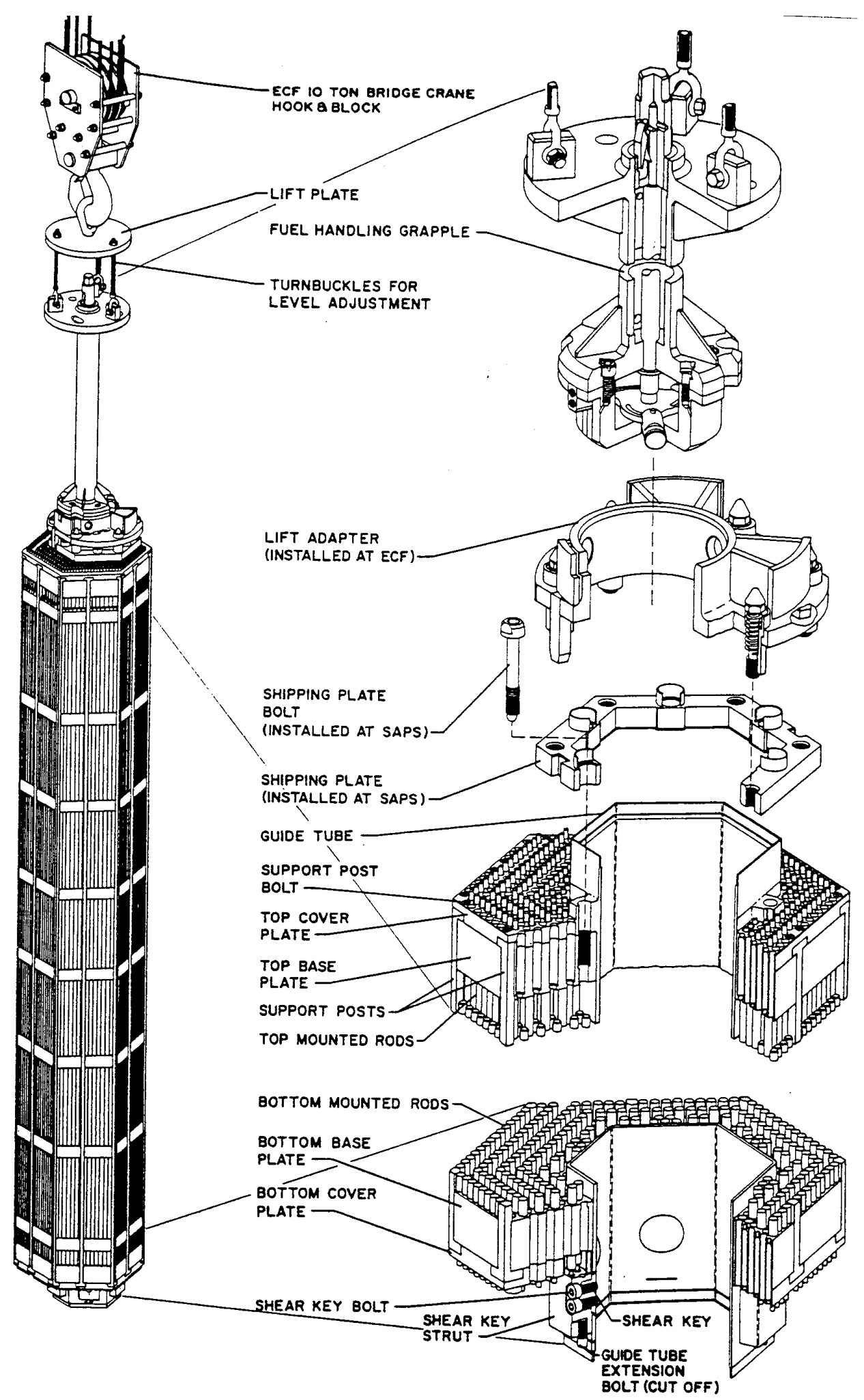

Figure 6-2. Light Water Breeder Reactor blanket module as received at Expended Core Facility (Hodges 1987, WAPD-TM-1601, Figure 1-2). 


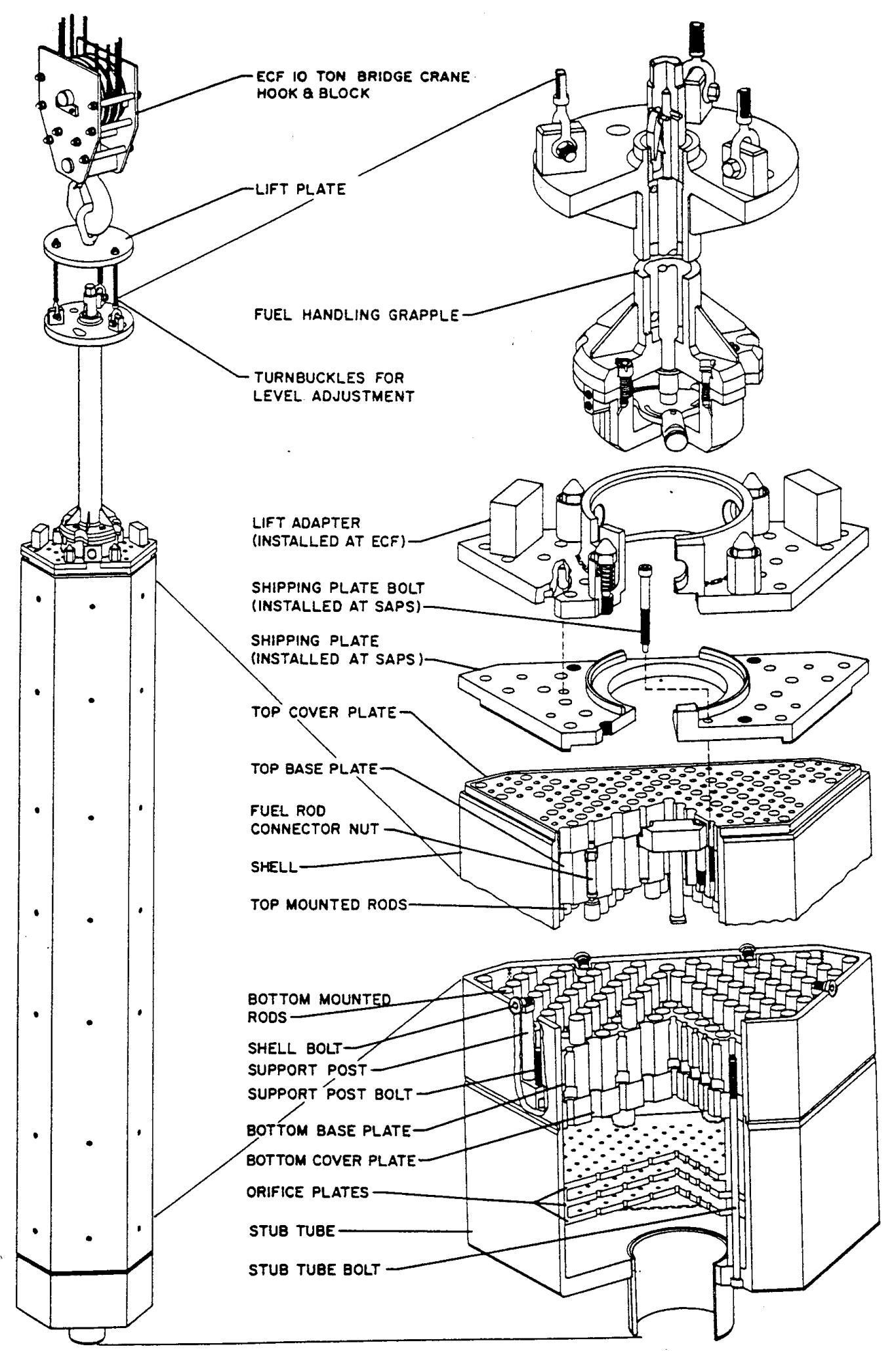

Figure 6-3. Light Water Breeder Reactor reflector module as received at Expended Core Facility (Hodges 1987, WAPD-TM-1601, Figure 1-3). 


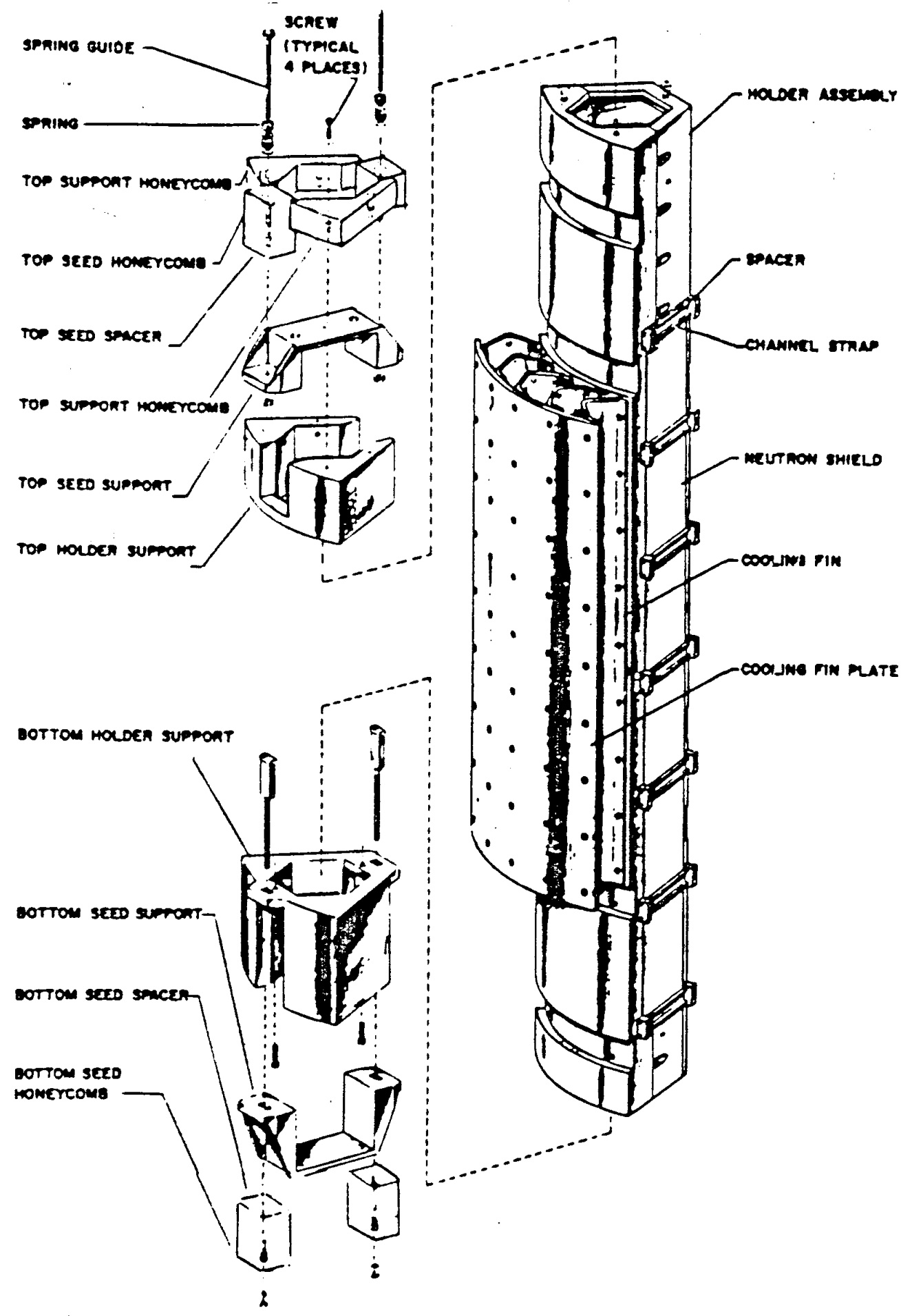

Figure 6-4. Module holder for seed modules (Selsley 1987b, WAPD-TM-1553, Figure A1-3). 


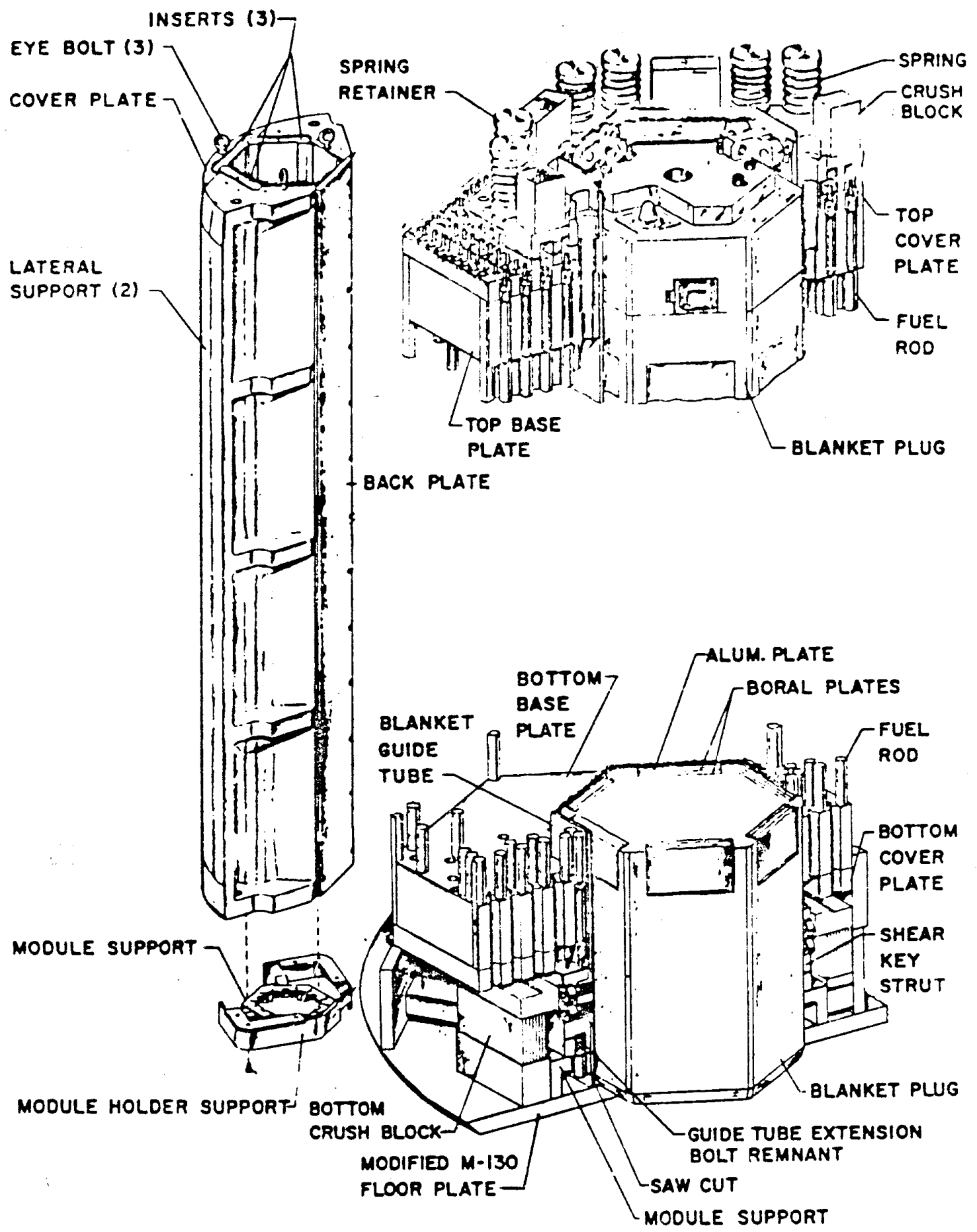

Figure 6-5. Module holder for blanket modules (Selsley 1987b, WAPD-TM-1553, Figure A1-4). 


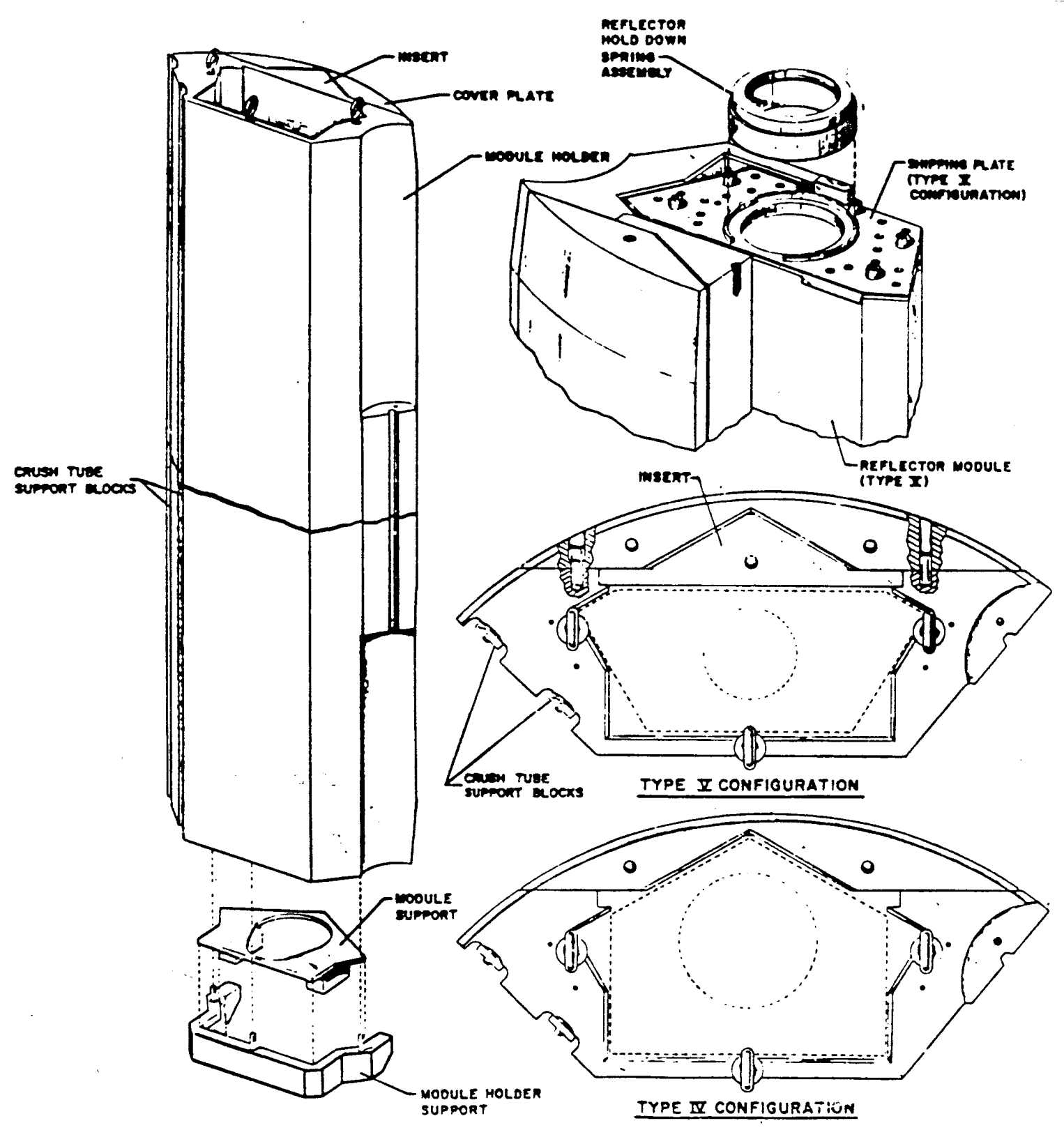

Figure 6-6. Module holder for reflector modules (Selsley 1987b, WAPD-TM-1553, Figure A1-5). 


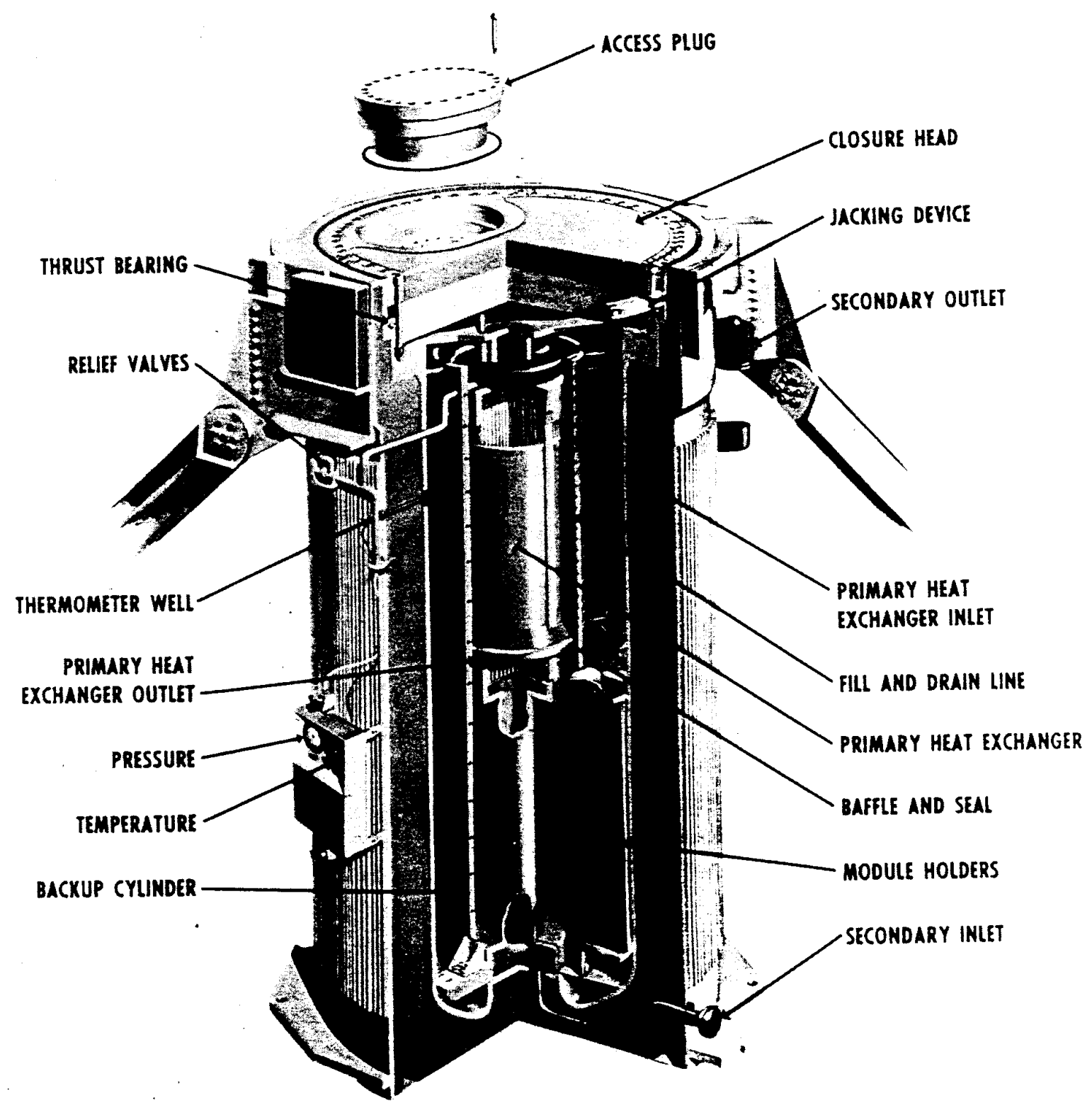

Figure 6-7. M-130 shipping container as modified for Light Water Breeder Reactor fuel shipments (Williams 1987, WAPD-TM-1611, Figure 8). 


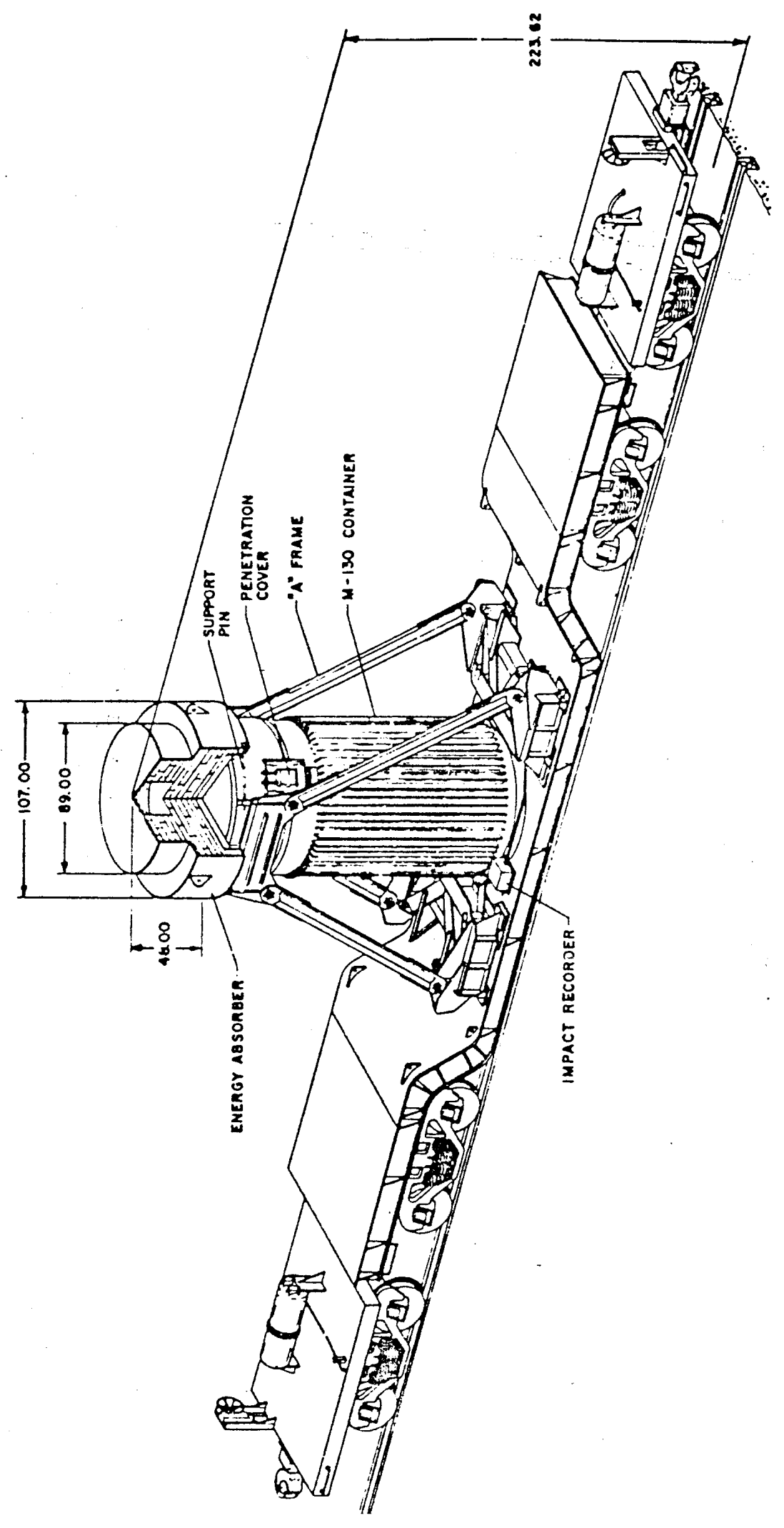

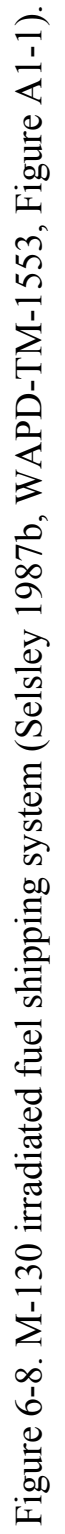


M-130 preparations for shipment were as follows:

1. Loaded containers were flushed with nonborated water to reduce boron residue. Surfactant was added to the water used to flush the seed module container to enhance drainage from horizontal surfaces that were not present in other containers.

2. Containers were filled with neon gas.

3. Decay heat generation values for the seed shipments and for the first blanket shipment were obtained by performing a calorimetric test (Selsley 1987b, WAPD-TM-1553).

All shipments were completed successfully with no damage to fuel modules. Details for the shipping operations from Shippingport to ECF are provided in Selsley 1987b (WAPD-TM-1553).

\subsection{Handling, Disassembly of Selected Modules, and Storage at Expended Core Facility}

The modules were sent to ECF (with shipping plates attached) in 10 shipments. Upon receipt, the internal atmosphere of each M-130 shipping cask was sampled for fission gases to determine the integrity of the fuel rod cladding, and the modules were placed in individual storage liners. The tests indicated that all shipments were completed without damage to the fuel cladding in any of the fuel modules (Hodges 1987, WAPD-TM-1601, p. 2-1).

The shipping container was transferred from the railcar to the water pit at ECF, and the fuel modules were transferred individually to one of two water pits for storage in the module storage racks. The fuel was stored in the ECF water pits for 3 to 5 years (depending on the liner). The fuel module grapple used to lift the modules is shown in Figure 6-9. The ECF water pits are shown in Figure 6-10. All LWBR modules were individually installed into a liner for storage purposes at ECF. Liners were constructed of stainless steel and were $25.50 \mathrm{in}$. in diameter and had a length, with the closure head installed, of 157.80 in. (Hodges 1987, WAPD-TM-1601, p. 3-1).

Twelve modules (four seed, four reflectors, and four blankets) were remotely disassembled underwater to free the core components and fuel rods (Greenberger and Miller 1987, WAPD-TM-1608, p. 15). Ten of the modules had their baseplates cut off, and two of the modules (a reflector IV-4 and a seed II-3) were deshelled, then had their baseplates cut off. The two modules were deshelled so that the exposed fuel rods could be visually examined and could free the module structural components for examination (including shells, grid sections, and grid fasteners). Deshelling took place in the module disassembly apparatus. Baseplate cutoff for all 12 modules was performed with the cutoff system, which cut off both ends of the module and severed the structural components to free all fuel rods (Greenberger and Miller 1987, WAPD-TM-1608). About 1000 rods were then removed from the 12 modules using the rod removal system and were later examined for EOL properties as described in Section 5.

Before cutting the 12 modules designated for EOL rod examination, remnant clamps were installed and the bandsaw was aligned for cutting at the top and bottom module baseplates. The cut location was approximately in the center of each baseplate, and the resulting module lengths after cutting ranged from about 116 to 124 inches (Greenberger and Miller 1987, WAPD-TM-1608, p. 51). Fuel assemblies excluded from the EOL program were transported from ECF to INTEC while examinations of the selected LWBR fuel assemblies were in progress (Hodges 1987, WAPD-TM-1601, p. 1-2). 


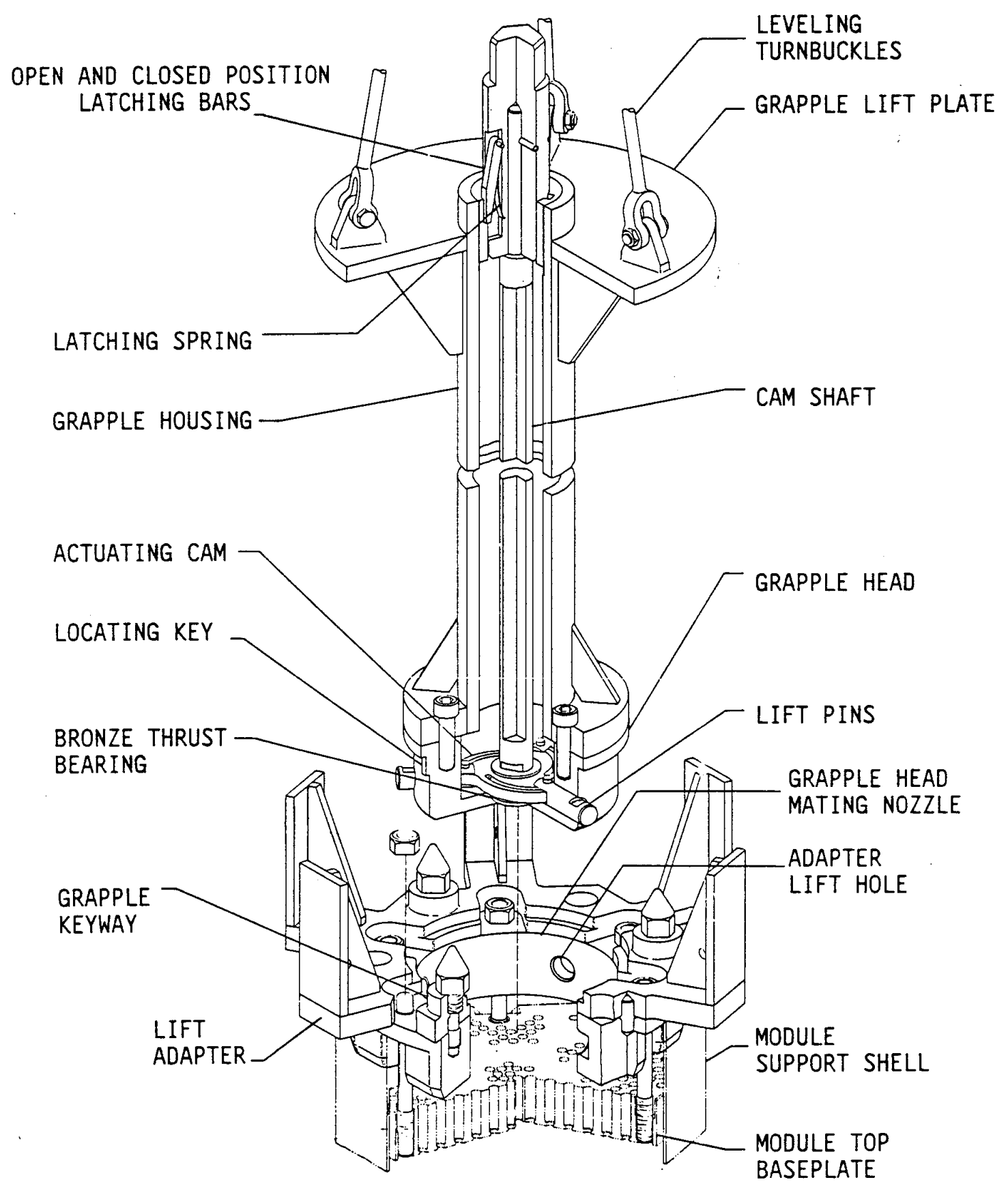

Figure 6-9. Light Water Breeder Reactor fuel module grapple shown with seed module (Greenberger and Miller 1987, WAPD-TM-1608, Figure 8). 


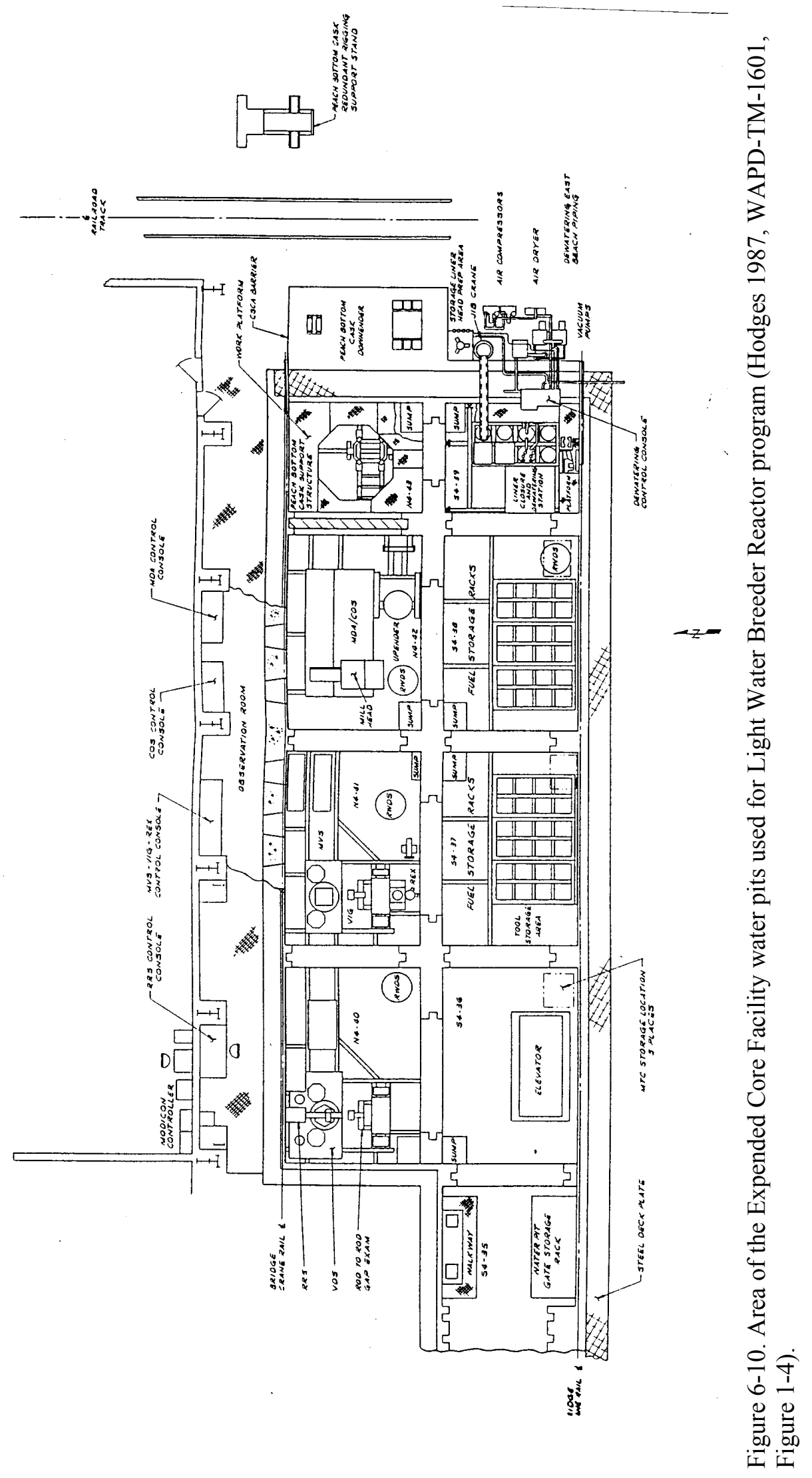


The cut modules were secured with stabilization clamps, which were designed to provide a means for vertical lifting and handling of the cutoff modules. The stabilization clamp assembly used for the seed modules is shown in Figure 6-11. Similar stabilization clamp assemblies were used for the blanket and reflector modules. The drawing numbers for the stabilization clamps, lift adaptors, modules, and rod storage liner are identified in Cole (2001).

After each module processing operation, the clamped modules were returned to their designated storage liners. When all scheduled module examinations were completed, the storage liners were transferred to the Liner Closure Station for final closure head installation and water removal.

\subsubsection{Water Removal at Expended Core Facility}

Fuel liner blowdown removed the bulk water from the liner. A schematic of the liner blowdown system is presented in Figure 6-12. The water blowdown process occurred under water. The liner head was bolted onto the storage liner. Compressed air was forced through the blowdown system until the flowmeter downstream of the blowdown tank registered 450 gallons, ensuring the fuel storage liner was empty of bulk water.

Air circulation through the fuel storage liner was the second fluid process. A schematic of the liner air circulation system is presented in Figure 6-13. Dry compressed air was pumped for 20 minutes at about $17 \mathrm{cfm}$ through the air dryer system, down through the fuel liner and filter system, and into the blowdown tank (Hodges 1987, WAPD-TM-1601). The forced air displaced the water out of the storage liner through the liner's standpipe, the drain fitting, and the drain umbilical tool, forcing the water out. Once the bulk amount of water was removed from the liner, only droplets of water remained on all the fuel and liner surfaces.

Residual water was removed using a vacuum pump, then the liner was backfilled with neon gas. Leak testing with neon gas to $150 \%$ of the maximum postulated liner pressure was performed underwater for 20 minutes to ensure that the storage liners were adequately sealed for shipment and storage. The dried and sealed liner was then transferred to the Peach Bottom Cask shipping container for subsequent shipment to INTEC for underground (dry) storage (Hodges 1987, WAPD-TM-1601).

The Part C Fuel Receipt Criteria for all the storage liners includes the certification checklists for the liners. The ECF Shift Supervisor and LWBR Engineering manager were required to check a box on a form indicating that they checked the following items for each liner: liner identification, module identification, liner vendor certification, fission product leakage certification (including water pit sample analysis), no liquid water in liner, and neon gas backfill of the liner.

\subsubsection{Shipment from Expended Core Facility to INTEC}

Two types of fuel storage liners (rod and module) were fabricated for the LWBR fuel disposal program. The exterior of all storage liners was a stainless steel cylindrical shell with an outer diameter of $25.50 \mathrm{in}$. and a length, with the closure head installed, of 157.80 in. (Hodges 1987, WAPD-TM-1601, p. 3-1). The exteriors of all the liners are identical, except for the unique labels painted on the top of the liner closure heads. Video tapes showing the loading of the liners into the Peach Bottom transport casks confirmed that all the labels were legible when the casks were loaded at ECF for shipment to INTEC for dry storage. ${ }^{c}$

c. Olson and McCardell viewed the tapes; tapes are in records storage with other LWBR records with Vicky Boyer at INTEC. 


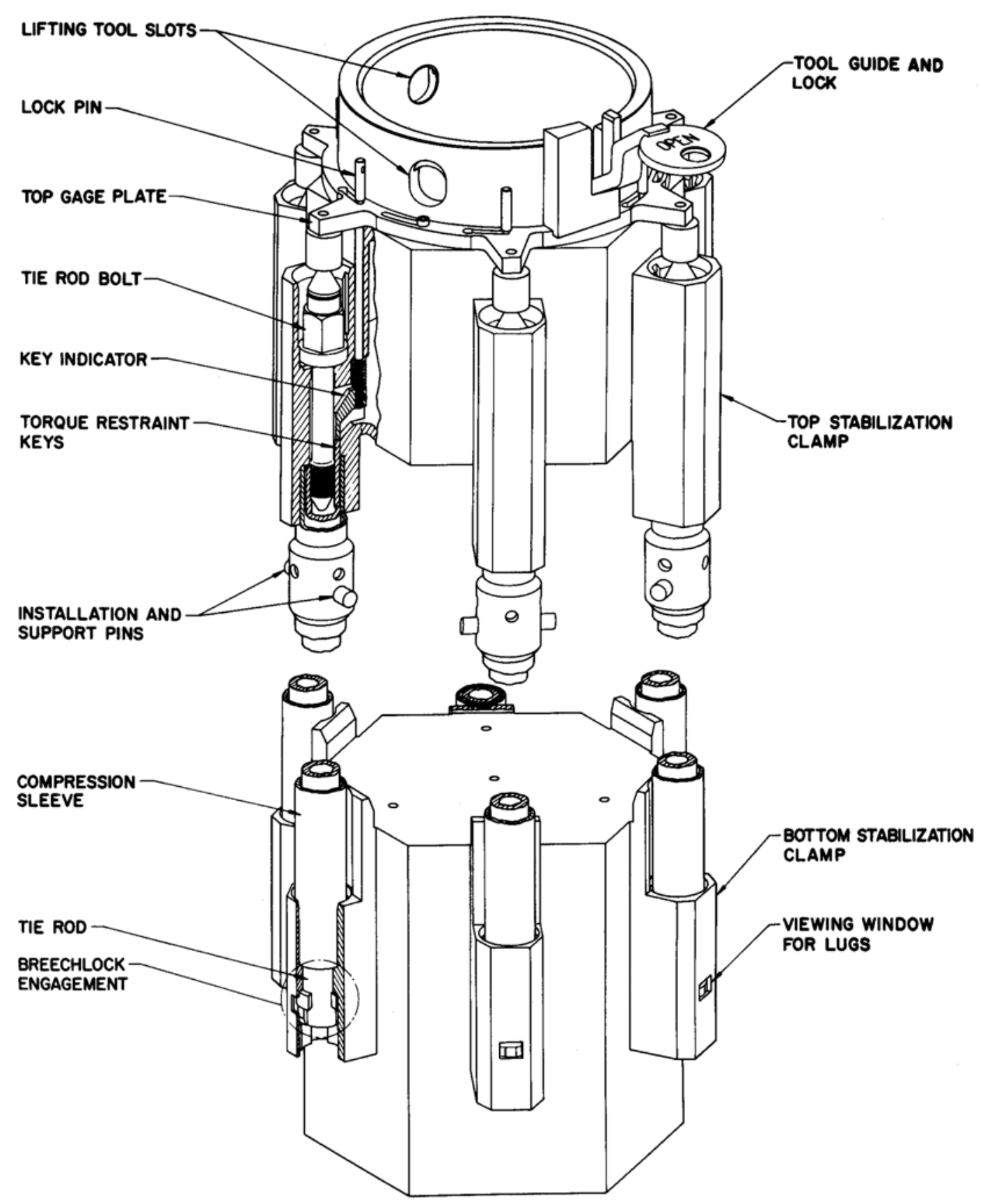

Figure 6-11. LWBR Seed Stabilization Clamp (Greenberger and Miller 1987, WAPD-TM-1608, Figure 27). 


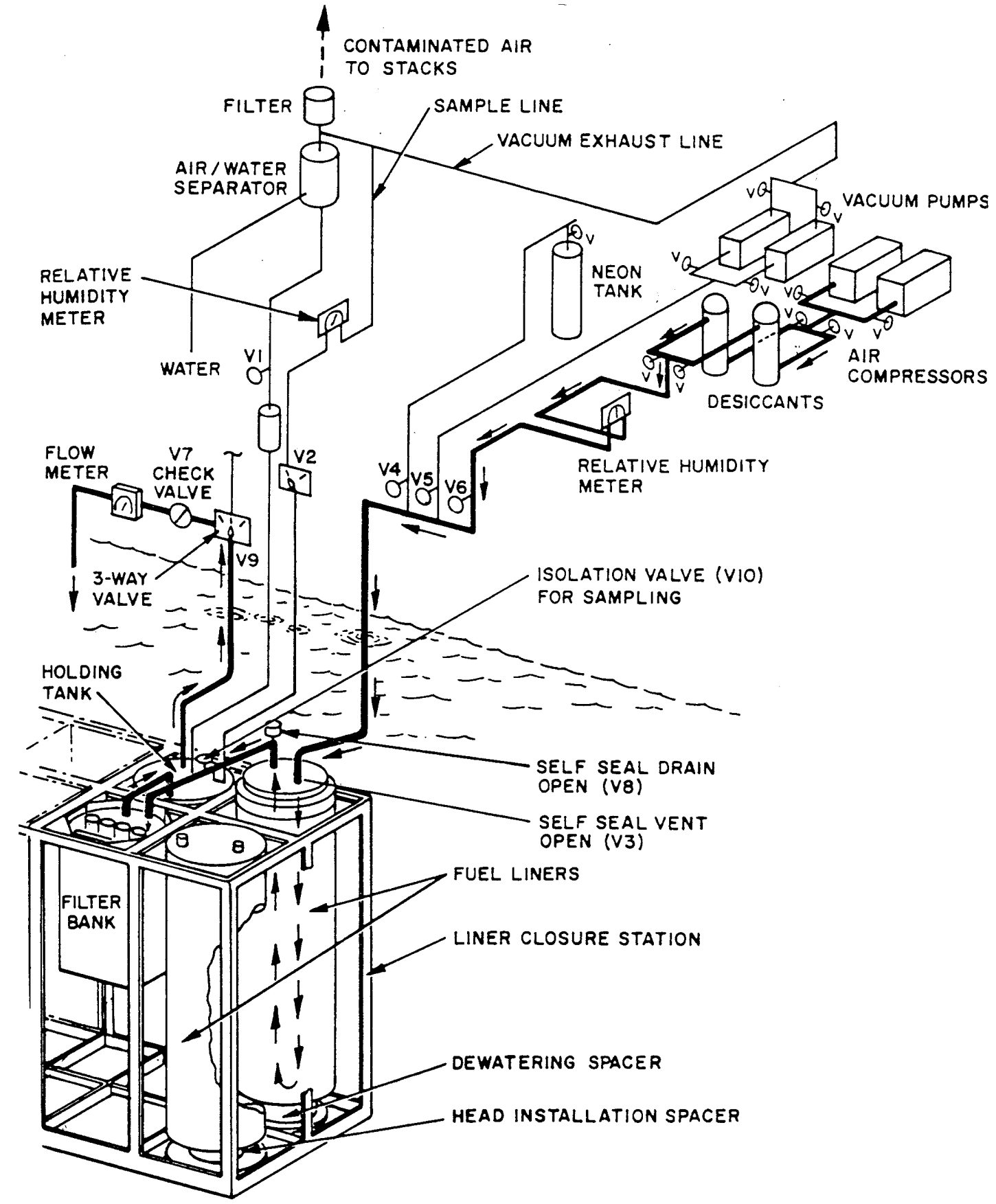

Figure 6-12. Light Water Breeder Reactor storage liner blowdown schematic (Hodges 1987, WAPD-TM-1601, Figure 3-11). 


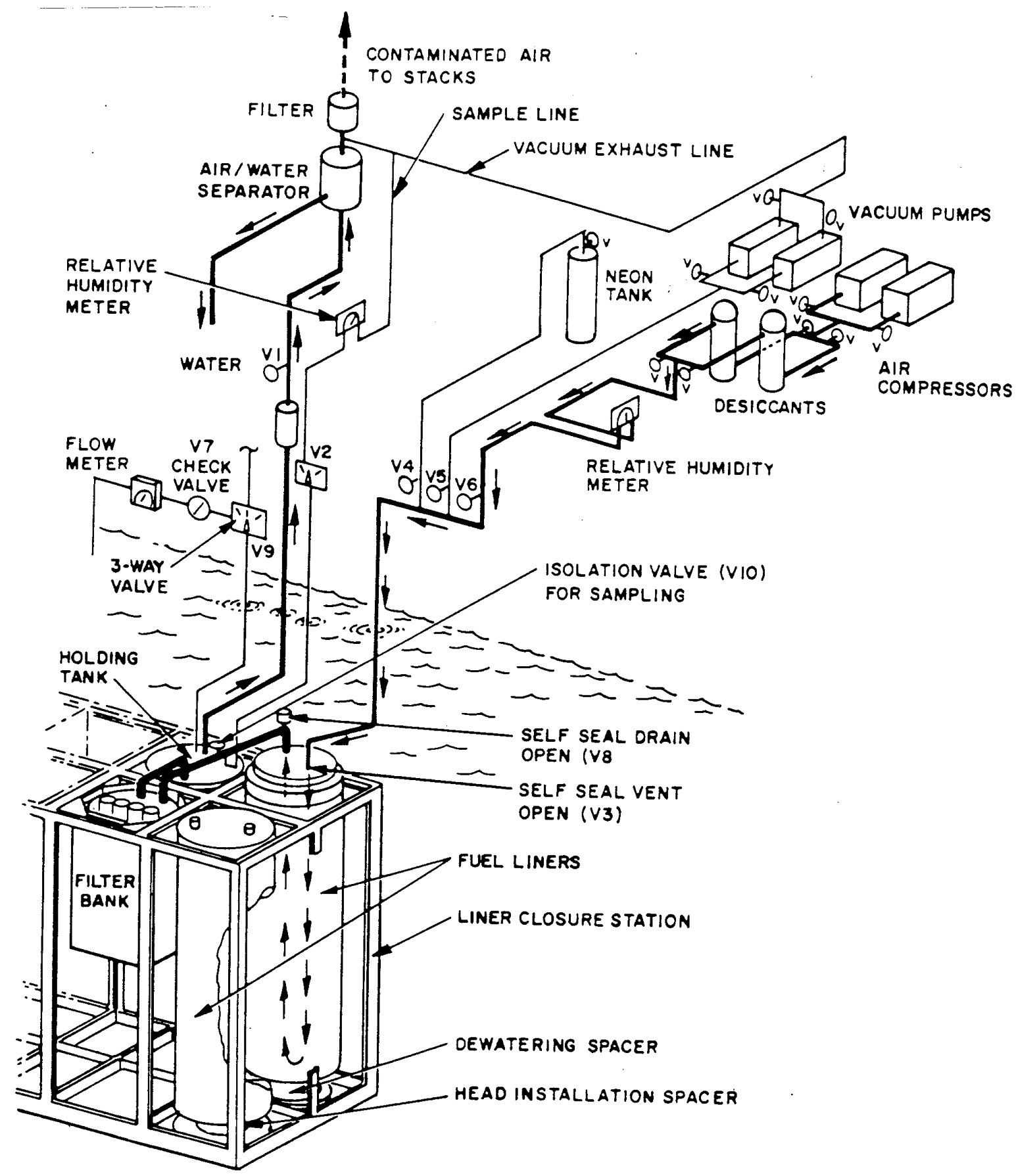

Figure 6-13. Light Water Breeder Reactor storage liner air circulation schematic (Hodges 1987, WAPD-TM-1601, Figure 3-15). 
The interior of the rod storage liners had tube bundle inserts to house the individual fuel rods. The interior of the module storage liners had features configured to the various module cross sections. A typical LWBR fuel module storage liner is shown in Figure 6-14. Each module type had a corresponding storage liner type because of the vastly different sizes and cross-sectional shapes of the LWBR fuel modules. Liner internals were fabricated to accept both as-received and cut modules. Liners containing LWBR assemblies and loose rods were shipped from ECF to INTEC in a Peach Bottom Cask from December of 1985 until the last of the test rods were packaged and shipped in 1987 (Fuel Receipt Criteria Package B and C).

The storage liner preparation process included monitoring for fission products (Cs-137 and Cs-134) and fission gas $(\mathrm{Kr}-85)$ to indicate the possible existence of through-clad defects in fuel rods. No through-clad defects were indicated by fill water analysis for cesium when the modules arrived at ECF from Shippingport. However, positive indications were discovered during ECF liner preparations of two of the 12 LWBR seed modules (3-5 and 3-6) at initiation of the neon gas bleed cycle (Hodges 1987, WAPD-TM-1601, p. 3-37). After further testing, it was determined that the results suggested that there were fuel rod cladding defects in seed Modules 3-5 and 3-6, although available data were insufficient to conclude that fuel rod defects actually existed in the modules (Hodges 1987, WAPD-TM-1601, p. 3-38). The mechanism that may have led to a cladding defect while the modules were in storage at ECF was not identified (Hodges 1987, WAPD-TM-1601, p. 3-39). The presence of through-clad defects in seed Modules 3-5 and 3-6 remains questionable (Hodges 1987, WAPD-TM-1601, p. 3-39). Part C of the Fuel Receipt and Storage papers confirms the potential for cladding defects:

For Seed 3-5: "An indication of radioactive gas was noted during initial bleedoff. A gas sample taken during neon bleedoff indicated $8 \times 10^{-6} \mu \mathrm{Ci} / \mathrm{mL} \mathrm{K}-85 \ldots$ Further sampling indicated no presence of Krypton 85" (Shipment No. 27, S-3-5, November 1986).

For Seed 3-6: "A gas sample taken during neon bleedoff indicated $1.2 \times 10^{-4} \mu \mathrm{Ci} / \mathrm{mL}$ $\mathrm{Kr}-85$...Further sampling indicated $3.2 \times 10^{-5} \mu \mathrm{Ci} / \mathrm{mL} \mathrm{Kr}-85$ at the initiation of vacuuming. However, sampling one hour into vacuuming and at the initiation of neon bleedoff indicated no presence of Krypton 85" (Shipment No. 28, S-3-6, December 1986).

\subsection{Storage at INTEC}

The 39 LWBR core modules, 7 containers of intact fuel rods, 1 container of cut fuel rods, and 1 container of an unirradiated seed (not discussed in this report) are presently in underground dry storage at CPP-749 in the upright position. The Dry Well Design for irradiated LWBR Fuel Storage Dry Wells is shown in Figure 6-15. The plot plan of LWBR fuel storage facility at CPP-749 is shown in Figure 6-16.

There are 27 Type A liners, which contain intact LWBR modules (i.e., modules from which no rods have been removed). Type A liners are configured to fit seed, standard, and power-flattening blanket, and reflector modules. There are 12 Type B liners, which contain partially derodded modules. Rods had been pulled from the various modules for testing and to access the rods chosen for testing. There are 7 Type $\mathrm{C}$ liners, which contain intact spent fuel rods (irradiated and unirradiated; unirradiated rods were used for calibration of instruments during postirradiation testing). Type $\mathrm{C}$ liners contain cells that are appropriately sized for the various diameters of the seed, blanket, and reflector rods. The exteriors of the liners are identical, except for their labels.

In addition to the Type A, B and C liners, there is one scrap can liner (Liner 15718), which contains sections and pieces of unirradiated rods and irradiated rods that have been cut up or punctured for testing purposes as well as unirradiated rods used for calibration. There are at least 22 containers 


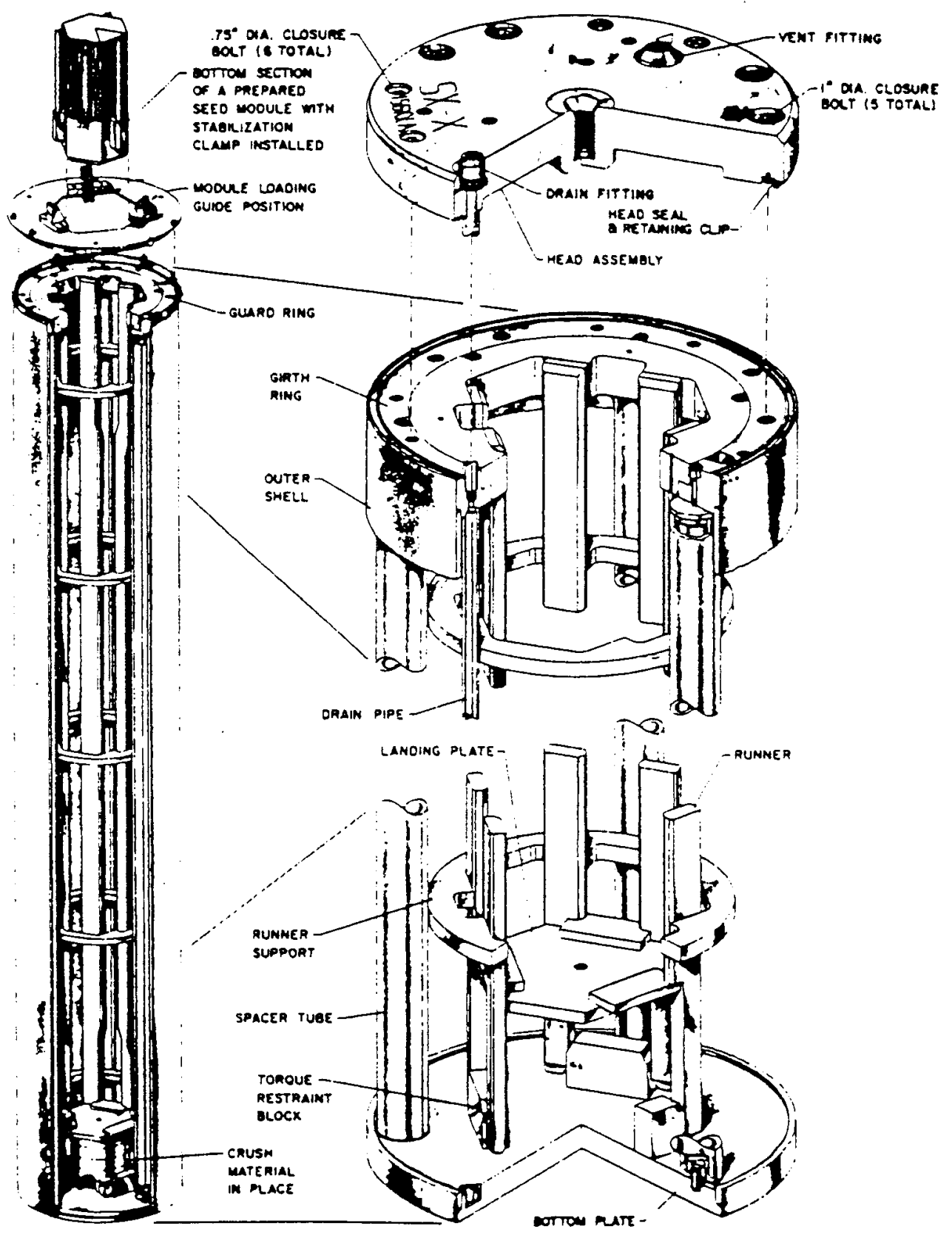

Figure 6-14. Typical Light Water Breeder Reactor fuel module storage liner (Hodges 1987, WAPD-TM-1601, Figure 3-1). 

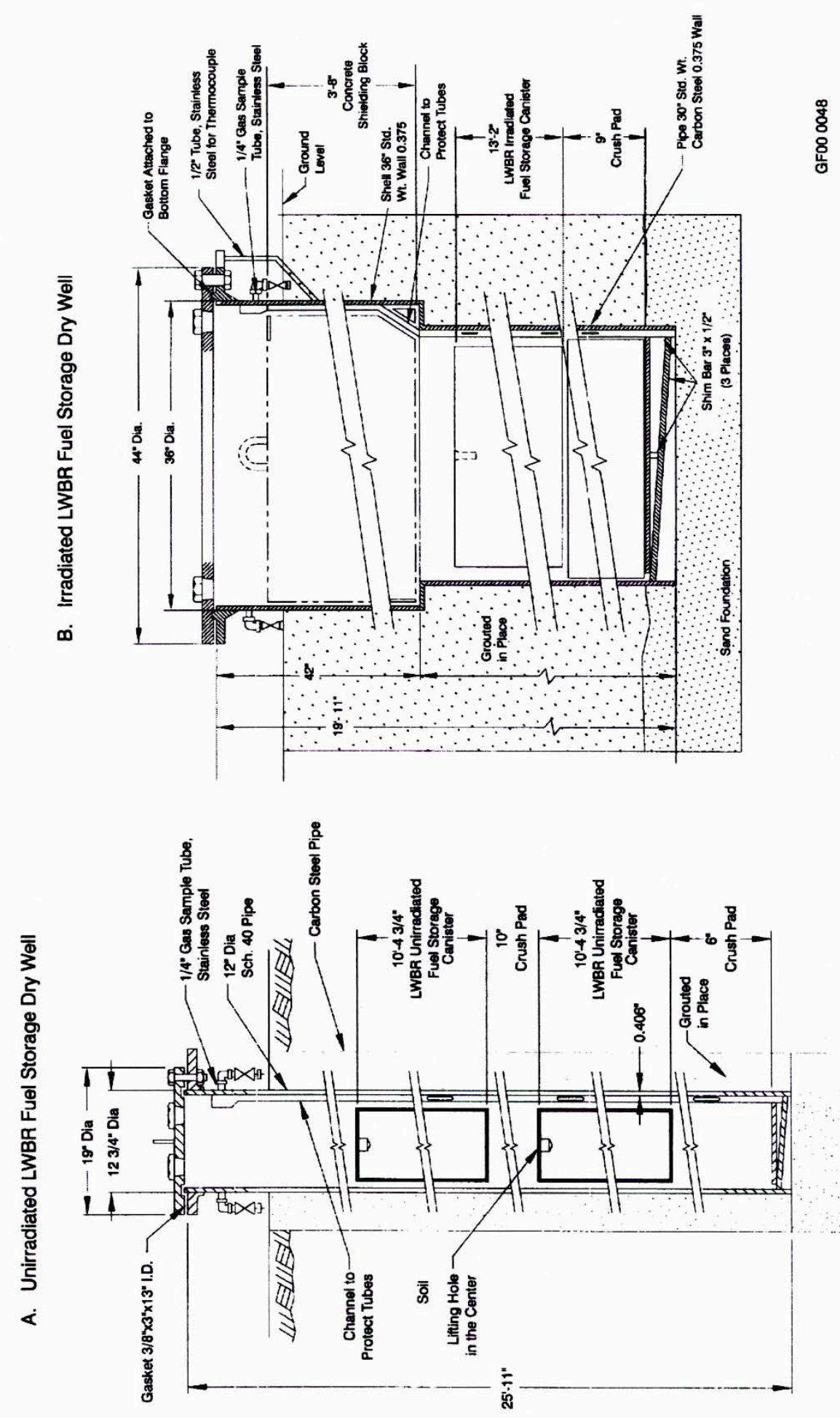

Figure 6-15. Section views of the dry well design for both unirradiated and irradiated Light Water Breeder Reactor fuel storage dry wells (INTEC Plant Safety Document 4.7A, 2002, Figure 4-7). 


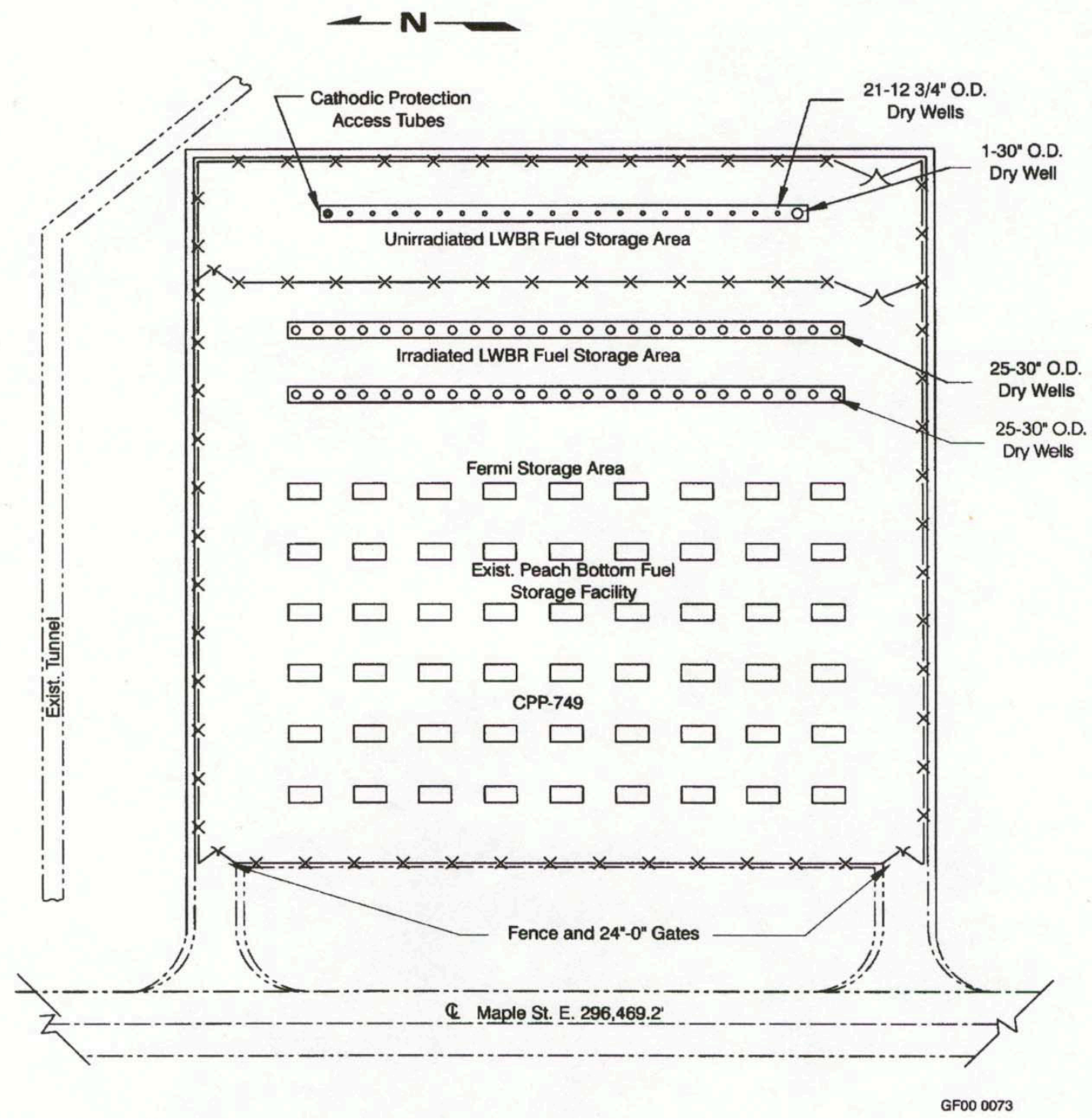

Figure 6-16. Plat plan of the Light Water Breeder Reactor fuel storage facility (INTEC Plant Safety Document, Section 4.7A, 2002, Figure 4-2). 
within the scrap can, and these containers contain irradiated, unirradiated, intact, and cut fuel rods. Many of the rods have been run through a variety of tests, which may have altered their physical, chemical, and radiological status. The contents of the scrap can and information about the various tests that were conducted on the fuels inside the scrap can are provided in Appendix C.

Table 6-1 identifies the types of storage liners, how many rods are in each type of storage liner, the liner number, and the INTEC dry well number. Table 6-2 details the number and type of fuel rods for each Type $\mathrm{C}$ liner. Appendix D lists the rod serial numbers and isotopic contents (modeled) of each of the rods stored in the Type $\mathrm{C}$ liners.

Figures 6-17 through 6-23 identify the location of the rods within the Type C liners. Liner numbers, module serial numbers, and module types were confirmed March 18, 1998, by viewing a video of the loading of the Peach Bottom casks taken at ECF. Postirradiation isotopic data for the rods in the Type $\mathrm{C}$ liners are presented by rod in Part $\mathrm{C}$ of the Fuel Receipt Criteria.

Table 6-1. Types and contents of Light Water Breeder Reactor storage liners.

\begin{tabular}{|c|c|c|c|c|c|c|c|c|c|}
\hline \begin{tabular}{|c|} 
Dry \\
Well \\
Number \\
\end{tabular} & $\begin{array}{c}\text { Module } \\
\text { ID }\end{array}$ & $\begin{array}{c}\text { Fuel Piece } \\
\text { Serial } \\
\text { Number } \\
\end{array}$ & $\begin{array}{c}\text { Liner } \\
\text { Number }\end{array}$ & $\begin{array}{l}\text { Liner } \\
\text { Type }^{\mathrm{a}} \\
\end{array}$ & $\begin{array}{c}\text { Number } \\
\text { of Rods } \\
\text { Initially b }\end{array}$ & $\begin{array}{c}\text { Number of } \\
\text { Rods in "A" } \\
\text { Liner" }\end{array}$ & $\begin{array}{c}\text { Number of Rods } \\
\text { Removed }^{\mathrm{d}}\end{array}$ & $\begin{array}{c}\text { Number of Rods } \\
\text { in "B" Liner }{ }^{d} \\
\end{array}$ & $\begin{array}{l}\text { Number of Rods } \\
\text { in "C" Liner }\end{array}$ \\
\hline $\mathrm{I}-7$ & S I-1 & L-BB01-04 & 15601 & $\mathrm{~B}$ & 619 & & 50 & 569 & \\
\hline $\mathrm{I}-34$ & S I-2 & L-BB01-05 & 15602 & A & 619 & 619 & & & \\
\hline $\mathrm{I}-37$ & $\mathrm{~S} \mathrm{I}-3$ & L-BB01-06 & 15603 & A & 619 & 619 & & & \\
\hline $\mathrm{I}-44$ & S II-1 & L-BB01-09 & 15604 & A & 619 & 619 & & & \\
\hline I-12 & S II-2 & L-BB01-10 & 15605 & A & 619 & 619 & & & \\
\hline $\mathrm{I}-46$ & S II-3 & L-BB01-13 & 15606 & $\mathrm{~B}$ & 619 & & 127 & 492 & \\
\hline I- 6 & S III-1 & L-BB01-07 & 15607 & B & 619 & & 42 & 577 & \\
\hline I- 5 & S III-2 & L-BB01-08 & 15608 & $\mathrm{~B}$ & 619 & & 39 & 580 & \\
\hline $\mathrm{I}-11$ & S III-3 & L-BB01-12 & 15609 & A & 619 & 619 & & & \\
\hline $\mathrm{I}-35$ & S III-4 & L-BB01-11 & 15610 & A & 619 & 619 & & & \\
\hline I-39 & S III-5 & L-BB01-14 & 15611 & A & 619 & 619 & & & \\
\hline $\mathrm{I}-38$ & S III-6 & L-BB01-16 & 15612 & A & 619 & 619 & & & \\
\hline $\mathrm{I}-15$ & B I-1 & L-GR01-01 & 15613 & A & $442^{\mathrm{e}}$ & $442^{\mathrm{e}}$ & & & \\
\hline $\mathrm{I}-30$ & B I-2 & L-GR01-02 & 15614 & A & $442^{\mathrm{e}}$ & $442^{\mathrm{e}}$ & & & \\
\hline $\mathrm{I}-13$ & B I-3 & L-GU51-01 & 15615 & $\mathrm{~B}$ & 443 & & 52 & $391^{\mathrm{e}}$ & \\
\hline I- 8 & B II-1 & L-GS01-01 & 15616 & A & $563^{\mathrm{e}}$ & $563^{e}$ & & & \\
\hline $\mathrm{I}-50$ & B II-2 & L-GS22-01 & 15617 & $\mathrm{~B}$ & 564 & & 84 & 480 & \\
\hline I-36 & B II-3 & L-GS01-02 & 15618 & A & $563^{\mathrm{e}}$ & $563^{\mathrm{e}}$ & & & \\
\hline I- 3 & B III-1 & L-GT01-01 ${ }^{\mathrm{f}}$ & 15619 & A & 632 & 632 & & & \\
\hline I-18 & B III-2 & L-GW52-01 & 15620 & $\mathrm{~B}$ & 632 & & 391 & $241^{\mathrm{e}}$ & \\
\hline I-16 & B III-3 & L-GT01-03 & 15621 & A & 633 & 633 & & & \\
\hline I- 9 & B III-4 & L-GT01-04 & 15622 & A & 633 & 633 & & & \\
\hline $\mathrm{I}-28$ & B III-5 & L-GT01-05 ${ }^{\mathrm{f}}$ & 15623 & A & 633 & 633 & & & \\
\hline $\mathrm{I}-14$ & B III-6 & L-GT22-03 & 15624 & $\mathrm{~B}$ & 633 & & 84 & 549 & \\
\hline I- 2 & R IV-1 & L-RA01-06 & 15625 & A & 228 & 228 & & & \\
\hline $\mathrm{I}-27$ & R IV-2 & L-RA01-02 & 15626 & A & 228 & 228 & & & \\
\hline $\mathrm{I}-41$ & R IV-3 & L-RA01-10 & 15627 & B & 228 & & 33 & 195 & \\
\hline
\end{tabular}


Table 6-1. (continued).

\begin{tabular}{|c|c|c|c|c|c|c|c|c|c|}
\hline $\begin{array}{c}\text { Dry } \\
\text { Well } \\
\text { Number }\end{array}$ & $\begin{array}{c}\text { Module } \\
\text { ID }\end{array}$ & $\begin{array}{c}\text { Fuel Piece } \\
\text { Serial } \\
\text { Number } \\
\end{array}$ & $\begin{array}{c}\text { Liner } \\
\text { Number } \\
\end{array}$ & $\begin{array}{l}\text { Liner } \\
\text { Type }^{\text {a }}\end{array}$ & $\begin{array}{c}\text { Number } \\
\text { of Rods } \\
\text { Initially } b \\
\end{array}$ & $\begin{array}{c}\text { Number of } \\
\text { Rods in "A" } \\
\text { Liner" }\end{array}$ & \begin{tabular}{|c|}
$\begin{array}{c}\text { Number of Rods } \\
\text { Removed }^{\mathrm{d}}\end{array}$ \\
\end{tabular} & $\begin{array}{c}\text { Number of Rods } \\
\text { in "B" Liner }\end{array}$ & $\begin{array}{c}\text { Number of Rods } \\
\text { in "C" Liner }\end{array}$ \\
\hline $\mathrm{I}-43$ & R IV-4 & L-RA01-09 & 15628 & $\mathrm{~B}$ & 228 & & 76 & 152 & \\
\hline $\mathrm{I}-40$ & R IV-5 & L-RA01-07 & 15629 & A & 228 & 228 & & & \\
\hline $\mathrm{I}-31$ & R IV-6 & L-RA01-04 & 15630 & $\mathrm{~A}$ & 228 & 228 & & & \\
\hline $\mathrm{I}-10$ & R IV-7 & L-RA01-05 & 15631 & $\mathrm{~A}$ & $227^{\mathrm{e}}$ & $227^{\mathrm{e}}$ & & & \\
\hline $\mathrm{I}-32$ & R IV-8 & L-RA01-08 & 15632 & A & 228 & 228 & & & \\
\hline $\mathrm{I}-42$ & R IV-9 & L-RA01-03 & 15633 & $\mathrm{~B}$ & 228 & & 57 & 171 & \\
\hline $\mathrm{I}-1$ & R V-1 & L-RB01-07 & 15634 & A & 166 & 166 & & & \\
\hline $\mathrm{I}-4$ & R V-2 & L-RB01-04 & 15635 & $\mathrm{~A}$ & 166 & 166 & & & \\
\hline $\mathrm{I}-26$ & R V-3 & L-RB01-06 & 15636 & A & 166 & 166 & & & \\
\hline $\mathrm{I}-17$ & R V-4 & L-RB01-08 & 15637 & $\mathrm{~B}$ & 166 & & 37 & 129 & \\
\hline $\mathrm{I}-33$ & R V-5 & L-RB01-03 & 15638 & $\mathrm{~A}$ & 166 & 166 & & & \\
\hline \multirow[t]{2}{*}{$\mathrm{I}-29$} & R V-6 & L-RB01-05 & 15639 & $\mathrm{~A}$ & 166 & 166 & & & \\
\hline & & & & Subtotal & 17,288 & 11,690 & 1,072 & & \\
\hline I-19 & FR-B-1 & Blanket $^{\mathrm{g}}$ & $15682^{\mathrm{g}}$ & $\mathrm{C}^{\mathrm{g}}$ & & & & & $175^{\mathrm{g}}$ \\
\hline $\mathrm{I}-20$ & FR-B2 & Blanket $^{\mathrm{h}}$ & $15684^{h}$ & $\mathrm{C}^{\mathrm{h}}$ & & & & & $144^{\mathrm{h}}$ \\
\hline $\mathrm{I}-48$ & FR-B3 & Blanket $^{\mathrm{i}}$ & $15685^{i}$ & $\mathrm{C}^{\mathrm{i}}$ & & & & & $243^{\mathrm{i}}$ \\
\hline $\mathrm{I}-21$ & FR-B4 & Blanket $^{\mathrm{j}}$ & $15687^{j}$ & $C^{j}$ & & & & & $62^{j}$ \\
\hline $\mathrm{I}-45$ & FR-R1 & Reflector $^{\mathrm{g}}$ & $15681^{\mathrm{g}}$ & $\mathrm{C}^{\mathrm{g}}$ & & & & & $127^{\mathrm{g}}$ \\
\hline $\mathrm{I}-47$ & FR-R2 & Reflector $^{\mathrm{h}}$ & $15683^{h}$ & $\mathrm{C}^{\mathrm{h}}$ & & & & & $80^{\mathrm{h}}$ \\
\hline $\mathrm{I}-22$ & FR-S1 & Seed $^{\mathrm{i}}$ & $15686^{\mathrm{i}}$ & $\mathrm{C}^{\mathrm{i}}$ & & & & & $270^{\mathrm{i}}$ \\
\hline \multirow[t]{2}{*}{$\mathrm{I}-23$} & & 624 sections & 15718 & & & & & & \\
\hline & & & & Total & 17,288 & 11,690 & 1,072 & & $1,101^{\mathrm{k}}$ \\
\hline $\begin{array}{l}\text { a. WAPD- } \\
\text { b. Hecker } \\
\text { c. WAPD- } \\
\text { d. WAPD } \\
\text { e. Plus on } \\
\text { f. Base pla } \\
\text { g. WAPD } \\
\text { h. WAPD } \\
\text { i. WAPD- } \\
\text { j. WAPD- } \\
\text { k. Some o }\end{array}$ & $\begin{array}{l}\text {-NRF(RE) } \\
\text { r 1979, WA } \\
\text {-NRF(RE) } \\
\text {-NRF(RE) } \\
\text { ne flux thim } \\
\text { late numbe } \\
\text {-NRF(L)C } \\
\text {-NRF(L)C } \\
\text {-NRF(L)C } \\
\text {-NRF(L)C } \\
\text { of the rods }\end{array}$ & $\begin{array}{l}\text { FP-139 (Catego } \\
\text { APD-TM-1326, } \\
\text { FP-192, p. 8; W } \\
\text { )FP-192, p. 8; W } \\
\text { nble } \\
\text {-93 } \\
-104 \\
-123 \\
\text { in the Type C lit }\end{array}$ & $\begin{array}{l}\text { ry A liners } \\
\text { Table A-14 } \\
\text { JAPD-NRF } \\
\text { JAPD-NRF }\end{array}$ & $\begin{array}{l}\text { s) and WAI } \\
4 \text { and A-15 } \\
\text { F(L)C-58 (f } \\
\text { F(L)C-58 ( }\end{array}$ & $\begin{array}{l}\text { D-NRF(RE } \\
\text { or module B } \\
\text { or module B }\end{array}$ & $\begin{array}{l}\text { FP-192 (Catego } \\
\text { III-2 only) } \\
\text { III-2 only) }\end{array}$ & ry B liners) & & \\
\hline
\end{tabular}


Table 6-2. Number and type of fuel rods in each liner.

\begin{tabular}{|c|c|c|c|c|c|c|c|c|}
\hline \multirow[b]{2}{*}{ Module Type } & \multicolumn{8}{|c|}{ Liner No. } \\
\hline & $15681^{\mathrm{a}}$ & $15682^{\mathrm{a}}$ & $15683^{b}$ & $15684^{\mathrm{c}}$ & $15685^{\mathrm{b}}$ & $15686^{\mathrm{b}}$ & $15687^{\mathrm{d}}$ & Total \\
\hline SI-1 & & & & & & 42 & & 42 \\
\hline SII-3 & & & & & & 128 & & 128 \\
\hline SIII-1 & & & & & & 43 & & 43 \\
\hline SIII-2 & & & & & & 39 & & 39 \\
\hline BI-3 & & 31 & & & 6 & & 8 & 45 \\
\hline BII-2 & & 7 & & 39 & 23 & & 11 & 80 \\
\hline BIII-2 & & 91 & & 91 & 180 & & 29 & 391 \\
\hline BIII-6 & & 46 & & 14 & 4 & & 14 & 78 \\
\hline RIV-3 & 27 & & 3 & & & & & 30 \\
\hline RIV-4 & 37 & & 39 & & & & & 76 \\
\hline RIV-9 & 56 & & 1 & & & & & 57 \\
\hline RV-4 & 7 & & 30 & & & & & 37 \\
\hline Unirradiated rods & 0 & 0 & 7 & 0 & 30 & 18 & 0 & 55 \\
\hline Total number rods & 127 & 175 & 80 & 144 & 243 & 270 & 62 & 1,101 \\
\hline $\begin{array}{l}\text { a. Reference: Letter WA } \\
\text { b. Reference: Letter WA } \\
\text { c. Reference: Letter WA } \\
\text { d. Reference: Letter WA }\end{array}$ & $\begin{array}{l}\mathrm{RF}(\mathrm{L})-\mathrm{C}-9 \\
\mathrm{RF}(\mathrm{L})-149 \\
\mathrm{RF}(\mathrm{L}) \mathrm{C}-10 \\
\mathrm{RF}(\mathrm{L})-123\end{array}$ & & & & & & & \\
\hline
\end{tabular}




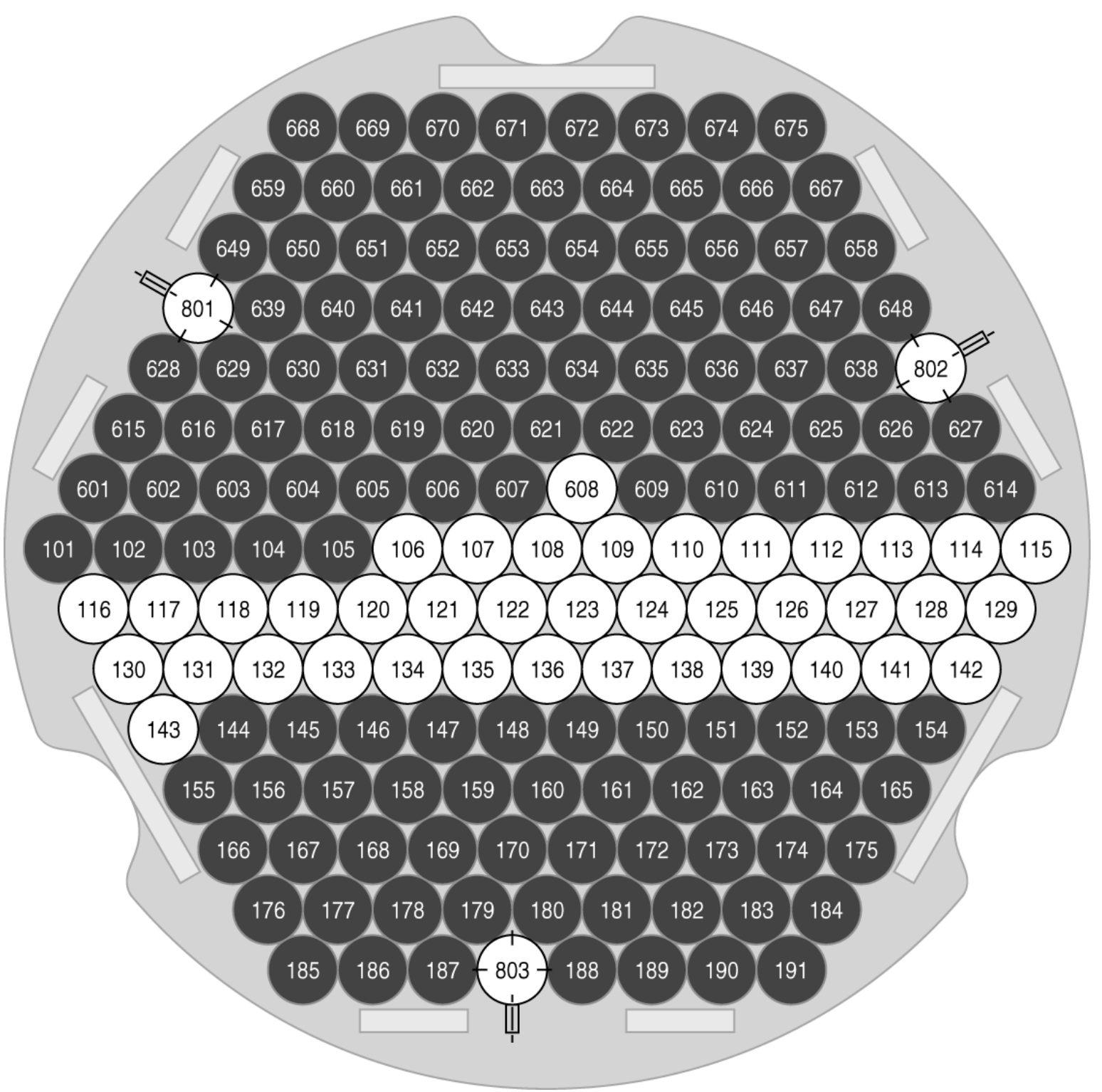

Figure 6-17. Occupied liner cells (in black) for reflector rod storage Liner 15681 (see attachment to letter WAPD-NRC(L) C-93). 


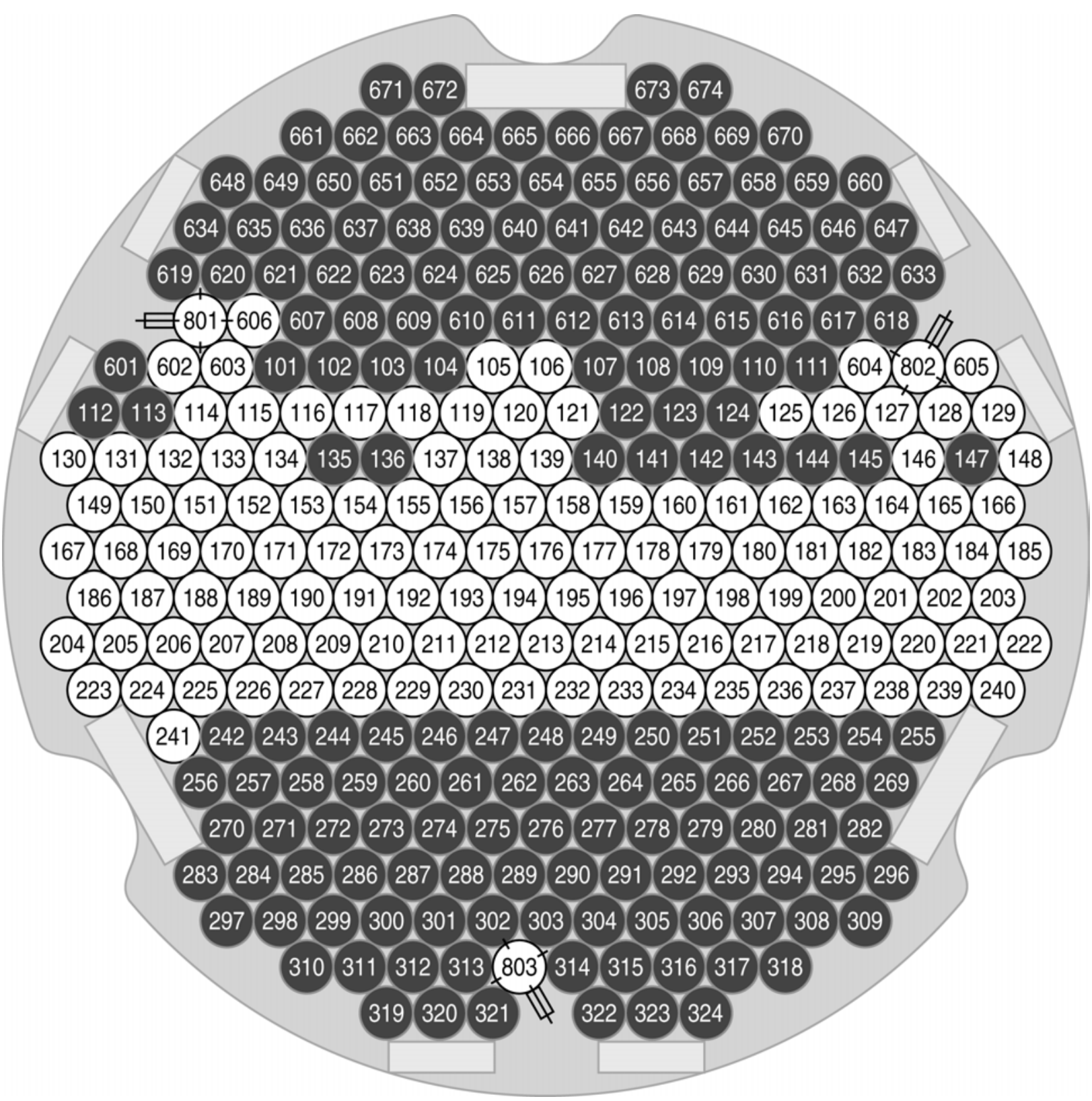

Figure 6-18. Occupied liner cells (in black) for blanket rod storage Liner 15682 (see attachment to letter WAPD-NRC(L) C-93). 


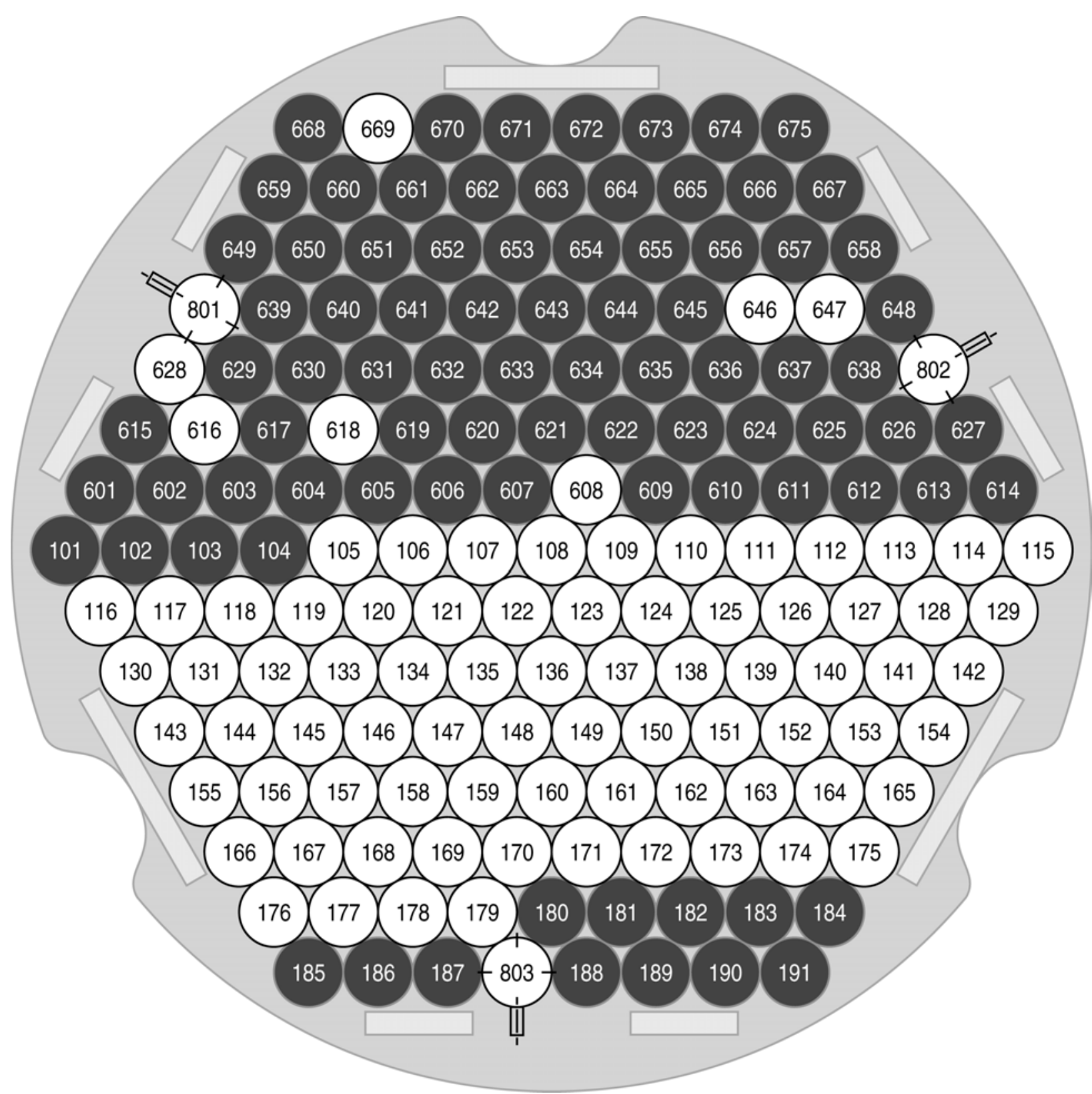

Figure 6-19. Occupied liner cells (in black) for reflector rod storage Liner 15683 (see attachment to letter WAPD-NRC(L)104 and WAPD-NRF(L)C-149). 


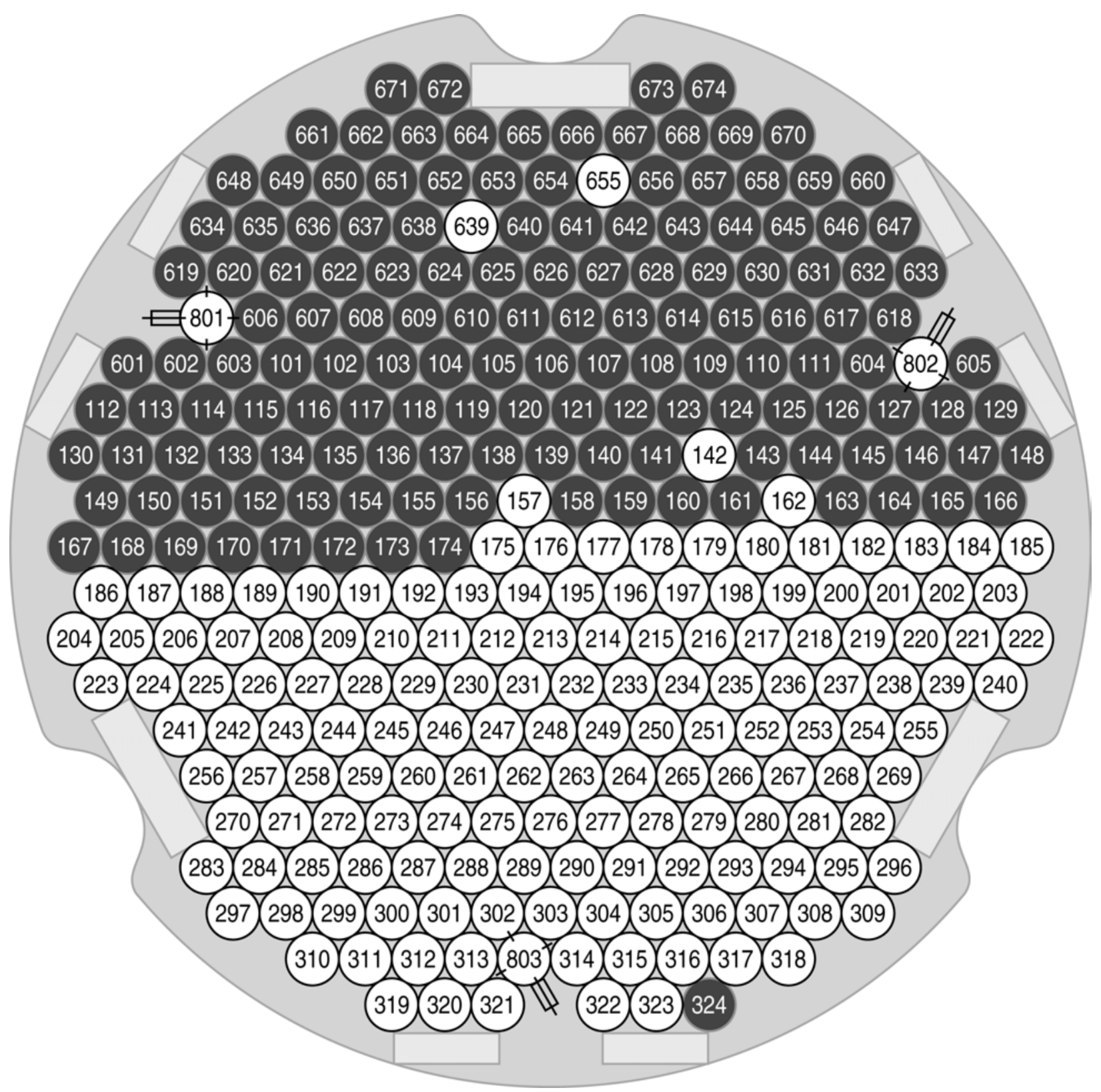

Figure 6-20. Occupied liner cells (in black) for blanket rod storage Liner 15684 (see attachment to letter WAPD-NRC(L) C-104). 


\section{2}

673674

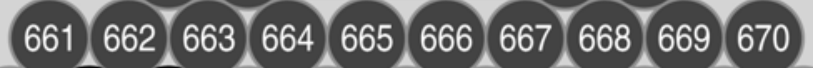

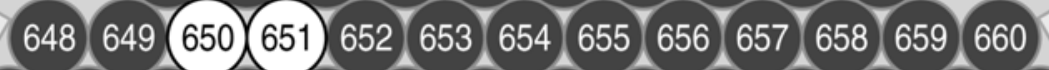

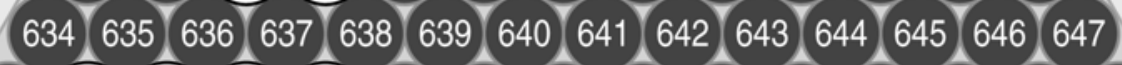

$\begin{array}{lllllllllllllll}619 & 620 & 621 & 622 & 623 & 624 & 625 & 626 & 627 & 628 & 629 & 630 & 631 & 632 & 633\end{array}$

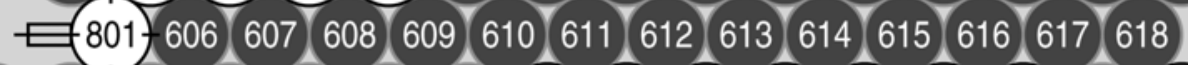

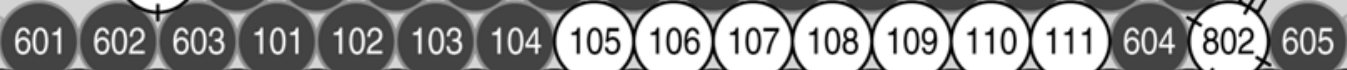

(112) (113) (114) (115) (117) (118) (119) (120) 121) (122) 123) (124) (125) (126) (128) 129

(130) (131) (132) (133) (134) (135)(136) (137) (138) (139) (140) (141) (142) (143) (144) (145) (146) (147) (148)

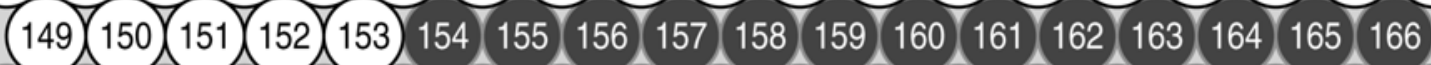

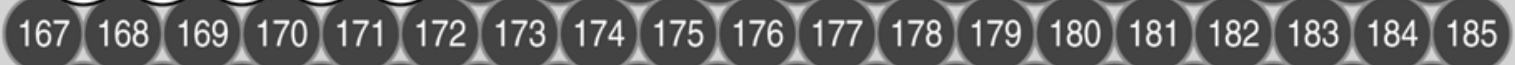
$\begin{array}{llllllllllllllllll}186 & 187 & 188 & 189 & 190 & 191 & 192 & 193 & 194 & 195 & 196 & 197 & 198 & 199 & 200 & 201 & 202 & 203\end{array}$

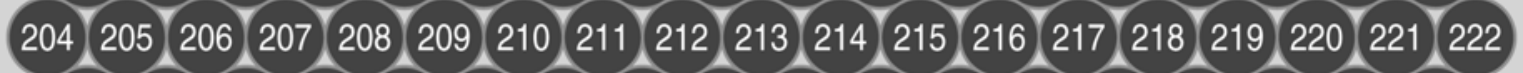

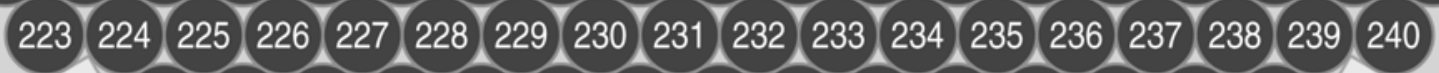

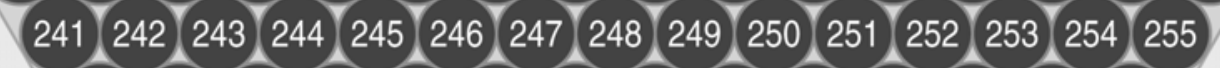

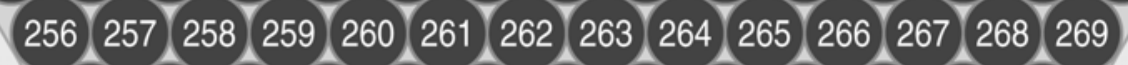

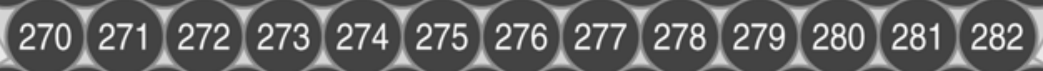

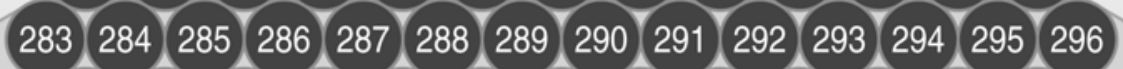

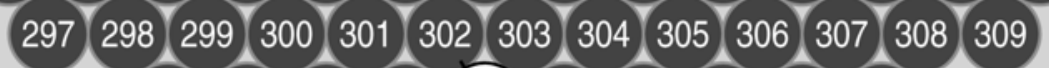

$310311312313(803) 314 \times 315 \quad 316 \quad 317 / 318$

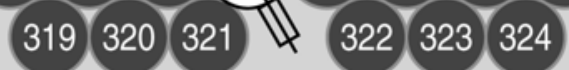

Figure 6-21. Occupied liner cells (in black) for blanket rod storage Liner 15685 (see attachment to letter WAPD-NRC(L)149). 
773774775

776777778

759 760 761 762 763764 765 766 767 768 769 770 771 772

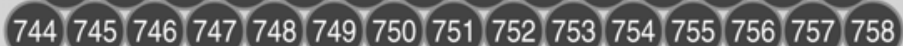

(726) (727) (728) (729) (730) (731) (732) (733) (734) (735) (736) (737) (738) (739) (740) 741 (742) 743

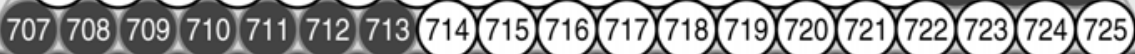

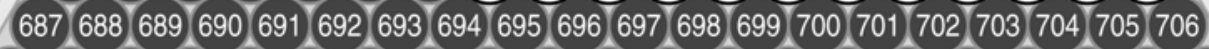

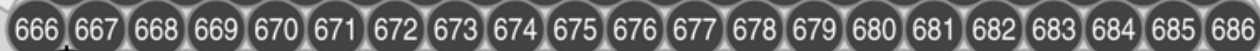

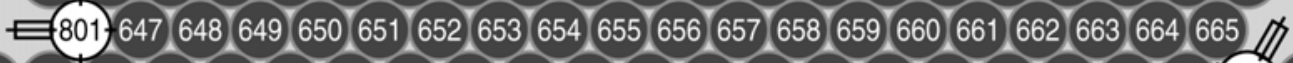

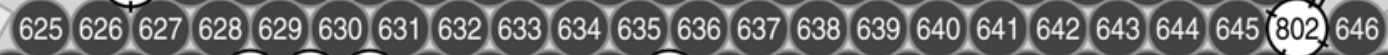

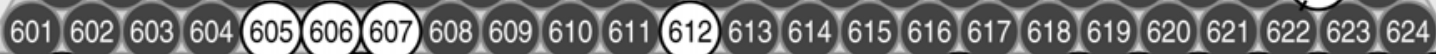

101 (102) 103 (104) $105 / 106$ (107) 108 (109) 110 (111) 112 (113) 114 (115) 116/117) 118 (119) (120) (121) (122) (123) (124)

(126) (127) (128) (129) (130)(131) (132) (133) (134) (135) (136) (137) (138) (139) (140) (141) (142) (143) (144) (145) (146) (147) (148) (149) (150) (151)

(152) (153) (154) (155) (156) (157) (158)(159) (160) (161) (162) (163) (164) (165) (166) (167) (168) (169) (170) (171) (172) (173) (174) (175) (176)

(177) (178) (179) (180) (181) (182) (183) (184) (185) (186) (187) (188) (189) (190) (191) (192) (193) (194) (195) (196) (197) (198) (199) (200) (201) (202)

(203) (204) (205) (206) (207) (208) (209) (210) (211) (212) (213) (214) (215) (216) (217) (218) (219) (220) (221) (222) (223) (224) (225) (226) (227) (228) (229)

(230) (231) (232) (233) (234) (235) (236) (237) (238) (239) (240) (241) (242) (243) (244) (245) (246) (247) (248) (249) (250) (251) (252) (253) (254) (255)

(256) (257) (258) (259) (260) (261) (262) (263) (264) (265) (266) (267) (268) (269) (270) (271) (272) (273) (274) (275) (276) (277) (278) (279) (280)

(281) (282) (283) (284) (285) (286) (287) (288) (289) (290) (291) (292) (293) (294) (295) (296) (297) (298) (299) (300) (301) (302) (303) (304) (305) (306)

(307) (308) (309) (310) (311) (312) (313) (314) (315) (316) (317) (318) (319) (320) (321) (322) (323) (324) (325) (326) (327) (328) (329) (330) (331)

(332) (333) (334) (335) (336) (337) (338) (339) (340) (341) (342) (343) (344) (345) (346) (347) (348) (349) (350) (351) (352) (353) (354) (355)

(356) (357) (358) (359) (360) (361) (362) (363) (364) (365) (366) (367) (368) (369) (370) (371) (372) (373) (374) (375) (376)

(377) (378) (379) (380) (381) (382) (383) (384) (385) (386) (387) (388) (389) (390) (391) (392) (393) (394) (395) (396)

(397) (398) (399) (400) $401 / 402 / 403 / 404 / 405 / 406 / 407 / 408 / 409 / 410 / 411 / 412 / 413 / 414 / 415)$

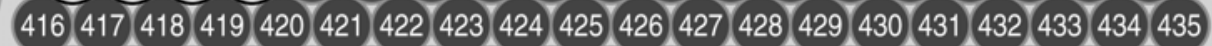

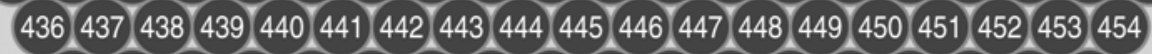

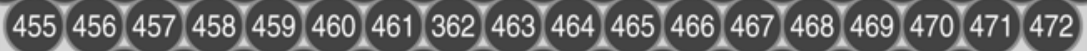

473 474 475 476 477 (478 479 480 481 (482 483 484 485 486 487

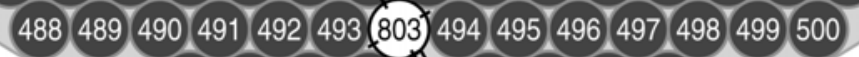

$501502503504 \times 505506507508$

Figure 6-22. Occupied liner cells (in black) for seed rod storage Liner 15686 (see attachment to letter

WAPD-NRC(L)149). 


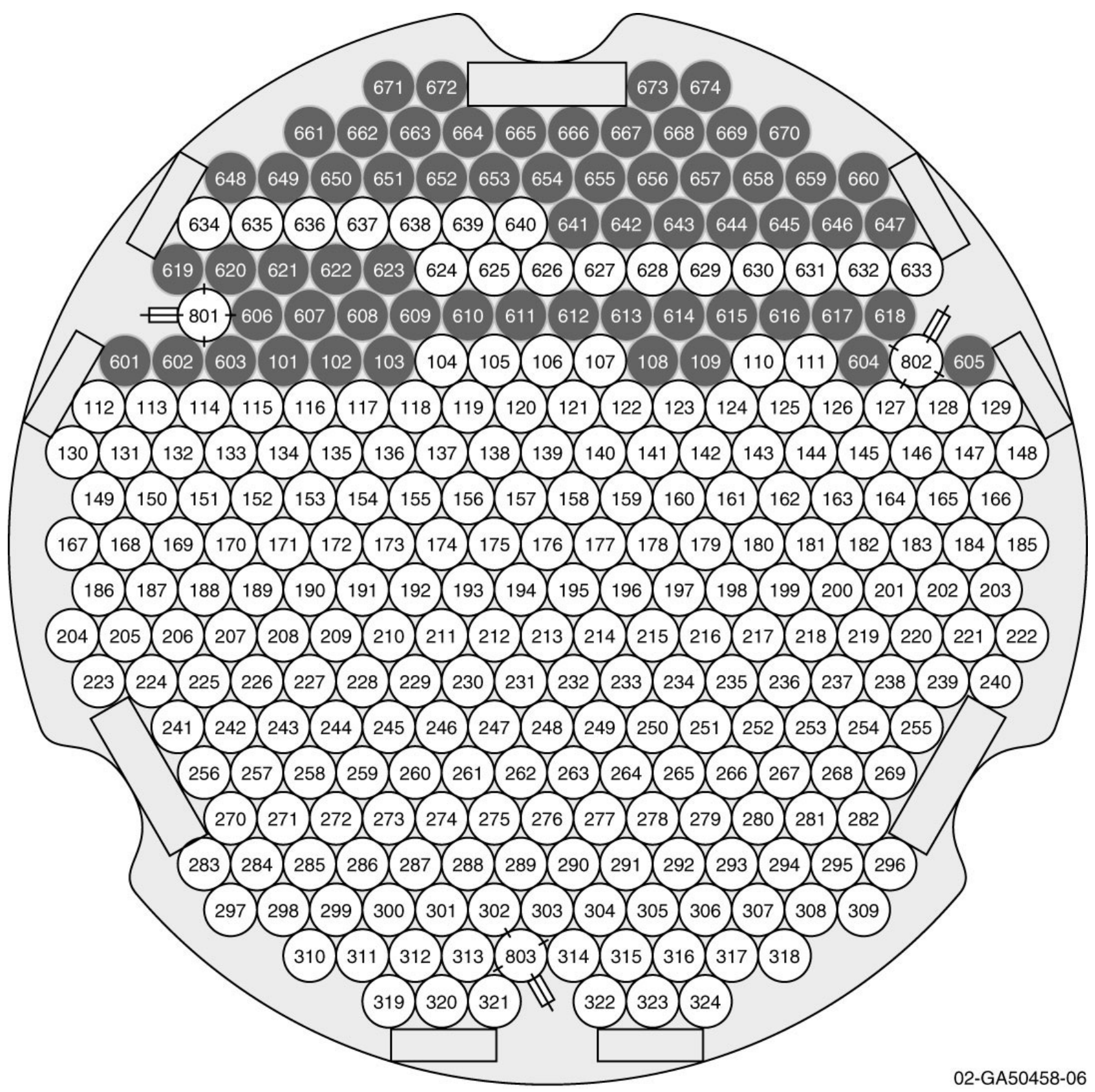

Figure 6-23. Occupied liner cells (in black) for blanket rod storage Liner 15687 (see attachment to letter WAPD-NRC(L)123). 


\subsection{Condition of SNF}

Fuel in Type A liners is likely intact, although there may have been some cladding breach on two Type A seed modules (see Section 6.2.2 above). The information provided in the Part B data did not indicate which seed modules contained the possible breached cladding. Part C FRC data indicated that Seeds 3-5 (Shipment 27) and 3-6 (Shipment 28) were suspect for breached cladding because radioactive gas was present when the can atmosphere was sampled. Further sampling of both of these Type A liners indicated no presence of Krypton-85, and in both cases, the conclusion was that the fuel was sealed in liner storage containers (see WAPD-NRF(L)C-117, Attachment page 3).

Type B liners contain partially derodded modules. Derodding involved sawing off the top of the core with the cutoff system described in Greenberger and Miller 1987 (WAPD-TM-1608). Type C liners contain rods that have been removed from the modules that now occupy the Type B canisters.

The cut fuel can (Liner 15718) contains fuel pieces that were part of testing during design of the LWBR fuel. The fuel pieces and rods are in various stages of disassembly and condition due to destructive and nondestructive tests on the rods. The descriptions of the tests and the rods used in the tests are provided in Appendix C. Liner 15718 contains remnants from 260 to 275 test rods, which were similar in size and composition to the LWBR fuel rods. Most of the test rods were tested under normal LWBR pressure and temperature conditions, but some operated at low system pressure and low coolant temperatures. With the exception of 2 of 271 rods described in WAPD-TM-1208, no breach of cladding integrity was observed in any test rod during normal operations; however, several rods were cut up. Intentionally severe overtest conditions resulted in two rods damaged (Conners et al. 1979, WAPD-TM-1208, p. 30).

\subsection{Thermal Output}

Heat output data for each of the storage liners at the time of shipping were provided in the Part $\mathrm{C}$ Fuel Receipt Criteria and are presented in Table 6-3, along with other data from Part C. The decay heat curves as a function of cooling time for the hottest fully rodded seed, blanket, and reflector modules (i.e., upper limit rates) were included in the Part B Fuel Receipt Criteria (e.g., WAPD-NRF(L)C-104), see Figure 6-24. The decay heat curve spans over a 10-year cooling time. Assuming a start date of December 2, 1982, the curve spans through December 2, 1992.

Sterbentz and Wahnschaffe (2001) predicted heat rate generation for a single seed (Type I), standard blanket (Type I), standard/power-flattening blanket (Type II), standard/power-flattening blanket (Type III), Reflector IV, and Reflector V module. Module heat rates are given as a function of decay date (2000-2030). These calculated module heat rates were compared to heat rates reported in WAPD-NRF(L)C-104, which were calculated values verified against actual LWBR module decay heat measurements. The calculated values from Sterbentz and Wahnschaffe (2001) were 33\% and 29\% higher than the WAPD Fuel Receipt Criteria values for a single seed module and a single standard/power-flattening blanket module, respectively. The Type IV Reflector decay heat value from Sterbentz and Wahnschaffe (2001) was approximately 29\% lower than the WAPD value. The estimated decay heat values from Sterbentz and Wahnschaffe for year 2005 are presented in Table 6-4.

\subsection{Liquid Content of Canister}

While at ECF, each fuel storage liner was stored in the ECF waterpit. Prior to shipment, each liner was dried to the extent that no liquid water remained (see p. 5 of the [Part B Fuel Receipt Criteria] attachment transmitted in WAPD-NRF(L)C-104, April 30, 1987). As stated in Part B FRC (p. 7 of Attachment to WAPD-NRF(L)C-104, April 30, 1987), "Prior to shipment, the LWBR fuel storage liner 


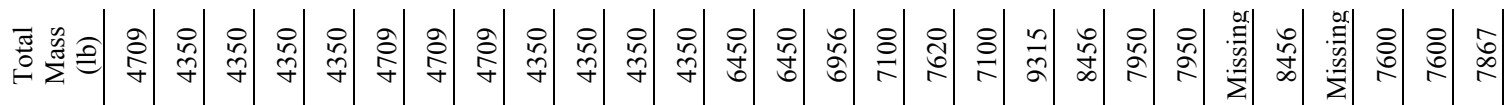

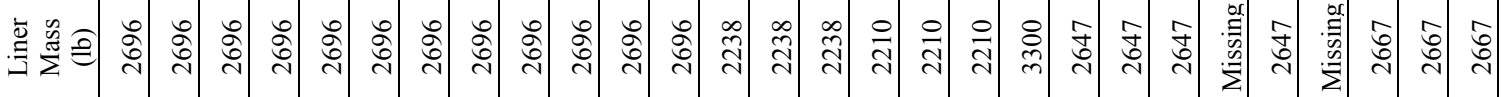

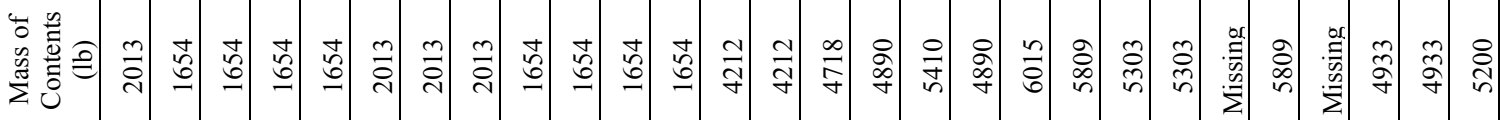

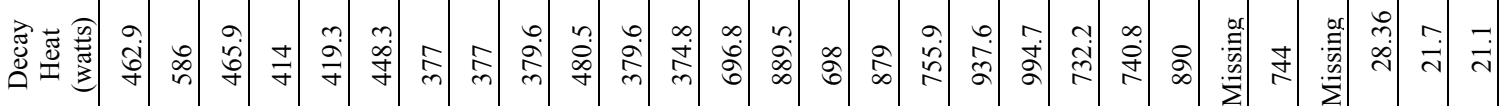

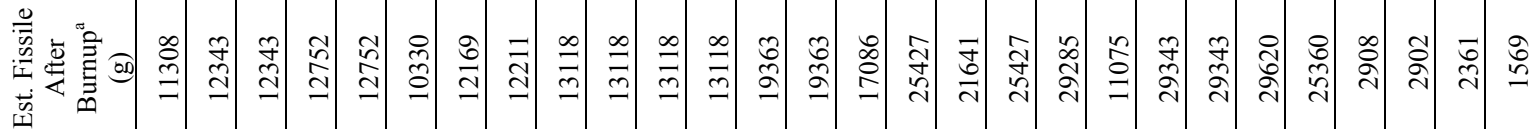

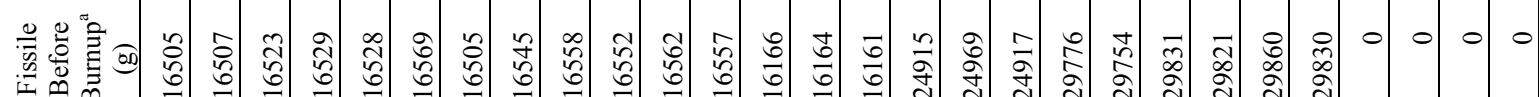

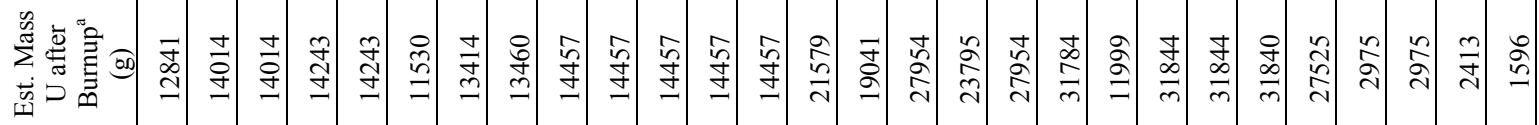

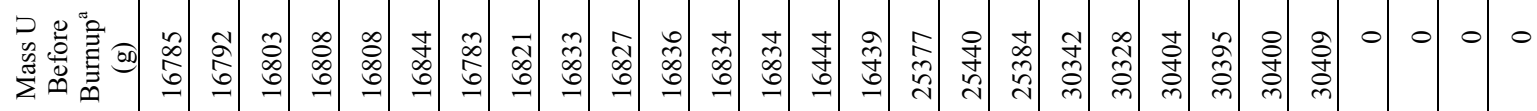
=

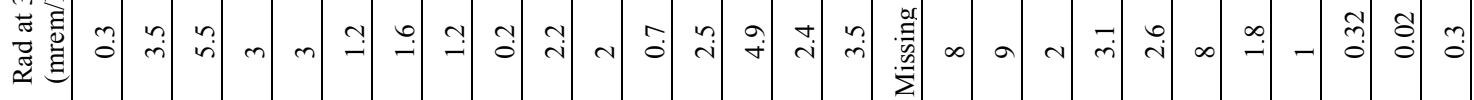
要

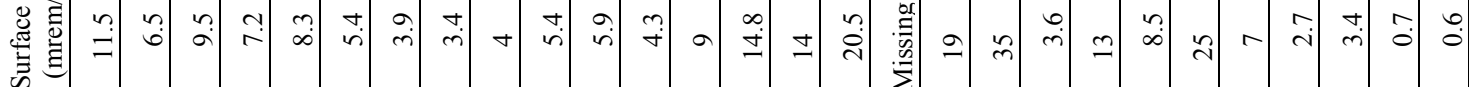

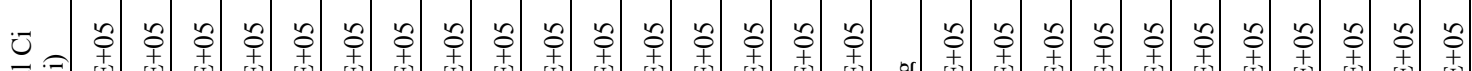

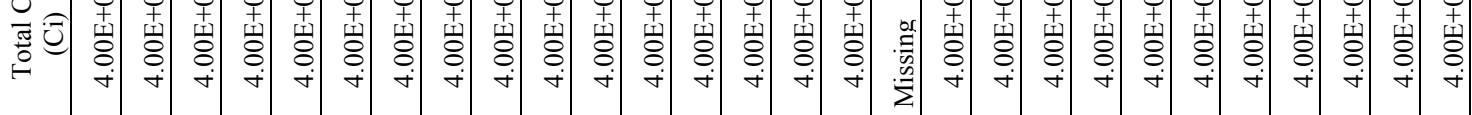

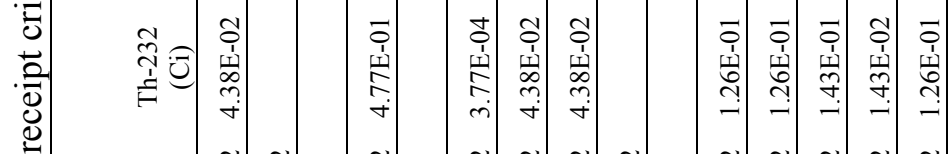

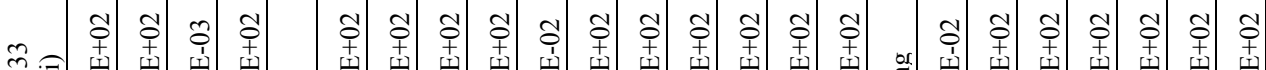

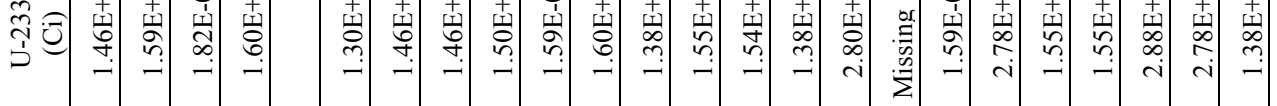

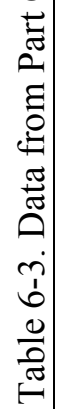

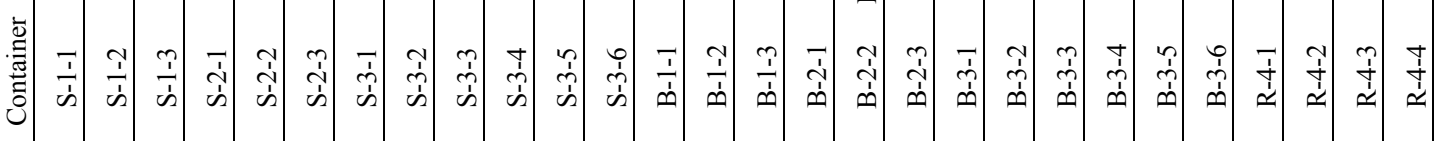

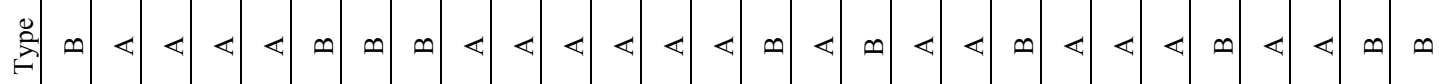

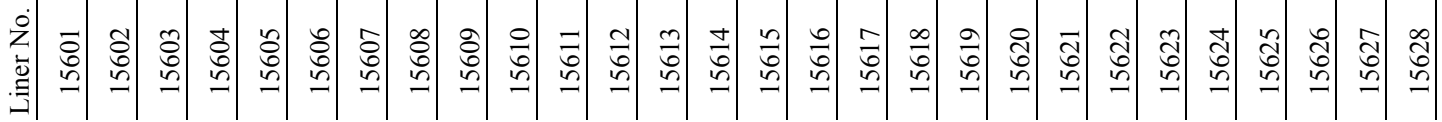




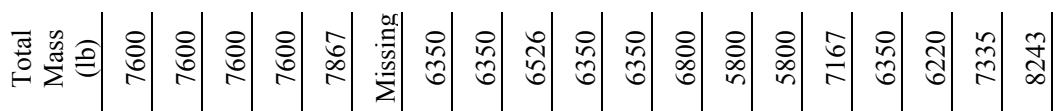

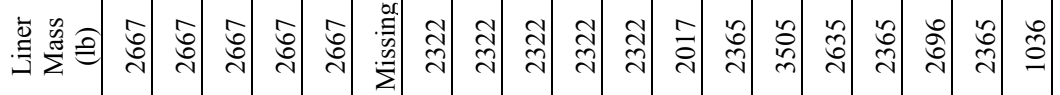

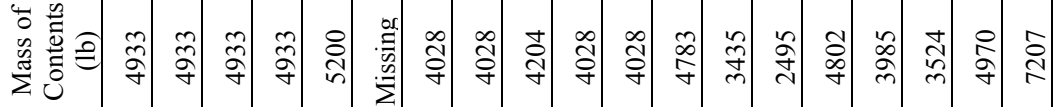

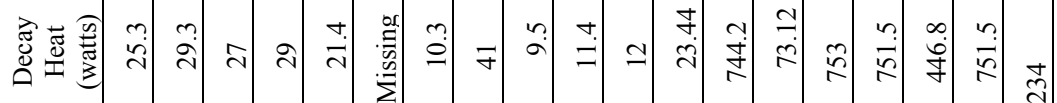

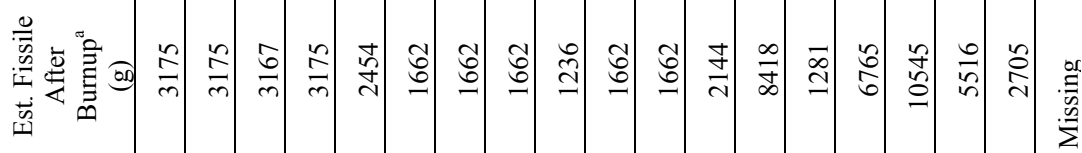

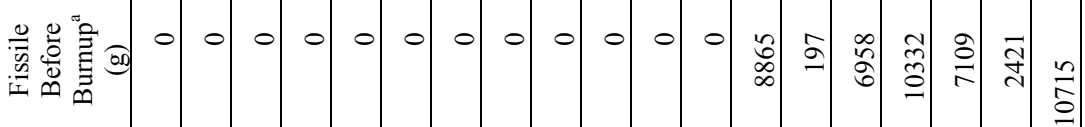

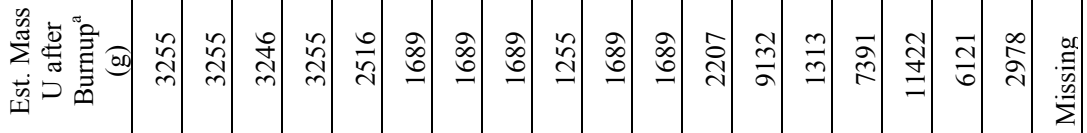

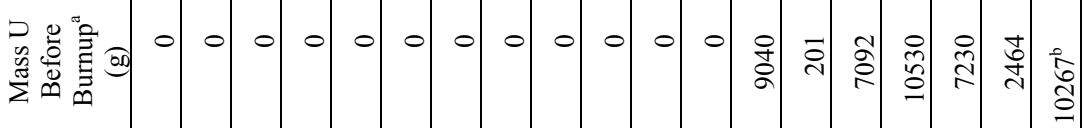
整善

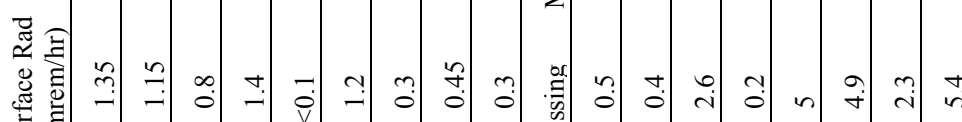

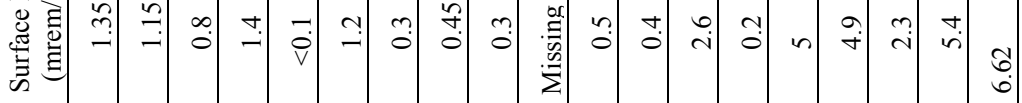

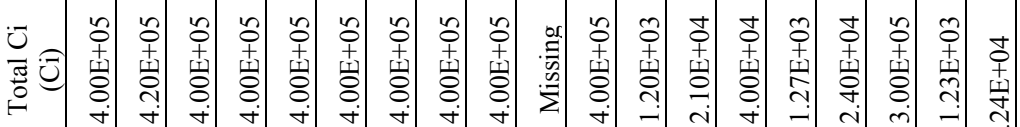

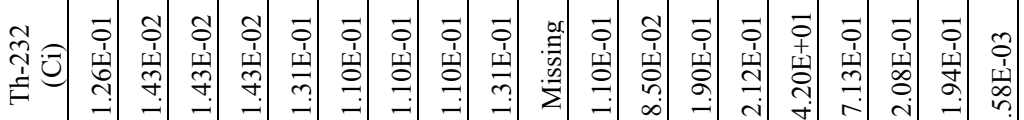
곡으

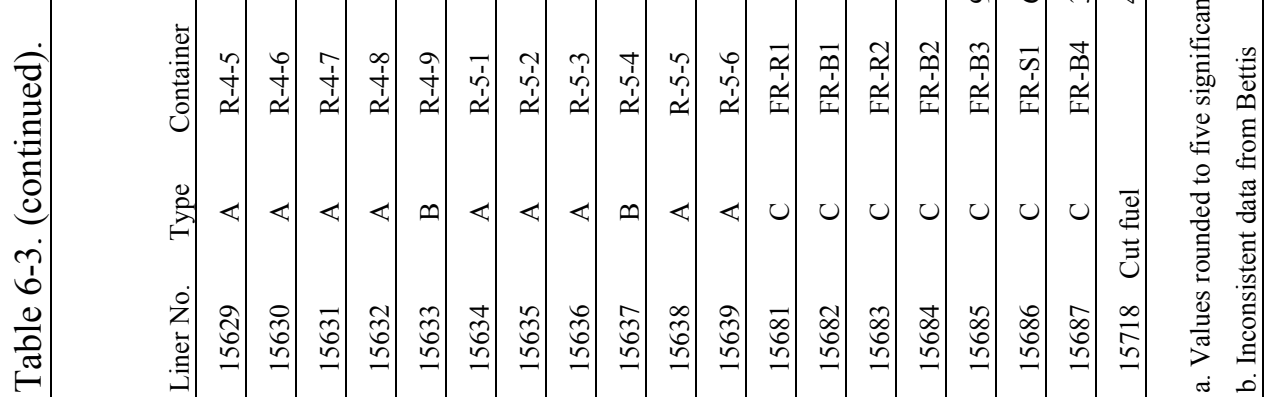




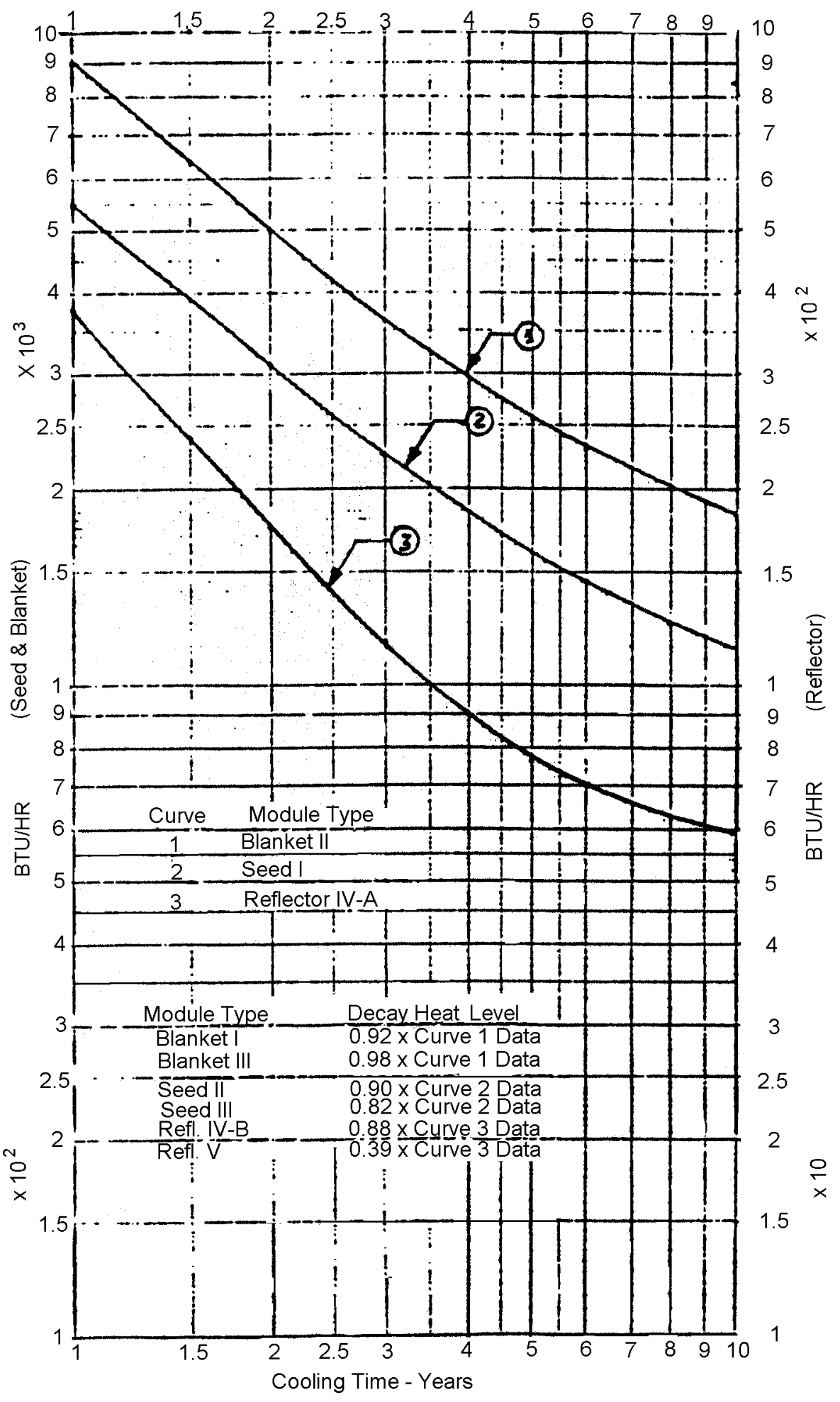

Figure 6-24. Decay heat as a function of cooling time for the hottest fully rodded seed, blanket, and reflector modules (attached to WAPD-NRF(L)C-104 [curve on p. 15, some discussion on p. 4-5], April 30, 1987, Fuel Receipt Criteria, Part B). 
Table 6-4. Estimated decay heat values for Light Water Breeder Reactor core modules in the year 2005 (Sterbentz and Wahnschaffe, 2001).

\begin{tabular}{lc}
\hline \multicolumn{1}{c}{ Module Type } & $\begin{array}{c}\text { Decay Heat } \\
\text { (Watts) }\end{array}$ \\
\hline Single seed (Type I) & 352.8 \\
Standard blanket (Type I) & 501.5 \\
Standard/power flattening blanket (Type II) & 517.1 \\
Standard/power flattening blanket (Type III) & 480.5 \\
Reflector IV & 9.62 \\
Reflector V & 4.7 \\
\hline
\end{tabular}

must be internally dry and contain an inert atmosphere. A liner is defined as dry when all liquid water has been removed. The drying process was confirmed by checkout and testing of the LWBR Liner Closure Station dewatering equipment used on an actual fuel storage liner both at a vendor shop and at ECF. ECF will certify that the liner for each fuel handling unit is dry and contains the inert atmosphere as required." Pressure testing (hydrostatic test, neon and helium gas tests, and a hydraulic jack test) was conducted prior to shipment, and the completed certification checklists for each shipment, including shift supervisor and engineering checkoffs for "no liquid water in liner" are included in the Part C Fuel Receipt Criteria. 


\section{REFERENCES}

Atherton, R. (coordinator), 1987, Water Cooled Breeder Program Summary Report (LWBR Development Program), WAPD-TM-1600, October 1987.

Beaudoin, B. R., 1987, Loading Assurance Methods Used in the Manufacture of the Light Water Breeder Reactor (LWBR), WAPD-TM-1315, September 1987.

Budd, W. A. (ed.), 1986, Shippingport Operations With the LWBR Core (LWBR Development Program), WAPD-TM-1542, March 1986.

Campbell, W. R., and J. F. Giovengo, 1987, Light Water Breeder Reactor Fuel Rod Design and Performance Characteristics (LWBR Development Program), WAPD-TM-1387, October 1987.

Cole, L. N., 2001, Shippingport LWBR Spent Nuclear Fuel Data for Transfer from CPP-749 to Spent Nuclear Fuel Dry Storage Project, EDF-2875.

Conners, D. R., S. Milani, J. A. Fest, and R. Atherton, 1979, Design of the Shippingport Light Water Breeder Reactor, WAPD-TM-1208, January 1979.

DeGeorge, V. V., and I. Goldberg, eds., 1986, The Fabrication and Loading of Fuel Rods for the Light Water Breeder Reactor (LWBR Development Program), WAPD-TM-1278, March 1986.

Eyler, J. H., 1981, Development and Control of the Process for the Manufacture of Zircaloy-4 Tubing for LWBR Fuel Rods (LWBR Development Program), WAPD-TM-1289, January 1981.

Freeman, L. B. (ed.), 1978, The Calculational Model Used in the Analysis of Nuclear performance of the Light Water Breeder Reactor (LWBR), WAPD-TM-1314, August 1978.

Fuel Receipt Criteria, Part A, sent from Westinghouse Electric Corporation LWBR Fuel Disassembly and Disposal Engineering, NRF Project to ECF LWBR Engineering at Naval Reactors Facility:

WAPD-NRF(L)D-96, August 10, 1987

WAPD-NRF(L)D-58, March 13, 1987

WAPD-NRF(L)D-5, September 22, 1986

WAPD-NRF(E)FD-09, Received March, 1985

WAPD-LP(CE)FD-38, October 12, 1984

Fuel Receipt Criteria, Part B sent from Westinghouse Electric Corporation to CPP-666 (listed alphabetically by letter number):

NRFE-LWBRE-1034, October 28, 1986

RDD-94-86 (transmittal letter from R.D. Denney, INEL, to R. E. Wilson, Manager, INEL Criticality Safety), transmitting WAPD-NRF(RE)FP-192, May 27, 1986

WAPD-NRF(E)-9, February 13, 1985 
WAPD-NRF(L)-149, September 15, 1987

WAPD-NRF(L)C-104, April 30, 1987

WAPD-NRF(L)C-117, June 26, 1987

WAPD-NRF(L)C-123, July 8, 1987

WAPD-NRF(L)C-58, January 9, 1987

WAPD-NRF(L)C-93, March 26, 1987

WAPD-NRF(L)D-110, September 23, 1987

WAPD-NRF(RE)FP-132, December 6, 1985

WAPD-NRF(RE)FP-139, December 27, 1985

WAPD-NRF(RE)FP-192, May 27, 1986

Fuel Receipt Criteria, Part C (arranged by canister):

NRFE-LWBRE-863-21, August 29, 1986 and Shipment \#21 (S-1-1) September 2, 1986

NRFE-LWBRE-863-12, Spril 17, 1986 and Shipment \#14 (S-1-2), April 25, 1986

Shipment \#15 (S-1-3), June 5, 1986

Shipment \#38 (S-2-1), April 20, 1987

Shipment \#16 [S-II-1 (sic)], June 12, 1986

Shipment \#44 (S-2-3), July 31, 1987

Shipment \#22 [S-III-I (sic)], September 12, 1986

Shipment \#23 [S-III-2 (sic)], September 29, 1986

Shipment \#17 (S-3-3), June 27, 1986

Shipment \# not identified (S-3-4), May 2, 1986

Shipment \#27 (S-3-5), November 24, 1986

Shipment \#28 (S-3-6), December 23, 1986

Shipment \#30 [B1-1 (sic)], January 29, 1987

Shipment \#8 (B-1-2), March 19, 1986

Shipment \#25 (B-1-3), November 3, 1986 
Shipment \#20 (B-2-1), August 25, 1986

Shipment \#32 (B-2-2), March 9, 1987

Shipment \#14 (B-2-3), May 28, 1986

Shipment \#1 [B31 (sic)], December 12, 1985

Shipment \#36 (B-3-2), April 2, 1987

Shipment \#31 [B3-3 (sic)], February 5, 1987

Shipment \#19 (B-3-4), August 8, 1986

Shipment \#2 (B-3-5), December 12, 1985

Shipment \#26 (B-3-6), November 14, 1986

Gorscak, D. A., W. R. Campbell, and J. C. Clayton, 1987, End-Of-Life Nondestructive Examination of Light Water Breeder Reactor Fuel Rods (LWBR Development Program), WAPD-TM-1605, October 1987.

Graczyk, D. G., J. C. Hoh, F. J. Martino, R. E. Nelson, J. Osudar, and N. M. Levitz, 1987, Final Report for the Light Water Breeder Reactor Proof-of-Breeding Analytical Support Project, ANL-87-2.

Greenberger, R. J., and E. L. Miller, 1987, Primary Disassembly of LWBR Modules for Core Evaluation (LWBR Development Program), WAPD-TM-1608, October 1987.

Hecker, H. C., 1979, Summary of the Nuclear Design and Performance of the Light Water Breeder Reactor (LWBR), WAPD-TM-1326, June 1979.

Hecker, H. C., and L. B. Freeman, 1981, Design Features of the Light Water Breeder Reactor Which Improve Fuel Utilization in LWRs (LWBR Development Program), WAPD-TM-1409, August 1981.

Hodges, B. W. (ed.), 1987, Preparation of LWBR Spent Fuel for Shipment to ICPP for Long Term Storage (LWBR Development Program), WAPD-TM-1601, October 1987.

Idaho Nuclear Technology and Engineering Center (INTEC) Plant Safety Document, Section 4.7A, 2002, Storage of Unirradiated and Irradiated Light Water Breeder Reactor Fuel in Underground Dry Wells at INTEC, Rev. 3, July 17, 2002.

Massimino, R. J., and D. A. Williams, 1983, The Installation of the Light Water Breeder Reactor at the Shippingport Atomic Power Station (LWBR Development Program), WAPD-TM-1342, May 1983.

Richardson, K. D., W. R. Campbell, J. C. Clayton, and B. C. Smith, 1987, End of Life Destructive Examination of Light Water Breeder Reactor Fuel Rods, WAPD-TM-1606, October 1987.

Sarber, W. K., 1983, Reactor Physics Test Program for the Light Water Breeder Reactor (LWBR) Core at Shippingport (LWBR Development Program), WAPD-TM-1455, Addendum, December 1983. 
Sarber, W. K., ed., 1976, Results of the Initial Nuclear Tests on the LWBR (LWBR Development Program), WAPD-TM-1336, June 1976.

Schick, W. C., Jr., B. R. Beaudoin, W. J. Beggs, L. B. Freeman, and G. Tessler, 1987, Proof of Breeding in the Light Water Breeder Reactor (LWBR Development Program), WAPD-TM-1612, September 1987.

Selsley, I. A., ed., 1987a, Defueling of the Light Water Breeder Reactor at the Shippingport Atomic Power Station, WAPD-TM-1551, September 1987.

Selsley, I. A., 1987b, Shipment of the Light Water Breeder Reactor Fuel Assemblies from the Shippingport Atomic Power Station to the Expended Core Facility (Idaho)(LWBR Development Program), WAPD-TM-1553, October 1987.

Selsley, I. A. (ed.), 1987c, Light Water Breeder Reactor Fuel Module Disassembly at the Shippingport Atomic Power Station (LWBR Development Program), WAPD-TM-1552, October 1987.

Sterbentz, J. W., 1999, Validation Work to Support the Idaho National Engineering and Environmental Laboratory Calculational Burnup Methodology Using Shippingport Light Water Vreeder Reactor (LWBR) Spent Fuel Assay Data, INEEL/EXT-99-00581, August 1999.

Sterbentz and Wahnschaffe (2001). Light Water Breeder Reactor (LWBR) Decay Heat Estimate Analysis. EDF 1781, rev. 1.

Tessler, G., B. R. Beaudoin, W. J. Beggs, L. B. Freeman, and W. C. Schick, 1987, Nondestructive Assay of Spent Fuel Rods From the LWBR (LWBR Development Program), WAPD-TM-1614, September 1987.

Walter, J. F., and W. A. Weinreich, eds., 1976, $\mathrm{ThO}_{2}$ and $\mathrm{ThO}_{2^{-}}{ }^{233} \mathrm{UO}_{2}$ High Density Fuel Pellet Manufacture for the Light Water Breeder Reactor, WAPD-TM-1244(L), January 1976.

Wargo, J. E., 1987, Light Water Breeder Reactor End-of-Life Component Examinations at Shippingport Atomic Power Station and Module Visual and Dimensional Examinations at Expended Core Facility, WAPD-TM-1602, October 1987.

Williams, J. T., 1987, Light Water Breeder Reactor Core Evaluation Operations at the Expended Core Facility, WAPD-TM-1611, October 1987. 


\section{Other References}

Bacvinskas, W. S. (ed.), 1987, Light Water Breeder Reactor Module and Rod Examinations LWBR Development Program, WAPD-TM-1610, October 1987.

Beaudoin, B. R., W. J. Beggs, C. R. Case, and R. Wilczynski, 1979, A System of Datatran Modules Which Process Core Fuel Loading for Use in As-Built Calculations (LWBR Development Program), WAPD-TM-1316, February 1979.

Benton, Hugh, et al., 1997, Technical Strategy for the Management of Spent Nuclear Fuel, March 1997.

Berman, R. M., H. B. Meieran, and P. W. Patterson, 1967, Irradiation Behavior of Zircaloy-Clad Fuel Rods Containing Dished-End $\mathrm{UO}_{2}$ Pellets (LWB-LSBR Development Program), WAPD-TM-629, July 1967.

Bolton, S. R., et al., ICPP Final Safety Analysis (Section 4.7) "Storage of Unirradiated and Irradiated Light Water Breeder Reactor Fuel in Underground Dry Wells at ICPP," WIN-107-4.7A-Rev. 1, March 1989.

Busby, C. C., and K. B. Marsh, 1970, High Temperature Deformation and Burst Characteristics of Recrystallized Zircaloy-4 Tubing (LWBR Development Program), WAPD-TM-900, January 1970.

Caffarel, A. J., 1979, The Inspection of Assembled LWBR Fuel Rods for Internal Dimensions and Pellet Integrity Utilizing In-Motion Radiography (LWBR Development Program), WAPD-TM-1239, February 1979.

Clayton, J. C., 1982, Corrosion and Hydriding of Irradiated Zircaloy Fuel Rod Cladding (LWBR Development Program), WAPD-TM-1440, September 1982.

Clayton, J. C., 1985, Cladding Corrosion and Hydriding in Irradiated Defected Zircaloy Fuel Rods (LWBR Development Program), WAPD-TM-1393, August 1985.

Clayton, J. C., 1987, In-Pile and Out-of-Pile Corrosion Behavior of Thoria-Urania Pellets (LWBR Development Program), WAPD-TM-1548, January 1987.

Daniel, R. C., 1971, In-Pile Dimensional Changes of Zircaloy-4 Tubing Having Low Hoop Stresses (LWBR Development Program), WAPD-TM-973, July 1971.

Duncombe, E., 1968, Analysis of Void Migration, Clad Collapse and Fuel Cracking in Bulk Oxide Fuel Rods (LWBR Development Program), WAPD-TM-794, July 1968.

Duncombe, E., and I. Goldberg, 1970, Comparison of Dimensional Changes in Fuel Rods With Predictions Under Cyclic Conditions of Power and System Pressure (LWBR Development Program), WAPD-TM-940, March 1970.

Duncombe, E., et al., Comparisons With Experiment of Calculated Dimensional Changes and Failure Analysis of Irradiated Bulk Oxide Fuel Test Rods Using the CYGRO-1 Computer Program, September 1966.

Emert, C. J., 1979, The Nondestructive Assay of $\mathrm{UO}_{2}-\mathrm{ThO}_{2}$ Fuel Pellets Using the Delayed Neutron Pellet Assay Gauge (LWBR Development Program), WAPD-TM-1368, June 1979. 
Engel, J. T., and H. B. Meieran, 1968, Performance of Fuel Rods Having 97 Percent Theoretical Density $\mathrm{UO}_{2}$ Pellets Sheathed in Zircaloy-4 and Irradiated at Low Thermal Ratings (LSBR/LWBR Development Program), WAPD-TM-631, July 1968.

Eyler, J. H., 1979, The Characteristics of the Zircaloy-4 Tubing in LWBR Fuel Rods (LWBR Development Program), WAPD-TM-869, November 1979.

Eyler, J. H., 1981, Development and Control of the Process for the Manufacture of Zircaloy-4 Tubing for LWBR Fuel Rods, WAPD-TM-1289, January 1981.

Fodor, G., 1987, Light Water Breeder Reactor Rod Removal System (LWBR Development Program), WAPD-TM-1609, October 1987.

Galtz, C. S., 1983, The Friction Grip Enclosure-A Means for Increasing the Fatigue Life of Fuel Rod End Welds (LWBR Development Program), WAPD-TM-1348, March 1983.

Giovengo, J. F., 1970, In-Pile Dimensional Changes of $\mathrm{ThO}_{2}-\mathrm{UO}_{2}$ With Non-Free-Standing Cladding (LWBR Development Program), WAPD-TM-986, November 1970.

Giovengo, J. F., I. Goldberg, and G. L. Spahr, 1982, Fission Gas Release From High Burnup ThO2 and $\mathrm{ThO}_{2}-\mathrm{UO}_{2}$ Fuels Irradiated at Low Temperature (LWBR/AWBA Development Program), WAPD-TM-1350, Addendum 2, May 1982.

Goldberg, I., L. A. Walman, J. F. Giovengo, and W. R. Campbell, 1979, Fission Gas Release and Grain Growth in $\mathrm{ThO}_{2}-\mathrm{UO}_{2}$ Fuel Irradiated at High Temperature (LWBR Development Program), WAPD-TM-1350, Addendum, July 1979.

Gourley, B. R. (ed.), 1981, Fabrication of Seed, Blanket and Reflector Fuel Assemblies for the Light Water Breeder Reactor (LWBR Development Program), WAPD-TM-1317, May 1981.

Green, S. J., et al., 1969, Critical Heat Flux Tests on a Coolant Channel Simulating a Closely Spaced Lattrice of Rods (LWBR Development Program), WAPD-TM-466, March 1969.

Hecker, H. C., 1984, Nuclear Analysis and Performance of the Light Water Breeder Reactor (LWBR) Core Power Operation at Shippingport (LWBR Development Program), WAPD-TM-1376, April 1984.

Hecker, H. C., and C. J. Simon, 1984, Idaho Chemical Processing Plant Part A Fuel Receipt Criteria for the LWBR Core, WAPD-LP(CE)FD-38 attachment, October 1984.

Hecker, H. C., and C. J. Simon, 1985, ICPP Fuel Receipt Criteria (Part A) for the LWBR Core (Rev. 3), WAPD-NRF(E)FD-09 attachment, January 1985.

Hersey, B. A., and H. B. Meieran, 1969, Behavior of an Intentionally Defected Fuel Rod Which Ruptured During Irradiation (Rod BETT 79-64D) (LWBR Development Program), WAPD-TM-628, July 1969.

Hoffman, R. C., and J. Sherman, 1978, Irradiation Testing of Internally Pressurized and/or Graphite Coated Zircaloy-4 Clad Fuel Rods in the NRX Reactor (LWBR Development Program), WAPD-TM-1421, November 1978. 
Hoffman, R. C., J. F. Yerman, and T. H. Alff, 1982, Experimental Results of the Irradiation of Long Rod Duplex Pellet Screening Tests in the NRX Reactor (NLDR-1 Test) (AWBA Development Program), WAPD-TM-1492, July 1982.

I. Goldberg, I., C. L. Spahr, L. S. White, L. A. Waldman, J. F. Giovengo, P. L. Pfenningwerth, and J. Sherman, 1978, Fission Gas Release From $\mathrm{ThO}_{2}$ and $\mathrm{ThO}_{2}-\mathrm{UO}_{2}$ Fuels (LWBR Development Program), WAPD-TM-1350, August 1978.

Ivak, D. M., and L. A. Waldman, 1979, Iodine and Cesium in Oxide Fuel Pellets and Zircaloy-4 Cladding of Irradiated Fuel Rods (LWBR Development Program), WAPD-TM-1394, March 1979.

Jacobs, D. C., 1969, The In-Pile Thermoconductivity of Selected ThO $\mathrm{O}_{2}-\mathrm{UO}_{2}$ Fuels at Low Depletions (LWBR Development Program), WAPD-TM-758. May 1969.

Jacobs, D. C., 1970, In-Pile and Unirradiated Thermal Conductivity of a Single-Fired $\mathrm{ThO}_{2}+10 \mathrm{w} / \mathrm{o}$ UO, (LWBR Development Program), WAPD-TM-901, February 1970.

Kass, S., 1968, Effects of Pressure Upon the Corrosion of Zircaloy-4 (LWBR Development Program), WAPD-TM-782, October 1968.

Kass, S., 1970, The Influence of Prior Corrosion History Upon the Hydrogen Pickup by Zircaloy During Subsequent Exposure in Hot Water (LWBR Development Program), WAPD-TM-906, December 1970.

Kotula, J., 1979, LWBR Automated Fuel Rod Loading Verification Gage System (LWBR Development Program), WAPD-TM-1226, February 1979.

Markowitz, J. M., and J. C. Clayton, 1970, Corrosion of Oxide Nuclear Fuels in High Temperature Water (LWBR Development Program), WAPD-TM-909, February 1970.

McCauley, J. E., 1969, Observations on the Irradiation Behavior of a Zircaloy-4 Clad Rod Containing Low Density $\mathrm{ThO}_{2}-5.3$ w/o UO ${ }_{2}$ Pellets (LWBR Development Program), WAPD-TM-664, December 1969.

Meieran, H. B., W. F. Bourgeois, and J. T. Engel, 1968, Short Term Irradiation of Zircaloy-4 Clad Fuel Rods Containing Low Density or Annular $\mathrm{ZrO}_{2}-\mathrm{UO}_{2}$ Ceramic Fuel Pellets: X-1-t Test (LWBR-LSBR Development Program), WAPD-TM-630, June 1968.

Milani, S. and S. H. Weiss, 1967, Small Uranium-233 Fueled Seed-and-Blanket Critical Experiments (LWBR-LSBR Development Program), WAPD-TM-614, November 1967.

Mitchell, J. A. (ed.), 1975, BMU Series of ${ }^{233}$ U Fueled Critical Experiments (LWBR Development Program), WAPD-TM-1117, January 1975.

Smith, B. C. (ed.), 1987, End-of-Life Examinations of Light Water Breeder Reactor Grids and Other Module Structural Components (LWBR Development Program), WAPD-TM-1607, October 1987.

Smith, B. C., and W. R. Campbell, 1987, Light Water Breeder Reactor Fuel Element Performance Characteristics for Extending Core Lifetime (LWBR Development Program), WAPD-TM-1603, October 1987. 
Smithnosky, A. J., 1982, In-Reactor Tests of Externally Pressurized, Short, Unsupported Lengths of Zircaloy Tubing (AWBA Development Program), WAPD-TM-1529, October 1982.

Sphar, C. D., and J. Sherman, 1979, Early-In-Life Performance of Short Rod Duplex Pellet Screening (D1) Test (AWBA Development Program), WAPD-TM-1378, November 1979.

Sphar, C. D., D. A. Mertz, W. S. Roesener, 1982, Irradiation Performance of Duplex Fuel Pellet Test Rods Depleted to $9 \times 10^{20}$ Fissions $/ \mathrm{cm}^{3}$ of Compartment - D-1 Test (AWBA Development Program), WAPD-TM-1460, January 1982.

Springer, J. R., et al., 1967, Fabrication, Characterization, and Thermal-Property Measurements of $\mathrm{ThO}_{2}-\mathrm{UO}_{2}$ Fuel Materials (LWBR Development Program), BMI-X-1020, October 1967.

Stackhouse, R. M. (ed.), 1979, Fuel Rod Grid Interaction Wear: In-Reactor Tests (LWBR Development Program), WAPD-TM-1347, November 1979.

Stooksberry, R. W., 1979, Conceptual Evaluation of Nondestructive Assay of ${ }^{233} \mathrm{UO}_{2}-\mathrm{ThO}_{2} \mathrm{Fuel}_{\text {Rods }}$ (LWBR Development Program), WAPD-TM-1256, January 1979.

Technical Specifications/Standards: 4.7B4 "Integrity of Storage Canisters and Canister Lifting Tools for Dry Well Storage of LWBR Fuels"; 4.7B6 "Spare Dry Well Requirement for LWBR Fuel Storage"; 4.7B7 "Handling of LWBR Fuel Storage Canisters—Peach Bottom Transfer Cask"; 4.7C2 "Surveillance of the LWBR Fuel Storage Dry Wells."

Waldman, L. A., C. D. Sphar, and T. H. Alff, 1982, Irradiation Performance of Long Rod Duplex Fuel Pellet Bundle Test-LDR Test (LWBR Development Program), WAPD-TM-1481, April 1982.

Wargo, J. E., and K. D. Richardson, 1987, Light Water Breeder Reactor End-Of-Life Component Examinations at Shippingport Atomic Power Station and Module Visual and Dimensional Examinations at the Expended Core Facility (LWBR Development Program), WAPD-TM-1602, October 1987. 


\section{Appendix A \\ End-of-Life Fissile Data from the Production Irradiated Fuel Assay Gauge (PIFAG)}




\section{Appendix A \\ End-of-Life Fissile Data from the Production Irradiated Fuel Assay Gauge (PIFAG)}

The following tables were copied from Tessler et al. 1987, WAPD-TM-1614, for convenience. The pages have not been altered, and retain the table numbers inherent from the original report. Rod numbers correspond to the rod types noted in Figures 3-2, 3-3, 3-6, 3-7, 3-9 and 3-10 in INEEL-EXT-98-00799, Fuel Summary Report: Shippingport Light Water Breeder Reactor. 
Table 26

Seed Module I-1 Fissile Fuel Loadings in Grams

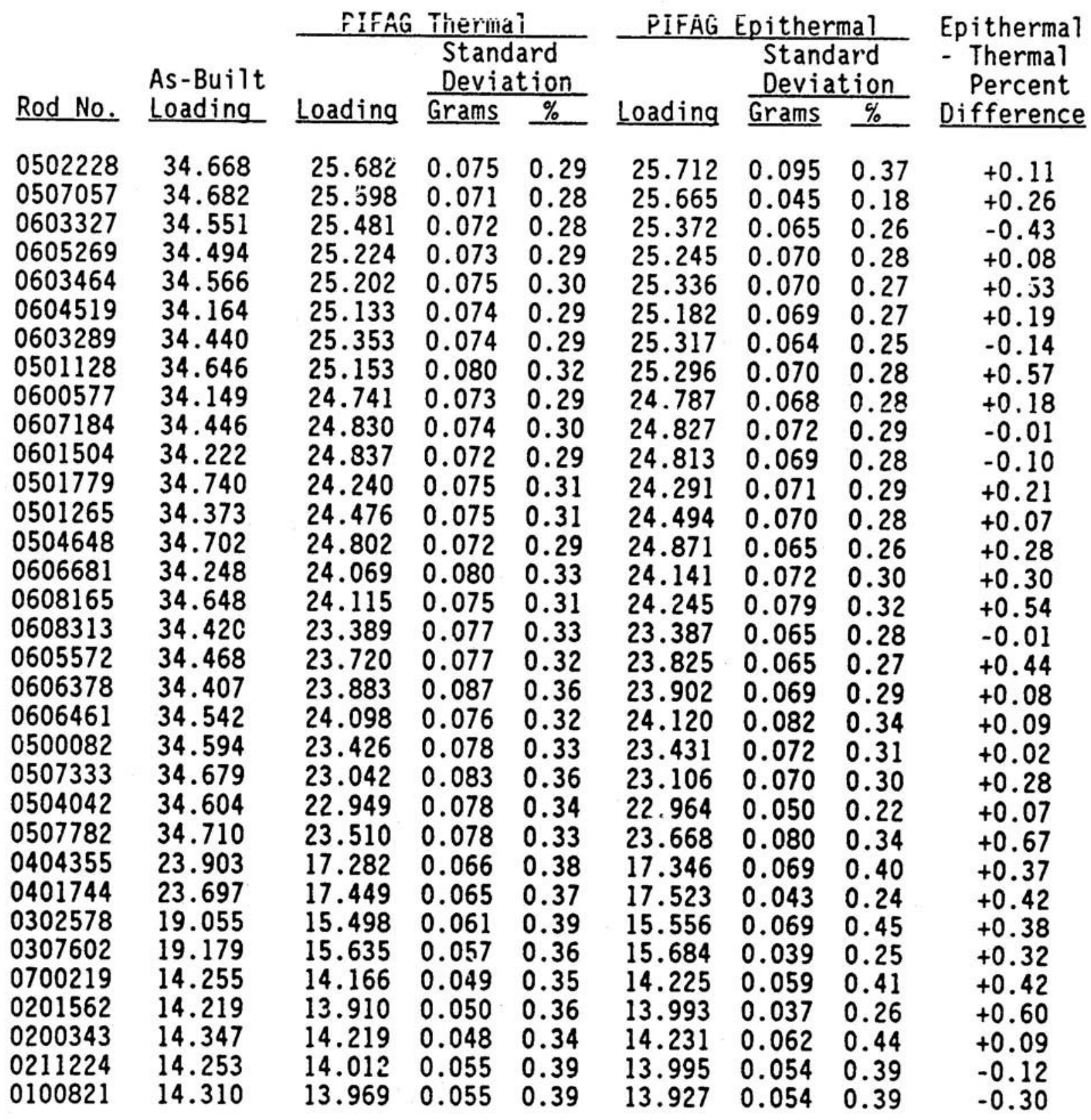


Table 27

Seed Module II-3 Fissile Fuel Loadings in Grams

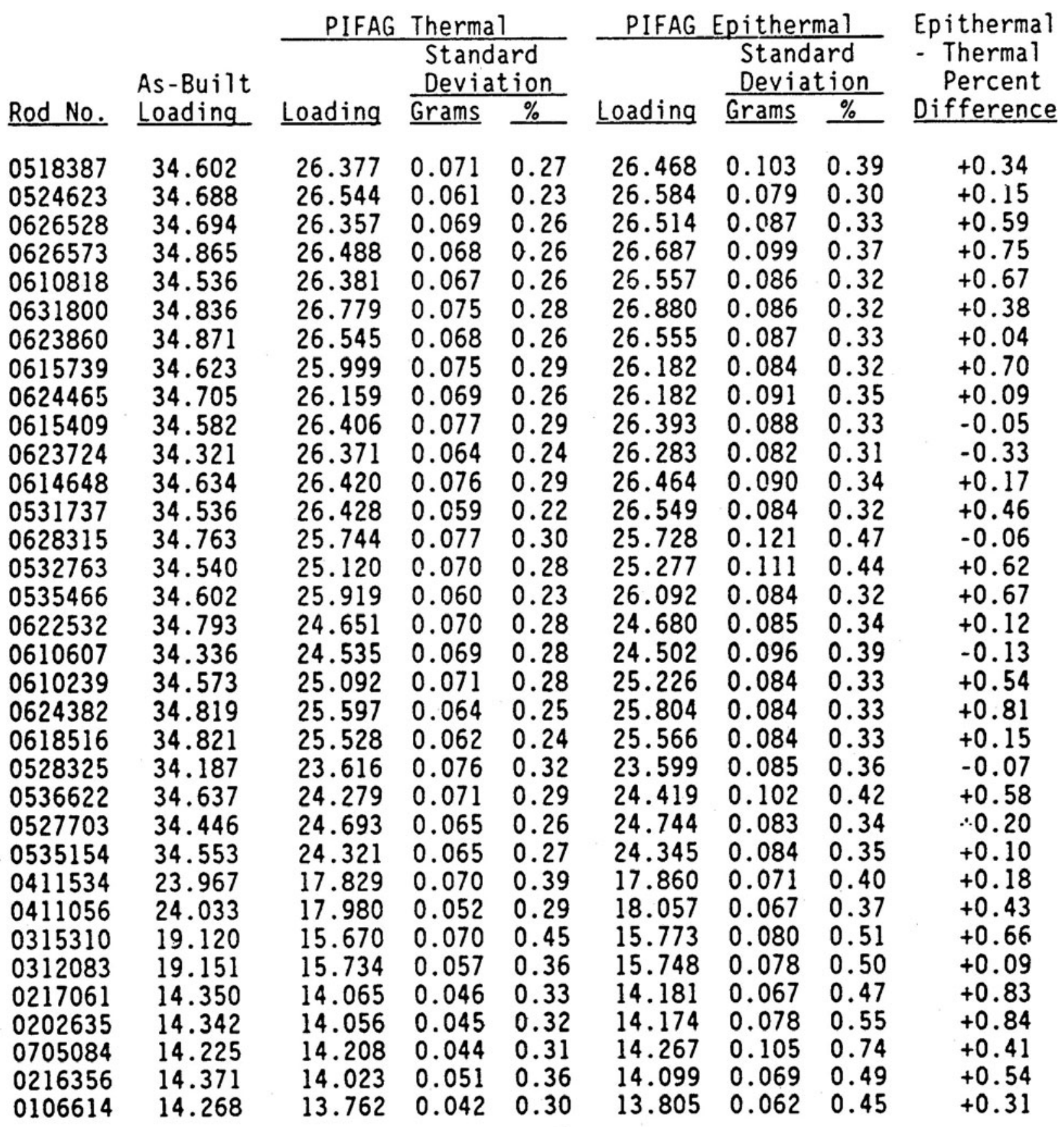


Table 28

Seed Module III-1 Fissile Fuel Loadings in Grams

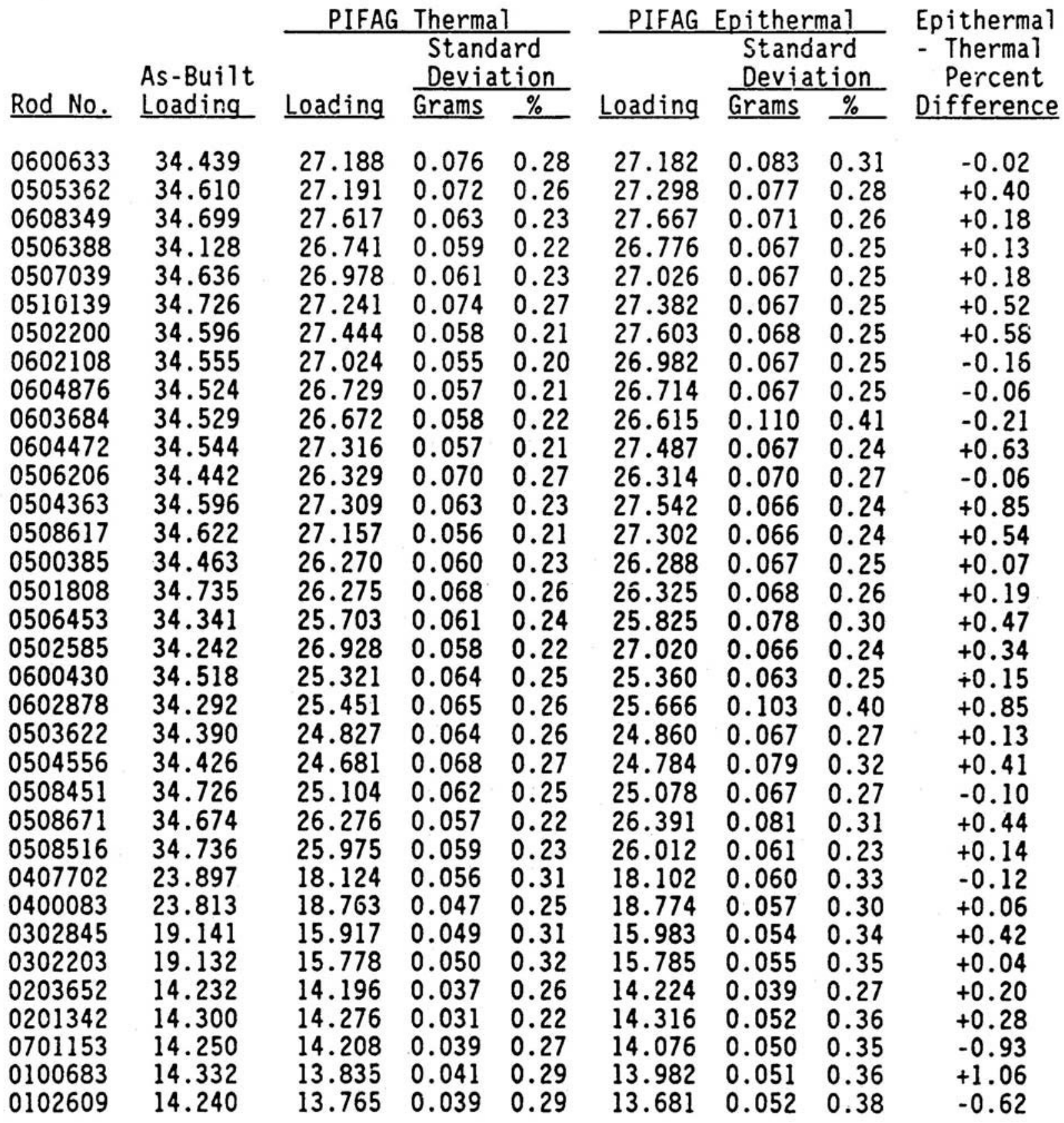


Table 29

Seed Module III-2 Fissile Fuel Loadings in Grams

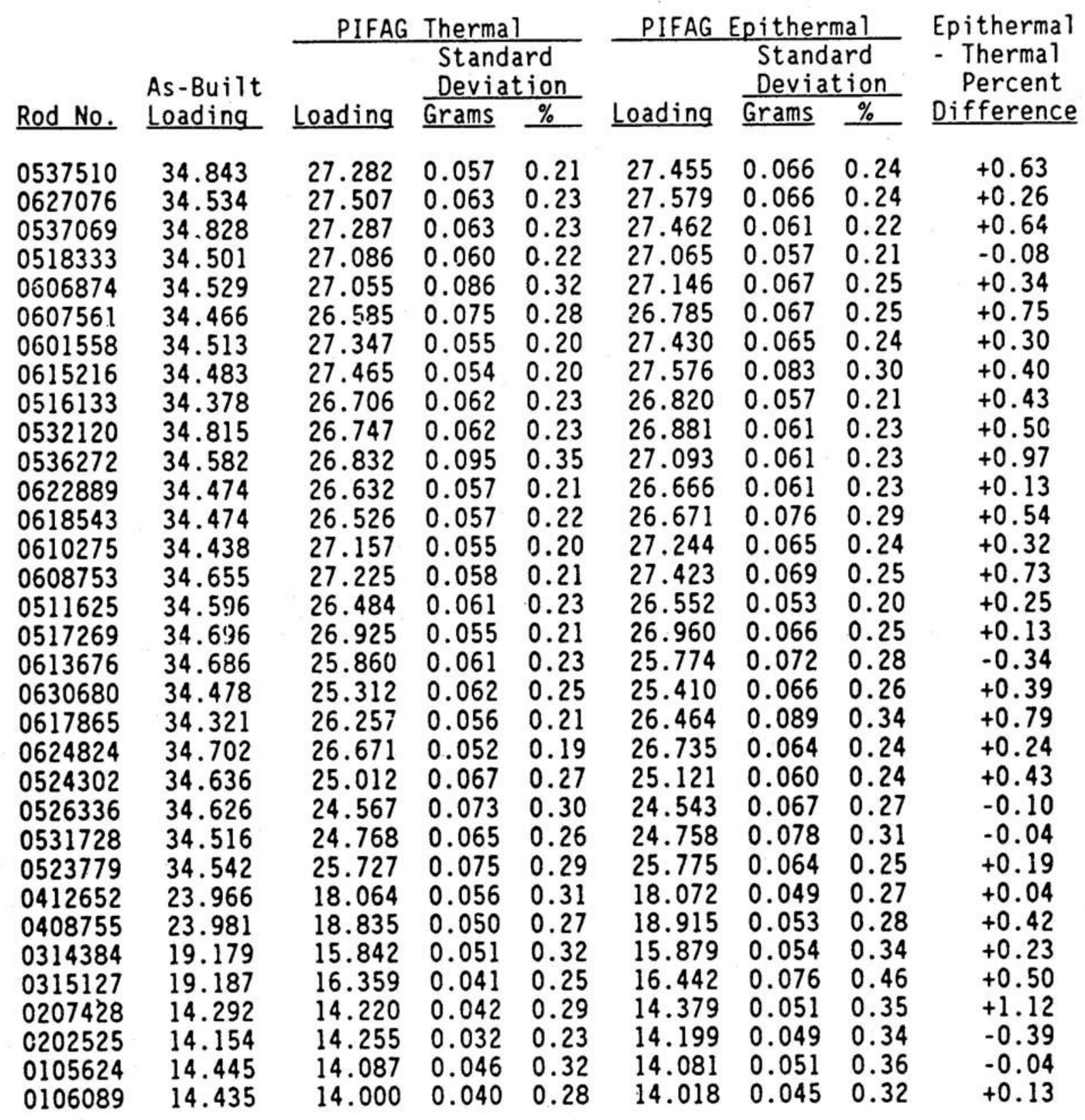


Table 30

Blanket Module I-3 RB Rod Fissile Fuel Loadings in Grams

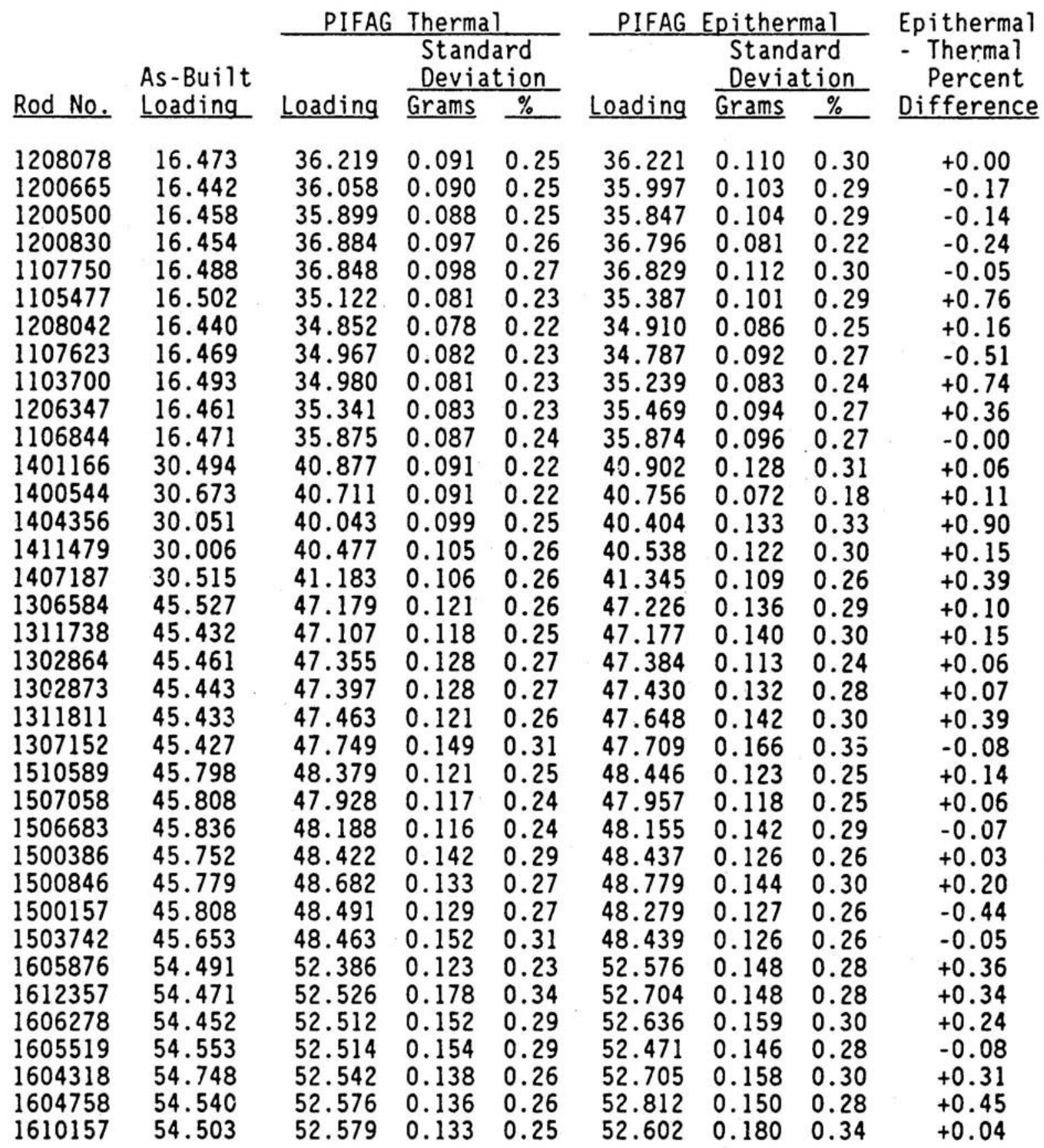


Table 31

Blanket Module II-2 RB Rod Fissile Fuel Loadings in Grams

\begin{tabular}{|c|c|c|c|c|c|c|c|c|}
\hline \multirow[b]{2}{*}{ Rod No. } & \multirow{2}{*}{$\begin{array}{l}\text { As-Built } \\
\text { Loading }\end{array}$} & PIFAG & $\begin{array}{l}\text { Therma } \\
\text { Stand } \\
\text { Devia }\end{array}$ & $\begin{array}{l}\frac{1}{\text { ard }} \\
\text { tion }\end{array}$ & PIFAG & $\begin{array}{l}\text { Epither } \\
\text { Stand } \\
\text { Devia }\end{array}$ & $\begin{array}{l}\text { nal } \\
\text { ard } \\
\text { tion }\end{array}$ & \multirow{2}{*}{$\begin{array}{l}\text { Epithermal } \\
\text { - Thermal } \\
\text { Percent } \\
\text { Difference } \\
\end{array}$} \\
\hline & & Loading & Grams & $\%$ & Loading & Grams & $\%$ & \\
\hline $\begin{array}{l}1210125 \\
1210226 \\
1103672 \\
1208657 \\
1106137 \\
1106586 \\
1104525 \\
1102470 \\
1404668 \\
1412846 \\
1407748 \\
1402660 \\
1303248 \\
1302579 \\
1311334 \\
1305787 \\
1505363 \\
1504658 \\
1507619 \\
1504667 \\
1608083 \\
1603676 \\
1607479 \\
1602181\end{array}$ & $\begin{array}{l}16.463 \\
16.484 \\
16.379 \\
16.475 \\
16.480 \\
16.457 \\
16.403 \\
16.404 \\
30.083 \\
30.607 \\
30.248 \\
30.038 \\
45.523 \\
45.273 \\
45.511 \\
45.408 \\
45.489 \\
45.754 \\
45.679 \\
45.638 \\
54.657 \\
54.855 \\
54.600 \\
54.636\end{array}$ & $\begin{array}{l}36.098 \\
35.977 \\
35.854 \\
34.293 \\
33.513 \\
34.134 \\
34.882 \\
33.962 \\
39.917 \\
40.829 \\
40.012 \\
39.462 \\
46.165 \\
46.937 \\
47.133 \\
46.736 \\
47.766 \\
48.090 \\
48.454 \\
47.729 \\
51.750 \\
52.624 \\
52.492 \\
52.628\end{array}$ & $\begin{array}{l}0.089 \\
0.091 \\
0.095 \\
0.076 \\
0.070 \\
0.078 \\
0.081 \\
0.075 \\
0.099 \\
0.105 \\
0.098 \\
0.092 \\
0.110 \\
0.121 \\
0.140 \\
0.108 \\
0.112 \\
0.122 \\
0.133 \\
0.116 \\
0.112 \\
0.133 \\
0.132 \\
0.131\end{array}$ & $\begin{array}{l}0.25 \\
0.25 \\
0.27 \\
0.22 \\
0.21 \\
0.23 \\
0.23 \\
0.22 \\
0.25 \\
0.26 \\
0.25 \\
0.23 \\
0.24 \\
0.26 \\
0.30 \\
0.23 \\
0.23 \\
0.25 \\
0.27 \\
0.24 \\
0.22 \\
0.25 \\
0.25 \\
0.25\end{array}$ & $\begin{array}{l}35.880 \\
35.804 \\
35.784 \\
34.260 \\
33.608 \\
33.948 \\
34.959 \\
33.954 \\
39.980 \\
40.960 \\
40.032 \\
39.319 \\
46.457 \\
47.344 \\
47.683 \\
46.968 \\
47.806 \\
47.943 \\
48.376 \\
47.829 \\
52.121 \\
52.883 \\
52.784 \\
52.831\end{array}$ & $\begin{array}{l}0.094 \\
0.086 \\
0.108 \\
0.100 \\
0.116 \\
0.109 \\
0.121 \\
0.109 \\
0.120 \\
0.159 \\
0.145 \\
0.117 \\
0.179 \\
0.160 \\
0.192 \\
0.163 \\
0.112 \\
0.140 \\
0.176 \\
0.135 \\
0.136 \\
0.157 \\
0.182 \\
0.166\end{array}$ & $\begin{array}{l}0.26 \\
0.24 \\
0.30 \\
0.29 \\
0.35 \\
0.32 \\
0.35 \\
0.32 \\
0.30 \\
0.39 \\
0.36 \\
0.30 \\
0.39 \\
0.34 \\
0.40 \\
0.35 \\
0.23 \\
0.29 \\
0.36 \\
0.28 \\
0.26 \\
0.30 \\
0.35 \\
0.31\end{array}$ & $\begin{array}{l}-0.60 \\
-0.48 \\
-0.19 \\
-0.10 \\
+0.28 \\
-0.54 \\
+0.22 \\
-0.02 \\
+0.16 \\
+0.32 \\
+0.05 \\
-0.36 \\
+0.63 \\
+0.87 \\
+1.17 \\
+0.50 \\
+0.09 \\
-0.31 \\
-0.16 \\
+0.21 \\
+0.72 \\
+0.49 \\
+0.56 \\
+0.39\end{array}$ \\
\hline
\end{tabular}


Table 32

Blanket Module III-2 RB Rod Fissile Fuel Loadings in Grams

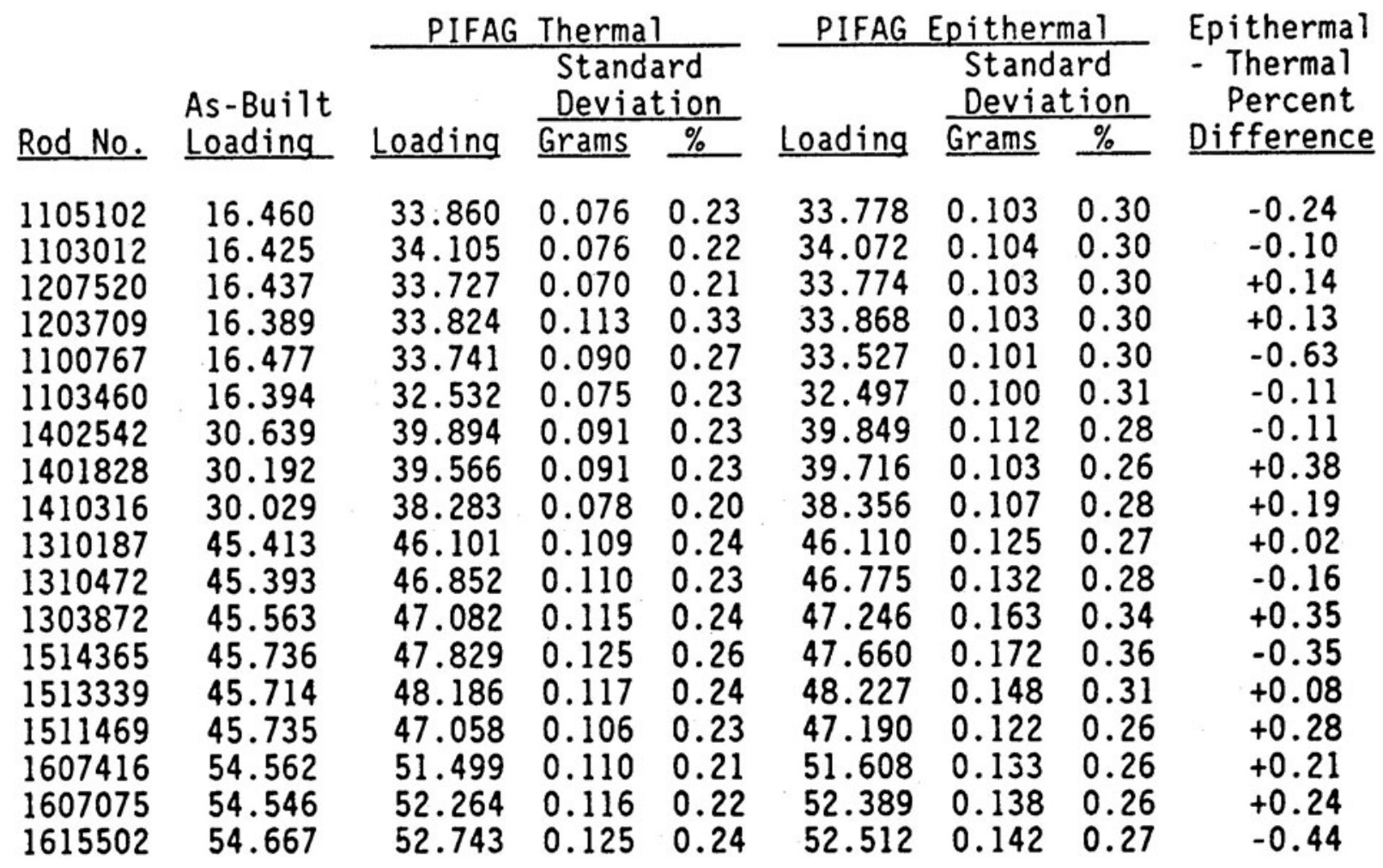


Table 33

Blanket Module III-6 RB Rod Fissile Fuel Loadings in Grams

\begin{tabular}{|c|c|c|c|c|c|c|c|c|}
\hline \multirow[b]{2}{*}{ Rod No. } & \multirow{2}{*}{$\begin{array}{l}\text { As-Built } \\
\text { Loading }\end{array}$} & \multicolumn{2}{|c|}{ PIFAG Thermal } & $\begin{array}{l} \\
\text { ard } \\
\text { tion }\end{array}$ & PIFAG & $\begin{array}{l}\text { Either } \\
\text { Stand } \\
\text { Devia }\end{array}$ & $\begin{array}{l}\text { mal } \\
\text { ard } \\
\text { tion } \\
\end{array}$ & \multirow{2}{*}{$\begin{array}{l}\text { Epithermal } \\
\text { - Thermal } \\
\text { Percent } \\
\text { Difference }\end{array}$} \\
\hline & & Loading & Grams & $\%$ & Loading & Grams & $\%$ & \\
\hline $\begin{array}{l}1204542 \\
1200344 \\
1103443 \\
1101059 \\
1103315 \\
1104800 \\
1401882 \\
1404448 \\
1410646 \\
1306117 \\
1308564 \\
1305724 \\
1507545 \\
1513265 \\
1512486 \\
1603483 \\
1612457\end{array}$ & $\begin{array}{l}16.457 \\
16.439 \\
16.450 \\
16.487 \\
16.399 \\
16.508 \\
30.705 \\
30.475 \\
30.523 \\
45.353 \\
45.529 \\
45.584 \\
45.760 \\
45.581 \\
45.619 \\
54.704 \\
54.482 \\
54.671\end{array}$ & $\begin{array}{l}34.555 \\
34.673 \\
34.117 \\
32.896 \\
33.108 \\
33.843 \\
38.748 \\
39.888 \\
38.704 \\
46.296 \\
46.917 \\
46.880 \\
47.751 \\
48.214 \\
47.736 \\
52.461 \\
52.333 \\
51.791\end{array}$ & $\begin{array}{l}0.084 \\
0.086 \\
0.079 \\
0.070 \\
0.076 \\
0.077 \\
0.085 \\
0.092 \\
0.082 \\
0.108 \\
0.118 \\
0.118 \\
0.109 \\
0.120 \\
0.111 \\
0.127 \\
0.135 \\
0.113\end{array}$ & $\begin{array}{l}0.24 \\
0.25 \\
0.23 \\
0.21 \\
0.23 \\
0.23 \\
0.22 \\
0.23 \\
0.21 \\
0.23 \\
0.25 \\
0.25 \\
0.23 \\
0.25 \\
0.23 \\
0.24 \\
0.26 \\
0.22\end{array}$ & $\begin{array}{l}34.721 \\
34.612 \\
34.134 \\
32.999 \\
32.994 \\
33.829 \\
38.943 \\
39.845 \\
38.891 \\
46.276 \\
47.065 \\
46.912 \\
47.770 \\
48.080 \\
47.815 \\
52.625 \\
52.640 \\
52.031\end{array}$ & $\begin{array}{l}0.108 \\
0.119 \\
0.127 \\
0.092 \\
0.094 \\
0.104 \\
0.110 \\
0.130 \\
0.129 \\
0.129 \\
0.169 \\
0.172 \\
0.117 \\
0.159 \\
0.125 \\
0.147 \\
0.178 \\
0.138\end{array}$ & $\begin{array}{l}0.31 \\
0.34 \\
0.37 \\
0.28 \\
0.29 \\
0.31 \\
0.28 \\
0.33 \\
0.33 \\
0.28 \\
0.36 \\
0.37 \\
0.25 \\
0.33 \\
0.26 \\
0.28 \\
0.34 \\
0.27\end{array}$ & $\begin{array}{l}+0.48 \\
-0.18 \\
+0.05 \\
+0.31 \\
-0.34 \\
-0.04 \\
+0.50 \\
-0.11 \\
+0.48 \\
-0.04 \\
+0.32 \\
+0.07 \\
+0.04 \\
-0.28 \\
+0.17 \\
+0.31 \\
+0.59 \\
+0.46\end{array}$ \\
\hline
\end{tabular}


Table 34

Blanket Module II-2 PFB Rod Fissile Fuel Loadings in Grams

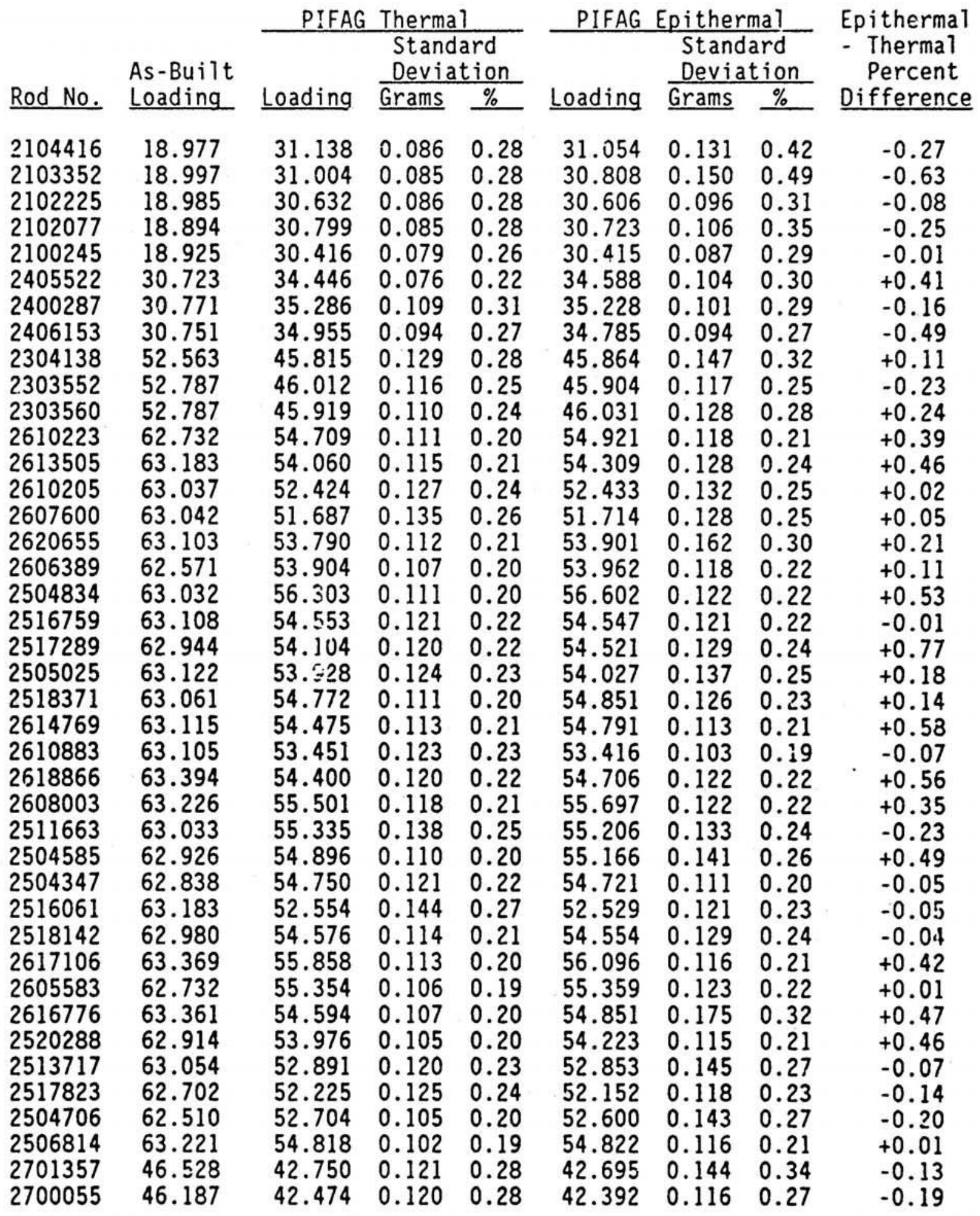




\section{Table 35}

Blanket Module III-2 PFB Rod Fissile Fuel Loadings in Grams

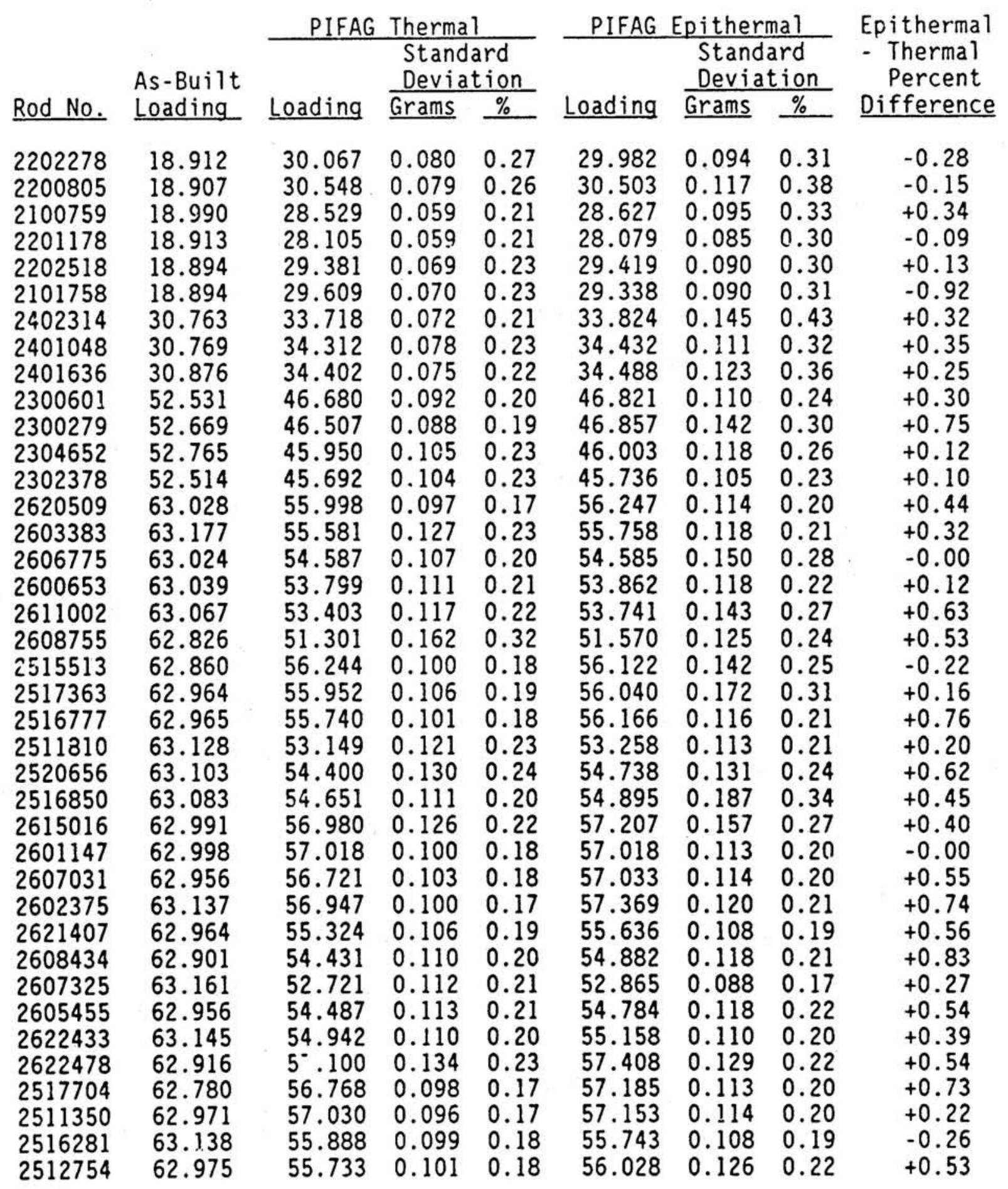




\section{Table 35 (Continued)}

\section{Blanket Module III-2 PFB Rod Fissile Fuel Loadings in Grams}

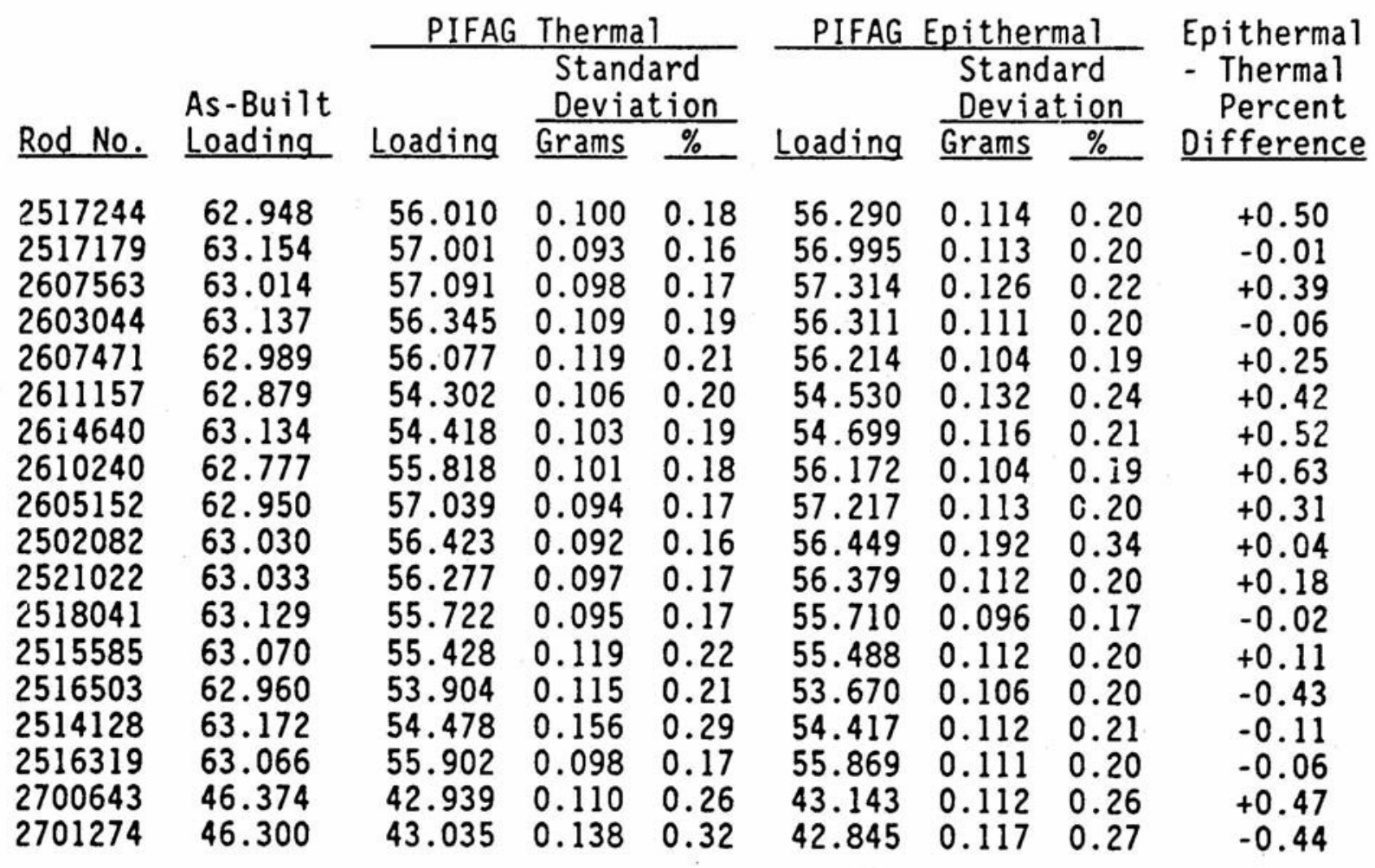


Table 36

Blanket Module III-6 PFB Rod Fissile Fuel Loadings in Grams

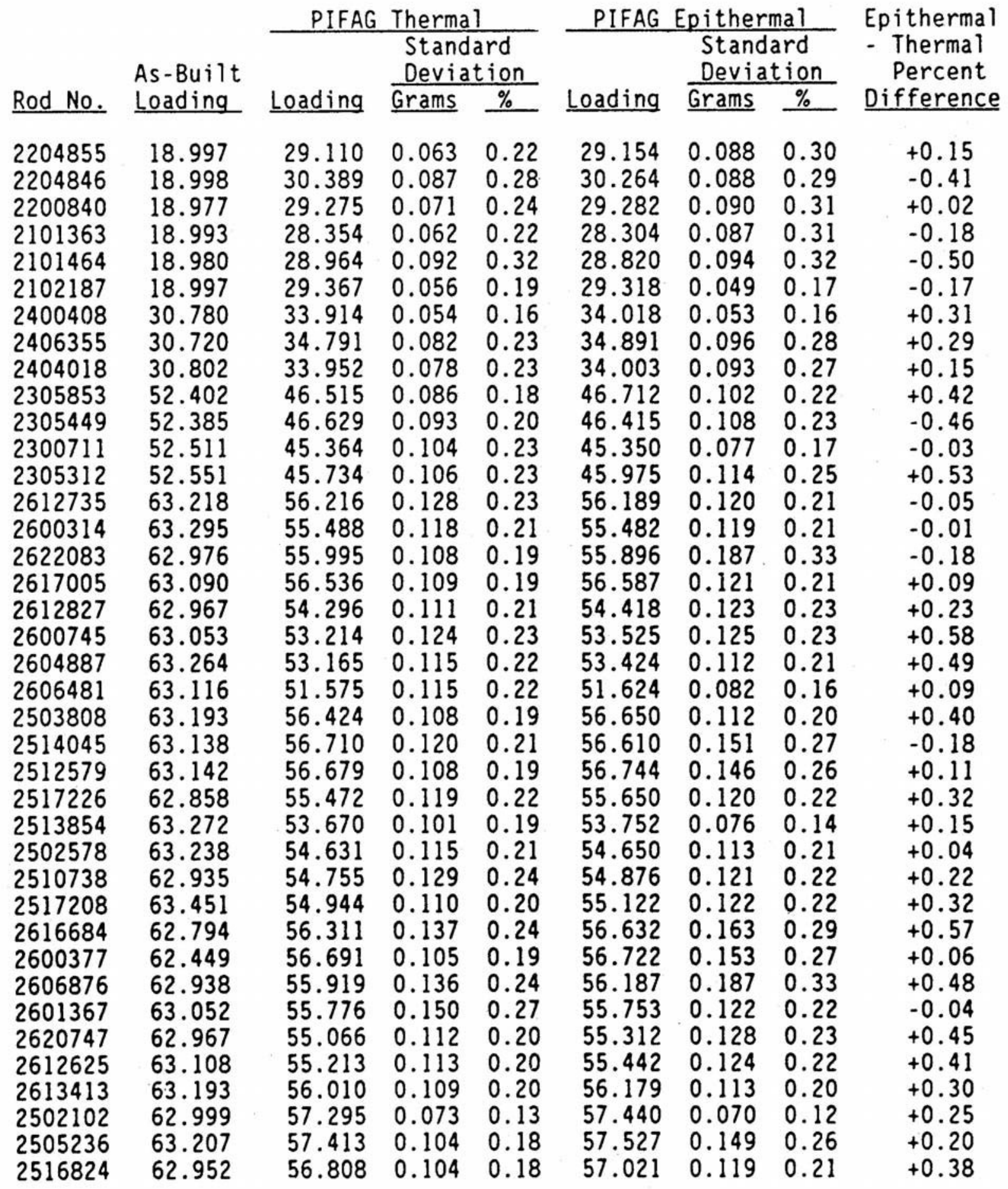


Table 36 (Continued)

Blanket Module III-6 PFB Rod Fissile Fuel Loadings in Grams

\begin{tabular}{|c|c|c|c|c|c|c|c|c|}
\hline \multirow[b]{3}{*}{ Rod No. } & \multirow{3}{*}{$\begin{array}{l}\text { As-Built } \\
\text { Loading }\end{array}$} & \multicolumn{3}{|c|}{ PIFAG Thermal } & \multicolumn{3}{|c|}{ PIFAG Epithermal } & \multirow{2}{*}{$\begin{array}{l}\text { Epithermal } \\
\text { - Thermal } \\
\text { Percent }\end{array}$} \\
\hline & & & $\begin{array}{l}\text { Stand } \\
\text { Devia }\end{array}$ & & & $\begin{array}{l}\text { Stand } \\
\text { Devia }\end{array}$ & $\begin{array}{l}\text { ard } \\
\text { tion } \\
\end{array}$ & \\
\hline & & Loading & Grams & $\%$ & Loading & Grams & $\%$ & Difference \\
\hline $\begin{array}{l}2500618 \\
2500589 \\
2503018 \\
2622175 \\
2610167 \\
2615512 \\
2622617 \\
2607509 \\
2605502 \\
2622507 \\
2513880 \\
2518169 \\
2507720 \\
2501670 \\
2513634 \\
\end{array}$ & $\begin{array}{l}63.204 \\
63.127 \\
62.711 \\
63.162 \\
62.934 \\
63.205 \\
63.366 \\
63.011 \\
63.280 \\
63.002 \\
63.239 \\
63.144 \\
63.226 \\
63.187 \\
63.122 \\
63.199 \\
46.562 \\
46.217\end{array}$ & $\begin{array}{l}57.485 \\
56.389 \\
55.376 \\
56.680 \\
56.988 \\
57.207 \\
57.336 \\
56.533 \\
53.224 \\
55.019 \\
56.656 \\
54.956 \\
52.943 \\
52.467 \\
54.042 \\
56.730 \\
42.732 \\
42.883\end{array}$ & $\begin{array}{l}0.125 \\
0.119 \\
0.108 \\
0.104 \\
0.142 \\
0.102 \\
0.117 \\
0.186 \\
0.116 \\
0.107 \\
0.140 \\
0.100 \\
0.116 \\
0.115 \\
0.110 \\
0.116 \\
0.125 \\
0.119\end{array}$ & $\begin{array}{l}0.22 \\
0.21 \\
0.20 \\
0.18 \\
0.25 \\
0.18 \\
0.20 \\
0.33 \\
0.22 \\
0.19 \\
0.25 \\
0.18 \\
0.22 \\
0.22 \\
0.20 \\
0.20 \\
0.29 \\
0.28\end{array}$ & & $\begin{array}{l}0.113 \\
0.125 \\
0.120 \\
0.110 \\
0.121 \\
0.152 \\
0.134 \\
0.132 \\
0.124 \\
0.145 \\
0.129 \\
0.158 \\
0.120 \\
0.120 \\
0.133 \\
0.167 \\
0.117 \\
0.116\end{array}$ & $\begin{array}{l}0.20 \\
0.22 \\
0.22 \\
0.19 \\
0.21 \\
0.27 \\
0.23 \\
0.23 \\
0.23 \\
0.26 \\
0.23 \\
0.29 \\
0.23 \\
0.23 \\
0.25 \\
0.30 \\
0.27 \\
0.27\end{array}$ & $\begin{array}{l}+0.06 \\
+0.47 \\
+0.10 \\
+0.64 \\
+0.32 \\
+0.03 \\
-0.08 \\
+0.61 \\
+0.72 \\
+0.05 \\
-0.61 \\
+0.32 \\
-0.13 \\
+0.02 \\
-0.63 \\
-0.76 \\
+0.28 \\
-0.37\end{array}$ \\
\hline
\end{tabular}


Table 37

Reflector Module IV-3 Fissile Fuel Loadings in Grams

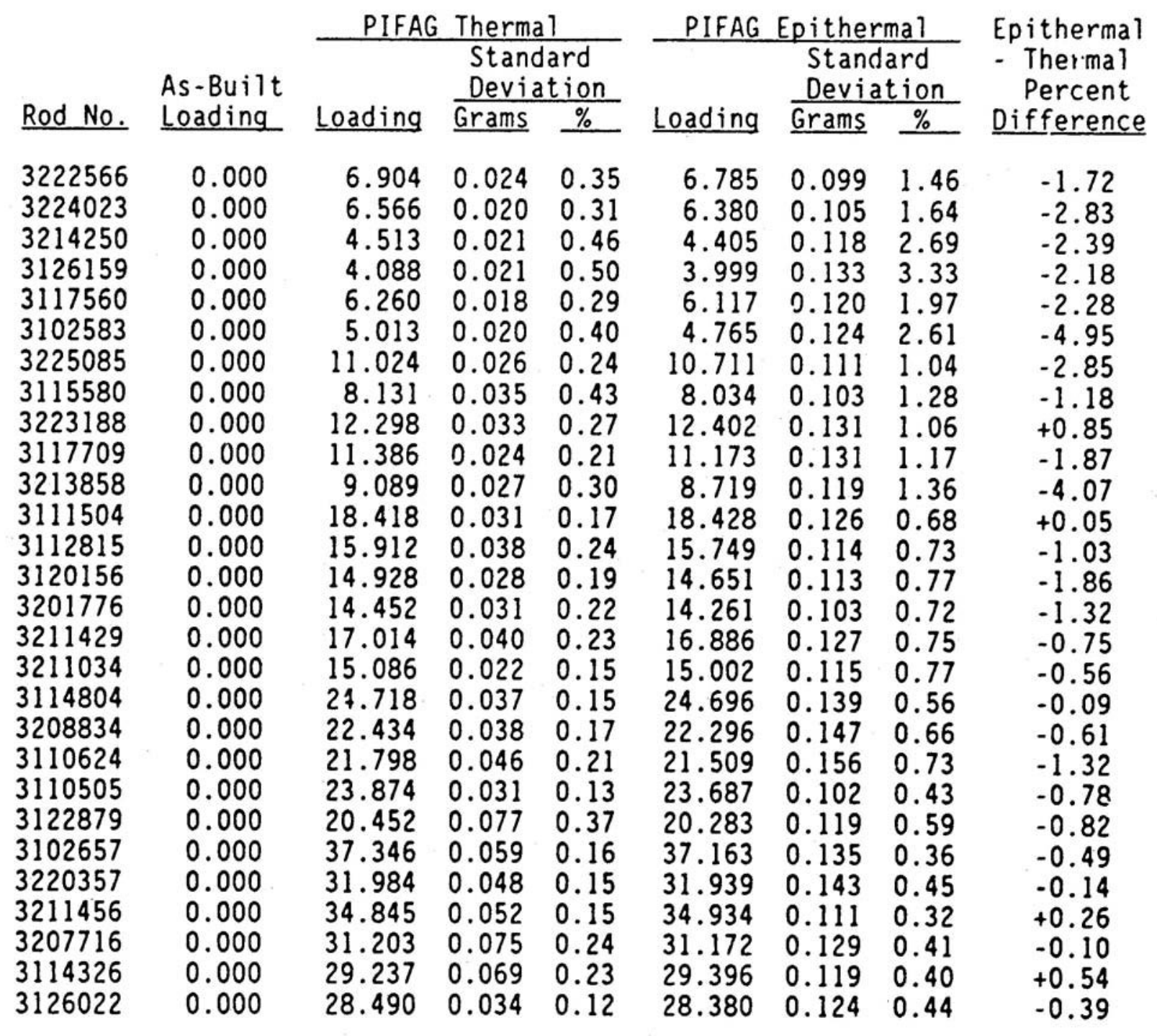




\section{Table 38}

Reflector Module IV-4 Fissile Fuel Loadings in Grams

Rod No. As-Built

Loading

3216258

3203774

3222474

3216139

3120744

3113006

3118019

3218669

3122163

3218413

3123245

3122605

3222833

31046,64

3127075

3217506

3105488

3126470

3208127

3118708

3103555

3203379

3203545

3107082

3217266

3211236

3214875

3116167

3220751

0.000

0.000

0.000

0.000

0.000

0.000

0.000

0.000

0.000

0.000

0.000

0.000

0.000

0.000

0.000

0.000

0.000

0.000

0.000

0.000

0.000

0.000

0.000

0.000

0.000

$\begin{array}{rrrr}0.000 & 8.124 & 0.026 & 0.32 \\ 0.000 & 6.148 & 0.024 & 0.39 \\ 0.000 & 4.920 & 0.018 & 0.36 \\ 0.000 & 6.385 & 0.025 & 0.39 \\ 0.000 & 5.239 & 0.024 & 0.45 \\ 0.000 & 6.905 & 0.033 & 0.48 \\ 0.000 & 6.206 & 0.026 & 0.43 \\ 0.000 & 11.718 & 0.029 & 0.25 \\ 0.000 & 8.855 & 0.027 & 0.30 \\ 0.000 & 14.517 & 0.027 & 0.19 \\ 0.000 & 13.375 & 0.054 & 0.40 \\ 0.000 & 11.319 & 0.030 & 0.27 \\ 0.000 & 9.260 & 0.024 & 0.26 \\ 0.000 & 16.343 & 0.055 & 0.34 \\ 0.000 & 15.663 & 0.028 & 0.18 \\ 0.000 & 16.087 & 0.069 & 0.43 \\ 0.000 & 16.326 & 0.024 & 0.15 \\ 0.000 & 18.584 & 0.035 & 0.19 \\ 0.000 & 22.792 & 0.039 & 0.17 \\ 0.000 & 25.674 & 0.049 & 0.19 \\ 0.000 & 21.224 & 0.033 & 0.16 \\ 0.000 & 21.800 & 0.062 & 0.29 \\ 0.000 & 24.727 & 0.046 & 0.19 \\ 0.000 & 39.323 & 0.063 & 0.16 \\ 0.000 & 36.574 & 0.057 & 0.16 \\ 0.000 & 33.092 & 0.059 & 0.18 \\ 0.000 & 29.115 & 0.050 & 0.17 \\ 0.000 & 35.794 & 0.055 & 0.15 \\ 0.000 & 28.963 & 0.057 & 0.20\end{array}$

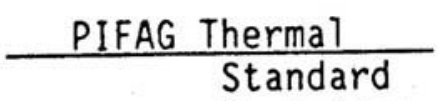

Standard

oading $\frac{\text { Deviation }}{\text { Grams } \%}$

$$
8.124
$$

6.148

6.385

5.239

6.905

6.206

11.718

8.855

14.517

13.375

11.319

9.260

16.343

15.663

16.087

16.326

18.584

22.792

25.674

21.224

21.800

24.727

39.323

29.115

28.963

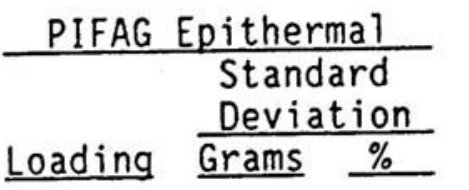

Epithermal

- Thermal

Percent

Difference

$$
8.093
$$

6.225

4.925

6.398

5.242

6.893

6.051

11.544

8.798

14.286

12.999

11.100

9.204

16.177

15.612

15.999

16.181

18.640

22.544

25.442

21.144

21.662

24.703

39.343

36.275

32.948

28.943

36.000

29.081
$0.120 \quad 1.48$

0.1312 .11

$0.127 \quad 2.57$

$0.112 \quad 1.75$

$0.115 \quad 2.20$

$0.119 \quad 1.73$

$0.117 \quad 1.93$

$0.124 \quad 1.07$

0.1391 .58

$0.133 \quad 0.93$

$0.123 \quad 0.95$

0.1151 .03

$0.121 \quad 1.32$

$0.143 \quad 0.89$

$0.122 \quad 0.78$

0.2151 .34

$0.178 \quad 1.10$

0.2261 .21

0.1350 .60

$\begin{array}{ll}0.158 & 0.62\end{array}$

0.1330 .63

0.1350 .62

0.1750 .71

$\begin{array}{ll}0.175 & 0.45\end{array}$

$\begin{array}{lll}0.173 & 0.48\end{array}$

0.170

0.52

$\begin{array}{ll}0.142 & 0.49\end{array}$

$0.140 \quad 0.39$

0.164
$-0.39$

$+1.25$

$+0.11$

$+0.19$

$+0.07$

$-0.17$

$-2.49$

$-1.49$

$-0.64$

$-1.59$

$-2.81$

$-1.94$

$-0.60$

$-1.01$

$-0.33$

$-0.55$

$-0.89$

$+0.30$

$-1.09$

$-0.90$

$-0.38$

$-0.63$

$-0.09$

$+0.05$

$-0.82$

$-0.44$

$-0.59$

$+0.58$

$+0.41$ 
Table 39

Reflector Module IV-9 Fissile Fuel Loadings in Grams

\begin{tabular}{|c|c|c|c|c|c|c|c|c|}
\hline \multirow[b]{2}{*}{ Rod No. } & \multirow{2}{*}{$\begin{array}{l}\text { As-Built } \\
\text { Loading }\end{array}$} & PIFAG & $\begin{array}{l}\text { Therme } \\
\text { Stanc } \\
\text { Devic }\end{array}$ & $\begin{array}{l}1 \\
\text { ard } \\
\text { tion }\end{array}$ & PIFAG & $\begin{array}{l}\text { Epither } \\
\text { Stand } \\
\text { Devia }\end{array}$ & $\begin{array}{l}\text { mal } \\
\text { ard } \\
\text { tion }\end{array}$ & \multirow[t]{2}{*}{$\begin{array}{c}\text { Epithermal } \\
\text { - Thermal } \\
\text { Percent } \\
\text { Difference }\end{array}$} \\
\hline & & Loading & Grams & $\%$ & Loading & Grams & $\%$ & \\
\hline $\begin{array}{l}3124805 \\
3124556 \\
3222815 \\
3218540 \\
3226176 \\
3223529 \\
3111448 \\
3224683 \\
3221530 \\
3222567 \\
3223050 \\
3215048 \\
3220229 \\
3125005 \\
3121265 \\
3124886 \\
3207256 \\
3121476 \\
3121173 \\
3104417 \\
3223152 \\
3224564 \\
3218743 \\
3202757 \\
3126140 \\
3211135 \\
3225783 \\
3222135 \\
3224748 \\
3218844 \\
3121586 \\
3125389 \\
3224739 \\
3221448 \\
3221659 \\
3123474 \\
3123135 \\
3122513 \\
3220404 \\
3123263 \\
3120165 \\
3218577 \\
3221062 \\
3100282 \\
3123236 \\
3118836 \\
3206542\end{array}$ & $\begin{array}{l}0.000 \\
0.000 \\
0.000 \\
0.000 \\
0.000 \\
0.000 \\
0.000 \\
0.000 \\
0.000 \\
0.000 \\
0.000 \\
0.000 \\
0.000 \\
0.000 \\
0.000 \\
0.000 \\
0.000 \\
0.000 \\
0.000 \\
0.000 \\
0.000 \\
0.000 \\
0.000 \\
0.000 \\
0.000 \\
0.000 \\
0.000 \\
0.000 \\
0.000 \\
0.000 \\
0.000 \\
0.000 \\
0.000 \\
0.000 \\
0\end{array}$ & $\begin{array}{r}7.593 \\
6.937 \\
7.104 \\
7.359 \\
6.344 \\
5.490 \\
5.590 \\
5.464 \\
5.890 \\
4.827 \\
8.088 \\
5.819 \\
4.648 \\
5.425 \\
4.955 \\
4.713 \\
7.305 \\
5.140 \\
4.736 \\
4.647 \\
13.737 \\
13.188 \\
10.658 \\
9.222 \\
8.692 \\
13.133 \\
9.390 \\
10.652 \\
9.696 \\
10.854 \\
11.361 \\
8.823 \\
13.716 \\
20.296 \\
16.077 \\
20.216 \\
17.233 \\
15.744 \\
26.358 \\
21.170 \\
21.654 \\
27.276 \\
20.679 \\
39.550 \\
35.777 \\
31.837 \\
29.191 \\
27.846\end{array}$ & $\begin{array}{l}0.026 \\
0.019 \\
0.026 \\
0.021 \\
0.020 \\
0.017 \\
0.028 \\
0.027 \\
0.018 \\
0.022 \\
0.027 \\
0.021 \\
0.022 \\
0.023 \\
0.023 \\
0.017 \\
0.026 \\
0.031 \\
0.030 \\
0.022 \\
0.031 \\
0.028 \\
0.042 \\
0.029 \\
0.025 \\
0.047 \\
0.028 \\
0.026 \\
0.024 \\
0.029 \\
0.030 \\
0.027 \\
0.033 \\
0.035 \\
0.054 \\
0.044 \\
0.038 \\
0.032 \\
0.046 \\
0.031 \\
0.040 \\
0.050 \\
0.046 \\
0.074 \\
0.060 \\
0.061 \\
0.053 \\
0.050\end{array}$ & $\begin{array}{l}0.34 \\
0.28 \\
0.36 \\
0.28 \\
0.32 \\
0.32 \\
0.50 \\
0.50 \\
0.30 \\
0.45 \\
0.33 \\
0.37 \\
0.48 \\
0.43 \\
0.46 \\
0.37 \\
0.35 \\
0.60 \\
0.63 \\
0.47 \\
0.23 \\
0.21 \\
0.39 \\
0.32 \\
0.29 \\
0.35 \\
0.30 \\
0.24 \\
0.25 \\
0.27 \\
0.27 \\
0.31 \\
0.24 \\
0.17 \\
0.34 \\
0.22 \\
0.22 \\
0.20 \\
0.17 \\
0.15 \\
0.19 \\
0.18 \\
0.22 \\
0.19 \\
0.17 \\
0.19 \\
0.18 \\
0.18\end{array}$ & $\begin{array}{r}7.334 \\
6.730 \\
7.174 \\
7.383 \\
6.440 \\
5.584 \\
5.423 \\
5.208 \\
5.547 \\
4.878 \\
7.948 \\
5.757 \\
4.616 \\
5.219 \\
4.782 \\
4.574 \\
7.198 \\
5.136 \\
4.613 \\
4.688 \\
13.600 \\
12.958 \\
10.599 \\
9.013 \\
8.662 \\
12.926 \\
9.234 \\
10.701 \\
9.651 \\
10.688 \\
11.151 \\
8.577 \\
13.562 \\
20.313 \\
15.821 \\
19.939 \\
17.126 \\
15.768 \\
26.405 \\
21.113 \\
21.668 \\
27.068 \\
20.643 \\
39.687 \\
35.766 \\
31.806 \\
29.033 \\
28.005\end{array}$ & $\begin{array}{l}0.148 \\
0.116 \\
0.135 \\
0.120 \\
0.135 \\
0.136 \\
0.114 \\
0.120 \\
0.126 \\
0.139 \\
0.117 \\
0.158 \\
0.114 \\
0.116 \\
0.135 \\
0.114 \\
0.117 \\
0.170 \\
0.1144 \\
0.1144 \\
0.129 \\
0.190 \\
0.123 \\
0.163 \\
0.119 \\
0.136 \\
0.136 \\
0.119 \\
0.151 \\
0.113 \\
0.119 \\
0.116 \\
0.129 \\
0.128 \\
0.1177 \\
0.127 \\
0.190 \\
0.116 \\
0.134 \\
0.179 \\
0.120 \\
0.134 \\
0.136 \\
0.147 \\
0.158 \\
0.168 \\
0.135 \\
0.179\end{array}$ & $\begin{array}{l}2.02 \\
1.72 \\
1.80 \\
1.62 \\
2.10 \\
2.43 \\
2.10 \\
2.30 \\
2.27 \\
2.84 \\
1.48 \\
2.75 \\
2.48 \\
2.22 \\
2.83 \\
2.48 \\
1.63 \\
3.31 \\
2.47 \\
2.44 \\
0.95 \\
1.46 \\
1.16 \\
1.81 \\
1.37 \\
1.05 \\
1.48 \\
1.12 \\
1.56 \\
1.06 \\
1.07 \\
1.36 \\
0.95 \\
0.63 \\
0.74 \\
0.64 \\
1.11 \\
0.73 \\
0.51 \\
0.85 \\
0.56 \\
0.49 \\
0.66 \\
0.37 \\
0.44 \\
0.53 \\
0.47 \\
0.64\end{array}$ & $\begin{array}{l}-3.41 \\
-2.98 \\
+0.99 \\
+0.33 \\
+1.51 \\
+1.69 \\
-2.98 \\
-4.67 \\
-5.82 \\
+1.05 \\
-1.73 \\
-1.07 \\
-0.68 \\
-3.80 \\
-3.50 \\
-2.94 \\
-1.47 \\
-0.08 \\
-2.60 \\
+0.88 \\
-0.99 \\
-1.74 \\
-0.56 \\
-2.27 \\
-0.33 \\
-1.58 \\
-1.65 \\
+0.46 \\
-0.47 \\
-1.53 \\
-1.85 \\
-2.78 \\
-1.13 \\
+0.08 \\
-1.59 \\
-1.37 \\
-0.67 \\
+0.15 \\
+0.18 \\
-0.27 \\
+0.06 \\
-0.76 \\
-0.18 \\
+0.35 \\
-0.03 \\
-0.10 \\
-0.54 \\
+0.57\end{array}$ \\
\hline
\end{tabular}


Table 40

Reflector Module V-4 Fissile Fuel Loadings in Grams

\begin{tabular}{|c|c|c|c|c|c|c|c|c|}
\hline \multirow[b]{3}{*}{ Rod No. } & \multirow{3}{*}{$\begin{array}{l}\text { As-Built } \\
\text { Loading }\end{array}$} & \multicolumn{3}{|c|}{ PIFAG Thermal } & \multicolumn{3}{|c|}{ PIFAG Enithermal } & \multirow{2}{*}{$\begin{array}{l}\text { Epithermal } \\
\text { - Th -mai } \\
\text { Percent }\end{array}$} \\
\hline & & & $\begin{array}{l}\text { Stan } \\
\text { Devi }\end{array}$ & $\begin{array}{l}\text { ard } \\
\text { tion }\end{array}$ & & $\begin{array}{l}\text { Stand } \\
\text { Devia }\end{array}$ & $\begin{array}{l}\text { ard } \\
\text { tion }\end{array}$ & \\
\hline & & Loading & Grams & $\%$ & Loading & Grams & $\%$ & Difference \\
\hline & 0.000 & 6.947 & 0.021 & 0.30 & 6.994 & 0.168 & 2.40 & +0.68 \\
\hline & 0.000 & 7.723 & 0.025 & 0.33 & 7.581 & 0.118 & 1.56 & -1.84 \\
\hline $\begin{array}{l}3 \\
3\end{array}$ & 0.000 & 7.309 & 0.025 & 0.35 & 7.279 & 0.113 & 1.55 & $\begin{array}{l}-0.42 \\
-0.37\end{array}$ \\
\hline $\begin{array}{l}3204810 \\
3106635\end{array}$ & $\begin{array}{l}0.000 \\
0.000\end{array}$ & $\begin{array}{l}0.958 \\
5.663\end{array}$ & 0.018 & $\begin{array}{l}0.48 \\
0.32\end{array}$ & $\begin{array}{l}0.932 \\
5.681\end{array}$ & $\begin{array}{l}0.119 \\
0.116\end{array}$ & $\begin{array}{l}1.71 \\
2.05\end{array}$ & $\begin{array}{l}-0.31 \\
+0.32\end{array}$ \\
\hline 3102620 & 0.000 & 6.436 & 0.020 & 0.32 & 6.294 & 0.120 & 1.90 & -2.22 \\
\hline 08852 & 0.000 & 4.763 & 0.019 & 0.40 & 4.742 & 0.126 & 2.65 & -0.43 \\
\hline 23675 & 0.000 & 5.372 & 0.024 & 0.45 & 5.353 & 0.117 & 2.19 & -0.35 \\
\hline & 0.000 & 4.388 & 0.022 & 0.46 & 4.796 & 0.173 & 3.61 & -1.89 \\
\hline 01160 & 0.000 & 4.683 & 0.020 & 0.42 & 4.672 & 0.117 & 2.51 & -0.23 \\
\hline 10136 & 0.000 & 4.241 & 0.019 & 0.45 & 4.133 & 0.145 & 3.52 & -2.53 \\
\hline 13336 & 0.000 & 4.998 & 0.023 & 0.46 & 4.838 & 0.116 & 2.39 & -3.20 \\
\hline 05167 & 0.000 & 12.657 & 0.031 & 0.25 & 12.656 & 0.152 & 1.20 & -0.01 \\
\hline 04663 & 0.000 & 12.730 & 0.030 & 0.24 & 12.667 & 0.164 & 1.30 & -0.49 \\
\hline 03030 & 0.000 & 12.152 & 0.022 & 0.18 & 12.133 & 0.123 & 1.02 & -0.16 \\
\hline 06423 & 0.000 & 825 & 0.036 & 0.34 & 10.201 & 0.135 & 1.32 & -5.76 \\
\hline 20182 & 0.000 & .359 & 0.041 & 0.36 & 11.581 & 0.190 & 1.64 & +1.95 \\
\hline & 0.000 & & 0.029 & 0.26 & 10.819 & 0.123 & 1.14 & +0.13 \\
\hline 17275 & 0.000 & 10.48 & 0.029 & 0.27 & 10.517 & 0.123 & 1.17 & +0.28 \\
\hline 00705 & 0.0 & & 0.027 & 0.31 & 8.657 & 0.121 & 1.40 & -0.77 \\
\hline $\begin{array}{l}05315 \\
04636\end{array}$ & $\begin{array}{l}0.000 \\
0.000\end{array}$ & $\begin{array}{l}9.330 \\
9.403\end{array}$ & $\begin{array}{l}0.029 \\
0.027\end{array}$ & $\begin{array}{l}0.32 \\
0.29\end{array}$ & $\begin{array}{l}9.030 \\
9.201\end{array}$ & 0.120 & $\begin{array}{l}1.33 \\
1.80\end{array}$ & $\begin{array}{l}-3.21 \\
-2\end{array}$ \\
\hline 02015 & 0.000 & & 0.038 & 0.18 & 21.027 & 0.134 & 0.64 & -0.32 \\
\hline & 0.000 & & 0.044 & 0.18 & 24.192 & 0.138 & 0.57 & -0.02 \\
\hline 13629 & 0.000 & 21. & 0.040 & 0.18 & 22.044 & 0.166 & 0.75 & +0.27 \\
\hline & 0.000 & 18. & 0.035 & 0.20 & 17.828 & 0.131 & 0.73 & -1.46 \\
\hline 26636 & 0.000 & & 0.027 & 0.13 & 20.090 & 0.126 & 0.63 & -0.73 \\
\hline & 0.000 & 20. & 0.040 & 0.20 & 20.184 & 0.134 & 0.67 & -0.08 \\
\hline 00228 & 0.000 & & 0.0 & 0.28 & & & 0.98 & -1.89 \\
\hline & 0.00 & & 0.0 & 0.18 & 15.116 & 0.129 & 0.85 & -0.46 \\
\hline $\begin{array}{l}06819 \\
11228\end{array}$ & $\begin{array}{l}0.00 \\
0.00\end{array}$ & 15. & $\begin{array}{l}0.044 \\
0.035\end{array}$ & $\begin{array}{l}0.29 \\
0.21\end{array}$ & $\begin{array}{l}14.926 \\
15.850\end{array}$ & $\begin{array}{l}0.164 \\
0.133\end{array}$ & $\begin{array}{l}1.10 \\
0.84\end{array}$ & $\begin{array}{l}-3.39 \\
-2.31\end{array}$ \\
\hline 54 & 0.0 & & & 0.23 & & & 0.8 & +0.17 \\
\hline & & & & 0.20 & 14.319 & 0.121 & 0.84 & -0.97 \\
\hline
\end{tabular}




\section{Appendix B \\ Results from ANL-E Destructive Examinations}




\section{FOREWORD}

Destructive examination data contained in this appendix were transmitted to G. L. Olson (INEEL) from Donald Graczyk (Analytical Chemistry, Chemistry Technology Division, Argonne National Laboratory-East) in a letter dated June 8, 1998 (no letter number). The attachment to this letter is a copy of "Information Package, ANL Destructive Chemical Assay of 33-Rod LWBR EOL Sample" transmitted to Bettis Atomic Power Laboratory on July 31, 1980. This information is available in the INEEL Electronic Records Vault, record number LWBR-0129. Chemist Steve McKinney (INEEL) reviewed the analytical methods used to obtain the data, then entered the data into an electronic format (spreadsheets), which is published here. Steve McKinney prepared the following writeup. 
Extensive chemical and physical measurements were performed on 17 LWBR rods. These measurements were subject to the following predefined error requirements and specifications.

\begin{tabular}{|c|c|c|}
\hline Analysis & Percent Relative Bias & $\begin{array}{l}\text { Percent Relative } \\
\text { Standard Deviation }\end{array}$ \\
\hline $\begin{array}{l}\text { U-isotopic (U-233 }+ \text { U-235) (percent } \\
\text { abundance) }\end{array}$ & $\begin{array}{l}0.05 \text { (or } 0.01 \mathrm{~g} / \mathrm{U} \text {-total per } \\
\text { segment) }\end{array}$ & $\begin{array}{l}0.08 \text { (or } 0.01 \mathrm{~g} / \mathrm{U} \text {-total per } \\
\text { segment) }{ }^{\mathrm{a}}\end{array}$ \\
\hline U-total (g/segment) & 0.15 & 0.15 \\
\hline Cs-137 (atoms/segment) & 0.5 & 1.25 \\
\hline Ce-144 (atoms/segment) & 2.0 & 2.0 \\
\hline Zr-95 (atoms/segment) & $2.5^{\mathrm{b}}$ & $4.0^{\mathrm{b}}$ \\
\hline Rod Weight $(\mathrm{g})^{\mathrm{c}}$ & 0.1 & 0.10 \\
\hline Rod length (in.) & 0.001 & 0.010 \\
\hline Segment weight $(g)^{c}$ & $\begin{array}{l}0.001 \text { if } \mathrm{wt}<286 \mathrm{~g} \\
\text { otherwise } 0.01 \mathrm{~g}\end{array}$ & 0.005 \\
\hline Cladding segment length (in.) & 0.001 & 0.005 \\
\hline Fuel segment length (in.) & 0.005 & 0.015 \\
\hline Cladding segment boundary location (in.) & 0.010 total & \\
\hline Fuel segment boundary location (in.) & 0.005 & 0.015 \\
\hline \multicolumn{3}{|l|}{ a. The larger of the two shall apply. } \\
\hline \multicolumn{3}{|c|}{ b. Waived after 2 years out of the reactor (10/84), for low burnup, or low concentration segments. } \\
\hline \multicolumn{3}{|c|}{ c. Weights are given as mass in air relative to $8.0 \mathrm{~g} / \mathrm{cm}^{3}$ density standard weights. } \\
\hline \multicolumn{3}{|c|}{ d. Not including the average fuel shear-plane displacement, which will be corrected. } \\
\hline
\end{tabular}

\section{Dissolution, Sample Preparation and Sampling}

The physical measurements performed on the fuel rods were weight, length, and temperature of the rod surface. The rods were then sheared into predefined lengths (segments) and collected in aluminum buckets. The shearing also served to pulverize the ceramic fuel material, aiding sample dissolution. The segments (and bucket) were then dissolved in one of two high pressure, high temperature dissolver systems. The dissolution was carried out using a 4-hour dissolution in Thorex (13.6 $\left.\underline{\mathrm{M} \mathrm{HNO}} \mathrm{HN}_{3}, 0.06 \underline{\mathrm{M}} \mathrm{HF}\right)$ followed by a dilute nitric acid rinse, then a 3-hour secondary dissolution in a Thorex-0.06 $\mathrm{M} \mathrm{Al}^{+3}$ solution, followed by a reflux rinse (hot rinse) and cold rinse with dilute nitric acid. Operating conditions for both dissolutions were $195^{\circ} \mathrm{C}$ and $120 \mathrm{psig}$. A sample of the second dissolution was obtained to measure the completeness of the dissolution scheme. Both dissolutions and all rinses were then combined in a blend tank and mixed prior to further sampling. Gases emitted during dissolution were collected and analyzed for krypton and xenon.

In all, three sets of samples were obtained from each segment. The first set (two samples) was taken from the secondary dissolution prior to blending to assess the completeness of the dissolution scheme. The second set (four samples) was then taken from the blended (both dissolutions and all rinses) 
tank contents. The third set (four samples) was taken after the addition of a known amount of U-238 spike (NBS Standard Sample 950a). Half of the samples were analyzed, and the other half was placed in archive. Batch carryover or cross contamination was controlled and monitored by analyzing a blank (a full dissolution scheme with no segment material) between each rod, and all segments were analyzed in order of increasing uranium content.

Implicit in all measurements is that dissolution is complete, and the fuel in solution is quantitatively transferred to the blend tank.

\section{Uranium Analysis}

Total uranium and uranium isotopic (U-233, U-234, U-235, U-236, U-238) analyses were performed by thermal ionization mass spectrometry. Because of the interference of Th-232, U-232 was determined by alpha spectrometry.

Rod B - 2606481: The uncertainties for uranium results for segments B-03, B-04, and B-05 may be slightly more than reported due to losses in dissolution (order of $0.01 \%-0.02 \%$ ).

\section{$\mathrm{Kr} / \mathrm{Xe}$ Analysis}

Fission gases (krypton and xenon) collected from the fuel rod plenum and during dissolution were determined by gas mass spectrometry on a "best effort" basis. Gases released during shearing were estimated by using the in line radiation monitor in the cell ventilation system. The plenum (rod void volume) contained between $0.01 \%$ and $0.15 \%$, and about $0.17 \%$ to $0.58 \%$ of the gas was released during shearing. The rest (>99\%) was released during dissolution.

Rod B-2606481: The total gram weight given in column entitled "gas released in dissolution" is incorrect. The total reflects the 0.0037 contribution of the plenum gases.

Rod C - 2513854: The krypton and xenon values for C-04 were estimated using fission gas data from C-03 and C-05 and an assumed correlation with Cs-137 over the three segments.

\section{Cs-137, Ce-144, Nb-95 Analysis}

The fission products Cs-137, Ce-144, and Nb-95 were determined by gamma spectrometry (high purity germanium detector with associated automated multi-channel analyzer/data management system) on weighed aliquots of the samples obtained prior to spiking the blend tank with 950a. Cs-137 and Ce-144 were determined on a sample aliquot by direct counting. Zr-95 was obtained after processing the sample aliquot through a cleanup procedure to reduce interferences. The losses of Zr-95 were accounted for by using before and after values of the Ce-144. Error requirements for Zr-95 measurements made after October 1984 were waived because of the short half-life (64.02 days). 
Rod "B" 2606481 (PFB III-6 E31)

\begin{tabular}{|c|c|c|c|c|c|c|c|}
\hline & B-00 & B-01 & B-02 & B-03 & B-04 & B-05 & B-06 \\
\hline seg length (in) ${ }^{a}$ & 10.993 & 10.992 & 18.091 & 17.5 & 17.5 & 17.497 & 14.5 \\
\hline \multicolumn{8}{|l|}{ total length (in) } \\
\hline & & & & & & & \\
\hline U-232 wt $\%^{b}$ & 0 & 0.0113 & 0.0283 & 0.1091 & 0.1468 & 0.1152 & 0.0 \\
\hline$+-^{\mathrm{b}}$ & 0 & 0.0004 & 0.0009 & 0.0034 & 0.0046 & 0.0036 & 0.00 \\
\hline $\mathrm{U}-232 \mathrm{~g}^{\mathrm{i}}$ & $0.0000 \mathrm{E}+00$ & $3.2265 \mathrm{E}-05$ & 3.5353E-03 & 1.2495E-02 & 1.6474E-02 & $1.2847 \mathrm{E}-02$ & $3.3564 \mathrm{E}-1$ \\
\hline$+/^{j}$ & NA & 1.1422E-06 & 1.1243E-04 & 3.8941E-04 & 5.1622E-04 & $4.0147 \mathrm{E}-04$ & $1.0549 \mathrm{E}-1$ \\
\hline \multicolumn{8}{|l|}{ Segment Total } \\
\hline \multicolumn{8}{|l|}{$+/-^{n}$} \\
\hline & & & & & & & \\
\hline $\mathrm{U}-233 \mathrm{wt} \%{ }^{\mathrm{b}}$ & 100 & 99.2297 & 93.6514 & 87.8209 & 85.6132 & 87.066 & 92.1 \\
\hline$+/{ }^{\mathrm{b}}$ & 0 & 0.021 & 0.0048 & 0.0055 & 0.0061 & 0.0056 & 0.0 \\
\hline $\mathrm{U}-233 \mathrm{~g}^{\mathrm{i}}$ & $4.0000 \mathrm{E}-05$ & $2.8333 \mathrm{E}-01$ & $1.1699 \mathrm{E}+01$ & $1.0058 \mathrm{E}+01$ & $9.6073 E+00$ & $9.7092 \mathrm{E}+00$ & $8.8375 \mathrm{E}+1$ \\
\hline$+/{ }^{j}$ & $1.0000 \mathrm{E}-05$ & 1.3332E-04 & $3.2861 \mathrm{E}-03$ & $2.8971 \mathrm{E}-03$ & 2.7077E-03 & 2.7619E-03 & $2.4345 \mathrm{E}-1$ \\
\hline \multicolumn{8}{|l|}{ Segment Total } \\
\hline \multicolumn{8}{|l|}{$+/-^{n}$} \\
\hline $\mathrm{U}-234 \mathrm{wt} \%{ }^{\mathrm{b}}$ & 0 & 0.7163 & 5.3256 & 9.9797 & 11.6472 & 10.5888 & 6.6 \\
\hline$+/-^{\mathrm{b}}$ & 0 & 0.0006 & 0.0007 & 0.0009 & 0.0011 & 0.001 & 0.00 \\
\hline $\mathrm{U}-234 \mathrm{~g}^{\mathrm{i}}$ & $0.0000 \mathrm{E}+00$ & $2.0453 \mathrm{E}-03$ & $6.6528 \mathrm{E}-01$ & $1.1429 E+00$ & $1.3070 \mathrm{E}+00$ & $1.1808 \mathrm{E}+00$ & $6.3301 \mathrm{E}-1$ \\
\hline$+/-^{j}$ & NA & 1.9167E-06 & $2.0348 \mathrm{E}-04$ & 3.3747E-04 & 3.7718E-04 & $3.4568 \mathrm{E}-04$ & $1.8367 \mathrm{E}-1$ \\
\hline \multicolumn{8}{|l|}{ Segment Total } \\
\hline \multicolumn{8}{|l|}{$+-^{\mathrm{n}}$} \\
\hline & & & & & & & \\
\hline U-235 wt $\%^{b}$ & 0 & 0.0125 & 0.6384 & 1.6482 & 2.0943 & 1.7634 & 0.82 \\
\hline$+/-^{\mathrm{b}}$ & 0 & 0.0149 & 0.0035 & 0.0036 & 0.0037 & 0.0036 & 0.00 \\
\hline $\mathrm{U}-235 \mathrm{~g}^{\mathrm{i}}$ & $0.0000 \mathrm{E}+00$ & $3.5691 \mathrm{E}-05$ & 7.9750E-02 & 1.8876E-01 & $2.3502 \mathrm{E}-01$ & 1.9665E-01 & $7.8750 \mathrm{E}-1$ \\
\hline$+/-^{j}$ & NA & $4.2544 \mathrm{E}-05$ & $4.3778 \mathrm{E}-04$ & 4.1570E-04 & $4.2012 \mathrm{E}-04$ & $4.0514 \mathrm{E}-04$ & $3.5545 \mathrm{E}-1$ \\
\hline \multicolumn{8}{|l|}{ Segment Total } \\
\hline \multicolumn{8}{|l|}{$+/-^{\mathrm{n}}$} \\
\hline U-236 wt ${ }^{b}$ & 0 & 0.0004 & 0.081 & 0.1725 & 0.2315 & 0.1902 & 0.09 \\
\hline$+/-^{\mathrm{b}}$ & 0 & 0.0002 & 0.0001 & 0.0001 & 0.0001 & 0.0001 & 0.00 \\
\hline $\mathrm{U}-236 \mathrm{~g}^{\mathrm{i}}$ & $0.0000 \mathrm{E}+00$ & 1.1421E-06 & 1.0119E-02 & 1.9756E-02 & $2.5978 \mathrm{E}-02$ & $2.1210 \mathrm{E}-02$ & $9.4074 \mathrm{E}-1$ \\
\hline$+/-^{j}$ & NA & 5.7106E-07 & $1.2801 \mathrm{E}-05$ & $1.2729 \mathrm{E}-05$ & $1.3271 \mathrm{E}-05$ & $1.2605 \mathrm{E}-05$ & 9.9205E-1 \\
\hline \multicolumn{8}{|l|}{ Segment Total } \\
\hline$+-^{\mathrm{n}}$ & & & & & & & \\
\hline
\end{tabular}


Rod "B" 2606481 (PFB III-6 E31)

\begin{tabular}{|c|c|c|c|c|c|c|c|}
\hline & B-00 & B-01 & B-02 & B-03 & B-04 & B-05 & B-06 \\
\hline seg length (in) ${ }^{a}$ & 10.993 & 10.992 & 18.091 & 17.5 & 17.5 & 17.497 & 14.5 \\
\hline \multicolumn{8}{|l|}{ total length (in) } \\
\hline & & & & & & & \\
\hline U-238 wt ${ }^{b}$ & 0 & 0.0298 & 0.2752 & 0.2696 & 0.2669 & 0.2764 & 0.28 \\
\hline$+-^{\mathrm{b}}$ & 0 & 0.015 & 0.0035 & 0.0036 & 0.0038 & 0.0037 & 0.00 \\
\hline $\mathrm{U}-238 \mathrm{~g}^{\mathrm{i}}$ & $0.0000 \mathrm{E}+00$ & $8.5088 \mathrm{E}-05$ & $3.4378 \mathrm{E}-02$ & $3.0876 \mathrm{E}-02$ & $2.9951 \mathrm{E}-02$ & 3.0823E-02 & $2.7589 \mathrm{E}-$ \\
\hline$+-^{j}$ & NA & $4.2830 \mathrm{E}-05$ & $4.3733 E-04$ & $4.1239 \mathrm{E}-04$ & $4.2651 \mathrm{E}-04$ & 4.1269E-04 & $3.5489 \mathrm{E}-$ \\
\hline \multicolumn{8}{|l|}{ Segment Total } \\
\hline \multicolumn{8}{|l|}{$+/^{n}$} \\
\hline & & & & & & & \\
\hline tot $U^{c}$ & 0.00004 & 0.28553 & 12.49217 & 11.45266 & 11.22176 & 11.15151 & 9.58 \\
\hline$+/{ }^{c}$ & 0.00001 & 0.00012 & 0.00345 & 0.00322 & 0.00306 & 0.00309 & 0.002 \\
\hline $\mathrm{Kr}-82(\mathrm{~mol} \%)^{\mathrm{d}}$ & 0.2 & 0.2 & 0.2 & 0.2 & 0.2 & 0.2 & \\
\hline$+/-^{\mathrm{d}}$ & 0.2 & 0.2 & 0.2 & 0.2 & 0.2 & 0.2 & \\
\hline $\mathrm{Kr}-82(\mathrm{~g})^{\mathrm{K}}$ & $1.1468 \mathrm{E}-06$ & $0.0000 \mathrm{E}+00$ & 1.8464E-04 & $3.2681 \mathrm{E}-04$ & $4.1340 \mathrm{E}-04$ & 3.3844E-04 & 1.6291E- \\
\hline$+/-^{j}$ & $1.1468 \mathrm{E}-06$ & NA & $1.8510 \mathrm{E}-04$ & $3.2834 \mathrm{E}-04$ & $4.1461 \mathrm{E}-04$ & $3.3898 \mathrm{E}-04$ & $1.6382 \mathrm{E}-$ \\
\hline \multicolumn{8}{|l|}{ Segment Total } \\
\hline \multicolumn{8}{|l|}{$+/-^{\mathrm{n}}$} \\
\hline & & & & & & & \\
\hline $\mathrm{Kr}-83(\mathrm{~mol} \%)^{\mathrm{d}}$ & 15.4 & 15.4 & 15.4 & 15.4 & 15.4 & 15.4 & 15 \\
\hline$+/^{\mathrm{d}}$ & 0.1 & 0.1 & 0.1 & 0.1 & 0.1 & 0.1 & \\
\hline $\mathrm{Kr}-83(\mathrm{~g})^{\mathrm{k}}$ & $8.9381 \mathrm{E}-05$ & $0.0000 \mathrm{E}+00$ & $1.4391 \mathrm{E}-02$ & $2.5472 \mathrm{E}-02$ & $3.2221 \mathrm{E}-02$ & $2.6378 \mathrm{E}-02$ & $1.2697 \mathrm{E}-$ \\
\hline$+/-^{j}$ & 5.8040E-07 & NA & $1.0258 \mathrm{E}-03$ & $2.4700 \mathrm{E}-03$ & $2.4733 \mathrm{E}-03$ & $1.5038 \mathrm{E}-03$ & $1.3433 \mathrm{E}-$ \\
\hline \multicolumn{8}{|l|}{ Segment Total } \\
\hline \multicolumn{8}{|l|}{$+/^{\mathrm{n}}$} \\
\hline $\mathrm{Kr}-84(\mathrm{~mol} \%)^{\mathrm{d}}$ & 30.1 & 30.1 & 30.1 & 30.1 & 30.1 & 30.1 & 30 \\
\hline$+/^{\mathrm{d}}$ & 0.3 & 0.3 & 0.3 & 0.3 & 0.3 & 0.3 & \\
\hline $\mathrm{Kr}-84(\mathrm{~g})^{\mathrm{k}}$ & 1.7680E-04 & $0.0000 \mathrm{E}+00$ & 2.8465E-02 & $5.0385 \mathrm{E}-02$ & $6.3734 \mathrm{E}-02$ & $5.2178 \mathrm{E}-02$ & $2.5116 \mathrm{E}-$ \\
\hline$+/-^{j}$ & $1.7621 \mathrm{E}-06$ & NA & 2.0404E-03 & 4.9005E-03 & $4.9160 \mathrm{E}-03$ & 3.0007E-03 & $2.6639 \mathrm{E}-$ \\
\hline \multicolumn{8}{|l|}{ Segment Total } \\
\hline$+-^{\mathrm{n}}$ & & & & & & & \\
\hline
\end{tabular}


Rod "B" 2606481 (PFB III-6 E31)

\begin{tabular}{|c|c|c|c|c|c|c|c|c|}
\hline \multicolumn{9}{|l|}{ total length (in) } \\
\hline $\mathrm{Kr}-85(\mathrm{~mol} \%)^{\mathrm{d}}$ & 6.2 & 6.2 & 6.2 & 6.2 & 6.2 & 6.2 & 6.2 & \\
\hline$+-^{\mathrm{d}}$ & 0.1 & 0.1 & 0.1 & 0.1 & 0.1 & 0.1 & 0.1 & \\
\hline $\mathrm{Kr}-85(\mathrm{~g})^{\mathrm{K}}$ & 3.6852E-05 & $0.0000 \mathrm{E}+00$ & 5.9333E-03 & $1.0502 \mathrm{E}-02$ & $1.3285 \mathrm{E}-02$ & 1.0876E-02 & $5.2352 \mathrm{E}-03$ & 2.82 \\
\hline \multicolumn{9}{|l|}{$+/-^{n}$} \\
\hline $\mathrm{Kr}-86(\mathrm{~mol} \%)^{\mathrm{d}}$ & 48.2 & 48.2 & 48.2 & 48.2 & 48.2 & 48.2 & 48.2 & \\
\hline$+/-^{d}$ & 0.3 & 0.3 & 0.3 & 0.3 & 0.3 & 0.3 & 0.3 & \\
\hline $\mathrm{Kr}-86(\mathrm{~g})^{\mathrm{K}}$ & 2.8986E-04 & $0.0000 \mathrm{E}+00$ & 4.6669E-02 & $8.2605 \mathrm{E}-02$ & 1.0449E-01 & $8.5545 \mathrm{E}-02$ & $4.1178 \mathrm{E}-02$ & 2.22 \\
\hline$+L_{-}^{j}$ & $1.8041 \mathrm{E}-06$ & NA & $3.3255 \mathrm{E}-03$ & $8.0086 \mathrm{E}-03$ & $8.0186 \mathrm{E}-03$ & 4.8743E-03 & 4.3556E-03 & 1.57 \\
\hline & & & & & & & & \\
\hline shear gas $(\mathrm{g})^{\mathrm{e}}$ & 0 & 0 & 0.0012 & 0.003 & 0.0039 & 0.0037 & 0.002 & \\
\hline$+/-^{\mathrm{e}}$ & NA & NA & 0.0002 & 0.0006 & 0.0008 & 0.0008 & 0.0004 & \\
\hline moles $\mathrm{Kr}\left(\right.$ diss+pl) ${ }^{\mathrm{d}}$ & 0.000007 & 0 & 0.001125 & 0.00199 & 0.002517 & 0.00206 & 0.000991 & 0. \\
\hline$+/^{-\mathrm{d}}$ & 0 & NA & 0.00008 & 0.000193 & 0.000193 & 0.000117 & 0.000105 & 0. \\
\hline $\mathrm{Kr}+\mathrm{Xe}$ diss\&pl $(\mathrm{g})^{\mathrm{d}}$ & 0.0037 & 0 & 0.6693 & 1.2299 & 1.5355 & 1.3033 & 0.5808 & \\
\hline$+/^{-\mathrm{d}}$ & 0.0002 & NA & 0.0408 & 0.0544 & 0.0547 & 0.0564 & 0.0168 & \\
\hline moles $\mathrm{kr}$ (tot) $^{\circ}$ & $7.0000 \mathrm{E}-06$ & 0 & $1.1270 \mathrm{E}-03$ & $1.9949 \mathrm{E}-03$ & $2.5234 \mathrm{E}-03$ & $2.0658 \mathrm{E}-03$ & $9.9441 \mathrm{E}-04$ & 5.36 \\
\hline$+/-^{\mathrm{p}}$ & & NA & $8.0001 \mathrm{E}-05$ & $1.9300 \mathrm{E}-04$ & 1.9301E-04 & $1.1701 \mathrm{E}-04$ & $1.0500 \mathrm{E}-04$ & 3.80 \\
\hline Xe-128 (mol\%) $)^{d}$ & 0.1 & 0.1 & 0.1 & 0.1 & 0.1 & 0.1 & 0.1 & \\
\hline$+/{ }^{\mathrm{d}}$ & 0 & 0 & 0 & 0 & 0 & 0 & 0 & \\
\hline
\end{tabular}


od "B" 2606481 (PFB III-6 E31)

\begin{tabular}{|c|c|c|c|c|c|c|c|}
\hline & B-00 & B-01 & B-02 & B-03 & B-04 & B-05 & B-06 \\
\hline seg length (in) ${ }^{a}$ & 10.993 & 10.992 & 18.091 & 17.5 & 17.5 & 17.497 & 14.5 \\
\hline \multicolumn{8}{|l|}{ total length (in) } \\
\hline $\mathrm{Xe}-130(\mathrm{~mol} \%)^{\mathrm{d}}$ & 0.1 & 0.1 & 0.1 & 0.1 & 0.1 & 0.1 & c \\
\hline$+{ }^{\mathrm{d}}{ }^{\mathrm{a}}$ & 0 & 0 & 0 & 0 & 0 & 0 & \\
\hline Xe-130 $(g)^{k}$ & $2.9878 \mathrm{E}-06$ & $0.0000 \mathrm{E}+00$ & 5.5633E-04 & 1.0293E-03 & $1.2825 \mathrm{E}-03$ & $1.0951 \mathrm{E}-03$ & $4.8230 \mathrm{E}-$ \\
\hline$+/-{ }^{j}$ & 1.2990E-07 & NA & $3.8842 \mathrm{E}-05$ & $5.0016 \mathrm{E}-05$ & $5.0277 \mathrm{E}-05$ & $5.3525 \mathrm{E}-05$ & $1.3644 \mathrm{E}-$ \\
\hline \multicolumn{8}{|l|}{ SegmentTotal } \\
\hline \multicolumn{8}{|l|}{$+/-^{n}$} \\
\hline $\mathrm{Xe}-131(\mathrm{~mol} \%)^{\mathrm{d}}$ & 11.9 & 11.9 & 11.9 & 11.9 & 11.9 & 11.9 & 11 \\
\hline$+/-^{\mathrm{d}}$ & 0.1 & 0.1 & 0.1 & 0.1 & 0.1 & 0.1 & $\mathrm{c}$ \\
\hline $\mathrm{Xe}-131(\mathrm{~g})^{\mathrm{k}}$ & 3.5829E-04 & $0.0000 \mathrm{E}+00$ & $6.6714 \mathrm{E}-02$ & 1.2343E-01 & $1.5380 \mathrm{E}-01$ & $1.3132 \mathrm{E}-01$ & $5.7836 \mathrm{E}-$ \\
\hline$+/{ }_{-}^{\mathrm{j}}$ & 1.5866E-05 & NA & 4.6914E-03 & $6.0868 \mathrm{E}-03$ & $6.1661 \mathrm{E}-03$ & $6.5127 \mathrm{E}-03$ & $1.7068 \mathrm{E}-$ \\
\hline \multicolumn{8}{|l|}{ SegmentTotal } \\
\hline \multicolumn{8}{|l|}{$+/-^{n}$} \\
\hline & & & & & & & \\
\hline $\mathrm{Xe}-132(\mathrm{~mol} \%)^{\mathrm{d}}$ & 22.3 & 22.3 & 22.3 & 22.3 & 22.3 & 22.3 & 22 \\
\hline$+-_{-}^{\mathrm{d}}$ & 0.2 & 0.2 & 0.2 & 0.2 & 0.2 & 0.2 & c \\
\hline $\mathrm{Xe}-132(\mathrm{~g})^{\mathrm{k}}$ & $6.7654 \mathrm{E}-04$ & $0.0000 \mathrm{E}+00$ & 1.2597E-01 & $2.3306 \mathrm{E}-01$ & $2.9041 \mathrm{E}-01$ & $2.4796 \mathrm{E}-01$ & $1.0921 \mathrm{E}-$ \\
\hline$+/{ }^{\mathrm{j}}$ & $3.0034 \mathrm{E}-05$ & NA & $8.8673 \mathrm{E}-03$ & 1.1517E-02 & 1.1679E-02 & $1.2322 \mathrm{E}-02$ & $3.2410 \mathrm{E}-$ \\
\hline \multicolumn{8}{|l|}{ SegmentTotal } \\
\hline \multicolumn{8}{|l|}{$+-^{n}$} \\
\hline $\mathrm{Xe}-134(\mathrm{~mol} \%)^{d}$ & 25.4 & 25.4 & 25.4 & 25.4 & 25.4 & 25.4 & 25 \\
\hline$+/^{\mathrm{d}}$ & 0.3 & 0.3 & 0.3 & 0.3 & 0.3 & 0.3 & $\mathrm{c}$ \\
\hline $\mathrm{Xe}-134(\mathrm{~g})^{\mathrm{k}}$ & $7.8228 \mathrm{E}-04$ & $0.0000 \mathrm{E}+00$ & 1.4566E-01 & $2.6949 \mathrm{E}-01$ & $3.3580 \mathrm{E}-01$ & $2.8672 \mathrm{E}-01$ & $1.2628 \mathrm{E}-$ \\
\hline$+/{ }^{j}$ & $3.5245 \mathrm{E}-05$ & NA & $1.0314 \mathrm{E}-02$ & $1.3477 \mathrm{E}-02$ & $1.3748 \mathrm{E}-02$ & 1.4417E-02 & $3.8712 \mathrm{E}-$ \\
\hline \multicolumn{8}{|l|}{ SegmentTotal } \\
\hline$+/^{\mathrm{n}}$ & & & & & & & \\
\hline
\end{tabular}


Rod "B" 2606481 (PFB III-6 E31)

\begin{tabular}{|c|c|c|c|c|c|c|c|}
\hline & B-00 & B-01 & B-02 & B-03 & B-04 & B-05 & B-06 \\
\hline seg length (in) ${ }^{a}$ & 10.993 & 10.992 & 18.091 & 17.5 & 17.5 & 17.497 & 14.562 \\
\hline \multicolumn{8}{|l|}{ total length (in) } \\
\hline & & & & & & & \\
\hline $\mathrm{Xe}-136(\mathrm{~mol} \%)^{\mathrm{d}}$ & 40.1 & 40.1 & 40.1 & 40.1 & 40.1 & 40.1 & 40.1 \\
\hline$+/-^{\mathrm{d}}$ & 0.2 & 0.2 & 0.2 & 0.2 & 0.2 & 0.2 & 0.2 \\
\hline Xe-136 $(g)^{k}$ & 1.2535E-03 & $0.0000 \mathrm{E}+00$ & $2.3340 \mathrm{E}-01$ & $4.3181 \mathrm{E}-01$ & 5.3807E-01 & $4.5942 \mathrm{E}-01$ & $2.0234 \mathrm{E}-01$ \\
\hline$+/{ }_{-}^{j}$ & 5.4856E-05 & NA & 1.6337E-02 & $2.1093 \mathrm{E}-02$ & $2.1263 \mathrm{E}-02$ & $2.2572 \mathrm{E}-02$ & $5.8124 \mathrm{E}-03$ \\
\hline \multicolumn{8}{|l|}{ SegmentTotal } \\
\hline \multicolumn{8}{|l|}{$+/-^{n}$} \\
\hline \multicolumn{8}{|l|}{ Rod total } \\
\hline \multicolumn{8}{|l|}{$+/-^{n}$} \\
\hline & & & & & & & \\
\hline shear gas $(g)^{e}$ & 0 & 0 & 0.0012 & 0.003 & 0.0039 & 0.0037 & 0.002 \\
\hline$+/{ }^{\mathrm{e}}$ & 0 & 0 & 0.0002 & 0.0006 & 0.0008 & 0.0008 & 0.0004 \\
\hline moles Xe (diss+pl) $)^{d}$ & 0.000023 & 0 & 0.004275 & 0.007904 & 0.009848 & 0.008406 & 0.0037 \\
\hline$+/^{\mathrm{d}}$ & 0.000001 & 0 & 0.000299 & 0.000385 & 0.000387 & 0.000412 & 0.000105 \\
\hline $\mathrm{Kr}+\mathrm{Xe}$ diss\&pl $(\mathrm{g})^{\mathrm{d}}$ & 0.0037 & 0 & 0.6693 & 1.2299 & 1.5355 & 1.3033 & 0.5808 \\
\hline$+/^{\mathrm{d}}$ & 0.0002 & 0 & 0.0408 & 0.0544 & 0.0547 & 0.0564 & 0.0168 \\
\hline moles Xe (tot) $^{\circ}$ & $2.3000 \mathrm{E}-05$ & 0 & $4.2827 \mathrm{E}-03$ & $7.9233 E-03$ & 9.8730E-03 & $8.4299 \mathrm{E}-03$ & $3.7127 \mathrm{E}-03$ \\
\hline$+/-^{p}$ & $1.0000 \mathrm{E}-06$ & 0 & $2.9900 \mathrm{E}-04$ & $3.8502 \mathrm{E}-04$ & 3.8704E-04 & 4.1204E-04 & 1.0503E-04 \\
\hline \multicolumn{8}{|c|}{ Values corrected to 1/1/84 (page 181, Final Report for the LWBR Proof of Breeding Analytical Support Project } \\
\hline & & & & & & & \\
\hline Cs-137 (atoms) & NA & $2.7440 \mathrm{E}+18$ & $6.6220 \mathrm{E}+20$ & 1.3800E+21 & $1.6610 \mathrm{E}+21$ & $1.4600 \mathrm{E}+21$ & $6.8260 \mathrm{E}+20$ \\
\hline$+/-^{f}$ & NA & $1.1800 \mathrm{E}+16$ & $2.7500 \mathrm{E}+18$ & $5.9300 \mathrm{E}+18$ & $7.1300 \mathrm{E}+18$ & $6.2700 \mathrm{E}+18$ & $2.9300 \mathrm{E}+18$ \\
\hline Cs-137 (g) ${ }^{\mathrm{m}}$ & NA & 6.2375E-04 & 1.5053E-01 & 3.1369E-01 & 3.7757E-01 & 3.3188E-01 & $1.5516 \mathrm{E}-01$ \\
\hline$+/-^{m}$ & NA & $2.6823 \mathrm{E}-06$ & $6.2511 \mathrm{E}-04$ & 1.3480E-03 & 1.6208E-03 & $1.4253 \mathrm{E}-03$ & $6.6603 \mathrm{E}-04$ \\
\hline \multicolumn{8}{|l|}{ Total } \\
\hline \multicolumn{8}{|l|}{$+/-^{n}$} \\
\hline $\mathrm{Ce}-144$ (atoms) $^{g}$ & NA & $34950 \mathrm{E}+17$ & $42590 \mathrm{E}+19$ & $70130 \mathrm{E}+19$ & $8.0720 \mathrm{E}+19$ & $66070 F+19$ & $25620 F+10$ \\
\hline$+/^{9}$ & NA & $2.5600 \mathrm{E}+15$ & $3.1700 \mathrm{E}+17$ & $5.5500 \mathrm{E}+17$ & $6.5300 \mathrm{E}+17$ & $5.3600 \mathrm{E}+17$ & $2.2900 \mathrm{E}+17$ \\
\hline $\mathrm{Ce}-144(\mathrm{~g})^{\mathrm{m}}$ & NA & $8.3512 \mathrm{E}-05$ & 1.0177E-02 & 1.6757E-02 & 1.9288E-02 & $1.5787 \mathrm{E}-02$ & $6.1218 \mathrm{E}-03$ \\
\hline$+/-^{m}$ & NA & $6.1171 \mathrm{E}-07$ & $7.5746 \mathrm{E}-05$ & $1.3262 \mathrm{E}-04$ & 1.5603E-04 & $1.2808 \mathrm{E}-04$ & $5.4719 \mathrm{E}-05$ \\
\hline \multicolumn{8}{|l|}{ Total } \\
\hline$+/-^{n}$ & & & & & & & \\
\hline
\end{tabular}


Rod "B" 2606481 (PFB III-6 E31)

\begin{tabular}{|c|c|c|c|c|c|c|c|}
\hline & B-00 & B-01 & B-02 & B-03 & B-04 & B-05 & B-06 \\
\hline seg length (in) ${ }^{a}$ & 10.993 & 10.992 & 18.091 & 17.5 & 17.5 & 17.497 & 14.5 \\
\hline \multicolumn{8}{|l|}{ total length (in) } \\
\hline & & & & & & & \\
\hline Zr-95 (atoms) ${ }^{h}$ & NA & $3.8830 \mathrm{E}+15$ & $3.5110 \mathrm{E}+17$ & $5.3390 \mathrm{E}+17$ & $5.8830 \mathrm{E}+17$ & $3.4900 \mathrm{E}+17$ & $6.3080 \mathrm{E}+$ \\
\hline$+-^{\mathrm{h}}$ & NA & $7.9700 \mathrm{E}+13$ & $4.2500 \mathrm{E}+15$ & $1.1000 \mathrm{E}+16$ & $9.7100 \mathrm{E}+15$ & $7.6500 \mathrm{E}+15$ & $2.3700 \mathrm{E}+$ \\
\hline Zr-95 (g) & NA & $6.1189 \mathrm{E}-07$ & 5.5327E-05 & 8.4133E-05 & 9.2705E-05 & 5.4996E-05 & $9.9402 \mathrm{E}$ \\
\hline$+/-^{m}$ & NA & $1.2559 \mathrm{E}-08$ & 6.6972E-07 & 1.7334E-06 & $1.5301 \mathrm{E}-06$ & $1.2055 \mathrm{E}-06$ & $3.7347 \mathrm{E}$ \\
\hline \multicolumn{8}{|l|}{ Total } \\
\hline$+/-^{n}$ & & & & & & & \\
\hline
\end{tabular}

a. ANL Destructive Chemical Assay of 33-Rod LWBR EOL Sample - Rod B, 2606481, page 4

b. ANL Destructive Chemical Assay of 33-Rod LWBR EOL Sample - Rod B, 2606481, page 7

c. ANL Destructive Chemical Assay of 33-Rod LWBR EOL Sample - Rod B, 2606481, page 8

d. ANL Destructive Chemical Assay of 33-Rod LWBR EOL Sample - Rod B, 2606481, page 10

e. ANL Destructive Chemical Assay of 33-Rod LWBR EOL Sample - Rod B, 2606481, page 11

f. ANL Destructive Chemical Assay of 33-Rod LWBR EOL Sample - Rod B, 2606481, page 12

g. ANL Destructive Chemical Assay of 33-Rod LWBR EOL Sample - Rod B, 2606481, page 13

h. ANL Destructive Chemical Assay of 33-Rod LWBR EOL Sample - Rod B, 2606481, page 14

i. (abundance of the specified isotope)(total weight of uranium) / 100

j. Error Propagation $=\left(\left(s d_{x} / x\right)^{2}+\left(s d_{y} / y\right)^{2}\right)^{1 / 2}(x y)$, where sd is the $+/-$ in the table

k. (mole\%)(number moles gas recovered)(molec wt) / 100

m. (number of atoms per segment)(atomic weight) / 6.0228E+23

n. Error Propagation $=\left(\operatorname{SUM}\left(\mathrm{sd}_{\mathrm{i}}^{2}\right)\right)^{1 / 2}$, where sd is the $+/-$ in the table

o. ((shear gas / Xe $+\mathrm{Kr}$ (diss\&pl ))(moles $\mathrm{Xe}$ or $\mathrm{Kr}($ diss $+\mathrm{pl}))+$ moles $\mathrm{Xe}$ or $\mathrm{Kr}$ (diss $+\mathrm{pl})$

p. Error Propagation $=\left(\left(\left(\left(s d_{x} / x\right)^{2}+\left(s d_{y} / y\right)^{2}+\left(s d_{z} / z\right)^{2}\right)^{1 / 2}(x y / z)\right)^{2}+\left(s d_{y}\right)^{2}\right)^{1 / 2}$, where sd is the $+/-$ in the table 
Rod "C" 2513854 (PFB III-6 F73)

\begin{tabular}{|c|c|c|c|c|c|c|c|}
\hline & C-00 & C-01 & C-02 & C-03 & C-04 & C-05 & C-06 \\
\hline seg length (in) ${ }^{a}$ & 11.146 & 7.991 & 17.955 & 17.498 & 17.502 & 17.498 & 14.5 \\
\hline \multicolumn{8}{|l|}{ total length (in) } \\
\hline & & & & & & & \\
\hline $\mathrm{U}-232 \mathrm{wt} \%^{\mathrm{b}}$ & 0 & 0.0101 & 0.0208 & 0.0841 & 0.114 & 0.0869 & 0.02 \\
\hline$+1-{ }^{\mathrm{b}}$ & 0 & 0.0003 & 0.0006 & 0.0026 & 0.0035 & 0.0027 & 0.00 \\
\hline $\mathrm{U}-232 \mathrm{~g}^{\mathrm{i}}$ & $0.0000 \mathrm{E}+00$ & $2.1858 \mathrm{E}-05$ & $2.6513 \mathrm{E}-03$ & 9.8567E-03 & 1.3131E-02 & 1.0056E-02 & $2.4883 \mathrm{E}-$ \\
\hline$+/-^{j}$ & NA & $6.5052 \mathrm{E}-07$ & $7.6484 \mathrm{E}-05$ & 3.0474E-04 & $4.0315 \mathrm{E}-04$ & 3.1247E-04 & $7.9947 \mathrm{E}-$ \\
\hline \multicolumn{8}{|l|}{ Segment Total } \\
\hline \multicolumn{8}{|l|}{$+/^{\mathrm{n}}$} \\
\hline & & & & & & & \\
\hline U-233 wt $\%^{b}$ & 100 & 99.2944 & 94.5303 & 89.6714 & 87.918 & 89.3639 & 93.83 \\
\hline$+/-^{\mathrm{b}}$ & 0 & 0.0345 & 0.0047 & 0.0052 & 0.0059 & 0.0055 & 0.00 \\
\hline $\mathrm{U}-233 \mathrm{~g}^{\mathrm{i}}$ & $1.6000 \mathrm{E}-04$ & $2.1489 \mathrm{E}-01$ & $1.2050 \mathrm{E}+01$ & $1.0510 \mathrm{E}+01$ & $1.0126 \mathrm{E}+01$ & $1.0342 \mathrm{E}+01$ & $9.3769 \mathrm{E}+$ \\
\hline$+/-^{j}$ & $2.0000 \mathrm{E}-05$ & $4.0413 \mathrm{E}-04$ & 3.1951E-03 & 3.1795E-03 & 2.8772E-03 & 2.8686E-03 & $2.6768 \mathrm{E}-$ \\
\hline \multicolumn{8}{|l|}{ Segment Total } \\
\hline \multicolumn{8}{|l|}{$+/-^{\mathrm{n}}$} \\
\hline $\mathrm{U}-234 \mathrm{wt} \%^{\mathrm{b}}$ & 0 & 0.6313 & 4.585 & 8.5514 & 99101 & 88104 & \\
\hline$+/-^{b}$ & 0 & 0.0011 & 0.001 & 0.0011 & 0.0012 & $\begin{array}{l}8.8104 \\
0.0012 \\
\end{array}$ & $\frac{5.19}{0.00}$ \\
\hline $\mathrm{U}-234 \mathrm{~g}^{\mathrm{i}}$ & $0.0000 \mathrm{E}+00$ & 1.3663E-03 & 5.8444E-01 & $1.0022 \mathrm{E}+00$ & $1.1414 \mathrm{E}+00$ & $1.0196 \mathrm{E}+00$ & $5.1913 \mathrm{E}-$ \\
\hline$+/_{-}^{j}$ & NA & $3.4704 \mathrm{E}-06$ & 1.9854E-04 & $3.2431 \mathrm{E}-04$ & 3.4412E-04 & $3.0876 \mathrm{E}-04$ & $1.8108 \mathrm{E}-$ \\
\hline \multicolumn{8}{|l|}{ Segment Total } \\
\hline \multicolumn{8}{|l|}{$+/-^{\mathrm{n}}$} \\
\hline & & & & & & & \\
\hline $\mathrm{U}-235 \mathrm{wt} \%^{\mathrm{b}}$ & 0 & 0.0325 & 0.5209 & 1.2935 & 1.6242 & 1.3304 & 0.5 \\
\hline$+/-^{\mathrm{b}}$ & 0 & 0.0249 & 0.0034 & 0.0036 & 0.004 & 0.0038 & 0.00 \\
\hline $\mathrm{U}-235 \mathrm{~g}^{\mathrm{i}}$ & $0.0000 \mathrm{E}+00$ & 7.0337E-05 & $6.6398 \mathrm{E}-02$ & $1.5160 \mathrm{E}-01$ & $1.8708 \mathrm{E}-01$ & 1.5396E-01 & $5.9059 \mathrm{E}-$ \\
\hline$+/^{j}$ & NA & $5.3889 \mathrm{E}-05$ & $4.3374 \mathrm{E}-04$ & $4.2432 \mathrm{E}-04$ & $4.6361 \mathrm{E}-04$ & 4.4172E-04 & 4.7994E- \\
\hline \multicolumn{8}{|l|}{ Segment Total } \\
\hline \multicolumn{8}{|l|}{$+/^{\mathrm{n}}$} \\
\hline & & & & & & & \\
\hline U-236 wt $\%^{b}$ & 0 & 0.0002 & 0.0744 & 0.1342 & 0.17 & 0.1398 & 0.08 \\
\hline$+-_{-}^{\mathrm{b}}$ & 0 & 0.0002 & 0.0002 & 0.0002 & 0.0002 & 0.0002 & 0.00 \\
\hline $\mathrm{U}-236 \mathrm{~g}^{\mathrm{i}}$ & $0.0000 \mathrm{E}+00$ & 4.3284E-07 & 9.4836E-03 & 1.5729E-02 & 1.9581E-02 & 1.6178E-02 & $8.0344 \mathrm{E}-\mathrm{-}$ \\
\hline$+/^{j}$ & NA & $4.3284 \mathrm{E}-07$ & $2.5613 \mathrm{E}-05$ & $2.3901 \mathrm{E}-05$ & 2.3662E-05 & 2.3555E-05 & $2.0110 \mathrm{E}-$ \\
\hline \multicolumn{8}{|l|}{ Segment Total } \\
\hline$+/-^{n}$ & & & & & & & \\
\hline
\end{tabular}


Rod "C" 2513854 (PFB III-6 F73)

\begin{tabular}{|c|c|c|c|c|c|c|c|}
\hline & C-00 & C-01 & C-02 & C-03 & C-04 & C-05 & C-06 \\
\hline seg length (in) ${ }^{a}$ & 11.146 & 7.991 & 17.955 & 17.498 & 17.502 & 17.498 & 14.5 \\
\hline \multicolumn{8}{|l|}{ total length (in) } \\
\hline & & & & & & & \\
\hline U-238 wt $\%^{b}$ & 0 & 0.0314 & 0.2685 & 0.2655 & 0.2636 & 0.2687 & 0.27 \\
\hline$+-^{\mathrm{b}}$ & 0 & 0.0242 & 0.0033 & 0.0035 & 0.0039 & 0.0037 & 0.00 \\
\hline $\mathrm{U}-238 \mathrm{~g}^{\mathrm{i}}$ & $0.0000 \mathrm{E}+00$ & $6.7956 \mathrm{E}-05$ & $3.4225 \mathrm{E}-02$ & $3.1117 \mathrm{E}-02$ & $3.0361 \mathrm{E}-02$ & $3.1095 \mathrm{E}-02$ & $2.7361 \mathrm{E}-$ \\
\hline$+{ }^{j}$ & NA & $5.2374 \mathrm{E}-05$ & 4.2074E-04 & 4.1031E-04 & $4.4928 \mathrm{E}-04$ & $4.2826 \mathrm{E}-04$ & 4.5974E- \\
\hline \multicolumn{8}{|l|}{ Segment Total } \\
\hline \multicolumn{8}{|l|}{$+/-^{\mathrm{n}}$} \\
\hline & & & & & & & \\
\hline tot $U^{c}$ & 0.00016 & 0.21642 & 12.74682 & 11.72025 & 11.51799 & 11.57236 & 9.992 \\
\hline$+-^{\mathrm{C}}$ & 0.00002 & 0.0004 & 0.00332 & 0.00348 & 0.00318 & 0.00313 & 0.002 \\
\hline $\mathrm{Kr}-82(\mathrm{~mol} \%)^{\mathrm{d}}$ & 0.1 & 0.1 & 0.1 & 0.1 & 0.1 & 0.1 & \\
\hline$+/^{d}$ & 0.1 & 0.1 & 0.1 & 0.1 & 0.1 & 0.1 & \\
\hline $\mathrm{Kr}-82(\mathrm{~g})^{\mathrm{K}}$ & $3.2765 \mathrm{E}-07$ & $0.0000 \mathrm{E}+00$ & 7.7214E-05 & $1.5535 \mathrm{E}-04$ & 1.8619E-04 & 1.6113E-04 & $6.9034 \mathrm{E}-$ \\
\hline$+/-^{j}$ & $3.2765 \mathrm{E}-07$ & NA & 7.7748E-05 & $1.5691 \mathrm{E}-04$ & 1.8836E-04 & $1.6211 \mathrm{E}-04$ & 6.9509E- \\
\hline \multicolumn{8}{|l|}{ Segment Total } \\
\hline \multicolumn{8}{|l|}{$+-^{n}$} \\
\hline $\mathrm{Kr}-83(\mathrm{~mol} \%)^{\mathrm{d}}$ & 15.6 & 15.6 & 15.6 & 15.6 & 15.6 & 15.6 & 15 \\
\hline$+/^{\mathrm{d}}$ & 0.1 & 0.1 & 0.1 & 0.1 & 0.1 & 0.1 & \\
\hline $\mathrm{Kr}-83(\mathrm{~g})^{\mathrm{k}}$ & $5.1738 \mathrm{E}-05$ & $0.0000 \mathrm{E}+00$ & 1.2193E-02 & $2.4530 \mathrm{E}-02$ & $2.9400 \mathrm{E}-02$ & $2.5443 \mathrm{E}-02$ & $1.0901 \mathrm{E}-$ \\
\hline$+/^{j}$ & 3.3166E-07 & NA & 1.4379E-03 & 3.4959E-03 & $4.5053 \mathrm{E}-03$ & $2.8245 \mathrm{E}-03$ & $1.2824 \mathrm{E}-$ \\
\hline \multicolumn{8}{|l|}{ Segment Total } \\
\hline \multicolumn{8}{|l|}{$+/^{\mathrm{n}}$} \\
\hline & & & & & & & \\
\hline $\mathrm{Kr}-84(\mathrm{~mol} \%)^{\mathrm{d}}$ & 29.9 & 29.9 & 29.9 & 29.9 & 29.9 & 29.9 & 29 \\
\hline$+/^{d}$ & 0.2 & 0.2 & 0.2 & 0.2 & 0.2 & 0.2 & \\
\hline $\mathrm{Kr}-84(\mathrm{~g})^{\mathrm{k}}$ & 1.0036E-04 & $0.0000 \mathrm{E}+00$ & $2.3650 \mathrm{E}-02$ & $4.7582 \mathrm{E}-02$ & $5.7028 \mathrm{E}-02$ & $4.9352 \mathrm{E}-02$ & $2.1145 \mathrm{E}-$ \\
\hline$+{ }^{j}-{ }^{j}$ & $6.7129 \mathrm{E}-07$ & NA & $2.7894 \mathrm{E}-03$ & 6.7817E-03 & $8.7396 \mathrm{E}-03$ & $5.4796 \mathrm{E}-03$ & $2.4879 \mathrm{E}-$ \\
\hline \multicolumn{8}{|l|}{ Segment Total } \\
\hline$+/^{n}$ & & & & & & & \\
\hline
\end{tabular}


Rod "C" 2513854 (PFB III-6 F73)

\begin{tabular}{|c|c|c|c|c|c|c|c|}
\hline & $\mathrm{C}-00$ & $\mathrm{C}-01$ & C-02 & C-03 & C-04 & C-05 & C-06 \\
\hline seg length (in) ${ }^{a}$ & 11.146 & 7.991 & 17.955 & 17.498 & 17.502 & 17.498 & 14.5 \\
\hline \multicolumn{8}{|l|}{ total length (in) } \\
\hline & & & & & & & \\
\hline $\mathrm{Kr}-85(\mathrm{~mol} \%)^{\mathrm{d}}$ & 6 & 6 & 6 & 6 & 6 & 6 & \\
\hline$+/{ }^{d}$ & 0.1 & 0.1 & 0.1 & 0.1 & 0.1 & 0.1 & \\
\hline $\mathrm{Kr}-85(\mathrm{~g})^{\mathrm{k}}$ & $2.0379 \mathrm{E}-05$ & $0.0000 \mathrm{E}+00$ & $4.8025 \mathrm{E}-03$ & $9.6620 \mathrm{E}-03$ & 1.1580E-02 & $1.0021 \mathrm{E}-02$ & 4.2937E- \\
\hline$+/-^{j}$ & $3.3965 \mathrm{E}-07$ & NA & $5.7116 \mathrm{E}-04$ & $1.3850 \mathrm{E}-03$ & $1.7835 \mathrm{E}-03$ & $1.1232 \mathrm{E}-03$ & 5.0944E- \\
\hline \multicolumn{8}{|l|}{ Segment Total } \\
\hline \multicolumn{8}{|l|}{$+/-^{n}$} \\
\hline & & & & & & & \\
\hline $\mathrm{Kr}-86(\mathrm{~mol} \%)^{\mathrm{d}}$ & 48.5 & 48.5 & 48.5 & 48.5 & 48.5 & 48.5 & 48 \\
\hline$+-^{\mathrm{d}}$ & 0.2 & 0.2 & 0.2 & 0.2 & 0.2 & 0.2 & \\
\hline $\mathrm{Kr}-86(\mathrm{~g})^{\mathrm{k}}$ & 1.6667E-04 & $0.0000 \mathrm{E}+00$ & $3.9276 \mathrm{E}-02$ & $7.9019 \mathrm{E}-02$ & 9.4707E-02 & 8.1959E-02 & $3.5116 \mathrm{E}-\mathrm{C}$ \\
\hline$+/-^{j}$ & $6.8728 \mathrm{E}-07$ & NA & $4.6279 \mathrm{E}-03$ & $1.1255 \mathrm{E}-02$ & $1.4505 \mathrm{E}-02$ & 9.0898E-03 & $4.1276 \mathrm{E}-\mathrm{C}$ \\
\hline \multicolumn{8}{|l|}{ Segment Total } \\
\hline \multicolumn{8}{|l|}{$+/-^{\mathrm{n}}$} \\
\hline \multicolumn{8}{|l|}{ Rod Total } \\
\hline \multicolumn{8}{|l|}{$+/-^{n}$} \\
\hline shear gas $(g)^{e}$ & 0 & 0 & 0.001 & 0.0034 & 0.0043 & 0.0037 & 0.00 \\
\hline$+/{ }^{\mathrm{e}}$ & 0 & 0 & 0.0002 & 0.0006 & 0.0009 & 0.0008 & 0.00 \\
\hline moles $\mathrm{Kr}(\text { diss }+\mathrm{pl})^{\mathrm{d}}$ & 0.000004 & 0 & 0.000941 & 0.001891 & 0.002266 & 0.001961 & 0.0008 \\
\hline$+/^{-\mathrm{d}}$ & 0 & 0 & 0.000111 & 0.00027 & 0.000348 & 0.000218 & 0.0000 \\
\hline $\mathrm{Kr}+\mathrm{Xe}$ diss\&pl $(\mathrm{g})^{\mathrm{d}}$ & 0.0017 & 0 & 0.5773 & 1.1758 & 1.3996 & 1.2047 & 0.56 \\
\hline$+/^{-\mathrm{d}}$ & 0 & 0 & 0.0528 & 0.0761 & 0.107 & 0.0755 & 0.04 \\
\hline moles kr (tot) $^{\circ}$ & $4.0000 \mathrm{E}-06$ & 0 & $9.4263 \mathrm{E}-04$ & 1.8965E-03 & $2.2730 \mathrm{E}-03$ & 1.9670E-03 & $8.4277 \mathrm{E}-\mathrm{C}$ \\
\hline$+-^{\mathrm{p}}$ & 0 & NA & $1.1100 \mathrm{E}-04$ & 2.7000 E-04 & $3.4801 \mathrm{E}-04$ & $2.1801 \mathrm{E}-04$ & $9.9001 \mathrm{E}-$ \\
\hline $\mathrm{Xe}-128(\mathrm{~mol} \%)^{\mathrm{d}}$ & 0.1 & 0.1 & 0.1 & 0.1 & 0.1 & 0.1 & \\
\hline$+/-^{\mathrm{d}}$ & 0.1 & 0.1 & 0.1 & 0.1 & 0.1 & 0.1 & \\
\hline $\mathrm{Xe}-128(\mathrm{~g})^{\mathrm{k}}$ & $1.5348 \mathrm{E}-06$ & $0.0000 \mathrm{E}+00$ & $4.7496 \mathrm{E}-04$ & $9.7039 \mathrm{E}-04$ & $1.1542 \mathrm{E}-03$ & $9.9250 \mathrm{E}-04$ & $4.7565 \mathrm{E}-\mathrm{C}$ \\
\hline$+/{ }^{\mathrm{j}}$ & $1.5348 \mathrm{E}-06$ & NA & 4.7753E-04 & 9.7284E-04 & $1.1583 \mathrm{E}-03$ & 9.9495E-04 & 4.7770E- \\
\hline \multicolumn{8}{|l|}{ SegmentTotal } \\
\hline$+-^{n}$ & & & & & & & \\
\hline
\end{tabular}




\begin{tabular}{|c|c|c|c|c|c|c|c|}
\hline & $\mathrm{C}-00$ & C-01 & $\mathrm{C}-02$ & C-03 & C-04 & C-05 & C-06 \\
\hline seg length (in) ${ }^{a}$ & 11.146 & 7.991 & 17.955 & 17.498 & 17.502 & 17.498 & 14.5 \\
\hline total length (in) & & & & & & & \\
\hline $\mathrm{Xe}-130(\mathrm{~mol} \%)^{\mathrm{d}}$ & 0.1 & 01 & 01 & 01 & 01 & 01 & \\
\hline$+/-^{\mathrm{d}}$ & 0.1 & 0.1 & 0.1 & 0.1 & 0.1 & 0.1 & \\
\hline Xe-130 $(g)^{k}$ & 1.5588E-06 & $0.0000 \mathrm{E}+00$ & 4.8239E-04 & 9.8556E-04 & 1.1722E-03 & $1.0080 \mathrm{E}-03$ & $4.8309 \mathrm{E}-$ \\
\hline$+/-^{j}$ & $1.5588 \mathrm{E}-06$ & NA & $4.8500 \mathrm{E}-04$ & $9.8806 \mathrm{E}-04$ & 1.1764E-03 & 1.0105E-03 & $4.8517 \mathrm{E}-$ \\
\hline SegmentTotal & & & & & & & \\
\hline$+/-^{n}$ & & & & & & & \\
\hline $\mathrm{Xe}-131(\mathrm{~mol} \%)^{\mathrm{d}}$ & 12.4 & 12.4 & 12.4 & 12.4 & 12.4 & 124 & 1 \\
\hline$+/{ }^{\mathrm{d}}$ & 0.1 & 0.1 & 0.1 & $\begin{array}{l}12.4 \\
0.1\end{array}$ & 0.1 & \begin{tabular}{r|}
12.4 \\
0.1
\end{tabular} & 1 \\
\hline $\mathrm{Xe-131}(\mathrm{g})^{\mathrm{k}}$ & 1.9479E-04 & $0.0000 \mathrm{E}+00$ & $6.0277 \mathrm{E}-02$ & 1.2315E-01 & 1.4647E-01 & $1.2596 \mathrm{E}-01$ & $6.0365 \mathrm{E}$ \\
\hline$+/{ }_{-}^{j}$ & 1.5709E-06 & NA & $6.3007 \mathrm{E}-03$ & $8.8218 \mathrm{E}-03$ & 1.2490E-02 & 8.9052E-03 & $5.6375 \mathrm{E}-$ \\
\hline SegmentTotal & & & & & & & \\
\hline$+/-^{n}$ & & & & & & & \\
\hline $\mathrm{X}_{0} 132(\mathrm{~mol} /)^{d}$ & & & & & & & \\
\hline $\mathrm{Xe-132}(\mathrm{mol} \%)^{a}$ & 22.6 & 22.6 & 22.6 & 22.6 & 22.6 & 22.6 & 2 \\
\hline 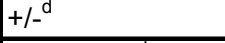 & 0.1 & 0.1 & 0.1 & 0.1 & 0.1 & 0.1 & \\
\hline $\mathrm{Xe}-132(\mathrm{~g})^{\mathrm{k}}$ & $3.5772 \mathrm{E}-04$ & $0.0000 \mathrm{E}+00$ & $1.1070 \mathrm{E}-01$ & $2.2617 \mathrm{E}-01$ & $2.6900 \mathrm{E}-01$ & $2.3132 \mathrm{E}-01$ & $1.1086 \mathrm{E}-$ \\
\hline$+/{ }_{-}^{j}$ & $1.5828 \mathrm{E}-06$ & NA & 1.1547E-02 & $1.6129 \mathrm{E}-02$ & $2.2867 \mathrm{E}-02$ & $1.6280 \mathrm{E}-02$ & $1.0326 \mathrm{E}-$ \\
\hline SegmentTotal & & & & & & & \\
\hline$+/-^{n}$ & & & & & & & \\
\hline & & & & & & & \\
\hline $\mathrm{Xe}-134(\mathrm{~mol} \%)^{\mathrm{d}}$ & 25.9 & 25.9 & 25.9 & 25.9 & 25.9 & 25.9 & 2 \\
\hline$+/{ }^{\mathrm{d}}$ & 0.2 & 0.2 & 0.2 & 0.2 & 0.2 & 0.2 & \\
\hline Xe-134 $(g)^{k}$ & $4.1618 \mathrm{E}-04$ & $0.0000 \mathrm{E}+00$ & $1.2879 \mathrm{E}-01$ & $2.6312 \mathrm{E}-01$ & $3.1295 \mathrm{E}-01$ & 2.6912E-01 & $1.2897 \mathrm{E}$ \\
\hline$+/{ }_{-}^{j}$ & $3.2137 \mathrm{E}-06$ & NA & 1.3459E-02 & 1.8839E-02 & $2.6677 \mathrm{E}-02$ & 1.9016E-02 & $1.2041 \mathrm{E}$ \\
\hline SegmentTotal & & & & & & & \\
\hline$+/-^{\mathrm{n}}$ & & & & & & & \\
\hline
\end{tabular}


Rod "C" 2513854 (PFB III-6 F73)

\begin{tabular}{|c|c|c|c|c|c|c|c|}
\hline & $\mathrm{C}-00$ & C-01 & C-02 & C-03 & C-04 & C-05 & C-06 \\
\hline seg length (in) ${ }^{\mathrm{a}}$ & 11.146 & 7.991 & 17.955 & 17.498 & 17.502 & 17.498 & 14.527 \\
\hline \multicolumn{8}{|l|}{ total length (in) } \\
\hline $\mathrm{Xe}-136(\mathrm{~mol} \%)^{\mathrm{d}}$ & 39 & 39 & 39 & 39 & 39 & 39 & 39 \\
\hline$+/-^{\mathrm{d}}$ & 0.1 & 0.1 & 0.1 & 0.1 & 0.1 & 0.1 & 0.1 \\
\hline $\mathrm{Xe-136}(\mathrm{g})^{\mathrm{k}}$ & $6.3605 \mathrm{E}-04$ & $0.0000 \mathrm{E}+00$ & 1.9683E-01 & $4.0213 \mathrm{E}-01$ & 4.7829E-01 & $4.1130 \mathrm{E}-01$ & $1.9711 \mathrm{E}-01$ \\
\hline$+/{ }^{j}$ & 1.6309E-06 & NA & $2.0519 \mathrm{E}-02$ & $2.8642 \mathrm{E}-02$ & $4.0621 \mathrm{E}-02$ & $2.8908 \mathrm{E}-02$ & $1.8346 \mathrm{E}-02$ \\
\hline \multicolumn{8}{|l|}{ SegmentTotal } \\
\hline \multicolumn{8}{|l|}{$+/-^{n}$} \\
\hline \multicolumn{8}{|l|}{ Rod total } \\
\hline \multicolumn{8}{|l|}{$+1-^{n}$} \\
\hline shear gas $(g)^{e}$ & 0 & 0 & 0.001 & 0.0034 & 0.0043 & 0.0037 & 0.0012 \\
\hline$+/-^{\mathrm{e}}$ & 0 & 0 & 0.0002 & 0.0006 & 0.0009 & 0.0008 & 0.0002 \\
\hline moles Xe (diss+pl) $)^{d}$ & 0.000012 & 0 & 0.003707 & 0.007565 & 0.008996 & 0.007736 & 0.003711 \\
\hline$+-^{\mathrm{d}}$ & 0 & 0 & 0.000387 & 0.00054 & 0.000766 & 0.000545 & 0.000346 \\
\hline $\mathrm{Kr}+\mathrm{Xe}$ diss\&pl $(\mathrm{g})^{\mathrm{d}}$ & 0.0017 & 0 & 0.5773 & 1.1758 & 1.3996 & 1.2047 & 0.5694 \\
\hline$+/-^{\mathrm{d}}$ & 0 & 0 & 0.0528 & 0.0761 & 0.107 & 0.0755 & 0.0472 \\
\hline moles Xe (tot) $^{\circ}$ & $1.2000 \mathrm{E}-05$ & 0 & $3.7134 \mathrm{E}-03$ & $7.5869 \mathrm{E}-03$ & 9.0236E-03 & $7.7598 \mathrm{E}-03$ & $3.7188 \mathrm{E}-03$ \\
\hline$+/^{\mathrm{p}}$ & $0.0000 \mathrm{E}+00$ & NA & $3.8700 \mathrm{E}-04$ & $5.4002 \mathrm{E}-04$ & 7.6603E-04 & $5.4503 \mathrm{E}-04$ & $3.4600 \mathrm{E}-04$ \\
\hline \multicolumn{8}{|c|}{ Values corrected to 1/1/84 (page 181, Final Report for the LWBR Proof of Breeding Analytical Support Project } \\
\hline Cs-137 (atoms) ${ }^{f}$ & NA & $1.8840 \mathrm{E}+18$ & $5.3660 \mathrm{E}+20$ & $1.1590 \mathrm{E}+21$ & $1.3840 \mathrm{E}+21$ & 1.1950E+21 & $5.0590 \mathrm{E}+20$ \\
\hline 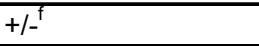 & NA & $6.1200 \mathrm{E}+15$ & $1.4900 \mathrm{E}+18$ & $3.2200 \mathrm{E}+18$ & $3.8000 \mathrm{E}+18$ & $3.3200 \mathrm{E}+18$ & $1.3900 \mathrm{E}+18$ \\
\hline Cs-137 (g) ${ }^{\mathrm{m}}$ & NA & 4.2826E-04 & 1.2198E-01 & $2.6346 \mathrm{E}-01$ & 3.1460E-01 & 2.7164E-01 & $1.1500 \mathrm{E}-01$ \\
\hline$+/-^{m}$ & NA & $1.3912 \mathrm{E}-06$ & 3.3870E-04 & 7.3195E-04 & $8.6379 \mathrm{E}-04$ & $7.5468 \mathrm{E}-04$ & $3.1597 \mathrm{E}-04$ \\
\hline \multicolumn{8}{|l|}{ Total } \\
\hline \multicolumn{8}{|l|}{$+/-^{n}$} \\
\hline $\mathrm{Ce}-144$ (atoms) $^{\mathrm{g}}$ & NA & $2.3460 \mathrm{E}+17$ & $3.4930 \mathrm{E}+19$ & $6.0240 E+19$ & $6.9510 E+19$ & $5.5770 E+19$ & $1.9580 \mathrm{E}+19$ \\
\hline$+/^{9}$ & NA & $1.3700 \mathrm{E}+15$ & $1.9700 \mathrm{E}+17$ & $3.5700 \mathrm{E}+17$ & $4.0400 \mathrm{E}+17$ & $3.3100 \mathrm{E}+17$ & $1.1600 \mathrm{E}+17$ \\
\hline $\mathrm{Ce}-144(\mathrm{~g})^{\mathrm{m}}$ & NA & 5.6057E-05 & 8.3464E-03 & $1.4394 \mathrm{E}-02$ & 1.6609E-02 & 1.3326E-02 & $4.6786 \mathrm{E}-03$ \\
\hline$+/-^{m}$ & NA & 3.2736E-07 & 4.7073E-05 & $8.5304 \mathrm{E}-05$ & 9.6535E-05 & $7.9092 \mathrm{E}-05$ & $2.7718 \mathrm{E}-05$ \\
\hline \multicolumn{8}{|l|}{ Total } \\
\hline$+/-^{n}$ & & & & & & & \\
\hline
\end{tabular}


Rod "C" 2513854 (PFB III-6 F73)

\begin{tabular}{|c|c|c|c|c|c|c|c|}
\hline & C- -00 & C-01 & C-02 & C-03 & C-04 & C-05 & C-06 \\
\hline seg length (in) $)^{a}$ & 11.146 & 7.991 & 17.955 & 17.498 & 17.502 & 17.498 & 14.52 \\
\hline \multicolumn{8}{|l|}{ total length (in) } \\
\hline & & & & & & & \\
\hline Zr-95 (atoms) ${ }^{\mathrm{h}}$ & NA & $2.6170 \mathrm{E}+15$ & $2.8670 \mathrm{E}+17$ & $4.6840 \mathrm{E}+17$ & $5.0360 \mathrm{E}+17$ & $3.0430 \mathrm{E}+17$ & $5.3700 \mathrm{E}+1$ \\
\hline$+/-^{\mathrm{h}}$ & NA & $4.0400 \mathrm{E}+13$ & $4.5500 \mathrm{E}+15$ & $8.5600 \mathrm{E}+15$ & $1.0200 E+16$ & $6.0600 \mathrm{E}+15$ & $1.4800 \mathrm{E}+1$ \\
\hline Zr-95 (g) ${ }^{\mathrm{m}}$ & NA & $4.1239 \mathrm{E}-07$ & $4.5178 \mathrm{E}-05$ & $7.3811 \mathrm{E}-05$ & $7.9358 \mathrm{E}-05$ & 4.7952E-05 & $8.4621 \mathrm{E}-\mathrm{C}$ \\
\hline$+/-^{m}$ & NA & $6.3663 \mathrm{E}-09$ & $7.1699 \mathrm{E}-07$ & 1.3489E-06 & 1.6073E-06 & 9.5494E-07 & $2.3322 \mathrm{E}-\mathrm{C}$ \\
\hline \multicolumn{8}{|l|}{ Total } \\
\hline$+/-^{n}$ & & & & & & & \\
\hline
\end{tabular}

Footnotes

a. ANL Destructive Chemical Assay of 33-Rod LWBR EOL Sample -Rod C, 2513854, page 3

b. ANL Destructive Chemical Assay of 33-Rod LWBR EOL Sample - Rod C, 2513854, page 6

c. ANL Destructive Chemical Assay of 33-Rod LWBR EOL Sample - Rod C, 2513854, page 7

d. ANL Destructive Chemical Assay of 33-Rod LWBR EOL Sample - Rod C, 2513854, page 9

e. ANL Destructive Chemical Assay of 33-Rod LWBR EOL Sample - Rod C, 2513854, page 10

f. ANL Destructive Chemical Assay of 33-Rod LWBR EOL Sample - Rod C, 2513854, page 11

g. ANL Destructive Chemical Assay of 33-Rod LWBR EOL Sample - Rod C, 2513854, page 12

h. ANL Destructive Chemical Assay of 33-Rod LWBR EOL Sample - Rod C, 2513854, page 13

i. (abundance of the specified isotope)(total weight of uranium) / 100

j. Error Propagation $=\left(\left(s d_{x} / x\right)^{2}+\left(s d_{y} / y\right)^{2}\right)^{1 / 2}(x y)$, where sd is the $+/-$ in the table

k. (mole\%)(number moles gas recovered)(molec wt) / 100

m. (number of atoms per segment)(atomic weight) / 6.0228E+23

n. Error Propagation $=\left(\operatorname{SUM}\left({s d_{i}}^{2}\right)\right)^{1 / 2}$, where sd is the $+/$ - in the table

o. ((shear gas / Xe $+\mathrm{Kr}$ (diss\&pl ))(moles Xe or $\mathrm{Kr}($ diss $+\mathrm{pl}))+$ moles $\mathrm{Xe}$ or $\mathrm{Kr}(\mathrm{diss}+\mathrm{pl})$

p. Error Propagation $=\left(\left(\left(\left(s d_{x} / x\right)^{2}+\left(s d_{y} / y\right)^{2}+\left(s d_{z} / z\right)^{2}\right)^{1 / 2}(x y / z)\right)^{2}+\left(s d_{y}\right)^{2}\right)^{1 / 2}$, where sd is the $+/-$ in the table 
Rod "D" 2502102 (PFB III-6 H1)

\begin{tabular}{|c|c|c|c|c|c|c|c|}
\hline & D-00 & D-01 & D-02 & D-03 & D-04 & D-05 & D-06 \\
\hline seg length (in) ${ }^{a}$ & 11.18 & 8.063 & 17.815 & 17.499 & 17.502 & 17.5 & 14.46 \\
\hline \multicolumn{8}{|l|}{ total length (in) } \\
\hline & & & & & & & \\
\hline $\mathrm{U}-232 \mathrm{wt} \%^{\mathrm{b}}$ & 0 & 0.0049 & 0.0058 & 0.0238 & 0.0336 & 0.0239 & 0.006 \\
\hline$+/-^{\mathrm{b}}$ & 0 & 0.0002 & 0.0002 & 0.0007 & 0.001 & 0.0007 & 0.00 \\
\hline $\mathrm{U}-232 \mathrm{~g}^{\mathrm{i}}$ & $0.0000 \mathrm{E}+00$ & 5.3557E-06 & 7.5157E-04 & 2.9247E-03 & $4.0642 \mathrm{E}-03$ & 2.9273E-03 & $6.7653 \mathrm{E}-$ \\
\hline$+/^{j}$ & NA & $2.1872 \mathrm{E}-07$ & $2.5917 \mathrm{E}-05$ & 8.6026E-05 & 1.2096E-04 & $8.5742 \mathrm{E}-05$ & $2.0817 \mathrm{E}-$ \\
\hline \multicolumn{8}{|l|}{ Segment Total } \\
\hline \multicolumn{8}{|l|}{$+/_{-}^{\mathrm{n}}$} \\
\hline & & & & & & & \\
\hline $\mathrm{U}-233 \mathrm{wt} \%^{\mathrm{b}}$ & 100 & 99.603 & 96.326 & 93.932 & 92.9686 & 93.9009 & 96.14 \\
\hline$+/-^{\mathrm{b}}$ & 0 & 0.1209 & 0.0056 & 0.0058 & 0.0056 & 0.006 & 0.00 \\
\hline $\mathrm{U}-233 \mathrm{~g}^{\mathrm{i}}$ & $4.0000 \mathrm{E}-05$ & $1.0887 \mathrm{E}-01$ & $1.2482 \mathrm{E}+01$ & $1.1543 \mathrm{E}+01$ & $1.1245 \mathrm{E}+01$ & $1.1501 \mathrm{E}+01$ & $1.0007 \mathrm{E}+$ \\
\hline$+/^{j}$ & $1.0000 \mathrm{E}-05$ & 1.9946E-04 & 3.3263E-03 & 3.3089E-03 & $3.1600 \mathrm{E}-03$ & 3.2944E-03 & $2.7964 \mathrm{E}-$ \\
\hline \multicolumn{8}{|l|}{ Segment Total } \\
\hline \multicolumn{8}{|l|}{$+/-^{n}$} \\
\hline $\mathrm{U}-234 \mathrm{wt} \%^{\mathrm{b}}$ & 0 & 0.3175 & 2.7086 & 4.8011 & 5.6131 & 4.8292 & 2.86 \\
\hline$+/-^{b}$ & 0 & 0.0008 & 0.0006 & 0.0007 & 0.0007 & $\begin{array}{l}4.0292 \\
0.0007 \\
\end{array}$ & 0.00 \\
\hline$U-234 g^{i}$ & $0.0000 \mathrm{E}+00$ & $3.4703 \mathrm{E}-04$ & $3.5098 \mathrm{E}-01$ & $5.9000 \mathrm{E}-01$ & $6.7895 \mathrm{E}-01$ & $5.9149 \mathrm{E}-01$ & $2.9831 \mathrm{E}-$ \\
\hline$+/_{-}^{j}$ & NA & $9.9569 \mathrm{E}-07$ & 1.1990E-04 & 1.8622E-04 & 2.0469E-04 & 1.8609E-04 & 1.0903E- \\
\hline \multicolumn{8}{|l|}{ Segment Total } \\
\hline \multicolumn{8}{|l|}{$+-^{n}$} \\
\hline & & & & & & & \\
\hline U-235 wt $\%{ }^{b}$ & 0 & 0.0042 & 0.1856 & 0.4553 & 0.5872 & 0.455 & 0.205 \\
\hline$+/-^{b}$ & 0 & 0.0858 & 0.0048 & 0.005 & 0.0048 & 0.0051 & 0.005 \\
\hline $\mathrm{U}-235 \mathrm{~g}^{\mathrm{i}}$ & $0.0000 \mathrm{E}+00$ & $4.5906 \mathrm{E}-06$ & $2.4050 \mathrm{E}-02$ & 5.5951E-02 & $7.1026 \mathrm{E}-02$ & $5.5729 \mathrm{E}-02$ & $2.1399 \mathrm{E}-$ \\
\hline$+/-^{j}$ & NA & 9.3779E-05 & $6.2202 \mathrm{E}-04$ & 6.1464E-04 & 5.8092E-04 & $6.2485 \mathrm{E}-04$ & $5.4126 \mathrm{E}-$ \\
\hline \multicolumn{8}{|l|}{ Segment Total } \\
\hline \multicolumn{8}{|l|}{$+/^{\mathrm{n}}$} \\
\hline & & & & & & & \\
\hline $\mathrm{U}-236 \mathrm{wt} \%^{\mathrm{b}}$ & 0 & 0.0003 & 0.0162 & 0.0266 & 0.0336 & 0.0266 & 0.016 \\
\hline$+1-{ }^{\mathrm{b}}$ & 0 & 0.0003 & 0.0002 & 0.0002 & 0.0002 & 0.0002 & 0.00 \\
\hline $\mathrm{U}-236 \mathrm{~g}^{\mathrm{i}}$ & $0.0000 \mathrm{E}+00$ & $3.2790 \mathrm{E}-07$ & 2.0992E-03 & $3.2688 \mathrm{E}-03$ & $4.0642 \mathrm{E}-03$ & $3.2580 \mathrm{E}-03$ & 1.7069E-( \\
\hline$+/-^{j}$ & NA & $3.2790 \mathrm{E}-07$ & 2.5922E-05 & $2.4595 \mathrm{E}-05$ & $2.4217 \mathrm{E}-05$ & $2.4513 \mathrm{E}-05$ & $2.0822 \mathrm{E}-$ \\
\hline \multicolumn{8}{|l|}{ Segment Total } \\
\hline$+/-^{n}$ & & & & & & & \\
\hline
\end{tabular}


Rod "D" 2502102 (PFB III-6 H1)

\begin{tabular}{|c|c|c|c|c|c|c|c|}
\hline & D-00 & D-01 & D-02 & D-03 & D-04 & D-05 & D-06 \\
\hline seg length (in) ${ }^{a}$ & 11.18 & 8.063 & 17.815 & 17.499 & 17.502 & 17.5 & 14.46 \\
\hline \multicolumn{8}{|l|}{ total length (in) } \\
\hline & & & & & & & \\
\hline U-238 wt $\%^{\mathrm{b}}$ & 0 & 0.0701 & 0.7578 & 0.7612 & 0.7639 & 0.7644 & 0.76 \\
\hline$+/-^{\mathrm{b}}$ & 0 & 0.0858 & 0.0031 & 0.0035 & 0.0033 & 0.0037 & 0.00 \\
\hline $\mathrm{U}-238 \mathrm{~g}^{\mathrm{i}}$ & $0.0000 \mathrm{E}+00$ & $7.6619 \mathrm{E}-05$ & 9.8196E-02 & 9.3543E-02 & 9.2399E-02 & $9.3626 \mathrm{E}-02$ & $7.9206 \mathrm{E}-\mathrm{C}$ \\
\hline$+{ }^{j}$ & NA & 9.3779E-05 & $4.0251 \mathrm{E}-04$ & $4.3091 \mathrm{E}-04$ & 3.9996E-04 & 4.5394E-04 & $3.8570 \mathrm{E}-$ \\
\hline \multicolumn{8}{|l|}{ Segment Total } \\
\hline \multicolumn{8}{|l|}{$+/-^{\mathrm{n}}$} \\
\hline & & & & & & & \\
\hline tot $U^{c}$ & 0.00042 & 0.1093 & 12.95802 & 12.28886 & 12.09575 & 12.24824 & 10.408 \\
\hline$+-_{-}^{\mathrm{C}}$ & 0.00002 & 0.00015 & 0.00337 & 0.00344 & 0.00332 & 0.00342 & 0.002 \\
\hline $\mathrm{Kr}-82(\mathrm{~mol} \%)^{\mathrm{d}}$ & 0 & 0 & 0 & 0 & 0 & 0 & \\
\hline$+/^{d}$ & 0 & 0 & 0 & 0 & 0 & 0 & \\
\hline $\mathrm{Kr}-82(\mathrm{~g})^{\mathrm{K}}$ & $0.0000 \mathrm{E}+00$ & $0.0000 \mathrm{E}+00$ & $0.0000 \mathrm{E}+00$ & $0.0000 \mathrm{E}+00$ & $0.0000 \mathrm{E}+00$ & $0.0000 \mathrm{E}+00$ & $0.0000 \mathrm{E}+$ \\
\hline$+1-{ }^{j}$ & NA & NA & NA & NA & NA & NA & NA \\
\hline \multicolumn{8}{|l|}{ Segment Total } \\
\hline \multicolumn{8}{|l|}{$+-^{n}$} \\
\hline $\mathrm{Kr}-83(\mathrm{~mol} \%)^{\mathrm{d}}$ & 16.4 & 16.4 & 16.4 & 16.4 & 16.4 & 16.4 & 16 \\
\hline$+/^{\mathrm{d}}$ & 0.1 & 0.1 & 0.1 & 0.1 & 0.1 & 0.1 & 0 \\
\hline $\mathrm{Kr}-83(\mathrm{~g})^{\mathrm{k}}$ & $0.0000 \mathrm{E}+00$ & $0.0000 \mathrm{E}+00$ & 6.0609E-03 & 1.1997E-02 & 1.6864E-02 & $1.3516 \mathrm{E}-02$ & $5.4763 \mathrm{E}-\mathrm{C}$ \\
\hline$+/-^{j}$ & NA & NA & $1.5098 \mathrm{E}-03$ & 1.7964E-03 & 1.4044E-03 & 1.3487E-03 & $1.0883 \mathrm{E}-\mathrm{C}$ \\
\hline \multicolumn{8}{|l|}{ Segment Total } \\
\hline \multicolumn{8}{|l|}{$+/-^{n}$} \\
\hline & & & & & & & \\
\hline $\mathrm{Kr}-84(\mathrm{~mol} \%)^{\mathrm{d}}$ & 29.1 & 29.1 & 29.1 & 29.1 & 29.1 & 29.1 & 29 \\
\hline$+/^{\mathrm{d}}$ & 0.2 & 0.2 & 0.2 & 0.2 & 0.2 & 0.2 & 0 \\
\hline $\mathrm{Kr}-84(\mathrm{~g})^{\mathrm{k}}$ & $0.0000 \mathrm{E}+00$ & $0.0000 \mathrm{E}+00$ & $1.0884 \mathrm{E}-02$ & $2.1543 E-02$ & 3.0283E-02 & $2.4272 \mathrm{E}-02$ & 9.8339E-C \\
\hline$+{ }^{j}-{ }^{j}$ & NA & NA & $2.7115 \mathrm{E}-03$ & $3.2266 \mathrm{E}-03$ & $2.5238 \mathrm{E}-03$ & 2.4232E-03 & 1.9546E- \\
\hline \multicolumn{8}{|l|}{ Segment Total } \\
\hline$+/^{n}$ & & & & & & & \\
\hline
\end{tabular}


Rod "D" 2502102 (PFB III-6 H1)

\begin{tabular}{|c|c|c|c|c|c|c|c|}
\hline & D-00 & D-01 & D-02 & D-03 & D-04 & D-05 & D-06 \\
\hline seg length (in) ${ }^{a}$ & 11.18 & 8.063 & 17.815 & 17.499 & 17.502 & 17.5 & 14.4 \\
\hline \multicolumn{8}{|l|}{ total length (in) } \\
\hline & & & & & & & \\
\hline $\mathrm{Kr}-85(\mathrm{~mol} \%)^{\mathrm{d}}$ & 6.1 & 6.1 & 6.1 & 6.1 & 6.1 & 6.1 & \\
\hline$+/^{\mathrm{d}}$ & 0.1 & 0.1 & 0.1 & 0.1 & 0.1 & 0.1 & $\mathrm{C}$ \\
\hline $\mathrm{Kr}-85(\mathrm{~g})^{\mathrm{K}}$ & $0.0000 \mathrm{E}+00$ & $0.0000 \mathrm{E}+00$ & $2.3087 \mathrm{E}-03$ & $4.5698 \mathrm{E}-03$ & 6.4236E-03 & 5.1485E-03 & $2.0860 \mathrm{E}-\mathrm{C}$ \\
\hline$+L^{j}$ & NA & NA & $5.7619 \mathrm{E}-04$ & $6.8781 \mathrm{E}-04$ & 5.4382E-04 & 5.1970E-04 & $4.1578 \mathrm{E}-\mathrm{C}$ \\
\hline \multicolumn{8}{|l|}{ Segment Total } \\
\hline \multicolumn{8}{|l|}{$+-^{n}$} \\
\hline $\mathrm{Kr}-86(\mathrm{~mol} \%)^{d}$ & 48.5 & 48.5 & 48.5 & 48.5 & 48.5 & 48.5 & \\
\hline$+/^{\mathrm{d}}$ & 0.3 & 0.3 & 0.3 & 0.3 & 0.3 & $\begin{array}{r}40.0 \\
0.3 \\
\end{array}$ & 40 \\
\hline $\mathrm{Kr}-86(\mathrm{~g})^{\mathrm{K}}$ & $0.0000 \mathrm{E}+00$ & $0.0000 \mathrm{E}+00$ & 1.8572E-02 & 3.6761E-02 & 5.1673E-02 & $4.1416 \mathrm{E}-02$ & $1.6780 \mathrm{E}-$ \\
\hline$+{ }^{j}-{ }^{j}$ & NA & NA & 4.6265E-03 & $5.5048 \mathrm{E}-03$ & 4.3037E-03 & $4.1330 \mathrm{E}-03$ & $3.3349 \mathrm{E}-$ \\
\hline \multicolumn{8}{|l|}{ Segment Total } \\
\hline \multicolumn{8}{|l|}{$+/-^{n}$} \\
\hline \multicolumn{8}{|l|}{ Rod Total } \\
\hline \multicolumn{8}{|l|}{$+-^{n}$} \\
\hline shear gas $(\mathrm{g})^{\mathrm{e}}$ & 0 & 0 & 0.0004 & 0.0015 & 0.0024 & 0.0017 & 0.00 \\
\hline$+/-^{\mathrm{e}}$ & 0 & 0.0001 & 0.0003 & 0.0003 & 0.0005 & 0.0003 & 0.00 \\
\hline moles $\mathrm{Kr}(\text { diss }+\mathrm{pl})^{\mathrm{d}}$ & 0 & 0 & 0.000445 & 0.00088 & 0.001236 & 0.000991 & 0.0004 \\
\hline$+/^{-d}$ & 0 & 0 & 0.000111 & 0.000132 & 0.000103 & 0.000099 & 0.000 \\
\hline $\mathrm{Kr}+\mathrm{Xe}$ diss\&pl $(\mathrm{g})^{\mathrm{d}}$ & 0.0003 & 0 & 0.2469 & 0.5823 & 0.7126 & 0.5627 & 0.22 \\
\hline$+/^{-\mathrm{d}}$ & 0 & 0 & 0.0313 & 0.0543 & 0.0424 & 0.0408 & 0.02 \\
\hline moles $\mathrm{kr}$ (tot) $^{\circ}$ & $0.0000 \mathrm{E}+00$ & $0.0000 \mathrm{E}+00$ & $4.4572 \mathrm{E}-04$ & 8.8227E-04 & 1.2402E-03 & 9.9399E-04 & 4.0273E- \\
\hline$+-^{\mathrm{p}}$ & 0 & NA & 1.1100E-04 & 1.3200E-04 & 1.0300E-04 & 9.9002E-05 & $8.0000 \mathrm{E}-$ \\
\hline $\mathrm{Xe}-128(\mathrm{~mol} \%)^{\mathrm{d}}$ & 0 & 0 & 0 & 0 & 0 & 0 & \\
\hline$+/{ }^{\mathrm{d}}$ & 0 & 0 & 0 & 0 & 0 & 0 & \\
\hline $\mathrm{Xe}-128(\mathrm{~g})^{\mathrm{k}}$ & $0.0000 \mathrm{E}+00$ & $0.0000 \mathrm{E}+00$ & $0.0000 \mathrm{E}+00$ & $0.0000 \mathrm{E}+00$ & $0.0000 \mathrm{E}+00$ & $0.0000 \mathrm{E}+00$ & $0.0000 \mathrm{E}+$ \\
\hline$+/-^{j}$ & NA & NA & NA & NA & NA & NA & NA \\
\hline \multicolumn{8}{|l|}{ SegmentTotal } \\
\hline$+/-^{n}$ & & & & & & & \\
\hline
\end{tabular}


Rod "D" 2502102 (PFB III-6 H1)

\begin{tabular}{|c|c|c|c|c|c|c|c|}
\hline & D-00 & D-01 & D-02 & D-03 & D-04 & D-05 & D-06 \\
\hline seg length (in) ${ }^{a}$ & 11.18 & 8.063 & 17.815 & 17.499 & 17.502 & 17.5 & 14.46 \\
\hline \multicolumn{8}{|l|}{ total length (in) } \\
\hline & & & & & & & \\
\hline $\mathrm{Xe}-130(\mathrm{~mol} \%)^{\mathrm{d}}$ & 0 & 0 & 0 & 0 & 0 & 0 & \\
\hline$+/{ }^{\mathrm{d}}$ & 0 & 0 & 0 & 0 & 0 & 0 & \\
\hline $\mathrm{Xe}-130(\mathrm{~g})^{\mathrm{k}}$ & $0.0000 \mathrm{E}+00$ & $0.0000 \mathrm{E}+00$ & $0.0000 \mathrm{E}+00$ & $0.0000 \mathrm{E}+00$ & $0.0000 \mathrm{E}+00$ & $0.0000 \mathrm{E}+00$ & $0.0000 \mathrm{E}+\mathrm{C}$ \\
\hline$+/-^{j}$ & NA & NA & NA & NA & NA & NA & NA \\
\hline \multicolumn{8}{|l|}{ SegmentTotal } \\
\hline \multicolumn{8}{|l|}{$+-^{\mathrm{n}}$} \\
\hline & & & & & & & \\
\hline $\mathrm{Xe}-131(\mathrm{~mol} \%)^{d}$ & 13.9 & 13.9 & 13.9 & 13.9 & 13.9 & 13.9 & 13 \\
\hline$+/-^{\mathrm{d}}$ & 0.1 & 0.1 & 0.1 & 0.1 & 0.1 & 0.1 & 0 \\
\hline $\mathrm{Xe}-131(\mathrm{~g})^{\mathrm{k}}$ & 3.6392E-05 & $0.0000 \mathrm{E}+00$ & $2.8413 \mathrm{E}-02$ & $6.9030 \mathrm{E}-02$ & $8.2723 \mathrm{E}-02$ & $6.5119 \mathrm{E}-02$ & $2.5411 \mathrm{E}-\mathrm{C}$ \\
\hline$+/{ }^{j}$ & $2.6181 \mathrm{E}-07$ & NA & 4.0630E-03 & $7.2228 \mathrm{E}-03$ & $5.6543 \mathrm{E}-03$ & $5.4246 \mathrm{E}-03$ & $2.9354 \mathrm{E}-\mathrm{C}$ \\
\hline \multicolumn{8}{|l|}{ SegmentTotal } \\
\hline \multicolumn{8}{|l|}{$+-^{\mathrm{n}}$} \\
\hline $\mathrm{Xe}-132(\mathrm{~mol} \%)^{\mathrm{d}}$ & 22.3 & 22.3 & 22.3 & 22.3 & 22.3 & 22.3 & 22 \\
\hline$+/{ }^{\mathrm{d}}$ & 0.1 & 0.1 & 0.1 & 0.1 & 0.1 & 0.1 & 0 \\
\hline $\mathrm{Xe}-132(\mathrm{~g})^{\mathrm{k}}$ & $5.8829 \mathrm{E}-05$ & $0.0000 \mathrm{E}+00$ & $4.5932 \mathrm{E}-02$ & 1.1159E-01 & $1.3373 \mathrm{E}-01$ & 1.0527E-01 & $4.1078 \mathrm{E}-\mathrm{C}$ \\
\hline$+/{ }^{j}$ & $2.6381 \mathrm{E}-07$ & NA & 6.5629E-03 & 1.1659E-02 & 9.1095E-03 & $8.7491 \mathrm{E}-03$ & 4.7397E-C \\
\hline \multicolumn{8}{|l|}{ SegmentTotal } \\
\hline \multicolumn{8}{|l|}{$+-^{n}$} \\
\hline $\mathrm{Xe}-134(\mathrm{~mol} \%)^{d}$ & 27.3 & 27.3 & 27.3 & 27.3 & 27.3 & 27.3 & 27 \\
\hline$+/-^{\mathrm{d}}$ & 0.1 & 0.1 & 0.1 & 0.1 & 0.1 & 0.1 & 0 \\
\hline $\mathrm{Xe}-134(\mathrm{~g})^{\mathrm{k}}$ & $7.3112 \mathrm{E}-05$ & $0.0000 \mathrm{E}+00$ & $5.7083 \mathrm{E}-02$ & $1.3868 \mathrm{E}-01$ & $1.6619 \mathrm{E}-01$ & 1.3083E-01 & $5.1051 \mathrm{E}-\mathrm{C}$ \\
\hline$+/{ }^{\mathrm{j}}$ & $2.6781 \mathrm{E}-07$ & NA & $8.1550 \mathrm{E}-03$ & $1.4485 \mathrm{E}-02$ & $1.1313 \mathrm{E}-02$ & $1.0868 \mathrm{E}-02$ & $5.8889 \mathrm{E}-\mathrm{C}$ \\
\hline \multicolumn{8}{|l|}{ SegmentTotal } \\
\hline$+/-^{\mathrm{n}}$ & & & & & & & \\
\hline
\end{tabular}


Rod "D" 2502102 (PFB III-6 H1)

\begin{tabular}{|c|c|c|c|c|c|c|c|c|}
\hline & D-00 & D-01 & D-02 & D-03 & D-04 & D-05 & D-06 & $D$ \\
\hline seg length (in) ${ }^{a}$ & 11.18 & 8.063 & 17.815 & 17.499 & 17.502 & 17.5 & 14.464 & \\
\hline \multicolumn{9}{|l|}{ total length (in) } \\
\hline & & & & & & & & \\
\hline $\mathrm{Xe}-136(\mathrm{~mol} \%)^{\mathrm{d}}$ & 36.5 & 36.5 & 36.5 & 36.5 & 36.5 & 36.5 & 36.5 & \\
\hline$+-_{-}^{\mathrm{d}}$ & 0.1 & 0.1 & 0.1 & 0.1 & 0.1 & 0.1 & 0.1 & \\
\hline $\mathrm{Xe}-136(\mathrm{~g})^{\mathrm{k}}$ & $9.9212 \mathrm{E}-05$ & $0.0000 \mathrm{E}+00$ & 7.7461E-02 & 1.8819E-01 & $2.2552 \mathrm{E}-01$ & 1.7753E-01 & $6.9276 \mathrm{E}-02$ & \\
\hline$+/{ }^{j}$ & $2.7181 \mathrm{E}-07$ & NA & $1.1065 \mathrm{E}-02$ & $1.9651 \mathrm{E}-02$ & $1.5342 \mathrm{E}-02$ & $1.4741 \mathrm{E}-02$ & 7.9894E-03 & \\
\hline \multicolumn{9}{|l|}{ SegmentTotal } \\
\hline \multicolumn{9}{|l|}{$+/-^{\mathrm{n}}$} \\
\hline \multicolumn{9}{|l|}{ Rod total } \\
\hline \multicolumn{9}{|l|}{$+-^{n}$} \\
\hline & & & & & & & & \\
\hline shear gas $(\mathrm{g})^{\mathrm{e}}$ & 0 & 0 & 0.0004 & 0.0015 & 0.0024 & 0.0017 & 0.0004 & \\
\hline$+/-^{\mathrm{e}}$ & 0 & 0.0001 & 0.0003 & 0.0003 & 0.0005 & 0.0003 & 0.0003 & \\
\hline moles Xe (diss+pl) ${ }^{d}$ & 0.000002 & 0 & 0.001559 & 0.003784 & 0.004531 & 0.003568 & 0.001394 & \\
\hline$+/^{\mathrm{d}}$ & 0 & 0 & 0.000223 & 0.000396 & 0.000309 & 0.000297 & 0.000161 & \\
\hline $\mathrm{Kr}+\mathrm{Xe}$ diss\&pl $(\mathrm{g})^{\mathrm{d}}$ & 0.0003 & 0 & 0.2469 & 0.5823 & 0.7126 & 0.5627 & 0.2211 & \\
\hline$+-^{\mathrm{d}}$ & 0 & 0 & 0.0313 & 0.0543 & 0.0424 & 0.0408 & 0.0226 & \\
\hline moles Xe (tot) $^{\circ}$ & $2.0000 \mathrm{E}-06$ & 0 & $1.5615 \mathrm{E}-03$ & $3.7937 \mathrm{E}-03$ & $4.5463 \mathrm{E}-03$ & $3.5788 \mathrm{E}-03$ & $1.3965 \mathrm{E}-03$ & \\
\hline$+/_{-}^{\mathrm{p}}$ & $0.0000 \mathrm{E}+00$ & 0 & $2.2301 \mathrm{E}-04$ & $3.9601 \mathrm{E}-04$ & $3.0902 \mathrm{E}-04$ & $2.9701 \mathrm{E}-04$ & 1.6101E-04 & \\
\hline \multicolumn{9}{|c|}{ Values corrected to 1/1/84 (page 181, Final Report for the LWBR Proof of Breeding Analytical Support Project } \\
\hline & & & & & & & & \\
\hline Cs-137 (atoms) & NA & $5.3940 \mathrm{E}+17$ & $2.6590 \mathrm{E}+20$ & $6.0010 \mathrm{E}+20$ & $7.3300 \mathrm{E}+20$ & $6.0410 \mathrm{E}+20$ & $2.3460 \mathrm{E}+20$ & \\
\hline$+l^{f}$ & NA & $2.1500 \mathrm{E}+15$ & $9.1300 \mathrm{E}+17$ & $2.0600 \mathrm{E}+18$ & $2.5800 \mathrm{E}+18$ & $2.0600 \mathrm{E}+18$ & $8.0600 \mathrm{E}+17$ & \\
\hline Cs-137 (g) ${ }^{\mathrm{m}}$ & NA & $1.2261 \mathrm{E}-04$ & $6.0443 E-02$ & 1.3641E-01 & 1.6662E-01 & 1.3732E-01 & $5.3328 \mathrm{E}-02$ & \\
\hline$+/^{m}$ & NA & 4.8873E-07 & $2.0754 \mathrm{E}-04$ & $4.6827 \mathrm{E}-04$ & 5.8647E-04 & $4.6827 \mathrm{E}-04$ & 1.8322E-04 & \\
\hline \multicolumn{9}{|l|}{ Total } \\
\hline \multicolumn{9}{|l|}{$+-^{n}$} \\
\hline & & & & & & & & \\
\hline $\mathrm{Ce}-144$ (atoms) $^{\mathrm{g}}$ & NA & $6.6290 \mathrm{E}+16$ & $1.7390 \mathrm{E}+19$ & $3.2310 \mathrm{E}+19$ & $3.8610 \mathrm{E}+19$ & $2.8740 \mathrm{E}+19$ & $9.4270 \mathrm{E}+18$ & \\
\hline$+/-^{9}$ & NA & $3.9800 \mathrm{E}+14$ & $1.0100 \mathrm{E}+17$ & $1.9400 \mathrm{E}+17$ & $2.3100 \mathrm{E}+17$ & $1.7200 \mathrm{E}+17$ & $5.6600 \mathrm{E}+16$ & \\
\hline $\mathrm{Ce}-144(\mathrm{~g})^{\mathrm{m}}$ & NA & $1.5840 \mathrm{E}-05$ & $4.1553 \mathrm{E}-03$ & 7.7204E-03 & $9.2258 \mathrm{E}-03$ & $6.8674 \mathrm{E}-03$ & $2.2526 \mathrm{E}-03$ & \\
\hline$+/-^{m}$ & NA & $9.5101 \mathrm{E}-08$ & $2.4134 \mathrm{E}-05$ & $4.6356 \mathrm{E}-05$ & 5.5197E-05 & $4.1099 \mathrm{E}-05$ & $1.3524 \mathrm{E}-05$ & \\
\hline \multicolumn{8}{|l|}{ Total } & \\
\hline$+/-^{n}$ & & & & & & & & \\
\hline
\end{tabular}


Rod "D" 2502102 (PFB III-6 H1)

\begin{tabular}{|c|c|c|c|c|c|c|c|}
\hline & D-00 & D-01 & D-02 & D-03 & D-04 & D-05 & D-06 \\
\hline seg length (in) $)^{a}$ & 11.18 & 8.063 & 17.815 & 17.499 & 17.502 & 17.5 & 14.4 \\
\hline \multicolumn{8}{|l|}{ total length (in) } \\
\hline & & & & & & & \\
\hline Zr-95 (atoms) ${ }^{h}$ & NA & $6.7580 \mathrm{E}+14$ & 1.4830E+17 & $2.6000 \mathrm{E}+17$ & $2.9880 \mathrm{E}+17$ & $1.5980 \mathrm{E}+17$ & $2.8380 \mathrm{E}+$ \\
\hline$+-_{-}^{\mathrm{h}}$ & NA & $1.0800 \mathrm{E}+13$ & $1.8800 \mathrm{E}+15$ & $3.4800 \mathrm{E}+15$ & $4.6900 \mathrm{E}+15$ & $3.1600 \mathrm{E}+15$ & $9.5600 \mathrm{E}+$ \\
\hline Zr-95 $(\mathrm{g})^{\mathrm{m}}$ & NA & 1.0649E-07 & $2.3369 \mathrm{E}-05$ & 4.0971E-05 & 4.7085E-05 & $2.5181 \mathrm{E}-05$ & $4.4721 \mathrm{E}$ \\
\hline$+/-^{m}$ & NA & 1.7019E-09 & $2.9625 \mathrm{E}-07$ & $5.4838 \mathrm{E}-07$ & $7.3906 \mathrm{E}-07$ & 4.9796E-07 & $1.5065 \mathrm{E}$ \\
\hline \multicolumn{8}{|l|}{ Total } \\
\hline$+/-^{n}$ & & & & & & & \\
\hline
\end{tabular}

a. ANL Destructive Chemical Assay of 33-Rod LWBR EOL Sample - Rod D, 2502102, page 3

b. ANL Destructive Chemical Assay of 33-Rod LWBR EOL Sample - Rod D, 2502102, page 6

c. ANL Destructive Chemical Assay of 33-Rod LWBR EOL Sample - Rod D, 2502102, page 7

d. ANL Destructive Chemical Assay of 33-Rod LWBR EOL Sample - Rod D, 2502102, page 9

e. ANL Destructive Chemical Assay of 33-Rod LWBR EOL Sample - Rod D, 2502102, page 10

f. ANL Destructive Chemical Assay of 33-Rod LWBR EOL Sample - Rod D, 2502102, page 11

g. ANL Destructive Chemical Assay of 33-Rod LWBR EOL Sample - Rod D, 2502102, page 12

h. ANL Destructive Chemical Assay of 33-Rod LWBR EOL Sample - Rod D, 2502102, page 13

i. (abundance of the specified isotope)(total weight of uranium) $/ 100$

j. Error Propagation $=\left(\left(s d_{x} / x\right)^{2}+\left(s d_{y} / y\right)^{2}\right)^{1 / 2}(x y)$, where sd is the $+/$ - in the table

k. (mole\%)(number moles gas recovered)(molec $w t) / 100$

m. (number of atoms per segment)(atomic weight) / 6.0228E+23

n. Error Propagation $=\left(\operatorname{SUM}\left(\mathrm{sd}_{\mathrm{i}}^{2}\right)\right)^{1 / 2}$, where sd is the $+/-$ in the table

o. ((shear gas / Xe $+\mathrm{Kr}$ (diss\&pl ))(moles Xe or $\mathrm{Kr}($ diss $+\mathrm{pl}))+$ moles $\mathrm{Xe}$ or $\mathrm{Kr}($ diss $+\mathrm{pl})$

p. Error Propagation $=\left(\left(\left(\left(s d_{x} / x\right)^{2}+\left(s d_{y} / y\right)^{2}+\left(s d_{z} / z\right)^{2}\right)^{1 / 2}(x y / z)\right)^{2}+\left(s d_{y}\right)^{2}\right)^{1 / 2}$, where sd is the $+/-$ in the table 
Rod "E" 2102187 (PFB III-6 B62)

\begin{tabular}{|c|c|c|c|c|c|c|c|}
\hline & $E-00$ & E-01 & E-02 & E-03 & E-04 & E-05 & E-06 \\
\hline seg length (in) ${ }^{a}$ & 11.327 & 8.489 & 14.129 & 14 & 14.101 & 17.498 & 17.5 \\
\hline \multicolumn{8}{|l|}{ total length (in) } \\
\hline & & & & & & & \\
\hline U-232 wt $\%^{b}$ & 0 & 0.0116 & 0.0245 & 0.0926 & 0.1448 & 0.2068 & 0.146 \\
\hline$+/-^{\mathrm{b}}$ & 0 & 0.0004 & 0.0008 & 0.0029 & 0.0045 & 0.0064 & 0.00 \\
\hline $\mathrm{U}-232 \mathrm{~g}^{\mathrm{i}}$ & $0.0000 \mathrm{E}+00$ & $2.9860 \mathrm{E}-05$ & $1.6122 \mathrm{E}-03$ & $6.2204 \mathrm{E}-03$ & $9.9839 \mathrm{E}-03$ & $1.1219 \mathrm{E}-02$ & $6.2710 \mathrm{E}-\mathrm{C}$ \\
\hline$+{ }^{j}$ & NA & 1.0297E-06 & $5.2646 \mathrm{E}-05$ & $1.9481 \mathrm{E}-04$ & $3.1029 \mathrm{E}-04$ & $3.4722 \mathrm{E}-04$ & $1.9316 \mathrm{E}-\mathrm{C}$ \\
\hline \multicolumn{8}{|l|}{ Segment Total } \\
\hline \multicolumn{8}{|l|}{$+/-^{n}$} \\
\hline & & & & & & & \\
\hline U-233 wt $\%^{b}$ & 100 & 99.2317 & 94.611 & 90.1459 & 87.6984 & 90.8655 & 93.13 \\
\hline$+/-^{\mathrm{b}}$ & 0 & 0.0237 & 0.0076 & 0.0076 & 0.0082 & 0.0079 & 0.008 \\
\hline $\mathrm{U}-233 \mathrm{~g}^{\mathrm{i}}$ & $4.0000 \mathrm{E}-05$ & $2.5543 \mathrm{E}-01$ & $6.2259 \mathrm{E}+00$ & $6.0555 \mathrm{E}+00$ & $6.0468 \mathrm{E}+00$ & $4.9295 \mathrm{E}+00$ & $3.9976 \mathrm{E}+1$ \\
\hline$+/-^{j}$ & $1.0000 \mathrm{E}-05$ & $1.1648 \mathrm{E}-04$ & 1.7115E-03 & 1.6667E-03 & 1.7181E-03 & 1.1970E-03 & 9.9159E- \\
\hline \multicolumn{8}{|l|}{ Segment Total } \\
\hline \multicolumn{8}{|l|}{$+/-^{n}$} \\
\hline & & & & & & & \\
\hline $\mathrm{U}-234 \mathrm{wt} \%{ }^{\mathrm{b}}$ & 0 & 0.7098 & 4.6147 & 8.2562 & 10.1189 & 7.7469 & 5.98 \\
\hline$+/-^{\mathrm{b}}$ & 0 & 0.0004 & 0.0006 & 0.0009 & 0.0012 & 0.0008 & 0.00 \\
\hline $\mathrm{U}-234 \mathrm{~g}^{\mathrm{i}}$ & $0.0000 \mathrm{E}+00$ & $1.8271 \mathrm{E}-03$ & 3.0367E-01 & $5.5461 \mathrm{E}-01$ & $6.9770 \mathrm{E}-01$ & $4.2028 \mathrm{E}-01$ & $2.5699 \mathrm{E}-($ \\
\hline$+{ }^{j}{ }^{j}$ & NA & $1.2506 \mathrm{E}-06$ & $8.9064 \mathrm{E}-05$ & $1.5738 \mathrm{E}-04$ & 2.0467E-04 & $1.0471 \mathrm{E}-04$ & $6.6454 \mathrm{E}-\mathrm{-}$ \\
\hline \multicolumn{8}{|l|}{ Segment Total } \\
\hline \multicolumn{8}{|l|}{$+-^{\mathrm{n}}$} \\
\hline & & & & & & & \\
\hline $\mathrm{U}-235 \mathrm{wt} \%{ }^{\mathrm{b}}$ & 0 & 0.0134 & 0.452 & 1.1787 & 1.6747 & 1.1076 & 0.69 \\
\hline$+/-^{\mathrm{b}}$ & 0 & 0.0169 & 0.0057 & 0.0058 & 0.0057 & 0.0042 & 0.00 \\
\hline $\mathrm{U}-235 \mathrm{~g}^{\mathrm{i}}$ & $0.0000 \mathrm{E}+00$ & $3.4493 \mathrm{E}-05$ & $2.9744 \mathrm{E}-02$ & $7.9179 \mathrm{E}-02$ & 1.1547E-01 & $6.0088 \mathrm{E}-02$ & $2.9806 \mathrm{E}-1$ \\
\hline$+/{ }^{j}$ & NA & $4.3502 \mathrm{E}-05$ & 3.7517E-04 & $3.9016 \mathrm{E}-04$ & 3.9423E-04 & $2.2826 \mathrm{E}-04$ & $2.4047 \mathrm{E}-\mathrm{-}$ \\
\hline \multicolumn{8}{|l|}{ Segment Total } \\
\hline \multicolumn{8}{|l|}{$+/_{-}^{\mathrm{n}}$} \\
\hline & & & & & & & \\
\hline $\mathrm{U}-236 w t \%^{b}$ & 0 & 0.0003 & 0.0454 & 0.0981 & 0.1511 & 0.0697 & 0.03 \\
\hline$+/-^{\mathrm{b}}$ & 0 & 0.0001 & 0.0001 & 0.0001 & 0.0001 & 0.0001 & 0.000 \\
\hline $\mathrm{U}-236 \mathrm{~g}^{\mathrm{i}}$ & $0.0000 \mathrm{E}+00$ & $7.7223 \mathrm{E}-07$ & $2.9875 \mathrm{E}-03$ & $6.5898 \mathrm{E}-03$ & $1.0418 \mathrm{E}-02$ & $3.7813 \mathrm{E}-03$ & $1.4551 \mathrm{E}-1$ \\
\hline$+/-^{j}$ & NA & $2.5741 \mathrm{E}-07$ & $6.6272 \mathrm{E}-06$ & $6.9358 \mathrm{E}-06$ & $7.4401 \mathrm{E}-06$ & $5.4924 \mathrm{E}-06$ & $4.3054 \mathrm{E}-\mathrm{-}$ \\
\hline \multicolumn{8}{|l|}{ Segment Total } \\
\hline$+/-^{\mathrm{n}}$ & & & & & & & \\
\hline
\end{tabular}


Rod "E" 2102187 (PFB III-6 B62)

\begin{tabular}{|c|c|c|c|c|c|c|c|}
\hline & E-00 & E-01 & E-02 & E-03 & E-04 & E-05 & E-06 \\
\hline seg length (in) ${ }^{\mathrm{a}}$ & 11.327 & 8.489 & 14.129 & 14 & 14.101 & 17.498 & 17.5 \\
\hline \multicolumn{8}{|l|}{ total length (in) } \\
\hline & & & & & & & \\
\hline U-238 wt $\%^{b}$ & 0 & 0.0332 & 0.2524 & 0.2284 & 0.2122 & 0.0035 & 0.0 \\
\hline$+/-{ }^{b}$ & 0 & 0.0169 & 0.0056 & 0.0055 & 0.0058 & 0.0041 & 0.0 \\
\hline $\mathrm{U}-238 \mathrm{~g}^{\mathrm{i}}$ & $0.0000 \mathrm{E}+00$ & $8.5460 \mathrm{E}-05$ & $1.6609 \mathrm{E}-02$ & 1.5343E-02 & 1.4631E-02 & 1.8988E-04 & $1.5881 \mathrm{E}$ \\
\hline$+/_{-}^{j}$ & NA & $4.3502 \mathrm{E}-05$ & 3.6853E-04 & $3.6948 \mathrm{E}-04$ & $3.9993 \mathrm{E}-04$ & $2.2243 \mathrm{E}-04$ & $2.3608 \mathrm{E}$ \\
\hline \multicolumn{8}{|l|}{ Segment Total } \\
\hline \multicolumn{8}{|l|}{$+-^{n}$} \\
\hline tot $U^{C}$ & 00008 & 025741 & 658019 & 671715 & 689190 & 512500 & 1207 \\
\hline$+-^{c}$ & 0.00002 & 0.0001 & 0.00173 & 0.00176 & 0.00185 & 0.00123 & 0.00 \\
\hline $\mathrm{Kr}-82(\mathrm{~mol} \%)^{\mathrm{d}}$ & 0.1 & 0.1 & 0.1 & 0.1 & 0.1 & 0.1 & \\
\hline$+/^{\mathrm{d}}$ & 0.1 & 0.1 & 0.1 & 0.1 & 0.1 & 0.1 & \\
\hline $\mathrm{Kr}-82(\mathrm{~g})^{\mathrm{K}}$ & 8.1913E-08 & $0.0000 E+00$ & 4.8389E-05 & 9.8201E-05 & 1.3335E-04 & 8.0324E-05 & 4.2103E \\
\hline$+/^{j}$ & 8.1913E-08 & $0.0000 \mathrm{E}+00$ & $5.0154 \mathrm{E}-05$ & 9.9029E-05 & $1.3401 \mathrm{E}-04$ & $8.0819 \mathrm{E}-05$ & $4.2585 \mathrm{E}$ \\
\hline \multicolumn{8}{|l|}{ Segment Total } \\
\hline \multicolumn{8}{|l|}{$+/-^{n}$} \\
\hline $\mathrm{Kr}-83(\mathrm{~mol} \%)^{\mathrm{d}}$ & 15.6 & 15.6 & 15.6 & 15.6 & 15.6 & 15.6 & 1 \\
\hline$+/^{\mathrm{d}}$ & 0.2 & 0.2 & 0.2 & 0.2 & 0.2 & 0.2 & \\
\hline $\mathrm{Kr}-83(\mathrm{~g})^{\mathrm{k}}$ & 1.2935E-05 & $0.0000 \mathrm{E}+00$ & $7.6408 \mathrm{E}-03$ & $1.5507 \mathrm{E}-02$ & $2.1057 \mathrm{E}-02$ & $1.2684 \mathrm{E}-02$ & $6.6483 \mathrm{E}$ \\
\hline$+/-^{j}$ & 1.6583E-07 & $0.0000 \mathrm{E}+00$ & $2.0848 \mathrm{E}-03$ & $2.0276 \mathrm{E}-03$ & $2.1128 \mathrm{E}-03$ & 1.4192E-03 & $1.0125 \mathrm{E}$ \\
\hline \multicolumn{8}{|l|}{ Segment Total } \\
\hline \multicolumn{8}{|l|}{$+/_{-}^{n}$} \\
\hline $\mathrm{Kr}-84(\mathrm{~mol} \%)^{\mathrm{d}}$ & 29.7 & 29.7 & 29.7 & 29.7 & 29.7 & 29.7 & 2 \\
\hline$+/^{\mathrm{d}}$ & 0.3 & 0.3 & 0.3 & 0.3 & 0.3 & 0.3 & \\
\hline $\mathrm{Kr}-84(\mathrm{~g})^{\mathrm{k}}$ & 2.4922E-05 & $0.0000 \mathrm{E}+00$ & $1.4722 \mathrm{E}-02$ & $2.9877 \mathrm{E}-02$ & 4.0572E-02 & $2.4438 \mathrm{E}-02$ & $1.2810 \mathrm{E}$ \\
\hline$+/^{j}$ & 2.5173E-07 & $0.0000 \mathrm{E}+00$ & 4.0152E-03 & $3.8995 \mathrm{E}-03$ & $4.0581 \mathrm{E}-03$ & $2.7277 \mathrm{E}-03$ & $1.9482 \mathrm{E}$ \\
\hline \multicolumn{8}{|l|}{ Segment Total } \\
\hline$+/^{n}$ & & & & & & & \\
\hline
\end{tabular}


Rod "E" 2102187 (PFB III-6 B62)

\begin{tabular}{|c|c|c|c|c|c|c|c|}
\hline & $\mathrm{E}-00$ & E-01 & E-02 & E-03 & E-04 & E-05 & E-06 \\
\hline seg length (in) ${ }^{a}$ & 11.327 & 8.489 & 14.129 & 14 & 14.101 & 17.498 & 17.504 \\
\hline \multicolumn{8}{|l|}{ total length (in) } \\
\hline & & & & & & & \\
\hline $\mathrm{Kr}-85(\mathrm{~mol} \%)^{\mathrm{d}}$ & 6.1 & 6.1 & 6.1 & 6.1 & 6.1 & 6.1 & 6.1 \\
\hline$+{ }^{\mathrm{d}}$ & 0.2 & 0.2 & 0.2 & 0.2 & 0.2 & 0.2 & 0.2 \\
\hline $\mathrm{Kr}-85(\mathrm{~g})^{\mathrm{k}}$ & $5.1797 \mathrm{E}-06$ & $0.0000 \mathrm{E}+00$ & $3.0598 \mathrm{E}-03$ & 6.2096E-03 & $8.4324 \mathrm{E}-03$ & 5.0792E-03 & $2.6623 \mathrm{E}-03$ \\
\hline$+/-^{j}$ & 1.6982E-07 & $0.0000 \mathrm{E}+00$ & 8.3994E-04 & $8.3329 \mathrm{E}-04$ & $8.8349 \mathrm{E}-04$ & 5.8864E-04 & $4.1334 \mathrm{E}-04$ \\
\hline \multicolumn{8}{|l|}{ Segment Total } \\
\hline \multicolumn{8}{|l|}{$+-^{\mathrm{n}}$} \\
\hline & & & & & & & \\
\hline $\mathrm{Kr}-86(\mathrm{~mol} \%)^{\mathrm{d}}$ & 48.6 & 48.6 & 48.6 & 48.6 & 48.6 & 48.6 & 48.6 \\
\hline$+/{ }^{\mathrm{d}}$ & 0.3 & 0.3 & 0.3 & 0.3 & 0.3 & 0.3 & 0.3 \\
\hline $\mathrm{Kr}-86(\mathrm{~g})^{\mathrm{k}}$ & $4.1753 \mathrm{E}-05$ & $0.0000 E+00$ & $2.4664 \mathrm{E}-02$ & $5.0055 \mathrm{E}-02$ & $6.7973 \mathrm{E}-02$ & 4.0943E-02 & $2.1460 \mathrm{E}-02$ \\
\hline$+I^{j}$ & $2.5773 \mathrm{E}-07$ & $0.0000 \mathrm{E}+00$ & $6.7239 \mathrm{E}-03$ & $6.5208 \mathrm{E}-03$ & $6.7770 \mathrm{E}-03$ & $4.5581 \mathrm{E}-03$ & $3.2594 \mathrm{E}-03$ \\
\hline \multicolumn{8}{|l|}{ Segment Total } \\
\hline \multicolumn{8}{|l|}{$+1-^{\mathrm{n}}$} \\
\hline \multicolumn{8}{|l|}{ Rod Total } \\
\hline \multicolumn{8}{|l|}{$+-^{\mathrm{n}}$} \\
\hline & & & & & & & \\
\hline shear gas $(\mathrm{g})^{\mathrm{e}}$ & 0 & 0 & 0.0004 & 0.0016 & 0.0023 & 0.0015 & 0.0006 \\
\hline$+{ }^{-\mathrm{e}}$ & 0 & 0.0001 & 0.0001 & 0.0003 & 0.0005 & 0.0003 & 0.0001 \\
\hline moles Kr (diss+pl) ${ }^{d}$ & 0.000001 & 0 & 0.00059 & 0.001196 & 0.001624 & 0.000978 & 0.000513 \\
\hline$+/^{-\mathrm{d}}$ & 0 & 0 & 0.000161 & 0.000156 & 0.000162 & 0.000109 & 0.000078 \\
\hline $\mathrm{Kr}+\mathrm{Xe}$ diss\&pl $(\mathrm{g})^{\mathrm{d}}$ & 0.0005 & 0 & 0.3238 & 0.674 & 0.937 & 0.5643 & 0.3104 \\
\hline$+l^{-\mathrm{d}}$ & 0 & 0 & 0.0319 & 0.0248 & 0.0322 & 0.0238 & 0.0289 \\
\hline moles kr (tot) $^{\circ}$ & $1.0000 \mathrm{E}-06$ & $0.0000 \mathrm{E}+00$ & $5.9073 \mathrm{E}-04$ & $1.1988 \mathrm{E}-03$ & $1.6280 \mathrm{E}-03$ & $9.8060 \mathrm{E}-04$ & $5.1399 \mathrm{E}-04$ \\
\hline$+/-^{\mathrm{p}}$ & \multicolumn{2}{|c|}{\begin{tabular}{r|r|}
0 & $N A$ \\
\end{tabular}} & 1.6100E-04 & $1.5600 \mathrm{E}-04$ & $1.6200 \mathrm{E}-04$ & $1.0900 \mathrm{E}-04$ & $7.8000 \mathrm{E}-05$ \\
\hline \multicolumn{8}{|l|}{$\mathrm{Xe}-128(\mathrm{~mol} \%)^{\mathrm{d}}$} \\
\hline$+/-^{\mathrm{d}}$ & 0.1 & 0.1 & 0.1 & 0.1 & 0.1 & 0.1 & 0.1 \\
\hline $\mathrm{Xe}-128(\mathrm{~g})^{\mathrm{k}}$ & $3.8371 \mathrm{E}-07$ & $0.0000 \mathrm{E}+00$ & $2.6112 \mathrm{E}-04$ & $5.4680 \mathrm{E}-04$ & $7.6328 \mathrm{E}-04$ & $4.5975 \mathrm{E}-04$ & $2.5476 \mathrm{E}-04$ \\
\hline$+/{ }^{j}$ & $3.8371 \mathrm{E}-07$ & NA & $2.6256 \mathrm{E}-04$ & 5.4717E-04 & $7.6378 \mathrm{E}-04$ & 4.6023E-04 & $2.5616 \mathrm{E}-04$ \\
\hline \multicolumn{8}{|l|}{ SegmentTotal } \\
\hline$+/-^{\mathrm{n}}$ & & & & & & & \\
\hline
\end{tabular}


Rod "E" 2102187 (PFB III-6 B62)

\begin{tabular}{|c|c|c|c|c|c|c|c|}
\hline & E-00 & E-01 & $\mathrm{E}-02$ & E-03 & E-04 & E-05 & E-06 \\
\hline seg length (in) ${ }^{a}$ & 11.327 & 8.489 & 14.129 & 14 & 14.101 & 17.498 & 17.50 \\
\hline \multicolumn{8}{|l|}{ total length (in) } \\
\hline & & & & & & & \\
\hline $\mathrm{Xe}-130(\mathrm{~mol} \%)^{\mathrm{d}}$ & 0.1 & 0.1 & 0.1 & 0.1 & 0.1 & 0.1 & 0 \\
\hline$+/{ }^{\mathrm{d}}$ & 0.1 & 0.1 & 0.1 & 0.1 & 0.1 & 0.1 & 0 \\
\hline $\mathrm{Xe}-130(\mathrm{~g})^{\mathrm{k}}$ & $3.8971 \mathrm{E}-07$ & $0.0000 \mathrm{E}+00$ & $2.6520 \mathrm{E}-04$ & 5.5535E-04 & $7.7521 \mathrm{E}-04$ & 4.6694E-04 & $2.5875 \mathrm{E}-\mathrm{C}$ \\
\hline$+/{ }^{j}$ & $3.8971 \mathrm{E}-07$ & NA & 2.6667E-04 & 5.5572E-04 & 7.7573E-04 & 4.6742E-04 & 2.6017E-C \\
\hline \multicolumn{8}{|l|}{ SegmentTotal } \\
\hline \multicolumn{8}{|l|}{$+-^{\mathrm{n}}$} \\
\hline & & & & & & & \\
\hline $\mathrm{Xe}-131(\mathrm{~mol} \%)^{d}$ & 12.1 & 12.1 & 12.1 & 12.1 & 12.1 & 12.1 & 12 \\
\hline$+/-^{\mathrm{d}}$ & 0.1 & 0.1 & 0.1 & 0.1 & 0.1 & 0.1 & 0 \\
\hline $\mathrm{Xe}-131(\mathrm{~g})^{\mathrm{k}}$ & $4.7519 \mathrm{E}-05$ & $0.0000 \mathrm{E}+00$ & $3.2337 \mathrm{E}-02$ & 6.7716E-02 & $9.4524 \mathrm{E}-02$ & $5.6936 \mathrm{E}-02$ & $3.1550 \mathrm{E}-\mathrm{C}$ \\
\hline$+/{ }^{j}$ & $3.9272 \mathrm{E}-07$ & NA & $3.4160 \mathrm{E}-03$ & 2.5337E-03 & $3.5252 \mathrm{E}-03$ & $2.6246 \mathrm{E}-03$ & 3.3207E-C \\
\hline \multicolumn{8}{|l|}{ SegmentTotal } \\
\hline \multicolumn{8}{|l|}{$+/-^{n}$} \\
\hline $\mathrm{Xe}-132(\mathrm{~mol} \%)^{\mathrm{d}}$ & 21.9 & 21.9 & 21.9 & 21.9 & 21.9 & 21.9 & 21 \\
\hline$+/{ }^{\mathrm{d}}$ & 0.1 & 0.1 & 0.1 & 0.1 & 0.1 & 0.1 & 0 \\
\hline $\mathrm{Xe}-132(\mathrm{~g})^{\mathrm{k}}$ & $8.6661 \mathrm{E}-05$ & $0.0000 \mathrm{E}+00$ & $5.8973 \mathrm{E}-02$ & 1.2350E-01 & 1.7239E-01 & $1.0384 \mathrm{E}-01$ & $5.7538 \mathrm{E}-\mathrm{C}$ \\
\hline$+{ }^{j}{ }^{j}$ & $3.9571 \mathrm{E}-07$ & NA & 6.2166E-03 & 4.5419E-03 & $6.3184 \mathrm{E}-03$ & 4.7327E-03 & 6.0431E-C \\
\hline \multicolumn{8}{|l|}{ SegmentTotal } \\
\hline \multicolumn{8}{|l|}{$+-^{\mathrm{n}}$} \\
\hline $\mathrm{Xe}-134(\mathrm{~mol} \%)^{d}$ & 25.4 & 25.4 & 25.4 & 25.4 & 25.4 & 25.4 & 25 \\
\hline$+/-^{\mathrm{d}}$ & 0.2 & 0.2 & 0.2 & 0.2 & 0.2 & 0.2 & 0 \\
\hline $\mathrm{Xe}-134(\mathrm{~g})^{\mathrm{k}}$ & $1.0204 \mathrm{E}-04$ & $0.0000 \mathrm{E}+00$ & $6.9436 \mathrm{E}-02$ & $1.4541 \mathrm{E}-01$ & $2.0297 \mathrm{E}-01$ & $1.2226 \mathrm{E}-01$ & $6.7746 \mathrm{E}-\mathrm{C}$ \\
\hline$+/{ }^{\mathrm{j}}$ & 8.0343E-07 & NA & 7.3330E-03 & $5.4284 \mathrm{E}-03$ & $7.5525 \mathrm{E}-03$ & $5.6273 \mathrm{E}-03$ & $7.1285 \mathrm{E}-\mathrm{C}$ \\
\hline \multicolumn{8}{|l|}{ SegmentTotal } \\
\hline$+/-^{\mathrm{n}}$ & & & & & & & \\
\hline
\end{tabular}


Rod "E" 2102187 (PFB III-6 B62)

\begin{tabular}{|c|c|c|c|c|c|c|c|}
\hline & $E-00$ & E-01 & E-02 & E-03 & E-04 & E-05 & E-06 \\
\hline seg length (in) ${ }^{\mathrm{a}}$ & 11.327 & 8.489 & 14.129 & 14 & 14.101 & 17.498 & 17.504 \\
\hline \multicolumn{8}{|l|}{ total length (in) } \\
\hline & & & & & & & \\
\hline $\mathrm{Xe}-136(\mathrm{~mol} \%)^{\mathrm{d}}$ & 40.4 & 40.4 & 40.4 & 40.4 & 40.4 & 40.4 & 40.4 \\
\hline$+/-^{\mathrm{d}}$ & 0.2 & 0.2 & 0.2 & 0.2 & 0.2 & 0.2 & 0.2 \\
\hline $\mathrm{Xe-136}(\mathrm{g})^{\mathrm{k}}$ & 1.6472E-04 & $0.0000 \mathrm{E}+00$ & 1.1209E-01 & $2.3473 \mathrm{E}-01$ & 3.2766E-01 & 1.9736E-01 & 1.0937E-01 \\
\hline$+/{ }^{j}$ & $8.1544 \mathrm{E}-07$ & NA & $1.1818 \mathrm{E}-02$ & 8.6446E-03 & $1.2026 \mathrm{E}-02$ & $9.0036 \mathrm{E}-03$ & $1.1488 \mathrm{E}-02$ \\
\hline \multicolumn{8}{|l|}{ SegmentTotal } \\
\hline \multicolumn{8}{|l|}{$+/-^{n}$} \\
\hline \multicolumn{8}{|l|}{ Rod total } \\
\hline \multicolumn{8}{|l|}{$+/-^{n}$} \\
\hline & & & & & & & \\
\hline shear gas $(g)^{e}$ & 0 & 0 & 0.0004 & 0.0016 & 0.0023 & 0.0015 & 0.0006 \\
\hline$+/{ }^{\mathrm{e}}$ & 0 & 0.0001 & 0.0001 & 0.0003 & 0.0005 & 0.0003 & 0.0001 \\
\hline moles Xe (diss+pl) $)^{d}$ & 0.000003 & 0 & 0.002039 & 0.004265 & 0.005953 & 0.003585 & 0.001988 \\
\hline$+/{ }^{\mathrm{d}}$ & 0 & 0 & 0.000215 & 0.000156 & 0.000217 & 0.000163 & 0.000209 \\
\hline $\mathrm{Kr}+\mathrm{Xe}$ diss\&pl $(\mathrm{g})^{\mathrm{d}}$ & 0.0005 & 0 & 0.3238 & 0.674 & 0.937 & 0.5643 & 0.3104 \\
\hline$+/^{\mathrm{d}}$ & 0 & 0 & 0.0319 & 0.0248 & 0.0322 & 0.0238 & 0.0289 \\
\hline moles Xe (tot) $^{\circ}$ & $3.0000 \mathrm{E}-06$ & 0 & $2.0415 \mathrm{E}-03$ & $4.2751 \mathrm{E}-03$ & $5.9676 \mathrm{E}-03$ & 3.5945E-03 & 1.9918E-03 \\
\hline$+/-^{\mathrm{p}}$ & $0.0000 \mathrm{E}+00$ & NA & 2.1500E-04 & $1.5601 \mathrm{E}-04$ & 2.1702E-04 & $1.6301 \mathrm{E}-04$ & 2.0900E-04 \\
\hline \multicolumn{8}{|c|}{ Values corrected to 1/1/84 (page 181, Final Report for the LWBR Proof of Breeding Analytical Support Project } \\
\hline Cs-137 (atoms) ${ }^{f}$ & NA & $2.4670 E+18$ & $3.0540 E+20$ & $6.7250 \mathrm{E}+20$ & $8.8880 E+20$ & $5.2550 \mathrm{E}+20$ & $3.1760 E+20$ \\
\hline$+/_{-}^{f}$ & NA & $9.0570 \mathrm{E}+15$ & $1.0580 \mathrm{E}+18$ & $2.3980 \mathrm{E}+18$ & $3.0740 \mathrm{E}+18$ & $1.9270 \mathrm{E}+18$ & $1.1640 \mathrm{E}+18$ \\
\hline Cs-137 (g) ${ }^{\mathrm{m}}$ & NA & 5.6078E-04 & 6.9422E-02 & 1.5287E-01 & 2.0204E-01 & 1.1945E-01 & $7.2195 \mathrm{E}-02$ \\
\hline$+/-^{m}$ & NA & $2.0588 \mathrm{E}-06$ & $2.4050 \mathrm{E}-04$ & $5.4510 \mathrm{E}-04$ & 6.9876E-04 & $4.3803 \mathrm{E}-04$ & $2.6459 \mathrm{E}-04$ \\
\hline \multicolumn{8}{|l|}{ Total } \\
\hline \multicolumn{8}{|l|}{$+/-^{n}$} \\
\hline $\mathrm{Ce}-144$ (atoms) $^{\mathrm{g}}$ & NA & $3.1840 E+17$ & $2.1360 \mathrm{E}+19$ & $3.7720 \mathrm{E}+19$ & $4.6570 E+19$ & $3.8390 \mathrm{E}+19$ & $2.0250 \mathrm{E}+19$ \\
\hline$+/^{\mathrm{g}}$ & NA & $2.3330 \mathrm{E}+15$ & $1.5470 \mathrm{E}+17$ & $2.7950 \mathrm{E}+17$ & $3.4510 \mathrm{E}+17$ & $2.8450 \mathrm{E}+17$ & $1.5000 \mathrm{E}+17$ \\
\hline $\mathrm{Ce}-144(\mathrm{~g})^{\mathrm{m}}$ & NA & 7.6081E-05 & $5.1039 \mathrm{E}-03$ & $9.0131 \mathrm{E}-03$ & $1.1128 \mathrm{E}-02$ & 9.1732E-03 & $4.8387 \mathrm{E}-03$ \\
\hline$+/-^{m}$ & NA & 5.5747E-07 & 3.6965E-05 & $6.6786 \mathrm{E}-05$ & $8.2461 \mathrm{E}-05$ & $6.7981 \mathrm{E}-05$ & 3.5842E-05 \\
\hline \multicolumn{8}{|l|}{ Total } \\
\hline$+/-^{n}$ & & & & & & & \\
\hline
\end{tabular}


Rod "E" 2102187 (PFB III-6 B62)

\begin{tabular}{|c|c|c|c|c|c|c|c|}
\hline & $E-00$ & E-01 & E-02 & E-03 & E-04 & E-05 & E-06 \\
\hline seg length (in) ${ }^{a}$ & 11.327 & 8.489 & 14.129 & 14 & 14.101 & 17.498 & 17.504 \\
\hline \multicolumn{8}{|l|}{ total length (in) } \\
\hline & & & & & & & \\
\hline Zr-95 (atoms) ${ }^{\mathrm{h}, \mathrm{r}}$ & NA & $3.4020 \mathrm{E}+15$ & $1.8000 \mathrm{E}+17$ & $2.9640 \mathrm{E}+17$ & $3.5200 \mathrm{E}+17$ & $2.7990 \mathrm{E}+17$ & $9.4330 \mathrm{E}+16$ \\
\hline$+/_{-}^{\mathrm{h}, \mathrm{r}}$ & NA & $4.4230 \mathrm{E}+13$ & $2.4600 \mathrm{E}+15$ & $5.8530 \mathrm{E}+15$ & $9.7460 \mathrm{E}+15$ & $6.8750 \mathrm{E}+15$ & $2.6110 \mathrm{E}+15$ \\
\hline Zr-95 (g) & NA & 5.3609E-07 & $2.8365 \mathrm{E}-05$ & 4.6707E-05 & $5.5469 \mathrm{E}-05$ & 4.4107E-05 & $1.4865 \mathrm{E}-05$ \\
\hline$+/-^{m}$ & NA & 6.9698E-09 & $3.8765 \mathrm{E}-07$ & $9.2232 \mathrm{E}-07$ & $1.5358 \mathrm{E}-06$ & 1.0834E-06 & 4.1144E-07 \\
\hline \multicolumn{8}{|l|}{ Total } \\
\hline$+/^{n}$ & & & & & & & \\
\hline
\end{tabular}

Footnotes

a. ANL Destructive Chemical Assay of 33-Rod LWBR EOL Sample - Rod E, 2102187, page 3

b. ANL Destructive Chemical Assay of 33-Rod LWBR EOL Sample - Rod E, 2102187, page 6

c. ANL Destructive Chemical Assay of 33-Rod LWBR EOL Sample - Rod E, 2102187, page 7

d. ANL Destructive Chemical Assay of 33-Rod LWBR EOL Sample - Rod E, 2102187, page 10

e. ANL Destructive Chemical Assay of 33-Rod LWBR EOL Sample - Rod E, 2102187, page 11

f. ANL Destructive Chemical Assay of 33-Rod LWBR EOL Sample - Rod E, 2102187, page 12

g. ANL Destructive Chemical Assay of 33-Rod LWBR EOL Sample - Rod E, 2102187, page 13

h. ANL Destructive Chemical Assay of 33-Rod LWBR EOL Sample - Rod E, 2102187, page 14

i. (abundance of the specified isotope)(total weight of uranium) / 100

j. Error Propagation $=\left(\left(s d_{x} / x\right)^{2}+\left(s d_{y} / y\right)^{2}\right)^{1 / 2}(x y)$, where sd is the $+/-$ in the table

k. (mole\%)(number moles gas recovered)(molec wt) / 100

m. (number of atoms per segment)(atomic weight) / 6.0228E+23

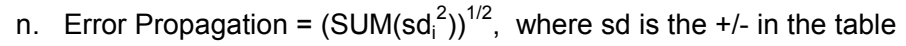

o. ((shear gas / Xe $+\mathrm{Kr}$ (diss\&pl )) (moles $\mathrm{Xe}$ or $\mathrm{Kr}($ diss $+\mathrm{pl}))+$ moles $\mathrm{Xe}$ or $\mathrm{Kr}$ (diss $+\mathrm{pl})$

p. Error Propagation $=\left(\left(\left(\left(s d_{x} / x\right)^{2}+\left(s d_{y} / y\right)^{2}+\left(s d_{z} / z\right)^{2}\right)^{1 / 2}(x y / z)\right)^{2}+\left(s d_{y}\right)^{2}\right)^{1 / 2}$, where sd is the $+/-$ in the table

r. Zr-95 values for segments 5 and 6 corrected per LWBR EOL Sample - Rod E, 2102187, page 14, February 1985 
Rod "F" 2400408 (PFB III-6 C13)

\begin{tabular}{|c|c|c|c|c|c|c|c|c|}
\hline & $F-00$ & $F-01$ & $F-02$ & $\mathrm{~F}-03$ & F-04 & F-05 & $F-06$ & $F-07$ \\
\hline seg length (in) ${ }^{a}$ & 11.283 & 11.575 & 14.019 & 14 & 14 & 14.198 & 14.003 & 1 \\
\hline \multicolumn{9}{|l|}{ total length (in) } \\
\hline & & & & & & & & \\
\hline U-232 wt $\%^{b}$ & 0 & 0.0092 & 0.0134 & 0.0528 & 0.0858 & 0.0907 & 0.1463 & 0 \\
\hline$+1-^{\mathrm{b}}$ & 0 & 0.0003 & 0.0004 & 0.0016 & 0.0027 & 0.0028 & 0.0045 & 0 \\
\hline $\mathrm{U}-232 \mathrm{~g}^{\mathrm{i}}$ & $0.0000 \mathrm{E}+00$ & $1.9378 \mathrm{E}-05$ & $1.0351 \mathrm{E}-03$ & $4.0766 \mathrm{E}-03$ & 6.6307E-03 & 6.9198E-03 & $4.4870 \mathrm{E}-03$ & 1.167 \\
\hline$+/_{-}^{j}$ & NA & 6.3197E-07 & $3.0901 \mathrm{E}-05$ & $1.2354 \mathrm{E}-04$ & $2.0867 \mathrm{E}-04$ & $2.1363 \mathrm{E}-04$ & 1.3802E-04 & 3.656 \\
\hline \multicolumn{9}{|l|}{ Segment Total } \\
\hline \multicolumn{9}{|l|}{$+/^{n}$} \\
\hline & & & & & & & & \\
\hline U-233 wt $\%^{b}$ & 100 & 99.4304 & 95.7489 & 92.572 & 90.6675 & 89.9319 & 94.6369 & 96 \\
\hline$+/_{-}^{\mathrm{b}}$ & 0 & 0.0369 & 0.0055 & 0.0067 & 0.0073 & 0.0068 & 0.0083 & 0 \\
\hline $\mathrm{U}-233 \mathrm{~g}^{\mathrm{i}}$ & $4.0000 \mathrm{E}-05$ & $2.0943 \mathrm{E}-01$ & $7.3964 \mathrm{E}+00$ & $7.1474 \mathrm{E}+00$ & $7.0069 \mathrm{E}+00$ & $6.8612 \mathrm{E}+00$ & $2.9025 \mathrm{E}+00$ & 1.4704 \\
\hline$+/^{j}$ & $1.0000 \mathrm{E}-05$ & $1.3418 \mathrm{E}-04$ & $2.1583 \mathrm{E}-03$ & $2.1911 \mathrm{E}-03$ & $2.2567 \mathrm{E}-03$ & $2.1412 \mathrm{E}-03$ & $8.1671 \mathrm{E}-04$ & 4.718 \\
\hline \multicolumn{9}{|l|}{ Segment Total } \\
\hline \multicolumn{9}{|l|}{$+/-^{n}$} \\
\hline & & & & & & & & \\
\hline $\mathrm{U}-234 \mathrm{wt} \%^{\mathrm{b}}$ & 0 & 0.4954 & 3.6109 & 6.2902 & 7.8107 & 8.4044 & 4.7359 & 3 \\
\hline$+1-{ }^{\mathrm{b}}$ & 0 & 0.0004 & 0.0004 & 0.0007 & 0.0009 & 0.0009 & 0.0006 & 0 \\
\hline $\mathrm{U}-234 \mathrm{~g}^{\mathrm{i}}$ & $0.0000 \mathrm{E}+00$ & 1.0435E-03 & $2.7894 \mathrm{E}-01$ & 4.8566E-01 & $6.0362 \mathrm{E}-01$ & $6.4120 \mathrm{E}-01$ & 1.4525E-01 & 4.857 \\
\hline$+{ }^{j}$ & NA & $1.0034 \mathrm{E}-06$ & $8.5574 \mathrm{E}-05$ & $1.5444 \mathrm{E}-04$ & $2.0068 \mathrm{E}-04$ & $2.0593 \mathrm{E}-04$ & $4.2974 \mathrm{E}-05$ & 1.652 \\
\hline \multicolumn{9}{|l|}{ Segment Total } \\
\hline \multicolumn{9}{|l|}{$+/-^{n}$} \\
\hline & & & & & & & & \\
\hline U-235 wt $\%{ }^{b}$ & 0 & 0.0153 & 0.3238 & 0.7696 & 1.1037 & 1.2264 & 0.4598 & 0 \\
\hline$+/_{-}^{\mathrm{b}}$ & 0 & 0.0267 & 0.0042 & 0.005 & 0.0054 & 0.005 & 0.0054 & 0 \\
\hline U-235 gi & $0.0000 \mathrm{E}+00$ & 3.2226E-05 & $2.5013 \mathrm{E}-02$ & $5.9420 \mathrm{E}-02$ & $8.5295 \mathrm{E}-02$ & 9.3567E-02 & 1.4102E-02 & 3.249 \\
\hline$+/{ }^{j}$ & NA & $5.6238 \mathrm{E}-05$ & 3.2452E-04 & $3.8645 \mathrm{E}-04$ & $4.1817 \mathrm{E}-04$ & 3.8252E-04 & 1.6566E-04 & 1.158 \\
\hline \multicolumn{9}{|l|}{ Segment Total } \\
\hline \multicolumn{9}{|l|}{$+-^{\mathrm{n}}$} \\
\hline & & & & & & & & \\
\hline U-236 wt $\%{ }^{b}$ & 0 & 0.0002 & 0.0391 & 0.063 & 0.0882 & 0.1001 & 0.0167 & 0 \\
\hline$+1-{ }^{\mathrm{b}}$ & 0 & 0.0001 & 0 & 0 & 0 & 0 & 0 & \\
\hline $\mathrm{U}-236 \mathrm{~g}^{\mathrm{i}}$ & $0.0000 \mathrm{E}+00$ & $4.2126 \mathrm{E}-07$ & $3.0204 \mathrm{E}-03$ & $4.8641 \mathrm{E}-03$ & $6.8162 \mathrm{E}-03$ & $7.6370 \mathrm{E}-03$ & $5.1219 \mathrm{E}-04$ & 8.227 \\
\hline$+/-^{j}$ & NA & $2.1063 \mathrm{E}-07$ & $8.6411 \mathrm{E}-07$ & $1.4490 \mathrm{E}-06$ & $2.1256 \mathrm{E}-06$ & $2.3123 \mathrm{E}-06$ & 1.3694E-07 & 2.484 \\
\hline \multicolumn{9}{|l|}{ Segment Total } \\
\hline$+/^{\mathrm{n}}$ & & & & & & & & \\
\hline
\end{tabular}


Rod "F" 2400408 (PFB III-6 C13)

\begin{tabular}{|c|c|c|c|c|c|c|c|c|}
\hline & $\mathrm{F}-00$ & $\mathrm{~F}-01$ & $\mathrm{~F}-02$ & $\mathrm{~F}-03$ & $F-04$ & $\mathrm{~F}-05$ & $\mathrm{~F}-06$ & $F-07$ \\
\hline seg length (in) ${ }^{a}$ & 11.283 & 11.575 & 14.019 & 14 & 14 & 14.198 & 14.003 & \\
\hline total length (in) & & & & & & & & \\
\hline & & & & & & & & \\
\hline $\mathrm{U}-238 \mathrm{wt} \%^{\mathrm{b}}$ & 0 & 0.0495 & 0.2638 & 0.2523 & 0.2441 & 0.2466 & 0.0044 & \\
\hline$+/_{-}^{\mathrm{b}}$ & 0 & 0.0258 & 0.0039 & 0.0048 & 0.0052 & 0.0048 & 0.0052 & \\
\hline $\mathrm{U}-238 \mathrm{~g}^{\mathrm{i}}$ & $0.0000 \mathrm{E}+00$ & 1.0426E-04 & $2.0378 \mathrm{E}-02$ & 1.9480E-02 & 1.8864E-02 & 1.8814E-02 & 1.3495E-04 & 1.081 \\
\hline$+/_{-}^{j}$ & \begin{tabular}{|l|} 
NA \\
\end{tabular} & 5.4343E-05 & $3.0133 \mathrm{E}-04$ & $3.7065 \mathrm{E}-04$ & $4.0191 \mathrm{E}-04$ & $3.6625 \mathrm{E}-04$ & 1.5948E-04 & 1.112 \\
\hline Segment Total & & & & & & & & \\
\hline$+/^{\mathrm{n}}$ & & & & & & & & \\
\hline & & & & & & & & \\
\hline tot $U^{\mathrm{C}}$ & 0.00006 & 0.21063 & 7.72484 & 7.72086 & 7.72813 & 7.62938 & 3.06699 & 1 \\
\hline$+/-^{\mathrm{C}}$ & 0.00001 & 0.00011 & 0.00221 & 0.0023 & 0.00241 & 0.00231 & 0.00082 & 0 \\
\hline $\mathrm{Kr}-82(\mathrm{~mol} \%)^{\mathrm{d}}$ & 0 & 0 & 0 & 0 & 0 & 0 & 0 & \\
\hline$+/^{\mathrm{d}}$ & 0 & 0 & 0 & 0 & 0 & 0 & 0 & \\
\hline $\mathrm{Kr}-82(\mathrm{~g})^{\mathrm{K}}$ & $0.0000 \mathrm{E}+00$ & $0.0000 \mathrm{E}+00$ & $0.0000 \mathrm{E}+00$ & $0.0000 \mathrm{E}+00$ & $0.0000 \mathrm{E}+00$ & $0.0000 \mathrm{E}+00$ & $0.0000 \mathrm{E}+00$ & 0.000 \\
\hline$+-^{j}$ & \begin{tabular}{|l|} 
NA \\
\end{tabular} & NA & NA & NA & NA & \begin{tabular}{|l|}
$N A$ \\
\end{tabular} & NA & NA \\
\hline Segment Total & & & & & & & & \\
\hline$+/_{-}^{\mathrm{n}}$ & & & & & & & & \\
\hline & & & & & & & & \\
\hline $\mathrm{Kr}-83(\mathrm{~mol} \%)^{\mathrm{d}}$ & 15.9 & 15.9 & 15.9 & 15.9 & 15.9 & 15.9 & 15.9 & \\
\hline$+/-^{d}$ & 0.2 & 0.2 & 0.2 & 0.2 & 0.2 & 0.2 & 0.2 & \\
\hline $\mathrm{Kr}-83(\mathrm{~g})^{\mathrm{K}}$ & 1.3183E-05 & $0.0000 \mathrm{E}+00$ & 5.6471E-03 & $1.0908 \mathrm{E}-02$ & 1.4307E-02 & $1.7861 \mathrm{E}-02$ & $3.7483 \mathrm{E}-03$ & 1.357 \\
\hline$+/^{j}$ & 1.6583E-07 & NA & 6.4988E-04 & $1.1028 \mathrm{E}-03$ & $1.4351 \mathrm{E}-03$ & 1.4414E-03 & 3.4599E-04 & 3.958 \\
\hline Segment Total & & & & & & & & \\
\hline$+/-^{n}$ & & & & & & & & \\
\hline & & & & & & & & \\
\hline $\mathrm{Kr}-84(\mathrm{~mol} \%)^{\mathrm{d}}$ & 29.3 & 29.3 & 29.3 & 29.3 & 29.3 & 29.3 & 29.3 & \\
\hline$+/^{\mathrm{d}}$ & 0.2 & 0.2 & 0.2 & 0.2 & 0.2 & 0.2 & 0.2 & \\
\hline $\mathrm{Kr}-84(\mathrm{~g})^{\mathrm{K}}$ & $2.4586 \mathrm{E}-05$ & $0.0000 \mathrm{E}+00$ & $1.0532 \mathrm{E}-02$ & $2.0343 \mathrm{E}-02$ & $2.6682 \mathrm{E}-02$ & $3.3309 \mathrm{E}-02$ & $6.9904 \mathrm{E}-03$ & 2.532 \\
\hline$+/^{j}$ & 1.6782E-07 & NA & $1.2069 \mathrm{E}-03$ & $2.0454 \mathrm{E}-03$ & $2.6616 \mathrm{E}-03$ & $2.6650 \mathrm{E}-03$ & $6.4102 \mathrm{E}-04$ & 7.377 \\
\hline Segment Total & & & & & & & & \\
\hline$+/-^{n}$ & & & & & & & & \\
\hline
\end{tabular}


Rod "F" 2400408 (PFB III-6 C13)

\begin{tabular}{|c|c|c|c|c|c|c|c|c|}
\hline & $F-00$ & F-01 & F-02 & $F-03$ & F-04 & F-05 & F-06 & $F-07$ \\
\hline seg length (in) ${ }^{a}$ & 11.283 & 11.575 & 14.019 & 14 & 14 & 14.198 & 14.003 & 10 \\
\hline total length (in) & & & & & & & & \\
\hline & & & & & & & & \\
\hline $\mathrm{Kr}-85(\mathrm{~mol} \%)^{\mathrm{d}}$ & 6 & 6 & 6 & 6 & 6 & 6 & 6 & \\
\hline$+/{ }^{\mathrm{d}}$ & 0.1 & $\begin{array}{r}0.1 \\
\end{array}$ & 0.1 & 0.1 & 0.1 & 0.1 & 0.1 & \\
\hline $\mathrm{Kr}-85(\mathrm{~g})^{\mathrm{K}}$ & $5.0947 \mathrm{E}-06$ & $0.0000 \mathrm{E}+00$ & $2.1823 \mathrm{E}-03$ & $4.2155 \mathrm{E}-03$ & $5.5291 \mathrm{E}-03$ & $6.9024 \mathrm{E}-03$ & $1.4486 \mathrm{E}-03$ & 5.2476 \\
\hline$+/-^{j}$ & $8.4912 \mathrm{E}-08$ & NA & $2.5228 \mathrm{E}-04$ & $4.2866 \mathrm{E}-04$ & $5.5790 \mathrm{E}-04$ & $5.6214 \mathrm{E}-04$ & $1.3465 \mathrm{E}-04$ & 1.5309 \\
\hline Segment Total & & & & & & & & \\
\hline$+/-^{n}$ & & & & & & & & \\
\hline & & & & & & & & \\
\hline $\mathrm{Kr}-86(\mathrm{~mol} \%)^{\mathrm{d}}$ & 48.8 & 48.8 & 48.8 & 48.8 & 48.8 & 48.8 & 48.8 & \\
\hline$+/-^{\mathrm{d}}$ & 0.2 & 0.2 & 0.2 & 0.2 & 0.2 & 0.2 & 0.2 & \\
\hline $\mathrm{Kr}-86(\mathrm{~g})^{\mathrm{k}}$ & $4.1924 \mathrm{E}-05$ & $0.0000 \mathrm{E}+00$ & $1.7958 \mathrm{E}-02$ & $3.4689 \mathrm{E}-02$ & $4.5498 \mathrm{E}-02$ & $5.6799 \mathrm{E}-02$ & $1.1920 \mathrm{E}-02$ & 4.3182 \\
\hline$+/^{j}$ & 1.7182E-07 & NA & $2.0556 \mathrm{E}-03$ & $3.4827 \mathrm{E}-03$ & $4.5317 \mathrm{E}-03$ & $4.5339 \mathrm{E}-03$ & $1.0911 \mathrm{E}-03$ & 1.2579 \\
\hline Segment Total & & & & & & & & \\
\hline$+/-^{n}$ & & & & & & & & \\
\hline Rod Total & & & & & & & & \\
\hline$+/-^{n}$ & & & & & & & & \\
\hline & & & & & & & & \\
\hline shear gas $(\mathrm{g})^{\mathrm{e}}$ & 0 & 0 & 0.0002 & 0.0009 & 0.0014 & 0.0017 & 0.0002 & \\
\hline$+{ }_{-}^{\mathrm{e}}$ & 0 & 0 & 0 & 0.0002 & 0.0003 & 0.0003 & 0 & \\
\hline moles Kr (diss+pl) ${ }^{d}$ & 0.000001 & 0 & 0.000428 & 0.000826 & 0.001083 & 0.001352 & 0.000284 & 0.00 \\
\hline$+l^{-d}$ & 0 & 0 & 0.000049 & 0.000083 & 0.000108 & 0.000108 & 0.000026 & 0.0 \\
\hline $\mathrm{Kr}+\mathrm{Xe}$ diss\&pl $(\mathrm{g})^{\mathrm{d}}$ & 0.0005 & 0 & 0.2427 & 0.5243 & 0.6734 & 0.819 & 0.1758 & 0. \\
\hline$+/^{-\mathrm{d}}$ & 0 & 0 & 0.0085 & 0.0449 & 0.0446 & 0.0375 & 0.0118 & 0.1 \\
\hline moles kr (tot) ${ }^{\circ}$ & $1.0000 \mathrm{E}-06$ & 0 & $4.2835 \mathrm{E}-04$ & $8.2742 \mathrm{E}-04$ & 1.0853E-03 & $1.3548 \mathrm{E}-03$ & $2.8432 \mathrm{E}-04$ & 1.0300 \\
\hline$+/-^{\mathrm{p}}$ & $0.0000 \mathrm{E}+00$ & NA & $4.9000 \mathrm{E}-05$ & $8.3001 \mathrm{E}-05$ & $1.0800 \mathrm{E}-04$ & $1.0800 \mathrm{E}-04$ & $2.6000 \mathrm{E}-05$ & 3.0000 \\
\hline $\mathrm{Xe}-128(\mathrm{~mol} \%)^{\mathrm{d}}$ & 0 & 0 & 0 & 0 & 0 & 0 & 0 & \\
\hline$+/_{-}^{\mathrm{d}}$ & 0 & 0 & 0 & 0 & 0 & 0 & 0 & \\
\hline $\mathrm{Xe}-128(\mathrm{~g})^{\mathrm{k}}$ & $0.0000 \mathrm{E}+00$ & $0.0000 \mathrm{E}+00$ & $0.0000 \mathrm{E}+00$ & $0.0000 \mathrm{E}+00$ & $0.0000 \mathrm{E}+00$ & $0.0000 \mathrm{E}+00$ & $0.0000 \mathrm{E}+00$ & 0.0000 \\
\hline$+/_{-}^{j}$ & \begin{tabular}{|l|}
$N A$ \\
\end{tabular} & \begin{tabular}{|l|}
$N A$ \\
\end{tabular} & NA & NA & NA & NA & \begin{tabular}{|l|} 
NA \\
\end{tabular} & NA \\
\hline SegmentTotal & & & & & & & & \\
\hline$+/-^{n}$ & & & & & & & & \\
\hline
\end{tabular}


Rod "F" 2400408 (PFB III-6 C13)

\begin{tabular}{|c|c|c|c|c|c|c|c|c|}
\hline & $F-00$ & F-01 & $\mathrm{F}-02$ & $\mathrm{~F}-03$ & F-04 & F-05 & $F-06$ & F-07 \\
\hline seg length (in) ${ }^{a}$ & 11.283 & 11.575 & 14.019 & 14 & 14 & 14.198 & 14.003 & \\
\hline \multicolumn{9}{|l|}{ total length (in) } \\
\hline & & & & & & & & \\
\hline Xe-130 (mol\%) $)^{d}$ & 0 & 0 & 0 & 0 & 0 & 0 & 0 & \\
\hline$+/{ }^{\mathrm{d}}$ & 0 & 0 & 0 & 0 & 0 & 0 & 0 & \\
\hline$X e-130(g)^{k}$ & $0.0000 \mathrm{E}+00$ & $0.0000 \mathrm{E}+00$ & $0.0000 \mathrm{E}+00$ & $0.0000 \mathrm{E}+00$ & $0.0000 \mathrm{E}+00$ & $0.0000 \mathrm{E}+00$ & $0.0000 \mathrm{E}+00$ & 0.0000 \\
\hline$+/_{-}^{j}$ & NA & NA & NA & NA & NA & NA & NA & NA \\
\hline \multicolumn{9}{|l|}{ SegmentTotal } \\
\hline \multicolumn{9}{|l|}{$+/-^{n}$} \\
\hline & & & & & & & & \\
\hline $\mathrm{Xe}-131(\mathrm{~mol} \%)^{\mathrm{d}}$ & 12.9 & 12.9 & 12.9 & 12.9 & 12.9 & 12.9 & 12.9 & \\
\hline$+/{ }^{\mathrm{d}}$ & 0.1 & 0.1 & 0.1 & 0.1 & 0.1 & 0.1 & 0.1 & \\
\hline $\mathrm{Xe}-131(\mathrm{~g})^{\mathrm{k}}$ & $5.0660 \mathrm{E}-05$ & $0.0000 \mathrm{E}+00$ & $2.5976 \mathrm{E}-02$ & $5.7260 \mathrm{E}-02$ & $7.3322 \mathrm{E}-02$ & $8.8789 \mathrm{E}-02$ & 1.9121E-02 & 5.775 \\
\hline$+/_{-}^{j}$ & $3.9272 \mathrm{E}-07$ & NA & $9.5035 \mathrm{E}-04$ & $5.5903 \mathrm{E}-03$ & $5.5177 \mathrm{E}-03$ & $4.6112 \mathrm{E}-03$ & $1.4598 \mathrm{E}-03$ & 1.284 \\
\hline \multicolumn{9}{|l|}{ SegmentTotal } \\
\hline \multicolumn{9}{|l|}{$+/-^{n}$} \\
\hline Xe-132(mol\%) & & & & & & 1 & & \\
\hline$+/^{\mathrm{d}}$ & $\frac{22.1}{0.2}$ & $\begin{array}{r}22.1 \\
0.2\end{array}$ & $\frac{2 L .1}{0.2}$ & \begin{tabular}{r|}
22.1 \\
0.2
\end{tabular} & $\frac{22.1}{0.2}$ & \begin{tabular}{r|}
22.1 \\
0.2
\end{tabular} & $\frac{22.1}{0.2}$ & \\
\hline $\mathrm{Xe}-132(\mathrm{~g})^{\mathrm{k}}$ & $8.7452 \mathrm{E}-05$ & $0.0000 \mathrm{E}+00$ & $4.4842 \mathrm{E}-02$ & $9.8845 \mathrm{E}-02$ & $1.2657 \mathrm{E}-01$ & $1.5327 \mathrm{E}-01$ & 3.3007E-02 & 9.969 \\
\hline$+/_{-}^{j}$ & $7.9142 \mathrm{E}-07$ & NA & 1.6539E-03 & $9.6614 \mathrm{E}-03$ & $9.5432 \mathrm{E}-03$ & $7.9922 \mathrm{E}-03$ & $2.5247 \mathrm{E}-03$ & 2.217 \\
\hline \multicolumn{9}{|l|}{ SegmentTotal } \\
\hline \multicolumn{9}{|l|}{$+/-^{n}$} \\
\hline Xe-134(mol\%) d & 26.2 & 26 ? & 262 & 262 & 260 & 26 & 262 & \\
\hline$+/-^{\mathrm{d}}$ & 0.1 & 0.1 & 0.1 & \begin{tabular}{r|}
20.2 \\
0.1
\end{tabular} & 0.1 & \begin{tabular}{r|}
20.2 \\
0.1
\end{tabular} & 26.2 & \\
\hline$X e-134(g)^{k}$ & $1.0525 \mathrm{E}-04$ & $0.0000 \mathrm{E}+00$ & 5.3967E-02 & 1.1896E-01 & $1.5233 \mathrm{E}-01$ & $1.8446 \mathrm{E}-01$ & $3.9724 \mathrm{E}-02$ & 1.199 \\
\hline$+/-^{j}$ & 4.0172E-07 & NA & 1.9405E-03 & 1.1586E-02 & $1.1417 \mathrm{E}-02$ & $9.4989 \mathrm{E}-03$ & $3.0210 \mathrm{E}-03$ & 2.666 \\
\hline \multicolumn{9}{|l|}{ SegmentTotal } \\
\hline$+/-^{\mathrm{n}}$ & & & & & & & & \\
\hline
\end{tabular}


Rod "F" 2400408 (PFB III-6 C13)

\begin{tabular}{|c|c|c|c|c|c|c|c|c|}
\hline & $\mathrm{F}-00$ & $\mathrm{~F}-01$ & $\mathrm{~F}-02$ & $\mathrm{~F}-03$ & $\mathrm{~F}-04$ & $F-05$ & $F-06$ & $\mathrm{~F}-07$ \\
\hline seg length (in) ${ }^{a}$ & 11.283 & 11.575 & 14.019 & 14 & 14 & 14.198 & 14.003 & $\overline{1}$ \\
\hline \multicolumn{9}{|l|}{ total length (in) } \\
\hline & & & & & & & & \\
\hline $\mathrm{Xe}-136(\mathrm{~mol} \%)^{\mathrm{d}}$ & 38.8 & 38.8 & 38.8 & 38.8 & 38.8 & 38.8 & 38.8 & \\
\hline$+/^{\mathrm{d}}$ & 0.2 & 0.2 & 0.2 & 0.2 & 0.2 & 0.2 & 0.2 & \\
\hline $\mathrm{Xe}-136(\mathrm{~g})^{\mathrm{k}}$ & $1.5820 \mathrm{E}-04$ & $0.0000 \mathrm{E}+00$ & $8.1116 \mathrm{E}-02$ & $1.7880 \mathrm{E}-01$ & $2.2896 \mathrm{E}-01$ & $2.7726 \mathrm{E}-01$ & $5.9708 \mathrm{E}-02$ & 1.803 \\
\hline$+/{ }^{j}$ & $8.1544 \mathrm{E}-07$ & NA & $2.9302 \mathrm{E}-03$ & $1.7426 \mathrm{E}-02$ & 1.7179E-02 & $1.4310 \mathrm{E}-02$ & $4.5454 \mathrm{E}-03$ & 4.008 \\
\hline \multicolumn{9}{|l|}{ SegmentTotal } \\
\hline \multicolumn{9}{|l|}{$+/^{\mathrm{n}}$} \\
\hline \multicolumn{9}{|l|}{ Rod total } \\
\hline \multicolumn{9}{|l|}{$+/^{n}$} \\
\hline shear gas $(\mathrm{g})^{\mathrm{e}}$ & 0 & 0 & 0.0002 & 0.0009 & 0.0014 & 0.0017 & 0.0002 & \\
\hline$+/{ }^{e}$ & 0 & 0 & 0 & 0.0002 & 0.0003 & 0.0003 & 0 & \\
\hline${\text { moles Xe (diss }+p l)^{d}}^{d}$ & 0.000003 & 0 & 0.001537 & 0.003385 & 0.004333 & 0.005247 & 0.001131 & 0.00 \\
\hline$+/_{-}^{\mathrm{d}}$ & 0 & 0 & 0.000055 & 0.00033 & 0.000325 & 0.00027 & 0.000086 & 0.00 \\
\hline $\mathrm{Kr}+\mathrm{Xe}$ diss\&pl $(\mathrm{g})^{\mathrm{d}}$ & 0.0005 & 0 & 0.2427 & 0.5243 & 0.6734 & 0.819 & 0.1758 & 0 \\
\hline$+/^{\mathrm{d}}$ & 0 & 0 & 0.0085 & 0.0449 & 0.0446 & 0.0375 & 0.0118 & 0 \\
\hline moles Xe (tot) $^{\circ}$ & $3.0000 \mathrm{E}-06$ & 0 & $1.5383 \mathrm{E}-03$ & $3.3908 \mathrm{E}-03$ & $4.3420 \mathrm{E}-03$ & 5.2579E-03 & 1.1323E-03 & 3.4200 \\
\hline$+/-^{\mathrm{p}}$ & $0.0000 \mathrm{E}+00$ & 0 & $5.5000 \mathrm{E}-05$ & $3.3000 \mathrm{E}-04$ & $3.2501 \mathrm{E}-04$ & $2.7001 \mathrm{E}-04$ & $8.6000 \mathrm{E}-05$ & 7.6000 \\
\hline \multicolumn{9}{|c|}{ Values corrected to 1/1/84 (page 181, Final Report for the LWBR Proof of Breeding Analytical Support Project } \\
\hline & & & & & & & & \\
\hline Cs-137 (atoms) & NA & $1.5000 \mathrm{E}+18$ & $2.3740 \mathrm{E}+20$ & $5.2670 \mathrm{E}+20$ & $6.9990 \mathrm{E}+20$ & $7.7010 \mathrm{E}+20$ & $1.7460 \mathrm{E}+20$ & 5.8670 \\
\hline$+/_{-}^{f}$ & NA & $5.0790 \mathrm{E}+15$ & $8.0300 \mathrm{E}+17$ & $1.7800 \mathrm{E}+18$ & $2.2890 \mathrm{E}+18$ & $2.4290 \mathrm{E}+18$ & $5.9030 \mathrm{E}+17$ & 1.9210 \\
\hline Cs-137 (g) ${ }^{\mathrm{m}}$ & NA & $3.4097 \mathrm{E}-04$ & $5.3964 \mathrm{E}-02$ & 1.1973E-01 & $1.5910 \mathrm{E}-01$ & $1.7505 \mathrm{E}-01$ & $3.9689 \mathrm{E}-02$ & 1.333 \\
\hline$+/-^{m}$ & NA & $1.1545 \mathrm{E}-06$ & 1.8253E-04 & $4.0462 \mathrm{E}-04$ & $5.2032 \mathrm{E}-04$ & $5.5215 \mathrm{E}-04$ & $1.3418 \mathrm{E}-04$ & 4.3667 \\
\hline \multicolumn{9}{|l|}{ Total } \\
\hline \multicolumn{9}{|l|}{$+1-^{n}$} \\
\hline Ce-144 (atoms) & NA & $1.9660 \mathrm{E}+17$ & $1.6810 \mathrm{E}+19$ & $2.9810 \mathrm{E}+19$ & $3.7130 \mathrm{E}+19$ & $3.9680 E+19$ & $1.2010 \mathrm{E}+19$ & 3.4880 \\
\hline$+/^{\mathrm{g}}$ & NA & $1.3690 \mathrm{E}+15$ & $1.1710 \mathrm{E}+17$ & $2.1490 \mathrm{E}+17$ & $2.6320 \mathrm{E}+17$ & $2.7630 \mathrm{E}+17$ & $8.5140 \mathrm{E}+16$ & 2.3980 \\
\hline $\mathrm{Ce}-144(\mathrm{~g})^{\mathrm{m}}$ & NA & 4.6977E-05 & 4.0167E-03 & $7.1230 \mathrm{E}-03$ & $8.8721 \mathrm{E}-03$ & $9.4814 \mathrm{E}-03$ & $2.8698 \mathrm{E}-03$ & $8.334 !$ \\
\hline$+/^{\mathrm{m}}$ & NA & $3.2712 \mathrm{E}-07$ & $2.7981 \mathrm{E}-05$ & $5.1350 \mathrm{E}-05$ & $6.2891 \mathrm{E}-05$ & $6.6021 \mathrm{E}-05$ & $2.0344 \mathrm{E}-05$ & 5.7300 \\
\hline \multicolumn{9}{|l|}{ Total } \\
\hline$+/-^{n}$ & & & & & & & & \\
\hline
\end{tabular}


Rod "F" 2400408 (PFB III-6 C13)

\begin{tabular}{|c|c|c|c|c|c|c|c|c|}
\hline & $\mathrm{F}-00$ & $\mathrm{~F}-01$ & $\mathrm{~F}-02$ & F-03 & F-04 & F-05 & F-06 & $\mathrm{F}-07$ \\
\hline seg length (in) ${ }^{a}$ & 11.283 & 11.575 & 14.019 & 14 & 14 & 14.198 & 14.003 & \\
\hline \multicolumn{9}{|l|}{ total length (in) } \\
\hline Zr-95 (atoms) & NA & $19980 \mathrm{E}+15$ & $14220 \mathrm{E}+17$ & $25240 \mathrm{E}+17$ & $27950 \mathrm{E}+17$ & $28920 \mathrm{E}+17$ & $69420 \mathrm{E}+16$ & 110 \\
\hline$+/-^{\mathrm{h}}$ & NA & $3.9780 \mathrm{E}+13$ & $2.0000 E+15$ & $7.2930 \mathrm{E}+15$ & $9.0260 \mathrm{E}+15$ & $9.3340 \mathrm{E}+15$ & $2.8510 \mathrm{E}+15$ & 3.03 \\
\hline Zr-95 (g) & NA & $3.1485 E-07$ & $2.2408 \mathrm{E}-05$ & $3.9773 \mathrm{E}-05$ & $4.4044 \mathrm{E}-05$ & $4.5572 \mathrm{E}-05$ & $1.0939 \mathrm{E}-05$ & 1.74 \\
\hline$+/-^{m}$ & NA & $6.2686 \mathrm{E}-09$ & $3.1516 \mathrm{E}-07$ & 1.1492E-06 & $1.4223 \mathrm{E}-06$ & $1.4709 \mathrm{E}-06$ & $4.4926 \mathrm{E}-07$ & 4.77 \\
\hline Total & & & & & & & & \\
\hline$+/^{n}$ & & & & & & & & \\
\hline
\end{tabular}

Footnotes

a. ANL Destructive Chemical Assay of 33-Rod LWBR EOL Sample - Rod F, 2400408, page 3

b. ANL Destructive Chemical Assay of 33-Rod LWBR EOL Sample - Rod F, 2400408, page 6

c. ANL Destructive Chemical Assay of 33-Rod LWBR EOL Sample - Rod F, 2400408, page 7

d. ANL Destructive Chemical Assay of 33-Rod LWBR EOL Sample - Rod F, 2400408, page 10

e. ANL Destructive Chemical Assay of 33-Rod LWBR EOL Sample - Rod F, 2400408, page 11

f. ANL Destructive Chemical Assay of 33-Rod LWBR EOL Sample - Rod F, 2400408, page 12

W $\quad$ g. ANL Destructive Chemical Assay of 33-Rod LWBR EOL Sample - Rod F, 2400408, page 13

h. ANL Destructive Chemical Assay of 33-Rod LWBR EOL Sample - Rod F, 2400408, page 14

i. (abundance of the specified isotope)(total weight of uranium) / 100

j. $\quad$ Error Propagation $=\left(\left(s d_{x} / x\right)^{2}+\left(s d_{y} / y\right)^{2}\right)^{1 / 2}(x y)$, where sd is the $+/$ - in the table

k. (mole\%)(number moles gas recovered)(molec wt) / 100

m. (number of atoms per segment)(atomic weight) / 6.0228E+23

n. Error Propagation $=\left(\operatorname{SUM}\left({s d_{i}}^{2}\right)\right)^{1 / 2}$, where sd is the $+/$ - in the table

o. ((shear gas / Xe $+\mathrm{Kr}$ (diss\&pl )) (moles Xe or $\mathrm{Kr}$ (diss $+\mathrm{pl}))+$ moles $\mathrm{Xe}$ or $\mathrm{Kr}$ (diss $+\mathrm{pl})$

p. Error Propagation $=\left(\left(\left(\left(s d_{x} / x\right)^{2}+\left(s d_{y} / y\right)^{2}+\left(s d_{z} / z\right)^{2}\right)^{1 / 2}(x y / z)\right)^{2}+\left(s d_{y}\right)^{2}\right)^{1 / 2}$, where sd is the $+/$ - in the table 
Rod "G" 2300711 (PFB III-6 D29)

\begin{tabular}{|c|c|c|c|c|c|c|c|}
\hline & G-00 & G-01 & G-02 & G-03 & G-04 & G-05 & G-06 \\
\hline seg length (in) ${ }^{a}$ & 11.163 & 8.374 & 17.971 & 17.501 & 17.499 & 17.601 & 10.499 \\
\hline \multicolumn{8}{|l|}{ total length (in) } \\
\hline & & & & & & & \\
\hline $\mathrm{U}-232 \mathrm{wt} \%^{\mathrm{b}}$ & 0 & 0.0134 & 0.0281 & 0.1073 & 0.1403 & 0.1134 & 0.1209 \\
\hline$+/_{-}^{\mathrm{b}}$ & 0 & 0.0004 & 0.0009 & 0.0033 & 0.0043 & 0.0035 & 0.0038 \\
\hline $\mathrm{U}-232 \mathrm{~g}^{\mathrm{i}}$ & $0.0000 \mathrm{E}+00$ & 3.6948E-05 & 3.5407E-03 & $1.2369 \mathrm{E}-02$ & $1.5820 \mathrm{E}-02$ & $1.2608 \mathrm{E}-02$ & $2.5015 \mathrm{E}-03$ \\
\hline$+/{ }^{j}$ & NA & 1.1030E-06 & $1.1341 \mathrm{E}-04$ & 3.8043E-04 & 4.8487E-04 & 3.8914E-04 & $7.8625 \mathrm{E}-05$ \\
\hline \multicolumn{8}{|l|}{ Segment Total } \\
\hline \multicolumn{8}{|l|}{$+/-^{n}$} \\
\hline & & & & & & & \\
\hline $\mathrm{U}-233 \mathrm{wt} \%^{\mathrm{b}}$ & 100 & 99.1676 & 93.7298 & 88.0241 & 85.7769 & 86.8602 & 94.9615 \\
\hline$+/-^{\mathrm{b}}$ & 0 & 0.0154 & 0.0041 & 0.005 & 0.0053 & 0.005 & 0.0103 \\
\hline $\mathrm{U}-233 \mathrm{~g}^{\mathrm{i}}$ & $4.0000 \mathrm{E}-05$ & $2.7343 \mathrm{E}-01$ & $1.1810 \mathrm{E}+01$ & $1.0147 \mathrm{E}+01$ & $9.6719 \mathrm{E}+00$ & $9.6571 \mathrm{E}+00$ & $1.9648 \mathrm{E}+00$ \\
\hline$+/_{-}^{j}$ & $1.0000 \mathrm{E}-05$ & 1.0788E-04 & $2.9697 \mathrm{E}-03$ & $2.5569 \mathrm{E}-03$ & $2.3669 \mathrm{E}-03$ & $2.5541 \mathrm{E}-03$ & $5.1179 \mathrm{E}-04$ \\
\hline \multicolumn{8}{|l|}{ Segment Total } \\
\hline \multicolumn{8}{|l|}{$+/-^{n}$} \\
\hline & & & & & & & \\
\hline $\mathrm{U}-234 \mathrm{wt} \%^{\mathrm{b}}$ & 0 & 0.7748 & 5.2705 & 9.8282 & 11.5306 & 10.7444 & 4.4859 \\
\hline$+/-^{\mathrm{b}}$ & 0 & 0.0005 & 0.0006 & 0.0009 & 0.001 & 0.0009 & 0.0008 \\
\hline $\mathrm{U}-234 \mathrm{~g}^{\mathrm{i}}$ & $0.0000 \mathrm{E}+00$ & $2.1364 \mathrm{E}-03$ & 6.6410E-01 & $1.1330 \mathrm{E}+00$ & $1.3001 \mathrm{E}+00$ & $1.1946 \mathrm{E}+00$ & $9.2815 \mathrm{E}-02$ \\
\hline$+/^{j}$ & NA & 1.5815E-06 & 1.8099E-04 & $2.9686 \mathrm{E}-04$ & $3.2787 \mathrm{E}-04$ & 3.2419E-04 & $2.7516 \mathrm{E}-05$ \\
\hline \multicolumn{8}{|l|}{ Segment Total } \\
\hline \multicolumn{8}{|l|}{$+/-^{n}$} \\
\hline & & & & & & & \\
\hline $\mathrm{U}-235 \mathrm{wt} \%^{\mathrm{b}}$ & 0 & 0.0138 & 0.6276 & 1.6139 & 2.0687 & 1.8205 & 0.4116 \\
\hline$+/-^{\mathrm{b}}$ & 0 & 0.0109 & 0.003 & 0.0031 & 0.003 & 0.0031 & 0.0071 \\
\hline $\mathrm{U}-235 \mathrm{~g}^{\mathrm{i}}$ & $0.0000 \mathrm{E}+00$ & $3.8051 \mathrm{E}-05$ & $7.9080 \mathrm{E}-02$ & $1.8605 \mathrm{E}-01$ & $2.3326 \mathrm{E}-01$ & $2.0240 \mathrm{E}-01$ & $8.5161 \mathrm{E}-03$ \\
\hline$+/_{-}^{j}$ & NA & 3.0055E-05 & 3.7852E-04 & 3.6027E-04 & 3.4275E-04 & $3.4860 \mathrm{E}-04$ & $1.4691 \mathrm{E}-04$ \\
\hline \multicolumn{8}{|l|}{ Segment Total } \\
\hline \multicolumn{8}{|l|}{$+/-^{n}$} \\
\hline & & & & & & & \\
\hline $\mathrm{U}-236 \mathrm{wt} \%^{\mathrm{b}}$ & 0 & 0.0001 & 0.0774 & 0.1652 & 0.2243 & 0.1927 & 0.0148 \\
\hline$+/-^{\mathrm{b}}$ & 0 & 0.0001 & 0.0001 & 0.0001 & 0.0001 & 0.0001 & 0.0001 \\
\hline $\mathrm{U}-236 \mathrm{~g}^{\mathrm{i}}$ & $0.0000 \mathrm{E}+00$ & 2.7573E-07 & 9.7527E-03 & $1.9044 \mathrm{E}-02$ & $2.5291 \mathrm{E}-02$ & $2.1424 \mathrm{E}-02$ & 3.0622E-04 \\
\hline$+/-^{j}$ & \begin{tabular}{|l|}
$N A$ \\
\end{tabular} & $2.7573 \mathrm{E}-07$ & $1.2830 \mathrm{E}-05$ & $1.2440 \mathrm{E}-05$ & 1.2767E-05 & $1.2418 \mathrm{E}-05$ & $2.0703 \mathrm{E}-06$ \\
\hline \multicolumn{8}{|l|}{ Segment Total } \\
\hline$+/-^{n}$ & & & & & & & \\
\hline
\end{tabular}


Rod "G" 2300711 (PFB III-6 D29)

\begin{tabular}{|c|c|c|c|c|c|c|c|}
\hline & G-00 & G-01 & G-02 & G-03 & G-04 & G-05 & G-06 \\
\hline seg length (in) ${ }^{a}$ & 11.163 & 8.374 & 17.971 & 17.501 & 17.499 & 17.601 & 10.4 \\
\hline \multicolumn{8}{|l|}{ total length (in) } \\
\hline & & & & & & & \\
\hline U-238 wt $\%^{b}$ & 0 & 0.0303 & 0.2667 & 0.2613 & 0.2592 & 0.2689 & 0.00 \\
\hline$+/-^{\mathrm{b}}$ & 0 & 0.011 & 0.003 & 0.0032 & 0.0031 & 0.0032 & 0.0 \\
\hline$U-238 g^{i}$ & $0.0000 \mathrm{E}+00$ & $8.3546 \mathrm{E}-05$ & $3.3605 \mathrm{E}-02$ & $3.0122 \mathrm{E}-02$ & $2.9226 \mathrm{E}-02$ & 2.9896E-02 & $1.1173 \mathrm{E}$ \\
\hline$+/_{-}^{j}$ & NA & $3.0330 \mathrm{E}-05$ & $3.7810 \mathrm{E}-04$ & $3.6896 \mathrm{E}-04$ & $3.4961 \mathrm{E}-04$ & $3.5586 \mathrm{E}-04$ & $1.5104 \mathrm{E}$ \\
\hline \multicolumn{8}{|l|}{ Segment Total } \\
\hline \multicolumn{8}{|l|}{$+/-^{n}$} \\
\hline & & & & & & & \\
\hline tot $U^{c}$ & 0.00011 & 0.27573 & 12.60037 & 11.52779 & 11.27561 & 11.11803 & 2.06 \\
\hline$+/^{\mathrm{C}}$ & 0.00001 & 0.0001 & 0.00312 & 0.00283 & 0.00267 & 0.00287 & 0.001 \\
\hline $\mathrm{Kr}-82(\mathrm{~mol} \%)^{\mathrm{d}}$ & 0.1 & 0.1 & 0.1 & 0.1 & 0.1 & 0.1 & \\
\hline$+-^{\mathrm{d}}$ & 0 & 0 & 0 & 0 & 0 & 0 & \\
\hline $\mathrm{Kr}-82(\mathrm{~g})^{\mathrm{K}}$ & 4.0957E-07 & $0.0000 \mathrm{E}+00$ & $1.0021 \mathrm{E}-04$ & 1.7297E-04 & $2.1641 \mathrm{E}-04$ & $1.8871 \mathrm{E}-04$ & $1.4863 \mathrm{E}$ \\
\hline$+{ }^{\mathrm{j}}$ & $0.0000 \mathrm{E}+00$ & NA & 1.8135E-05 & $1.8038 \mathrm{E}-05$ & 2.0476E-05 & 2.0229E-05 & $2.9419 \mathrm{E}$ \\
\hline \multicolumn{8}{|l|}{ Segment Total } \\
\hline \multicolumn{8}{|l|}{$+/-^{n}$} \\
\hline $\mathrm{Kr}-83(\mathrm{~mol} \%)^{\mathrm{d}}$ & 15.6 & 15.6 & 15.6 & 15.6 & 15.6 & 15.6 & \\
\hline$+/{ }^{d}$ & 0.1 & 0.1 & 0.1 & 0.1 & 0.1 & 0.1 & \\
\hline $\mathrm{Kr}-83(\mathrm{~g})^{\mathrm{K}}$ & $6.4673 \mathrm{E}-05$ & $0.0000 \mathrm{E}+00$ & $1.5824 \mathrm{E}-02$ & $2.7313 \mathrm{E}-02$ & $3.4173 \mathrm{E}-02$ & $2.9799 \mathrm{E}-02$ & $2.3469 \mathrm{E}$ \\
\hline$+/-^{j}$ & 4.1457E-07 & NA & 2.8733E-03 & $2.8640 \mathrm{E}-03$ & $3.2542 \mathrm{E}-03$ & $3.2136 \mathrm{E}-03$ & 4.6593E \\
\hline \multicolumn{8}{|l|}{ Segment Total } \\
\hline \multicolumn{8}{|l|}{$+/-^{n}$} \\
\hline $\mathrm{Kr}-84(\mathrm{~mol} \%)^{\mathrm{d}}$ & 29.9 & 29.9 & 29.9 & 29.9 & 29.9 & 29.9 & 2 \\
\hline$+{ }^{\mathrm{d}}$ & 0.2 & 0.2 & 0.2 & 0.2 & 0.2 & 0.2 & \\
\hline $\mathrm{Kr}-84(\mathrm{~g})^{\mathrm{K}}$ & 1.2545E-04 & $0.0000 \mathrm{E}+00$ & $3.0693 \mathrm{E}-02$ & $5.2980 \mathrm{E}-02$ & $6.6286 \mathrm{E}-02$ & $5.7801 \mathrm{E}-02$ & $4.5524 \mathrm{E}$ \\
\hline$+/{ }^{j}$ & 8.3912E-07 & NA & 5.5737E-03 & $5.5563 \mathrm{E}-03$ & $6.3134 \mathrm{E}-03$ & $6.2345 \mathrm{E}-03$ & $9.0381 \mathrm{E}$ \\
\hline \multicolumn{8}{|l|}{ Segment Total } \\
\hline$+/-^{n}$ & & & & & & & \\
\hline
\end{tabular}


Rod "G" 2300711 (PFB III-6 D29)

\begin{tabular}{|c|c|c|c|c|c|c|c|}
\hline & G-00 & G-01 & G-02 & G-03 & G-04 & G-05 & G-06 \\
\hline seg length (in) ${ }^{a}$ & 11.163 & 8.374 & 17.971 & 17.501 & 17.499 & 17.601 & $10.4 \mathrm{~S}$ \\
\hline \multicolumn{8}{|l|}{ total length (in) } \\
\hline & & & & & & & \\
\hline $\mathrm{Kr}-85(\mathrm{~mol} \%)^{\mathrm{d}}$ & 5.9 & 5.9 & 5.9 & 5.9 & 5.9 & 5.9 & 5 \\
\hline$+/{ }^{\mathrm{d}}$ & 0.1 & 0.1 & 0.1 & 0.1 & 0.1 & 0.1 & 0 \\
\hline $\mathrm{Kr}-85(\mathrm{~g})^{\mathrm{k}}$ & $2.5049 \mathrm{E}-05$ & $0.0000 E+00$ & $6.1288 \mathrm{E}-03$ & 1.0579E-02 & 1.3236E-02 & 1.1542E-02 & $9.0901 \mathrm{E}-\mathrm{C}$ \\
\hline$+/{ }^{j}$ & 4.2456E-07 & NA & 1.1170E-03 & 1.1216E-03 & 1.2774E-03 & $1.2578 \mathrm{E}-03$ & $1.8103 \mathrm{E}-\mathrm{C}$ \\
\hline \multicolumn{8}{|l|}{ Segment Total } \\
\hline \multicolumn{8}{|l|}{$+/-^{\mathrm{n}}$} \\
\hline & & & & & & & \\
\hline $\mathrm{Kr}-86(\mathrm{~mol} \%)^{\mathrm{d}}$ & 48.7 & 48.7 & 48.7 & 48.7 & 48.7 & 48.7 & 48 \\
\hline$+/_{-}^{\mathrm{d}}$ & 0.2 & 0.2 & 0.2 & 0.2 & 0.2 & 0.2 & 0 \\
\hline $\mathrm{Kr}-86(\mathrm{~g})^{\mathrm{k}}$ & 2.0919E-04 & $0.0000 \mathrm{E}+00$ & 5.1183E-02 & $8.8348 \mathrm{E}-02$ & 1.1054E-01 & 9.6387E-02 & $7.5914 \mathrm{E}-\mathrm{C}$ \\
\hline$+/^{j}$ & $8.5911 \mathrm{E}-07$ & NA & 9.2906E-03 & 9.2538E-03 & $1.0512 \mathrm{E}-02$ & $1.0384 \mathrm{E}-02$ & $1.5066 \mathrm{E}-\mathrm{C}$ \\
\hline \multicolumn{8}{|l|}{ Segment Total } \\
\hline \multicolumn{8}{|l|}{$+/^{n}$} \\
\hline \multicolumn{8}{|l|}{ Rod Total } \\
\hline \multicolumn{8}{|l|}{$+-^{\mathrm{n}}$} \\
\hline & & & & & & & \\
\hline shear gas $(\mathrm{g})^{\mathrm{e}}$ & 0 & 0 & 0.0018 & 0.0047 & 0.0062 & 0.0058 & 0.000 \\
\hline$+/-^{\mathrm{e}}$ & 0 & 0.0003 & 0.0004 & 0.0009 & 0.0012 & 0.0012 & 0.000 \\
\hline moles $\mathrm{Kr}\left(\right.$ diss+pl) ${ }^{\mathrm{d}}$ & 0.000005 & 0 & 0.00122 & 0.002104 & 0.002631 & 0.002294 & 0.00018 \\
\hline$+I^{-\mathrm{d}}$ & 0 & 0 & 0.000222 & 0.000221 & 0.000251 & 0.000248 & 0.00003 \\
\hline $\mathrm{Kr}+\mathrm{Xe}$ diss\&pl $(\mathrm{g})^{\mathrm{d}}$ & 0.003 & 0 & 0.6543 & 1.2938 & 1.4851 & 1.3601 & 0.122 \\
\hline$+/^{-\mathrm{d}}$ & 0.0001 & 0 & 0.0554 & 0.1499 & 0.1696 & 0.1678 & 0.015 \\
\hline moles kr (tot) $^{\circ}$ & $5.0000 \mathrm{E}-06$ & 0 & 1.2234E-03 & $2.1116 \mathrm{E}-03$ & $2.6420 \mathrm{E}-03$ & $2.3038 \mathrm{E}-03$ & 1.8144E-C \\
\hline$+/^{\mathrm{p}}$ & $0.0000 \mathrm{E}+00$ & $0.0000 \mathrm{E}+00$ & $2.2200 \mathrm{E}-04$ & $2.2101 \mathrm{E}-04$ & $2.5101 \mathrm{E}-04$ & $2.4801 \mathrm{E}-04$ & $3.6003 \mathrm{E}-\mathrm{C}$ \\
\hline $\mathrm{Xe}-128(\mathrm{~mol} \%)^{\mathrm{d}}$ & 0.1 & 0.1 & 0.1 & 0.1 & 0.1 & 0.1 & 0 \\
\hline$+/-^{\mathrm{d}}$ & 0 & 0 & 0 & 0 & 0 & 0 & \\
\hline $\mathrm{Xe}-128(\mathrm{~g})^{\mathrm{k}}$ & $2.4302 \mathrm{E}-06$ & $0.0000 \mathrm{E}+00$ & $5.2610 \mathrm{E}-04$ & 1.0664E-03 & $1.2071 \mathrm{E}-03$ & 1.1151E-03 & $1.0206 \mathrm{E}-\mathrm{C}$ \\
\hline$+/-^{j}$ & 1.2790E-07 & NA & $4.9628 \mathrm{E}-05$ & 1.4172E-04 & 1.6027E-04 & $1.5861 \mathrm{E}-04$ & $1.8548 \mathrm{E}-\mathrm{C}$ \\
\hline \multicolumn{8}{|l|}{ SegmentTotal } \\
\hline$+/-^{n}$ & & & & & & & \\
\hline
\end{tabular}


Rod "G" 2300711 (PFB III-6 D29)

\begin{tabular}{|c|c|c|c|c|c|c|c|}
\hline & G-00 & G-01 & G-02 & G-03 & G-04 & G-05 & G-06 \\
\hline seg length (in) ${ }^{a}$ & 11.163 & 8.374 & 17.971 & 17.501 & 17.499 & 17.601 & $10.4 ?$ \\
\hline \multicolumn{8}{|l|}{ total length (in) } \\
\hline & & & & & & & \\
\hline $\mathrm{Xe}-130(\mathrm{~mol} \%)^{\mathrm{d}}$ & 0.1 & 0.1 & 0.1 & 0.1 & 0.1 & 0.1 & 0 \\
\hline$+/_{-}^{\mathrm{d}}$ & 0 & 0 & 0 & 0 & 0 & 0 & \\
\hline $\mathrm{Xe}-130(\mathrm{~g})^{\mathrm{k}}$ & $2.4682 \mathrm{E}-06$ & $0.0000 \mathrm{E}+00$ & 5.3433E-04 & 1.0830E-03 & $1.2259 \mathrm{E}-03$ & $1.1325 \mathrm{E}-03$ & $1.0366 \mathrm{E}-\mathrm{C}$ \\
\hline$+/{ }^{\mathrm{j}}$ & 1.2990E-07 & NA & 5.0404E-05 & 1.4394E-04 & 1.6277E-04 & $1.6109 \mathrm{E}-04$ & $1.8838 \mathrm{E}-\mathrm{C}$ \\
\hline \multicolumn{8}{|l|}{ SegmentTotal } \\
\hline \multicolumn{8}{|l|}{$+-^{\mathrm{n}}$} \\
\hline & & & & & & & \\
\hline $\mathrm{Xe}-131(\mathrm{~mol} \%)^{d}$ & 11.7 & 11.7 & 11.7 & 11.7 & 11.7 & 11.7 & 11 \\
\hline$+/-^{d}$ & 0.1 & 0.1 & 0.1 & 0.1 & 0.1 & 0.1 & 0 \\
\hline $\mathrm{Xe}-131(\mathrm{~g})^{\mathrm{k}}$ & $2.9100 \mathrm{E}-04$ & $0.0000 \mathrm{E}+00$ & 6.2999E-02 & 1.2769E-01 & $1.4454 \mathrm{E}-01$ & $1.3352 \mathrm{E}-01$ & $1.2221 \mathrm{E}-\mathrm{C}$ \\
\hline$+/{ }^{j}$ & 1.5517E-05 & NA & $5.9671 \mathrm{E}-03$ & $1.7005 \mathrm{E}-02$ & $1.9231 \mathrm{E}-02$ & $1.9027 \mathrm{E}-02$ & $2.2235 \mathrm{E}-\mathrm{C}$ \\
\hline \multicolumn{8}{|l|}{ SegmentTotal } \\
\hline \multicolumn{8}{|l|}{$+-^{\mathrm{n}}$} \\
\hline & & & & & & & \\
\hline $\mathrm{Xe}-132(\mathrm{~mol} \%)^{\mathrm{d}}$ & 22.4 & 22.4 & 22.4 & 22.4 & 22.4 & 22.4 & 22 \\
\hline$+/-^{\mathrm{d}}$ & 0.1 & 0.1 & 0.1 & 0.1 & 0.1 & 0.1 & 0 \\
\hline $\mathrm{Xe}-132(\mathrm{~g})^{\mathrm{k}}$ & $5.6138 \mathrm{E}-04$ & $0.0000 \mathrm{E}+00$ & 1.2153E-01 & $2.4633 \mathrm{E}-01$ & $2.7884 \mathrm{E}-01$ & $2.5759 \mathrm{E}-01$ & $2.3577 \mathrm{E}-\mathrm{C}$ \\
\hline$+/{ }^{\mathrm{j}}$ & 2.9653E-05 & NA & 1.1477E-02 & 3.2757E-02 & $3.7044 \mathrm{E}-02$ & 3.6657E-02 & $4.2860 \mathrm{E}-\mathrm{C}$ \\
\hline \multicolumn{8}{|l|}{ SegmentTotal } \\
\hline \multicolumn{8}{|l|}{$+/-^{n}$} \\
\hline & & & & & & & \\
\hline $\mathrm{Xe}-134(\mathrm{~mol} \%)^{\mathrm{d}}$ & 25.4 & 25.4 & 25.4 & 25.4 & 25.4 & 25.4 & 25 \\
\hline$+/^{\mathrm{d}}$ & 0.1 & 0.1 & 0.1 & 0.1 & 0.1 & 0.1 & 0 \\
\hline $\mathrm{Xe-134}(\mathrm{g})^{\mathrm{k}}$ & $6.4623 \mathrm{E}-04$ & $0.0000 \mathrm{E}+00$ & 1.3990E-01 & $2.8356 \mathrm{E}-01$ & $3.2098 \mathrm{E}-01$ & $2.9652 \mathrm{E}-01$ & $2.7140 \mathrm{E}-\mathrm{C}$ \\
\hline$+/{ }^{j}$ & 3.4107E-05 & NA & $1.3208 \mathrm{E}-02$ & 3.7703E-02 & $4.2637 \mathrm{E}-02$ & $4.2192 \mathrm{E}-02$ & 4.9334E-( \\
\hline \multicolumn{8}{|l|}{ SegmentTotal } \\
\hline$+-^{\mathrm{n}}$ & & & & & & & \\
\hline
\end{tabular}


Rod "G" 2300711 (PFB III-6 D29)

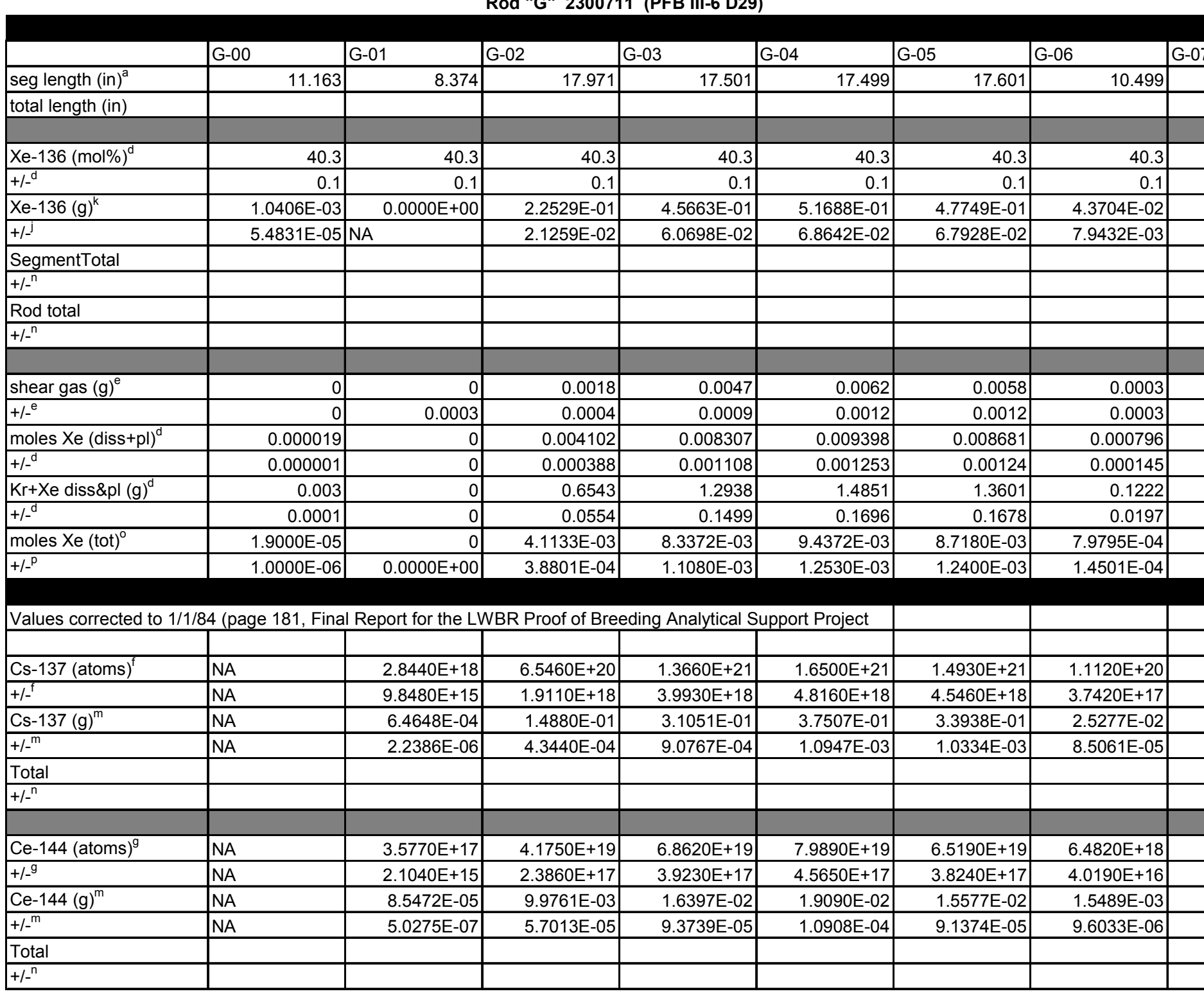


Rod "G" 2300711 (PFB III-6 D29)

\begin{tabular}{|c|c|c|c|c|c|c|c|c|}
\hline & G-00 & G-01 & G-02 & G-03 & G-04 & G-05 & G-06 & G- \\
\hline seg length (in) ${ }^{a}$ & 11.163 & 8.374 & 17.971 & 17.501 & 17.499 & 17.601 & 10.499 & \\
\hline \multicolumn{8}{|l|}{ total length (in) } & \\
\hline $\mathrm{Zr}-95$ (atoms) $^{\mathrm{h}}$ & NA & $38060 \mathrm{~F}+15$ & $35190 F+17$ & $54050 \mathrm{~F}+17$ & $57580 \mathrm{~F}+17$ & $35670 \mathrm{~F}+17$ & $20800 \mathrm{~F}+16$ & \\
\hline$+/-^{\mathrm{h}}$ & NA & $9.7270 \mathrm{E}+13$ & $9.3530 \mathrm{E}+15$ & $1.7500 \mathrm{E}+16$ & $1.5930 \mathrm{E}+16$ & $1.4870 \mathrm{E}+16$ & $8.6540 \mathrm{E}+14$ & \\
\hline $\mathrm{Zr}-95(\mathrm{~g})^{\mathrm{m}}$ & NA & 5.9975E-07 & $5.5453 \mathrm{E}-05$ & $8.5173 \mathrm{E}-05$ & $9.0735 \mathrm{E}-05$ & $5.6209 \mathrm{E}-05$ & $3.2919 \mathrm{E}-06$ & \\
\hline$+/-^{m}$ & NA & $1.5328 \mathrm{E}-08$ & 1.4739E-06 & $2.7577 \mathrm{E}-06$ & $2.5103 \mathrm{E}-06$ & $2.3432 \mathrm{E}-06$ & 1.3637E-07 & \\
\hline \multicolumn{8}{|l|}{ Total } & \\
\hline$+/^{\mathrm{n}}$ & & & & & & & & \\
\hline
\end{tabular}

a. ANL Destructive Chemical Assay of 33-Rod LWBR EOL Sample - Rod G, 2300711, page 3

b. ANL Destructive Chemical Assay of 33-Rod LWBR EOL Sample - Rod G, 2300711, page 6

c. ANL Destructive Chemical Assay of 33-Rod LWBR EOL Sample - Rod G, 2300711, page 7

d. ANL Destructive Chemical Assay of 33-Rod LWBR EOL Sample - Rod G, 2300711, page 10

e. ANL Destructive Chemical Assay of 33-Rod LWBR EOL Sample - Rod G, 2300711, page 11

f. ANL Destructive Chemical Assay of 33-Rod LWBR EOL Sample - Rod G, 2300711, page 12

g. ANL Destructive Chemical Assay of 33-Rod LWBR EOL Sample - Rod G, 2300711, page 13

h. ANL Destructive Chemical Assay of 33-Rod LWBR EOL Sample - Rod G, 2300711, page 14

i. (abundance of the specified isotope)(total weight of uranium) / 100

j. Error Propagation $=\left(\left(s d_{x} / x\right)^{2}+\left(s d_{y} / y\right)^{2}\right)^{1 / 2}(x y)$, where sd is the $+/-$ in the table

k. (mole\%)(number moles gas recovered)(molec wt) / 100

$\mathrm{m}$. (number of atoms per segment)(atomic weight) / 6.0228E+23

n. Error Propagation $=\left(\operatorname{SUM}\left(\mathrm{sd}_{\mathrm{i}}^{2}\right)\right)^{1 / 2}$, where sd is the $+/$ - in the table

o. ((shear gas / Xe $+\mathrm{Kr}$ (diss\&pl ))(moles Xe or $\mathrm{Kr}$ (diss $+\mathrm{pl}))+$ moles $\mathrm{Xe}$ or $\mathrm{Kr}$ (diss $+\mathrm{pl})$

p. Error Propagation $=\left(\left(\left(\left(s d_{x} / x\right)^{2}+\left(s d_{y} / y\right)^{2}+\left(s d_{z} / z\right)^{2}\right)^{1 / 2}(x y / z)\right)^{2}+\left(s d_{y}\right)^{2}\right)^{1 / 2}$, where sd is the $+/-$ in the table 
Rod "H" 3211456 (RN-3B1)

\begin{tabular}{|c|c|c|c|c|c|c|c|c|c|c|c|c|c|c|}
\hline & $\mathrm{H}-00$ & $\mathrm{H}-01$ & $\mathrm{H}-02$ & $\mathrm{H}-03$ & $\mathrm{H}-04$ & $\mathrm{H}-05$ & $\mathrm{H}-06$ & $\mathrm{H}-07$ & $\mathrm{H}-08$ & $\mathrm{H}-09$ & $\mathrm{H}-10$ & $\mathrm{H}-11$ & $\mathrm{H}-12$ & H -13 \\
\hline seg length (in) & 6.262 & 6.434 & 6.99 & 6.954 & 6.99 & 6.989 & 6.962 & 6.982 & 6.97 & 6.982 & $\begin{array}{ll}6.949 \\
\end{array}$ & 7.011 & 6.963 & \\
\hline \multicolumn{15}{|l|}{ total length (in) } \\
\hline $\mathrm{U}-232 \mathrm{wt} \mathrm{o}^{\mathrm{b}}$ & 0 & 0.0031 & 0.0184 & 0.0432 & 0.0691 & 0.0958 & 0.1125 & 0.1259 & 0.129 & 0.1266 & 0.1197 & 0.101 & 0.0794 & \\
\hline$+j-^{\mathrm{D}}$ & 0 & 0.0001 & 0.0006 & 0.0013 & 0.0021 & 0.003 & 0.0035 & 0.0039 & 0.004 & 0.0039 & 0.0037 & 0.0031 & 0.0025 & \\
\hline $\mathrm{U}-232 \mathrm{~g}^{\prime}$ & $0.0000 \mathrm{E}+00$ & $5.2142 \mathrm{E}-06$ & $1.3360 \mathrm{E}-04$ & $6.7697 \mathrm{E}-04$ & \begin{tabular}{|c|}
$1.6291 \mathrm{E}-03$ \\
\end{tabular} & $3.0159 \mathrm{E}-03$ & $4.0274 \mathrm{E}-03$ & $4.8931 \mathrm{E}-03$ & $5.0960 \mathrm{E}-03$ & $4.9242 \mathrm{E}-03$ & \begin{tabular}{|l|}
$4.5181 \mathrm{E}-03$ \\
\end{tabular} & \begin{tabular}{|c|}
$3.4419 \mathrm{E}-03$ \\
\end{tabular} & \begin{tabular}{|l|}
$2.1571 \mathrm{E}-03$ \\
\end{tabular} & 9.369: \\
\hline$++y^{-1}$ & NA & $1.6822 \mathrm{E}-07$ & $4.3565 \mathrm{E}-06$ & $2.0372 \mathrm{E}-05$ & \begin{tabular}{|l}
$4.9510 \mathrm{E}-05$ \\
\end{tabular} & \begin{tabular}{|c|}
$9.4446 \mathrm{E}-05$ \\
\end{tabular} & \begin{tabular}{|c|}
$1.2530 \mathrm{E}-04$ \\
\end{tabular} & $1.5158 \mathrm{E}-04$ & $1.5806 \mathrm{E}-04$ & $1.5170 \mathrm{E}-04$ & $1.3966 \mathrm{E}-04$ & $1.0565 \mathrm{E}-04$ & $6.7919 \mathrm{E}-05$ & 2.845 \\
\hline \multirow{2}{*}{\multicolumn{15}{|c|}{ ， }} \\
\hline & & & & & & & & & & & & & & \\
\hline \multicolumn{15}{|l|}{$+\ldots-1$} \\
\hline $\mathrm{U}-233 w+\%^{\mathrm{D}}$ & 100 & 99.6564 & 99.0447 & 97.9966 & 96.8945 & 95.5857 & 94.7745 & 94.2144 & 94.0069 & 94.1914 & 94.3476 & 95.0824 & 96.2119 & 97 \\
\hline$+j-^{\mathrm{b}}$ & 0 & 0.0412 & 0.0122 & 0.0083 & 0.007 & 0.0072 & 0.0078 & 0.0081 & 0.0079 & 0.0081 & 0.0077 & 0.0084 & 0.0089 & \\
\hline $\mathrm{U}-233 \mathrm{~g}^{\prime}$ & $4.0000 \mathrm{E}-05$ & $1.6762 \mathrm{E}-01$ & $7.1912 \mathrm{E}-01$ & $1.5357 \mathrm{E}+00$ & $2.2844 \mathrm{E}+00$ & $3.0092 \mathrm{E}+00$ & $3.3929 \mathrm{E}+00$ & $3.6616 \mathrm{E}+00$ & $3.7136 \mathrm{E}+00$ & $3.6636 \mathrm{E}+00$ & $3.5611 \mathrm{E}+00$ & $3.2403 \mathrm{E}+00$ & $2.6138 \mathrm{E}+00$ & 1.8493 \\
\hline$++1-1$ & $1.0000 \mathrm{E}-05$ & \begin{tabular}{|c|}
$1.1334 \mathrm{E}-04$ \\
\end{tabular} & $1.9025 \mathrm{E}-04$ & $3.4856 \mathrm{E}-04$ & $5.3941 \mathrm{E}-04$ & \begin{tabular}{|c|}
$5.9894 \mathrm{E}-04$ \\
\end{tabular} & \begin{tabular}{|l|l|}
$7.1107 \mathrm{E}-04$ \\
\end{tabular} & $7.9081 \mathrm{E}-04$ & \begin{tabular}{|l|}
$2.8468 \mathrm{E}-03$ \\
\end{tabular} & $7.8212 \mathrm{E}-04$ & \begin{tabular}{|c|}
$7.4755 \mathrm{E}-04$ \\
\end{tabular} & \begin{tabular}{|l|}
$7.0710 \mathrm{E}-04$ \\
\end{tabular} & \begin{tabular}{|c|c|}
$5.8179 \mathrm{E}-04$ \\
\end{tabular} & 4.701 \\
\hline \multicolumn{15}{|l|}{ Segment Total } \\
\hline \multirow{2}{*}{\multicolumn{15}{|c|}{$+y^{-1}$}} \\
\hline & & & & & & & & & & & & & & \\
\hline $\mathrm{U}-234 \mathrm{wt} \%^{\mathrm{b}}$ & 0 & 0.2609 & 0.8942 & 1.8737 & 2.8474 & 3.9693 & 4.6345 & 5.0898 & 5.2635 & 5.1124 & 4.9977 & 4.4001 & 3.4468 & \\
\hline$+j j^{\mathrm{b}}$ & 0 & 0.0006 & 0.0006 & 0.0006 & 0.0006 & 0.0007 & 0.0007 & 0.0008 & 0.0008 & 0.0008 & 0.0007 & 0.0007 & 0.0007 & \\
\hline $\mathrm{U}-234 \mathrm{~g}^{\prime}$ & $0.0000 \mathrm{E}+00$ & $4.3883 \mathrm{E}-04$ & $6.4924 \mathrm{E}-03$ & $2.9362 \mathrm{E}-02$ & \begin{tabular}{|c|}
$6.7129 \mathrm{E}-02$ \\
\end{tabular} & \begin{tabular}{|l|}
$1.2496 \mathrm{E}-01$ \\
\end{tabular} & \begin{tabular}{|c|}
$1.6591 \mathrm{E}-01$ \\
\end{tabular} & \begin{tabular}{|c|}
$1.9781 \mathrm{E}-01$ \\
\end{tabular} & $2.0793 \mathrm{E}-01$ & $1.9885 \mathrm{E}-01$ & 1.8864E-01 & $1.4995 \mathrm{E}-01$ & $9.3640 \mathrm{E}-02$ & 4.400 \\
\hline$+3-1$ & NA & $1.0362 \mathrm{E}-06$ & $4.6140 \mathrm{E}-06$ & $1.1253 \mathrm{E}-05$ & \begin{tabular}{|l}
$2.0684 \mathrm{E}-05$ \\
\end{tabular} & \begin{tabular}{|l|}
$3.1869 \mathrm{E}-05$ \\
\end{tabular} & $4.0627 \mathrm{E}-05$ & $5.0027 \mathrm{E}-05$ & \begin{tabular}{|l|}
$1.6155 \mathrm{E}-04$ \\
\end{tabular} & $4.9778 \mathrm{E}-05$ & \begin{tabular}{|l|}
$4.5046 \mathrm{E}-05$ \\
\end{tabular} & $3.8266 \mathrm{E}-05$ & \begin{tabular}{|l|}
$2.6852 \mathrm{E}-05$ \\
\end{tabular} & 1.544 \\
\hline \multicolumn{15}{|c|}{ 管 } \\
\hline \multicolumn{15}{|l|}{$+k^{\prime}$} \\
\hline $\mathrm{U}-235 \mathrm{wt} \%^{\mathrm{b}}$ & 0 & 0.0039 & 0.0185 & 0.0766 & 0.1783 & 0.334 & 0.458 & 0.5438 & 0.5738 & 0.5438 & 0.511 & 0.3987 & 0.2493 & 0 \\
\hline$+j_{-}^{\mathrm{b}}$ & & $\begin{array}{r}0.0305 \\
\end{array}$ & 0.0092 & 0.0063 & 0.0052 & 0.0052 & 0.0056 & $\begin{array}{r}0.0057 \\
\end{array}$ & 0.0055 & 0.0057 & 0.0054 & 0.0062 & 0.0066 & \\
\hline $\mathrm{U}-235 \mathrm{~g}^{\prime}$ & $0.0000 \mathrm{E}+00$ & $6.5598 \mathrm{E}-06$ & $1.3432 \mathrm{E}-04$ & $1.2004 \mathrm{E}-03$ & $4.2035 \mathrm{E}-03$ & $1.0515 \mathrm{E}-02$ & $1.6396 \mathrm{E}-02$ & $2.1135 \mathrm{E}-02$ & \begin{tabular}{|l|}
$2.2667 \mathrm{E}-02$ \\
\end{tabular} & $2.1151 \mathrm{E}-02$ & \begin{tabular}{|l|}
$1.9288 \mathrm{E}-02$ \\
\end{tabular} & 1.3587E-02 & $6.7728 \mathrm{E}-03$ & 2.179 \\
\hline$++1-1$ & NA & $5.1301 \mathrm{E}-05$ & $6.6798 \mathrm{E}-05$ & $9.8725 \mathrm{E}-05$ & \begin{tabular}{|l}
$1.2260 \mathrm{E}-04$ \\
\end{tabular} & \begin{tabular}{|l|l|}
$1.6371 \mathrm{E}-04$ \\
\end{tabular} & \begin{tabular}{|l|}
$2.0050 \mathrm{E}-04$ \\
\end{tabular} & \begin{tabular}{|c|}
$2.2157 \mathrm{E}-04$ \\
\end{tabular} & \begin{tabular}{|l|}
$2.1796 \mathrm{E}-04$ \\
\end{tabular} & $2.2174 \mathrm{E}-04$ & $2.0386 \mathrm{E}-04$ & \begin{tabular}{|l|}
$2.1130 \mathrm{E}-04$ \\
\end{tabular} & \begin{tabular}{|l|l|}
$1.7931 \mathrm{E}-04$ \\
\end{tabular} & 1.270 \\
\hline \multicolumn{15}{|c|}{ | } \\
\hline \multirow{2}{*}{\multicolumn{15}{|c|}{$+\xi^{\prime}$}} \\
\hline & & & & & & & & & & & & & & \\
\hline $\mathrm{U}-236 \mathrm{wt} \%^{\mathrm{b}}$ & 0 & 0.0014 & 0.0003 & 0.0012 & 0.0042 & 0.01 & 0.0159 & 0.0214 & 0.0229 & 0.0212 & 0.0193 & 0.013 & 0.0065 & \\
\hline$+j_{-1}^{\mathrm{b}}$ & 0 & 0.0002 & 0.0002 & 0.0002 & 0.0001 & 0.0001 & 0.0001 & 0.0001 & 0.0001 & 0.0001 & 0.0001 & 0.0001 & 0.0001 & \\
\hline $\mathrm{U}-236 \mathrm{~g}^{\prime}$ & $0.0000 \mathrm{E}+00$ & $2.3548 \mathrm{E}-06$ & $2.1782 \mathrm{E}-06$ & $1.8805 \mathrm{E}-05$ & $9.9018 \mathrm{E}-05$ & \begin{tabular}{|c|}
$3.1481 \mathrm{E}-04$ \\
\end{tabular} & $5.6921 \mathrm{E}-04$ & $8.3170 \mathrm{E}-04$ & 9.0463E-04 & \begin{tabular}{|c|c|}
$8.2458 \mathrm{E}-04$ \\
\end{tabular} & \begin{tabular}{|c|}
$7.2847 \mathrm{E}-04$ \\
\end{tabular} & \begin{tabular}{|c|}
$4.4302 \mathrm{E}-04$ \\
\end{tabular} & \begin{tabular}{|c|}
$1.7659 \mathrm{E}-04$ \\
\end{tabular} & $4.741:$ \\
\hline$+p-1$ & NA & $3.3640 \mathrm{E}-07$ & $1.4521 \mathrm{E}-06$ & $3.1341 \mathrm{E}-06$ & \begin{tabular}{|l}
$2.3577 \mathrm{E}-06$ \\
\end{tabular} & \begin{tabular}{|c|}
$3.1487 \mathrm{E}-06$ \\
\end{tabular} & \begin{tabular}{|c|}
$3.5816 \mathrm{E}-06$ \\
\end{tabular} & \begin{tabular}{|c|}
$3.8900 \mathrm{E}-06$ \\
\end{tabular} & $4.0101 \mathrm{E}-06$ & $3.8929 \mathrm{E}-06$ & \begin{tabular}{|c|}
$3.7771 \mathrm{E}-06$ \\
\end{tabular} & \begin{tabular}{|c|}
$3.4090 \mathrm{E}-06$ \\
\end{tabular} & \begin{tabular}{|l|l|}
$2.7169 \mathrm{E}-06$ \\
\end{tabular} & 1.896 \\
\hline \multirow{2}{*}{\multicolumn{15}{|c|}{$\frac{\text { Segment Total }}{++t^{\prime}}$}} \\
\hline \multirow{2}{*}{\multicolumn{15}{|c|}{$+f-y^{\prime \prime}$}} \\
\hline & & & & & & & & & & & & & & \\
\hline $\mathrm{U}-238 \mathrm{wt} \%^{\mathrm{D}}$ & 0 & 0.0744 & 0.024 & 0.0086 & 0.0065 & 0.0053 & 0.0045 & 0.0048 & 0.0039 & 0.0047 & 0.0048 & 0.0048 & 0.0061 & \\
\hline$+j^{-1}$ & 0 & 0.0278 & 0.0082 & 0.0055 & $\begin{array}{l}0.0045 \\
\end{array}$ & \begin{tabular}{|l|}
0.0045 \\
\end{tabular} & \begin{tabular}{|l|}
0.0049 \\
\end{tabular} & 0.005 & 0.0048 & 0.005 & 0.0048 & 0.0054 & 0.0059 & \\
\hline $\mathrm{U}-238 \mathrm{~g}^{\prime}$ & $0.0000 \mathrm{E}+00$ & $1.2514 \mathrm{E}-04$ & $1.7425 \mathrm{E}-04$ & 1.3477E-04 & \begin{tabular}{|l}
$1.5324 \mathrm{E}-04$ \\
\end{tabular} & 1.6685E-04 & $1.6110 \mathrm{E}-04$ & \begin{tabular}{|l|}
$1.8655 \mathrm{E}-04$ \\
\end{tabular} & \begin{tabular}{|l|}
$1.5406 \mathrm{E}-04$ \\
\end{tabular} & \begin{tabular}{|l|}
$1.8281 \mathrm{E}-04$ \\
\end{tabular} & \begin{tabular}{|l|}
$1.8118 \mathrm{E}-04$ \\
\end{tabular} & \begin{tabular}{|l|}
$1.6358 \mathrm{E}-04$ \\
\end{tabular} & $1.6572 \mathrm{E}-04$ & 1.669 \\
\hline$+p-1$ & NA & \begin{tabular}{|l|}
$4.6760 \mathrm{E}-05$ \\
\end{tabular} & $5.9537 \mathrm{E}-05$ & $8.6188 \mathrm{E}-05$ & $1.0609 \mathrm{E}-04$ & \begin{tabular}{|c|}
$1.4167 \mathrm{E}-04$ \\
\end{tabular} & \begin{tabular}{|c|}
$1.7542 \mathrm{E}-04$ \\
\end{tabular} & $1.9432 \mathrm{E}-04$ & $1.8962 \mathrm{E}-04$ & 1.9448E-04 & \begin{tabular}{|c|}
$1.8118 \mathrm{E}-04$ \\
\end{tabular} & \begin{tabular}{|l|l|}
$1.8402 \mathrm{E}-04$ \\
\end{tabular} & \begin{tabular}{|c|}
$1.6029 \mathrm{E}-04$ \\
\end{tabular} & 1.138 \\
\hline \multirow{2}{*}{\multicolumn{15}{|c|}{$\frac{\text { Segment Total }}{++t^{\prime}}$}} \\
\hline \multirow{2}{*}{\multicolumn{8}{|c|}{$+y^{-1}$}} & & & & & & & \\
\hline tot $U^{\circ}$ & 0.00005 & 0.1682 & 0.72606 & 1.56706 & 2.35757 & 3.14813 & 3.57994 & & & & & & & \\
\hline$+\xi^{\circ}$ & 0.00001 & 0.00009 & 0.00017 & 0.00033 & 0.00053 & 0.00058 & 0.00069 & $\begin{array}{l}3.88647 \\
0.00077\end{array}$ & $\begin{array}{l}3.95037 \\
0.00301\end{array}$ & $\begin{array}{r}3.88954 \\
0.0007 \\
\end{array}$ & $\begin{array}{r}3.77448 \\
0.00073\end{array}$ & $\begin{array}{l}3.40785 \\
0.00060\end{array}$ & $\frac{2.716 / 1}{0.00055}$ & 1.8 \\
\hline \multirow{2}{*}{\multicolumn{15}{|c|}{$\mathrm{Kr}-82(\mathrm{~mol} \%)^{\mathrm{d}}$}} \\
\hline & & & & & & & & & & & & & & \\
\hline$+j^{\mathrm{d}}$ & 0 & & 0 & 0 & 0 & 0 & 0 & 0 & 0 & 0 & 0 & 0 & 0 & \\
\hline $\mathrm{Kr}-82(\mathrm{~g})^{\mathrm{k}}$ & $0.0000 \mathrm{E}+00$ & $0.0000 \mathrm{E}+00$ & $0.0000 \mathrm{E}+00$ & $0.0000 \mathrm{E}+00$ & $0.0000 \mathrm{E}+00$ & $0.0000 \mathrm{E}+00$ & $0.0000 \mathrm{E}+00$ & $0.0000 \mathrm{E}+00$ & $0.0000 \mathrm{E}+00$ & $0.0000 \mathrm{E}+00$ & $0.0000 \mathrm{E}+00$ & $0.0000 \mathrm{E}+00$ & $0.0000 \mathrm{E}+00$ & 0.0000 \\
\hline$+p-1$ & NA & NA & NA & NA & NA & NA & NA & NA & NA & \begin{tabular}{|l|l|} 
NA & A \\
\end{tabular} & \begin{tabular}{|l|l|} 
NA & A \\
\end{tabular} & \begin{tabular}{|l|} 
NA \\
\end{tabular} & NA & NA \\
\hline \multirow{2}{*}{\multicolumn{15}{|c|}{$\begin{array}{l}\text { Segment Total } \\
++-^{\prime}\end{array}$}} \\
\hline & & & & & & & & & & & & & & \\
\hline
\end{tabular}


Rod "H" 3211456 (R N-3 B1)

\begin{tabular}{|c|c|c|c|c|c|c|c|c|c|c|c|c|c|c|}
\hline & $\mathrm{H}-00$ & $\mathrm{H}-01$ & $\mathrm{H}-02$ & $\mathrm{H}-03$ & $\mathrm{H}-04$ & $\mathrm{H}-05$ & $\mathrm{H}-06$ & $\mathrm{H}-07$ & $\mathrm{H}-08$ & $\mathrm{H}-09$ & $\mathrm{H}-10$ & $\mathrm{H}-11$ & $\mathrm{H}-12$ & $\mathrm{H}-13$ \\
\hline seg length (in) ${ }^{a}$ & 6.262 & 6.434 & 6.99 & 6.954 & 6.99 & 6.989 & 6.962 & 6.982 & 6.97 & 6.982 & 6.949 & 7.011 & 6.963 & \\
\hline \multicolumn{15}{|l|}{ total length (in) } \\
\hline & & & & & & & & & & & & & & \\
\hline $\mathrm{Kr}-83(\mathrm{mo} / \%)^{d}$ & 15.6 & 15.6 & 15.6 & 15.6 & 15.6 & 15.6 & 15.6 & 15.6 & 15.6 & 15.6 & 15.6 & 15.6 & 15.6 & \\
\hline$+1_{-}^{d}$ & 0.2 & 0.2 & 0.2 & 0.2 & 0.2 & 0.2 & 0.2 & 0.2 & 0.2 & 0.2 & 0.2 & 0.2 & 0.2 & \\
\hline $\mathrm{Kr}-83(\mathrm{~g})^{\mathrm{K}}$ & $0.0000 \mathrm{E}+00$ & $0.0000 E+00$ & $0.0000 \mathrm{E}+00$ & $1.0994 \mathrm{E}-03$ & $1.8108 \mathrm{E}-03$ & $3.2382 \mathrm{E}-03$ & $3.7187 \mathrm{E}-03$ & $5.8217 \mathrm{E}-03$ & $6.4289 \mathrm{E}-03$ & $6.3507 \mathrm{E}-03$ & $5.0662 \mathrm{E}-03$ & 5.1437E-03 & $3.6375 \mathrm{E}-03$ & 1.3 \\
\hline$+3-1$ & NA & \begin{tabular}{|l|l} 
NA & 1 \\
\end{tabular} & NA & $3.6244 \mathrm{E}-04$ & $4.6622 \mathrm{E}-04$ & $6.4806 \mathrm{E}-04$ & $5.3246 \mathrm{E}-04$ & $8.0542 \mathrm{E}-04$ & $1.4769 \mathrm{E}-03$ & $7.0320 \mathrm{E}-04$ & $7.4013 \mathrm{E}-04$ & $7.4022 \mathrm{E}-04$ & $1.2167 \mathrm{E}-03$ & 2.4 \\
\hline \multicolumn{15}{|l|}{ Segment Total } \\
\hline \multicolumn{15}{|l|}{$+1--^{\prime}$} \\
\hline & & & & & & & & & & & & & & \\
\hline $\mathrm{Kr}-84(\mathrm{~mol} \%)^{\mathrm{d}}$ & 29.3 & 29.3 & 29.3 & 29.3 & 29.3 & 29.3 & 29.3 & 29.3 & 29.3 & 29.3 & 29.3 & 29.3 & 29.3 & \\
\hline$+j^{d}$ & 0.3 & 0.3 & 0.3 & 0.3 & 0.3 & 0.3 & 0.3 & 0.3 & 0.3 & 0.3 & 0.3 & 0.3 & 0.3 & \\
\hline $\mathrm{Kr}-84(\mathrm{~g})^{\mathrm{k}}$ & $0.0000 \mathrm{E}+00$ & $0.0000 E+00$ & $0.0000 \mathrm{E}+00$ & $2.0898 \mathrm{E}-03$ & $3.4421 \mathrm{E}-03$ & $6.1552 \mathrm{E}-03$ & $7.0684 \mathrm{E}-03$ & 1.1066E-02 & $1.2220 \mathrm{E}-02$ & $1.2071 \mathrm{E}-02$ & $9.6297 \mathrm{E}-03$ & $9.7771 \mathrm{E}-03$ & $6.9142 \mathrm{E}-03$ & 2.5 \\
\hline$+j-1$ & NA & \begin{tabular}{|l|l} 
NA \\
\end{tabular} & NA & $6.8874 \mathrm{E}-04$ & $8.8580 \mathrm{E}-04$ & 1.2309E-03 & $1.0106 \mathrm{E}-03$ & 1.5286E-03 & $2.8056 \mathrm{E}-03$ & 1.3334E-03 & 1.4049E-03 & 1.4050E-03 & $2.3122 \mathrm{E}-03$ & 4.6 \\
\hline \multicolumn{15}{|l|}{ Segment Total } \\
\hline \multirow{2}{*}{\multicolumn{15}{|c|}{$+j-1$}} \\
\hline & & & & & & & & & & & & & & \\
\hline $\mathrm{Kr}-85(\mathrm{mo} / \%)^{d}$ & 6.1 & 6.1 & 6.1 & 6.1 & 6.1 & 6.1 & 6.1 & 6.1 & 6.1 & 6.1 & 6.1 & 6.1 & 6.1 & \\
\hline$+j_{-}^{-\alpha}$ & 0.2 & $\begin{array}{r}0.2 \\
\end{array}$ & 0.2 & 0.2 & 0.2 & 0.2 & 0.2 & 0.2 & 0.2 & 0.2 & 0.2 & 0.2 & 0.2 & \\
\hline $\mathrm{Kr}-85(\mathrm{~g})^{\mathrm{k}}$ & $0.0000 \mathrm{E}+00$ & $0.0000 E+00$ & $0.0000 \mathrm{E}+00$ & 4.4027E-04 & $7.2515 \mathrm{E}-04$ & $1.2967 \mathrm{E}-03$ & $1.4891 \mathrm{E}-03$ & $2.3313 \mathrm{E}-03$ & $2.5745 \mathrm{E}-03$ & $2.5432 \mathrm{E}-03$ & $2.0287 \mathrm{E}-03$ & $2.0598 \mathrm{E}-03$ & 1.4567E-03 & 5.4 \\
\hline$+1-1$ & NA & NA & NA & $1.4575 \mathrm{E}-04$ & $1.8798 \mathrm{E}-04$ & $2.6245 \mathrm{E}-04$ & $2.1791 \mathrm{E}-04$ & $3.3011 \mathrm{E}-04$ & $5.9649 \mathrm{E}-04$ & $2.9187 \mathrm{E}-04$ & $3.0264 \mathrm{E}-04$ & \begin{tabular}{|c|}
$3.0287 \mathrm{E}-04$ \\
\end{tabular} & $4.8922 \mathrm{E}-04$ & 1.0 \\
\hline \multicolumn{15}{|l|}{ Segment Total } \\
\hline \multicolumn{15}{|l|}{$++-^{\prime}$} \\
\hline & & & & & & & & & & & & & & \\
\hline $\mathrm{Kr}-86(\mathrm{mo} / \%)^{\mathrm{d}}$ & 49.2 & 49.2 & 49.2 & 49.2 & 49.2 & 49.2 & 49.2 & 49.2 & 49.2 & 49.2 & 49.2 & 49.2 & 49.2 & \\
\hline$+j_{-}^{\mathrm{d}}$ & 0.3 & 0.3 & 0.3 & 0.3 & 0.3 & 0.3 & 0.3 & 0.3 & 0.3 & 0.3 & 0.3 & 0.3 & 0.3 & \\
\hline $\mathrm{Kr}-86(\mathrm{~g})^{\mathrm{K}}$ & $0.0000 \mathrm{E}+00$ & $0.0000 \mathrm{E}+00$ & $0.0000 \mathrm{E}+00$ & $3.5928 \mathrm{E}-03$ & $5.9175 \mathrm{E}-03$ & $1.0582 \mathrm{E}-02$ & $1.2152 \mathrm{E}-02$ & $1.9024 \mathrm{E}-02$ & $2.1009 \mathrm{E}-02$ & $2.0753 \mathrm{E}-02$ & $1.6555 \mathrm{E}-02$ & 1.6809E-02 & 1.1887E-02 & 4.4 \\
\hline$+3-1$ & NA & \begin{tabular}{|l|l} 
NA & 1 \\
\end{tabular} & NA & 1.1837E-03 & $1.5221 \mathrm{E}-03$ & $2.1144 \mathrm{E}-03$ & $1.7346 \mathrm{E}-03$ & $2.6232 \mathrm{E}-03$ & $4.8203 \mathrm{E}-03$ & $2.2860 \mathrm{E}-03$ & $2.4114 \mathrm{E}-03$ & $2.4115 \mathrm{E}-03$ & $3.9739 \mathrm{E}-03$ & 8.0 \\
\hline \multicolumn{15}{|l|}{ Segment Total } \\
\hline \multicolumn{15}{|l|}{$+z_{-1}^{\prime}$} \\
\hline \multicolumn{15}{|l|}{ Rod Total } \\
\hline \multirow{2}{*}{\multicolumn{15}{|c|}{$+\xi--^{\prime}$}} \\
\hline & & & & & & & & & & & & & & \\
\hline shear gas $(\mathrm{g})^{\mathrm{e}}$ & 0 & 0 & 0 & 0 & 0 & 0.0002 & 0.0003 & 0.0006 & 0.0006 & 0.0006 & 0.0004 & 0.0003 & 0.0001 & \\
\hline$+j--^{e}$ & 0 & 0 & 0 & 0 & 0 & 0 & 0.0001 & 0.0001 & 0.0001 & 0.0001 & 0.0001 & 0.0001 & 0 & \\
\hline moles $\mathrm{Kr}$ (diss+pl) ${ }^{d}$ & 0 & 0 & 0 & 0.000085 & 0.00014 & 0.00025 & 0.000287 & 0.000449 & 0.000496 & 0.00049 & 0.000391 & 0.000397 & 0.000281 & 0 \\
\hline$+r^{d}$ & 0 & 0 & 0 & 0.000028 & 0.000036 & 0.00005 & 0.000041 & 0.000062 & 0.000114 & 0.000054 & 0.000057 & 0.000057 & 0.000094 & \\
\hline $\mathrm{Kr}+\mathrm{Xe}$ diss\&pl $(\mathrm{g})^{\mathrm{d}}$ & 0.0001 & 0 & 0 & 0.0476 & 0.073 & 0.1419 & 0.1729 & 0.2471 & 0.288 & 0.2973 & 0.232 & 0.1782 & 0.1244 & \\
\hline$+r^{d}$ & 0 & 0 & 0 & 0.0068 & 0.007 & 0.0141 & 0.0169 & 0.0342 & 0.0372 & 0.0296 & 0.0137 & 0.016 & 0.0149 & \\
\hline moles $\mathrm{kr}(\mathrm{tot})^{\circ}$ & 0 & 0 & 0 & $8.5000 \mathrm{E}-05$ & $1.4000 \mathrm{E}-04$ & $2.5035 \mathrm{E}-04$ & $2.8750 \mathrm{E}-04$ & $4.5009 \mathrm{E}-04$ & $4.9703 \mathrm{E}-04$ & 4.9099E-04 & $3.9167 \mathrm{E}-04$ & $3.9767 \mathrm{E}-04$ & $2.8123 \mathrm{E}-04$ & 1.0 \\
\hline$+j_{-P}^{-P}$ & 0 & 0 & 0 & $2.8000 \mathrm{E}-05$ & $3.6000 \mathrm{E}-05$ & $5.0000 \mathrm{E}-05$ & $4.1000 \mathrm{E}-05$ & $6.2001 \mathrm{E}-05$ & $1.1400 \mathrm{E}-04$ & $5.4000 \mathrm{E}-05$ & $5.7000 \mathrm{E}-05$ & 5.7001E-05 & $9.4000 \mathrm{E}-05$ & 1.9 \\
\hline $\mathrm{Xe}-128(\mathrm{~mol} \mathrm{\alpha})^{\mathrm{d}}$ & 0 & 0 & 0 & 0 & 0 & 0 & 0 & 0 & 0 & 0 & 0 & 0 & 0 & \\
\hline$+j_{-}^{\mathrm{d}}$ & 0 & 0 & 0 & 0 & 0 & 0 & 0 & 0 & 0 & 0 & 0 & $\begin{array}{r}0 \\
\end{array}$ & 0 & \\
\hline $\mathrm{xe}-128(\mathrm{~g})^{\mathrm{k}}$ & $0.0000 \mathrm{E}+00$ & $0.0000 \mathrm{E}+00$ & $0.0000 \mathrm{E}+00$ & $0.0000 \mathrm{E}+00$ & $0.0000 \mathrm{E}+00$ & $0.0000 \mathrm{E}+00$ & $0.0000 \mathrm{E}+00$ & $0.0000 \mathrm{E}+00$ & $0.0000 \mathrm{E}+00$ & $0.0000 \mathrm{E}+00$ & $0.0000 \mathrm{E}+00$ & $0.0000 \mathrm{E}+00$ & $0.0000 \mathrm{E}+00$ & 0.00 \\
\hline$+y_{-1}^{-1}$ & NA & NA & NA & \begin{tabular}{|l|l} 
NA \\
\end{tabular} & NA & \begin{tabular}{|l|l} 
NA & \\
\end{tabular} & NA & \begin{tabular}{|l|l}
$N A$ & \\
\end{tabular} & NA & \begin{tabular}{|l|l} 
NA & \\
\end{tabular} & NA & NA & NA & NA \\
\hline \multicolumn{14}{|l|}{ SegmentTotal } & \\
\hline$+1-1$ & & & & & & & & & & & & & & \\
\hline
\end{tabular}


Rod "H" 3211456 (R N-3B1)

\begin{tabular}{|c|c|c|c|c|c|c|c|c|c|c|c|c|c|}
\hline & $\mathrm{H}-00$ & $\mathrm{H}-01$ & $\mathrm{H}-02$ & $\mathrm{H}-03$ & $\mathrm{H}-04$ & $\mathrm{H}-05$ & $\mathrm{H}-06$ & $\mathrm{H}-07$ & $\mathrm{H}-08$ & $\mathrm{H}-09$ & $\mathrm{H}-10$ & $\mathrm{H}-11$ & $\mathrm{H}-12$ \\
\hline seg length (in) ${ }^{a}$ & 6.262 & 6.434 & 6.99 & 6.954 & 6.99 & 6.989 & 6.962 & 6.982 & 6.97 & 6.982 & 6.949 & 7.011 & 6.963 \\
\hline \multicolumn{14}{|l|}{ total length (in) } \\
\hline & & & & & & & & & & & & & \\
\hline $\mathrm{Xe}-130(\mathrm{~mol} \%)^{\mathrm{d}}$ & 0 & 0 & 0 & 0 & 0 & 0 & 0 & 0 & 0 & 0 & 0 & 0 & 0 \\
\hline$+l^{\mathrm{d}}$ & 0 & 0 & 0 & 0 & 0 & 0 & 0 & 0 & 0 & 0 & 0 & 0 & 0 \\
\hline $\mathrm{Xe}-130(\mathrm{~g})^{\mathrm{k}}$ & $0.0000 \mathrm{E}+00$ & $0.0000 \mathrm{E}+00$ & $0.0000 \mathrm{E}+00$ & $0.0000 \mathrm{E}+00$ & $0.0000 \mathrm{E}+00$ & $0.0000 \mathrm{E}+00$ & $0.0000 \mathrm{E}+00$ & $0.0000 \mathrm{E}+00$ & $0.0000 \mathrm{E}+00$ & $0.0000 \mathrm{E}+00$ & $0.0000 \mathrm{E}+00$ & $0.0000 \mathrm{E}+00$ & $0.0000 \mathrm{E}+00$ \\
\hline$+y^{1}$ & \begin{tabular}{|l|l} 
NA & 1 \\
\end{tabular} & NA & NA & NA & NA & NA & NA & NA & NA & \begin{tabular}{|l|l} 
NA & I \\
\end{tabular} & \begin{tabular}{|l|l} 
NA & I \\
\end{tabular} & \begin{tabular}{|l|l} 
NA & 1 \\
\end{tabular} & \begin{tabular}{|l|l}
$N A$ & 1 \\
\end{tabular} \\
\hline \multicolumn{14}{|l|}{ SegmentTotal } \\
\hline \multicolumn{14}{|l|}{$+j^{\prime}$} \\
\hline & & & & & & & & & & & & & \\
\hline $\mathrm{Xe}-131(\mathrm{mo} / \%)^{\mathrm{d}}$ & 12.7 & 12.7 & 12.7 & 12.7 & 12.7 & 12.7 & 12.7 & 12.7 & 12.7 & 12.7 & 12.7 & 12.7 & 12.7 \\
\hline$+j^{\mathrm{d}}$ & 0.1 & 0.1 & 0.1 & 0.1 & 0.1 & 0.1 & 0.1 & 0.1 & 0.1 & 0.1 & 0.1 & 0.1 & 0.1 \\
\hline $\mathrm{xe}-131(\mathrm{~g})^{\mathrm{k}}$ & $1.6625 \mathrm{E}-05$ & $0.0000 \mathrm{E}+00$ & $0.0000 \mathrm{E}+00$ & $5.0041 \mathrm{E}-03$ & $7.5644 \mathrm{E}-03$ & $1.4967 \mathrm{E}-02$ & $1.8419 \mathrm{E}-02$ & $2.5965 \mathrm{E}-02$ & $3.0504 \mathrm{E}-02$ & $3.1734 \mathrm{E}-02$ & $2.4664 \mathrm{E}-02$ & $1.7919 \mathrm{E}-02$ & $1.2462 \mathrm{E}-02$ \\
\hline$+1-1$ & $1.3091 \mathrm{E}-07$ & NA & \begin{tabular}{|l|}
$N A$ \\
\end{tabular} & $7.8237 \mathrm{E}-04$ & $7.8364 \mathrm{E}-04$ & 1.6667E-03 & $2.0500 \mathrm{E}-03$ & $3.5968 \mathrm{E}-03$ & $4.4454 \mathrm{E}-03$ & $3.6329 \mathrm{E}-03$ & $1.5913 \mathrm{E}-03$ & $1.8839 \mathrm{E}-03$ & $1.5658 \mathrm{E}-03$ \\
\hline \multicolumn{14}{|l|}{ SegmentTotal } \\
\hline \multicolumn{14}{|l|}{$+1-1$} \\
\hline & & & & & & & & & & & & & \\
\hline $\mathrm{Xe}-132(\mathrm{~mol} \%)^{\mathrm{d}}$ & 21.2 & 21.2 & 21.2 & 21.2 & 21.2 & 21.2 & 21.2 & 21.2 & 21.2 & 21.2 & 21.2 & 21.2 & 21.2 \\
\hline$+t^{\mathrm{d}}$ & 0.2 & 0.2 & 0.2 & 0.2 & 0.2 & 0.2 & 0.2 & 0.2 & 0.2 & \begin{tabular}{l|l}
0.2 \\
\end{tabular} & 0.2 & \begin{tabular}{l|}
0.2 \\
\end{tabular} & 0.2 \\
\hline $\mathrm{xe}-132(\mathrm{~g})^{\mathrm{k}}$ & $2.7964 \mathrm{E}-05$ & $0.0000 \mathrm{E}+00$ & $0.0000 \mathrm{E}+00$ & $8.4171 \mathrm{E}-03$ & $1.2723 \mathrm{E}-02$ & $2.5175 \mathrm{E}-02$ & $3.0981 \mathrm{E}-02$ & $4.3673 \mathrm{E}-02$ & $5.1308 \mathrm{E}-02$ & $5.3378 \mathrm{E}-02$ & \begin{tabular}{|l|}
$4.1486 \mathrm{E}-02$ \\
\end{tabular} & \begin{tabular}{|c|}
$3.0140 \mathrm{E}-02$ \\
\end{tabular} & $2.0962 \mathrm{E}-02$ \\
\hline$+1-1$ & $2.6381 \mathrm{E}-07$ & NA & NA & $1.3167 \mathrm{E}-03$ & $1.3198 \mathrm{E}-03$ & $2.8064 \mathrm{E}-03$ & $3.4520 \mathrm{E}-03$ & $6.0543 \mathrm{E}-03$ & $7.4820 \mathrm{E}-03$ & 6.1169E-03 & $2.6853 \mathrm{E}-03$ & $3.1727 \mathrm{E}-03$ & $2.6360 \mathrm{E}-03$ \\
\hline \multicolumn{14}{|l|}{ SegmentTotal } \\
\hline$+1--^{\prime}$ & & & & & & & & & & & & & \\
\hline & & & & & & & & & & & & & \\
\hline $\mathrm{Xe}-134(\mathrm{~mol} \%)^{\mathrm{d}}$ & 26.1 & 26.1 & 26.1 & 26.1 & 26.1 & 26.1 & 26.1 & 26.1 & 26.1 & 26.1 & 26.1 & 26.1 & 26.1 \\
\hline$+j^{\mathrm{d}}$ & 0.2 & 0.2 & 0.2 & 0.2 & 0.2 & 0.2 & 0.2 & 0.2 & 0.2 & 0.2 & 0.2 & 0.2 & 0.2 \\
\hline $\mathrm{Xe}-134(\mathrm{~g})^{\mathrm{k}}$ & $3.4949 \mathrm{E}-05$ & $0.0000 \mathrm{E}+00$ & $0.0000 \mathrm{E}+00$ & $1.0520 \mathrm{E}-02$ & $1.5902 \mathrm{E}-02$ & $3.1464 \mathrm{E}-02$ & $3.8721 \mathrm{E}-02$ & $5.4583 \mathrm{E}-02$ & $6.4125 \mathrm{E}-02$ & $6.6713 \mathrm{E}-02$ & 5.1849E-02 & $3.7669 \mathrm{E}-02$ & $2.6198 \mathrm{E}-02$ \\
\hline$+1-1$ & $2.6781 \mathrm{E}-07$ & NA & \begin{tabular}{|l|} 
NA \\
\end{tabular} & $1.6446 \mathrm{E}-03$ & $1.6471 \mathrm{E}-03$ & $3.5032 \mathrm{E}-03$ & $4.3091 \mathrm{E}-03$ & $7.5607 \mathrm{E}-03$ & $9.3445 \mathrm{E}-03$ & $7.6361 \mathrm{E}-03$ & $3.3440 \mathrm{E}-03$ & 3.9599E-03 & $3.2914 \mathrm{E}-03$ \\
\hline \multicolumn{14}{|l|}{ SegmentTotal } \\
\hline \multicolumn{14}{|l|}{$+1--^{\prime}$} \\
\hline & & & & & & & & & & & & & \\
\hline $\mathrm{Xe}-136(\mathrm{~mol} \%)^{\mathrm{d}}$ & 40.1 & 40.1 & 40.1 & 40.1 & 40.1 & 40.1 & 40.1 & 40.1 & 40.1 & 40.1 & 40.1 & 40.1 & 40.1 \\
\hline$+t^{\mathrm{d}}$ & 0.3 & 0.3 & 0.3 & 0.3 & 0.3 & 0.3 & 0.3 & 0.3 & 0.3 & 0.3 & 0.3 & \begin{tabular}{l|l}
0.3 \\
\end{tabular} & 0.3 \\
\hline $\mathrm{Xe}-136(\mathrm{~g})^{\mathrm{k}}$ & 5.4499E-05 & $0.0000 \mathrm{E}+00$ & $0.0000 \mathrm{E}+00$ & $1.6404 \mathrm{E}-02$ & $2.4797 \mathrm{E}-02$ & $4.9063 \mathrm{E}-02$ & $6.0380 \mathrm{E}-02$ & $8.5115 \mathrm{E}-02$ & $9.9995 \mathrm{E}-02$ & $1.0403 \mathrm{E}-01$ & $8.0852 \mathrm{E}-02$ & $5.8739 \mathrm{E}-02$ & $4.0852 \mathrm{E}-02$ \\
\hline$+y-1$ & $4.0772 \mathrm{E}-07$ & NA & \begin{tabular}{|l|l} 
NA \\
\end{tabular} & $2.5644 \mathrm{E}-03$ & $2.5682 \mathrm{E}-03$ & $5.4622 \mathrm{E}-03$ & $6.7187 \mathrm{E}-03$ & $1.1789 \mathrm{E}-02$ & $1.4570 \mathrm{E}-02$ & $1.1906 \mathrm{E}-02$ & $5.2127 \mathrm{E}-03$ & $6.1741 \mathrm{E}-03$ & $5.1320 \mathrm{E}-03$ \\
\hline \multicolumn{14}{|l|}{ SegmentTotal } \\
\hline \multicolumn{14}{|l|}{$+1--^{\prime}$} \\
\hline \multicolumn{14}{|l|}{ Rod total } \\
\hline \multicolumn{14}{|l|}{$+\xi^{\prime}$} \\
\hline & & & & & & & & & & & & & \\
\hline shear gas $(g)^{e}$ & 0 & 0 & 0 & 0 & 0 & 0.0002 & 0.0003 & 0.0006 & 0.0006 & 0.0006 & 0.0004 & 0.0003 & 0.0001 \\
\hline$+1--^{e}$ & 0 & 0 & 0 & 0 & 0 & 0 & 0.0001 & 0.0001 & 0.0001 & 0.0001 & 0.0001 & 0.0001 & 0 \\
\hline moles Xe (diss $+p l)^{d}$ & 0.000001 & 0 & 0 & 0.000301 & 0.000455 & 0.000899 & 0.001106 & 0.001558 & 0.001831 & 0.001905 & 0.001481 & 0.001076 & 0.000749 \\
\hline$+j_{-}^{\alpha}$ & 0 & 0 & 0 & 0.000047 & 0.000047 & 0.0001 & 0.000123 & 0.000216 & 0.000267 & 0.000218 & 0.000095 & 0.000113 & 0.000094 \\
\hline $\mathrm{Kr}+\mathrm{Xe}$ diss\&pl $(\mathrm{g})^{\mathrm{d}}$ & 0.0001 & 0 & 0 & 0.0476 & 0.073 & 0.1419 & 0.1729 & 0.2471 & 0.288 & 0.2973 & 0.232 & 0.1782 & 0.1244 \\
\hline$+j^{\mathrm{d}}$ & 0 & 0 & 0 & 0.0068 & 0.007 & 0.0141 & 0.0169 & 0.0342 & 0.0372 & 0.0296 & 0.0137 & 0.016 & 0.0149 \\
\hline moles Xe (tot) $^{\circ}$ & $1.0000 \mathrm{E}-06$ & 0 & 0 & $3.0100 \mathrm{E}-04$ & $4.5500 \mathrm{E}-04$ & $9.0027 \mathrm{E}-04$ & $1.1079 \mathrm{E}-03$ & $1.5618 \mathrm{E}-03$ & $1.8348 \mathrm{E}-03$ & $1.9088 \mathrm{E}-03$ & $1.4836 \mathrm{E}-03$ & $1.0778 \mathrm{E}-03$ & $7.4960 \mathrm{E}-04$ \\
\hline$++--^{\mathrm{P}}$ & $0.0000 \mathrm{E}+00$ & 0 & 0 & 4.7000E-05 & 4.7000E-05 & $1.0000 \mathrm{E}-04$ & $1.2300 \mathrm{E}-04$ & $2.1600 \mathrm{E}-04$ & $2.6700 \mathrm{E}-04$ & $2.1800 \mathrm{E}-04$ & $9.5002 \mathrm{E}-05$ & $1.1300 \mathrm{E}-04$ & $9.4000 \mathrm{E}-05$ \\
\hline
\end{tabular}




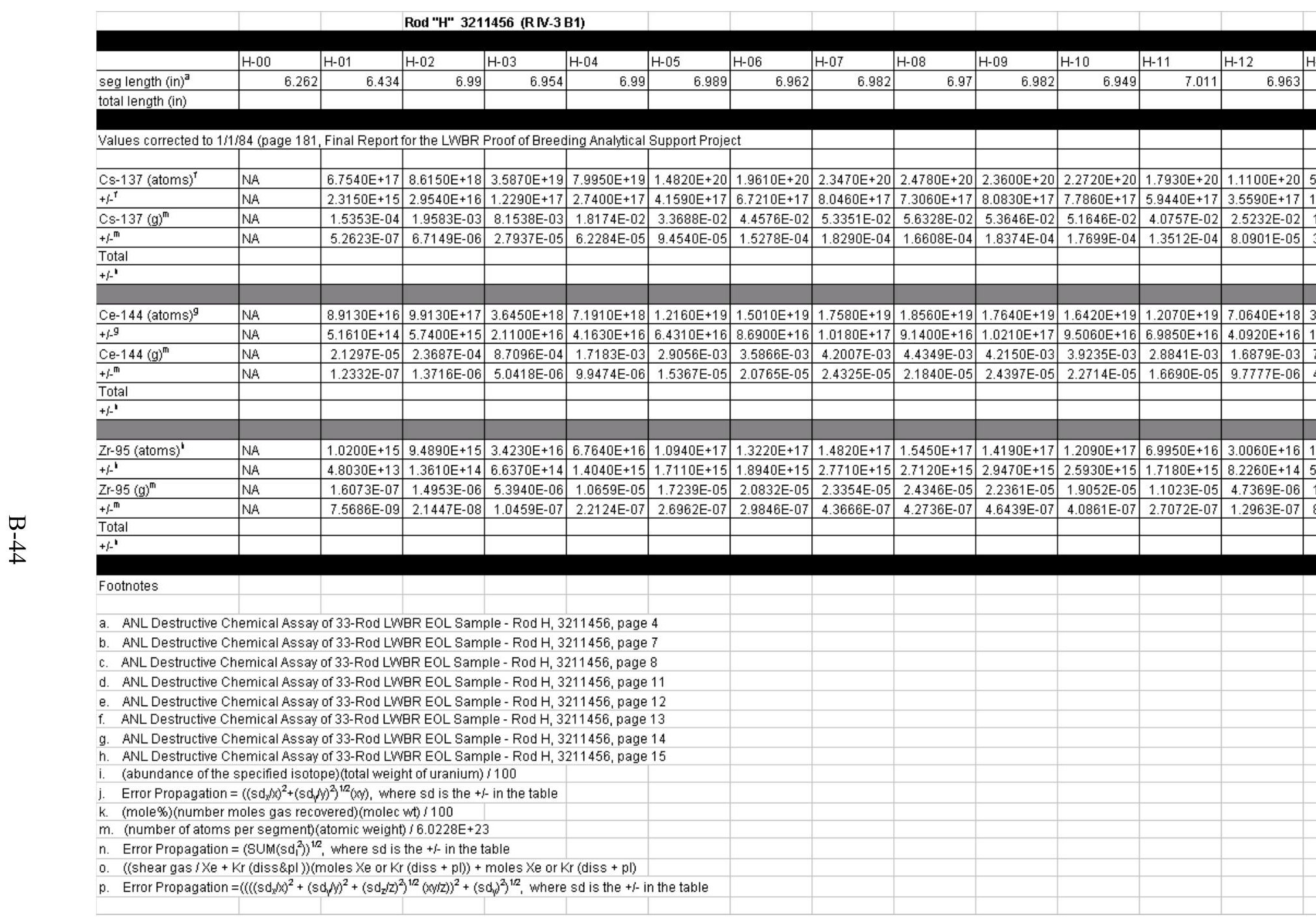


Rod "I" 1605519 (SBI-3 E56)

\begin{tabular}{|c|c|c|c|c|c|c|c|c|}
\hline & $1-00$ & $\mid-01$ & $1-02$ & $1-03$ & I-04 & $1-05$ & | $1-06$ & I-07 \\
\hline seg length (in) ${ }^{a}$ & 11.027 & 11.202 & 14.297 & 14.095 & 14.098 & 14.097 & 14.096 & 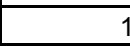 \\
\hline \multicolumn{9}{|l|}{ total length (in) } \\
\hline & & & & & & & & \\
\hline U-232 wt $\%^{b}$ & 0 & 0.0158 & 0.0358 & 0.1227 & 0.1852 & 0.1947 & 0.1575 & \\
\hline$+/_{-}^{\mathrm{b}}$ & 0 & 0.0005 & 0.0011 & 0.0038 & 0.0057 & 0.006 & 0.0049 & 0 \\
\hline U-232 $\mathrm{g}^{\mathrm{i}}$ & $0.0000 \mathrm{E}+00$ & $6.6753 \mathrm{E}-05$ & $3.3265 \mathrm{E}-03$ & $1.1649 \mathrm{E}-02$ & $1.8055 \mathrm{E}-02$ & 1.8929E-02 & 1.4799E-02 & 5.359 \\
\hline$+/{ }^{j}$ & NA & $2.1125 \mathrm{E}-06$ & $1.0221 \mathrm{E}-04$ & $3.6078 \mathrm{E}-04$ & 5.5569E-04 & $5.8334 \mathrm{E}-04$ & 4.6044E-04 & 1.697 \\
\hline \multicolumn{9}{|l|}{ Segment Total } \\
\hline \multicolumn{9}{|l|}{$+/-^{n}$} \\
\hline & & & & & & & & \\
\hline$U-233 w t \%^{b}$ & 100 & 99.061 & 94.0117 & 88.9998 & 86.0057 & 85.4541 & 86.8993 & 91 \\
\hline$+/_{-}^{\mathrm{b}}$ & 0 & 0.0146 & 0.0062 & 0.0063 & 0.0069 & 0.0068 & 0.0069 & 0 \\
\hline $\mathrm{U}-233 \mathrm{~g}^{\mathrm{i}}$ & $4.0000 \mathrm{E}-05$ & 4.1852E-01 & $8.7354 \mathrm{E}+00$ & $8.4494 \mathrm{E}+00$ & $8.3844 \mathrm{E}+00$ & $8.3079 \mathrm{E}+00$ & $8.1654 \mathrm{E}+00$ & 8.176 \\
\hline$+/^{j}$ & $1.0000 \mathrm{E}-05$ & 1.3392E-04 & $2.3014 \mathrm{E}-03$ & $2.2267 \mathrm{E}-03$ & $2.1628 \mathrm{E}-03$ & $2.2281 \mathrm{E}-03$ & $2.1095 \mathrm{E}-03$ & 1.915 \\
\hline \multicolumn{9}{|l|}{ Segment Total } \\
\hline \multicolumn{9}{|l|}{$+/-^{n}$} \\
\hline & & & & & & & & \\
\hline U-234 wt $\%{ }^{b}$ & 0 & 0.8865 & 5.1233 & 9.0783 & 11.2823 & 11.6908 & 10.6757 & 7 \\
\hline$+/_{-}^{b}$ & 0 & 0.0021 & 0.0019 & 0.0019 & 0.0019 & 0.0019 & 0.0019 & 0 \\
\hline $\mathrm{U}-234 \mathrm{~g}^{\mathrm{i}}$ & $0.0000 \mathrm{E}+00$ & $3.7454 \mathrm{E}-03$ & $4.7605 \mathrm{E}-01$ & $8.6187 \mathrm{E}-01$ & $1.0999 \mathrm{E}+00$ & $1.1366 \mathrm{E}+00$ & $1.0031 \mathrm{E}+00$ & 6.390 \\
\hline$+L^{j}$ & NA & $8.9358 \mathrm{E}-06$ & $2.1427 \mathrm{E}-04$ & $2.8356 \mathrm{E}-04$ & $3.2714 \mathrm{E}-04$ & 3.4476E-04 & $3.0445 \mathrm{E}-04$ & 2.233 \\
\hline \multicolumn{9}{|l|}{ Segment Total } \\
\hline \multicolumn{9}{|l|}{$+/-^{\mathrm{n}}$} \\
\hline & & & & & & & & \\
\hline $\mathrm{U}-235 \mathrm{wt} \%{ }^{\mathrm{b}}$ & 0 & 0.0187 & 0.5588 & 1.4793 & 2.1395 & 2.255 & 1.9008 & 0 \\
\hline$+/_{-}^{\mathrm{b}}$ & 0 & 0.0103 & 0.0044 & 0.004 & 0.0037 & 0.0034 & 0.0041 & 0 \\
\hline U-235 gi & $0.0000 \mathrm{E}+00$ & $7.9006 \mathrm{E}-05$ & 5.1923E-02 & 1.4044E-01 & $2.0857 \mathrm{E}-01$ & 2.1923E-01 & $1.7861 \mathrm{E}-01$ & 8.473 \\
\hline$+I_{-}^{j}$ & NA & $4.3516 \mathrm{E}-05$ & $4.0905 \mathrm{E}-04$ & $3.8142 \mathrm{E}-04$ & 3.6431E-04 & $3.3528 \mathrm{E}-04$ & 3.8774E-04 & 3.132 \\
\hline \multicolumn{9}{|l|}{ Segment Total } \\
\hline \multicolumn{9}{|l|}{$+/-^{n}$} \\
\hline & & & & & & & & \\
\hline U-236 wt $\%{ }^{b}$ & 0 & 0 & 0.037 & 0.1122 & 0.1964 & 0.2143 & 0.1631 & 0 \\
\hline$+1-^{\mathrm{b}}$ & 0 & 0.0002 & 0.0002 & 0.0002 & 0.0002 & 0.0002 & 0.0002 & 0 \\
\hline $\mathrm{U}-236 \mathrm{~g}^{\mathrm{i}}$ & $0.0000 \mathrm{E}+00$ & $0.0000 \mathrm{E}+00$ & $3.4380 \mathrm{E}-03$ & 1.0652E-02 & 1.9146E-02 & $2.0834 \mathrm{E}-02$ & 1.5325E-02 & 5.797 \\
\hline$+/-^{j}$ & NA & NA & $1.8604 \mathrm{E}-05$ & 1.9179E-05 & $2.0054 \mathrm{E}-05$ & $2.0163 \mathrm{E}-05$ & 1.9167E-05 & 1.791 \\
\hline \multicolumn{9}{|l|}{ Segment Total } \\
\hline$+-^{\mathrm{n}}$ & & & & & & & & \\
\hline
\end{tabular}


Rod "I" 1605519 (SBI-3 E56)

\begin{tabular}{|c|c|c|c|c|c|c|c|c|}
\hline & $1-00$ & $\mid-01$ & $1-02$ & $\mid-03$ & I-04 & I-05 & I-06 & I-07 \\
\hline seg length (in) ${ }^{a}$ & 11.027 & 11.202 & 14.297 & 14.095 & 14.098 & 14.097 & 14.096 & 1 \\
\hline \multicolumn{9}{|l|}{ total length (in) } \\
\hline & & & & & & & & \\
\hline $\mathrm{U}-238 \mathrm{wt} \%^{\mathrm{b}}$ & 0 & 0.018 & 0.2334 & 0.2076 & 0.191 & 0.1912 & 0.2037 & 0 \\
\hline$+/_{-}^{\mathrm{b}}$ & 0 & 0.0103 & 0.0043 & 0.004 & 0.0037 & 0.0034 & 0.0042 & 0 \\
\hline $\mathrm{U}-238 \mathrm{~g}^{\mathrm{i}}$ & $0.0000 \mathrm{E}+00$ & $7.6048 \mathrm{E}-05$ & $2.1687 \mathrm{E}-02$ & 1.9709E-02 & $1.8620 \mathrm{E}-02$ & 1.8589E-02 & 1.9140E-02 & 2.093 \\
\hline$+/^{\mathrm{j}}$ & \begin{tabular}{|l|}
$N A$ \\
\end{tabular} & $4.3516 \mathrm{E}-05$ & $3.9959 \mathrm{E}-04$ & 3.7978E-04 & 3.6073E-04 & $3.3058 \mathrm{E}-04$ & $3.9468 \mathrm{E}-04$ & 3.126 \\
\hline \multicolumn{9}{|l|}{ Segment Total } \\
\hline \multicolumn{9}{|l|}{$+/-^{n}$} \\
\hline & & & & & & & & \\
\hline tot $U^{C}$ & 0.00011 & 0.42249 & 9.29183 & 9.49378 & 9.74871 & 9.72203 & 9.39636 & 8. \\
\hline$+/^{\mathrm{C}}$ & 0.00001 & 0.00012 & 0.00237 & 0.00241 & 0.00239 & 0.00249 & 0.00231 & $\overline{0.1}$ \\
\hline $\mathrm{Kr}-82(\mathrm{~mol} \%)^{\mathrm{d}}$ & 0.2 & 0.2 & 0.2 & 0.2 & 0.2 & 0.2 & 0.2 & \\
\hline$+/{ }^{\mathrm{d}}$ & 0.1 & 0.1 & 0.1 & 0.1 & 0.1 & 0.1 & 0.1 & \\
\hline $\mathrm{Kr}-82(\mathrm{~g})^{\mathrm{K}}$ & 9.8296E-07 & $0.0000 \mathrm{E}+00$ & $1.3670 \mathrm{E}-04$ & $2.6405 \mathrm{E}-04$ & $4.5848 \mathrm{E}-04$ & 3.5089E-04 & $3.7442 \mathrm{E}-04$ & 1.920 \\
\hline$+-^{j}$ & 4.9148E-07 & NA & $7.0440 \mathrm{E}-05$ & 1.3417E-04 & $2.3408 \mathrm{E}-04$ & 1.7973E-04 & 1.9106E-04 & 1.027 \\
\hline \multicolumn{9}{|l|}{ Segment Total } \\
\hline \multicolumn{9}{|l|}{$+/-^{n}$} \\
\hline & & & & & & & & \\
\hline $\mathrm{Kr}-83(\mathrm{~mol} \%)^{\mathrm{d}}$ & 15.4 & 15.4 & 15.4 & 15.4 & 15.4 & 15.4 & 15.4 & \\
\hline$+/^{\mathrm{d}}$ & 0.1 & 0.1 & 0.1 & 0.1 & 0.1 & 0.1 & 0.1 & \\
\hline $\mathrm{Kr}-83(\mathrm{~g})^{\mathrm{k}}$ & $7.6613 \mathrm{E}-05$ & $0.0000 \mathrm{E}+00$ & $1.0654 \mathrm{E}-02$ & $2.0580 \mathrm{E}-02$ & $3.5734 \mathrm{E}-02$ & $2.7349 \mathrm{E}-02$ & $2.9182 \mathrm{E}-02$ & 1.497 \\
\hline$+/-{ }^{j}$ & 4.9748E-07 & NA & $1.3298 \mathrm{E}-03$ & $1.8691 \mathrm{E}-03$ & 3.6975E-03 & 3.0442E-03 & $2.9812 \mathrm{E}-03$ & 2.849 \\
\hline \multicolumn{9}{|l|}{ Segment Total } \\
\hline \multicolumn{9}{|l|}{$+/_{-}^{n}$} \\
\hline & & & & & & & & \\
\hline $\mathrm{Kr}-84(\mathrm{~mol} \%)^{\mathrm{d}}$ & 30.2 & 30.2 & 30.2 & 30.2 & 30.2 & 30.2 & 30.2 & \\
\hline$+/^{\mathrm{d}}$ & 0.2 & 0.2 & 0.2 & 0.2 & 0.2 & 0.2 & 0.2 & \\
\hline $\mathrm{Kr}-84(\mathrm{~g})^{\mathrm{K}}$ & $1.5205 \mathrm{E}-04$ & $0.0000 \mathrm{E}+00$ & $2.1145 \mathrm{E}-02$ & 4.0844E-02 & $7.0919 \mathrm{E}-02$ & 5.4277E-02 & 5.7916E-02 & 2.971 \\
\hline$+/^{j}$ & 1.0069E-06 & NA & $2.6392 \mathrm{E}-03$ & 3.7098E-03 & $7.3388 \mathrm{E}-03$ & $6.0420 \mathrm{E}-03$ & $5.9171 \mathrm{E}-03$ & 5.654 \\
\hline \multicolumn{9}{|l|}{ Segment Total } \\
\hline$+/-^{n}$ & & & & & & & & \\
\hline
\end{tabular}


Rod "I" 1605519 (SBI-3 E56)

\begin{tabular}{|c|c|c|c|c|c|c|c|c|}
\hline & $1-00$ & $\mid-01$ & |-02 & I-03 & |-04 & 1-05 & 1-06 & | I-07 \\
\hline seg length (in) ${ }^{a}$ & 11.027 & 11.202 & 14.297 & 14.095 & 14.098 & 14.097 & 14.096 & 1. \\
\hline \multicolumn{9}{|l|}{ total length (in) } \\
\hline & & & & & & & & \\
\hline $\mathrm{Kr}-85(\mathrm{~mol} \%)^{\mathrm{d}}$ & 5.8 & 5.8 & 5.8 & 5.8 & 5.8 & 5.8 & 5.8 & \\
\hline$+/-^{d}$ & 0.1 & 0.1 & 0.1 & 0.1 & 0.1 & 0.1 & 0.1 & \\
\hline $\mathrm{Kr}-85(\mathrm{~g})^{\mathrm{k}}$ & $2.9550 \mathrm{E}-05$ & $0.0000 \mathrm{E}+00$ & 4.1093E-03 & $7.9377 \mathrm{E}-03$ & $1.3783 \mathrm{E}-02$ & $1.0548 \mathrm{E}-02$ & 1.1256E-02 & 5.774 \\
\hline$+/{ }^{j}$ & $5.0947 \mathrm{E}-07$ & \begin{tabular}{|l|} 
NA \\
\end{tabular} & $5.1707 \mathrm{E}-04$ & $7.3196 \mathrm{E}-04$ & $1.4430 \mathrm{E}-03$ & $1.1862 \mathrm{E}-03$ & $1.1638 \mathrm{E}-03$ & 1.1028 \\
\hline \multicolumn{9}{|l|}{ Segment Total } \\
\hline \multicolumn{9}{|l|}{$+/-^{n}$} \\
\hline $\mathrm{Kr}-86(\mathrm{~mol} \%)^{\mathrm{d}}$ & 48.6 & 48.6 & 48.6 & 48.6 & 48.6 & 48.6 & 48.6 & \\
\hline$+/_{-}^{\mathrm{d}}$ & 0.2 & 0.2 & 0.2 & 0.2 & 0.2 & 0.2 & 0.2 & \\
\hline $\mathrm{Kr}-86(\mathrm{~g})^{\mathrm{k}}$ & $2.5052 \mathrm{E}-04$ & $0.0000 \mathrm{E}+00$ & $3.4838 \mathrm{E}-02$ & 6.7295E-02 & $1.1685 \mathrm{E}-01$ & 8.9427E-02 & 9.5423E-02 & 4.895 \\
\hline$+I^{j}$ & $1.0309 \mathrm{E}-06$ & NA & $4.3447 \mathrm{E}-03$ & $6.1023 \mathrm{E}-03$ & $1.2076 \mathrm{E}-02$ & $9.9441 \mathrm{E}-03$ & $9.7364 \mathrm{E}-03$ & 9.313 \\
\hline \multicolumn{9}{|l|}{ Segment Total } \\
\hline \multicolumn{9}{|l|}{$+/-^{n}$} \\
\hline \multicolumn{9}{|l|}{ Rod Total } \\
\hline \multicolumn{9}{|l|}{$+/-^{n}$} \\
\hline & & & & & & & & \\
\hline shear gas $(\mathrm{g})^{\mathrm{e}}$ & 0 & 0 & 0.0009 & 0.0023 & 0.0033 & 0.0033 & 0.003 & 0 \\
\hline$+/-^{\mathrm{e}}$ & 0 & 0.0003 & 0.0003 & 0.0005 & 0.0007 & 0.0007 & 0.0006 & 0 \\
\hline moles Kr (diss+pl) ${ }^{d}$ & 0.000006 & 0 & 0.000833 & 0.001608 & 0.002793 & 0.002137 & 0.00228 & 0.00 \\
\hline$+l^{-\mathrm{d}}$ & 0 & 0 & 0.000104 & 0.000146 & 0.000289 & 0.000238 & 0.000233 & 0.00 \\
\hline $\mathrm{Kr}+\mathrm{Xe}$ diss\&pl $(\mathrm{g})^{\mathrm{d}}$ & 0.0033 & 0 & 0.5392 & 0.9869 & 1.6595 & 1.4567 & 1.2554 & 0 \\
\hline$+/^{-\mathrm{d}}$ & 0.0002 & 0 & 0.0228 & 0.0666 & 0.1317 & 0.1291 & 0.1265 & 0 \\
\hline moles kr (tot) ${ }^{\circ}$ & $6.0000 \mathrm{E}-06$ & 0 & $8.3439 \mathrm{E}-04$ & 1.6117E-03 & $2.7986 \mathrm{E}-03$ & $2.1418 \mathrm{E}-03$ & $2.2854 \mathrm{E}-03$ & 1.172 \\
\hline$+/^{\mathrm{p}}$ & $0.0000 \mathrm{E}+00$ & $0.0000 \mathrm{E}+00$ & $1.0400 \mathrm{E}-04$ & $1.4600 \mathrm{E}-04$ & $2.8900 \mathrm{E}-04$ & $2.3800 \mathrm{E}-04$ & $2.3300 \mathrm{E}-04$ & 2.2300 \\
\hline $\mathrm{Xe}-128(\mathrm{~mol} \%)^{\mathrm{d}}$ & 0.1 & 0.1 & 0.1 & 0.1 & 0.1 & 0.1 & 0.1 & \\
\hline$+/{ }^{\mathrm{d}}$ & 0 & 0 & 0 & 0 & 0 & 0 & 0 & \\
\hline $\mathrm{Xe}-128(\mathrm{~g})^{\mathrm{k}}$ & $2.6860 \mathrm{E}-06$ & $0.0000 \mathrm{E}+00$ & $4.4713 \mathrm{E}-04$ & $8.1216 \mathrm{E}-04$ & $1.3578 \mathrm{E}-03$ & $1.2177 \mathrm{E}-03$ & $1.0141 \mathrm{E}-03$ & 5.856 \\
\hline$+/_{-}^{j}$ & $1.2790 \mathrm{E}-13$ & NA & 1.9955E-05 & $6.2291 \mathrm{E}-05$ & 1.2317E-04 & $1.2151 \mathrm{E}-04$ & 1.1908E-04 & 5.6918 \\
\hline SegmentTotal & & & & & & & & \\
\hline$+/^{n}$ & & & & & & & & \\
\hline
\end{tabular}


Rod "I" 1605519 (SBI-3 E56)

\begin{tabular}{|c|c|c|c|c|c|c|c|c|}
\hline & $1-00$ & I-01 & 1-02 & I-03 & I-04 & I-05 & I-06 & I-07 \\
\hline seg length (in) ${ }^{a}$ & 11.027 & 11.202 & 14.297 & 14.095 & 14.098 & 14.097 & 14.096 & \\
\hline \multicolumn{9}{|l|}{ total length (in) } \\
\hline & & & & & & & & \\
\hline $\mathrm{Xe}-130(\mathrm{~mol} \%)^{\mathrm{d}}$ & 0.1 & 0.1 & 0.1 & 0.1 & 0.1 & 0.1 & 0.1 & \\
\hline$+/_{-}^{\mathrm{d}}$ & 0 & 0 & 0 & 0 & 0 & 0 & 0 & \\
\hline $\mathrm{Xe}-130(\mathrm{~g})^{\mathrm{k}}$ & $2.7280 \mathrm{E}-06$ & $0.0000 \mathrm{E}+00$ & $4.5412 \mathrm{E}-04$ & $8.2486 \mathrm{E}-04$ & $1.3791 \mathrm{E}-03$ & $1.2367 \mathrm{E}-03$ & $1.0300 \mathrm{E}-03$ & 5.947 \\
\hline$+/^{j}$ & $1.2990 \mathrm{E}-13$ & NA & $2.0267 \mathrm{E}-05$ & $6.3265 \mathrm{E}-05$ & $1.2510 \mathrm{E}-04$ & $1.2341 \mathrm{E}-04$ & 1.2094E-04 & 5.780 \\
\hline \multicolumn{9}{|l|}{ SegmentTotal } \\
\hline \multicolumn{9}{|l|}{$+/-^{n}$} \\
\hline & & & & & & & & \\
\hline $\mathrm{Xe}-131(\mathrm{~mol} \%)^{\mathrm{d}}$ & 11.4 & 11.4 & 11.4 & 11.4 & 11.4 & 11.4 & 11.4 & \\
\hline$+/{ }^{\mathrm{d}}$ & 0.1 & 0.1 & 0.1 & 0.1 & 0.1 & 0.1 & 0.1 & \\
\hline $\mathrm{Xe}-131(\mathrm{~g})^{\mathrm{k}}$ & 3.1339E-04 & $0.0000 \mathrm{E}+00$ & $5.2169 \mathrm{E}-02$ & $9.4759 \mathrm{E}-02$ & 1.5843E-01 & $1.4208 \mathrm{E}-01$ & 1.1832E-01 & 6.832 \\
\hline$+/^{j}$ & $2.7490 \mathrm{E}-06$ & NA & $2.3728 \mathrm{E}-03$ & $7.3152 \mathrm{E}-03$ & $1.4438 \mathrm{E}-02$ & $1.4232 \mathrm{E}-02$ & $1.3932 \mathrm{E}-02$ & 6.668 \\
\hline \multicolumn{9}{|l|}{ SegmentTotal } \\
\hline \multicolumn{9}{|l|}{$+/-^{n}$} \\
\hline & & & & & & & & \\
\hline $\mathrm{Xe}-132(\mathrm{~mol} \%)^{\mathrm{d}}$ & 22.7 & 22.7 & 22.7 & 22.7 & 22.7 & 22.7 & 22.7 & \\
\hline$+/_{-}^{\mathrm{d}}$ & 0.1 & 0.1 & 0.1 & 0.1 & 0.1 & 0.1 & 0.1 & \\
\hline $\mathrm{Xe}-132(\mathrm{~g})^{\mathrm{k}}$ & $6.2879 \mathrm{E}-04$ & $0.0000 \mathrm{E}+00$ & 1.0467E-01 & 1.9013E-01 & 3.1787E-01 & $2.8507 \mathrm{E}-01$ & $2.3741 \mathrm{E}-01$ & 1.370 \\
\hline$+/_{-}^{j}$ & $2.7700 \mathrm{E}-06$ & NA & $4.6941 \mathrm{E}-03$ & 1.4606E-02 & $2.8869 \mathrm{E}-02$ & $2.8473 \mathrm{E}-02$ & $2.7896 \mathrm{E}-02$ & 1.333 \\
\hline \multicolumn{9}{|l|}{ SegmentTotal } \\
\hline \multicolumn{9}{|l|}{$+/^{\mathrm{n}}$} \\
\hline $\mathrm{Xe}-134(\mathrm{~mol} \%)^{d}$ & 25.8 & 25.8 & 25.8 & 25.8 & 25.8 & 25.8 & 25.8 & \\
\hline$+/{ }^{\mathrm{d}}$ & 0.1 & 0.1 & 0.1 & 0.1 & 0.1 & 0.1 & 0.1 & \\
\hline $\mathrm{Xe}-134(\mathrm{~g})^{\mathrm{k}}$ & $7.2550 \mathrm{E}-04$ & $0.0000 \mathrm{E}+00$ & 1.2077E-01 & $2.1937 \mathrm{E}-01$ & $3.6676 \mathrm{E}-01$ & 3.2891E-01 & $2.7392 \mathrm{E}-01$ & 1.581 \\
\hline$+/-^{j}$ & $2.8120 \mathrm{E}-06$ & NA & $5.4101 \mathrm{E}-03$ & 1.6847E-02 & $3.3300 \mathrm{E}-02$ & $3.2845 \mathrm{E}-02$ & $3.2182 \mathrm{E}-02$ & 1.538 \\
\hline \multicolumn{9}{|l|}{ SegmentTotal } \\
\hline$+/-^{n}$ & & & & & & & & \\
\hline
\end{tabular}


Rod "I" 1605519 (SBI-3 E56)

\begin{tabular}{|c|c|c|c|c|c|c|c|c|}
\hline & $\mathrm{I}-00$ & $\mid-01$ & I-02 & |-03 & I-04 & I-05 & I-06 & |-07 \\
\hline seg length (in) ${ }^{a}$ & 11.027 & 11.202 & 14.297 & 14.095 & 14.098 & 14.097 & 14.096 & \\
\hline \multicolumn{9}{|l|}{ total length (in) } \\
\hline & & & & & & & & \\
\hline $\mathrm{Xe}-136(\mathrm{~mol} \%)^{\mathrm{d}}$ & 40 & 40 & 40 & 40 & 40 & 40 & 40 & \\
\hline$+/_{-}^{\mathrm{d}}$ & 0.1 & 0.1 & 0.1 & 0.1 & 0.1 & 0.1 & 0.1 & \\
\hline $\mathrm{Xe}-136(\mathrm{~g})^{\mathrm{k}}$ & 1.1416E-03 & $0.0000 \mathrm{E}+00$ & 1.9004E-01 & 3.4519E-01 & 5.7712E-01 & 5.1756E-01 & $4.3104 \mathrm{E}-01$ & 2.48 \\
\hline$+\alpha_{-}^{j}$ & $2.8541 \mathrm{E}-06$ & \begin{tabular}{|l|} 
NA \\
\end{tabular} & $8.4946 \mathrm{E}-03$ & $2.6489 \mathrm{E}-02$ & $5.2372 \mathrm{E}-02$ & $5.1662 \mathrm{E}-02$ & $5.0624 \mathrm{E}-02$ & 2.42 \\
\hline \multicolumn{9}{|l|}{ SegmentTotal } \\
\hline \multicolumn{9}{|l|}{$+/^{n}$} \\
\hline \multicolumn{9}{|l|}{ Rod total } \\
\hline \multicolumn{9}{|l|}{$+-^{n}$} \\
\hline & & & & & & & & \\
\hline shear gas $(g)^{e}$ & 0 & 0 & 0.0009 & 0.0023 & 0.0033 & 0.0033 & 0.003 & \\
\hline$+/-^{\mathrm{e}}$ & 0 & 0.0003 & 0.0003 & 0.0005 & 0.0007 & 0.0007 & 0.0006 & \\
\hline moles Xe (diss+pl) ${ }^{d}$ & 0.000021 & 0 & 0.00349 & 0.006335 & 0.010595 & 0.009499 & 0.00791 & 0. \\
\hline$+/_{-}^{\mathrm{d}}$ & 0.000001 & 0 & 0.000156 & 0.000487 & 0.000963 & 0.00095 & 0.000931 & 0 . \\
\hline $\mathrm{Kr}+\mathrm{Xe}$ diss\&pl $(\mathrm{g})^{\mathrm{d}}$ & 0.0033 & 0 & 0.5392 & 0.9869 & 1.6595 & 1.4567 & 1.2554 & \\
\hline$+/-^{\mathrm{d}}$ & 0.0002 & 0 & 0.0228 & 0.0666 & 0.1317 & 0.1291 & 0.1265 & \\
\hline moles Xe (tot) $^{\circ}$ & $2.1000 \mathrm{E}-05$ & 0 & 3.4958E-03 & $6.3498 \mathrm{E}-03$ & $1.0616 \mathrm{E}-02$ & $9.5205 \mathrm{E}-03$ & $7.9289 \mathrm{E}-03$ & 4.57 \\
\hline$+/^{\mathrm{p}}$ & $1.0000 \mathrm{E}-12$ & $0.0000 \mathrm{E}+00$ & $1.5601 \mathrm{E}-04$ & 4.8701E-04 & $9.6301 \mathrm{E}-04$ & $9.5002 \mathrm{E}-04$ & $9.3101 \mathrm{E}-04$ & 4.45 \\
\hline \multicolumn{9}{|c|}{ Values corrected to 1/1/84 (page 181, Final Report for the LWBR Proof of Breeding Analytical Support Project } \\
\hline & & & & & & & & \\
\hline Cs-137 (atoms) & ND & $4.7130 \mathrm{E}+18$ & $4.8210 \mathrm{E}+20$ & $1.0350 \mathrm{E}+21$ & $1.3880 \mathrm{E}+21$ & $1.4450 \mathrm{E}+21$ & $1.2550 \mathrm{E}+21$ & 7.26 \\
\hline$+/-^{f}$ & NA & $2.0920 \mathrm{E}+16$ & $2.1300 \mathrm{E}+18$ & $4.5800 \mathrm{E}+18$ & $6.1340 \mathrm{E}+18$ & $6.1360 \mathrm{E}+18$ & $5.3250 \mathrm{E}+18$ & 3.21 \\
\hline Cs-137 (g) & NA & $1.0713 \mathrm{E}-03$ & 1.0959E-01 & $2.3527 \mathrm{E}-01$ & $3.1551 \mathrm{E}-01$ & 3.2847E-01 & $2.8528 \mathrm{E}-01$ & 1.65 \\
\hline$+-^{\mathrm{m}}$ & NA & $4.7554 \mathrm{E}-06$ & $4.8418 \mathrm{E}-04$ & $1.0411 \mathrm{E}-03$ & 1.3943E-03 & $1.3948 \mathrm{E}-03$ & $1.2104 \mathrm{E}-03$ & 7.29 \\
\hline \multicolumn{9}{|l|}{ Total } \\
\hline \multicolumn{9}{|l|}{$+-^{n}$} \\
\hline $\mathrm{Ce}-144$ (atoms) $^{\mathrm{g}}$ & ND & $5.9550 \mathrm{E}+17$ & $3.2600 \mathrm{E}+19$ & $5.5100 \mathrm{E}+19$ & $6.8020 \mathrm{E}+19$ & $7.1360 \mathrm{E}+19$ & $5.5720 \mathrm{E}+19$ & 2.72 \\
\hline$+/-^{g}$ & NA & $3.7660 \mathrm{E}+15$ & $2.2010 \mathrm{E}+17$ & $3.8120 \mathrm{E}+17$ & $4.5920 \mathrm{E}+17$ & $4.6020 \mathrm{E}+17$ & $3.6670 \mathrm{E}+17$ & 1.88 \\
\hline Ce-144 $(g)^{m}$ & NA & $1.4229 \mathrm{E}-04$ & 7.7897E-03 & 1.3166E-02 & 1.6253E-02 & $1.7051 \mathrm{E}-02$ & $1.3314 \mathrm{E}-02$ & 6.49 \\
\hline$+/{ }^{\mathrm{m}}$ & NA & $8.9988 \mathrm{E}-07$ & $5.2592 \mathrm{E}-05$ & 9.1087E-05 & $1.0972 \mathrm{E}-04$ & 1.0996E-04 & $8.7622 \mathrm{E}-05$ & 4.49 \\
\hline \multicolumn{9}{|l|}{ Total } \\
\hline$+1-^{n}$ & & & & & & & & \\
\hline
\end{tabular}


Rod "I" 1605519 (SBI-3 E56)

\begin{tabular}{|c|c|c|c|c|c|c|c|c|}
\hline & $1-00$ & |-01 & |-02 & $1-03$ & I-04 & I-05 & $1-06$ & |-07 \\
\hline seg length (in) ${ }^{a}$ & 11.027 & 11.202 & 14.297 & 14.095 & 14.098 & 14.097 & 14.096 & \\
\hline \multicolumn{9}{|l|}{ total length (in) } \\
\hline & & & & & & & & \\
\hline Zr-95 (atoms) ${ }^{\mathrm{h}}$ & ND & $6.5160 \mathrm{E}+15$ & $2.6370 \mathrm{E}+17$ & $4.4440 \mathrm{E}+17$ & $5.2800 \mathrm{E}+17$ & $5.3660 \mathrm{E}+17$ & $2.6590 \mathrm{E}+17$ & 7.15 \\
\hline$+/-^{\mathrm{h}}$ & NA & $1.3700 \mathrm{E}+14$ & $1.0230 \mathrm{E}+16$ & $1.9070 \mathrm{E}+16$ & $1.9940 \mathrm{E}+16$ & $2.6800 \mathrm{E}+16$ & $1.6250 \mathrm{E}+16$ & 8.72 \\
\hline Zr-95 (g) ${ }^{\mathrm{m}}$ & NA & $1.0268 \mathrm{E}-06$ & 4.1554E-05 & $7.0029 \mathrm{E}-05$ & $8.3203 E-05$ & $8.4558 \mathrm{E}-05$ & $4.1901 \mathrm{E}-05$ & 1.12 \\
\hline$+/-^{m}$ & NA & $2.1589 \mathrm{E}-08$ & $1.6121 \mathrm{E}-06$ & $3.0051 \mathrm{E}-06$ & 3.1422E-06 & $4.2232 \mathrm{E}-06$ & $2.5607 \mathrm{E}-06$ & 1.37 \\
\hline \multicolumn{9}{|l|}{ Total } \\
\hline$+1-^{n}$ & & & & & & & & \\
\hline
\end{tabular}

Footnotes

a. ANL Destructive Chemical Assay of 33-Rod LWBR EOL Sample - Rod I, 1605519, page 3

b. ANL Destructive Chemical Assay of 33-Rod LWBR EOL Sample - Rod I, 1605519, page 6

c. ANL Destructive Chemical Assay of 33-Rod LWBR EOL Sample - Rod I, 1605519, page 7

d. ANL Destructive Chemical Assay of 33-Rod LWBR EOL Sample - Rod I, 1605519, page 10

e. ANL Destructive Chemical Assay of 33-Rod LWBR EOL Sample - Rod I, 1605519, page 11

f. ANL Destructive Chemical Assay of 33-Rod LWBR EOL Sample - Rod I, 1605519, page 12

g. ANL Destructive Chemical Assay of 33-Rod LWBR EOL Sample - Rod I, 1605519, page 13

h. ANL Destructive Chemical Assay of 33-Rod LWBR EOL Sample - Rod I, 1605519, page 14

i. (abundance of the specified isotope)(total weight of uranium) / 100

j. $\quad$ Error Propagation $=\left(\left(s d_{x} / x\right)^{2}+\left(s d_{y} / y\right)^{2}\right)^{1 / 2}(x y)$, where sd is the $+/-$ in the table

k. (mole\%)(number moles gas recovered)(molec wt) / 100

m. (number of atoms per segment)(atomic weight) / 6.0228E+23

n. Error Propagation $=\left(\operatorname{SUM}\left({s d_{i}}^{2}\right)\right)^{1 / 2}$, where sd is the $+/$ - in the table

o. $\quad(($ shear gas $/ \mathrm{Xe}+\mathrm{Kr}$ (diss\&pl ))(moles $\mathrm{Xe}$ or $\mathrm{Kr}$ (diss $+\mathrm{pl}))+$ moles $\mathrm{Xe}$ or $\mathrm{Kr}$ (diss $+\mathrm{pl})$

p. Error Propagation $=\left(\left(\left(\left(s d_{x} / x\right)^{2}+\left(s d_{y} / y\right)^{2}+\left(s d_{z} / z\right)^{2}\right)^{1 / 2}(x y / z)\right)^{2}+\left(s d_{y}\right)^{2}\right)^{1 / 2}$, where sd is the $+/$ - in the table 
Rod "J" 1200830 (SBI-3 A49)

\begin{tabular}{|c|c|c|c|c|c|c|c|c|}
\hline & $\mathrm{J}-00$ & $\mathrm{~J}-01$ & \begin{tabular}{|l|}
$\mathrm{J}-02$ \\
\end{tabular} & $\mathrm{~J}-03$ & $\mathrm{~J}-04$ & $\mathrm{~J}-05$ & $\mathrm{~J}-06$ & J-07 \\
\hline seg length (in) ${ }^{a}$ & 11.319 & 11.439 & 14.242 & 14.043 & 14.133 & 13.913 & 10.498 & \\
\hline \multicolumn{9}{|l|}{ total length (in) } \\
\hline & & & & & & & & \\
\hline $\mathrm{U}-232 \mathrm{wt} \%^{\mathrm{b}}$ & 0 & 0.0176 & 0.0564 & 0.1686 & 0.236 & 0.2702 & 0.2543 & 0 \\
\hline$+1-{ }^{\mathrm{b}}$ & 0 & 0.0005 & 0.0017 & 0.0052 & 0.0073 & 0.0084 & 0.0079 & 0 \\
\hline$U-232 g^{i}$ & $0.0000 \mathrm{E}+00$ & $9.7451 \mathrm{E}-05$ & $3.7210 \mathrm{E}-03$ & $1.2703 \mathrm{E}-02$ & $1.9381 \mathrm{E}-02$ & $1.8384 \mathrm{E}-02$ & 1.1966E-02 & 8.084 \\
\hline$+/{ }^{j}$ & NA & $2.7686 \mathrm{E}-06$ & 1.1216E-04 & $3.9190 \mathrm{E}-04$ & 5.9953E-04 & $5.7154 \mathrm{E}-04$ & 3.7173E-04 & 2.501 \\
\hline \multicolumn{9}{|l|}{ Segment Total } \\
\hline \multicolumn{9}{|l|}{$+1-^{n}$} \\
\hline & & & & & & & & \\
\hline $\mathrm{U}-233 \mathrm{wt} \%^{\mathrm{b}}$ & 100 & 98.733 & 92.715 & 86.8737 & 83.8016 & 86.2766 & 87.817 & 91 \\
\hline$+/-^{\mathrm{b}}$ & 0 & 0.0119 & 0.0091 & 0.009 & 0.0093 & 0.0107 & 0.0094 & 0 \\
\hline$U-233 g^{i}$ & $4.0000 \mathrm{E}-05$ & $5.4668 \mathrm{E}-01$ & $6.1169 \mathrm{E}+00$ & $6.5455 \mathrm{E}+00$ & $6.8822 \mathrm{E}+00$ & $5.8700 \mathrm{E}+00$ & $4.1321 \mathrm{E}+00$ & 4.2491 \\
\hline$+/-^{j}$ & $1.0000 \mathrm{E}-05$ & 1.5313E-04 & $1.7998 \mathrm{E}-03$ & $4.8173 \mathrm{E}-03$ & $2.1044 \mathrm{E}-03$ & $1.8173 \mathrm{E}-03$ & $1.0945 \mathrm{E}-03$ & 9.163 \\
\hline \multicolumn{9}{|l|}{ Segment Total } \\
\hline \multicolumn{9}{|l|}{$+/-^{n}$} \\
\hline & & & & & & & & \\
\hline $\mathrm{U}-234 \mathrm{wt} \%^{\mathrm{b}}$ & 0 & 1.1844 & 6.2385 & 10.6871 & 12.8591 & 11.0657 & 9.9651 & 7 \\
\hline$+/-^{\mathrm{b}}$ & 0 & 0.0008 & 0.001 & 0.0015 & 0.0017 & 0.0017 & 0.0013 & 0 \\
\hline$U-234 g^{i}$ & $0.0000 \mathrm{E}+00$ & $6.5580 \mathrm{E}-03$ & 4.1159E-01 & $8.0522 \mathrm{E}-01$ & $1.0560 \mathrm{E}+00$ & $7.5288 \mathrm{E}-01$ & 4.6889E-01 & 3.272 \\
\hline$+/{ }^{j}$ & NA & $4.7298 \mathrm{E}-06$ & $1.3186 \mathrm{E}-04$ & $5.9751 \mathrm{E}-04$ & $3.3171 \mathrm{E}-04$ & $2.4288 \mathrm{E}-04$ & 1.2902E-04 & 7.603 \\
\hline \multicolumn{9}{|l|}{ Segment Total } \\
\hline \multicolumn{9}{|l|}{$+/^{n}$} \\
\hline & & & & & & & & \\
\hline U-235 wt $\%^{b}$ & 0 & 0.0375 & 0.744 & 1.9413 & 2.6703 & 2.1709 & 1.8062 & 0 \\
\hline$+1-{ }^{b}$ & 0 & 0.0093 & 0.0075 & 0.0069 & 0.0063 & 0.0069 & 0.0057 & 0 \\
\hline$U-235 g^{i}$ & $0.0000 \mathrm{E}+00$ & $2.0764 \mathrm{E}-04$ & $4.9086 \mathrm{E}-02$ & 1.4627E-01 & $2.1930 \mathrm{E}-01$ & 1.4770E-01 & $8.4988 \mathrm{E}-02$ & 4.551 \\
\hline$+/-^{j}$ & NA & $5.1494 \mathrm{E}-05$ & $4.9501 \mathrm{E}-04$ & $5.3069 \mathrm{E}-04$ & $5.2114 \mathrm{E}-04$ & $4.7132 \mathrm{E}-04$ & $2.6899 \mathrm{E}-04$ & 1.994 \\
\hline \multicolumn{9}{|l|}{ Segment Total } \\
\hline \multicolumn{9}{|l|}{$+/-^{n}$} \\
\hline & & & & & & & & \\
\hline $\mathrm{U}-236 \mathrm{wt} \%{ }^{\mathrm{b}}$ & 0 & 0.0012 & 0.0457 & 0.1746 & 0.3007 & 0.2136 & 0.1553 & 0 \\
\hline$+/^{\mathrm{b}}$ & 0 & 0.0001 & 0.0001 & 0.0001 & 0.0001 & 0.0001 & 0.0001 & 0 \\
\hline $\mathrm{U}-236 \mathrm{~g}^{\mathrm{i}}$ & $0.0000 \mathrm{E}+00$ & $6.6444 \mathrm{E}-06$ & $3.0151 \mathrm{E}-03$ & $1.3155 \mathrm{E}-02$ & $2.4695 \mathrm{E}-02$ & $1.4533 \mathrm{E}-02$ & $7.3074 \mathrm{E}-03$ & 2.765 \\
\hline$+/-^{j}$ & NA & $5.5370 \mathrm{E}-07$ & $6.6504 \mathrm{E}-06$ & $1.2192 \mathrm{E}-05$ & $1.0815 \mathrm{E}-05$ & $7.9552 \mathrm{E}-06$ & $5.0274 \mathrm{E}-06$ & 4.666 \\
\hline \multicolumn{9}{|l|}{ Segment Total } \\
\hline$+/-^{n}$ & & & & & & & & \\
\hline
\end{tabular}


Rod "J" 1200830 (SBI-3 A49)

\begin{tabular}{|c|c|c|c|c|c|c|c|c|}
\hline & $\mathrm{J}-00$ & $\mathrm{~J}-01$ & $\mathrm{~J}-02$ & $\mathrm{~J}-03$ & $\mathrm{~J}-04$ & $\mathrm{~J}-05$ & $\mathrm{~J}-06$ & $\mathrm{~J}-07$ \\
\hline seg length (in) ${ }^{a}$ & 11.319 & 11.439 & 14.242 & 14.043 & 14.133 & 13.913 & 10.498 & 1 \\
\hline \multicolumn{9}{|l|}{ total length (in) } \\
\hline & & & & & & & & \\
\hline U-238 wt $\%^{b}$ & 0 & 0.0263 & 0.2004 & 0.1548 & 0.1324 & 0.003 & 0.0021 & 0 \\
\hline$+1-^{\mathrm{b}}$ & 0 & 0.0076 & 0.006 & 0.0055 & 0.0051 & 0.0056 & 0.0043 & $\underline{0}$ \\
\hline $\mathrm{U}-238 \mathrm{~g}^{\mathrm{i}}$ & $0.0000 \mathrm{E}+00$ & 1.4562E-04 & $1.3222 \mathrm{E}-02$ & 1.1663E-02 & $1.0873 \mathrm{E}-02$ & $2.0411 \mathrm{E}-04$ & $9.8813 \mathrm{E}-05$ & 8.802 \\
\hline$+/-^{j}$ & \begin{tabular}{|l|}
$N A$ \\
\end{tabular} & $4.2081 \mathrm{E}-05$ & 3.9587E-04 & $4.1449 \mathrm{E}-04$ & $4.1885 \mathrm{E}-04$ & $3.8101 \mathrm{E}-04$ & $2.0233 \mathrm{E}-04$ & 1.111 \\
\hline \multicolumn{9}{|l|}{ Segment Total } \\
\hline \multicolumn{9}{|l|}{$+/-^{n}$} \\
\hline & & & & & & & & \\
\hline tot $U^{c}$ & 0.00015 & 0.5537 & 6.59757 & 7.53452 & 8.21244 & 6.80373 & 4.70536 & 4.6 \\
\hline$+/-^{c}$ & 0.00008 & 0.00014 & 0.00183 & 0.00549 & 0.00234 & 0.00193 & 0.00114 & 0.1 \\
\hline $\mathrm{Kr}-82(\mathrm{~mol} \%)^{\mathrm{d}}$ & 0.2 & 0.2 & 0.2 & 0.2 & 0.2 & 0.2 & 0.2 & \\
\hline$+/^{\mathrm{d}}$ & 0.1 & 0.1 & 0.1 & 0.1 & 0.1 & 0.1 & 0.1 & \\
\hline $\mathrm{Kr}-82(\mathrm{~g})^{\mathrm{K}}$ & 4.9148E-07 & $0.0000 \mathrm{E}+00$ & $1.1788 \mathrm{E}-04$ & $2.8961 \mathrm{E}-04$ & 3.9549E-04 & $2.3680 \mathrm{E}-04$ & 1.4257E-04 & 1.462 \\
\hline$+/^{j}$ & $2.4574 \mathrm{E}-07$ & NA & $7.0761 \mathrm{E}-05$ & 1.5215E-04 & $2.0165 \mathrm{E}-04$ & $1.2127 \mathrm{E}-04$ & $7.4124 \mathrm{E}-05$ & 7.533 \\
\hline \multicolumn{9}{|l|}{ Segment Total } \\
\hline \multicolumn{9}{|l|}{$+/^{\mathrm{n}}$} \\
\hline $\mathrm{Kr}-83(\mathrm{~mol} \%)^{\mathrm{d}}$ & 14.7 & 14.7 & 14.7 & 14.7 & 14.7 & 14.7 & 14.7 & \\
\hline$+/^{\mathrm{d}}$ & 0.1 & 0.1 & 0.1 & 0.1 & 0.1 & 0.1 & 0.1 & \\
\hline $\mathrm{Kr}-83(\mathrm{~g})^{\mathrm{k}}$ & $3.6565 \mathrm{E}-05$ & $0.0000 \mathrm{E}+00$ & $8.7702 \mathrm{E}-03$ & $2.1546 \mathrm{E}-02$ & $2.9423 \mathrm{E}-02$ & 1.7617E-02 & $1.0607 \mathrm{E}-02$ & $1.087 i$ \\
\hline$+/{ }^{j}$ & 2.4874E-07 & NA & $2.9136 \mathrm{E}-03$ & $3.4768 \mathrm{E}-03$ & $2.9443 \mathrm{E}-03$ & $1.9539 \mathrm{E}-03$ & $1.5131 \mathrm{E}-03$ & 1.355 \\
\hline \multicolumn{9}{|l|}{ Segment Total } \\
\hline \multicolumn{9}{|l|}{$+/-^{n}$} \\
\hline & & & & & & & & \\
\hline $\mathrm{Kr}-84(\mathrm{~mol} \%)^{\mathrm{d}}$ & 30.6 & 30.6 & 30.6 & 30.6 & 30.6 & 30.6 & 30.6 & \\
\hline$+/{ }^{\mathrm{d}}$ & 0.1 & 0.1 & 0.1 & 0.1 & 0.1 & 0.1 & 0.1 & \\
\hline $\mathrm{Kr}-84(\mathrm{~g})^{\mathrm{K}}$ & $7.7031 \mathrm{E}-05$ & $0.0000 \mathrm{E}+00$ & $1.8476 \mathrm{E}-02$ & $4.5391 \mathrm{E}-02$ & $6.1985 \mathrm{E}-02$ & $3.7114 \mathrm{E}-02$ & $2.2345 \mathrm{E}-02$ & 2.291! \\
\hline$+/-^{j}$ & $2.5173 \mathrm{E}-07$ & NA & $6.1371 \mathrm{E}-03$ & 7.3195E-03 & $6.1916 \mathrm{E}-03$ & $4.1103 \mathrm{E}-03$ & $3.1849 \mathrm{E}-03$ & 2.851 \\
\hline \multicolumn{9}{|l|}{ Segment Total } \\
\hline$+/-^{n}$ & & & & & & & & \\
\hline
\end{tabular}


Rod "J" 1200830 (SBI-3 A49)

\begin{tabular}{|c|c|c|c|c|c|c|c|c|}
\hline & $\mathrm{J}-00$ & $\mathrm{~J}-01$ & $\mathrm{~J}-02$ & $\mathrm{~J}-03$ & $\mathrm{~J}-04$ & $\mathrm{~J}-05$ & $\mathrm{~J}-06$ & $\mathrm{~J}-07$ \\
\hline seg length (in) ${ }^{a}$ & 11.319 & 11.439 & 14.242 & 14.043 & 14.133 & 13.913 & 10.498 & \\
\hline \multicolumn{9}{|l|}{ total length (in) } \\
\hline & & & & & & & & \\
\hline $\mathrm{Kr}-85(\mathrm{~mol} \%)^{\mathrm{d}}$ & 6 & 6 & 6 & 6 & 6 & 6 & 6 & \\
\hline$+/^{\mathrm{d}}$ & 0.1 & 0.1 & 0.1 & 0.1 & 0.1 & 0.1 & 0.1 & \\
\hline $\mathrm{Kr}-85(\mathrm{~g})^{\mathrm{k}}$ & $1.5284 \mathrm{E}-05$ & $0.0000 \mathrm{E}+00$ & 3.6659E-03 & $9.0064 \mathrm{E}-03$ & 1.2299E-02 & $7.3641 \mathrm{E}-03$ & $4.4337 \mathrm{E}-03$ & 4.54 \\
\hline$+/{ }^{\mathrm{j}}$ & $2.5474 \mathrm{E}-07$ & NA & $1.2192 \mathrm{E}-03$ & $1.4598 \mathrm{E}-03$ & $1.2449 \mathrm{E}-03$ & $8.2438 \mathrm{E}-04$ & $6.3608 \mathrm{E}-04$ & 5.70 \\
\hline \multicolumn{9}{|l|}{ Segment Total } \\
\hline \multicolumn{9}{|l|}{$+/-^{\mathrm{n}}$} \\
\hline & & & & & & & & \\
\hline $\mathrm{Kr}-86(\mathrm{~mol} \%)^{\mathrm{d}}$ & 48.6 & 48.6 & 48.6 & 48.6 & 48.6 & 48.6 & 48.6 & \\
\hline$+/^{\mathrm{d}}$ & 0.2 & 48.6 & 48.6 & 48.6 & 48.6 & 48.6 & 48.6 & \\
\hline $\mathrm{Kr}-86(\mathrm{~g})^{\mathrm{K}}$ & $1.2526 \mathrm{E}-04$ & $0.0000 \mathrm{E}+00$ & 3.0043E-02 & $7.3809 \mathrm{E}-02$ & $1.0079 \mathrm{E}-01$ & $6.0350 \mathrm{E}-02$ & 3.6335E-02 & 3.72 \\
\hline$+/-^{j}$ & $5.1546 \mathrm{E}-07$ & NA & 3.1657E-02 & $7.4762 \mathrm{E}-02$ & 1.0129E-01 & 6.0719E-02 & $3.6702 \mathrm{E}-02$ & 3.75 \\
\hline \multicolumn{9}{|l|}{ Segment Total } \\
\hline \multicolumn{9}{|l|}{$+/-^{\mathrm{n}}$} \\
\hline \multicolumn{9}{|l|}{ Rod Total } \\
\hline \multicolumn{9}{|l|}{$+-^{n}$} \\
\hline & & & & & & & & \\
\hline shear gas $(g)^{e}$ & 0 & 0 & 0.001 & 0.0029 & 0.0041 & 0.0037 & 0.0024 & \\
\hline$+/-^{\mathrm{e}}$ & 0 & 0.0003 & 0.0003 & 0.0006 & 0.0008 & 0.0007 & 0.0005 & \\
\hline moles $\mathrm{Kr}(\text { diss }+\mathrm{pl})^{\mathrm{d}}$ & 0.000003 & 0 & 0.000718 & 0.001763 & 0.002407 & 0.00144 & 0.000866 & \\
\hline$+/^{-\mathrm{d}}$ & 0 & 0 & 0.000239 & 0.000285 & 0.000241 & 0.00016 & 0.000124 & 0. \\
\hline $\mathrm{Kr}+\mathrm{Xe}$ diss\&pl $(\mathrm{g})^{\mathrm{d}}$ & 0.0016 & 0.0099 & 0.4625 & 1.0696 & 1.4004 & 0.9815 & 0.4887 & \\
\hline$+/^{-\mathrm{d}}$ & 0 & 0.0099 & 0.0829 & 0.1727 & 0.115 & 0.1439 & 0.0509 & \\
\hline moles kr (tot) $^{\circ}$ & $3.0000 \mathrm{E}-06$ & $0.0000 \mathrm{E}+00$ & 7.1955E-04 & $1.7678 \mathrm{E}-03$ & $2.4140 \mathrm{E}-03$ & 1.4454E-03 & $8.7025 \mathrm{E}-04$ & 8.92 \\
\hline$+/-^{\mathrm{p}}$ & 0 & $0.0000 \mathrm{E}+00$ & $2.3900 \mathrm{E}-04$ & $2.8500 \mathrm{E}-04$ & $2.4101 \mathrm{E}-04$ & $1.6001 \mathrm{E}-04$ & $1.2401 \mathrm{E}-04$ & 1.11 \\
\hline $\mathrm{Xe}-128(\mathrm{~mol} \%)^{\mathrm{d}}$ & 0.1 & 0.1 & 0.1 & 0.1 & 0.1 & 0.1 & 0.1 & \\
\hline$+/_{-}^{\mathrm{d}}$ & 0 & 0 & 0 & 0 & 0 & 0 & 0 & \\
\hline $\mathrm{Xe}-128(\mathrm{~g})^{\mathrm{k}}$ & $1.2790 \mathrm{E}-06$ & $9.4649 \mathrm{E}-06$ & 3.8326E-04 & $8.7851 \mathrm{E}-04$ & $1.1423 \mathrm{E}-03$ & $8.2141 \mathrm{E}-04$ & $3.9742 \mathrm{E}-04$ & 4.13 \\
\hline$+/_{-}^{\mathrm{j}}$ & $0.0000 \mathrm{E}+00$ & $9.4649 \mathrm{E}-06$ & 7.6487E-05 & 1.4146E-04 & $1.0540 \mathrm{E}-04$ & 1.3635E-04 & 4.7455E-05 & 2.85 \\
\hline SegmentTotal & & & & & & & & \\
\hline$+/-^{n}$ & & & & & & & & \\
\hline
\end{tabular}


Rod "J" 1200830 (SBI-3 A49)

\begin{tabular}{|c|c|c|c|c|c|c|c|c|}
\hline & $\mathrm{J}-00$ & $\mathrm{~J}-01$ & $\mathrm{~J}-02$ & $\mathrm{~J}-03$ & $\mathrm{~J}-04$ & $\mathrm{~J}-05$ & $\mathrm{~J}-06$ & $\mathrm{~J}-07$ \\
\hline seg length (in) ${ }^{a}$ & 11.319 & 11.439 & 14.242 & 14.043 & 14.133 & 13.913 & 10.498 & 1 \\
\hline \multicolumn{9}{|l|}{ total length (in) } \\
\hline & & & & & & & & \\
\hline $\mathrm{Xe}-130(\mathrm{~mol} \%)^{\mathrm{d}}$ & 0.2 & 0.2 & 0.2 & 0.2 & 0.2 & 0.2 & 0.2 & \\
\hline$+/_{-}^{\mathrm{d}}$ & 0 & 0 & 0 & 0 & 0 & 0 & 0 & \\
\hline $\mathrm{Xe}-130(\mathrm{~g})^{\mathrm{k}}$ & $2.5981 \mathrm{E}-06$ & $1.9226 \mathrm{E}-05$ & $7.7850 \mathrm{E}-04$ & $1.7845 \mathrm{E}-03$ & $2.3204 \mathrm{E}-03$ & $1.6685 \mathrm{E}-03$ & $8.0727 \mathrm{E}-04$ & 8.404 \\
\hline$+/_{-}^{j}$ & $0.0000 \mathrm{E}+00$ & $1.9226 \mathrm{E}-05$ & 1.5537E-04 & $2.8735 \mathrm{E}-04$ & $2.1409 \mathrm{E}-04$ & $2.7696 \mathrm{E}-04$ & $9.6394 \mathrm{E}-05$ & 5.793 \\
\hline \multicolumn{9}{|l|}{ SegmentTotal } \\
\hline \multicolumn{9}{|l|}{$+-^{n}$} \\
\hline & & & & & & & & \\
\hline $\mathrm{Xe}-131(\mathrm{~mol} \%)^{\mathrm{d}}$ & 10.6 & 10.6 & 10.6 & 10.6 & 10.6 & 10.6 & 10.6 & \\
\hline$+/^{\mathrm{d}}$ & 0.1 & 0.1 & 0.1 & 0.1 & 0.1 & 0.1 & 0.1 & \\
\hline $\mathrm{Xe}-131(\mathrm{~g})^{\mathrm{k}}$ & 1.3876E-04 & $1.0268 \mathrm{E}-03$ & $4.1579 \mathrm{E}-02$ & $9.5308 \mathrm{E}-02$ & 1.2393E-01 & $8.9113 \mathrm{E}-02$ & $4.3115 \mathrm{E}-02$ & 4.488 \\
\hline$+{ }^{\mathrm{j}}$ & $1.3091 \mathrm{E}-06$ & $1.0269 \mathrm{E}-03$ & $8.3072 \mathrm{E}-03$ & $1.5373 \mathrm{E}-02$ & 1.1494E-02 & 1.4816E-02 & $5.1643 \mathrm{E}-03$ & 3.123 \\
\hline \multicolumn{9}{|l|}{ SegmentTotal } \\
\hline \multicolumn{9}{|l|}{$+/^{n}$} \\
\hline & & & & & & & & \\
\hline $\mathrm{Xe}-132(\mathrm{~mol} \%)^{\mathrm{d}}$ & 22.3 & 22.3 & 22.3 & 22.3 & 22.3 & 22.3 & 22.3 & \\
\hline$+/-^{\mathrm{d}}$ & 0.1 & 0.1 & 0.1 & 0.1 & 0.1 & 0.1 & 0.1 & \\
\hline $\mathrm{Xe}-132(\mathrm{~g})^{\mathrm{k}}$ & $2.9415 \mathrm{E}-04$ & $2.1767 \mathrm{E}-03$ & $8.8140 \mathrm{E}-02$ & $2.0204 \mathrm{E}-01$ & $2.6270 \mathrm{E}-01$ & $1.8890 \mathrm{E}-01$ & $9.1397 \mathrm{E}-02$ & 9.515 \\
\hline$+/{ }^{j}$ & $1.3190 \mathrm{E}-06$ & $2.1767 \mathrm{E}-03$ & $1.7595 \mathrm{E}-02$ & $3.2546 \mathrm{E}-02$ & $2.4267 \mathrm{E}-02$ & $3.1368 \mathrm{E}-02$ & $1.0921 \mathrm{E}-02$ & 6.573 \\
\hline \multicolumn{9}{|l|}{ SegmentTotal } \\
\hline \multicolumn{9}{|l|}{$+/^{\mathrm{n}}$} \\
\hline & & & & & & & & \\
\hline $\mathrm{Xe}-134(\mathrm{~mol} \%)^{\mathrm{d}}$ & 24.7 & 24.7 & 24.7 & 24.7 & 24.7 & 24.7 & 24.7 & \\
\hline$+/_{-}^{\mathrm{d}}$ & 0.1 & 0.1 & 0.1 & 0.1 & 0.1 & 0.1 & 0.1 & \\
\hline Xe-134 (g) & $3.3075 \mathrm{E}-04$ & $2.4475 \mathrm{E}-03$ & 9.9107E-02 & $2.2718 \mathrm{E}-01$ & $2.9539 \mathrm{E}-01$ & $2.1241 \mathrm{E}-01$ & 1.0277E-01 & 1.069 \\
\hline$+/{ }^{\mathrm{j}}$ & $1.3391 \mathrm{E}-06$ & $2.4475 \mathrm{E}-03$ & 1.9783E-02 & 3.6593E-02 & $2.7280 \mathrm{E}-02$ & $3.5269 \mathrm{E}-02$ & $1.2278 \mathrm{E}-02$ & 7.388 \\
\hline \multicolumn{9}{|l|}{ SegmentTotal } \\
\hline$+-^{n}$ & & & & & & & & \\
\hline
\end{tabular}


Rod "J" 1200830 (SBI-3 A49)

\begin{tabular}{|c|c|c|c|c|c|c|c|c|}
\hline & $\mathrm{J}-00$ & $\mathrm{~J}-01$ & $\mathrm{~J}-02$ & $\mathrm{~J}-03$ & $\mathrm{~J}-04$ & $\mathrm{~J}-05$ & $\mathrm{~J}-06$ & $\mathrm{~J}-07$ \\
\hline seg length (in) ${ }^{a}$ & 11.319 & 11.439 & 14.242 & 14.043 & 14.133 & 13.913 & 10.498 & \\
\hline \multicolumn{9}{|l|}{ total length (in) } \\
\hline & & & & & & & & \\
\hline $\mathrm{Xe}-136(\mathrm{~mol} \%)^{\mathrm{d}}$ & 42.1 & 42.1 & 42.1 & 42.1 & 42.1 & 42.1 & 42.1 & \\
\hline$+/_{-}^{\mathrm{d}}$ & 0.1 & 0.1 & 0.1 & 0.1 & 0.1 & 0.1 & 0.1 & \\
\hline $\mathrm{Xe}-136(\mathrm{~g})^{\mathrm{k}}$ & 5.7217E-04 & $4.2341 \mathrm{E}-03$ & 1.7145E-01 & $3.9300 \mathrm{E}-01$ & $5.1101 \mathrm{E}-01$ & 3.6745E-01 & 1.7778E-01 & 1.85 \\
\hline$+/-{ }^{j}$ & $1.3591 \mathrm{E}-06$ & $4.2341 \mathrm{E}-03$ & $3.4218 \mathrm{E}-02$ & $6.3290 \mathrm{E}-02$ & $4.7164 \mathrm{E}-02$ & $6.1001 \mathrm{E}-02$ & $2.1233 \mathrm{E}-02$ & 1.27 \\
\hline \multicolumn{9}{|l|}{ SegmentTotal } \\
\hline \multicolumn{9}{|l|}{$+/-^{\mathrm{n}}$} \\
\hline \multicolumn{9}{|l|}{ Rod total } \\
\hline \multicolumn{9}{|l|}{$+/^{\mathrm{n}}$} \\
\hline & & & & & & & & \\
\hline shear gas $(\mathrm{g})^{\mathrm{e}}$ & 0 & 0 & 0.001 & 0.0029 & 0.0041 & 0.0037 & 0.0024 & \\
\hline$+/ \mathrm{e}^{\mathrm{e}}$ & 0 & 0.0003 & 0.0003 & 0.0006 & 0.0008 & 0.0007 & 0.0005 & \\
\hline moles Xe (diss+pl) ${ }^{d}$ & 0.00001 & 0.000074 & 0.00299 & 0.00685 & 0.008905 & 0.006398 & 0.003092 & 0. \\
\hline$+/^{\mathrm{d}}$ & 0 & 0.000074 & 0.000598 & 0.001106 & 0.000824 & 0.001066 & 0.000371 & 0. \\
\hline $\mathrm{Kr}+\mathrm{Xe}$ diss\&pl $(\mathrm{g})^{\mathrm{d}}$ & 0.0016 & 0.0099 & 0.4625 & 1.0696 & 1.4004 & 0.9815 & 0.4887 & \\
\hline$+/{ }^{\mathrm{d}}$ & 0 & 0.0099 & 0.0829 & 0.1727 & 0.115 & 0.1439 & 0.0509 & \\
\hline moles Xe (tot) $^{\circ}$ & $1.0000 \mathrm{E}-05$ & $7.4000 \mathrm{E}-05$ & $2.9965 \mathrm{E}-03$ & $6.8686 \mathrm{E}-03$ & $8.9311 \mathrm{E}-03$ & $6.4221 \mathrm{E}-03$ & $3.1072 \mathrm{E}-03$ & 3.23 \\
\hline$+/^{\mathrm{p}}$ & $0.0000 \mathrm{E}+00$ & $7.4000 \mathrm{E}-05$ & $5.9801 \mathrm{E}-04$ & $1.1060 \mathrm{E}-03$ & $8.2402 \mathrm{E}-04$ & 1.0660E-03 & $3.7102 \mathrm{E}-04$ & 2.23 \\
\hline \multicolumn{9}{|c|}{ Values corrected to 1/1/84 (page 181, Final Report for the LWBR Proof of Breeding Analytical Support Project } \\
\hline & & & & & & & & \\
\hline Cs-137 (atoms) & NA & $7.9560 \mathrm{E}+18$ & $4.7870 \mathrm{E}+20$ & $1.0570 \mathrm{E}+21$ & $1.4330 \mathrm{E}+21$ & $9.5010 \mathrm{E}+20$ & $5.7340 \mathrm{E}+20$ & 3.92 \\
\hline$+-^{f}$ & NA & $3.0260 \mathrm{E}+16$ & $1.7590 \mathrm{E}+18$ & $3.3690 \mathrm{E}+18$ & $5.1170 \mathrm{E}+18$ & $3.4210 \mathrm{E}+18$ & $2.0630 \mathrm{E}+18$ & 1.40 \\
\hline Cs-137 (g) ${ }^{\mathrm{m}}$ & NA & $1.8085 \mathrm{E}-03$ & $1.0882 \mathrm{E}-01$ & $2.4027 \mathrm{E}-01$ & 3.2574E-01 & 2.1597E-01 & $1.3034 \mathrm{E}-01$ & 8.91 \\
\hline$+/^{\mathrm{m}}$ & NA & $6.8785 \mathrm{E}-06$ & 3.9985E-04 & $7.6582 \mathrm{E}-04$ & 1.1632E-03 & 7.7764E-04 & 4.6895E-04 & 3.18 \\
\hline \multicolumn{9}{|l|}{ Total } \\
\hline \multicolumn{9}{|l|}{$+1-^{n}$} \\
\hline Ce-144 (atoms) ${ }^{g}$ & NA & $9.4980 \mathrm{E}+17$ & $3.2740 \mathrm{E}+19$ & $5.9000 \mathrm{E}+19$ & $7.5920 \mathrm{E}+19$ & $6.4530 \mathrm{E}+19$ & $3.7170 \mathrm{E}+19$ & 2.26 \\
\hline$+/^{9}$ & NA & $6.8400 \mathrm{E}+15$ & $2.3930 \mathrm{E}+17$ & $3.8520 \mathrm{E}+17$ & $5.4560 \mathrm{E}+17$ & $4.6480 \mathrm{E}+17$ & $2.6760 \mathrm{E}+17$ & 1.63 \\
\hline Ce-144 (g) ${ }^{\mathrm{m}}$ & NA & $2.2695 \mathrm{E}-04$ & $7.8231 \mathrm{E}-03$ & $1.4098 \mathrm{E}-02$ & $1.8141 \mathrm{E}-02$ & $1.5419 \mathrm{E}-02$ & 8.8817E-03 & 5.41 \\
\hline$+/-^{m}$ & NA & 1.6344E-06 & $5.7180 \mathrm{E}-05$ & $9.2043 \mathrm{E}-05$ & $1.3037 \mathrm{E}-04$ & 1.1106E-04 & 6.3942E-05 & 3.89 \\
\hline \multicolumn{9}{|l|}{ Total } \\
\hline$+1-^{n}$ & & & & & & & & \\
\hline
\end{tabular}


Rod "J" 1200830 (SBI-3 A49)

\begin{tabular}{|c|c|c|c|c|c|c|c|c|}
\hline & $\mathrm{J}-00$ & $\mathrm{~J}-01$ & $\mathrm{~J}-02$ & $\mathrm{~J}-03$ & $\mathrm{~J}-04$ & $\mathrm{~J}-05$ & $\mathrm{~J}-06$ & $\mathrm{~J}-07$ \\
\hline seg length (in) ${ }^{a}$ & 11.319 & 11.439 & 14.242 & 14.043 & 14.133 & 13.913 & 10.498 & \\
\hline \multicolumn{9}{|l|}{ total length (in) } \\
\hline & & & & & & & & \\
\hline Zr-95 (atoms) ${ }^{\mathrm{h}}$ & NA & $9.4020 \mathrm{E}+15$ & $3.0250 \mathrm{E}+17$ & $4.6690 \mathrm{E}+17$ & $5.8520 \mathrm{E}+17$ & $4.9840 \mathrm{E}+17$ & $2.2260 \mathrm{E}+17$ & 8.82 \\
\hline$+/-^{\mathrm{h}}$ & NA & $1.9670 \mathrm{E}+14$ & $1.0230 \mathrm{E}+16$ & $2.0470 \mathrm{E}+16$ & $2.8950 \mathrm{E}+16$ & $1.4380 \mathrm{E}+16$ & $1.0920 \mathrm{E}+16$ & 6.71 \\
\hline Zr-95 (g) ${ }^{m}$ & NA & $1.4816 \mathrm{E}-06$ & $4.7668 \mathrm{E}-05$ & $7.3575 \mathrm{E}-05$ & $9.2216 \mathrm{E}-05$ & $7.8538 \mathrm{E}-05$ & $3.5078 \mathrm{E}-05$ & 1.39 \\
\hline$+/-^{m}$ & NA & $3.0996 \mathrm{E}-08$ & $1.6121 \mathrm{E}-06$ & $3.2257 \mathrm{E}-06$ & $4.5620 \mathrm{E}-06$ & $2.2660 \mathrm{E}-06$ & $1.7208 \mathrm{E}-06$ & 1.05 \\
\hline \multicolumn{9}{|l|}{ Total } \\
\hline$+1-^{n}$ & & & & & & & & \\
\hline
\end{tabular}

Footnotes

a. ANL Destructive Chemical Assay of 33-Rod LWBR EOL Sample - Rod J, 1200830, page 3

b. ANL Destructive Chemical Assay of 33-Rod LWBR EOL Sample - Rod J, 1200830, page 6

c. ANL Destructive Chemical Assay of 33-Rod LWBR EOL Sample - Rod J, 1200830, page 7

d. ANL Destructive Chemical Assay of 33-Rod LWBR EOL Sample - Rod J, 1200830, page 10

e. ANL Destructive Chemical Assay of 33-Rod LWBR EOL Sample - Rod J, 1200830, page 11

f. ANL Destructive Chemical Assay of 33-Rod LWBR EOL Sample - Rod J, 1200830, page 12

g. ANL Destructive Chemical Assay of 33-Rod LWBR EOL Sample - Rod J, 1200830, page 13

h. ANL Destructive Chemical Assay of 33-Rod LWBR EOL Sample - Rod J, 1200830, page 14

i. (abundance of the specified isotope)(total weight of uranium) / 100

j. $\quad$ Error Propagation $=\left(\left(s d_{x} / x\right)^{2}+\left(s d_{y} / y\right)^{2}\right)^{1 / 2}(x y)$, where sd is the $+/-$ in the table

k. (mole\%)(number moles gas recovered)(molec wt) / 100

m. (number of atoms per segment)(atomic weight) / 6.0228E+23

n. Error Propagation $=\left(\operatorname{SUM}\left(\mathrm{sd}_{\mathrm{i}}^{2}\right)\right)^{1 / 2}$, where sd is the $+/$ - in the table

o. ((shear gas $/ \mathrm{Xe}+\mathrm{Kr}$ (diss\&pl ))(moles Xe or $\mathrm{Kr}($ diss $+\mathrm{pl}))+$ moles Xe or $\mathrm{Kr}$ (diss + pl)

p. Error Propagation $=\left(\left(\left(\left(s d_{x} / x\right)^{2}+\left(s d_{y} / y\right)^{2}+\left(s d_{z} / z\right)^{2}\right)^{1 / 2}(x y / z)\right)^{2}+\left(s d_{y}\right)^{2}\right)^{1 / 2}$, where sd is the $+/$ - in the table 
Rod "K" 1302864 (SBI-3 D24)

\begin{tabular}{|c|c|c|c|c|c|c|c|c|}
\hline & $\mathrm{K}-00$ & K-01 & $\mathrm{K}-02$ & $\mathrm{~K}-03$ & $\mathrm{~K}-04$ & K-05 & $\mathrm{K}-06$ & $\mathrm{~K}-07$ \\
\hline seg length (in) ${ }^{a}$ & 11.38 & 8.308 & 14.235 & 14.034 & 14.034 & 14.019 & 14.135 & 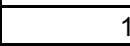 \\
\hline \multicolumn{9}{|l|}{ total length (in) } \\
\hline & & & & & & & & \\
\hline U-232 wt $\%^{b}$ & 0 & 0.0128 & 0.0291 & 0.1049 & 0.1592 & 0.1676 & 0.133 & 0 \\
\hline$+1-{ }^{\mathrm{b}}$ & 0 & 0.0004 & 0.0009 & 0.0032 & 0.0049 & 0.0052 & 0.0041 & 0 \\
\hline $\mathrm{U}-232 \mathrm{~g}^{\mathrm{i}}$ & $0.0000 \mathrm{E}+00$ & $5.8481 \mathrm{E}-05$ & $2.7294 \mathrm{E}-03$ & $9.9356 \mathrm{E}-03$ & $1.5410 \mathrm{E}-02$ & 1.6117E-02 & $1.2302 \mathrm{E}-02$ & 3.544 \\
\hline$+/^{j}$ & NA & 1.8276E-06 & $8.4417 \mathrm{E}-05$ & $3.0310 \mathrm{E}-04$ & $4.7433 \mathrm{E}-04$ & $5.0006 \mathrm{E}-04$ & 3.7925E-04 & 1.109 \\
\hline \multicolumn{9}{|l|}{ Segment Total } \\
\hline \multicolumn{9}{|l|}{$+/-^{n}$} \\
\hline & & & & & & & & \\
\hline$U-233 w t \%{ }^{b}$ & 100 & 98.3699 & 94.4057 & 89.9048 & 87.363 & 86.6543 & 87.5838 & 94 \\
\hline$+/_{-}^{\mathrm{b}}$ & 0 & 0.0138 & 0.0055 & 0.0064 & 0.0063 & 0.007 & 0.0064 & 0 \\
\hline $\mathrm{U}-233 \mathrm{~g}^{\mathrm{i}}$ & $4.0000 \mathrm{E}-05$ & 4.4943E-01 & $8.8547 \mathrm{E}+00$ & $8.5154 \mathrm{E}+00$ & $8.4566 \mathrm{E}+00$ & $8.3328 \mathrm{E}+00$ & $8.1012 \mathrm{E}+00$ & 2.4410 \\
\hline$+/{ }^{j}$ & $1.0000 \mathrm{E}-05$ & $1.4258 \mathrm{E}-04$ & $2.3790 \mathrm{E}-03$ & $2.3801 \mathrm{E}-03$ & $2.1584 \mathrm{E}-03$ & 2.2934E-03 & $2.2091 \mathrm{E}-03$ & 7.773 \\
\hline \multicolumn{9}{|l|}{ Segment Total } \\
\hline \multicolumn{9}{|l|}{$+/-^{n}$} \\
\hline & & & & & & & & \\
\hline U-234 wt ${ }^{b}$ & 0 & 1.4383 & 4.7304 & 8.3343 & 10.2387 & 10.7721 & 10.1038 & 4 \\
\hline$+1-^{b}$ & 0 & 0.0007 & 0.0007 & 0.0009 & 0.001 & 0.0012 & 0.0011 & 0 \\
\hline $\mathrm{U}-234 \mathrm{~g}^{\mathrm{i}}$ & $0.0000 \mathrm{E}+00$ & $6.5713 \mathrm{E}-03$ & $4.4368 \mathrm{E}-01$ & 7.8939E-01 & $9.9109 \mathrm{E}-01$ & $1.0359 \mathrm{E}+00$ & $9.3456 \mathrm{E}-01$ & 1.220 \\
\hline$+I^{\mathrm{j}}$ & NA & $3.7046 \mathrm{E}-06$ & $1.3361 \mathrm{E}-04$ & $2.2976 \mathrm{E}-04$ & $2.6125 \mathrm{E}-04$ & 2.9596E-04 & $2.6577 \mathrm{E}-04$ & 4.187 \\
\hline \multicolumn{9}{|l|}{ Segment Total } \\
\hline \multicolumn{9}{|l|}{$+/-^{n}$} \\
\hline & & & & & & & & \\
\hline $\mathrm{U}-235 \mathrm{wt} \%{ }^{\mathrm{b}}$ & 0 & 0.0848 & 0.5397 & 1.3262 & 1.8664 & 2.0106 & 1.8017 & 0 \\
\hline$+-_{-}^{b}$ & 0 & 0.01 & 0.0041 & 0.0045 & 0.0037 & 0.0043 & 0.0042 & 0 \\
\hline $\mathrm{U}-235 \mathrm{~g}^{\mathrm{i}}$ & $0.0000 \mathrm{E}+00$ & 3.8743E-04 & $5.0621 \mathrm{E}-02$ & $1.2561 \mathrm{E}-01$ & 1.8066E-01 & 1.9334E-01 & 1.6665E-01 & 1.256 \\
\hline+$]^{j}$ & NA & $4.5688 \mathrm{E}-05$ & $3.8478 \mathrm{E}-04$ & $4.2757 \mathrm{E}-04$ & 3.6087E-04 & $4.1661 \mathrm{E}-04$ & $3.9094 \mathrm{E}-04$ & 1.883 \\
\hline \multicolumn{9}{|l|}{ Segment Total } \\
\hline \multicolumn{9}{|l|}{$+/-^{n}$} \\
\hline & & & & & & & & \\
\hline $\mathrm{U}-236 \mathrm{wt} \%{ }^{\mathrm{b}}$ & 0 & 0.0131 & 0.0601 & 0.1188 & 0.1789 & 0.1986 & 0.1706 & 0 \\
\hline$+1-^{\mathrm{b}}$ & 0 & 0.0001 & 0.0001 & 0.0001 & 0.0001 & 0.0001 & 0.0001 & 0 \\
\hline $\mathrm{U}-236 \mathrm{~g}^{\mathrm{i}}$ & $0.0000 \mathrm{E}+00$ & $5.9851 \mathrm{E}-05$ & $5.6370 \mathrm{E}-03$ & $1.1252 \mathrm{E}-02$ & 1.7317E-02 & $1.9098 \mathrm{E}-02$ & $1.5780 \mathrm{E}-02$ & 4.695 \\
\hline$+{ }^{j}$ & NA & $4.5720 \mathrm{E}-07$ & 9.4952E-06 & $9.9478 \mathrm{E}-06$ & $1.0568 \mathrm{E}-05$ & $1.0850 \mathrm{E}-05$ & 1.0136E-05 & 2.583 \\
\hline \multicolumn{9}{|l|}{ Segment Total } \\
\hline$+/_{-}^{n}$ & & & & & & & & \\
\hline
\end{tabular}


Rod "K" 1302864 (SBI-3 D24)

\begin{tabular}{|c|c|c|c|c|c|c|c|c|}
\hline & $\mathrm{K}-00$ & K-01 & $\mathrm{K}-02$ & K-03 & K-04 & K-05 & K-06 & K-07 \\
\hline seg length (in) ${ }^{a}$ & 11.38 & 8.308 & 14.235 & 14.034 & 14.034 & 14.019 & 14.135 & \begin{tabular}{|l|} 
\\
\end{tabular} \\
\hline \multicolumn{9}{|l|}{ total length (in) } \\
\hline & & & & & & & & \\
\hline U-238 wt $\%^{b}$ & 0 & 0.0811 & 0.2349 & 0.211 & 0.1938 & 0.1967 & 0.2071 & 0 \\
\hline$+1-^{\mathrm{b}}$ & 0 & 0.0098 & 0.0039 & 0.0044 & 0.0036 & 0.0042 & 0.0041 & $\underline{0}$ \\
\hline $\mathrm{U}-238 \mathrm{~g}^{\mathrm{i}}$ & $0.0000 \mathrm{E}+00$ & 3.7053E-04 & $2.2032 \mathrm{E}-02$ & 1.9985E-02 & 1.8759E-02 & 1.8915E-02 & 1.9156E-02 & 1.057 \\
\hline$+/-^{j}$ & \begin{tabular}{|l|}
$N A$ \\
\end{tabular} & 4.4774E-05 & $3.6584 \mathrm{E}-04$ & $4.1678 \mathrm{E}-04$ & $3.4850 \mathrm{E}-04$ & $4.0391 \mathrm{E}-04$ & 3.7927E-04 & 1.857 \\
\hline \multicolumn{9}{|l|}{ Segment Total } \\
\hline \multicolumn{9}{|l|}{$+/-^{n}$} \\
\hline & & & & & & & & \\
\hline tot $U^{c}$ & 0.00236 & 0.45688 & 9.37938 & 9.47154 & 9.67982 & 9.61619 & 9.24963 & 2.5 \\
\hline$+/-^{c}$ & 0.00002 & 0.00013 & 0.00246 & 0.00256 & 0.00237 & 0.00253 & 0.00243 & 0.1 \\
\hline $\mathrm{Kr}-82(\mathrm{~mol} \%)^{\mathrm{d}}$ & 0.2 & 0.2 & 0.2 & 0.2 & 0.2 & 0.2 & 0.2 & \\
\hline$+/^{\mathrm{d}}$ & 0.1 & 0.1 & 0.1 & 0.1 & 0.1 & 0.1 & 0.1 & \\
\hline $\mathrm{Kr}-82(\mathrm{~g})^{\mathrm{K}}$ & $4.9148 \mathrm{E}-07$ & 1.8878E-07 & $1.2123 \mathrm{E}-04$ & $2.6573 \mathrm{E}-04$ & $3.3803 E-04$ & $3.9079 \mathrm{E}-04$ & 3.8142E-04 & 4.574 \\
\hline$+/^{j}$ & $1.5171 \mathrm{E}-05$ & NA & 6.2459E-05 & $1.3518 \mathrm{E}-04$ & 1.7192E-04 & 1.9890E-04 & 1.9412E-04 & 2.464 \\
\hline \multicolumn{9}{|l|}{ Segment Total } \\
\hline \multicolumn{9}{|l|}{$+/^{\mathrm{n}}$} \\
\hline $\mathrm{Kr}-83(\mathrm{~mol} \%)^{\mathrm{d}}$ & 15.6 & 15.6 & 15.6 & 15.6 & 15.6 & 15.6 & 15.6 & \\
\hline$+/^{\mathrm{d}}$ & 0.1 & 0.1 & 0.1 & 0.1 & 0.1 & 0.1 & 0.1 & \\
\hline $\mathrm{Kr}-83(\mathrm{~g})^{\mathrm{k}}$ & $3.8804 \mathrm{E}-05$ & 1.4904E-05 & $9.5711 \mathrm{E}-03$ & $2.0980 \mathrm{E}-02$ & $2.6688 \mathrm{E}-02$ & $3.0854 \mathrm{E}-02$ & $3.0114 \mathrm{E}-02$ & 3.611 \\
\hline$+/{ }^{j}$ & 1.1976E-03 & NA & $1.1916 \mathrm{E}-03$ & 1.9707E-03 & $2.4894 \mathrm{E}-03$ & $2.9428 \mathrm{E}-03$ & $2.8651 \mathrm{E}-03$ & 7.247 \\
\hline \multicolumn{9}{|l|}{ Segment Total } \\
\hline \multicolumn{9}{|l|}{$+/-^{n}$} \\
\hline & & & & & & & & \\
\hline $\mathrm{Kr}-84(\mathrm{~mol} \%)^{\mathrm{d}}$ & 29.8 & 29.8 & 29.8 & 29.8 & 29.8 & 29.8 & 29.8 & \\
\hline$+/{ }^{\mathrm{d}}$ & 0.1 & 0.1 & 0.1 & 0.1 & 0.1 & 0.1 & 0.1 & \\
\hline $\mathrm{Kr}-84(\mathrm{~g})^{\mathrm{K}}$ & $7.5017 \mathrm{E}-05$ & $2.8814 \mathrm{E}-05$ & $1.8503 \mathrm{E}-02$ & $4.0560 \mathrm{E}-02$ & $5.1595 \mathrm{E}-02$ & 5.9647E-02 & $5.8218 \mathrm{E}-02$ & 6.981 \\
\hline$+/{ }^{j}$ & $2.3153 \mathrm{E}-03$ & NA & $2.3014 \mathrm{E}-03$ & 3.8033E-03 & 4.8043E-03 & $5.6798 \mathrm{E}-03$ & 5.5297E-03 & 1.400 \\
\hline \multicolumn{9}{|l|}{ Segment Total } \\
\hline$+/-^{n}$ & & & & & & & & \\
\hline
\end{tabular}


Rod "K" 1302864 (SBI-3 D24)

\begin{tabular}{|c|c|c|c|c|c|c|c|c|}
\hline & $\mathrm{K}-00$ & $\mathrm{~K}-01$ & $\mathrm{~K}-02$ & $\mathrm{~K}-03$ & K-04 & $\mathrm{K}-05$ & K-06 & K-07 \\
\hline seg length (in) ${ }^{a}$ & 11.38 & 8.308 & 14.235 & 14.034 & 14.034 & 14.019 & 14.135 & 1 \\
\hline \multicolumn{9}{|l|}{ total length (in) } \\
\hline & & & & & & & & \\
\hline $\mathrm{Kr}-85(\mathrm{~mol} \%)^{\mathrm{d}}$ & 5.8 & 5.8 & 5.8 & 5.8 & 5.8 & 5.8 & 5.8 & \\
\hline$+/-^{\mathrm{d}}$ & 0.1 & 0.1 & 0.1 & 0.1 & 0.1 & 0.1 & 0.1 & \\
\hline $\mathrm{Kr}-85(\mathrm{~g})^{\mathrm{k}}$ & $1.4775 \mathrm{E}-05$ & $5.6749 \mathrm{E}-06$ & 3.6442E-03 & $7.9883 \mathrm{E}-03$ & $1.0162 \mathrm{E}-02$ & $1.1748 \mathrm{E}-02$ & 1.1466E-02 & 1.375 \\
\hline$+/^{j}$ & $4.5601 \mathrm{E}-04$ & NA & $4.5744 \mathrm{E}-04$ & $7.6116 \mathrm{E}-04$ & $9.6169 \mathrm{E}-04$ & $1.1362 \mathrm{E}-03$ & 1.1062E-03 & 2.768 \\
\hline \multicolumn{9}{|l|}{ Segment Total } \\
\hline \multicolumn{9}{|l|}{$+/-^{n}$} \\
\hline & & & & & & & & \\
\hline $\mathrm{Kr}-86(\mathrm{~mol} \%)^{\mathrm{d}}$ & 48.6 & 48.6 & 48.6 & 48.6 & 48.6 & 48.6 & 48.6 & \\
\hline$+/-^{\mathrm{d}}$ & 0.1 & 0.1 & 0.1 & 0.1 & 0.1 & 0.1 & 0.1 & \\
\hline $\mathrm{Kr}-86(\mathrm{~g})^{\mathrm{k}}$ & $1.2526 \mathrm{E}-04$ & $4.8111 \mathrm{E}-05$ & 3.0895E-02 & $6.7723 \mathrm{E}-02$ & $8.6150 \mathrm{E}-02$ & 9.9595E-02 & $9.7208 \mathrm{E}-02$ & 1.165 \\
\hline$+/-^{j}$ & $3.8660 \mathrm{E}-03$ & NA & $3.8418 \mathrm{E}-03$ & $6.3480 \mathrm{E}-03$ & $8.0186 \mathrm{E}-03$ & $9.4801 \mathrm{E}-03$ & 9.2296E-03 & 2.338 \\
\hline \multicolumn{9}{|l|}{ Segment Total } \\
\hline \multicolumn{9}{|l|}{$+-^{n}$} \\
\hline \multicolumn{9}{|l|}{ Rod Total } \\
\hline \multicolumn{9}{|l|}{$+/^{n}$} \\
\hline & & & & & & & & \\
\hline shear gas $(\mathrm{g})^{\mathrm{e}}$ & 0 & 0.0006 & 0.0005 & 0.0017 & 0.0024 & 0.002 & 0.0018 & 0 \\
\hline$+\mathrm{I}^{\mathrm{e}}$ & 0 & 0.0003 & 0.0003 & 0.0003 & 0.0005 & 0.0004 & 0.0004 & 0 \\
\hline moles $\mathrm{Kr}(\text { diss }+\mathrm{pl})^{\mathrm{d}}$ & 0.000003 & 0 & 0.000739 & 0.001619 & 0.002059 & 0.002382 & 0.002325 & 0.0 \\
\hline$+l^{-\mathrm{d}}$ & 0 & 0 & 0.000092 & 0.000152 & 0.000192 & 0.000227 & 0.000221 & 0.0 \\
\hline $\mathrm{Kr}+\mathrm{Xe}$ diss\&pl $(\mathrm{g})^{\mathrm{d}}$ & 0.0018 & 0 & 0.3848 & 0.9115 & 1.1391 & 1.42 & 1.3119 & \\
\hline$+/^{-\mathrm{d}}$ & 0.0001 & 0 & 0.032 & 0.0558 & 0.1296 & 0.0786 & 0.1498 & 0 \\
\hline moles kr (tot) $^{\circ}$ & $3.0000 \mathrm{E}-06$ & $1.1523 \mathrm{E}-06$ & $7.3996 \mathrm{E}-04$ & $1.6220 \mathrm{E}-03$ & $2.0633 \mathrm{E}-03$ & $2.3854 \mathrm{E}-03$ & $2.3282 \mathrm{E}-03$ & 2.792 \\
\hline$+/_{-}^{\mathrm{p}}$ & $9.2593 \mathrm{E}-05$ & $6.0142 \mathrm{E}-07$ & $9.2002 \mathrm{E}-05$ & $1.5200 \mathrm{E}-04$ & $1.9200 \mathrm{E}-04$ & $2.2700 \mathrm{E}-04$ & $2.2100 \mathrm{E}-04$ & 5.600 \\
\hline $\mathrm{Xe}-128(\mathrm{~mol} \%)^{\mathrm{d}}$ & 0.1 & 0.1 & 0.1 & 0.1 & 0.1 & 0.1 & 0.1 & \\
\hline$+-^{\mathrm{d}}$ & 0 & 0 & 0 & 0 & 0 & 0 & 0 & \\
\hline $\mathrm{Xe}-128(\mathrm{~g})^{\mathrm{k}}$ & $1.4069 \mathrm{E}-06$ & 4.7864E-07 & 3.0737E-04 & $7.3900 \mathrm{E}-04$ & $9.2079 \mathrm{E}-04$ & $1.1621 \mathrm{E}-03$ & 1.0636E-03 & 1.071 \\
\hline$+/_{-}^{j}$ & $8.3276 \mathrm{E}-05$ & $2.4694 \mathrm{E}-07$ & $2.9547 \mathrm{E}-05$ & $5.1802 \mathrm{E}-05$ & 1.2253E-04 & $7.2522 \mathrm{E}-05$ & $1.4159 \mathrm{E}-04$ & 1.432 \\
\hline \multicolumn{9}{|l|}{ SegmentTotal } \\
\hline$+/^{\mathrm{n}}$ & & & & & & & & \\
\hline
\end{tabular}


Rod "K" 1302864 (SBI-3 D24)

\begin{tabular}{|c|c|c|c|c|c|c|c|c|}
\hline & $\mathrm{K}-00$ & $\mathrm{~K}-01$ & $\mathrm{~K}-02$ & $\mathrm{~K}-03$ & K-04 & K-05 & K-06 & K-07 \\
\hline seg length (in) ${ }^{a}$ & 11.38 & 8.308 & 14.235 & 14.034 & 14.034 & 14.019 & 14.135 & 1 \\
\hline \multicolumn{9}{|l|}{ total length (in) } \\
\hline $\mathrm{Xe}-130(\mathrm{~mol} \%)^{\mathrm{d}}$ & 0.2 & 0.2 & 0.2 & 0.2 & 0.2 & 0.2 & 0.2 & \\
\hline$+/_{-}^{\mathrm{d}}$ & 0 & 0 & 0 & 0 & 0 & 0 & 0 & \\
\hline $\mathrm{Xe}-130(\mathrm{~g})^{\mathrm{k}}$ & $2.8579 \mathrm{E}-06$ & $9.7225 \mathrm{E}-07$ & $6.2435 \mathrm{E}-04$ & $1.5011 \mathrm{E}-03$ & $1.8704 \mathrm{E}-03$ & $2.3605 \mathrm{E}-03$ & $2.1604 \mathrm{E}-03$ & 2.176 \\
\hline$+/_{-}^{j}$ & 1.6916E-04 & $5.0161 \mathrm{E}-07$ & $6.0017 \mathrm{E}-05$ & $1.0522 \mathrm{E}-04$ & $2.4890 \mathrm{E}-04$ & $1.4731 \mathrm{E}-04$ & $2.8761 \mathrm{E}-04$ & 2.910 \\
\hline \multicolumn{9}{|l|}{ SegmentTotal } \\
\hline \multicolumn{9}{|l|}{$+/^{n}$} \\
\hline & & & & & & & & \\
\hline $\mathrm{Xe}-131(\mathrm{~mol} \%)^{d}$ & 11.8 & 11.8 & 11.8 & 11.8 & 11.8 & 11.8 & 11.8 & \\
\hline$+/_{-}^{\mathrm{d}}$ & 0.1 & 0.1 & 0.1 & 0.1 & 0.1 & 0.1 & 0.1 & \\
\hline $\mathrm{Xe}-131(\mathrm{~g})^{\mathrm{k}}$ & 1.6991E-04 & $5.7805 \mathrm{E}-05$ & $3.7120 \mathrm{E}-02$ & $8.9248 \mathrm{E}-02$ & $1.1120 \mathrm{E}-01$ & 1.4035E-01 & $1.2845 \mathrm{E}-01$ & 1.293 \\
\hline$+/{ }^{j}$ & 1.0057E-02 & $2.9827 \mathrm{E}-05$ & $3.5822 \mathrm{E}-03$ & $6.3016 \mathrm{E}-03$ & $1.4828 \mathrm{E}-02$ & $8.8388 \mathrm{E}-03$ & 1.7134E-02 & 1.733 \\
\hline \multicolumn{9}{|l|}{ SegmentTotal } \\
\hline \multicolumn{9}{|l|}{$+-^{n}$} \\
\hline & & & & & & & & \\
\hline $\mathrm{Xe}-132(\mathrm{~mol} \%)^{\mathrm{d}}$ & 22.7 & 22.7 & 22.7 & 22.7 & 22.7 & 22.7 & 22.7 & \\
\hline$+/_{-}^{\mathrm{d}}$ & 0.1 & 0.1 & 0.1 & 0.1 & 0.1 & 0.1 & 0.1 & \\
\hline $\mathrm{Xe}-132(\mathrm{~g})^{\mathrm{k}}$ & 3.2936E-04 & 1.1205E-04 & $7.1955 \mathrm{E}-02$ & $1.7300 \mathrm{E}-01$ & $2.1556 \mathrm{E}-01$ & $2.7205 \mathrm{E}-01$ & $2.4898 \mathrm{E}-01$ & 2.508 \\
\hline$+/{ }^{j}$ & 1.9495E-02 & $5.7812 \mathrm{E}-05$ & 6.9242E-03 & $1.2151 \mathrm{E}-02$ & $2.8701 \mathrm{E}-02$ & $1.7020 \mathrm{E}-02$ & $3.3164 \mathrm{E}-02$ & 3.355 \\
\hline \multicolumn{9}{|l|}{ SegmentTotal } \\
\hline \multicolumn{9}{|l|}{$+/-^{n}$} \\
\hline Xe-134 (mol\%) $)^{d}$ & 25.8 & 25.8 & 25.8 & 25.8 & 25.8 & 25.8 & 25.8 & \\
\hline$+/_{-}^{\mathrm{d}}$ & 0.1 & 0.1 & 0.1 & 0.1 & 0.1 & 0.1 & 0.1 & \\
\hline $\mathrm{Xe-134}(\mathrm{g})^{\mathrm{k}}$ & $3.8002 \mathrm{E}-04$ & $1.2928 \mathrm{E}-04$ & $8.3022 \mathrm{E}-02$ & 1.9961E-01 & $2.4871 \mathrm{E}-01$ & 3.1389E-01 & $2.8728 \mathrm{E}-01$ & 2.893 \\
\hline$+/{ }^{\mathrm{j}}$ & $2.2493 \mathrm{E}-02$ & 6.6703E-05 & 7.9873E-03 & 1.4013E-02 & $3.3111 \mathrm{E}-02$ & $1.9626 \mathrm{E}-02$ & $3.8261 \mathrm{E}-02$ & 3.871 \\
\hline \multicolumn{9}{|l|}{ SegmentTotal } \\
\hline$+/-^{n}$ & & & & & & & & \\
\hline
\end{tabular}


Rod "K" 1302864 (SBI-3 D24)

\begin{tabular}{|c|c|c|c|c|c|c|c|c|}
\hline & K-00 & K-01 & K-02 & K-03 & K-04 & K-05 & K-06 & K-07 \\
\hline seg length (in) ${ }^{a}$ & 11.38 & 8.308 & 14.235 & 14.034 & 14.034 & 14.019 & 14.135 & 10. \\
\hline \multicolumn{9}{|l|}{ total length (in) } \\
\hline & & & & & & & & \\
\hline $\mathrm{Xe}-136(\mathrm{~mol} \%)^{\mathrm{d}}$ & 39.4 & 39.4 & 39.4 & 39.4 & 39.4 & 39.4 & 39.4 & \\
\hline$+/_{-}^{\mathrm{d}}$ & 0.1 & 0.1 & 0.1 & 0.1 & 0.1 & 0.1 & 0.1 & \\
\hline $\mathrm{Xe}-136(\mathrm{~g})^{\mathrm{k}}$ & $5.8902 \mathrm{E}-04$ & $2.0039 \mathrm{E}-04$ & $1.2868 \mathrm{E}-01$ & $3.0938 \mathrm{E}-01$ & $3.8550 \mathrm{E}-01$ & 4.8652E-01 & $4.4527 \mathrm{E}-01$ & $4.4852 \mathrm{E}$ \\
\hline$+I_{-}^{j}$ & $3.4864 \mathrm{E}-02$ & 1.0339E-04 & $1.2374 \mathrm{E}-02$ & $2.1701 \mathrm{E}-02$ & $5.1308 \mathrm{E}-02$ & $3.0387 \mathrm{E}-02$ & $5.9288 \mathrm{E}-02$ & $5.9992 \mathrm{E}$ \\
\hline \multicolumn{9}{|l|}{ SegmentTotal } \\
\hline \multicolumn{9}{|l|}{$+/-^{n}$} \\
\hline \multicolumn{9}{|l|}{ Rod total } \\
\hline \multicolumn{9}{|l|}{$+-^{\mathrm{n}}$} \\
\hline & & & & & & & & \\
\hline shear gas $(g)^{e}$ & 0 & 0.0006 & 0.0005 & 0.0017 & 0.0024 & 0.002 & 0.0018 & 0.0 \\
\hline$+/-^{e}$ & 0 & 0.0003 & 0.0003 & 0.0003 & 0.0005 & 0.0004 & 0.0004 & 0.0 \\
\hline moles Xe (diss+pl) ${ }^{d}$ & 0.000011 & 0 & 0.0024 & 0.005767 & 0.007184 & 0.009073 & 0.008304 & 0.000 \\
\hline$+/{ }^{\mathrm{d}}$ & 0.000001 & 0 & 0.000231 & 0.000405 & 0.000958 & 0.000567 & 0.001107 & 0.000 \\
\hline $\mathrm{Kr}+\mathrm{Xe}$ diss\&pl $(\mathrm{g})^{\mathrm{d}}$ & 0.0018 & 0 & 0.3848 & 0.9115 & 1.1391 & 1.42 & 1.3119 & 0 \\
\hline$+-^{\mathrm{d}}$ & 0.0001 & 0 & 0.032 & 0.0558 & 0.1296 & 0.0786 & 0.1498 & 0.0 \\
\hline moles Xe (tot) ${ }^{\circ}$ & $1.1000 \mathrm{E}-05$ & $3.7422 \mathrm{E}-06$ & $2.4031 \mathrm{E}-03$ & $5.7778 \mathrm{E}-03$ & $7.1991 \mathrm{E}-03$ & $9.0858 \mathrm{E}-03$ & $8.3154 \mathrm{E}-03$ & $8.3762 \mathrm{E}$ \\
\hline$+/-^{\mathrm{p}}$ & $6.5108 \mathrm{E}-04$ & $1.9307 \mathrm{E}-06$ & $2.3101 \mathrm{E}-04$ & $4.0501 \mathrm{E}-04$ & $9.5801 \mathrm{E}-04$ & $5.6701 \mathrm{E}-04$ & 1.1070E-03 & $1.1202 \mathrm{E}$ \\
\hline \multicolumn{9}{|c|}{ Values corrected to 1/1/84 (page 181, Final Report for the LWBR Proof of Breeding Analytical Support Project } \\
\hline & & & & & & & & \\
\hline Cs-137 (atoms) & NA & $6.2820 \mathrm{E}+18$ & $4.2230 \mathrm{E}+20$ & $9.1210 \mathrm{E}+20$ & $1.2080 \mathrm{E}+21$ & $1.2810 \mathrm{E}+21$ & $1.1440 \mathrm{E}+21$ & $1.3930 \mathrm{E}$ \\
\hline$+/_{-}^{f}$ & NA & $2.2020 \mathrm{E}+16$ & $1.4210 \mathrm{E}+18$ & $2.9660 \mathrm{E}+18$ & $3.9320 \mathrm{E}+18$ & $4.1660 \mathrm{E}+18$ & $3.7150 \mathrm{E}+18$ & $4.7270 \mathrm{E}$ \\
\hline Cs-137 (g) ${ }^{\mathrm{m}}$ & NA & $1.4280 \mathrm{E}-03$ & $9.5995 \mathrm{E}-02$ & 2.0733E-01 & $2.7460 \mathrm{E}-01$ & $2.9119 \mathrm{E}-01$ & $2.6005 \mathrm{E}-01$ & $3.1665 \mathrm{E}$ \\
\hline$+/_{-}^{\mathrm{m}}$ & NA & $5.0055 \mathrm{E}-06$ & $3.2301 \mathrm{E}-04$ & $6.7421 \mathrm{E}-04$ & $8.9380 \mathrm{E}-04$ & 9.4699E-04 & 8.4447E-04 & $1.0745 \mathrm{E}$ \\
\hline \multicolumn{9}{|l|}{ Total } \\
\hline \multicolumn{9}{|l|}{$+1-^{n}$} \\
\hline & & & & & & & & \\
\hline $\mathrm{Ce}-144$ (atoms) $^{9}$ & NA & $6.7410 \mathrm{E}+17$ & $2.9070 \mathrm{E}+19$ & $4.9780 \mathrm{E}+19$ & $6.1220 \mathrm{E}+19$ & $6.4670 \mathrm{E}+19$ & $5.0810 \mathrm{E}+19$ & $8.0980 \mathrm{E}$ \\
\hline$+/^{9}$ & NA & $3.8260 \mathrm{E}+15$ & $1.6890 \mathrm{E}+17$ & $2.8160 \mathrm{E}+17$ & $3.4650 \mathrm{E}+17$ & $3.6580 \mathrm{E}+17$ & $2.8730 \mathrm{E}+17$ & $5.0540 \mathrm{E}$ \\
\hline Ce-144 $(\mathrm{g})^{\mathrm{m}}$ & NA & 1.6107E-04 & $6.9462 \mathrm{E}-03$ & $1.1895 \mathrm{E}-02$ & $1.4628 \mathrm{E}-02$ & $1.5453 \mathrm{E}-02$ & $1.2141 \mathrm{E}-02$ & $1.9350 \mathrm{E}$ \\
\hline$+{ }^{-m}{ }^{m}$ & NA & $9.1421 \mathrm{E}-07$ & $4.0358 \mathrm{E}-05$ & $6.7288 \mathrm{E}-05$ & $8.2795 \mathrm{E}-05$ & 8.7407E-05 & $6.8650 \mathrm{E}-05$ & $1.2076 \mathrm{E}$ \\
\hline \multicolumn{9}{|l|}{ Total } \\
\hline$+1-^{n}$ & & & & & & & & \\
\hline
\end{tabular}


Rod "K" 1302864 (SBI-3 D24)

\begin{tabular}{|c|c|c|c|c|c|c|c|c|}
\hline & $\mathrm{K}-00$ & $\mathrm{~K}-01$ & $\mathrm{~K}-02$ & $\mathrm{~K}-03$ & K-04 & $\mathrm{K}-05$ & K-06 & K-07 \\
\hline seg length (in) ${ }^{a}$ & 11.38 & 8.308 & 14.235 & 14.034 & 14.034 & 14.019 & 14.135 & \\
\hline \multicolumn{9}{|l|}{ total length (in) } \\
\hline & & & & & & & & \\
\hline Zr-95 (atoms) ${ }^{\mathrm{h}}$ & NA & $6.7480 \mathrm{E}+15$ & $2.5440 \mathrm{E}+17$ & $4.1470 \mathrm{E}+17$ & $4.2840 \mathrm{E}+17$ & $4.4320 \mathrm{E}+17$ & $2.5090 \mathrm{E}+17$ & 2.94 \\
\hline$+/-^{\mathrm{h}}$ & NA & $1.4920 \mathrm{E}+14$ & $7.0750 \mathrm{E}+15$ & $1.6760 \mathrm{E}+16$ & $2.6570 \mathrm{E}+16$ & $2.3570 \mathrm{E}+16$ & $2.0430 \mathrm{E}+16$ & 3.44 \\
\hline $\mathrm{Zr}-95(\mathrm{~g})^{\mathrm{m}}$ & NA & $1.0634 \mathrm{E}-06$ & $4.0089 \mathrm{E}-05$ & $6.5349 \mathrm{E}-05$ & $6.7508 \mathrm{E}-05$ & $6.9840 \mathrm{E}-05$ & 3.9537E-05 & 4.6 \\
\hline$+/-^{m}$ & NA & $2.3511 \mathrm{E}-08$ & $1.1149 \mathrm{E}-06$ & $2.6411 \mathrm{E}-06$ & $4.1869 \mathrm{E}-06$ & $3.7142 \mathrm{E}-06$ & $3.2194 \mathrm{E}-06$ & 5.4 \\
\hline \multicolumn{9}{|l|}{ Total } \\
\hline$+/-^{n}$ & & & & & & & & \\
\hline
\end{tabular}

Footnotes

a. ANL Destructive Chemical Assay of 33-Rod LWBR EOL Sample - Rod K, 1302864, page 3

b. ANL Destructive Chemical Assay of 33-Rod LWBR EOL Sample - Rod K, 1302864, page 6

c. ANL Destructive Chemical Assay of 33-Rod LWBR EOL Sample - Rod K, 1302864, page 7

d. ANL Destructive Chemical Assay of 33-Rod LWBR EOL Sample - Rod K, 1302864, page 10

e. ANL Destructive Chemical Assay of 33-Rod LWBR EOL Sample - Rod K, 1302864, page 11

f. ANL Destructive Chemical Assay of 33-Rod LWBR EOL Sample - Rod K, 1302864, page 12

g. ANL Destructive Chemical Assay of 33-Rod LWBR EOL Sample - Rod K, 1302864, page 13

h. ANL Destructive Chemical Assay of 33-Rod LWBR EOL Sample - Rod K, 1302864, page 14

i. (abundance of the specified isotope)(total weight of uranium) / 100

j. $\quad$ Error Propagation $=\left(\left(s d_{x} / x\right)^{2}+\left(s d_{y} / y\right)^{2}\right)^{1 / 2}(x y)$, where $s d$ is the $+/-$ in the table

k. (mole\%)(number moles gas recovered)(molec wt) / 100

m. (number of atoms per segment)(atomic weight) / 6.0228E+23

n. Error Propagation $=\left(\operatorname{SUM}\left({s d_{i}}^{2}\right)\right)^{1 / 2}$, where sd is the $+/-$ in the table

o. $\quad(($ shear gas $/ \mathrm{Xe}+\mathrm{Kr}($ diss\&pl $))($ moles $\mathrm{Xe}$ or $\mathrm{Kr}$ (diss $+\mathrm{pl}))+$ moles $\mathrm{Xe}$ or $\mathrm{Kr}$ (diss $+\mathrm{pl})$

p. Error Propagation $=\left(\left(\left(\left(s d_{x} / x\right)^{2}+\left(s d_{y} / y\right)^{2}+\left(s d_{z} / z\right)^{2}\right)^{1 / 2}(x y / z)\right)^{2}+\left(s d_{y}\right)^{2}\right)^{1 / 2}$, where sd is the $+/-$ in the table 
Rod "L" 1400544 (SBI-3 C3)

\begin{tabular}{|c|c|c|c|c|c|c|c|c|}
\hline & $\mathrm{L}-00$ & L-01 & L-02 & L-03 & L-04 & L-05 & L-06 & L-07 \\
\hline seg length (in) ${ }^{a}$ & 11.176 & 11.007 & 14.373 & 14.172 & 14.17 & 14.25 & 13.927 & \\
\hline \multicolumn{9}{|l|}{ total length (in) } \\
\hline & & & & & & & & \\
\hline $\mathrm{U}-232 \mathrm{wt} \%^{\mathrm{b}}$ & 0 & 0.0143 & 0.0336 & 0.1192 & 0.1774 & 0.1849 & 0.2232 & \\
\hline$+/_{-}^{\mathrm{b}}$ & 0 & 0.0004 & 0.001 & 0.0037 & 0.0055 & 0.0057 & 0.0069 & \\
\hline $\mathrm{U}-232 \mathrm{~g}^{\mathrm{i}}$ & $0.0000 \mathrm{E}+00$ & 5.3335E-05 & $2.7665 \mathrm{E}-03$ & 1.0328E-02 & $1.6010 \mathrm{E}-02$ & $1.6521 \mathrm{E}-02$ & $1.1600 \mathrm{E}-02$ & 3.574 \\
\hline$+/^{j}$ & NA & 1.4920E-06 & $8.2341 \mathrm{E}-05$ & $3.2060 \mathrm{E}-04$ & $4.9638 \mathrm{E}-04$ & $5.0932 \mathrm{E}-04$ & $3.5860 \mathrm{E}-04$ & 1.101 \\
\hline \multicolumn{9}{|l|}{ Segment Total } \\
\hline \multicolumn{9}{|l|}{$+-^{n}$} \\
\hline & & & & & & & & \\
\hline $\mathrm{U}-233 \mathrm{wt} \%^{\mathrm{b}}$ & 100 & 99.1263 & 94.4905 & 89.8566 & 87.2258 & 86.2043 & 91.2627 & 9 \\
\hline$+/_{-}^{\mathrm{b}}$ & 0 & 0.0165 & 0.0072 & 0.0069 & 0.0078 & 0.0078 & 0.0083 & \\
\hline $\mathrm{U}-233 \mathrm{~g}^{\mathrm{i}}$ & $4.0000 \mathrm{E}-05$ & $3.6971 \mathrm{E}-01$ & $7.7800 \mathrm{E}+00$ & $7.7855 \mathrm{E}+00$ & $7.8718 \mathrm{E}+00$ & $7.7023 \mathrm{E}+00$ & $4.7429 \mathrm{E}+00$ & 2.532 \\
\hline$+/-^{j}$ & $1.0000 \mathrm{E}-05$ & $1.4280 \mathrm{E}-04$ & $2.3989 \mathrm{E}-03$ & $2.3420 \mathrm{E}-03$ & $2.4748 \mathrm{E}-03$ & $2.3966 \mathrm{E}-03$ & $1.2538 \mathrm{E}-03$ & 7.433 \\
\hline \multicolumn{9}{|l|}{ Segment Total } \\
\hline \multicolumn{9}{|l|}{$+/-^{\mathrm{n}}$} \\
\hline & & & & & & & & \\
\hline U-234 wt $\%^{b}$ & 0 & 0.8088 & 4.7282 & 8.4153 & 10.371 & 11.1056 & 7.3494 & \\
\hline$+/_{-}^{\mathrm{b}}$ & 0 & 0.001 & 0.001 & 0.0012 & 0.0014 & 0.0014 & 0.0011 & \\
\hline $\mathrm{U}-234 \mathrm{~g}^{\mathrm{i}}$ & $0.0000 \mathrm{E}+00$ & $3.0166 \mathrm{E}-03$ & 3.8930E-01 & $7.2913 \mathrm{E}-01$ & $9.3595 \mathrm{E}-01$ & $9.9228 \mathrm{E}-01$ & 3.8195E-01 & 1.358 \\
\hline$+/-^{j}$ & NA & $3.8751 \mathrm{E}-06$ & $1.4251 \mathrm{E}-04$ & $2.3618 \mathrm{E}-04$ & 3.0909E-04 & $3.2080 \mathrm{E}-04$ & $1.1071 \mathrm{E}-04$ & 4.687 \\
\hline \multicolumn{9}{|l|}{ Segment Total } \\
\hline \multicolumn{9}{|l|}{$+/^{n}$} \\
\hline & & & & & & & & \\
\hline $\mathrm{U}-235 \mathrm{wt} \%^{\mathrm{b}}$ & 0 & 0.0168 & 0.4773 & 1.3112 & 1.8817 & 2.1282 & 1.0983 & \\
\hline$+1-^{\mathrm{b}}$ & 0 & 0.0118 & 0.0055 & 0.0048 & 0.005 & 0.005 & 0.0043 & \\
\hline U-235 $\mathrm{g}^{\mathrm{i}}$ & $0.0000 \mathrm{E}+00$ & $6.2659 \mathrm{E}-05$ & 3.9299E-02 & $1.1361 \mathrm{E}-01$ & 1.6982E-01 & 1.9015E-01 & $5.7078 \mathrm{E}-02$ & 1.481 \\
\hline$+/^{j}$ & NA & $4.4010 \mathrm{E}-05$ & $4.5300 \mathrm{E}-04$ & $4.1720 \mathrm{E}-04$ & $4.5413 \mathrm{E}-04$ & $4.5032 \mathrm{E}-04$ & $2.2392 \mathrm{E}-04$ & 1.290 \\
\hline \multicolumn{9}{|l|}{ Segment Total } \\
\hline \multicolumn{9}{|l|}{$+/^{n}$} \\
\hline U-236 wt $\%^{b}$ & 0 & 0.0002 & 0.025 & 0.0877 & 0.1539 & 0.1868 & 0.0646 & \\
\hline$+1-^{b}$ & 0 & 0.0001 & 0.0001 & 0.0001 & 0.0001 & 0.0001 & 0.0001 & \\
\hline $\mathrm{U}-236 \mathrm{~g}^{\mathrm{i}}$ & $0.0000 \mathrm{E}+00$ & 7.4594E-07 & $2.0584 \mathrm{E}-03$ & 7.5987E-03 & $1.3889 \mathrm{E}-02$ & $1.6690 \mathrm{E}-02$ & $3.3572 \mathrm{E}-03$ & 5.858 \\
\hline$+I^{j}$ & NA & 3.7297E-07 & $8.2566 \mathrm{E}-06$ & $8.9418 \mathrm{E}-06$ & 9.9483E-06 & $1.0224 \mathrm{E}-05$ & $5.2634 \mathrm{E}-06$ & 2.692 \\
\hline \multicolumn{9}{|l|}{ Segment Total } \\
\hline$+1-^{n}$ & & & & & & & & \\
\hline
\end{tabular}


Rod "L" 1400544 (SBI-3 C3)

\begin{tabular}{|c|c|c|c|c|c|c|c|c|}
\hline & L-00 & L-01 & L-02 & L-03 & L-04 & L-05 & L-06 & L-07 \\
\hline seg length (in) ${ }^{a}$ & 11.176 & 11.007 & 14.373 & 14.172 & 14.17 & 14.25 & 13.927 & \\
\hline total length (in) & & & & & & & & \\
\hline $\mathrm{U}-238 \mathrm{wt} \%{ }^{\mathrm{b}}$ & 0 & 0.0336 & 0.2453 & 0.2101 & 0.1904 & 0.1902 & 0.0019 & \\
\hline$+/-^{\mathrm{b}}$ & 0 & 0.0116 & 0.0051 & 0.0044 & 0.0047 & 0.0047 & 0.0038 & \\
\hline $\mathrm{U}-238 \mathrm{~g}^{\mathrm{i}}$ & $0.0000 \mathrm{E}+00$ & $1.2532 \mathrm{E}-04$ & $2.0197 \mathrm{E}-02$ & $1.8204 \mathrm{E}-02$ & $1.7183 \mathrm{E}-02$ & 1.6994E-02 & 9.8743E-05 & 7.256 \\
\hline$+/-^{j}$ & NA & $4.3265 \mathrm{E}-05$ & 4.1996E-04 & $3.8127 \mathrm{E}-04$ & $4.2419 \mathrm{E}-04$ & 4.1997E-04 & 1.9749E-04 & 1.182 \\
\hline Segment Total & & & & & & & & \\
\hline$+/^{n}$ & & & & & & & & \\
\hline & & & & & & & & \\
\hline tot $U^{C}$ & 0.00036 & 0.37297 & 8.23365 & 8.66438 & 9.02466 & 8.93494 & 5.19698 & 2 \\
\hline$+/^{\mathrm{C}}$ & 0.00002 & 0.00013 & 0.00246 & 0.00252 & 0.00272 & 0.00266 & 0.00129 & 0 \\
\hline $\mathrm{Kr}-82(\mathrm{~mol} \%)^{\mathrm{d}}$ & 0.1 & 0.1 & 0.1 & 0.1 & 0.1 & 0.1 & 0.1 & \\
\hline$+/^{\mathrm{d}}$ & 0.1 & 0.1 & 0.1 & 0.1 & 0.1 & 0.1 & 0.1 & \\
\hline $\mathrm{Kr}-82(\mathrm{~g})^{\mathrm{K}}$ & $3.2765 \mathrm{E}-07$ & $0.0000 \mathrm{E}+00$ & $5.7477 \mathrm{E}-05$ & 1.3365E-04 & $1.7176 \mathrm{E}-04$ & $1.5191 \mathrm{E}-04$ & 7.0627E-05 & 2.486 \\
\hline$+/^{j}$ & 6.7776E-06 & NA & 5.7991E-05 & $1.3451 \mathrm{E}-04$ & 1.7246E-04 & $1.5344 \mathrm{E}-04$ & $7.1252 \mathrm{E}-05$ & 2.536 \\
\hline Segment Total & & & & & & & & \\
\hline$+/-^{n}$ & & & & & & & & \\
\hline & & & & & & & & \\
\hline $\mathrm{Kr}-83(\mathrm{~mol} \%)^{\mathrm{d}}$ & 15.2 & 15.2 & 15.2 & 15.2 & 15.2 & 15.2 & 15.2 & \\
\hline$+/^{\mathrm{d}}$ & 0.2 & 0.2 & 0.2 & 0.2 & 0.2 & 0.2 & 0.2 & \\
\hline $\mathrm{Kr}-83(\mathrm{~g})^{\mathrm{K}}$ & $5.0412 \mathrm{E}-05$ & $0.0000 \mathrm{E}+00$ & $8.8433 \mathrm{E}-03$ & $2.0563 \mathrm{E}-02$ & $2.6426 \mathrm{E}-02$ & $2.3372 \mathrm{E}-02$ & $1.0866 \mathrm{E}-02$ & 3.825 \\
\hline$+{ }^{j}-{ }^{j}$ & $1.0416 \mathrm{E}-03$ & NA & $1.1904 \mathrm{E}-03$ & $2.3597 \mathrm{E}-03$ & $2.4197 \mathrm{E}-03$ & $3.3414 \mathrm{E}-03$ & $1.4564 \mathrm{E}-03$ & 7.704 \\
\hline Segment Total & & & & & & & & \\
\hline$+/-^{n}$ & & & & & & & & \\
\hline & & & & & & & & \\
\hline $\mathrm{Kr}-84(\mathrm{~mol} \%)^{\mathrm{d}}$ & 30.1 & 30.1 & 30.1 & 30.1 & 30.1 & 30.1 & 30.1 & \\
\hline$+/-^{\mathrm{d}}$ & 0.2 & 0.2 & 0.2 & 0.2 & 0.2 & 0.2 & 0.2 & \\
\hline $\mathrm{Kr}-84(\mathrm{~g})^{\mathrm{K}}$ & 1.0103E-04 & $0.0000 \mathrm{E}+00$ & $1.7723 \mathrm{E}-02$ & $4.1209 \mathrm{E}-02$ & $5.2961 \mathrm{E}-02$ & $4.6840 \mathrm{E}-02$ & $2.1777 \mathrm{E}-02$ & 7.666 \\
\hline$+/-^{j}$ & $2.0874 \mathrm{E}-03$ & NA & $2.3771 \mathrm{E}-03$ & 4.7059E-03 & $4.8118 \mathrm{E}-03$ & $6.6753 \mathrm{E}-03$ & $2.9082 \mathrm{E}-03$ & 1.541 \\
\hline Segment Total & & & & & & & & \\
\hline$+/-^{\mathrm{n}}$ & & & & & & & & \\
\hline
\end{tabular}


Rod "L" 1400544 (SBI-3 C3)

\begin{tabular}{|c|c|c|c|c|c|c|c|c|}
\hline & L-00 & L-01 & L-02 & L-03 & L-04 & L-05 & L-06 & L-07 \\
\hline seg length (in) ${ }^{a}$ & 11.176 & 11.007 & 14.373 & 14.172 & 14.17 & 14.25 & 13.927 & 10. \\
\hline \multicolumn{9}{|l|}{ total length (in) } \\
\hline & & & & & & & & \\
\hline $\mathrm{Kr}-85(\mathrm{~mol} \%)^{\mathrm{d}}$ & 5.4 & 5.4 & 5.4 & 5.4 & 5.4 & 5.4 & 5.4 & \\
\hline$+/-^{\mathrm{d}}$ & 0.2 & 0.2 & 0.2 & 0.2 & 0.2 & 0.2 & 0.2 & \\
\hline $\mathrm{Kr}-85(\mathrm{~g})^{\mathrm{K}}$ & $1.8341 \mathrm{E}-05$ & $0.0000 \mathrm{E}+00$ & $3.2174 \mathrm{E}-03$ & 7.4812E-03 & $9.6146 \mathrm{E}-03$ & $8.5034 \mathrm{E}-03$ & $3.9535 \mathrm{E}-03$ & $1.3918 \mathrm{E}$ \\
\hline$+/-{ }_{-}^{j}$ & 3.7895E-04 & NA & $4.4719 \mathrm{E}-04$ & $8.9675 \mathrm{E}-04$ & $9.4118 \mathrm{E}-04$ & $1.2508 \mathrm{E}-03$ & $5.4726 \mathrm{E}-04$ & $2.8442 \mathrm{E}$ \\
\hline \multicolumn{9}{|l|}{ Segment Total } \\
\hline \multicolumn{9}{|l|}{$+/-^{n}$} \\
\hline & & & & & & & & \\
\hline $\mathrm{Kr}-86(\mathrm{~mol} \%)^{\mathrm{d}}$ & 49.2 & 49.2 & 49.2 & 49.2 & 49.2 & 49.2 & 49.2 & 4 \\
\hline$+/^{\mathrm{d}}$ & 0.3 & 0.3 & 0.3 & 0.3 & 0.3 & 0.3 & 0.3 & \\
\hline $\mathrm{Kr}-86(\mathrm{~g})^{\mathrm{k}}$ & 1.6907E-04 & $0.0000 \mathrm{E}+00$ & $2.9659 \mathrm{E}-02$ & 6.8963E-02 & $8.8629 \mathrm{E}-02$ & $7.8386 \mathrm{E}-02$ & $3.6444 \mathrm{E}-02$ & $1.2830 \mathrm{E}$ \\
\hline$+/{ }_{-}^{j}$ & $3.4932 \mathrm{E}-03$ & NA & $3.9774 \mathrm{E}-03$ & $7.8731 \mathrm{E}-03$ & $8.0492 \mathrm{E}-03$ & 1.1169E-02 & $4.8660 \mathrm{E}-03$ & $2.5796 \mathrm{E}$ \\
\hline \multicolumn{9}{|l|}{ Segment Total } \\
\hline \multicolumn{9}{|l|}{$+1-^{n}$} \\
\hline \multicolumn{9}{|l|}{ Rod Total } \\
\hline \multicolumn{9}{|l|}{$+-^{\mathrm{n}}$} \\
\hline shear gas $(\mathrm{g})^{\mathrm{e}}$ & 0 & 0 & 0.0004 & 0.0015 & 0.0022 & 0.0025 & 0.0007 & 0.0 \\
\hline$+/^{\mathrm{e}}$ & 0 & 0.0003 & 0.0003 & 0.0003 & 0.0004 & 0.0005 & 0.0003 & 0.0 \\
\hline moles $\mathrm{Kr}(\text { diss }+\mathrm{pl})^{\mathrm{d}}$ & 0.000004 & 0 & 0.000701 & 0.001629 & 0.002093 & 0.00185 & 0.000861 & 0.000 \\
\hline$+r^{-\mathrm{d}}$ & 0 & 0 & 0.000094 & 0.000186 & 0.00019 & 0.000264 & 0.000115 & 0.000 \\
\hline $\mathrm{Kr}+\mathrm{Xe}$ diss\&pl $(\mathrm{g})^{\mathrm{d}}$ & 0.0022 & 0 & 0.4112 & 0.9508 & 1.1996 & 1.0265 & 0.4973 & 0.1 \\
\hline$+/^{-\mathrm{d}}$ & 0.0001 & 0 & 0.0324 & 0.0645 & 0.1288 & 0.0915 & 0.0473 & 0.0 \\
\hline moles kr (tot) ${ }^{\circ}$ & $4.0000 \mathrm{E}-06$ & 0 & $7.0168 \mathrm{E}-04$ & 1.6316E-03 & $2.0968 \mathrm{E}-03$ & 1.8545E-03 & $8.6221 \mathrm{E}-04$ & $3.0353 \mathrm{E}$ \\
\hline$+/^{\mathrm{p}}$ & $8.2645 \mathrm{E}-05$ & 0 & $9.4001 \mathrm{E}-05$ & $1.8600 \mathrm{E}-04$ & $1.9000 \mathrm{E}-04$ & $2.6400 \mathrm{E}-04$ & $1.1500 \mathrm{E}-04$ & $6.1002 \mathrm{E}$ \\
\hline Xe-128 (mol\%) ${ }^{d}$ & 0.1 & 0.1 & 0.1 & 0.1 & 0.1 & 0.1 & 0.1 & \\
\hline$+/{ }^{\mathrm{d}}$ & 0 & 0 & 0 & 0 & 0 & 0 & 0 & \\
\hline $\mathrm{Xe}-128(\mathrm{~g})^{\mathrm{k}}$ & 1.6627E-06 & $0.0000 \mathrm{E}+00$ & $3.3531 \mathrm{E}-04$ & 7.7517E-04 & $9.7526 \mathrm{E}-04$ & $8.3019 \mathrm{E}-04$ & 4.0462E-04 & $1.3979 \mathrm{E}$ \\
\hline$+/_{-}^{j}$ & $6.7530 \mathrm{E}-05$ & NA & $2.9930 \mathrm{E}-05$ & 5.9476E-05 & $1.2164 \mathrm{E}-04$ & $8.4546 \mathrm{E}-05$ & 4.4127E-05 & $1.5478 \mathrm{E}$ \\
\hline SegmentTotal & & & & & & & & \\
\hline$+-^{n}$ & & & & & & & & \\
\hline
\end{tabular}


Rod "L" 1400544 (SBI-3 C3)

\begin{tabular}{|c|c|c|c|c|c|c|c|c|}
\hline & L-00 & L-01 & L-02 & L-03 & L-04 & L-05 & L-06 & L-07 \\
\hline seg length (in) ${ }^{a}$ & 11.176 & 11.007 & 14.373 & 14.172 & 14.17 & 14.25 & 13.927 & 1 \\
\hline \multicolumn{9}{|l|}{ total length (in) } \\
\hline Xe-130 (mol\%) $)^{d}$ & 0.1 & 0.1 & 0.1 & 0.1 & 0.1 & 0.1 & 01 & \\
\hline$+/_{-}^{\mathrm{d}}$ & 0 & 0 & 0 & 0 & 0 & 0 & 0 & \\
\hline Xe-130 $(g)^{k}$ & 1.6887E-06 & $0.0000 \mathrm{E}+00$ & 3.4055E-04 & $7.8729 \mathrm{E}-04$ & $9.9051 \mathrm{E}-04$ & $8.4317 \mathrm{E}-04$ & 4.1094E-04 & 1.419 \\
\hline$+/_{-}^{j}$ & $6.8586 \mathrm{E}-05$ & NA & 3.0398E-05 & 6.0406E-05 & $1.2354 \mathrm{E}-04$ & $8.5868 \mathrm{E}-05$ & $4.4817 \mathrm{E}-05$ & 1.572 \\
\hline \multicolumn{9}{|l|}{ SegmentTotal } \\
\hline \multicolumn{9}{|l|}{$+/-^{n}$} \\
\hline & & & & & & & & \\
\hline $\mathrm{Xe}-131(\mathrm{~mol} \%)^{\mathrm{d}}$ & 11.1 & 11.1 & 11.1 & 11.1 & 11.1 & 11.1 & 11.1 & \\
\hline$+/_{-}^{\mathrm{d}}$ & 0.1 & 0.1 & 0.1 & 0.1 & 0.1 & 0.1 & 0.1 & \\
\hline $\mathrm{Xe}-131(\mathrm{~g})^{\mathrm{k}}$ & $1.8890 \mathrm{E}-04$ & $0.0000 \mathrm{E}+00$ & 3.8092E-02 & $8.8063 \mathrm{E}-02$ & 1.1079E-01 & $9.4314 \mathrm{E}-02$ & $4.5966 \mathrm{E}-02$ & 1.588 \\
\hline$+/{ }^{j}$ & 7.6717E-03 & NA & $3.4175 \mathrm{E}-03$ & $6.8032 \mathrm{E}-03$ & $1.3855 \mathrm{E}-02$ & $9.6423 \mathrm{E}-03$ & $5.0302 \mathrm{E}-03$ & 1.764 \\
\hline \multicolumn{9}{|l|}{ SegmentTotal } \\
\hline \multicolumn{9}{|l|}{$+-^{\mathrm{n}}$} \\
\hline $\mathrm{Xe}-132(\mathrm{~mol} \%)^{\mathrm{d}}$ & 22.6 & 22.6 & 22.6 & 22.6 & 22.6 & 22.6 & 22.6 & \\
\hline$+/_{-}^{\mathrm{d}}$ & 0.1 & 0.1 & 0.1 & 0.1 & 0.1 & 0.1 & 0.1 & \\
\hline $\mathrm{Xe}-132(\mathrm{~g})^{\mathrm{k}}$ & 3.8753E-04 & $0.0000 \mathrm{E}+00$ & 7.8149E-02 & 1.8067E-01 & $2.2730 \mathrm{E}-01$ & 1.9349E-01 & $9.4303 \mathrm{E}-02$ & 3.258 \\
\hline$+/_{-}^{j}$ & 1.5739E-02 & NA & 6.9844E-03 & $1.3885 \mathrm{E}-02$ & $2.8368 \mathrm{E}-02$ & $1.9724 \mathrm{E}-02$ & 1.0293E-02 & 3.610 \\
\hline \multicolumn{9}{|l|}{ SegmentTotal } \\
\hline \multicolumn{9}{|l|}{$+-_{-}^{n}$} \\
\hline $\mathrm{Xe}-134(\mathrm{~mol} \%)^{\mathrm{d}}$ & 25.6 & 25.6 & 25.6 & 25.6 & 25.6 & 25.6 & 25.6 & \\
\hline$+/_{-}^{\mathrm{d}}$ & 0.2 & 0.2 & 0.2 & 0.2 & 0.2 & 0.2 & 0.2 & \\
\hline $\mathrm{Xe-134}(\mathrm{g})^{\mathrm{k}}$ & 4.4564E-04 & $0.0000 \mathrm{E}+00$ & $8.9866 \mathrm{E}-02$ & $2.0775 \mathrm{E}-01$ & $2.6138 \mathrm{E}-01$ & $2.2250 \mathrm{E}-01$ & $1.0844 \mathrm{E}-01$ & 3.746 \\
\hline$+/{ }^{j}$ & 1.8099E-02 & NA & $8.0524 \mathrm{E}-03$ & 1.6023E-02 & 3.2664E-02 & $2.2726 \mathrm{E}-02$ & 1.1857E-02 & 4.158 \\
\hline \multicolumn{9}{|l|}{ SegmentTotal } \\
\hline$+/^{\mathrm{n}}$ & & & & & & & & \\
\hline
\end{tabular}


Rod "L" 1400544 (SBI-3 C3)

\begin{tabular}{|c|c|c|c|c|c|c|c|c|}
\hline & L-00 & L-01 & L-02 & L-03 & L-04 & L-05 & L-06 & L-07 \\
\hline seg length (in) ${ }^{\mathrm{a}}$ & 11.176 & 11.007 & 14.373 & 14.172 & 14.17 & 14.25 & 13.927 & 1 \\
\hline \multicolumn{9}{|l|}{ total length (in) } \\
\hline & & & & & & & & \\
\hline Xe-136 (mol\%) $)^{d}$ & 40.7 & 40.7 & 40.7 & 40.7 & 40.7 & 40.7 & 40.7 & \\
\hline$+/^{\mathrm{d}}$ & 0.2 & 0.2 & 0.2 & 0.2 & 0.2 & 0.2 & 0.2 & \\
\hline $\mathrm{Xe}-136(\mathrm{~g})^{\mathrm{k}}$ & $7.1909 \mathrm{E}-04$ & $0.0000 \mathrm{E}+00$ & $1.4501 \mathrm{E}-01$ & 3.3523E-01 & $4.2177 \mathrm{E}-01$ & 3.5903E-01 & $1.7498 \mathrm{E}-01$ & 6.045 \\
\hline$+z^{j}$ & $2.9204 \mathrm{E}-02$ & NA & 1.2964E-02 & $2.5774 \mathrm{E}-02$ & $5.2645 \mathrm{E}-02$ & $3.6606 \mathrm{E}-02$ & $1.9103 E-02$ & 6.700 \\
\hline \multicolumn{9}{|l|}{ SegmentTotal } \\
\hline \multicolumn{9}{|l|}{$+/^{\mathrm{n}}$} \\
\hline \multicolumn{9}{|l|}{ Rod total } \\
\hline \multicolumn{9}{|l|}{$+/-^{n}$} \\
\hline shear gas $(q)^{e}$ & 0 & 0 & 0.0004 & 0.0015 & 0.0022 & 0.0025 & 0.0007 & 0 \\
\hline$+{ }^{-e}$ & 0 & 0.0003 & 0.0003 & 0.0003 & 0.0004 & 0.0005 & 0.0003 & 0 \\
\hline moles Xe (diss+pl) ${ }^{d}$ & 0.000013 & 0 & 0.002619 & 0.006051 & 0.007611 & 0.006475 & 0.003159 & $\overline{0.00}$ \\
\hline$+/-^{\mathrm{d}}$ & 0.000001 & 0 & 0.000234 & 0.000465 & 0.000951 & 0.000661 & 0.000345 & 0.00 \\
\hline $\mathrm{Kr}+\mathrm{Xe}$ diss\&pl $(\mathrm{g})^{\mathrm{d}}$ & 0.0022 & 0 & 0.4112 & 0.9508 & 1.1996 & 1.0265 & 0.4973 & 0 \\
\hline$+/_{-}^{\mathrm{d}}$ & 0.0001 & 0 & 0.0324 & 0.0645 & 0.1288 & 0.0915 & 0.0473 & 0 \\
\hline moles Xe (tot) $^{\circ}$ & $1.3000 \mathrm{E}-05$ & 0 & $2.6215 \mathrm{E}-03$ & $6.0605 \mathrm{E}-03$ & $7.6250 \mathrm{E}-03$ & 6.4908E-03 & $3.1634 \mathrm{E}-03$ & $\overline{1.092 ?}$ \\
\hline$+/-^{\mathrm{p}}$ & $5.2797 \mathrm{E}-04$ & 0 & $2.3401 \mathrm{E}-04$ & 4.6500E-04 & $9.5101 \mathrm{E}-04$ & $6.6101 \mathrm{E}-04$ & $3.4501 \mathrm{E}-04$ & 1.210 \\
\hline \multicolumn{9}{|c|}{ Values corrected to 1/1/84 (page 181, Final Report for the LWBR Proof of Breeding Analytical Support Project } \\
\hline & & & & & & & & \\
\hline Cs-137 (atoms) ${ }^{f}$ & NA & $3.8080 \mathrm{E}+18$ & $3.9250 \mathrm{E}+20$ & $8.7130 \mathrm{E}+20$ & $1.1660 \mathrm{E}+21$ & $1.2680 \mathrm{E}+21$ & $4.4470 \mathrm{E}+20$ & 1.5580 \\
\hline$+/_{-}^{f}$ & NA & $1.1990 \mathrm{E}+16$ & $1.1260 \mathrm{E}+18$ & $2.5000 \mathrm{E}+18$ & $3.3460 \mathrm{E}+18$ & $3.6350 \mathrm{E}+18$ & $1.2750 \mathrm{E}+18$ & 4.5260 \\
\hline Cs-137 (g) & NA & $8.6561 \mathrm{E}-04$ & $8.9221 \mathrm{E}-02$ & 1.9806E-01 & $2.6505 \mathrm{E}-01$ & 2.8823E-01 & $1.0109 \mathrm{E}-01$ & 3.5416 \\
\hline$+/_{-}^{m}$ & NA & $2.7255 \mathrm{E}-06$ & $2.5596 \mathrm{E}-04$ & 5.6829E-04 & $7.6059 \mathrm{E}-04$ & $8.2629 \mathrm{E}-04$ & $2.8983 \mathrm{E}-04$ & 1.0288 \\
\hline \multicolumn{9}{|l|}{ Total } \\
\hline \multicolumn{9}{|l|}{$+1-^{n}$} \\
\hline Ce-144 (atoms) & NA & $4.9060 \mathrm{E}+17$ & $2.7450 \mathrm{E}+19$ & $4.8590 \mathrm{E}+19$ & $6.0730 \mathrm{E}+19$ & $6.4920 \mathrm{E}+19$ & $28980 \mathrm{E}+19$ & 8.7540 \\
\hline$+/-^{g}$ & NA & $3.6290 E+15$ & $2.0270 \mathrm{E}+17$ & $3.5880 \mathrm{E}+17$ & $4.4850 \mathrm{E}+17$ & $4.7940 \mathrm{E}+17$ & $2.1400 \mathrm{E}+17$ & 6.4770 \\
\hline $\mathrm{Ce}-144(\mathrm{~g})^{\mathrm{m}}$ & NA & $1.1723 \mathrm{E}-04$ & $6.5591 \mathrm{E}-03$ & $1.1610 \mathrm{E}-02$ & $1.4511 \mathrm{E}-02$ & $1.5512 \mathrm{E}-02$ & $6.9247 \mathrm{E}-03$ & 2.0917 \\
\hline$+1-{ }^{m}$ & NA & $8.6714 \mathrm{E}-07$ & $4.8435 \mathrm{E}-05$ & $8.5734 \mathrm{E}-05$ & 1.0717E-04 & 1.1455E-04 & $5.1135 \mathrm{E}-05$ & 1.5477 \\
\hline \multicolumn{9}{|l|}{ Total } \\
\hline$+/-^{n}$ & & & & & & & & \\
\hline
\end{tabular}


Rod "L" 1400544 (SBI-3 C3)

\begin{tabular}{|c|c|c|c|c|c|c|c|c|}
\hline & L-00 & L-01 & L-02 & L-03 & L-04 & L-05 & L-06 & L-07 \\
\hline seg length (in) ${ }^{a}$ & 11.176 & 11.007 & 14.373 & 14.172 & 14.17 & 14.25 & 13.927 & 1 \\
\hline \multicolumn{9}{|l|}{ total length (in) } \\
\hline & & & & & & & & \\
\hline Zr-95 (atoms) & NA & $5.3870 \mathrm{E}+15$ & $2.4560 \mathrm{E}+17$ & $3.7340 \mathrm{E}+17$ & $5.4680 \mathrm{E}+17$ & $4.1920 \mathrm{E}+17$ & $1.7670 \mathrm{E}+17$ & 2.7740 \\
\hline$+/-^{\mathrm{h}}$ & $\mathrm{NA}$ & $1.6110 \mathrm{E}+14$ & $9.0000 \mathrm{E}+15$ & $1.9010 \mathrm{E}+16$ & $4.1060 \mathrm{E}+16$ & $4.6580 \mathrm{E}+16$ & $1.5310 \mathrm{E}+16$ & 3.8210 \\
\hline $\mathrm{Zr}-95(\mathrm{~g})^{\mathrm{m}}$ & NA & 8.4889E-07 & 3.8702E-05 & $5.8841 \mathrm{E}-05$ & 8.6165E-05 & $6.6058 \mathrm{E}-05$ & 2.7845E-05 & 4.3713 \\
\hline$+-^{m}$ & NA & $2.5386 \mathrm{E}-08$ & 1.4182E-06 & $2.9956 \mathrm{E}-06$ & 6.4703E-06 & $7.3401 \mathrm{E}-06$ & $2.4126 \mathrm{E}-06$ & 6.0212 \\
\hline \multicolumn{9}{|l|}{ Total } \\
\hline$+/-^{n}$ & & & & & & & & \\
\hline
\end{tabular}

Footnotes

a. ANL Destructive Chemical Assay of 33-Rod LWBR EOL Sample - Rod L, 1400544, page 3

b. ANL Destructive Chemical Assay of 33-Rod LWBR EOL Sample - Rod L, 1400544, page 6

c. ANL Destructive Chemical Assay of 33-Rod LWBR EOL Sample - Rod L, 1400544, page 7

d. ANL Destructive Chemical Assay of 33-Rod LWBR EOL Sample - Rod L, 1400544, page 10

e. ANL Destructive Chemical Assay of 33-Rod LWBR EOL Sample - Rod L, 1400544, page 11

f. ANL Destructive Chemical Assay of 33-Rod LWBR EOL Sample - Rod L, 1400544, page 12

g. ANL Destructive Chemical Assay of 33-Rod LWBR EOL Sample - Rod L, 1400544, page 13

h. ANL Destructive Chemical Assay of 33-Rod LWBR EOL Sample - Rod L, 1400544, page 14

i. (abundance of the specified isotope)(total weight of uranium) / 100

j. Error Propagation $=\left(\left(s d_{x} / x\right)^{2}+\left(s d_{y} / y\right)^{2}\right)^{1 / 2}(x y)$, where sd is the $+/-$ in the table

k. (mole\%)(number moles gas recovered)(molec wt) $/ 100$

m. (number of atoms per segment)(atomic weight) / 6.0228E +23

n. Error Propagation $=\left(\operatorname{SUM}\left(\mathrm{sd}_{\mathrm{i}}^{2}\right)\right)^{1 / 2}$, where sd is the $+/$ - in the table

o. ((shear gas / Xe $+\mathrm{Kr}$ (diss\&pl )) (moles Xe or $\mathrm{Kr}$ (diss $+\mathrm{pl}))+$ moles Xe or $\mathrm{Kr}$ (diss $+\mathrm{pl})$

p. Error Propagation $=\left(\left(\left(\left(s d_{x} / x\right)^{2}+\left(s d_{y} / y\right)^{2}+\left(s d_{z} / z\right)^{2}\right)^{1 / 2}(x y / z)\right)^{2}+\left(s d_{y}\right)^{2}\right)^{1 / 2}$, where sd is the $+/-$ in the table 
Rod "M" 0504042 (SI-1, 5L29)

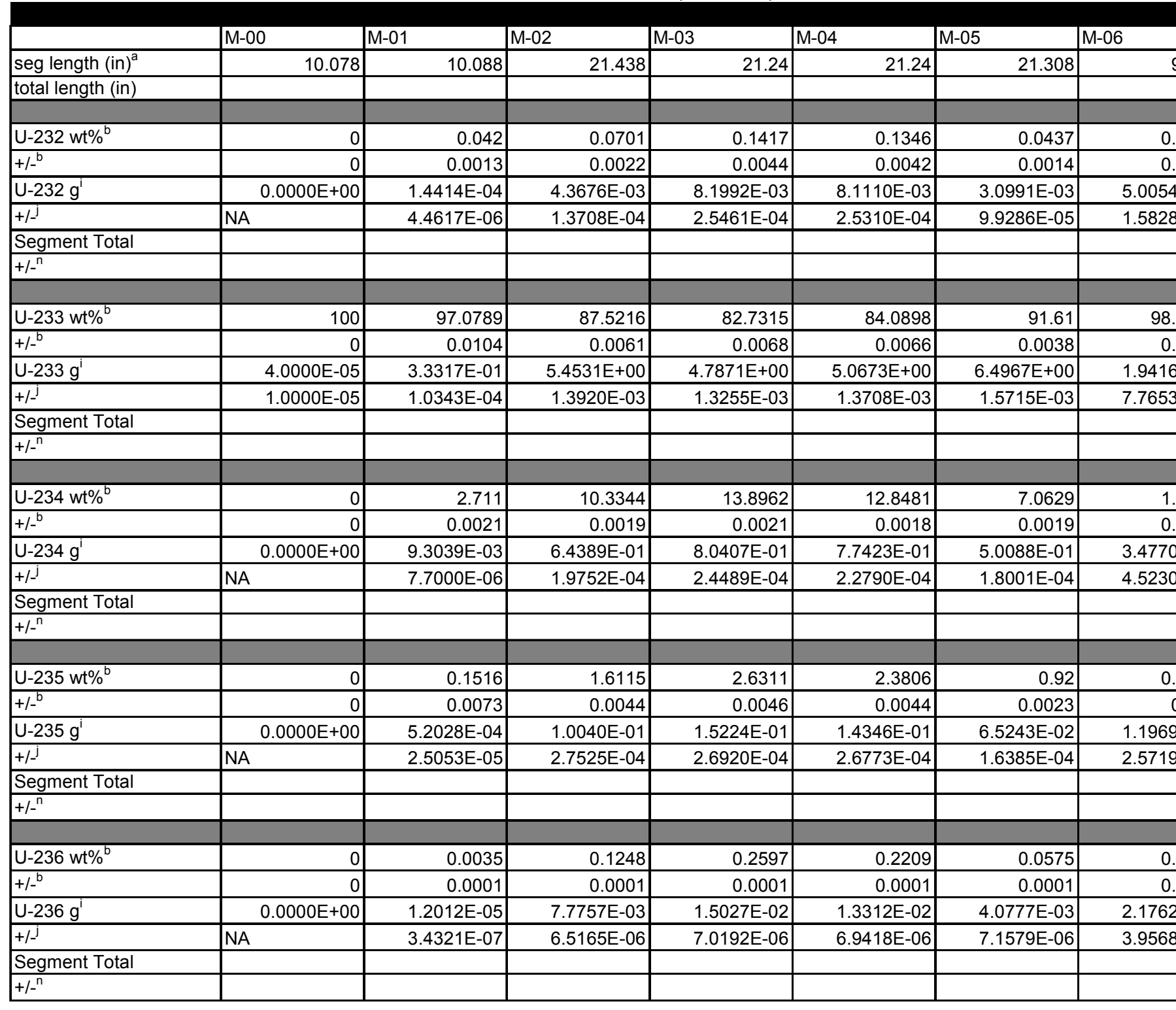


Rod "M" 0504042 (SI-1, 5L29)

\begin{tabular}{|c|c|c|c|c|c|c|c|}
\hline & M-00 & M-01 & M-02 & M-03 & M-04 & M-05 & M-06 \\
\hline seg length (in) ${ }^{a}$ & 10.078 & 10.088 & 21.438 & 21.24 & 21.24 & 21.308 & \\
\hline \multicolumn{8}{|l|}{ total length (in) } \\
\hline & & & & & & & \\
\hline U-238 wt $\%^{b}$ & 0 & 0.0129 & 0.3375 & 0.3397 & 0.326 & 0.3059 & \\
\hline$+-^{\mathrm{b}}$ & 0 & 0.0074 & 0.0045 & 0.0047 & 0.0045 & 0.0024 & \\
\hline U-238 $g^{i}$ & $0.0000 E+00$ & $4.4272 \mathrm{E}-05$ & $2.1028 \mathrm{E}-02$ & 1.9656E-02 & $1.9645 \mathrm{E}-02$ & $2.1693 \mathrm{E}-02$ & 3 \\
\hline$+{ }^{j}{ }^{j}$ & NA & $2.5396 \mathrm{E}-05$ & $2.8042 \mathrm{E}-04$ & $2.7200 \mathrm{E}-04$ & $2.7122 \mathrm{E}-04$ & $1.7028 \mathrm{E}-04$ & 2 \\
\hline \multicolumn{8}{|l|}{ Segment Total } \\
\hline \multicolumn{8}{|l|}{$+/-^{n}$} \\
\hline & & & & & & & \\
\hline tot $U^{C}$ & 0.00007 & 0.34319 & 6.23052 & 5.78628 & 6.02603 & 7.09168 & \\
\hline$+/-^{\mathrm{C}}$ & 0.00001 & 0.0001 & 0.00153 & 0.00153 & 0.00156 & 0.00169 & \\
\hline $\mathrm{Kr}-82(\mathrm{~mol} \%)^{\mathrm{d}}$ & 0.2 & 0.2 & 0.2 & 0.2 & 0.2 & 0.2 & \\
\hline$+/_{-}^{d}$ & 0 & 0 & 0 & 0 & 0 & 0 & \\
\hline $\mathrm{Kr}-82(\mathrm{~g})^{\mathrm{K}}$ & 8.1913E-07 & $0.0000 \mathrm{E}+00$ & 2.5197E-04 & 2.9777E-04 & 2.5897E-04 & 1.7157E-04 & 0 \\
\hline$+/-^{j}$ & $0.0000 \mathrm{E}+00$ & NA & $2.1790 \mathrm{E}-05$ & 3.1786E-05 & $3.1130 \mathrm{E}-05$ & $2.0151 \mathrm{E}-05$ & NA \\
\hline \multicolumn{8}{|l|}{ Segment Total } \\
\hline \multicolumn{8}{|l|}{$+/_{-}^{n}$} \\
\hline $\mathrm{Kr}-83(\mathrm{~mol} \%)^{\mathrm{d}}$ & 14.9 & 14.9 & 14.9 & 14.9 & 14.9 & 14.9 & \\
\hline$+/-^{d}$ & 0.1 & 0.1 & 0.1 & 0.1 & 0.1 & 0.1 & \\
\hline $\mathrm{Kr}-83(\mathrm{~g})^{\mathrm{k}}$ & $6.1771 \mathrm{E}-05$ & $0.0000 \mathrm{E}+00$ & $1.9001 \mathrm{E}-02$ & $2.2455 \mathrm{E}-02$ & 1.9529E-02 & $1.2938 \mathrm{E}-02$ & 0 \\
\hline$+/-^{j}$ & 4.1457E-07 & NA & $1.6481 \mathrm{E}-03$ & $2.4017 \mathrm{E}-03$ & $2.3511 \mathrm{E}-03$ & $1.5221 \mathrm{E}-03$ & NA \\
\hline \multicolumn{8}{|l|}{ Segment Total } \\
\hline \multicolumn{8}{|l|}{$+/-^{\mathrm{n}}$} \\
\hline $\mathrm{Kr}-84(\mathrm{~mol} \%)^{\mathrm{d}}$ & 30.8 & 30.8 & 30.8 & 30.8 & 30.8 & 30.8 & \\
\hline$+/_{-}^{\mathrm{d}}$ & 0.1 & 0.1 & 0.1 & 0.1 & 0.1 & 0.1 & \\
\hline $\mathrm{Kr}-84(\mathrm{~g})^{\mathrm{k}}$ & 1.2922E-04 & $0.0000 \mathrm{E}+00$ & $3.9750 \mathrm{E}-02$ & $4.6975 \mathrm{E}-02$ & $4.0855 \mathrm{E}-02$ & $2.7066 \mathrm{E}-02$ & 0 \\
\hline$+/^{j}$ & 4.1956E-07 & NA & 3.4399E-03 & 5.0167E-03 & 4.9127E-03 & $3.1802 \mathrm{E}-03$ & NA \\
\hline \multicolumn{8}{|l|}{ Segment Total } \\
\hline$+/-^{n}$ & & & & & & & \\
\hline
\end{tabular}


Rod "M" 0504042 (SI-1, 5L29)

\begin{tabular}{|c|c|c|c|c|c|c|c|}
\hline & $\mathrm{M}-00$ & M-01 & M-02 & M-03 & M-04 & M-05 & M-06 \\
\hline seg length (in) ${ }^{a}$ & 10.078 & 10.088 & 21.438 & 21.24 & 21.24 & 21.308 & \\
\hline \multicolumn{8}{|l|}{ total length (in) } \\
\hline $\mathrm{Kr}-85(\mathrm{~mol} \%)^{\mathrm{d}}$ & 5.7 & 5.7 & 5.7 & 5.7 & 5.7 & 5.7 & \\
\hline$+/-^{\mathrm{d}}$ & 0.1 & 0.1 & 0.1 & 0.1 & 0.1 & 0.1 & \\
\hline $\mathrm{Kr}-85(\mathrm{~g})^{\mathrm{k}}$ & $2.4200 \mathrm{E}-05$ & $0.0000 \mathrm{E}+00$ & $7.4441 \mathrm{E}-03$ & 8.7972E-03 & $7.6510 \mathrm{E}-03$ & 5.0687E-03 & 0.0 \\
\hline$+/-^{j}$ & $4.2456 \mathrm{E}-07$ & NA & $6.5686 \mathrm{E}-04$ & 9.5166E-04 & 9.2942E-04 & 6.0194E-04 & NA \\
\hline \multicolumn{8}{|l|}{ Segment Total } \\
\hline \multicolumn{8}{|l|}{$+/^{n}$} \\
\hline $\mathrm{Kr}-86(\mathrm{~mol} \%)^{\mathrm{d}}$ & 48.5 & 48.5 & 48.5 & 48.5 & 48.5 & 48.5 & \\
\hline$+/-^{\mathrm{d}}$ & 0.1 & 0.1 & 0.1 & 0.1 & 0.1 & 0.1 & \\
\hline $\mathrm{Kr}-86(\mathrm{~g})^{\mathrm{k}}$ & 2.0833E-04 & $0.0000 \mathrm{E}+00$ & 6.4085E-02 & 7.5733E-02 & 6.5866E-02 & 4.3636E-02 & 0.0 \\
\hline$+/-^{j}$ & 4.2955E-07 & NA & $5.5434 \mathrm{E}-03$ & 8.0857E-03 & 7.9184E-03 & 5.1259E-03 & NA \\
\hline \multicolumn{8}{|l|}{ Segment Total } \\
\hline \multicolumn{8}{|l|}{$+/-^{n}$} \\
\hline \multicolumn{8}{|l|}{ Rod Total } \\
\hline \multicolumn{8}{|l|}{$+/-^{n}$} \\
\hline shear gas $(\mathrm{g})^{\mathrm{e}}$ & 0 & 0.0001 & 0.0031 & 0.0071 & 0.006 & 0.002 & \\
\hline$+/-^{e}$ & 0 & 0.0003 & 0.0006 & 0.0014 & 0.0012 & 0.0004 & \\
\hline moles Kr (diss+pl) ${ }^{\mathrm{d}}$ & 0.000005 & 0 & 0.001533 & 0.001806 & 0.001571 & 0.001044 & \\
\hline$+I^{-\mathrm{d}}$ & 0 & 0 & 0.000133 & 0.000194 & 0.00019 & 0.000123 & \\
\hline $\mathrm{Kr}+\mathrm{Xe}$ diss\&pl $(\mathrm{g})^{\mathrm{d}}$ & 0.0029 & 0.0112 & 0.9443 & 1.1056 & 0.9644 & 0.641 & \\
\hline$+I^{-\mathrm{d}}$ & 0.0001 & 0.0112 & 0.0549 & 0.0881 & 0.066 & 0.0425 & \\
\hline moles kr (tot) ${ }^{\circ}$ & $5.0000 \mathrm{E}-06$ & $0.0000 \mathrm{E}+00$ & 1.5380E-03 & 1.8176E-03 & 1.5808E-03 & 1.0473E-03 & 0.0 \\
\hline$+/-^{p}$ & $0.0000 E+00$ & $0.0000 E+00$ & 1.3300E-04 & 1.9402E-04 & $1.9001 \mathrm{E}-04$ & 1.2300E-04 & 0.0 \\
\hline $\mathrm{Xe}-128(\mathrm{~mol} \%)^{\mathrm{d}}$ & 0.1 & 0.1 & 0.1 & 0.1 & 0.1 & 0.1 & \\
\hline$+-^{\mathrm{d}}$ & 0 & 0 & 0 & 0 & 0 & 0 & \\
\hline Xe-128 $(\mathrm{g})^{\mathrm{k}}$ & $2.4302 \mathrm{E}-06$ & $1.0711 \mathrm{E}-05$ & $7.7828 \mathrm{E}-04$ & $9.1317 \mathrm{E}-04$ & 7.9665E-04 & $5.2797 \mathrm{E}-04$ & 8.5 \\
\hline$+/^{j}$ & 1.2790E-07 & $1.0621 \mathrm{E}-05$ & 5.1164E-05 & $8.2509 \mathrm{E}-05$ & 6.0892E-05 & 3.9268E-05 & 8.5 \\
\hline \multicolumn{8}{|l|}{ SegmentTotal } \\
\hline$+/-^{n}$ & & & & & & & \\
\hline
\end{tabular}


Rod "M" 0504042 (SI-1, 5L29)

\begin{tabular}{|c|c|c|c|c|c|c|}
\hline & M-00 & M-01 & $\mathrm{M}-02$ & M-03 & M-04 & M-05 \\
\hline seg length (in) ${ }^{a}$ & 10.078 & 10.088 & 21.438 & 21.24 & 21.24 & 21.308 \\
\hline \multicolumn{7}{|l|}{ total length (in) } \\
\hline $\mathrm{Xe}-130(\mathrm{~mol} \%)^{d}$ & 0.1 & 0.1 & 0.1 & 0.1 & 0.1 & 0.1 \\
\hline$+-^{d}$ & 0 & 0 & 0 & 0 & 0 & 0 \\
\hline$X e-130(g)^{k}$ & $2.4682 \mathrm{E}-06$ & 1.0878E-05 & $7.9045 \mathrm{E}-04$ & 9.2745E-04 & 8.0911E-04 & 5.3622E-04 \\
\hline$+/-^{j}$ & 1.2990E-07 & 1.0787E-05 & $5.1964 \mathrm{E}-05$ & 8.3799E-05 & $6.1844 \mathrm{E}-05$ & 3.9882E-05 \\
\hline \multicolumn{7}{|l|}{ SegmentTotal } \\
\hline \multicolumn{7}{|l|}{$+-^{\mathrm{n}}$} \\
\hline $\mathrm{Xe}-131(\mathrm{~mol} \%)^{\mathrm{d}}$ & 10.7 & 10.7 & 10.7 & 10.7 & 10.7 & 10.7 \\
\hline$+/^{d}$ & 0.1 & 0.1 & 0.1 & 0.1 & 0.1 & 0.1 \\
\hline $\mathrm{Xe}-131(\mathrm{~g})^{\mathrm{k}}$ & $2.6613 \mathrm{E}-04$ & 1.1729E-03 & $8.5230 \mathrm{E}-02$ & 1.0000E-01 & 8.7242E-02 & $5.7818 \mathrm{E}-02$ \\
\hline$+/^{j}$ & $1.4226 \mathrm{E}-05$ & $1.1631 \mathrm{E}-03$ & 5.6594E-03 & $9.0838 \mathrm{E}-03$ & $6.7180 \mathrm{E}-03$ & $4.3341 \mathrm{E}-03$ \\
\hline \multicolumn{7}{|l|}{ SegmentTotal } \\
\hline \multicolumn{7}{|l|}{$+-^{\mathrm{n}}$} \\
\hline $\mathrm{Xe}-132(\mathrm{~mol} \%)^{\mathrm{d}}$ & 23.6 & 23.6 & 23.6 & 23.6 & 23.6 & 23.6 \\
\hline$+/-^{\mathrm{d}}$ & 0.1 & 0.1 & 0.1 & 0.1 & 0.1 & 0.1 \\
\hline $\mathrm{Xe}-132(\mathrm{~g})^{\mathrm{k}}$ & 5.9146E-04 & 2.6068E-03 & 1.8942E-01 & 2.2225E-01 & 1.9389E-01 & 1.2850E-01 \\
\hline$+I^{j}$ & $3.1230 \mathrm{E}-05$ & 2.5849E-03 & 1.2478E-02 & 2.0103E-02 & 1.4843E-02 & 9.5726E-03 \\
\hline \multicolumn{7}{|l|}{ SegmentTotal } \\
\hline \multicolumn{7}{|l|}{$+/-^{n}$} \\
\hline $\mathrm{Xe}-134(\mathrm{~mol} \%)^{\mathrm{d}}$ & 25.7 & 25.7 & 25.7 & 25.7 & 25.7 & 25.7 \\
\hline$+/-^{\mathrm{d}}$ & 0.1 & 0.1 & 0.1 & 0.1 & 0.1 & 0.1 \\
\hline $\mathrm{Xe}-134(\mathrm{~g})^{\mathrm{k}}$ & $6.5386 \mathrm{E}-04$ & 2.8818E-03 & 2.0940E-01 & $2.4570 \mathrm{E}-01$ & 2.1435E-01 & 1.4205E-01 \\
\hline$+/_{-}^{j}$ & $3.4508 \mathrm{E}-05$ & $2.8576 \mathrm{E}-03$ & 1.3790E-02 & $2.2220 \mathrm{E}-02$ & 1.6405E-02 & 1.0580E-02 \\
\hline \multicolumn{7}{|l|}{ SegmentTotal } \\
\hline$+/-^{\mathrm{n}}$ & & & & & & \\
\hline
\end{tabular}


Rod "M" 0504042 (SI-1, 5L29)

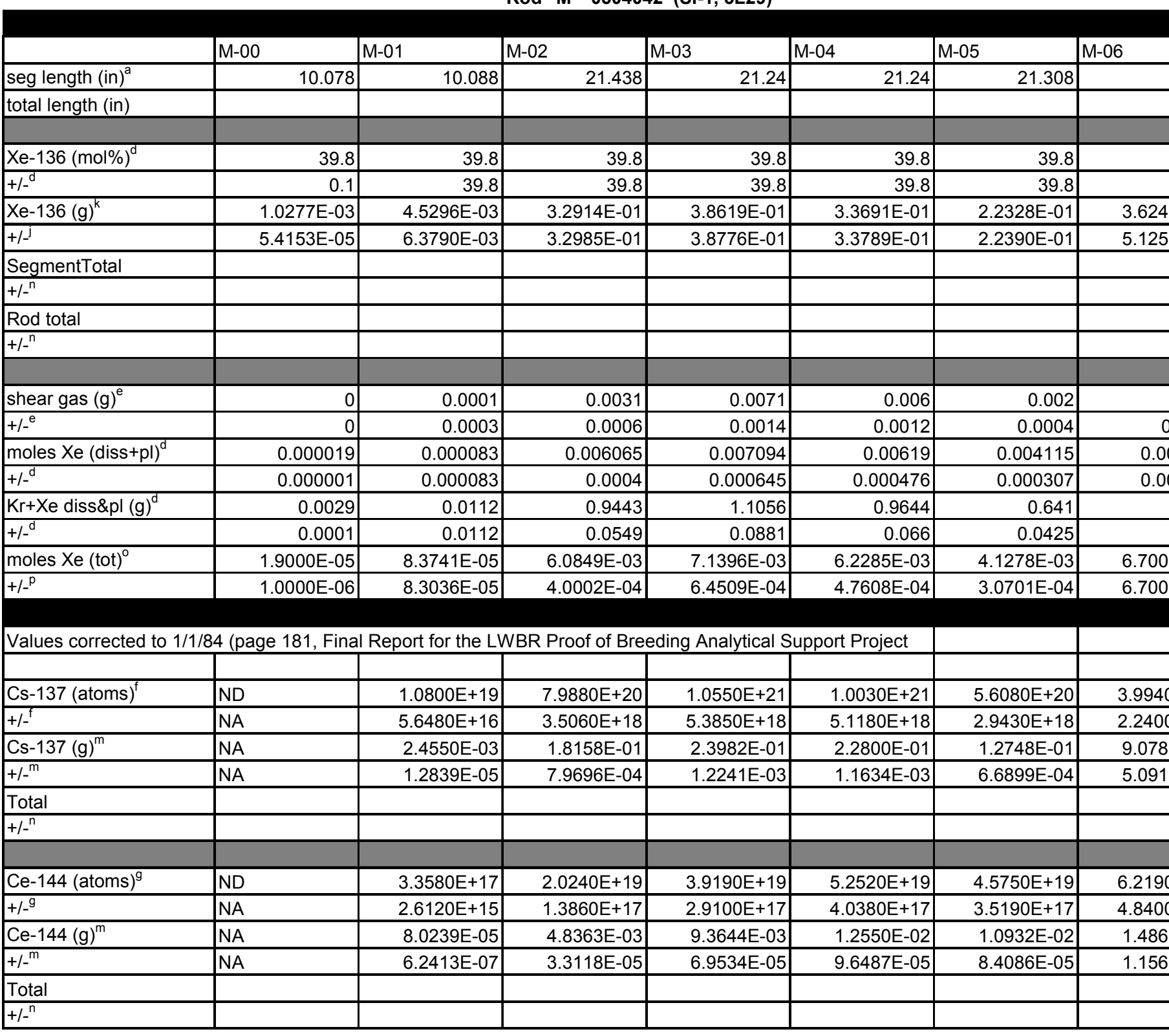


Rod "M" 0504042 (SI-1, 5L29)

\begin{tabular}{|c|c|c|c|c|c|c|}
\hline & M-00 & M-01 & $\mathrm{M}-02$ & M-03 & M-04 & M-05 \\
\hline seg length (in) ${ }^{a}$ & 10.078 & 10.088 & 21.438 & 21.24 & 21.24 & 21.308 \\
\hline \multicolumn{7}{|l|}{ total length (in) } \\
\hline & & & & & & \\
\hline Zr-95 (atoms) ${ }^{\mathrm{h}}$ & ND & ND & ND & $2.6190 \mathrm{E}+17$ & $4.6540 \mathrm{E}+17$ & $3.9990 \mathrm{E}+17$ \\
\hline$+-^{\mathrm{h}}$ & NA & NA & NA & $2.9000 \mathrm{E}+16$ & $5.5950 \mathrm{E}+16$ & $2.8960 \mathrm{E}+16$ \\
\hline Zr-95 (g) ${ }^{\mathrm{m}}$ & NA & NA & NA & 4.1270E-05 & $7.3338 \mathrm{E}-05$ & 6.3017E-05 \\
\hline$+/-^{m}$ & NA & NA & NA & 4.5698E-06 & 8.8167E-06 & $4.5635 \mathrm{E}-06$ \\
\hline \multicolumn{7}{|l|}{ Total } \\
\hline$+/-^{n}$ & & & & & & \\
\hline
\end{tabular}

Footnotes

a. ANL Destructive Chemical Assay of 33-Rod LWBR EOL Sample - Rod M, 0504042, page 4

b. ANL Destructive Chemical Assay of 33-Rod LWBR EOL Sample - Rod M, 0504042, page 7

c. ANL Destructive Chemical Assay of 33-Rod LWBR EOL Sample - Rod M, 0504042, page 8

d. ANL Destructive Chemical Assay of 33-Rod LWBR EOL Sample - Rod M, 0504042, page 11

e. ANL Destructive Chemical Assay of 33-Rod LWBR EOL Sample - Rod M, 0504042, page 12

f. ANL Destructive Chemical Assay of 33-Rod LWBR EOL Sample - Rod M, 0504042, page 13

g. ANL Destructive Chemical Assay of 33-Rod LWBR EOL Sample - Rod M, 0504042, page 14

h. ANL Destructive Chemical Assay of 33-Rod LWBR EOL Sample - Rod M, 0504042, page 15

i. (abundance of the specified isotope)(total weight of uranium) / 100

j. Error Propagation $=\left(\left(s d_{x} / x\right)^{2}+\left(s d_{y} / y\right)^{2}\right)^{1 / 2}(x y)$, where sd is the $+/-$ in the table

k. (mole\%)(number moles gas recovered)(molec $w t) / 100$

m. (number of atoms per segment)(atomic weight) / 6.0228E+23

n. Error Propagation $=\left(\operatorname{SUM}\left(\mathrm{sd}_{\mathrm{i}}^{2}\right)\right)^{1 / 2}$, where sd is the $+/-$ in the table

o. ((shear gas / Xe $+\mathrm{Kr}($ diss\&pl $))($ moles Xe or $\mathrm{Kr}($ diss $+\mathrm{pl}))+$ moles Xe or $\mathrm{Kr}($ diss $+\mathrm{pl})$

p. Error Propagation $=\left(\left(\left(\left(s d_{x} / x\right)^{2}+\left(s d_{y} / y\right)^{2}+\left(s d_{z} / z\right)^{2}\right)^{1 / 2}(x y / z)\right)^{2}+\left(s d_{y}\right)^{2}\right)^{1 / 2}$, where sd is the $+/-$ in the table 
Rod "N" 0507057 (SI-1, 5C10)

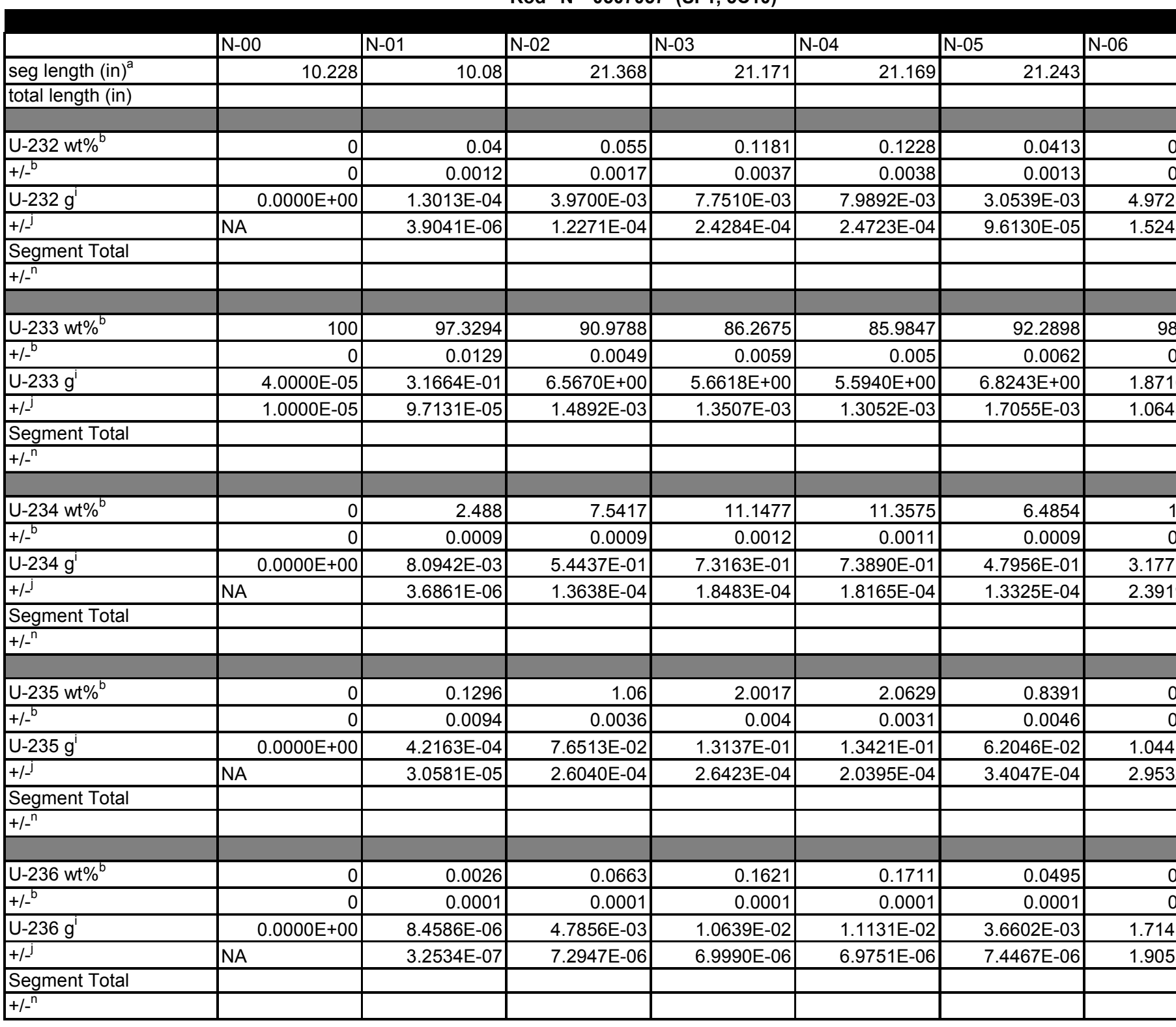


Rod "N" 0507057 (SI-1, 5C10)

\begin{tabular}{|c|c|c|c|c|c|c|c|}
\hline & $\mathrm{N}-00$ & $\mathrm{~N}-01$ & $\mathrm{~N}-02$ & $\mathrm{~N}-03$ & $\mathrm{~N}-04$ & $\mathrm{~N}-05$ & $\mathrm{~N}-06$ \\
\hline seg length (in) ${ }^{a}$ & 10.228 & 10.08 & 21.368 & 21.171 & 21.169 & 21.243 & \\
\hline \multicolumn{8}{|l|}{ total length (in) } \\
\hline$U-238 w t \%^{b}$ & 0 & 0.0104 & 0.2982 & 0.3029 & 0.301 & 0.2949 & \\
\hline$+I_{-}^{\mathrm{b}}$ & 0 & 0.0093 & 0.0035 & 0.0039 & 0.0029 & 0.0045 & \\
\hline $\mathrm{U}-238 \mathrm{~g}^{\mathrm{i}}$ & $0.0000 E+00$ & 3.3834E-05 & $2.1525 \mathrm{E}-02$ & 1.9880E-02 & 1.9583E-02 & $2.1806 \mathrm{E}-02$ & 4. \\
\hline$+/-^{j}$ & NA & $3.0256 \mathrm{E}-05$ & $2.5268 \mathrm{E}-04$ & $2.5600 \mathrm{E}-04$ & 1.8872E-04 & 3.3279E-04 & 2. \\
\hline \multicolumn{8}{|l|}{ Segment Total } \\
\hline \multicolumn{8}{|l|}{$+/-^{n}$} \\
\hline tot $U^{c}$ & 0.00009 & 0.32533 & 7.21817 & 6.56307 & 6.50583 & 7.39439 & \\
\hline$+-_{-}^{\mathrm{C}}$ & 0.00001 & 0.00009 & 0.00159 & 0.0015 & 0.00147 & 0.00178 & \\
\hline $\mathrm{Kr}-82(\mathrm{~mol} \%)^{\mathrm{d}}$ & 0.2 & 0.2 & 0.2 & 0.2 & 0.2 & 0.2 & \\
\hline$+/-^{d}$ & 0 & 0 & 0 & 0 & 0 & 0 & \\
\hline $\mathrm{Kr}-82(\mathrm{~g})^{\mathrm{k}}$ & 4.9148E-07 & $0.0000 \mathrm{E}+00$ & $2.0637 \mathrm{E}-04$ & $2.1579 \mathrm{E}-04$ & $2.7483 \mathrm{E}-04$ & $1.6324 \mathrm{E}-04$ & 1. \\
\hline$+/_{-}^{j}$ & $0.0000 \mathrm{E}+00$ & NA & 2.4247E-05 & $2.9818 \mathrm{E}-05$ & $3.0474 \mathrm{E}-05$ & $1.9168 \mathrm{E}-05$ & 8. \\
\hline \multicolumn{8}{|l|}{ Segment Total } \\
\hline \multicolumn{8}{|l|}{$+/-^{\mathrm{n}}$} \\
\hline $\mathrm{Kr}-83(\mathrm{~mol} \%)^{\mathrm{d}}$ & 15.7 & 15.7 & 15.7 & 15.7 & 15.7 & 15.7 & \\
\hline$+1^{d}$ & 0.2 & 0.2 & 0.2 & 0.2 & 0.2 & 0.2 & \\
\hline $\mathrm{Kr}-83(\mathrm{~g})^{\mathrm{k}}$ & $3.9053 \mathrm{E}-05$ & $0.0000 E+00$ & 1.6398E-02 & 1.7147E-02 & $2.1838 \mathrm{E}-02$ & $1.2971 \mathrm{E}-02$ & 8. \\
\hline$+/^{j}$ & 4.9748E-07 & NA & 1.9379E-03 & 2.3794E-03 & $2.4373 \mathrm{E}-03$ & 1.5320E-03 & 6. \\
\hline \multicolumn{8}{|l|}{ Segment Total } \\
\hline \multicolumn{8}{|l|}{$+/-^{n}$} \\
\hline & & & & & & & \\
\hline $\mathrm{Kr}-84(\mathrm{~mol} \%)^{\mathrm{d}}$ & 29.9 & 29.9 & 29.9 & 29.9 & 29.9 & 29.9 & \\
\hline$+/-^{\mathrm{d}}$ & 0.1 & 0.1 & 0.1 & 0.1 & 0.1 & 0.1 & \\
\hline $\mathrm{Kr}-84(\mathrm{~g})^{\mathrm{K}}$ & $7.5269 \mathrm{E}-05$ & $0.0000 \mathrm{E}+00$ & $3.1605 \mathrm{E}-02$ & 3.3048E-02 & 4.2090E-02 & 2.4999E-02 & 1. \\
\hline$+/-^{j}$ & 2.5173E-07 & NA & 3.7148E-03 & 4.5679E-03 & 4.6691E-03 & 2.9367E-03 & 1. \\
\hline \multicolumn{8}{|l|}{ Segment Total } \\
\hline$+/-^{n}$ & & & & & & & \\
\hline
\end{tabular}


Rod "N" 0507057 (SI-1, 5C10)

\begin{tabular}{|c|c|c|c|c|c|c|c|}
\hline & $\mathrm{N}-00$ & N-01 & $\mathrm{N}-02$ & $\mathrm{~N}-03$ & $\mathrm{~N}-04$ & $\mathrm{~N}-05$ & $\mathrm{~N}-06$ \\
\hline seg length (in) ${ }^{a}$ & 10.228 & 10.08 & 21.368 & 21.171 & 21.169 & 21.243 & \\
\hline \multicolumn{8}{|l|}{ total length (in) } \\
\hline $\mathrm{Kr}-85(\mathrm{~mol} \%)^{\mathrm{d}}$ & 5.7 & 5.7 & 5.7 & 5.7 & 5.7 & 5.7 & \\
\hline$+/-^{d}$ & 0.1 & 0.1 & 0.1 & 0.1 & 0.1 & 0.1 & \\
\hline $\mathrm{Kr}-85(\mathrm{~g})^{\mathrm{K}}$ & $1.4520 \mathrm{E}-05$ & $0.0000 \mathrm{E}+00$ & 6.0968E-03 & $6.3753 \mathrm{E}-03$ & 8.1196E-03 & $4.8225 \mathrm{E}-03$ & 3. \\
\hline$+/-^{j}$ & $2.5474 \mathrm{E}-07$ & NA & 7.2427E-04 & 8.8801E-04 & 9.1150E-04 & $5.7258 \mathrm{E}-04$ & 2. \\
\hline \multicolumn{8}{|l|}{ Segment Total } \\
\hline \multicolumn{8}{|l|}{$+/-^{n}$} \\
\hline $\mathrm{Kr}-86(\mathrm{~mol} \%)^{\mathrm{d}}$ & 48.5 & 48.5 & 48.5 & 48.5 & 48.5 & 48.5 & \\
\hline$+/{ }^{\mathrm{d}}$ & 0.1 & 0.1 & 0.1 & 0.1 & 0.1 & 0.1 & \\
\hline $\mathrm{Kr}-86(\mathrm{~g})^{\mathrm{k}}$ & $1.2500 \mathrm{E}-04$ & $0.0000 \mathrm{E}+00$ & 5.2486E-02 & 5.4883E-02 & 6.9900E-02 & 4.1516E-02 & 2.8 \\
\hline$+/-^{\mathrm{j}}$ & 2.5773E-07 & NA & 6.1677E-03 & 7.5846E-03 & 7.7518E-03 & 4.8759E-03 & 2. \\
\hline \multicolumn{8}{|l|}{ Segment Total } \\
\hline \multicolumn{8}{|l|}{$+-^{\mathrm{n}}$} \\
\hline \multicolumn{8}{|l|}{ Rod Total } \\
\hline \multicolumn{8}{|l|}{$+-^{\mathrm{n}}$} \\
\hline shear gas $(\mathrm{g})^{\mathrm{e}}$ & 0 & 0 & 0.0016 & 0.0041 & 0.005 & 0.002 & \\
\hline$+/-^{\mathrm{e}}$ & 0 & 0.0003 & 0.0003 & 0.0008 & 0.001 & 0.0004 & \\
\hline 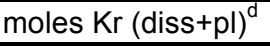 & 0.000003 & 0 & 0.001257 & 0.00131 & 0.001669 & 0.000993 & \\
\hline$+/^{-\mathrm{d}}$ & 0 & 0 & 0.000148 & 0.000182 & 0.000186 & 0.000117 & \\
\hline $\mathrm{Kr}+\mathrm{Xe}$ diss\&pl $(\mathrm{g})^{\mathrm{d}}$ & 0.0016 & 0.0164 & 0.7518 & 0.746 & 0.9713 & 0.5857 & \\
\hline$+/^{-\mathrm{d}}$ & 0.0001 & 0.0164 & 0.0417 & 0.0989 & 0.0845 & 0.0481 & \\
\hline moles kr (tot) ${ }^{\circ}$ & $3.0000 \mathrm{E}-06$ & $0.0000 \mathrm{E}+00$ & 1.2597E-03 & $1.3172 \mathrm{E}-03$ & 1.6776E-03 & 9.9639E-04 & 6. \\
\hline$+/^{\mathrm{p}}$ & $0.0000 \mathrm{E}+00$ & $0.0000 \mathrm{E}+00$ & 1.4800E-04 & $1.8201 \mathrm{E}-04$ & $1.8601 \mathrm{E}-04$ & 1.1700E-04 & 5. \\
\hline $\mathrm{Xe}-128(\mathrm{~mol} \%)^{\mathrm{d}}$ & 0.1 & 0.1 & 0.1 & 0.1 & 0.1 & 0.1 & \\
\hline$+{ }^{\mathrm{d}}$ & 0 & 0 & 0 & 0 & 0 & 0 & \\
\hline $\mathrm{Xe}-128(\mathrm{~g})^{\mathrm{k}}$ & $1.2790 \mathrm{E}-06$ & $1.5604 \mathrm{E}-05$ & 6.1627E-04 & $6.0844 \mathrm{E}-04$ & 7.9490E-04 & 4.7961E-04 & 3. \\
\hline$+/-^{j}$ & $0.0000 E+00$ & 1.5604E-05 & 3.7860E-05 & 9.3118E-05 & 7.9050E-05 & 4.4768E-05 & 2. \\
\hline SegmentTotal & & & & & & & \\
\hline$+/^{\mathrm{n}}$ & & & & & & & \\
\hline
\end{tabular}


Rod "N" 0507057 (SI-1, 5C10)

\begin{tabular}{|c|c|c|c|c|c|c|c|}
\hline & $\mathrm{N}-00$ & $\mathrm{~N}-01$ & $\mathrm{~N}-02$ & $\mathrm{~N}-03$ & $\mathrm{~N}-04$ & $\mathrm{~N}-05$ & $\mathrm{~N}$ \\
\hline seg length (in) ${ }^{a}$ & 10.228 & 10.08 & 21.368 & 21.171 & 21.169 & 21.243 & \\
\hline \multicolumn{8}{|l|}{ total length (in) } \\
\hline Xe-130 (mol\%) $)^{d}$ & 0.1 & 0.1 & 0.1 & 0.1 & 0.1 & 0.1 & \\
\hline$+-^{d}$ & 0 & 0 & 0 & 0 & 0 & 0 & \\
\hline $\mathrm{Xe}-130(\mathrm{~g})^{\mathrm{k}}$ & 1.2990E-06 & 1.5848E-05 & $6.2591 \mathrm{E}-04$ & 6.1795E-04 & 8.0733E-04 & 4.8711E-04 & \\
\hline$+/-^{j}$ & $0.0000 E+00$ & 1.5848E-05 & 3.8452E-05 & 9.4575E-05 & 8.0286E-05 & 4.5468E-05 & \\
\hline \multicolumn{8}{|l|}{ SegmentTotal } \\
\hline \multicolumn{8}{|l|}{$+/-^{n}$} \\
\hline Xe-131 (mol\%) ${ }^{d}$ & 11.8 & 11.8 & 11.8 & 11.8 & 11.8 & 11.8 & \\
\hline$+{ }^{-d}{ }^{d}$ & $\begin{array}{r}0.1 \\
\end{array}$ & 0.1 & 0.1 & 0.1 & 0.1 & 0.1 & \\
\hline $\mathrm{Xe}-131(\mathrm{~g})^{\mathrm{k}}$ & 1.5447E-04 & $1.8845 \mathrm{E}-03$ & $7.4426 \mathrm{E}-02$ & $7.3480 \mathrm{E}-02$ & 9.5999E-02 & 5.7922E-02 & \\
\hline$+/-^{j}$ & 1.3091E-06 & 1.8846E-03 & 4.6157E-03 & 1.1263E-02 & 9.5815E-03 & 5.4288E-03 & \\
\hline \multicolumn{8}{|l|}{ SegmentTotal } \\
\hline \multicolumn{8}{|l|}{$+/_{-}^{\mathrm{n}}$} \\
\hline Xe-132 (mol\%) $)^{d}$ & 24 & 24 & 24 & 24 & 24 & 24 & \\
\hline$+/^{d}$ & 0.1 & 0.1 & 0.1 & 0.1 & 0.1 & 0.1 & \\
\hline $\mathrm{Xe}-132(\mathrm{~g})^{\mathrm{k}}$ & 3.1657E-04 & $3.8622 \mathrm{E}-03$ & $1.5253 \mathrm{E}-01$ & 1.5059E-01 & 1.9674E-01 & 1.1871E-01 & \\
\hline$+/^{j}$ & 1.3190E-06 & $3.8622 \mathrm{E}-03$ & 9.3922E-03 & $2.3056 \mathrm{E}-02$ & 1.9583E-02 & 1.1091E-02 & \\
\hline \multicolumn{8}{|l|}{ SegmentTotal } \\
\hline \multicolumn{8}{|l|}{$+/^{\mathrm{n}}$} \\
\hline Xe-134 (mol\%) $)^{d}$ & 26.6 & 26.6 & 26.6 & 26.6 & 26.6 & 26.6 & \\
\hline$+/-^{d}$ & 0.1 & 0.1 & 0.1 & 0.1 & 0.1 & 0.1 & \\
\hline $\mathrm{Xe}-134(\mathrm{~g})^{\mathrm{k}}$ & $3.5619 \mathrm{E}-04$ & $4.3455 \mathrm{E}-03$ & 1.7162E-01 & 1.6944E-01 & $2.2136 \mathrm{E}-01$ & 1.3356E-01 & \\
\hline$+L^{j}$ & $1.3391 \mathrm{E}-06$ & $4.3455 \mathrm{E}-03$ & $1.0563 \mathrm{E}-02$ & $2.5940 \mathrm{E}-02$ & $2.2030 \mathrm{E}-02$ & 1.2477E-02 & \\
\hline \multicolumn{8}{|l|}{ SegmentTotal } \\
\hline$+-^{\mathrm{n}}$ & & & & & & & \\
\hline
\end{tabular}


Rod "N" 0507057 (SI-1, 5C10)

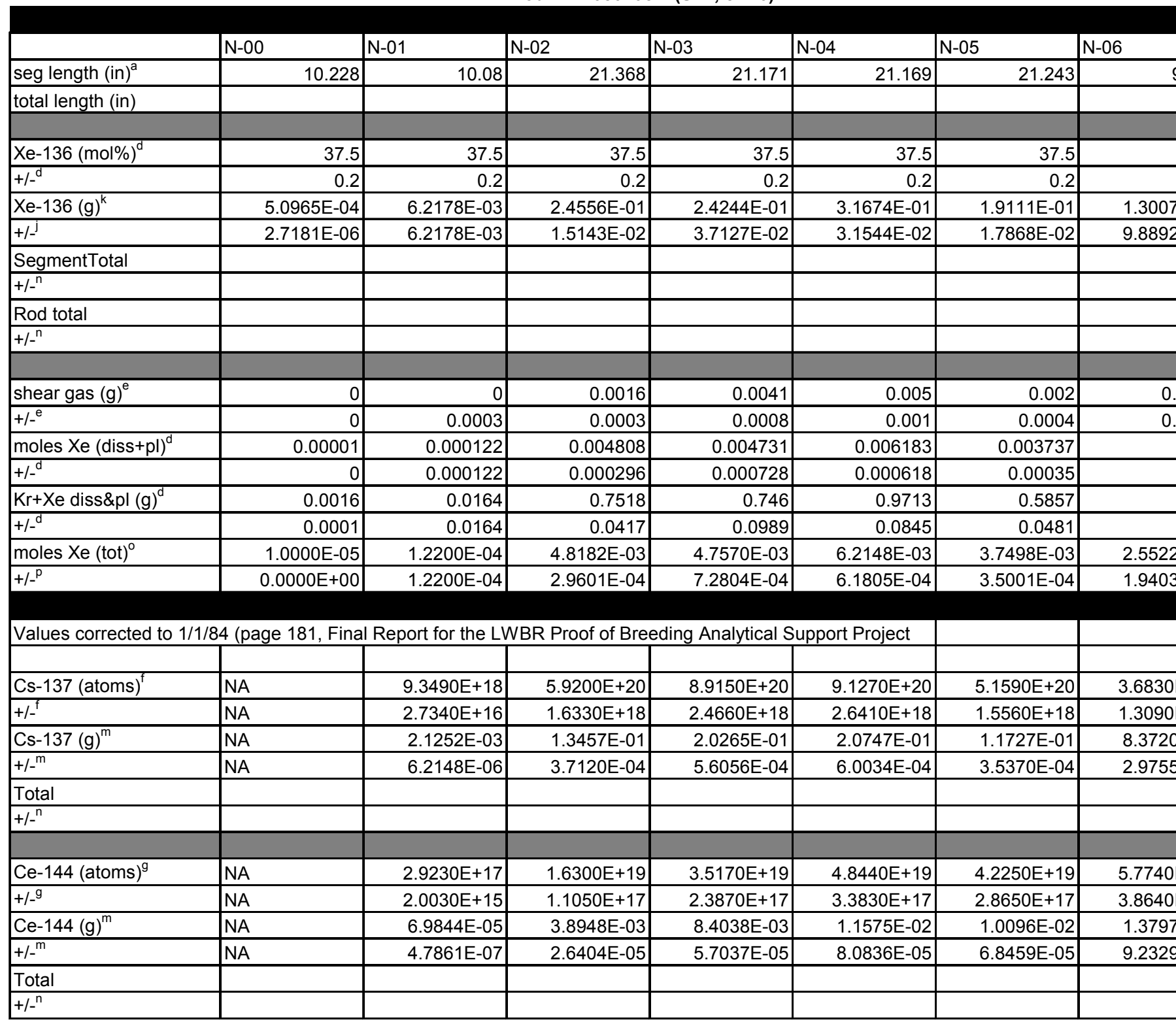


Rod "N" 0507057 (SI-1, 5C10)

\begin{tabular}{|c|c|c|c|c|c|c|}
\hline & $\mathrm{N}-00$ & $\mathrm{~N}-01$ & $\mathrm{~N}-02$ & $\mathrm{~N}-03$ & $\mathrm{~N}-04$ & $\mathrm{~N}-05$ \\
\hline seg length (in) & 10.228 & 10.08 & 21.368 & 21.171 & 21.169 & 21.243 \\
\hline \multicolumn{7}{|l|}{ total length (in) } \\
\hline & & & & & & \\
\hline Zr-95 (atoms) ${ }^{\mathrm{h}}$ & NA & ND & ND & $2.0490 \mathrm{E}+17$ & $3.9550 \mathrm{E}+17$ & $4.2690 \mathrm{E}+17$ \\
\hline$+-^{\mathrm{h}}$ & NA & NA & NA & $3.6920 \mathrm{E}+16$ & $5.3040 \mathrm{E}+16$ & $3.2790 \mathrm{E}+16$ \\
\hline Zr-95 $(\mathrm{g})^{\mathrm{m}}$ & NA & NA & NA & 3.2288E-05 & 6.2323E-05 & 6.7271E-05 \\
\hline$+/-^{m}$ & NA & NA & NA & 5.8179E-06 & 8.3581E-06 & 5.1671E-06 \\
\hline \multicolumn{7}{|l|}{ Total } \\
\hline$+/-^{n}$ & & & & & & \\
\hline
\end{tabular}

Footnotes

a. ANL Destructive Chemical Assay of 33-Rod LWBR EOL Sample - Rod N, 0507057, page 4

b. ANL Destructive Chemical Assay of 33-Rod LWBR EOL Sample - Rod N, 0507057, page 7

c. ANL Destructive Chemical Assay of 33-Rod LWBR EOL Sample - Rod N, 0507057, page 8

d. ANL Destructive Chemical Assay of 33-Rod LWBR EOL Sample - Rod N, 0507057, page 11

e. ANL Destructive Chemical Assay of 33-Rod LWBR EOL Sample-Rod N, 0507057, page 12

f. ANL Destructive Chemical Assay of 33-Rod LWBR EOL Sample - Rod N, 0507057, page 13

g. ANL Destructive Chemical Assay of 33-Rod LWBR EOL Sample - Rod N, 0507057, page 14

h. ANL Destructive Chemical Assay of 33-Rod LWBR EOL Sample - Rod N, 0507057, page 15

i. (abundance of the specified isotope)(total weight of uranium) / 100

j. Error Propagation $=\left(\left(\operatorname{sd}_{x} / x\right)^{2}+\left(s d_{y} / y\right)^{2}\right)^{1 / 2}(x y)$, where sd is the $+/-$ in the table

k. (mole\%)(number moles gas recovered)(molec $w) / 100$

m. (number of atoms per segment)(atomic weight) / 6.0228E+23

n. Error Propagation $=\left(\operatorname{SUM}\left(\mathrm{sd}_{\mathrm{i}}^{2}\right)\right)^{1 / 2}$, where sd is the $+/-$ in the table

o. $(($ shear gas $/ \mathrm{Xe}+\mathrm{Kr}($ diss\&pl $))($ moles Xe or $\mathrm{Kr}$ (diss $+\mathrm{pl}))+$ moles Xe or $\mathrm{Kr}($ diss $+\mathrm{pl})$

p. Error Propagation $=\left(\left(\left(\left(s d_{x} / x\right)^{2}+\left(s d_{y} / y\right)^{2}+\left(s d_{z} / z\right)^{2}\right)^{1 / 2}(x y / z)\right)^{2}+\left(s d_{y}\right)^{2}\right)^{1 / 2}$, where sd is the $+/-$ in the table 
Rod "O" 0201562 (SI-1, 2P39)

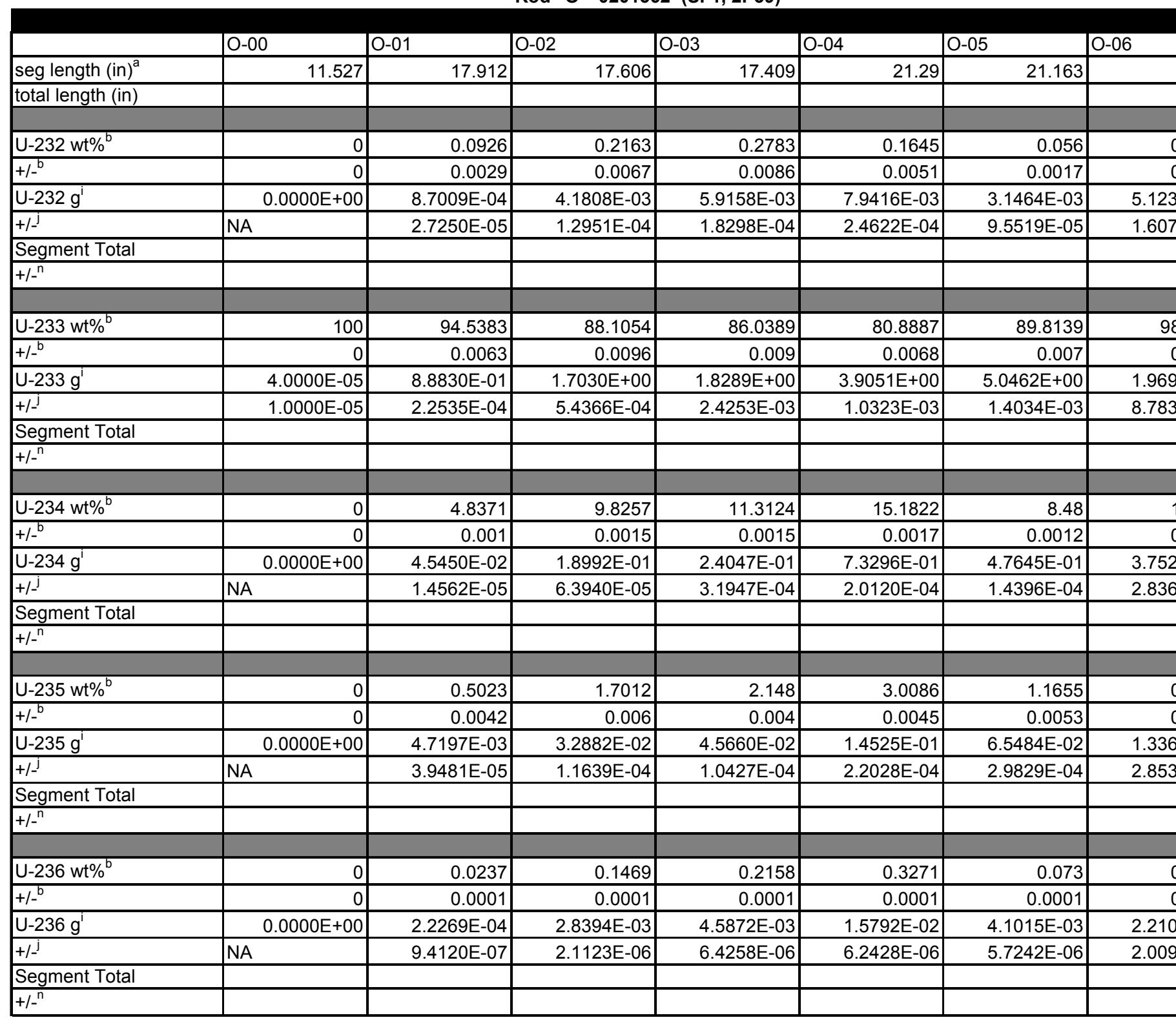


Rod "O" 0201562 (SI-1, 2P39)

\begin{tabular}{|c|c|c|c|c|c|c|c|}
\hline & $0-00$ & O-01 & O-02 & O-03 & O-04 & O-05 & O-06 \\
\hline seg length (in) $)^{a}$ & 11.527 & 17.912 & 17.606 & 17.409 & 21.29 & 21.163 & \\
\hline \multicolumn{8}{|l|}{ total length (in) } \\
\hline $\mathrm{U}-238 w \mathrm{wt}^{\mathrm{b}}$ & 0 & 0.0059 & 0.0045 & 0.0065 & 0.4288 & 0.4117 & \\
\hline$+-^{\mathrm{b}}$ & 0 & 0.0042 & 0.006 & 0.004 & 0.0046 & 0.0053 & \\
\hline $\mathrm{U}-238 \mathrm{~g}^{\mathrm{i}}$ & $0.0000 \mathrm{E}+00$ & 5.5438E-05 & 8.6980E-05 & 1.3817E-04 & $2.0701 \mathrm{E}-02$ & 2.3131E-02 & 4. \\
\hline$+{ }^{j}$ & NA & 3.9464E-05 & 1.1597E-04 & $8.5028 \mathrm{E}-05$ & $2.2214 \mathrm{E}-04$ & $2.9785 \mathrm{E}-04$ & 2.8 \\
\hline \multicolumn{8}{|l|}{ Segment Total } \\
\hline \multicolumn{8}{|l|}{$+/^{\mathrm{n}}$} \\
\hline & & & & & & & \\
\hline tot $U^{\mathrm{C}}$ & 0.00015 & 0.93962 & 1.93288 & 2.12569 & 4.82775 & 5.61852 & \\
\hline$+/-^{\mathrm{C}}$ & 0.00001 & 0.00023 & 0.00058 & 0.00281 & 0.00121 & 0.0015 & \\
\hline $\mathrm{Kr}-82(\mathrm{~mol} \%)^{\mathrm{d}}$ & 0.2 & 0.2 & 0.2 & 0.2 & 0.2 & 0.2 & \\
\hline$+/-^{\mathrm{d}}$ & 0 & 0 & 0 & 0 & 0 & 0 & \\
\hline $\mathrm{Kr}-82(\mathrm{~g})^{\mathrm{k}}$ & $3.2765 \mathrm{E}-07$ & 1.7229E-05 & 5.8050E-05 & 7.9274E-05 & 3.2903E-04 & 1.6849E-04 & 0.0 \\
\hline$+/-^{j}$ & $0.0000 \mathrm{E}+00$ & 2.1313E-06 & 7.0451E-06 & 1.9660E-05 & 4.8008E-05 & 1.9660E-05 & NA \\
\hline \multicolumn{8}{|l|}{ Segment Total } \\
\hline \multicolumn{8}{|l|}{$+/-^{n}$} \\
\hline $\mathrm{Kr}-83(\mathrm{~mol} \%)^{\mathrm{d}}$ & 15.2 & 15.2 & 15.2 & 15.2 & 15.2 & 15.2 & \\
\hline$+{ }^{\mathrm{d}}{ }^{\mathrm{d}}$ & 0.1 & 0.1 & 0.1 & 0.1 & 0.1 & 0.1 & \\
\hline $\mathrm{Kr}-83(\mathrm{~g})^{\mathrm{k}}$ & $2.5206 \mathrm{E}-05$ & $1.3254 \mathrm{E}-03$ & 4.4657E-03 & 6.0984E-03 & $2.5312 \mathrm{E}-02$ & 1.2962E-02 & 0.0 \\
\hline$+-^{j}$ & 1.6583E-07 & 1.6419E-04 & 5.4277E-04 & 1.5129E-03 & 3.6969E-03 & 1.5148E-03 & NA \\
\hline \multicolumn{8}{|l|}{ Segment Total } \\
\hline \multicolumn{8}{|l|}{$+/^{n}$} \\
\hline $\mathrm{Kr}-84(\mathrm{~mol} \%)^{\mathrm{d}}$ & 30.4 & 30.4 & 30.4 & 30.4 & 30.4 & 30.4 & \\
\hline$+/-^{d}$ & 0.1 & 0.1 & 0.1 & 0.1 & 0.1 & 0.1 & \\
\hline $\mathrm{Kr}-84(\mathrm{~g})^{\mathrm{k}}$ & $5.1018 \mathrm{E}-05$ & $2.6827 \mathrm{E}-03$ & $9.0388 \mathrm{E}-03$ & $1.2344 \mathrm{E}-02$ & $5.1233 \mathrm{E}-02$ & $2.6235 \mathrm{E}-02$ & 0.0 \\
\hline$+I^{j}$ & 1.6782E-07 & 3.3198E-04 & $1.0974 \mathrm{E}-03$ & 3.0614E-03 & 7.4771E-03 & 3.0624E-03 & NA \\
\hline \multicolumn{8}{|l|}{ Segment Total } \\
\hline$+/^{\mathrm{n}}$ & & & & & & & \\
\hline
\end{tabular}


Rod "O" 0201562 (SI-1, 2P39)

\begin{tabular}{|c|c|c|c|c|c|c|c|}
\hline & $0-00$ & O-01 & O-02 & O-03 & O-04 & O-05 & $0-06$ \\
\hline seg length (in) ${ }^{a}$ & 11.527 & 17.912 & 17.606 & 17.409 & 21.29 & 21.163 & \\
\hline \multicolumn{8}{|l|}{ total length (in) } \\
\hline & & & & & & & \\
\hline $\mathrm{Kr}-85(\mathrm{~mol} \%)^{d}$ & 5.7 & 5.7 & 5.7 & 5.7 & 5.7 & 5.7 & \\
\hline$+/-^{d}$ & 0.1 & 0.1 & 0.1 & 0.1 & 0.1 & 0.1 & \\
\hline $\mathrm{Kr}-85(\mathrm{~g})^{\mathrm{k}}$ & $9.6800 \mathrm{E}-06$ & $5.0900 \mathrm{E}-04$ & 1.7150E-03 & $2.3420 \mathrm{E}-03$ & 9.7207E-03 & 4.9778E-03 & 0.00 \\
\hline$+/-^{j}$ & 1.6982E-07 & 6.3596E-05 & $2.1030 \mathrm{E}-04$ & $5.8226 \mathrm{E}-04$ & $1.4285 \mathrm{E}-03$ & 5.8735E-04 & NA \\
\hline \multicolumn{8}{|l|}{ Segment Total } \\
\hline \multicolumn{8}{|l|}{$+/-^{n}$} \\
\hline $\mathrm{Kr}-86(\mathrm{~mol} \%)^{d}$ & 48.7 & 48.7 & 48.7 & 48.7 & 48.7 & 48.7 & \\
\hline$+/-^{\mathrm{d}}$ & 0.2 & 0.2 & 0.2 & 0.2 & 0.2 & 0.2 & \\
\hline $\mathrm{Kr}-86(\mathrm{~g})^{\mathrm{k}}$ & 8.3677E-05 & $4.4000 \mathrm{E}-03$ & $1.4825 \mathrm{E}-02$ & $2.0245 \mathrm{E}-02$ & $8.4029 \mathrm{E}-02$ & $4.3029 \mathrm{E}-02$ & 0.00 \\
\hline$+/-^{j}$ & 3.4364E-07 & 5.4460E-04 & 1.8002E-03 & $5.0214 \mathrm{E}-03$ & 1.2265E-02 & 5.0239E-03 & NA \\
\hline \multicolumn{8}{|l|}{ Segment Total } \\
\hline \multicolumn{8}{|l|}{$+/-^{n}$} \\
\hline \multicolumn{8}{|l|}{ Rod Total } \\
\hline \multicolumn{8}{|l|}{$+-^{n}$} \\
\hline shear gas $(g)^{e}$ & 0 & 0.0001 & 0.0008 & 0.0013 & 0.0111 & 0.0026 & \\
\hline$+/-^{e}$ & 0 & 0.0003 & 0.0003 & 0.0003 & 0.0022 & 0.0005 & \\
\hline moles $\mathrm{Kr}(\text { diss }+\mathrm{pl})^{\mathrm{d}}$ & 0.000002 & 0.000105 & 0.000353 & 0.000482 & 0.001991 & 0.001024 & \\
\hline$+l^{-\mathrm{d}}$ & 0 & 0.000013 & 0.000043 & 0.00012 & 0.000293 & 0.00012 & \\
\hline $\mathrm{Kr}+\mathrm{Xe}$ diss\&pl $(\mathrm{g})^{\mathrm{d}}$ & 0.0013 & 0.0635 & 0.2116 & 0.3319 & 1.2697 & 0.5963 & \\
\hline$+l^{-\mathrm{d}}$ & 0.0001 & 0.0054 & 0.0198 & 0.0417 & 0.1592 & 0.0496 & \\
\hline moles $\mathrm{kr}$ (tot) $^{\circ}$ & $2.0000 \mathrm{E}-06$ & 1.0517E-04 & 3.5433E-04 & 4.8389E-04 & 2.0084E-03 & 1.0285E-03 & 0.00 \\
\hline$+/-^{\mathrm{p}}$ & $0.0000 \mathrm{E}+00$ & 1.3009E-05 & 4.3003E-05 & $1.2000 \mathrm{E}-04$ & 2.9304E-04 & $1.2000 \mathrm{E}-04$ & 0.00 \\
\hline $\mathrm{Xe}-128(\mathrm{~mol} \%)^{d}$ & 0.1 & 0.1 & 0.1 & 0.1 & 0.1 & 0.1 & \\
\hline$+/^{\mathrm{d}}$ & 0 & 0 & 0 & 0 & 0 & 0 & \\
\hline $\mathrm{Xe}-128(\mathrm{~g})^{\mathrm{k}}$ & 1.0232E-06 & 5.2139E-05 & 1.7371E-04 & 3.0637E-04 & 1.0577E-03 & 4.8738E-04 & 1.4 \\
\hline$+/-^{j}$ & $0.0000 \mathrm{E}+00$ & 4.9943E-06 & 1.8548E-05 & 3.8501E-05 & 1.4980E-04 & 4.6176E-05 & 1.3 \\
\hline \multicolumn{8}{|l|}{ SegmentTotal } \\
\hline$+/-^{n}$ & & & & & & & \\
\hline
\end{tabular}


Rod "O" 0201562 (SI-1, 2P39)

\begin{tabular}{|c|c|c|c|c|c|c|}
\hline & O-00 & O-01 & O-02 & O-03 & O-04 & O-05 \\
\hline seg length (in) ${ }^{a}$ & 11.527 & 17.912 & 17.606 & 17.409 & 21.29 & 21.163 \\
\hline \multicolumn{7}{|l|}{ total length (in) } \\
\hline $\mathrm{Xe}-130(\mathrm{~mol} \%)^{\mathrm{d}}$ & 0.2 & 0.2 & 0.2 & 0.2 & 0.2 & 0.2 \\
\hline$+/^{\mathrm{d}}$ & 0 & 0 & 0 & 0 & 0 & 0 \\
\hline $\mathrm{Xe}-130(\mathrm{~g})^{\mathrm{k}}$ & $2.0785 \mathrm{E}-06$ & 1.0591E-04 & $3.5285 \mathrm{E}-04$ & $6.2233 \mathrm{E}-04$ & $2.1485 \mathrm{E}-03$ & $9.9001 \mathrm{E}-04$ \\
\hline$+/-^{j}$ & $0.0000 \mathrm{E}+00$ & 1.0145E-05 & 3.7676E-05 & $7.8205 \mathrm{E}-05$ & 3.0428E-04 & 9.3796E-05 \\
\hline \multicolumn{7}{|l|}{ SegmentTotal } \\
\hline \multicolumn{7}{|l|}{$+/-^{n}$} \\
\hline $\mathrm{Xe}-131(\mathrm{~mol} \%)^{\mathrm{d}}$ & 10.9 & 10.9 & 10.9 & 10.9 & 10.9 & 10.9 \\
\hline$+-^{d}$ & 0.1 & 0.1 & 0.1 & 0.1 & 0.1 & 0.1 \\
\hline $\mathrm{Xe}-131(\mathrm{~g})^{\mathrm{k}}$ & 1.1415E-04 & 5.8165E-03 & 1.9378E-02 & $3.4178 \mathrm{E}-02$ & 1.1800E-01 & $5.4371 \mathrm{E}-02$ \\
\hline$+/^{j}$ & $1.0472 \mathrm{E}-06$ & 5.5970 E-04 & $2.0768 \mathrm{E}-03$ & 4.3065E-03 & 1.6746E-02 & $5.1754 \mathrm{E}-03$ \\
\hline \multicolumn{7}{|l|}{ SegmentTotal } \\
\hline \multicolumn{7}{|l|}{$+-^{\mathrm{n}}$} \\
\hline $\mathrm{Xe}-132(\mathrm{~mol} \%)^{d}$ & 22.9 & 22.9 & 22.9 & 22.9 & 22.9 & 22.9 \\
\hline$+/-^{\mathrm{d}}$ & 0.1 & 0.1 & 0.1 & 0.1 & 0.1 & 0.1 \\
\hline $\mathrm{Xe}-132(\mathrm{~g})^{\mathrm{k}}$ & $2.4165 \mathrm{E}-04$ & 1.2313E-02 & 4.1023E-02 & 7.2354E-02 & $2.4979 \mathrm{E}-01$ & 1.1510E-01 \\
\hline$+/_{-}^{j}$ & 1.0552E-06 & 1.1807E-03 & $4.3840 \mathrm{E}-03$ & 9.0979E-03 & 3.5393E-02 & 1.0917E-02 \\
\hline \multicolumn{7}{|l|}{ SegmentTotal } \\
\hline \multicolumn{7}{|l|}{$+/-^{n}$} \\
\hline $\mathrm{Xe}-134(\mathrm{~mol} \%)^{d}$ & 25 & 25 & 25 & 25 & 25 & 25 \\
\hline$+/^{\mathrm{d}}$ & 0.1 & 0.1 & 0.1 & 0.1 & 0.1 & 0.1 \\
\hline $\mathrm{Xe}-134(\mathrm{~g})^{\mathrm{k}}$ & $2.6781 \mathrm{E}-04$ & 1.3646E-02 & 4.5465E-02 & 8.0187E-02 & $2.7684 \mathrm{E}-01$ & $1.2756 \mathrm{E}-01$ \\
\hline$+/-^{j}$ & $1.0712 \mathrm{E}-06$ & 1.3083E-03 & $4.8580 \mathrm{E}-03$ & $1.0082 \mathrm{E}-02$ & 3.9222E-02 & 1.2096E-02 \\
\hline \multicolumn{7}{|l|}{ SegmentTotal } \\
\hline$+-^{\mathrm{n}}$ & & & & & & \\
\hline
\end{tabular}




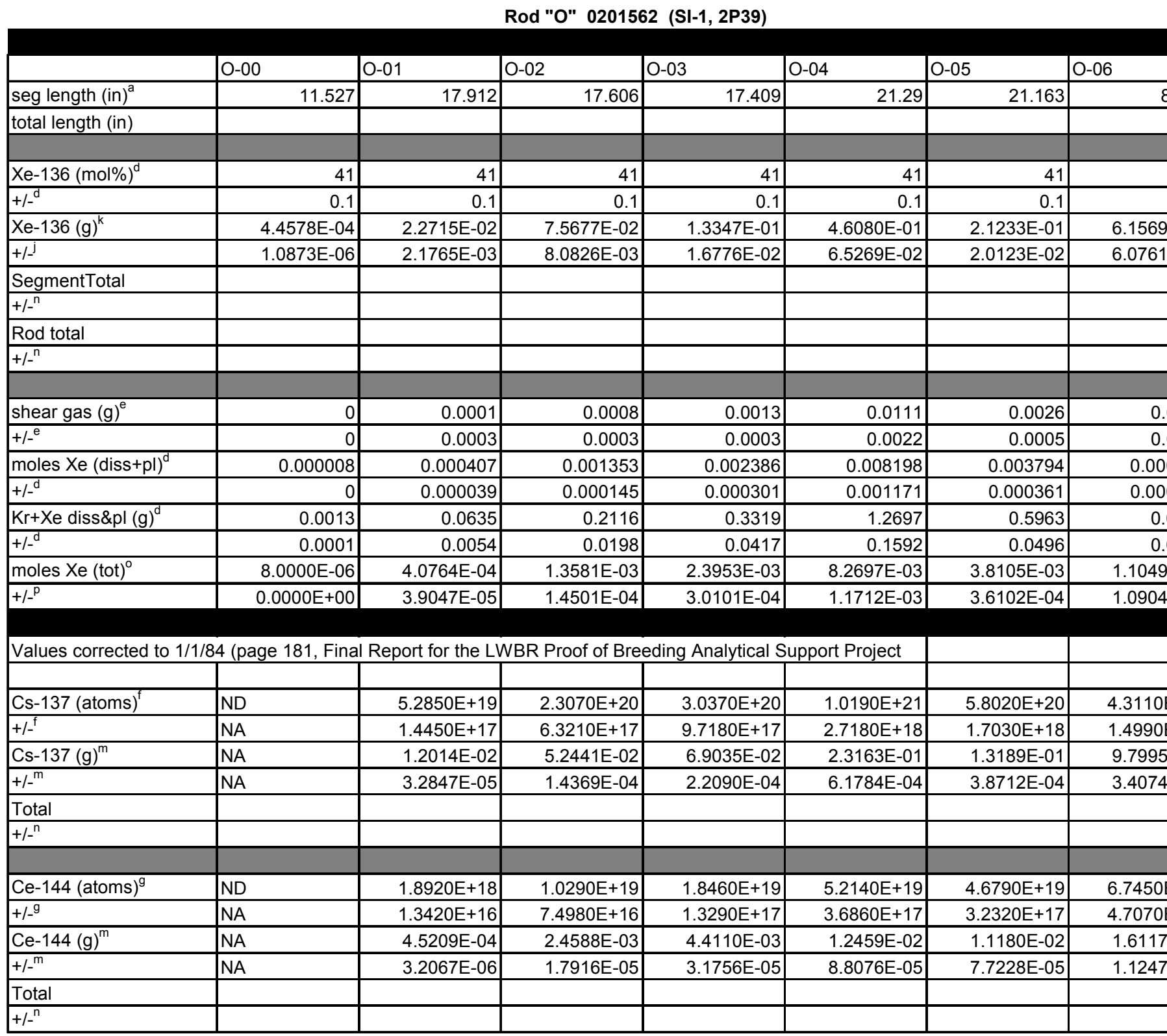


Rod "O" 0201562 (SI-1, 2P39)

\begin{tabular}{|c|c|c|c|c|c|c|}
\hline & O-00 & O-01 & O-02 & O-03 & O-04 & O-05 \\
\hline seg length (in) & 11.527 & 17.912 & 17.606 & 17.409 & 21.29 & 21.163 \\
\hline \multicolumn{7}{|l|}{ total length (in) } \\
\hline & & & & & & \\
\hline Zr-95 (atoms) ${ }^{\mathrm{h}}$ & ND & ND & $6.1270 \mathrm{E}+16$ & $1.4080 \mathrm{E}+17$ & $4.6280 \mathrm{E}+17$ & $4.3680 \mathrm{E}+17$ \\
\hline$+/_{-}^{\mathrm{h}}$ & NA & NA & $1.4150 \mathrm{E}+16$ & $2.2960 E+16$ & $9.4580 E+16$ & $3.6910 \mathrm{E}+16$ \\
\hline Zr-95 (g) ${ }^{\mathrm{m}}$ & NA & NA & $9.6550 \mathrm{E}-06$ & $2.2187 \mathrm{E}-05$ & $7.2928 \mathrm{E}-05$ & $6.8831 \mathrm{E}-05$ \\
\hline$+/-^{m}$ & NA & NA & 2.2298E-06 & 3.6181E-06 & 1.4904E-05 & 5.8163E-06 \\
\hline \multicolumn{7}{|l|}{ Total } \\
\hline$+-^{n}$ & & & & & & \\
\hline
\end{tabular}

Footnotes

a. ANL Destructive Chemical Assay of 33-Rod LWBR EOL Sample - Rod O, 0201562, page 4

b. ANL Destructive Chemical Assay of 33-Rod LWBR EOL Sample - Rod O, 0201562, page 7

c. ANL Destructive Chemical Assay of 33-Rod LWBR EOL Sample - Rod O, 0201562, page 8

d. ANL Destructive Chemical Assay of 33-Rod LWBR EOL Sample - Rod O, 0201562, page 11

e. ANL Destructive Chemical Assay of 33-Rod LWBR EOL Sample - Rod O, 0201562, page 12

f. ANL Destructive Chemical Assay of 33-Rod LWBR EOL Sample - Rod O, 0201562, page 13

g. ANL Destructive Chemical Assay of 33-Rod LWBR EOL Sample - Rod O, 0201562, page 14

h. ANL Destructive Chemical Assay of 33-Rod LWBR EOL Sample - Rod O, 0201562, page 15

i. (abundance of the specified isotope)(total weight of uranium) / 100

j. Error Propagation $=\left(\left(\operatorname{sd}_{x} / x\right)^{2}+\left(s d_{y} / y\right)^{2}\right)^{1 / 2}(x y)$, where sd is the $+/-$ in the table

k. (mole\%)(number moles gas recovered)(molec $w \mathrm{t}) / 100$

m. (number of atoms per segment)(atomic weight) / 6.0228E+23

n. Error Propagation $=\left(\operatorname{SUM}\left(s d_{i}^{2}\right)\right)^{1 / 2}$, where sd is the $+/-$ in the table

o. ((shear gas / Xe $+\mathrm{Kr}($ diss\&pl $))($ moles Xe or $\mathrm{Kr}$ (diss $+\mathrm{pl}))+$ moles $\mathrm{Xe}$ or $\mathrm{Kr}($ diss $+\mathrm{pl})$

p. Error Propagation $=\left(\left(\left(\left(s d_{x} / x\right)^{2}+\left(s d_{y} / y\right)^{2}+\left(s d_{z} / z\right)^{2}\right)^{1 / 2}(x y / z)\right)^{2}+\left(s d_{y}\right)^{2}\right)^{1 / 2}$, where sd is the $+/-$ in the table 
Rod "P" 0307602 (SI-1, 3N63)

\begin{tabular}{|c|c|c|c|c|c|c|c|}
\hline & $\mathrm{P}-00$ & P-01 & P-02 & $\mathrm{P}-03$ & P-04 & $\mathrm{P}-05$ & P-06 \\
\hline seg length (in) ${ }^{\mathrm{a}}$ & 10.355 & 17.587 & 20.541 & 21.401 & 17.671 & 17.74 & 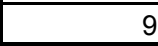 \\
\hline \multicolumn{8}{|l|}{ total length (in) } \\
\hline & & & & & & & \\
\hline $\mathrm{U}-232 \mathrm{wt} \%^{\mathrm{b}}$ & 0 & 0.0935 & 0.2329 & 0.1619 & 0.1269 & 0.0399 & 0.0 \\
\hline$+/-^{\mathrm{b}}$ & 0 & 0.0029 & 0.0072 & 0.005 & 0.0039 & 0.0012 & 0.0 \\
\hline $\mathrm{U}-232 \mathrm{~g}^{\mathrm{i}}$ & $0.0000 \mathrm{E}+00$ & $8.2375 \mathrm{E}-04$ & $5.0879 \mathrm{E}-03$ & 7.9195E-03 & $5.6130 \mathrm{E}-03$ & $2.0185 \mathrm{E}-03$ & 4.3078 \\
\hline$+/-^{j}$ & \begin{tabular}{|l|}
$N A$ \\
\end{tabular} & $2.5550 \mathrm{E}-05$ & $1.5730 \mathrm{E}-04$ & $2.4459 \mathrm{E}-04$ & $1.7251 \mathrm{E}-04$ & 6.0709E-05 & 1.3285 \\
\hline \multicolumn{8}{|l|}{ Segment Total } \\
\hline \multicolumn{8}{|l|}{$+/-^{n}$} \\
\hline & & & & & & & \\
\hline $\mathrm{U}-233 \mathrm{wt} \%^{\mathrm{b}}$ & 100 & 95.0065 & 89.4504 & 80.6674 & 84.5715 & 91.6893 & 98. \\
\hline$+/-^{b}$ & 0 & 0.007 & 0.0094 & 0.0073 & 0.0077 & 0.0071 & 0.0 \\
\hline $\mathrm{U}-233 \mathrm{~g}^{\mathrm{i}}$ & $4.0000 \mathrm{E}-05$ & $8.3703 \mathrm{E}-01$ & $1.9541 \mathrm{E}+00$ & $3.9459 \mathrm{E}+00$ & $3.7407 \mathrm{E}+00$ & $4.6385 \mathrm{E}+00$ & 1.8634 \\
\hline$+{ }^{j}$ & $1.0000 \mathrm{E}-05$ & $1.6404 \mathrm{E}-04$ & 5.1665E-04 & 9.3409E-04 & 9.0388E-04 & $1.1053 \mathrm{E}-03$ & 7.0289 \\
\hline \multicolumn{8}{|l|}{ Segment Total } \\
\hline \multicolumn{8}{|l|}{$+/-^{n}$} \\
\hline & & & & & & & \\
\hline $\mathrm{U}-234 \mathrm{wt} \%{ }^{\mathrm{b}}$ & 0 & 4.4433 & 8.7916 & 15.2482 & 12.4319 & 6.9345 & 1.6 \\
\hline$+/-^{\mathrm{b}}$ & 0 & 0.0014 & 0.0016 & 0.002 & 0.0018 & 0.0015 & 0.0 \\
\hline $\mathrm{U}-234 \mathrm{~g}^{\mathrm{i}}$ & $0.0000 \mathrm{E}+00$ & 3.9146E-02 & 1.9206E-01 & $7.4588 \mathrm{E}-01$ & $5.4988 \mathrm{E}-01$ & $3.5081 \mathrm{E}-01$ & 3.2160 \\
\hline$+/-^{j}$ & NA & 1.4236E-05 & $5.8249 \mathrm{E}-05$ & $1.9024 \mathrm{E}-04$ & $1.4658 \mathrm{E}-04$ & 1.0958E-04 & 3.0227 \\
\hline \multicolumn{8}{|l|}{ Segment Total } \\
\hline \multicolumn{8}{|l|}{$+/_{-}^{\mathrm{n}}$} \\
\hline & & & & & & & \\
\hline $\mathrm{U}-235 \mathrm{wt} \%{ }^{\mathrm{b}}$ & 0 & 0.4294 & 1.4143 & 3.1671 & 2.2858 & 0.9205 & 0.0 \\
\hline$+/-^{\mathrm{b}}$ & 0 & 0.0046 & 0.0052 & 0.005 & 0.0055 & 0.0052 & 0.0 \\
\hline $\mathrm{U}-235 \mathrm{~g}^{\mathrm{i}}$ & $0.0000 \mathrm{E}+00$ & $3.7831 \mathrm{E}-03$ & $3.0897 \mathrm{E}-02$ & 1.5492E-01 & $1.0110 \mathrm{E}-01$ & 4.6568E-02 & 1.1234 \\
\hline$+-^{j}$ & NA & $4.0533 \mathrm{E}-05$ & $1.1385 \mathrm{E}-04$ & $2.4692 \mathrm{E}-04$ & $2.4432 \mathrm{E}-04$ & $2.6328 \mathrm{E}-04$ & 2.7517 \\
\hline \multicolumn{8}{|l|}{ Segment Total } \\
\hline \multicolumn{8}{|l|}{$+-^{\mathrm{n}}$} \\
\hline $\mathrm{U}-236 \mathrm{wt} \%{ }^{\mathrm{b}}$ & 0 & 0.0181 & 0.1051 & 0.3862 & 0.2344 & 0.0792 & 0.0 \\
\hline$+1-^{\mathrm{b}}$ & 0 & 0.0002 & 0.0002 & 0.0002 & 0.0002 & 0.0002 & 0.0 \\
\hline $\mathrm{U}-236 \mathrm{~g}^{\mathrm{i}}$ & $0.0000 \mathrm{E}+00$ & $1.5946 \mathrm{E}-04$ & $2.2960 \mathrm{E}-03$ & $1.8891 \mathrm{E}-02$ & $1.0368 \mathrm{E}-02$ & 4.0067E-03 & 2.2772 \\
\hline$+/-^{j}$ & NA & 1.7623E-06 & $4.4046 \mathrm{E}-06$ & $1.0620 \mathrm{E}-05$ & $9.1456 \mathrm{E}-06$ & $1.0158 \mathrm{E}-05$ & 3.7954 \\
\hline \multicolumn{8}{|l|}{ Segment Total } \\
\hline$+/^{\mathrm{n}}$ & & & & & & & \\
\hline
\end{tabular}


Rod "P" 0307602 (SI-1, 3N63)

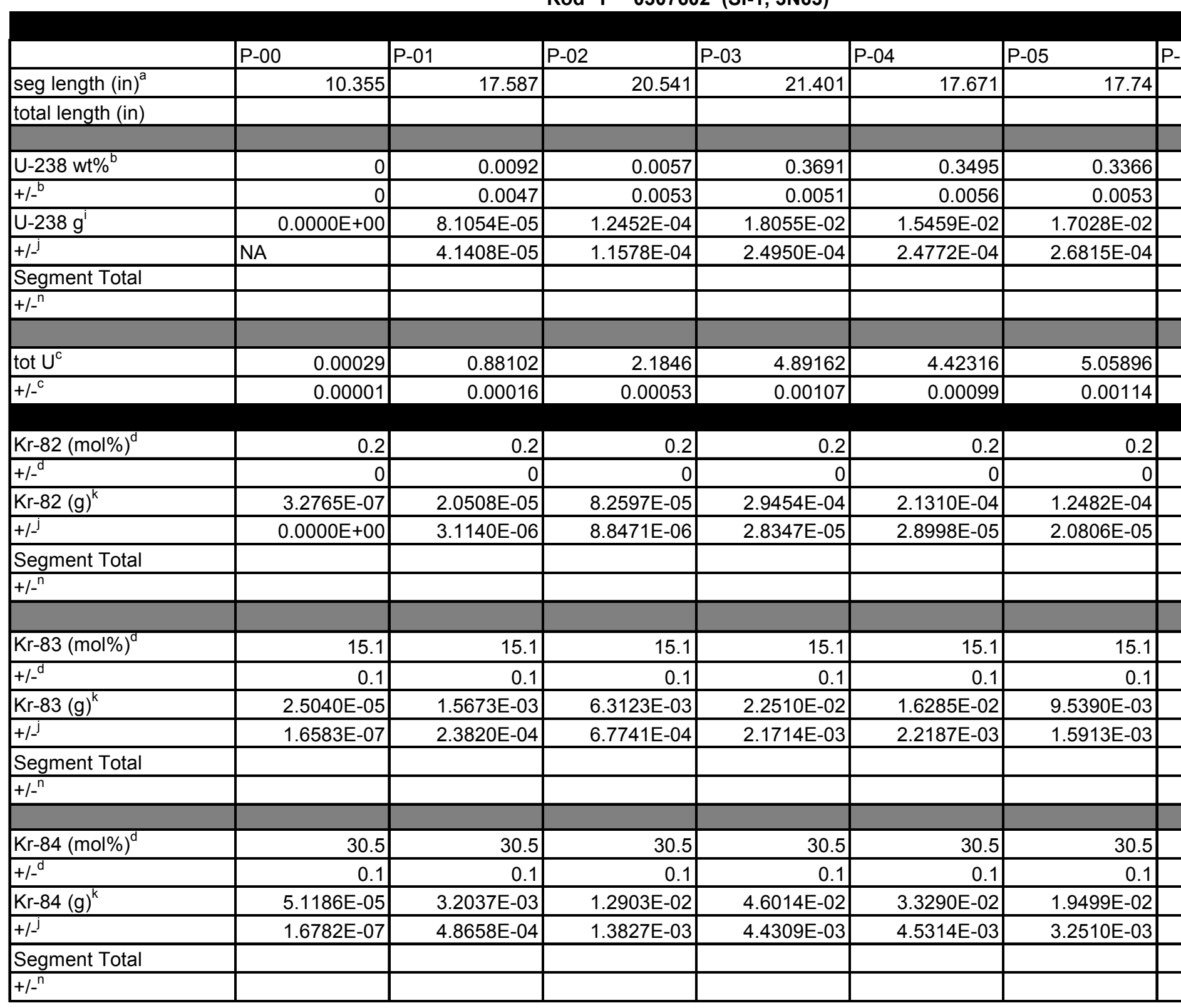


Rod "P" 0307602 (SI-1, 3N63)

\begin{tabular}{|c|c|c|c|c|c|c|c|}
\hline & P-00 & P-01 & $\mathrm{P}-02$ & P-03 & P-04 & P-05 & P-06 \\
\hline seg length (in) ${ }^{a}$ & 10.355 & 17.587 & 20.541 & 21.401 & 17.671 & 17.74 & \\
\hline \multicolumn{8}{|l|}{ total length (in) } \\
\hline $\mathrm{Kr}-85(\mathrm{~mol} \%)^{\mathrm{d}}$ & 5.7 & 5.7 & 5.7 & 5.7 & 5.7 & 5.7 & \\
\hline$+/{ }^{d}$ & 0.1 & 0.1 & 0.1 & 0.1 & 0.1 & 0.1 & \\
\hline $\mathrm{Kr}-85(\mathrm{~g})^{\mathrm{k}}$ & $9.6800 \mathrm{E}-06$ & 6.0587E-04 & $2.4402 \mathrm{E}-03$ & 8.7018E-03 & 6.2956E-03 & 3.6876E-03 & $1 . \subseteq$ \\
\hline$+/-^{j}$ & 1.6982E-07 & $9.2610 \mathrm{E}-05$ & 2.6486E-04 & 8.5125E-04 & 8.6380E-04 & $6.1808 \mathrm{E}-04$ & 1.8 \\
\hline \multicolumn{8}{|l|}{ Segment Total } \\
\hline \multicolumn{8}{|l|}{$+/-^{n}$} \\
\hline $\mathrm{Kr}-86(\mathrm{~mol} \%)^{\mathrm{d}}$ & 48.5 & 48.5 & 48.5 & 48.5 & 48.5 & 48.5 & \\
\hline$+-^{\mathrm{d}}$ & 0.1 & 0.1 & 0.1 & 0.1 & 0.1 & 0.1 & \\
\hline $\mathrm{Kr}-86(\mathrm{~g})^{\mathrm{K}}$ & $8.3333 \mathrm{E}-05$ & 5.2158E-03 & 2.1007E-02 & 7.4912E-02 & 5.4197E-02 & 3.1746E-02 & 1.6 \\
\hline$+/-^{j}$ & $1.7182 \mathrm{E}-07$ & 7.9206E-04 & 2.2505E-03 & 7.2111E-03 & 7.3761E-03 & 5.2921E-03 & 1.6 \\
\hline \multicolumn{8}{|l|}{ Segment Total } \\
\hline \multicolumn{8}{|l|}{$+-^{\mathrm{n}}$} \\
\hline \multicolumn{8}{|l|}{ Rod Total } \\
\hline \multicolumn{8}{|l|}{$+/-^{n}$} \\
\hline shear gas $(g)^{e}$ & 0 & 0.0001 & 0.0007 & 0.0078 & 0.0036 & 0.0012 & \\
\hline$+/{ }^{\mathrm{e}}$ & 0 & 0.0003 & 0.0003 & 0.0016 & 0.0007 & 0.0003 & \\
\hline 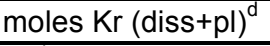 & 0.000002 & 0.000125 & 0.000503 & 0.001785 & 0.001295 & 0.00076 & \\
\hline$+l^{-\mathrm{d}}$ & 0 & 0.000019 & 0.000054 & 0.000173 & 0.000177 & 0.000127 & \\
\hline $\mathrm{Kr}+\mathrm{Xe}$ diss\&pl $(\mathrm{g})^{\mathrm{d}}$ & 0.0012 & 0.0694 & 0.2999 & 1.0794 & 0.8133 & 0.4813 & \\
\hline$+I^{-\mathrm{d}}$ & 0 & 0.0085 & 0.0246 & 0.0787 & 0.0727 & 0.0439 & \\
\hline moles kr (tot) $^{\circ}$ & $2.0000 \mathrm{E}-06$ & 1.2518E-04 & 5.0417E-04 & 1.7979E-03 & 1.3007E-03 & 7.6189E-04 & 4.0 \\
\hline$+/^{\mathrm{p}}$ & 0 & 1.9008E-05 & 5.4003E-05 & $1.7303 \mathrm{E}-04$ & $1.7701 \mathrm{E}-04$ & 1.2700E-04 & 4.1 \\
\hline $\mathrm{Xe}-128(\mathrm{~mol} \%)^{\mathrm{d}}$ & 0.1 & 0.1 & 0.1 & 0.1 & 0.1 & 0.1 & \\
\hline$+/_{-}^{\mathrm{d}}$ & 0 & 0 & 0 & 0 & 0 & 0 & \\
\hline Xe-128 $(g)^{k}$ & 1.0232E-06 & 5.6102E-05 & 2.4564E-04 & 8.9033E-04 & $6.7305 \mathrm{E}-04$ & $3.9800 \mathrm{E}-04$ & 6.8 \\
\hline$+/-^{j}$ & $0.0000 \mathrm{E}+00$ & 8.0616E-06 & $2.3024 \mathrm{E}-05$ & 7.3687E-05 & 6.7793E-05 & 4.0546E-05 & 6. \\
\hline \multicolumn{8}{|l|}{ SegmentTotal } \\
\hline$+/-^{\mathrm{n}}$ & & & & & & & \\
\hline
\end{tabular}


Rod "P" 0307602 (SI-1, 3N63)

\begin{tabular}{|c|c|c|c|c|c|c|}
\hline & P-00 & P-01 & P-02 & P-03 & P-04 & P-05 \\
\hline seg length (in) ${ }^{a}$ & 10.355 & 17.587 & 20.541 & 21.401 & 17.671 & 17.74 \\
\hline \multicolumn{7}{|l|}{ total length (in) } \\
\hline $\mathrm{Xe}-130(\mathrm{~mol} \%)^{d}$ & 0.2 & 0.2 & 0.2 & 0.2 & 0.2 & 0.2 \\
\hline$+/^{\mathrm{d}}$ & 0 & 0 & 0 & 0 & 0 & 0 \\
\hline $\mathrm{Xe}-130(\mathrm{~g})^{\mathrm{k}}$ & $2.0785 \mathrm{E}-06$ & 1.1396E-04 & $4.9895 \mathrm{E}-04$ & $1.8085 \mathrm{E}-03$ & 1.3672E-03 & $8.0845 \mathrm{E}-04$ \\
\hline$+/^{j}$ & $0.0000 \mathrm{E}+00$ & 1.6375E-05 & 4.6768E-05 & 1.4968E-04 & 1.3771E-04 & 8.2361E-05 \\
\hline \multicolumn{7}{|l|}{ SegmentTotal } \\
\hline \multicolumn{7}{|l|}{$+/-^{\mathrm{n}}$} \\
\hline $\mathrm{Xe}-131(\mathrm{~mol} \%)^{d}$ & 10.8 & 10.8 & 10.8 & 10.8 & 10.8 & 10.8 \\
\hline$+/^{d}$ & 0.1 & 0.1 & 0.1 & 0.1 & 0.1 & 0.1 \\
\hline $\mathrm{Xe-131}(\mathrm{g})^{\mathrm{k}}$ & $1.1310 \mathrm{E}-04$ & 6.2013E-03 & $2.7151 \mathrm{E}-02$ & $9.8412 \mathrm{E}-02$ & 7.4396E-02 & 4.3993E-02 \\
\hline$+L^{j}$ & $1.0472 \mathrm{E}-06$ & 8.9293E-04 & $2.5573 \mathrm{E}-03$ & $8.1958 \mathrm{E}-03$ & $7.5250 \mathrm{E}-03$ & $4.5002 E-03$ \\
\hline \multicolumn{7}{|l|}{ SegmentTotal } \\
\hline \multicolumn{7}{|l|}{$+/-^{\mathrm{n}}$} \\
\hline $\mathrm{Xe}-132(\mathrm{~mol} \%)^{d}$ & 23.1 & 23.1 & 23.1 & 23.1 & 23.1 & 23.1 \\
\hline$+/^{d}$ & 0.1 & 0.1 & 0.1 & 0.1 & 0.1 & 0.1 \\
\hline Xe-132 $(g)^{k}$ & 2.4376E-04 & 1.3365E-02 & 5.8517E-02 & 2.1210E-01 & 1.6034E-01 & 9.4814E-02 \\
\hline$+L^{j}$ & 1.0552E-06 & 1.9213E-03 & $5.4908 \mathrm{E}-03$ & $1.7578 \mathrm{E}-02$ & 1.6165E-02 & 9.6679E-03 \\
\hline \multicolumn{7}{|l|}{ SegmentTotal } \\
\hline \multicolumn{7}{|l|}{$+/-^{n}$} \\
\hline Xe-134 (mol\%) $)^{d}$ & 25.4 & 25.4 & 25.4 & 25.4 & 25.4 & 25.4 \\
\hline$+/^{d}$ & 0.2 & 0.2 & 0.2 & 0.2 & 0.2 & 0.2 \\
\hline Xe-134 $(g)^{k}$ & 2.7210E-04 & 1.4919E-02 & 6.5319E-02 & 2.3676E-01 & 1.7898E-01 & 1.0584E-01 \\
\hline$+/-^{j}$ & $2.1425 \mathrm{E}-06$ & 2.1469E-03 & $6.1441 \mathrm{E}-03$ & 1.9683E-02 & 1.8082E-02 & 1.0814E-02 \\
\hline \multicolumn{7}{|l|}{ SegmentTotal } \\
\hline$+-^{\mathrm{n}}$ & & & & & & \\
\hline
\end{tabular}


Rod "P" 0307602 (SI-1, 3N63)

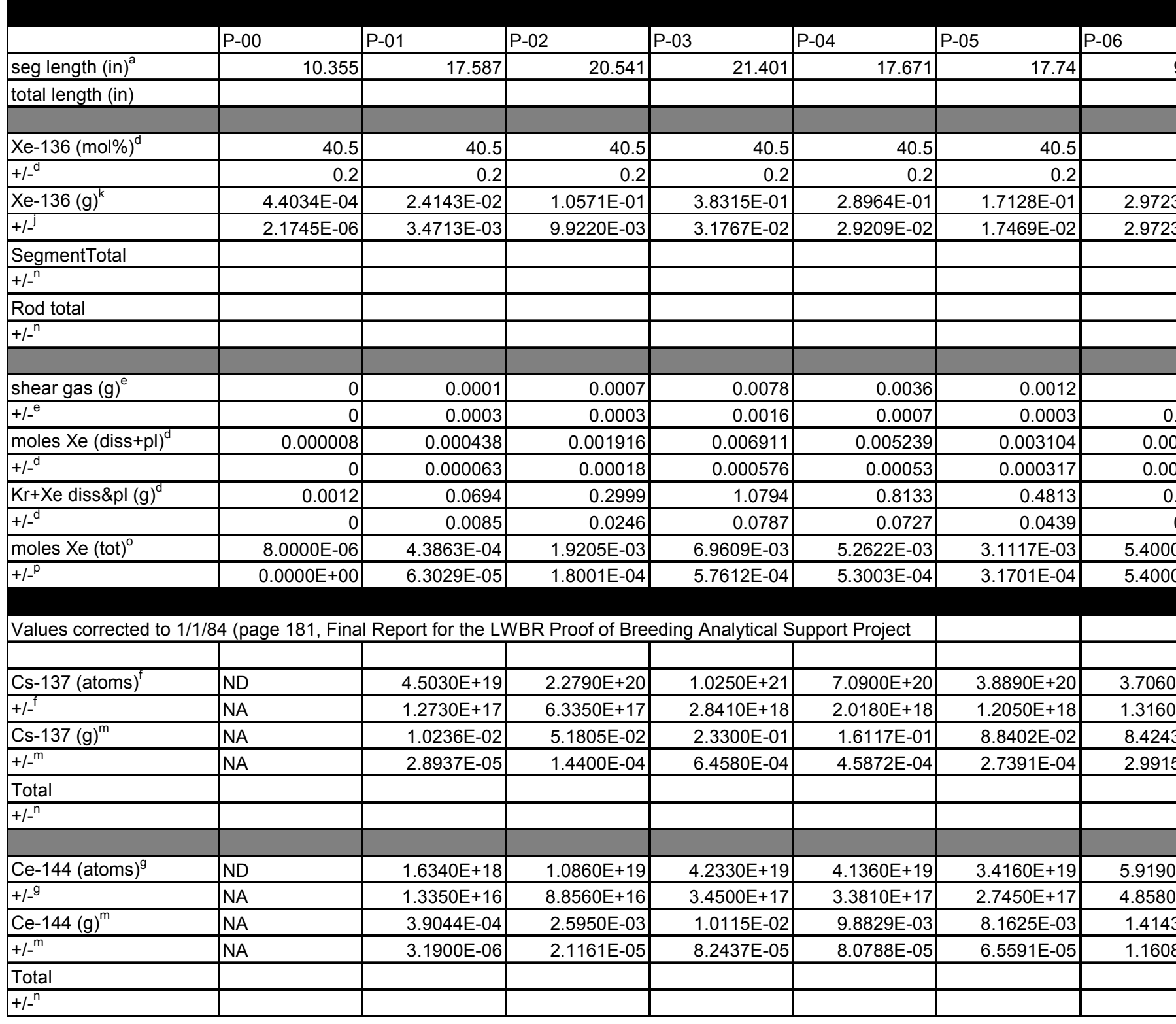


Rod "P" 0307602 (SI-1, 3N63)

\begin{tabular}{|c|c|c|c|c|c|c|c|}
\hline & P-00 & P-01 & P-02 & P-03 & P-04 & P-05 & $\mathrm{P}-0$ \\
\hline seg length (in) & 10.355 & 17.587 & 20.541 & 21.401 & 17.671 & 17.74 & \\
\hline \multicolumn{7}{|l|}{ total length (in) } & \\
\hline Zr-95 (atoms) ${ }^{\mathrm{h}}$ & D & ND & $81620 F+16$ & $2334 \mathrm{~F}+17$ & $35710 \mathrm{~F}+17$ & $20810 \mathrm{~F}+17$ & \\
\hline$+-^{\mathrm{h}}$ & NA & NA & $10020 F+16$ & 2.2UUULIII & $520605+16$ & 2.0040LII & \\
\hline $7 r-95(a)^{m}$ & INA & INA & $1.90<0<+10$ & $0.9900 \mathrm{CT} 10$ & $0.2000 \mathrm{C}+10$ & $2.20105+10$ & \\
\hline$\frac{t_{1} m}{21-30(y)}$ & IVA & INA & $1.20025-03$ & $0.02045-00$ & $\frac{0.0<1<5-U 5}{0}$ & $\frac{0.10305-40}{4.10<250}$ & \\
\hline \multicolumn{7}{|l|}{ Total } & \\
\hline$+/-^{n}$ & & & & & & & \\
\hline
\end{tabular}

\section{Footnotes}

a. ANL Destructive Chemical Assay of 33-Rod LWBR EOL Sample - Rod P, 0307602, page 3

b. ANL Destructive Chemical Assay of 33-Rod LWBR EOL Sample - Rod P, 0307602, page 6

c. ANL Destructive Chemical Assay of 33-Rod LWBR EOL Sample - Rod P, 0307602, page 7

d. ANL Destructive Chemical Assay of 33-Rod LWBR EOL Sample - Rod P, 0307602, page 10

e. ANL Destructive Chemical Assay of 33-Rod LWBR EOL Sample - Rod P, 0307602, page 11

f. ANL Destructive Chemical Assay of 33-Rod LWBR EOL Sample - Rod P, 0307602, page 12

g. ANL Destructive Chemical Assay of 33-Rod LWBR EOL Sample - Rod P, 0307602, page 13

h. ANL Destructive Chemical Assay of 33-Rod LWBR EOL Sample - Rod P, 0307602, page 14

i. (abundance of the specified isotope)(total weight of uranium) / 100

j. Error Propagation $=\left(\left(s d_{x} / x\right)^{2}+\left(s d_{y} / y\right)^{2}\right)^{1 / 2}(x y)$, where sd is the $+/-$ in the table

k. $($ mole $\%)$ (number moles gas recovered)(molec wt) $/ 100$

m. (number of atoms per segment)(atomic weight) $/ 6.0228 \mathrm{E}+23$

n. Error Propagation $=\left(\operatorname{SUM}\left(s d_{i}^{2}\right)\right)^{1 / 2}$, where sd is the $+/-$ in the table

o. $(($ shear gas $/ \mathrm{Xe}+\mathrm{Kr}$ (diss\&pl $))($ moles Xe or $\mathrm{Kr}($ diss $+\mathrm{pl}))+$ moles Xe or $\mathrm{Kr}(\mathrm{diss}+\mathrm{pl})$

p. Error Propagation $=\left(\left(\left(\left(s d_{x} / x\right)^{2}+\left(s d_{y} / y\right)^{2}+\left(s d_{z} / z\right)^{2}\right)^{1 / 2}(x y / z)\right)^{2}+\left(s d_{y}\right)^{2}\right)^{1 / 2}$, where sd is the $+/-$ in the table 
Rod "Q" 0401744 (SI-1, 4M49)

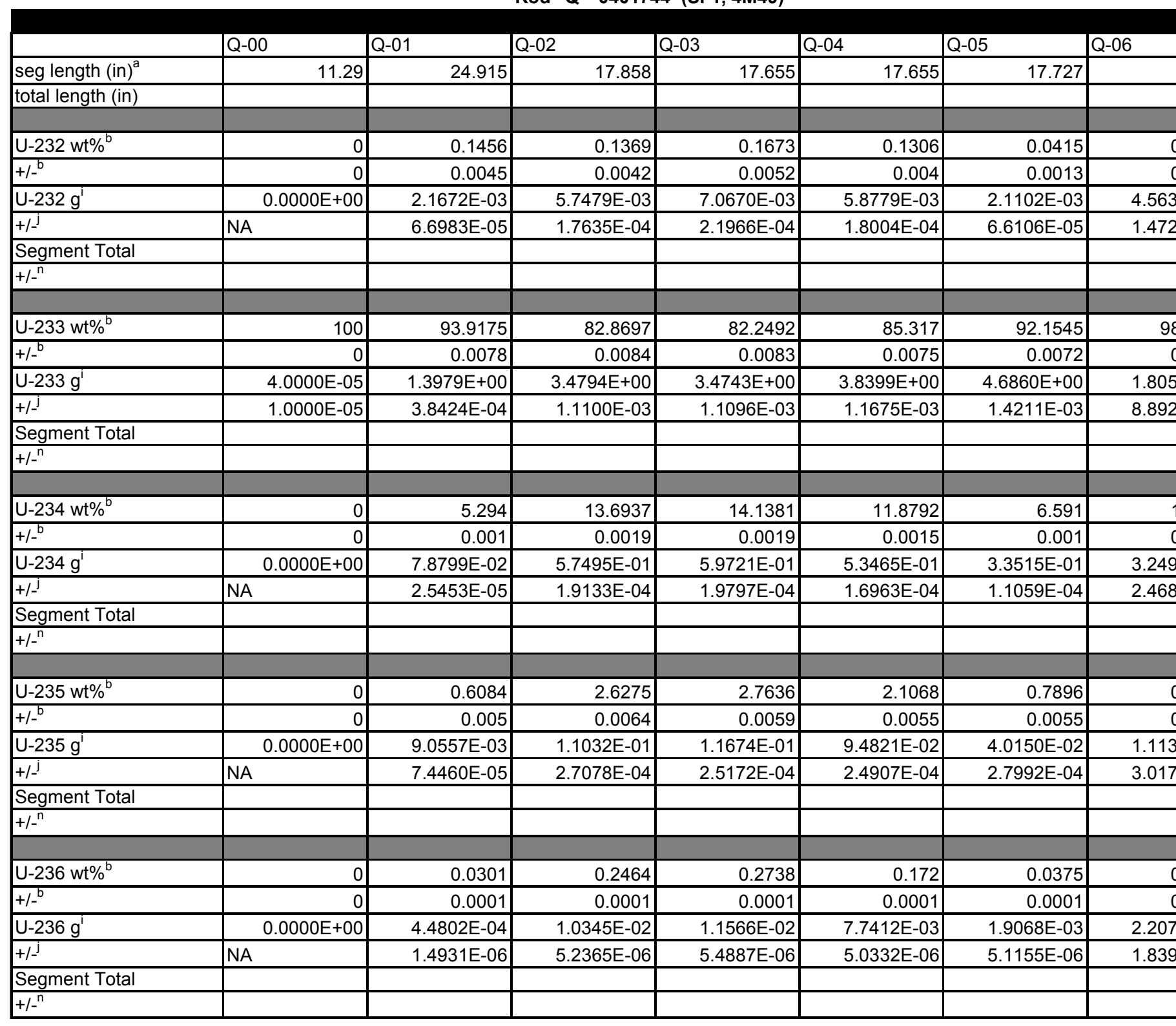


Rod "Q" 0401744 (SI-1, 4M49)

\begin{tabular}{|c|c|c|c|c|c|c|c|}
\hline & Q-00 & Q-01 & Q-02 & Q-03 & Q-04 & Q-05 & Q-06 \\
\hline seg length (in) ${ }^{a}$ & 11.29 & 24.915 & 17.858 & 17.655 & 17.655 & 17.727 & \\
\hline \multicolumn{8}{|l|}{ total length (in) } \\
\hline $\mathrm{U}-238 w \mathrm{wt}^{\mathrm{b}}$ & 0 & 0.0044 & 0.4258 & 0.408 & 0.3944 & 0.3858 & \\
\hline$+/-^{\mathrm{b}}$ & 0 & 0.0048 & 0.0063 & 0.0059 & 0.0053 & 0.0053 & \\
\hline $\mathrm{U}-238 \mathrm{~g}^{\mathrm{i}}$ & $0.0000 \mathrm{E}+00$ & 6.5492E-05 & 1.7878E-02 & 1.7234E-02 & $1.7751 \mathrm{E}-02$ & $1.9618 \mathrm{E}-02$ & 3.0 \\
\hline$+/_{-}^{j}$ & NA & 7.1446E-05 & 2.6457E-04 & $2.4928 \mathrm{E}-04$ & 2.3859E-04 & 2.6956E-04 & 2.8 \\
\hline \multicolumn{8}{|l|}{ Segment Total } \\
\hline \multicolumn{8}{|l|}{$+-^{n}$} \\
\hline tot $U^{c}$ & 0.00008 & 1.48845 & 4.19863 & 4.22412 & 4.50069 & 5.08489 & \\
\hline$+/^{\mathrm{C}}$ & 0.00001 & 0.00039 & 0.00127 & 0.00128 & 0.00131 & 0.00149 & \\
\hline $\mathrm{Kr}-82(\mathrm{~mol} \%)^{\mathrm{d}}$ & 0.2 & 0.2 & 0.2 & 0.2 & 0.2 & 0.2 & \\
\hline$+/^{d}$ & 0 & 0 & 0 & 0 & 0 & 0 & \\
\hline $\mathrm{Kr}-82(\mathrm{~g})^{\mathrm{k}}$ & 1.3106E-06 & 2.9873E-05 & $2.3273 \mathrm{E}-04$ & 2.5732E-04 & 1.9262E-04 & 1.1320E-04 & 0.0 \\
\hline$+{ }^{j}{ }^{j}$ & $0.0000 \mathrm{E}+00$ & 4.9156E-06 & $1.2291 \mathrm{E}-05$ & $3.0639 \mathrm{E}-05$ & 3.0309E-05 & $2.0479 \mathrm{E}-05$ & NA \\
\hline \multicolumn{8}{|l|}{ Segment Total } \\
\hline \multicolumn{8}{|l|}{$+/_{-}^{\mathrm{n}}$} \\
\hline $\mathrm{Kr}-83(\mathrm{~mol} \%)^{\mathrm{d}}$ & 15.2 & 15.2 & 15.2 & 15.2 & 15.2 & 15.2 & \\
\hline$+/_{-}^{\mathrm{d}}$ & 0.2 & 0.2 & 0.2 & 0.2 & 0.2 & 0.2 & \\
\hline $\mathrm{Kr}-83(\mathrm{~g})^{\mathrm{k}}$ & 1.0082E-04 & 2.2981E-03 & 1.7904E-02 & 1.9795E-02 & $1.4818 \mathrm{E}-02$ & 8.7082E-03 & 0.0 \\
\hline$+1-{ }^{j}$ & $1.3266 \mathrm{E}-06$ & 3.7935E-04 & 9.7443E-04 & $2.3714 \mathrm{E}-03$ & 2.3398E-03 & 1.5796E-03 & NA \\
\hline \multicolumn{8}{|l|}{ Segment Total } \\
\hline \multicolumn{8}{|l|}{$+-^{\mathrm{n}}$} \\
\hline $\mathrm{Kr}-84(\mathrm{~mol} \%)^{\mathrm{d}}$ & 30.6 & 30.6 & 30.6 & 30.6 & 30.6 & 30.6 & \\
\hline$+/^{d}$ & 0.2 & 0.2 & 0.2 & 0.2 & 0.2 & 0.2 & \\
\hline $\mathrm{Kr}-84(\mathrm{~g})^{\mathrm{k}}$ & $2.0542 \mathrm{E}-04$ & $4.6821 \mathrm{E}-03$ & 3.6476E-02 & $4.0330 \mathrm{E}-02$ & $3.0190 \mathrm{E}-02$ & $1.7742 \mathrm{E}-02$ & 0.0 \\
\hline$+/-^{j}$ & $1.3426 \mathrm{E}-06$ & 7.7103E-04 & 1.9411E-03 & 4.8094E-03 & $4.7545 \mathrm{E}-03$ & $3.2118 \mathrm{E}-03$ & NA \\
\hline \multicolumn{8}{|l|}{ Segment Total } \\
\hline$+/_{-}^{\mathrm{n}}$ & & & & & & & \\
\hline
\end{tabular}


Rod "Q" 0401744 (SI-1, 4M49)

\begin{tabular}{|c|c|c|c|c|c|c|c|}
\hline & Q-00 & Q-01 & Q-02 & Q-03 & Q-04 & Q-05 & Q-06 \\
\hline seg length (in) ${ }^{a}$ & 11.29 & 24.915 & 17.858 & 17.655 & 17.655 & 17.727 & \\
\hline \multicolumn{8}{|l|}{ total length (in) } \\
\hline & & & & & & & \\
\hline $\mathrm{Kr}-85(\mathrm{~mol} \%)^{\mathrm{d}}$ & 5.7 & 5.7 & 5.7 & 5.7 & 5.7 & 5.7 & \\
\hline$+{ }^{d}{ }^{d}$ & 0.1 & 0.1 & 0.1 & 0.1 & 0.1 & 0.1 & \\
\hline $\mathrm{Kr}-85(\mathrm{~g})^{\mathrm{k}}$ & $3.8720 \mathrm{E}-05$ & $8.8255 \mathrm{E}-04$ & $6.8756 \mathrm{E}-03$ & $7.6021 \mathrm{E}-03$ & $5.6906 \mathrm{E}-03$ & $3.3443 \mathrm{E}-03$ & 0.00 \\
\hline$+/-^{j}$ & $6.7930 \mathrm{E}-07$ & 1.4605E-04 & $3.8263 \mathrm{E}-04$ & $9.1496 \mathrm{E}-04$ & 9.0099E-04 & $6.0785 \mathrm{E}-04$ & NA \\
\hline \multicolumn{8}{|l|}{ Segment Total } \\
\hline \multicolumn{8}{|l|}{$+/_{-}^{\mathrm{n}}$} \\
\hline $\mathrm{Kr}-86(\mathrm{~mol} \%)^{\mathrm{d}}$ & 48.3 & 48.3 & 48.3 & 48.3 & 48.3 & 48.3 & \\
\hline$+{ }^{\mathrm{d}}$ & 0.2 & 0.2 & 0.2 & 0.2 & 0.2 & 0.2 & \\
\hline $\mathrm{Kr}-86(\mathrm{~g})^{\mathrm{k}}$ & $3.3196 \mathrm{E}-04$ & $7.5664 \mathrm{E}-03$ & 5.8947E-02 & $6.5175 \mathrm{E}-02$ & $4.8788 \mathrm{E}-02$ & $2.8672 \mathrm{E}-02$ & 0.00 \\
\hline$+/-^{j}$ & 1.3746E-06 & 1.2454E-03 & $3.1227 \mathrm{E}-03$ & $7.7651 \mathrm{E}-03$ & $7.6796 \mathrm{E}-03$ & 5.1883E-03 & NA \\
\hline \multicolumn{8}{|l|}{ Segment Total } \\
\hline \multicolumn{8}{|l|}{$+/-^{n}$} \\
\hline \multicolumn{8}{|l|}{ Rod Total } \\
\hline \multicolumn{8}{|l|}{$+/-^{n}$} \\
\hline shear gas $(g)^{e}$ & 0 & 0.0002 & 0.0053 & 0.0072 & 0.0042 & 0.0012 & \\
\hline$+/-^{e}$ & 0 & 0.0003 & 0.0011 & 0.0014 & 0.0008 & 0.0003 & \\
\hline moles Kr (diss+pl) ${ }^{d}$ & 0.000008 & 0.000182 & 0.001412 & 0.001559 & 0.001169 & 0.000689 & \\
\hline$+/^{-\mathrm{d}}$ & 0 & 0.00003 & 0.000075 & 0.000187 & 0.000185 & 0.000125 & \\
\hline $\mathrm{Kr}+\mathrm{Xe}$ diss\&pl $(\mathrm{g})^{\mathrm{d}}$ & 0.0046 & 0.1053 & 0.8716 & 0.961 & 0.7272 & 0.42 & \\
\hline$+/^{-\mathrm{d}}$ & 0.0002 & 0.0165 & 0.0462 & 0.0852 & 0.068 & 0.0353 & \\
\hline moles kr (tot) $^{\circ}$ & $8.0000 \mathrm{E}-06$ & 1.8235E-04 & 1.4206E-03 & 1.5707E-03 & 1.1758E-03 & 6.9097E-04 & \\
\hline$+/-^{p}$ & $0.0000 \mathrm{E}+00$ & 3.0005E-05 & $7.5024 \mathrm{E}-05$ & $1.8702 \mathrm{E}-04$ & $1.8501 \mathrm{E}-04$ & $1.2500 \mathrm{E}-04$ & \\
\hline $\mathrm{Xe}-128(\mathrm{~mol} \%)^{\mathrm{d}}$ & 0.1 & 0.1 & 0.1 & 0.1 & 0.1 & 0.1 & \\
\hline$+/^{d}$ & 0 & 0 & 0 & 0 & 0 & 0 & \\
\hline $\mathrm{Xe}-128(\mathrm{~g})^{\mathrm{k}}$ & $3.8371 \mathrm{E}-06$ & $8.5730 \mathrm{E}-05$ & $7.2062 \mathrm{E}-04$ & $7.9546 \mathrm{E}-04$ & $6.0179 \mathrm{E}-04$ & $3.4543 \mathrm{E}-04$ & 0.00 \\
\hline$+/-^{j}$ & $1.2790 \mathrm{E}-07$ & $1.5606 \mathrm{E}-05$ & $3.8000 \mathrm{E}-05$ & $7.9696 \mathrm{E}-05$ & $6.2934 \mathrm{E}-05$ & 3.1977E-05 & NA \\
\hline \multicolumn{8}{|l|}{ SegmentTotal } \\
\hline$+/-^{n}$ & & & & & & & \\
\hline
\end{tabular}


Rod "Q" 0401744 (SI-1, 4M49)

\begin{tabular}{|c|c|c|c|c|c|c|}
\hline & Q-00 & Q-01 & Q-02 & Q-03 & Q-04 & Q-05 \\
\hline seg length (in) ${ }^{a}$ & 11.29 & 24.915 & 17.858 & 17.655 & 17.655 & 17.727 \\
\hline \multicolumn{7}{|l|}{ total length (in) } \\
\hline $\mathrm{Xe}-130(\mathrm{~mol} \%)^{\mathrm{d}}$ & 0.2 & 0.2 & 0.2 & 0.2 & 0.2 & 0.2 \\
\hline$+/-^{d}$ & 0 & 0 & 0 & 0 & 0 & 0 \\
\hline $\mathrm{Xe}-130(\mathrm{~g})^{\mathrm{k}}$ & 7.7942E-06 & 1.7414E-04 & 1.4638E-03 & 1.6158E-03 & 1.2224E-03 & $7.0166 \mathrm{E}-04$ \\
\hline$+/^{j}$ & $2.5981 \mathrm{E}-07$ & 3.1700E-05 & 7.7187E-05 & 1.6188E-04 & 1.2784E-04 & 6.4954E-05 \\
\hline \multicolumn{7}{|l|}{ SegmentTotal } \\
\hline \multicolumn{7}{|l|}{$+/-^{n}$} \\
\hline Xe-131 (mol\%) & 10.9 & 10.9 & 10.9 & 10.9 & 10.9 & 10.9 \\
\hline$+/-^{d}$ & 0.1 & 0.1 & 0.1 & 0.1 & 0.1 & 0.1 \\
\hline $\mathrm{Xe}-131(\mathrm{~g})^{\mathrm{k}}$ & $4.2806 \mathrm{E}-04$ & 9.5639E-03 & $8.0390 \mathrm{E}-02$ & 8.8740E-02 & 6.7134E-02 & $3.8535 \mathrm{E}-02$ \\
\hline$+/_{-}^{j}$ & 1.4799E-05 & 1.7432E-03 & 4.3028E-03 & 8.9279E-03 & 7.0477E-03 & $3.5848 E-03$ \\
\hline \multicolumn{7}{|l|}{ SegmentTotal } \\
\hline \multicolumn{7}{|l|}{$+/-^{n}$} \\
\hline $\mathrm{Xe}-132(\mathrm{~mol} \%)^{\mathrm{d}}$ & 23.3 & 23.3 & 23.3 & 23.3 & 23.3 & 23.3 \\
\hline$+/-^{d}$ & 0.1 & 0.1 & 0.1 & 0.1 & 0.1 & 0.1 \\
\hline $\mathrm{Xe}-132(\mathrm{~g})^{\mathrm{k}}$ & $9.2201 \mathrm{E}-04$ & $2.0600 \mathrm{E}-02$ & 1.7316E-01 & 1.9114E-01 & 1.4460E-01 & $8.3002 E-02$ \\
\hline$+/^{j}$ & 3.0987E-05 & 3.7510E-03 & $9.1610 \mathrm{E}-03$ & 1.9168E-02 & 1.5135E-02 & 7.6920E-03 \\
\hline \multicolumn{7}{|l|}{ SegmentTotal } \\
\hline \multicolumn{7}{|l|}{$+-^{n}$} \\
\hline $\mathrm{Xe}-134(\mathrm{~mol} \%)^{\mathrm{d}}$ & 25.4 & 25.4 & 25.4 & 25.4 & 25.4 & 25.4 \\
\hline$+/^{\mathrm{d}}$ & 0.1 & 0.1 & 0.1 & 0.1 & 0.1 & 0.1 \\
\hline $\mathrm{Xe}-134(\mathrm{~g})^{\mathrm{k}}$ & 1.0204E-03 & 2.2797E-02 & 1.9163E-01 & 2.1153E-01 & 1.6003E-01 & 9.1856E-02 \\
\hline$+/^{j}$ & $3.4248 \mathrm{E}-05$ & 4.1510E-03 & 1.0133E-02 & $2.1209 E-02$ & 1.6747E-02 & $8.5110 \mathrm{E}-03$ \\
\hline \multicolumn{7}{|l|}{ SegmentTotal } \\
\hline$+/-^{\mathrm{n}}$ & & & & & & \\
\hline
\end{tabular}


Rod "Q" 0401744 (SI-1, 4M49)

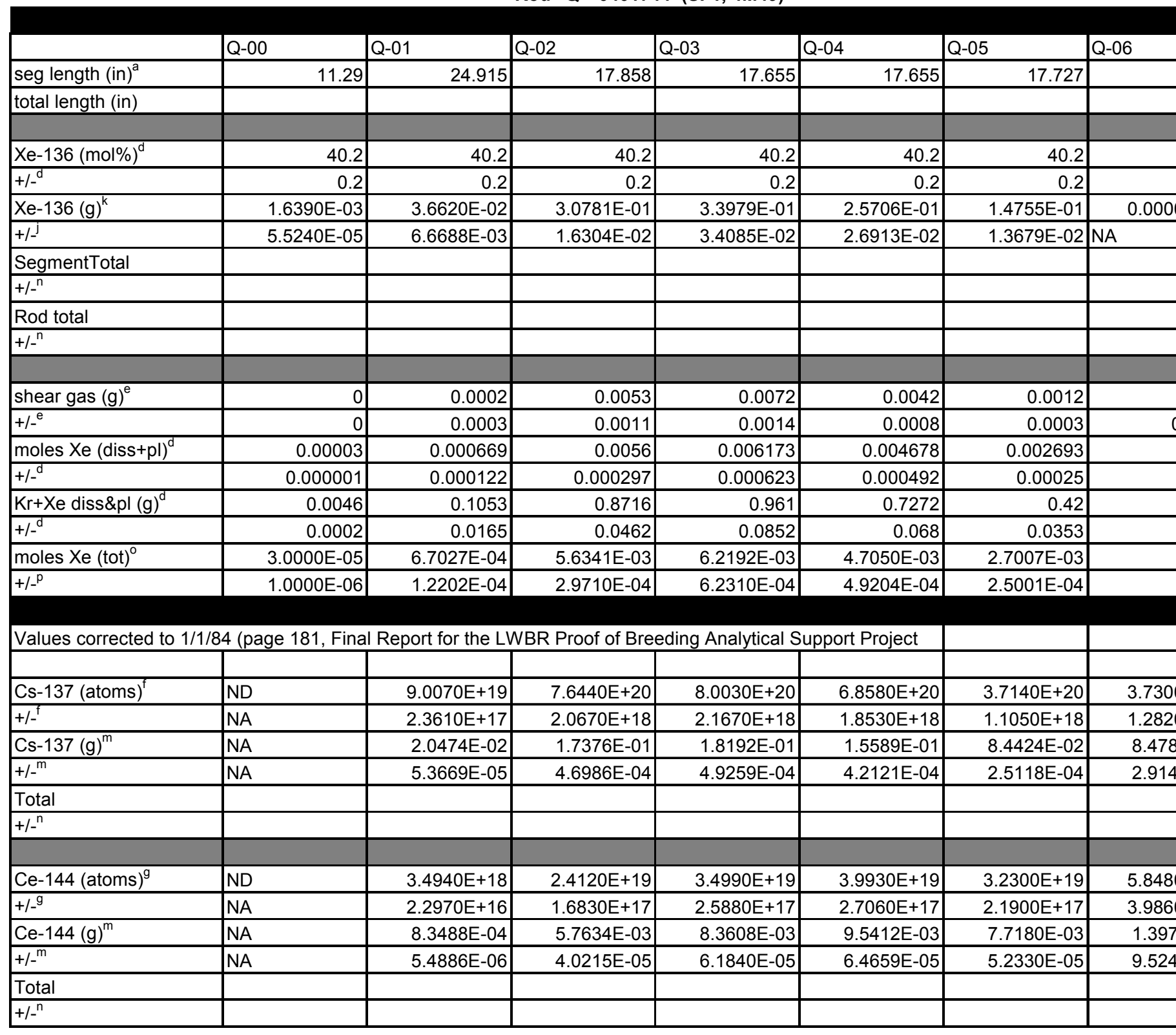


Rod "Q" 0401744 (SI-1, 4M49)

\begin{tabular}{|c|c|c|c|c|c|c|c|}
\hline & Q-00 & Q-01 & Q-02 & Q-03 & Q-04 & Q-05 & Q-06 \\
\hline seg length (in) ${ }^{a}$ & 11.29 & 24.915 & 17.858 & 17.655 & 17.655 & 17.727 & \\
\hline \multicolumn{7}{|l|}{ total length (in) } & \\
\hline Zr-95 (atoms) ${ }^{\mathrm{h}}$ & ND & ND & 1.6040E+17 & $2.1710 \mathrm{E}+17$ & $2.8820 \mathrm{E}+17$ & $3.4550 \mathrm{E}+17$ & \\
\hline$+/-^{\mathrm{h}}$ & NA & NA & $4.6110 \mathrm{E}+16$ & $6.2070 \mathrm{E}+16$ & $6.6950 \mathrm{E}+16$ & $3.4900 \mathrm{E}+16$ & \\
\hline Zr-95 (g) & NA & NA & $2.5276 \mathrm{E}-05$ & $3.4211 \mathrm{E}-05$ & 4.5415E-05 & 5.4444E-05 & \\
\hline$+/-^{m}$ & NA & NA & $7.2661 \mathrm{E}-06$ & $9.7811 \mathrm{E}-06$ & 1.0550E-05 & $5.4996 \mathrm{E}-06$ & \\
\hline \multicolumn{7}{|l|}{ Total } & \\
\hline$+/-^{n}$ & & & & & & & \\
\hline
\end{tabular}

\section{Footnotes}

a. ANL Destructive Chemical Assay of 33-Rod LWBR EOL Sample - Rod Q, 0401744, page 3

b. ANL Destructive Chemical Assay of 33-Rod LWBR EOL Sample - Rod Q, 0401744, page 6

c. ANL Destructive Chemical Assay of 33-Rod LWBR EOL Sample - Rod Q, 0401744 , page 7

d. ANL Destructive Chemical Assay of 33-Rod LWBR EOL Sample - Rod Q, 0401744, page 10

e. ANL Destructive Chemical Assay of 33-Rod LWBR EOL Sample - Rod Q, 0401744, page 11

f. ANL Destructive Chemical Assay of 33-Rod LWBR EOL Sample - Rod Q, 0401744, page 12

g. ANL Destructive Chemical Assay of 33-Rod LWBR EOL Sample - Rod Q, 0401744, page 13

h. ANL Destructive Chemical Assay of 33-Rod LWBR EOL Sample - Rod Q, 0401744, page 14

i. (abundance of the specified isotope)(total weight of uranium) / 100

j. Error Propagation $=\left(\left(s d_{x} / x\right)^{2}+\left(s d_{y} / y\right)^{2}\right)^{1 / 2}(x y)$, where sd is the $+/-$ in the table

k. $($ mole $\%)$ (number moles gas recovered)(molec wt) $/ 100$

m. (number of atoms per segment)(atomic weight) / 6.0228E+23

n. Error Propagation $=\left(\operatorname{SUM}\left(s d_{i}^{2}\right)\right)^{1 / 2}$, where $s d$ is the $+/$ - in the table

o. $\quad(($ shear gas $/ \mathrm{Xe}+\mathrm{Kr}($ diss\&pl $))($ moles Xe or $\mathrm{Kr}($ diss $+\mathrm{pl}))+$ moles Xe or $\mathrm{Kr}($ diss $+\mathrm{pl})$

p. Error Propagation $=\left(\left(\left(\left(s d_{x} / x\right)^{2}+\left(s d_{y} / y\right)^{2}+\left(s d_{z} / z\right)^{2}\right)^{1 / 2}(x y / z)\right)^{2}+\left(s d_{y}\right)^{2}\right)^{1 / 2}$, where sd is the $+/-$ in the table 
Rod "R" 3110505 (RV-3 E3)

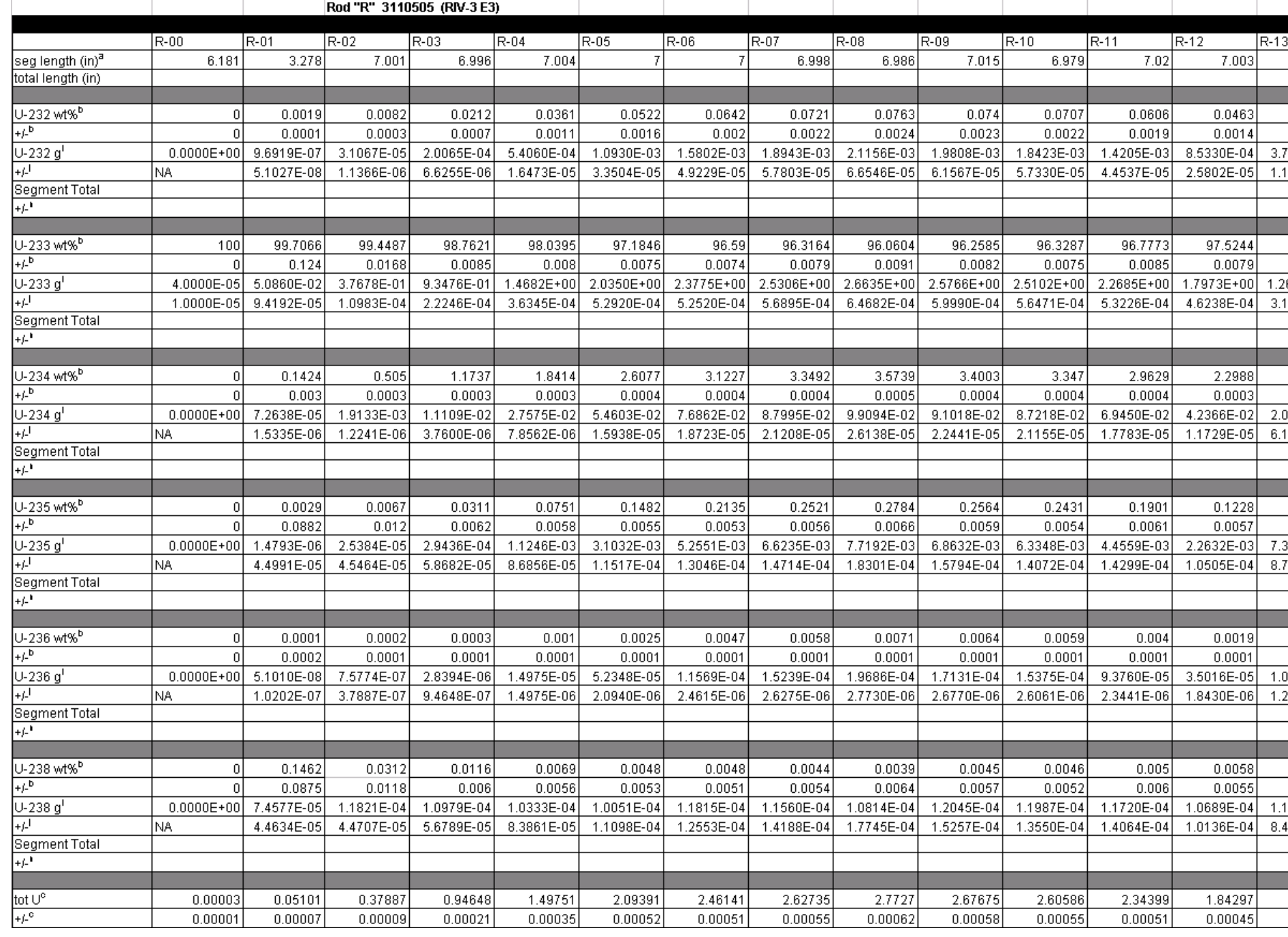


Rod "R" 3110505 (RN-3 E3)

\begin{tabular}{|c|c|c|c|c|c|c|c|c|c|c|c|c|c|c|}
\hline & R-00 & R-01 & $\mathrm{R}-02$ & $\mathrm{R}-03$ & R-04 & R-05 & R-06 & R-07 & R-08 & R-09 & R-10 & R-11 & R-12 & R-13 \\
\hline seg length (in) ${ }^{a}$ & 6.181 & 3.278 & 7.001 & 6.996 & 7.004 & 7 & 7 & 6.998 & 6.986 & 7.015 & 6.979 & 7.02 & 7.003 & \\
\hline \multicolumn{15}{|l|}{ total length (in) } \\
\hline \multicolumn{15}{|l|}{$\mathrm{Kr}-82(\mathrm{mo} \mid \%)^{\mathrm{d}}$} \\
\hline \multicolumn{15}{|l|}{$+j_{-1}^{\mathrm{d}}$} \\
\hline $\mathrm{Kr}-82(\mathrm{~g})^{\mathrm{k}}$ & $0.0000 \mathrm{E}+00$ & $0.0000 \mathrm{E}+00$ & $0.0000 E+00$ & $0.0000 E+00$ & $0.0000 E+00$ & $0.0000 \mathrm{E}+00$ & $0.0000 E+00$ & $0.0000 E+00$ & $0.0000 E+00$ & $0.0000 E+00$ & $0.0000 \mathrm{E}+00$ & $0.0000 E+00$ & $0.0000 E+00$ & 0.0000 \\
\hline$+j-1$ & NA & NA & NA & NA & NA & NA & NA & NA & NA & NA & NA & NA & NA & NA \\
\hline \multicolumn{15}{|l|}{ Segment Total } \\
\hline \multicolumn{15}{|l|}{$+1-1^{\prime}$} \\
\hline & & & & & & & & & & & & & & 1 \\
\hline \multicolumn{15}{|l|}{$\mathrm{Kr}-83(\mathrm{~mol} \%)^{\mathrm{d}}$} \\
\hline \multicolumn{15}{|l|}{$+j^{\mathrm{a}}$} \\
\hline $\mathrm{Kr}-83(\mathrm{~g})^{\mathrm{k}}$ & $0.000 \mathrm{E}+00$ & $0.000 \mathrm{E}+00$ & $0.000 \mathrm{E}+00$ & $0.000 \mathrm{E}+00$ & $0.000 \mathrm{E}+00$ & $0.000 \mathrm{E}+00$ & $0.000 \mathrm{E}+00$ & $0.000 \mathrm{E}+00$ & $0.000 E+00$ & $0.000 \mathrm{E}+00$ & $0.000 \mathrm{E}+00$ & $0.000 \mathrm{E}+00$ & $0.000 \mathrm{E}+00$ & 0.000 \\
\hline$+j-1$ & NA & NA & NA & NA & NA & NA & NA & NA & NA & NA & NA & NA & NA & NA \\
\hline \multicolumn{15}{|l|}{ Segment Total } \\
\hline \multicolumn{15}{|l|}{$+1-1^{\prime}$} \\
\hline & & & & & & & & & & & & & & 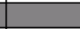 \\
\hline \multicolumn{15}{|l|}{$\mathrm{Kr}-84(\mathrm{mo} \mid \%)^{d}$} \\
\hline \multicolumn{15}{|l|}{$+j^{\text {d }}$} \\
\hline $\mathrm{Kr}-84(\mathrm{~g})^{\mathrm{K}}$ & $0.0000 \mathrm{E}+00$ & $0.0000 \mathrm{E}+00$ & $0.0000 \mathrm{E}+00$ & $0.0000 \mathrm{E}+00$ & $0.0000 \mathrm{E}+00$ & $0.0000 \mathrm{E}+00$ & $0.0000 E+00$ & $0.0000 \mathrm{E}+00$ & $0.0000 \mathrm{E}+00$ & $0.0000 \mathrm{E}+00$ & $0.0000 \mathrm{E}+00$ & $0.0000 \mathrm{E}+00$ & $0.0000 \mathrm{E}+00$ & 0.0000 \\
\hline$+j^{1}$ & NA & \begin{tabular}{|l|} 
NA \\
\end{tabular} & NA & NA & NA & NA & \begin{tabular}{|l|l} 
NA & \\
\end{tabular} & NA & NA & NA & NA & NA & NA & NA \\
\hline \multicolumn{15}{|l|}{ Segment Total } \\
\hline \multicolumn{15}{|l|}{$+1--^{-1}$} \\
\hline & & & & & & & & & & & & & & \\
\hline \multicolumn{15}{|l|}{$\mathrm{Kr}-85(\mathrm{~mol} \%)^{d}$} \\
\hline \multicolumn{15}{|l|}{$+j^{\mathrm{a}}$} \\
\hline $\mathrm{Kr}-85(\mathrm{~g})^{\mathrm{K}}$ & $0.0000 \mathrm{E}+00$ & $0.0000 \mathrm{E}+00$ & $0.0000 \mathrm{E}+00$ & $0.0000 \mathrm{E}+00$ & $0.0000 \mathrm{E}+00$ & $0.0000 \mathrm{E}+00$ & $0.0000 \mathrm{E}+00$ & $0.0000 \mathrm{E}+00$ & $0.0000 \mathrm{E}+00$ & $0.0000 \mathrm{E}+00$ & $0.0000 \mathrm{E}+00$ & $0.0000 \mathrm{E}+00$ & $0.0000 \mathrm{E}+00$ & 0.0000 \\
\hline$+1-1$ & NA & NA & NA & NA & NA & NA & NA & NA & NA & NA & NA & NA & NA & NA \\
\hline \multicolumn{15}{|l|}{ Segment Total } \\
\hline \multicolumn{15}{|l|}{$+f--^{-1}$} \\
\hline & & & & & & & & & & & & & & \\
\hline \multicolumn{15}{|l|}{$\mathrm{Kr}-86(\mathrm{~mol} \%)^{d}$} \\
\hline$+j_{-}^{\mathrm{a}}$ & & & & & & & & & & & & & & \\
\hline $\mathrm{Kr}-86(\mathrm{~g})^{\mathrm{k}}$ & $0.0000 \mathrm{E}+00$ & $0.0000 \mathrm{E}+00$ & $0.0000 \mathrm{E}+00$ & $0.0000 \mathrm{E}+00$ & $0.0000 \mathrm{E}+00$ & $0.0000 \mathrm{E}+00$ & $0.0000 \mathrm{E}+00$ & $0.0000 \mathrm{E}+00$ & $0.0000 \mathrm{E}+00$ & $0.0000 \mathrm{E}+00$ & $0.0000 \mathrm{E}+00$ & $0.0000 \mathrm{E}+00$ & $0.0000 \mathrm{E}+00$ & 0.0000 \\
\hline$+j-1$ & NA & \begin{tabular}{|l|}
$N A$ \\
\end{tabular} & NA & NA & NA & NA & NA & NA & NA & NA & NA & NA & NA & NA \\
\hline Segment Total & & & & & & & & & & & & & & \\
\hline$+f-c^{\prime}$ & & & & & & & & & & & & & & \\
\hline Rod Total & & & & & & & & & & & & & & \\
\hline$+1-1$ & & & & & & & & & & & & & & \\
\hline & & & & & & & & & & & & & & \\
\hline shear gas $(\mathrm{g})^{\mathrm{e}}$ & & & & & & & & & & & & & & \\
\hline$+j^{e}$ & & & & & & & & & & & & & & \\
\hline moles $\mathrm{Kr}$ (diss+ & & & & & & & & & & & & & & \\
\hline$+r^{d}$ & & & & & & & & & & & & & & \\
\hline $\mathrm{Kr}+\mathrm{Xe}$ diss\&pl & & & & & & & & & & & & & & \\
\hline$+r^{d}$ & & & & & & & & & & & & & & \\
\hline moles $\mathrm{kr}$ (tot) $^{\circ}$ & & & & & & & & & & & & & & \\
\hline$+j^{\mathrm{P}}$ & & & & & & & & & & & & & & \\
\hline
\end{tabular}




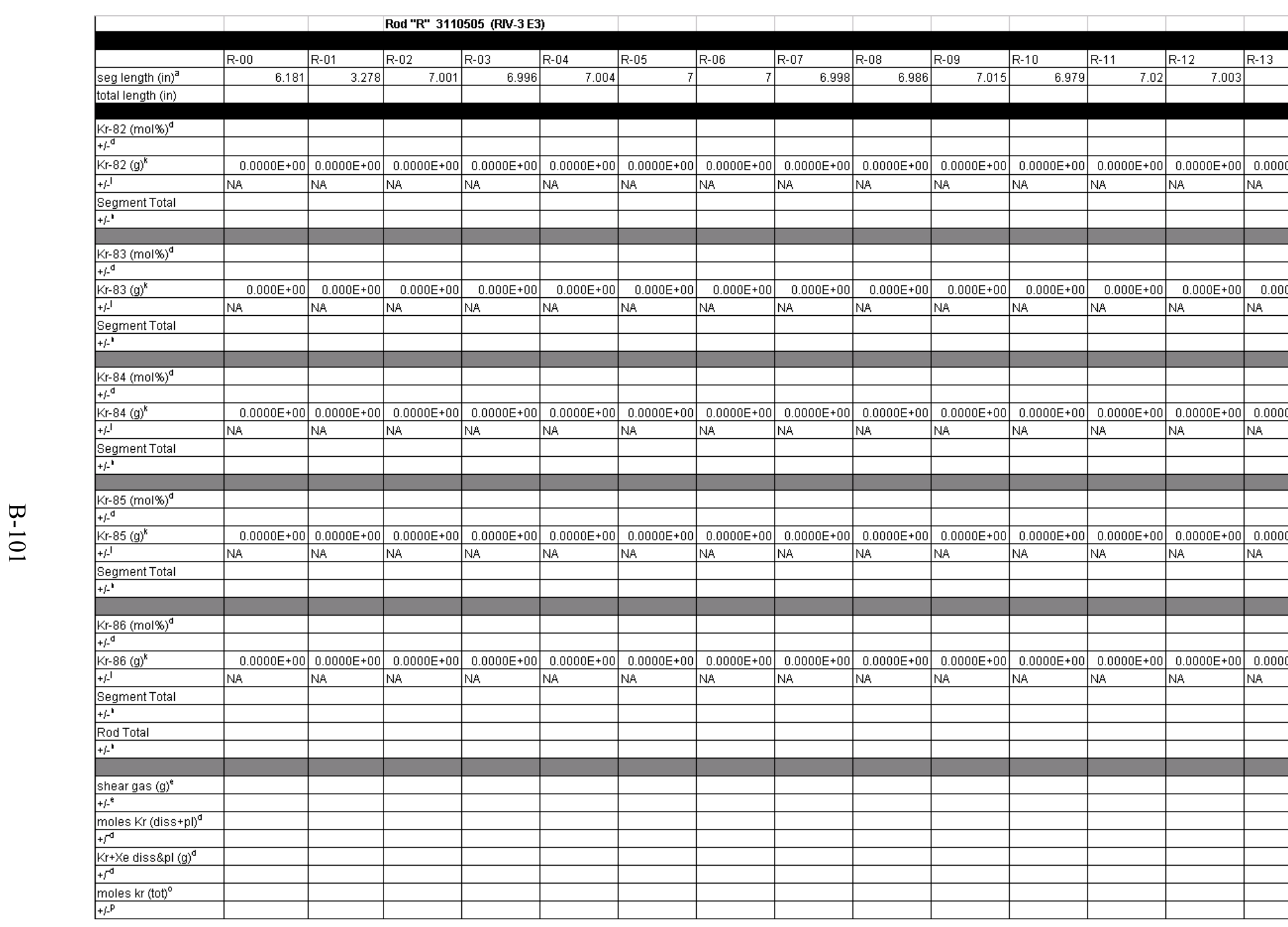


Rod "R" 3110505 (RV-3 E3)

\begin{tabular}{|c|c|c|c|c|c|c|c|c|c|c|c|c|c|c|}
\hline & R-00 & R-01 & $\mathrm{R}-02$ & R-03 & R-04 & R-05 & R-06 & R-07 & R-08 & R-09 & R-10 & R-11 & R-12 & R- \\
\hline seg length (in) ${ }^{a}$ & 6.181 & 3.278 & 7.001 & 6.996 & 7.004 & 7 & 7 & 6.998 & 6.986 & 7.015 & 6.979 & 7.02 & 7.003 & \\
\hline \multicolumn{15}{|l|}{ total length (in) } \\
\hline \multirow{2}{*}{\multicolumn{15}{|c|}{ Values corrected to $1 / 1 / 8$}} \\
\hline & & & & & & & & & & & & & & \\
\hline Cs-137 (atoms) ${ }^{\dagger}$ & ND & $1.3540 \mathrm{E}+17$ & $2.6310 \mathrm{E}+18$ & $1.3750 \mathrm{E}+19$ & $3.2750 \mathrm{E}+19$ & $6.4150 \mathrm{E}+19$ & $8.9490 \mathrm{E}+19$ & $1.0160 \mathrm{E}+20$ & $1.1500 \mathrm{E}+20$ & $1.0510 \mathrm{E}+20$ & $1.0180 \mathrm{E}+20$ & $8.0930 \mathrm{E}+19$ & $4.9090 \mathrm{E}+19$ & 9 \\
\hline$+j_{-1}^{\top}$ & NA & $5.0590 \mathrm{E}+14$ & $7.3040 \mathrm{E}+15$ & $3.8140 \mathrm{E}+16$ & $9.0500 \mathrm{E}+16$ & $1.6950 \mathrm{E}+17$ & $2.4900 \mathrm{E}+17$ & $2.8250 \mathrm{E}+17$ & $3.1980 \mathrm{E}+17$ & $2.7740 \mathrm{E}+17$ & $2.8320 \mathrm{E}+17$ & $2.2580 \mathrm{E}+17$ & $1.3650 \mathrm{E}+17$ & 7 \\
\hline $\mathrm{Cs}-137(\mathrm{~g})^{\mathrm{m}}$ & NA & $3.0778 \mathrm{E}-05$ & $5.9806 \mathrm{E}-04$ & $3.1256 \mathrm{E}-03$ & $7.4445 \mathrm{E}-03$ & $1.4582 \mathrm{E}-02$ & $2.0342 \mathrm{E}-02$ & $2.3095 \mathrm{E}-02$ & $2.6141 \mathrm{E}-02$ & $2.3891 \mathrm{E}-02$ & $2.3141 \mathrm{E}-02$ & $1.8397 \mathrm{E}-02$ & $1.1159 \mathrm{E}-02$ & \\
\hline$+j^{\mathrm{m}}$ & NA & $1.1500 \mathrm{E}-07$ & $1.6603 \mathrm{E}-06$ & $8.6698 \mathrm{E}-06$ & $2.0572 \mathrm{E}-05$ & $3.8530 \mathrm{E}-05$ & $5.6601 \mathrm{E}-05$ & $6.4216 \mathrm{E}-05$ & $7.2695 \mathrm{E}-05$ & $6.3057 \mathrm{E}-05$ & $6.4375 \mathrm{E}-05$ & $5.1328 \mathrm{E}-05$ & $3.1028 \mathrm{E}-05$ & \\
\hline \multicolumn{15}{|l|}{ Total } \\
\hline$+f_{-1}^{\prime}$ & & & & & & & & & & & & & & \\
\hline & & & & & & & & & & & & & & \\
\hline Ce-144 (atoms) ${ }^{9}$ & ND & $1.7900 \mathrm{E}+16$ & $3.1740 \mathrm{E}+17$ & $1.4680 \mathrm{E}+18$ & $3.1380 \mathrm{E}+18$ & $5.5920 \mathrm{E}+18$ & $7.3100 \mathrm{E}+18$ & $8.1310 \mathrm{E}+18$ & $9.1680 \mathrm{E}+18$ & $8.3640 \mathrm{E}+18$ & $7.7760 \mathrm{E}+18$ & $5.8990 \mathrm{E}+18$ & $3.3750 \mathrm{E}+18$ & 1 \\
\hline$+1-9$ & NA & $1.9640 \mathrm{E}+14$ & $2.4250 \mathrm{E}+15$ & $1.1220 \mathrm{E}+16$ & $2.3520 \mathrm{E}+16$ & $4.1910 \mathrm{E}+16$ & $5.6940 \mathrm{E}+16$ & $6.3340 \mathrm{E}+16$ & $6.8700 \mathrm{E}+16$ & $6.3920 \mathrm{E}+16$ & $5.9440 \mathrm{E}+16$ & $4.5960 \mathrm{E}+16$ & $2.6290 \mathrm{E}+16$ & 6 \\
\hline Ce-144(g) ${ }^{\mathrm{m}}$ & NA & $4.2772 \mathrm{E}-06$ & $7.5842 \mathrm{E}-05$ & $3.5078 \mathrm{E}-04$ & $7.4982 \mathrm{E}-04$ & $1.3362 \mathrm{E}-03$ & 1.7467E-03 & $1.9429 \mathrm{E}-03$ & 2.1907E-03 & $1.9986 \mathrm{E}-03$ & $1.8581 \mathrm{E}-03$ & $1.4096 \mathrm{E}-03$ & $8.0645 \mathrm{E}-04$ & \\
\hline$+j^{m}$ & NA & $4.6929 \mathrm{E}-08$ & $5.7945 \mathrm{E}-07$ & $2.6810 \mathrm{E}-06$ & $5.6201 \mathrm{E}-06$ & $1.0014 \mathrm{E}-05$ & $1.3606 \mathrm{E}-05$ & $1.5135 \mathrm{E}-05$ & $1.6416 \mathrm{E}-05$ & $1.5274 \mathrm{E}-05$ & $1.4203 \mathrm{E}-05$ & $1.0982 \mathrm{E}-05$ & $6.2819 \mathrm{E}-06$ & \\
\hline \multicolumn{15}{|l|}{ Total } \\
\hline \multicolumn{15}{|l|}{$+1--^{\prime}$} \\
\hline & & & & & & & & & & & & & & \\
\hline Zr-95 (atoms) & ND & ND & $4.3710 \mathrm{E}+15$ & $1.6040 \mathrm{E}+16$ & $2.9090 \mathrm{E}+16$ & $5.8980 \mathrm{E}+16$ & $7.5130 \mathrm{E}+16$ & $8.7750 \mathrm{E}+16$ & $9.0530 \mathrm{E}+16$ & $7.1950 \mathrm{E}+16$ & $4.7500 \mathrm{E}+16$ & $4.7420 \mathrm{E}+16$ & $2.1220 \mathrm{E}+16$ & $N \mathrm{NL}$ \\
\hline$+1-1$ & NA & NA & $4.3500 \mathrm{E}+14$ & $1.0600 \mathrm{E}+15$ & $3.1900 \mathrm{E}+15$ & $5.3760 \mathrm{E}+15$ & $6.0600 \mathrm{E}+15$ & $7.4730 \mathrm{E}+15$ & $9.8490 \mathrm{E}+15$ & $8.1450 \mathrm{E}+15$ & $7.0460 \mathrm{E}+15$ & $6.7800 \mathrm{E}+15$ & $3.2150 \mathrm{E}+15$ & 5 NA \\
\hline$Z r-95(g)^{m}$ & NA & NA & $6.8879 \mathrm{E}-07$ & $2.5276 \mathrm{E}-06$ & $4.5840 \mathrm{E}-06$ & $9.2941 \mathrm{E}-06$ & $1.1839 \mathrm{E}-05$ & $1.3828 \mathrm{E}-05$ & $1.4266 \mathrm{E}-05$ & $1.1338 \mathrm{E}-05$ & $7.4851 \mathrm{E}-06$ & $7.4725 \mathrm{E}-06$ & $3.3439 \mathrm{E}-06$ & 6 NA \\
\hline$+j^{\mathrm{m}}$ & NA & NA & $6.8548 \mathrm{E}-08$ & $1.6704 \mathrm{E}-07$ & $5.0268 \mathrm{E}-07$ & $8.4716 \mathrm{E}-07$ & $9.5494 \mathrm{E}-07$ & $1.1776 \mathrm{E}-06$ & $1.5520 \mathrm{E}-06$ & $1.2835 \mathrm{E}-06$ & $1.1103 \mathrm{E}-06$ & $1.0684 \mathrm{E}-06$ & $5.0662 \mathrm{E}-07$ & 7 NA \\
\hline \multicolumn{15}{|l|}{ Total } \\
\hline$+f-1$ & & & & & & & & & & & & & & \\
\hline
\end{tabular}

a. ANL Destructive Chemical Assay of 33-Rod LWBR EOL Sample - Rod R, 3110505, page 4

b. ANL Destructive Chemical Assay of 33-Rod LWBR EOL Sample - Rod R, 3110505, page 7

c. ANL Destructive Chemical Assay of 33-Rod LWBR EOL Sample - Rod R, 3110505, page 8

d. ANL Destructive Chemical Assay of 33-Rod LWBR EOL Sample - Rod R, 3110505, page 11

e. ANL Destructive Chemical Assay of 33-Rod LWBR EOL Sample - Rod R, 3110505, page 12

f. ANL Destructive Chemical Assay of 33-Rod LWBR EOL Sample - Rod R, 3110505, page 13

g. ANL Destructive Chemical Assay of 33-Rod LWBR EOL Sample - Rod R, 3110505, page 14

h. ANL Destructive Chemical Assay of 33-Rod LWBR EOL Sample - Rod R, 3110505, page 15

i. (abundance of the specified isotope)(total weight of uranium) / 100

j. $\quad$ Error Propagation $=\left(\left(s d_{x} / x\right)^{2}+\left(s d_{y} / y\right)^{2}\right)^{1 / 2}(x y)$, where sd is the $+/$ - in the table

k. (mole $\%)$ (number moles gas recovered)(molec wt) / 100

m. (number of atoms per segment)(atomic weight) / 6.0228E+23

n. Error Propagation $=\left(\operatorname{SUM}\left({s d_{i}^{2}}^{2}\right)\right)^{1 / 2}$, where $s d$ is the $+/-$ in the table

o. $(($ shear gas $/ \mathrm{Xe}+\mathrm{Kr}($ diss \& $\mathrm{pl}))($ moles $\mathrm{Xe}$ or $\mathrm{Kr}($ diss $+\mathrm{pl}))+$ moles $\mathrm{Xe}$ or $\mathrm{Kr}($ diss $+\mathrm{pl})$

p. Error Propagation $=\left(\left(\left(\left(s d_{x} / x\right)^{2}+\left(s d_{y} / y\right)^{2}+\left(s d_{z} / z\right)^{2}\right)^{1 / 2}(x y / z)\right)^{2}+\left(s d_{y}\right)^{2}\right)^{1 / 2}$, where $s d$ is the $+/-$ in the table 
Rod "W" 2514716 Calibration

\begin{tabular}{|c|c|c|c|c|c|c|}
\hline & W-00 & W-01 & W-02 & W-03 & W-04 & W-05 \\
\hline seg length (in) ${ }^{a}$ & 3.7 & 17.498 & 17.501 & 17.498 & 17.504 & 6.846 \\
\hline total length (in) & & & & & & $8.0547 E+01$ \\
\hline & & & & & & \\
\hline U-232 wt $\%^{b}$ & & 0.00073 & 0.00061 & 0.00058 & 0.00074 & \\
\hline$+/-^{\mathrm{b}}$ & & 0.00002 & 0.00002 & 0.00002 & 0.00002 & \\
\hline $\mathrm{U}-232 \mathrm{~g}^{\mathrm{i}}$ & & $2.3396 \mathrm{E}-05$ & 1.0216E-05 & $9.7224 \mathrm{E}-06$ & $2.3689 \mathrm{E}-05$ & \\
\hline$+/_{-}^{j}$ & & $6.4100 \mathrm{E}-07$ & $3.3500 \mathrm{E}-07$ & 3.3527E-07 & 6.4026E-07 & \\
\hline Segment Total & & & & & & $6.7022 \mathrm{E}-05$ \\
\hline$+/^{n}$ & & & & & & 1.0225E-06 \\
\hline & & & & & & \\
\hline $\mathrm{U}-233 \mathrm{wt} \%^{\mathrm{b}}$ & & 98.3346 & 97.7203 & 97.7221 & 98.3331 & \\
\hline$+/-^{\mathrm{b}}$ & & 0.0061 & 0.0274 & 0.0094 & 0.0063 & \\
\hline $\mathrm{U}-233 \mathrm{~g}^{\mathrm{i}}$ & & $3.1515 \mathrm{E}+00$ & $1.6365 \mathrm{E}+00$ & $1.6381 \mathrm{E}+00$ & $3.1478 \mathrm{E}+00$ & \\
\hline$+/^{j}$ & & 8.4883E-04 & 1.1419E-03 & 4.6713E-04 & 8.5026E-04 & \\
\hline Segment Total & & & & & & $9.5739 E+00$ \\
\hline$+/^{n}$ & & & & & & $1.7221 \mathrm{E}-03$ \\
\hline $\mathrm{U}-234 \mathrm{wt} \%{ }^{\mathrm{b}}$ & & 1.3063 & 1.1589 & 1.1576 & 1.307 & \\
\hline$+/-^{\mathrm{b}}$ & & 0.0002 & 0.0005 & 0.0002 & 0.0002 & \\
\hline $\mathrm{U}-234 \mathrm{~g}^{\mathrm{i}}$ & & $4.1865 \mathrm{E}-02$ & 1.9408E-02 & 1.9405E-02 & $4.1839 \mathrm{E}-02$ & \\
\hline$+/-^{j}$ & & $1.2708 \mathrm{E}-05$ & 1.4963E-05 & $6.1948 \mathrm{E}-06$ & 1.2709E-05 & \\
\hline Segment Total & & & & & & $1.2252 \mathrm{E}-01$ \\
\hline$+/^{\mathrm{n}}$ & & & & & & $2.4192 \mathrm{E}-05$ \\
\hline & & & & & & \\
\hline U-235 wt $\%^{b}$ & & 0.0761 & 0.0852 & 0.0846 & 0.0763 & \\
\hline$+1-{ }^{\mathrm{b}}$ & & 0.0044 & 0.0198 & 0.0068 & 0.0045 & \\
\hline $\mathrm{U}-235 \mathrm{~g}^{\mathrm{i}}$ & & 2.4389E-03 & $1.4268 \mathrm{E}-03$ & 1.4181E-03 & 2.4425E-03 & \\
\hline$+-^{j}$ & & 1.4102E-04 & 3.3159E-04 & 1.1399E-04 & 1.4405E-04 & \\
\hline Segment Total & & & & & & 7.7264E-03 \\
\hline$+/-^{n}$ & & & & & & $4.0445 \mathrm{E}-04$ \\
\hline & & & & & & \\
\hline $\mathrm{U}-236 \mathrm{wt} \%^{\mathrm{b}}$ & & 0.019 & 0.0126 & 0.0127 & 0.0192 & \\
\hline$+/_{-}^{b}$ & & 0.0001 & 0.0001 & 0.0001 & 0.0001 & \\
\hline $\mathrm{U}-236 \mathrm{~g}^{\mathrm{i}}$ & & 6.0893E-04 & $2.1101 \mathrm{E}-04$ & $2.1289 \mathrm{E}-04$ & $6.1462 \mathrm{E}-04$ & \\
\hline$+/^{j}$ & & $3.2088 \mathrm{E}-06$ & $1.6801 \mathrm{E}-06$ & 1.6773E-06 & $3.2052 \mathrm{E}-06$ & \\
\hline Segment Total & & & & & & $1.6474 \mathrm{E}-03$ \\
\hline$+/-^{n}$ & & & & & & $5.1192 \mathrm{E}-06$ \\
\hline
\end{tabular}


Rod "W" 2514716 Calibration

\begin{tabular}{|c|c|c|c|c|c|c|}
\hline & W-00 & W-01 & W-02 & W-03 & W-04 & W-05 \\
\hline seg length (in) & 3.7 & 17.498 & 17.501 & 17.498 & 17.504 & 6.846 \\
\hline total length (in) & & & & & & $8.0547 \mathrm{E}+01$ \\
\hline & & & & & & \\
\hline $\mathrm{U}-238 \mathrm{wt} \%^{\mathrm{b}}$ & & 0.2633 & 1.0224 & 1.0224 & 0.2636 & \\
\hline$+{ }^{-}{ }^{\mathrm{b}}$ & & 0.0044 & 0.0197 & 0.0067 & 0.0045 & \\
\hline$U-238 g^{i}$ & & 8.4384E-03 & 1.7122E-02 & $1.7138 \mathrm{E}-02$ & $8.4382 \mathrm{E}-03$ & \\
\hline$+/-^{j}$ & & 1.4103E-04 & $3.3010 \mathrm{E}-04$ & $1.1240 \mathrm{E}-04$ & 1.4407E-04 & \\
\hline Segment Total & & & & & & $5.1137 \mathrm{E}-02$ \\
\hline$+/-^{n}$ & & & & & & $4.0280 \mathrm{E}-04$ \\
\hline tot $U^{\mathrm{c}, \mathrm{q}}$ & & 3.20487 & 1.6747 & 1.67628 & 3.20115 & \\
\hline$+/_{-}^{\mathrm{c}, \mathrm{q}}$ & & 0.00084 & 0.00107 & 0.00045 & 0.00084 & \\
\hline
\end{tabular}

Footnotes

a. ANL Destructive Chemical Assay of 33-Rod LWBR EOL Sample - Rod W, 2514716, page 4

b. ANL Destructive Chemical Assay of 33-Rod LWBR EOL Sample - Rod W, 2514716, page 6

c. ANL Destructive Chemical Assay of 33-Rod LWBR EOL Sample - Rod W, 2514716, page 7

i. (abundance of the specified isotope)(total weight of uranium) / 100

j. Error Propagation $=\left(\left(s d_{x} / x\right)^{2}+\left(s d_{y} / y\right)^{2}\right)^{1 / 2}(x y)$, where sd is the $+/-$ in the table

n. Error Propagation $=\left(\operatorname{SUM}\left(\mathrm{sd}_{\mathrm{i}}{ }^{2}\right)\right)^{1 / 2}$, where $\mathrm{sd}$ is the $+/$ - in the table

q. Uranium values corrected for shear loss 


\section{Appendix C \\ Scrap Storage Liner}




\begin{abstract}
This appendix provides information about the test fuel contained in the scrap can, or Type D storage liner, in dry storage at the Idaho Nuclear Technology and Engineering Center (INTEC). The test fuel has been through irradiation tests that were conducted as part of the Light Water Breeder Reactor and Advanced Water Breeder Applications programs. Also included are summaries of reports for several of the tests. The fuel was irradiated at several reactors and includes a large variety of fuel compositions. Some of the fuel was sectioned for examination but the majority is intact. A small amount of the fuel is unirradiated. The test material currently stored at INTEC is contained in one fuel handling unit, a scrap storage liner. The intact fuel within this liner is stored in unsealed or sealed containers. The sectioned fuel within this liner is all stored in sealed containers.
\end{abstract}




\section{CONTENTS}

C1. INTRODUCTION C-7

C2. TESTS.

C3. FUEL ROD PROPERTIES. C-7

C4. IRRADIATED TEST REPORT SUMMARIES FOR SELECTED TESTS C-14

C4.1 Comparison of Dimensional Changes in Fuel Rods with Predictions under Cyclic Conditions of Power and System Pressure... C-14

C4.2 In-Pile Dimensional Changes of Zircaloy-4 Tubing Having Low Hoop Stresses.... C-15

C4.3 In-Pile Dimensional Changes of $\mathrm{ThO}_{2}-\mathrm{UO}_{2}$ Fuel Rods with Nonfreestanding Cladding C-16

C4.4 Fuel Rod-Grid Interaction Wear: In-Reactor Tests $\mathrm{C}-17$

C4.5 Fission Gas Release From $\mathrm{ThO}_{2}$ and $\mathrm{ThO}_{2}-\mathrm{UO}_{2}$ Fuels C-19

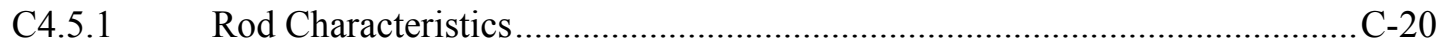

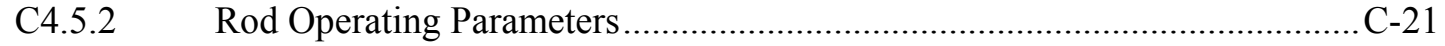

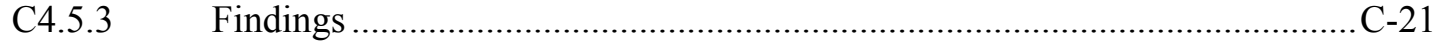

C4.6 Irradiation Testing of Internally Pressurized and/or Graphite Coated Zircaloy-4 Clad Fuel Rods in the NRX Reactor.

C4.7 Early-In-Life Performance of Short Rod Duplex Pellet Screening (D-1) Test

C4.8 Cladding Corrosion and Hydriding in Irradiated Defected Zircaloy Fuel Rods.

C4.8.1 Defected Fuel Rod Corrosion and Hydriding ….........................................

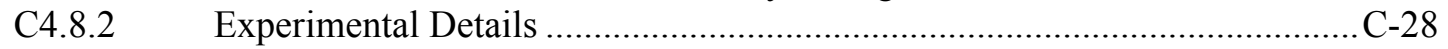

C4.8.3 Postirradiation Examination Results ……...................................................

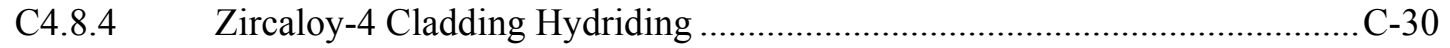

C4.8.5 Summary of Corrosion and Hydriding Behavior...........................................

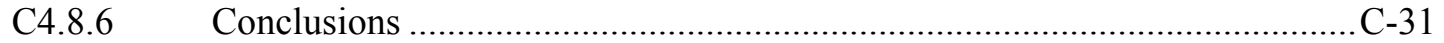

C4.9 Iodine and Cesium in Oxide Fuel Pellets and Zircaloy-4 Cladding of Irradiated

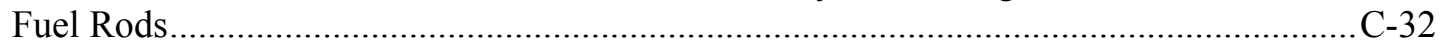

C4.10 Corrosion and Hydriding of Irradiated Zircaloy Fuel Rod Cladding ..................................33

C4.11 Irradiation Performance of Duplex Fuel Pellet Test Rods Depleted to $9 \times 10^{20}$

Fissions $/ \mathrm{cm}^{3}$ of Compartment-D-1 Test

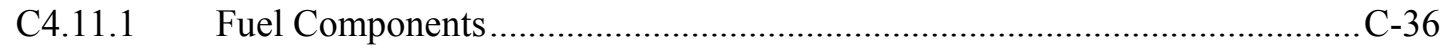

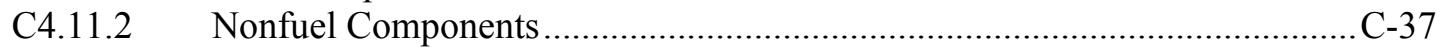

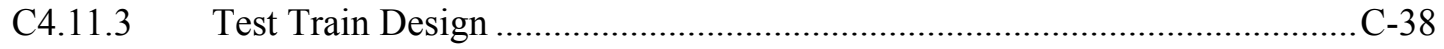




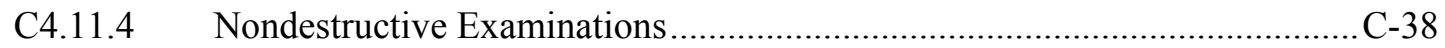

C4.11.5 Destructive Examinations ..............................................................................

C4.12 Irradiation Performance of Long Rod Duplex Fuel Pellet Bundle Test—LDR Test .........C-44

C4.13 Experimental Results of the Irradiation of Long Rod Duplex Pellet Screening

Tests in the NRX Reactor, New Long Duplex Rod (NLDR) Test ......................................46

C4.14 In-Pile and Out-of-Pile Corrosion Behavior of Thoria-Urania Pellets ................................47

C4.15 Internal Hydriding in Irradiated Defected Zircaloy Fuel Rods-A Review ......................49

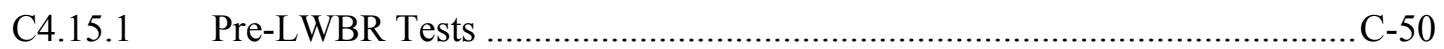

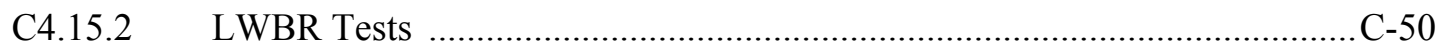

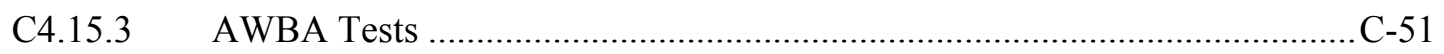

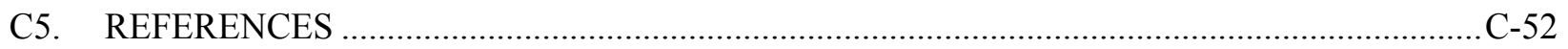

\section{FIGURES}

C-1. Internal loading arrangement of the scrap canister

C-8

TABLES

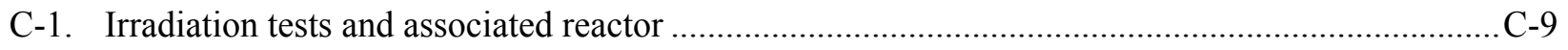

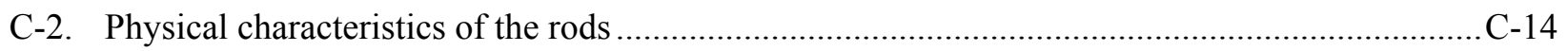

C-3. Environmental and operating characteristics of scrap canister rods ...........................................

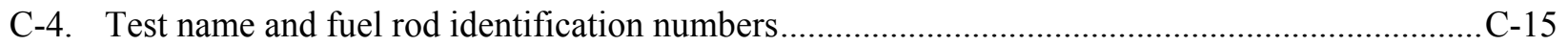

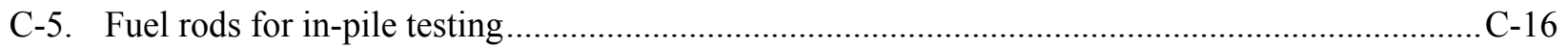

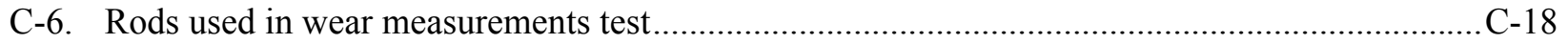

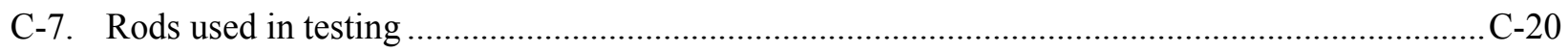

C-8. Percent of fission gas released from rods...........................................................................

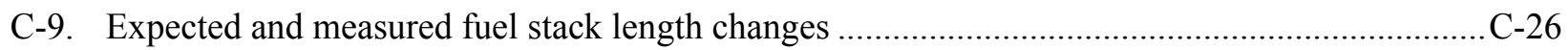

C-10. Rod identification numbers of rods from this test that are in the scrap canister .......................... -27

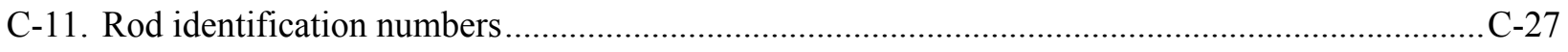

C-12. LWBR defected irradiation tests containing fuel rods examined for cladding corrosion and

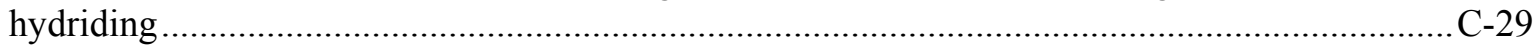

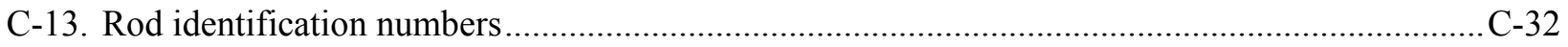




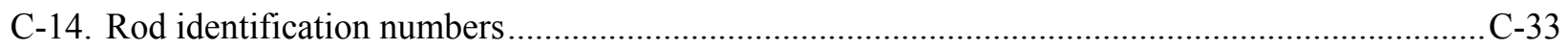

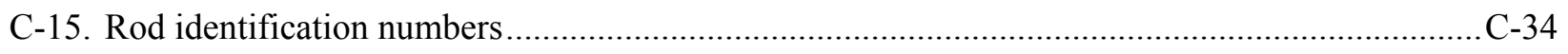

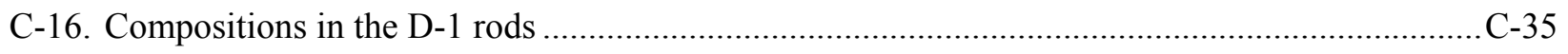

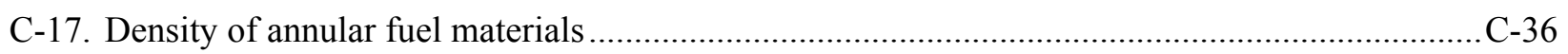

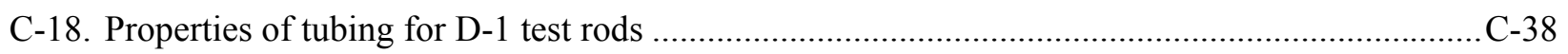

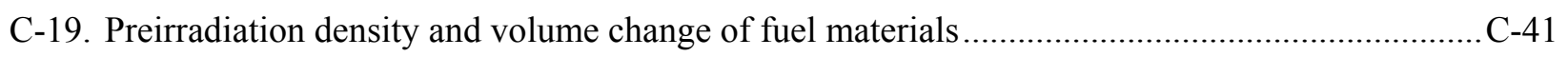

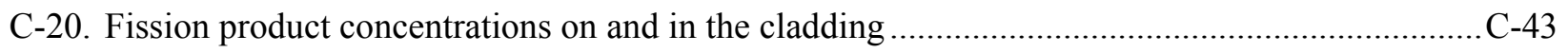

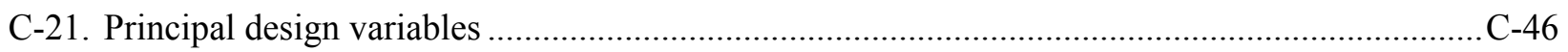




\section{ACRONYMS}

ATR Advanced Test Reactor

AWBA Advanced Water Breeder Applications

BOL beginning of life

CHORT Corrosion and Hydriding of Reactor Tubing computerized corrosion analysis program

ETR Engineering Test Reactor

INEEL Idaho National Engineering and Environmental Laboratory

$\mathrm{K}_{\mathrm{eff}} \quad$ The effective multiplication factor is a numerical value indicating how near a particular geometric configuration of nuclear material may be to sustaining a nuclear chain reactor $\left(\mathrm{K}_{\mathrm{eff}}=1.0\right.$ is a critical mass).

LDR Long Duplex Rod

LSR Long Small Rod

LWBR Light Water Breeder Reactor

NLDR New Long Duplex Rod

NRX (Canadian) National Research Experimental (Reactor)

OD outside diameter

$\mathrm{OD} / \mathrm{t} \quad$ outside diameter/thickness (cladding)

PCI pellet-cladding interaction

PWR pressurized water reactor

RXA recrystallization annealed

SP Special Physics (Tests)

SRA relief annealed

TD theoretical density

$\mathrm{U}^{\mathrm{D}} \quad$ depleted uranium

$\mathrm{U}^{\mathrm{E}} \quad$ enriched uranium

$\mathrm{U}^{\mathrm{N}} \quad$ natural uranium

w/o weight percent 


\section{Appendix C}

\section{Scrap Storage Liner}

\section{C1. INTRODUCTION}

Several irradiation tests were conducted as part of the Light Water Breeder Reactor (LWBR) and Advanced Water Breeder Applications (AWBA) programs. Most of the fuel rods used in these tests are contained in one cut fuel storage liner at the Idaho Nuclear Technology and Engineering Center. The cut fuel storage liner is also referred to as the scrap can or the LWBR "Type D" storage liner. The fuel handling unit identification number is engraved on the liner closure head. The can contains: (1) irradiated and unirradiated intact rods, (2) intact rods with intentional defects, (3) intact rod bundles, (4) and rod sections. Some of the rod sections are mounted in epoxy (Clayton 1982, WAPD-TM-1440). The intact rods and rod bundles are contained in 22 unsealed tubes and one special storage compartment within the storage liner in a configuration shown in Figure C-1 (Pruss 1987, WAPD-NRF(L)D-96 as revised by Babyak 1987, WAPD-NRF(L)D-110).

\section{C2. TESTS}

Over the course of the research, development, and testing program for the LWBR, 32 tests were conducted. Each test was conducted in a reactor that possessed the test conditions desired. Four different reactors were used. The Advanced Test Reactor (ATR), located at the Idaho National Engineering and Environmental Laboratory (INEEL), offers symmetrical experimental loops that enable a large number of samples to be irradiated at one time. The Engineering Test Reactor (ETR), also located at the INEEL, typically sustained a thermal operating level of 175 megawatts. Test rods were also irradiated at Shippingport Atomic Power Station, which operated two pressurized water reactor (PWR) cores and one LWBR core over the course of the station's life. The Canadian National Research Experimental (NRX) reactor at the Chalk River Nuclear Laboratory in Chalk River, Ontario, Canada, is owned and operated by Atomic Energy of Canada, Ltd. The reactor is equipped with several test loops that provide pressure, flow, and heat removal systems independent of the reactor for the irradiation of test specimens. The tests and the associated reactors are shown in Table C- 1 .

\section{C3. FUEL ROD PROPERTIES}

The test rods have varying properties. All the test rods had Zircaloy-4 cladding (recrystalliztion or stress relief annealed), ranging in thickness from 0.018 to 0.039 in. All the rods all also had an X-750 plenum spring, and all were pressurized with helium at beginning-of-life (BOL). Some of the test rods contained U-235, which ranged from about 1.92 to $30 \mathrm{wt} \%$ depending on the rod (most were about $93 \%$ enriched) and others contained U-233, which ranged from about 5 to $12 \% \mathrm{wt} \%$. Uranium- 233 enrichments were generally either $93.1 \%$ or $98.2 \%$ (see Table $3 \mathrm{~A}$ of WAPD-NRF(L)D-5). The length, outer diameter, and other rod properties varied. Specific details about each of the rods can be found in the Fuel Receipt Criteria (WAPD-NRF(L)D-5, WAPD-NRF(L)D-96, WAPD-NRF(L)D-58), or in greater detail in the test reports, outlined below. 


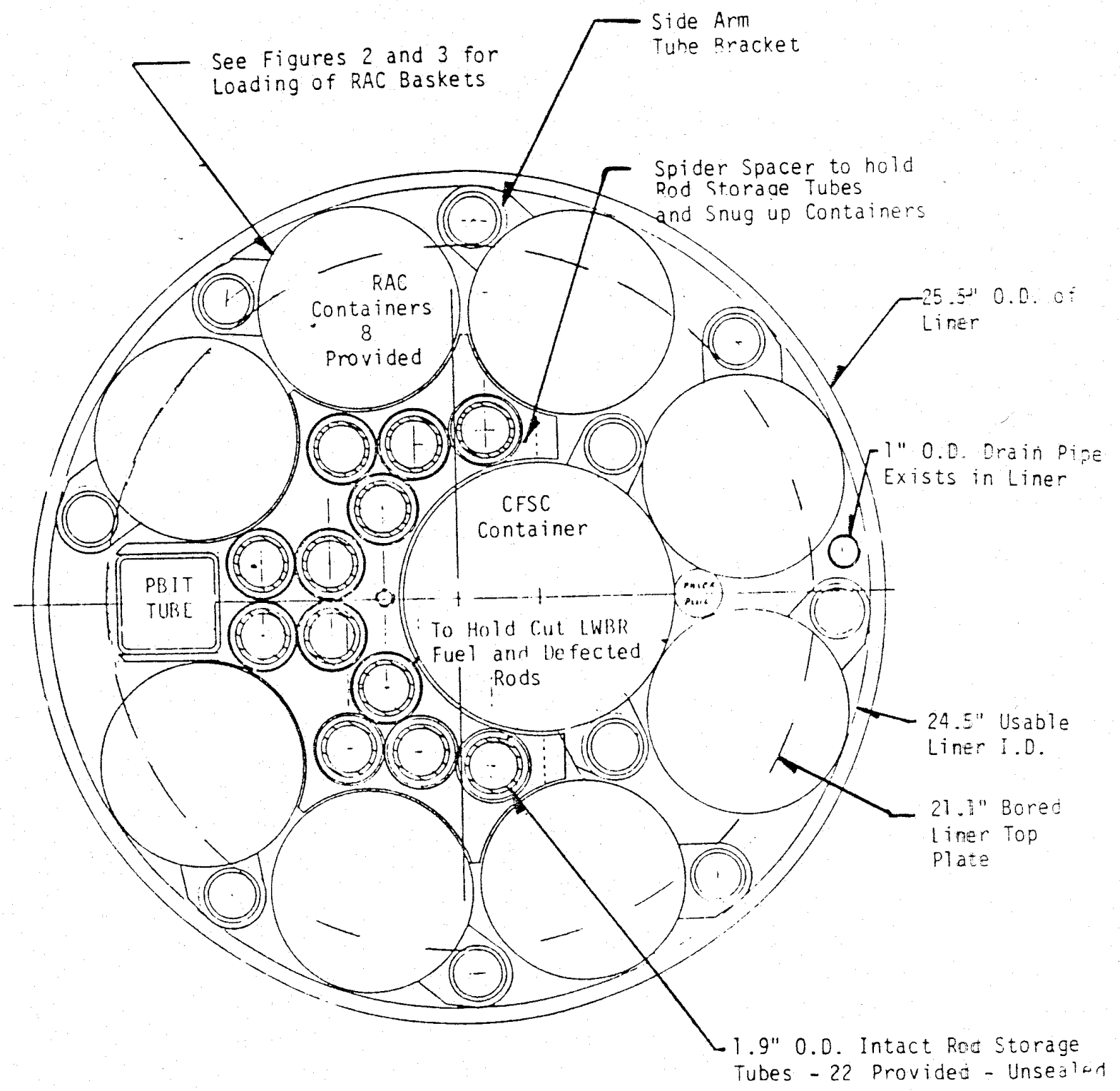

Figure C-1. Internal loading arrangement of the scrap canister. 
Table C-1. Irradiation tests and associated reactor (Pruss 1987, WAPD-NRF(L)D-96 as revised by Babyak 1987, WAPD-NRF(L)D-110).

\begin{tabular}{|c|c|c|}
\hline Test Identifier & Description & Reactor \\
\hline ACT-LPR & Advanced concept test, long pressurized rods & NRX \\
\hline ALT1 & Alternate short rod screening test & ATR \\
\hline ALT2 & Alternate short rod screening test & ATR \\
\hline B1 & Blanket rod screening test & ETR \\
\hline $\mathrm{B} 1 \mathrm{R}$ & Blanket rod screening test & ETR \\
\hline $\mathrm{B} 1 \mathrm{M}$ & Blanket rod screening test & ETR \\
\hline B3 & Six-rod assembly test & ETR \\
\hline B3A & Six-rod assembly test & ETR \\
\hline BBT & Blanket bundle test & ETR \\
\hline C7-LSBR & Large seed blanket reactor development & ETR \\
\hline D1 & Duplex short rod Screening test & ATR \\
\hline GRIP-I & Grid rod in-pile test & ETR \\
\hline GRIP-II & Grid rod in-pile test & ETR \\
\hline GRIP-IIIA & Grid rod in-pile test & ETR \\
\hline GRIP-IIIB & Grid rod in-pile test & ETR \\
\hline GRIP-IIIC & Grid rod in-pile test & ETR and ATR \\
\hline LBR & Long blanket rod test & NRX \\
\hline LDR & Long duplex rod screening test & ETR \\
\hline LSR & Long seed rod test & ETR \\
\hline L12-LSBR & Large seed blanket reactor development & ETR \\
\hline M13-S2 & Seed rod screening test & ETR \\
\hline M13-S2A & Seed rod screening test & ETR \\
\hline M13-S3 & Seed rod screening test & ETR \\
\hline M13-S5 & Seed rod touching test & ETR \\
\hline NLBR & New long blanket rod test & NRX \\
\hline NLDR-1 & NRX long duplex rod test & NRX \\
\hline NLDR-2 & NRX long duplex rod test & NRX \\
\hline NLDR-3 & NRX long duplex rod test & NRX \\
\hline NLDR-4 & NRX long duplex rod test & NRX \\
\hline NLSR & New long seed rod test & NRX \\
\hline PBIT & Prebreeder bundle irradiation test & ATR \\
\hline SABRE & Special assembly blanket rod elements & PWR C-1 S-4 \\
\hline SPIRE & Seed prototype irradiation rod experiment & ETR \\
\hline SWLD & Blanket swing-load test & ETR \\
\hline TIPPETT II & Thoria performance test & ETR \\
\hline SIDR & Short intentionally defected rod test & NRX \\
\hline PM & Power monitor-instrumented alloy rod & \\
\hline SP & Special physics tests & \\
\hline
\end{tabular}




\section{C4. IRRADIATED TEST REPORT SUMMARIES FOR SELECTED TESTS}

\section{C4.1 Comparison of Dimensional Changes in Fuel Rods with Predictions under Cyclic Conditions of \\ Power and System Pressure \\ (Duncombe and Goldberg 1970, WAPD-TM-940)}

Duncombe and Goldberg describe various additions for calculating ratcheting effects to CYGRO model; the effects include fuel cracking, clad collapse, friction between fuel and clad, clad anisotropy, and effects of neutron flux on clad creep. Physical, environmental, and operating characteristics of eight test rods are used to confirm the model. Three of the test rods (79-427, 79-430, and 79-468) are contained in the scrap canister. Physical characteristics of these rods are provided in Table C-2.

Table C-2. Physical characteristics of the rods.

\begin{tabular}{|c|c|c|c|c|c|c|c|}
\hline $\begin{array}{l}\text { Rod } \\
\text { No. }\end{array}$ & $\begin{array}{l}\text { Clad } \\
\text { OD } \\
\text { (in.) } \\
\end{array}$ & $\begin{array}{c}\text { Clad } \\
\text { Thickness } \\
\text { (mil) }\end{array}$ & $\begin{array}{c}\text { Clad } \\
\text { Type }^{\mathrm{a}}\end{array}$ & $\begin{array}{c}\text { Fuel-Clad } \\
\text { Diametric } \\
\text { Gap } \\
\text { (mil) }\end{array}$ & Fuel $^{b}$ & $\begin{array}{c}\text { Fuel } \\
\text { Density } \\
\text { (\% of } \\
\text { theoretical) }\end{array}$ & $\begin{array}{c}\text { Fuel Stack } \\
\text { Length } \\
\text { (in.) }\end{array}$ \\
\hline $79-427$ & 0.600 & 24 & SRA & 4 & $\mathrm{ThO}_{2}+1.98 \mathrm{w} / \mathrm{o} \mathrm{U}^{\mathrm{E}} \mathrm{O}_{2}$ & 98 & 29.8 \\
\hline $79-430$ & 0.600 & 24 & RXA & 10 & $\mathrm{ThO}_{2}+1.98$ w/o UE ${ }^{\mathrm{E}} \mathrm{O}_{2}$ & 98 & 29.8 \\
\hline $79-468$ & 0.600 & 24 & SRA & 11 & $\mathrm{ThO}_{2}+3.42 \mathrm{w} / \mathrm{o} \mathrm{U}{ }^{\mathrm{E}} \mathrm{O}_{2}$ & 98 & 84 \\
\hline
\end{tabular}

a. Zircaloy- 4 cladding, tube reduced, nominally $70 \%$ cold worked. SRA designates a stress relief at $950^{\circ} \mathrm{F}$ for 4 hours. RXA designates a recrystallization anneal at $1250^{\circ} \mathrm{F}$ for 4 hours.

b. Pressed and sintered pellets of length to diameter ratio between 1 and 2, with a 13-mil end-dish of 1.6 in. spherical radius.

Environmental and operating characteristics of scrap canister rods are given in Table C-3.

Table C-3. Environmental and operating characteristics of scrap canister rods.

\begin{tabular}{|c|c|c|c|c|c|}
\hline $\begin{array}{l}\text { Rod } \\
\text { No. }\end{array}$ & $\begin{array}{l}\text { Peak Heat Flux } \\
\left(10^{3} \mathrm{Btu} / \mathrm{hr}-\mathrm{ft}^{2}\right)\end{array}$ & $\begin{array}{l}\text { Peak Fuel } \\
\text { Temp. } \\
\left({ }^{\circ} \mathrm{F}\right)^{\mathrm{a}}\end{array}$ & $\begin{array}{c}\text { Peak Fast Flux }>1 \mathrm{Mev} \\
\left(10^{14} \mathrm{n} / \mathrm{cm}^{2}-\mathrm{s}\right)\end{array}$ & $\begin{array}{c}\text { Peak } \\
\text { Depletion } \\
\left(10^{20} \mathrm{f} / \mathrm{cc}\right) \\
\end{array}$ & $\begin{array}{c}\text { No. of } \\
\text { Depressurizations } \\
(10 \mathrm{f} / \mathrm{cc})\end{array}$ \\
\hline $79-427$ & 305 & 3075 & 1.21 & 0.37 & 2 \\
\hline $79-430$ & 301 & 3000 & 0.61 & 0.78 & 7 \\
\hline $79-468$ & 375 & 4525 & 0.15 & 1.94 & 15 \\
\hline $\begin{array}{l}\text { a. Tempe } \\
\text { b. Calcula }\end{array}$ & $\begin{array}{l}\text { es calculated usin } \\
\text { peak depletion at } t\end{array}$ & $\begin{array}{l}\text { computer pro } \\
\text { of most rece }\end{array}$ & xaminations. & & \\
\hline
\end{tabular}


The results of the testing are as follows:

1. Mechanisms important to ratcheting were incorporated into the CYGRO model.

2. The observed progressive length increase of fuel rods having nonfreestanding clad compared satisfactorily with the model.

3. When gross axial wrinkling is observed, the model is less exact; this may be expected because the size and nature of the fuel-clad contact forces are inherently less well known.

4. The choice of parameters that lead to correct axial elongation prediction often do not lead to good prediction of diameter shrinkage; this is believed to be associated with observed clad nonuniformity, such as ridging, ovalness and wrinkling, which invalidate the model to an extent depending on their severity.

5. Further progress may result from improved analysis of axial and circumferential nonuniformity, more accurate representation of clad collapse characteristics, and improved knowledge of the in-pile creep properties of fuel and clad.

\section{C4.2 In-Pile Dimensional Changes of Zircaloy-4 Tubing Having Low Hoop Stresses (Daniel 1970, WAPD-TM-973)}

Short screening rods were irradiated in the M13 test loop of the ETR. The Long Small Rod (LSR) full-length rods were irradiated in the E25 test loop of the Canadian NRX reactor. The test identifier and the fuel rods used are given in Table C-4.

Table C-4. Test name and fuel rod identification numbers.

\begin{tabular}{|c|c|c|c|}
\hline Test & No. of Rods & $\begin{array}{l}\text { No. Rods in } \\
\text { Scrap Canister }\end{array}$ & IDs of Rods \\
\hline M13-S2 & 14 & 7 & $\begin{array}{l}79-316,79-317,79-319,79-322 \mathrm{D}, 79-399,79-400 \text {, } \\
\text { and } 79-401\end{array}$ \\
\hline M13-S2A & 11 & 9 & $\begin{array}{l}\text { 79-377, 79-378, 79-379, 79-381, 79-383, 79-385, 79-386, } \\
\text { 79-390, and 79-394 }\end{array}$ \\
\hline M13-S3 & 14 & 7 & $79-332,79-337,79-340,79-435,79-436,79-437$, and $79-438$ \\
\hline M13-S3A & 10 & 3 & $79-485,79-491$, and $79-493$ \\
\hline M13-S4 & 7 & 0 & 0 \\
\hline LSR & 6 & 3 & $79-432,79-433 \mathrm{D}$, and $79-434$ \\
\hline
\end{tabular}

Several of the test rods were intentionally defected before irradiation by drilling a 5-mil-diameter hole through the cladding after preirradiation corrosion testing. These rods are identified by the letter " $D$ " following the rod number. Summary irradiation histories of the fuel rods are given by Daniel (1970).

The results of the testing are as follows:

- $\quad$ Comparison of length and diameter changes indicates that the diametric shrinkage of the short 0.25 -in. OD rods were due entirely to the external pressure, reaching a maximum of about 1-mil $(0.4 \%)$ at $17 \times 10^{20}$ fast nvt. 
- $\quad$ Diametric shrinkage in the bottom and middle regions of the long 0.25 -in. OD rods was influenced by axial tensile stresses, imposed on the cladding by the fuel. This fuel-clad interaction increased the generalized stress over that imposed by the external pressure. Near $2 \times 10^{20}$ fast nvt, shrinkage was about 6 mil ( $0.2 \%)$ in the absence of fuel-clad interactions but increased to about 2 mil $(0.8 \%)$ in the presence of such interactions. A model using a modified version of CYGRO was proposed for simulating the performance of these rods.

- $\quad$ The component of the length increase caused by zircaloy growth was about $0.075 \%$ at $17 \times 10^{20}$ fast nvt.

\section{C4.3 In-Pile Dimensional Changes of $\mathrm{ThO}_{2}-\mathrm{UO}_{2}$ Fuel Rods with Nonfreestanding Cladding (Giovengo 1970, WAPD-TM-986)}

Axial ratcheting is the progressive extension or elongation of fuel rods in-pile under cyclic conditions of power and system pressure resulting from irradiation. Axial ratcheting is made up of three components: (1) stress-free zircaloy growth, (2) diameter shrinkage due to system pressure, and (3) fuel-clad interaction. Data were presented for three series of irradiation testing of fuel rods with nonfreestanding cladding: the C7, NRX, and B1 series of tests. A physical description of the fuel rods along with a summary of the operational and measurement data is given. Rods used in this test are identified in Table C-5.

Table C-5. Fuel rods for in-pile testing.

\begin{tabular}{lccl}
\hline \multicolumn{1}{c}{ Test } & $\begin{array}{c}\text { No. of } \\
\text { Rods }\end{array}$ & $\begin{array}{c}\text { No. of Rods in the } \\
\text { Scrap Canister }\end{array}$ & \multicolumn{1}{c}{ Rod Identification Numbers } \\
\hline C7-B3 & 5 & 5 & $79-299,79-300,79-302,79-304$ and 79-308 \\
C7-B3A & 9 & 9 & $\begin{array}{l}79-349,79-350,79-352,79-353,79-356,79-374,79-375, \\
79-376 \text { and 79-405 }\end{array}$ \\
NRX & 6 & 3 & $79-310,79-467,79-468,79-495,79-575$ and 79-576 \\
B1 & 4 & 2 & $79-427,79-428,79-429$ and 79-430 \\
B1RA & 1 & 1 & $79-577$ \\
B1RB & 2 & 2 & $79-572,79-579$ and 79-581, 79-586 \\
\hline
\end{tabular}

The results of the testing are as follows:

- Annealed cladding and low fast-flux environment resulted in the maximum amount of elongation.

- Cold-worked cladding and low fast-flux environment resulted in the least amount of elongation.

- $\quad$ Both cold-worked and annealed cladding resulted in elongation in the midrange of the data.

- $\quad$ Flat-ended pellets resulted in substantially greater elongation than dished-end pellets.

- $\quad$ For flat-ended pellets high center temperature $\left(>2500^{\circ} \mathrm{F}\right)$ resulted in elongation $2-3$ times greater than rods operated at lower temperature $\left(<2000^{\circ} \mathrm{F}\right)$. 
- $\quad$ Fuel clad diametric gap and clad diameter-to-thickness ratio had a significant but less pronounced effect on ratcheting.

- $\quad$ Accelerated power cycling and fuel loading had no observed effect on ratcheting.

- $\quad$ Pressure cycling appears to be the predominant mechanism inducing elongation from fuel-clad interaction; a correlation could not be determined between the number of pressure cycles or cladding texture and the extent of ratcheting.

\section{C4.4 Fuel Rod-Grid Interaction Wear: In-Reactor Tests (Stackhouse 1979, WAPD-TM-1347)}

Wear of the zircaloy cladding of LWBR irradiation test fuel rods, resulting from relative motion between rod and rod support contacts, is reported. Measured wear depths were small, 0.0-2.7 mils, but are important in fuel element behavior assessment because of the local loss of cladding thickness as well as the effect on grid spring forces that laterally restrain the rods. An empirical wear analysis model, based on out-of-pile tests, is presented. The model was used to calculate the wear on the irradiation test fuel rods attributed to a combination of up-and-down motions resulting from power and pressure/temperature cycling of the test reactor, flow-induced vibrations, and assembly handling scratches. The calculated depths are generally deeper than the measured depths.

The LWBR core employs ordered arrays of long ( $10 \mathrm{ft})$, small diameter $(0.3-0.8 \mathrm{in}$.), zircaloy clad, cylindrical fuel elements. The fuel rods are supported axially by threaded end connectors on the rods attached to either the top or the bottom base plate of a module assembly. Each rod is thus fixed at one end and free at the other end. Lateral support for the rods is provided by a series of supports, called grids, at several axial locations along the length of the rods. Each grid contains, for each rod, a hexagonal-shaped cell with a spring and opposing fixed reaction dimples set at 120 degrees circumferentially from the spring. The spring applies lateral force on the fuel rod in the cell to hold it firmly against the dimples, while allowing relative axial movement between the rod and grid support points during reactor operation. Interaction between the fuel rod and the supporting springs and dimples caused by fuel rod length changes and vibration can result in wear on the zircaloy cladding of the fuel rods. Wear of the AM-350 stainless steel grid contact points has been found by test experience to be negligible relative to the fuel rod cladding wear.

Cladding wear may be caused by the combined effects of three types of interaction between fuel rods and support grids: (1) handling scratches, often along the full rod length, that occur when fuel rods are initially pulled into the grid supports; (2) axial motion of the rod relative to the grid supports due to fuel rod axial expansion and contraction during reactor power cycles and pressure/temperature cycles; and (3) flow-induced vibratory wear.

Cladding wear is of concern (1) because the thinning of the cladding increases stresses in the thinned section with a consequent reduction in margin-to-failure stress limits, and (2) because of its contribution to a reduction in the grid spring fuel rod support force with potential for reduced rod-to-rod and rod-to-structure clearances. In addition, a complete loss of grid contact force may result in excessive fuel rod vibration, creating a potential wear/fretting condition, as demonstrated in out-of-pile wear tests.

Stackhouse presents fuel rod cladding wear data obtained from in-reactor rod bundles tested in the LWBR fuel element development program and compares these data to wear estimates predicted using a model developed from out-of-pile wear tests. The LWBR fuel rods were composed of high density $\mathrm{ThO}_{2}-\mathrm{UO}_{2}$ and $\mathrm{ThO}_{2}$ fuel pellets contained within Zircaloy-4 tubes having outside diameters of about 
0.30 or 0.57 in., and lengths of about $8 \mathrm{ft}$. The rods were precorrosion filmed before insertion into the grid supports prior to irradiation.

Wear measurements were obtained on 34 fuel rods; all but one of the fuel rods are in the scrap liner. The rods were supported laterally by AM-350 stainless steel grids using of hexagonal-shaped grid cells that contain a spring and two dimples, or two pairs of dimples, set at 120 degrees circumferential from each other. Altogether 1298 support contact points are represented by the 34 fuel rods examined. (The number of support contact points for each rod was determined by multiplying the number of spring and dimple reaction points at each grid level by the number of grid levels supporting the rod. Multiple sets of wear marks on several rods are also included in the total.) Only 176 contact points were directly measured. The remaining 1122 support contact points were not measured because they were undetectable or obviously shallow; these are assumed to have wear depths of $0.0-0.5$ mils. Ninety-five percent of the wear spot depths are 1.0 mil or less, $4 \%$ are $1.1-2.0$ mils, and $1 \%$ are $2.1-2.7$ mils deep.

During examination of the irradiated fuel rods, wear depths were measured at the free end grid levels and at other levels where visual examination indicated that significant cladding wear had occurred. Other cladding wear spots that appeared to be smaller than 0.5 mil in depth were usually not measured. For all but six of the 34 rods, maximum rod wear occurred at the free-end grid support location. The occurrence of maximum wear at the rod free ends is attributed to the fact that this location is where the longest rod axial movement relative to grids occurs during power and pressure/temperature cycling, with resulting higher reciprocating wear. Flow-induced vibration wear also is expected to be a maximum at the free end of top mounted rods because of rod excitation by coolant flow impingement on the ends of the rods.

Wear mark depth was measured nondestructively with a profilometer considered to have an accuracy of \pm 0.2 mils. In addition, destructive examination of wear depth was performed metallographically on some rods by polishing transverse rod sections through the wear mark in successive planes about 20-30 mils apart. Photomicrographs taken at each plane were measured to obtain wear depth. The profilometry measurements agreed well with metallographic measurements.

All wear measurements and their location with respect to individual grids and to grid springs and dimple reaction points, are given by Stackhouse. Also given are test reactor exposure times, numbers of actual power and pressure/temperature cycles, stroke lengths, and measured overall rod length increases. The rod identification numbers are given in Table C-6 for 33 of the rods in the scrap canister that were used for the wear measurements tests.

Table C-6. Rods used in wear measurements test.

\begin{tabular}{llllllll}
\hline $79-610$ & $79-621$ & $79-630$ & $79-440$ & $79-444$ & $79-455$ & $79-509$ & $79-517$ \\
$79-613$ & $79-622$ & $79-631$ & $79-441 \mathrm{D}$ & $79-445$ & $79-459$ & $79-513$ & $79-522$ \\
$79-614 \mathrm{D}$ & $79-623$ & $79-632$ & $79-442$ & $79-449$ & $79-502$ & $79-514$ & $79-524$ \\
$79-617$ & $79-624$ & $79-439$ & $79-443 \mathrm{D}$ & $79-450$ & $79-504 \mathrm{D}$ & $79-516$ & $79-572$ \\
$79-619$ & $79-586$ & & & & & & \\
\hline
\end{tabular}

The conclusions drawn from the testing are as follows:

- $\quad$ Maximum measured wear depth on the irradiation-tested fuel rods supported in grids having geometry similar to the LWBR design was 2.7 mils and was located at the free-end grid support of a top-mounted fuel rod. 
- $\quad$ Fuel rod wear was deepest at the rod free-end grid support on 28 of 34 rods.

- $\quad$ Top mounted rods had greater wear depth at the free-end grid support than bottom mounted rods. This condition is attributed to greater vibratory wear experienced by the top mounted rods due to impingement of the coolant flow on the bottom free-ends of these rods.

- Wear depth on fuel rods that accumulated a high number of EFPH or power and pressure/temperature cycles was not significantly greater than that on rods with shorter test lives. This behavior is in accordance with the basis for the wear analysis model and is a result of rod axial growth during reactor operation.

- $\quad$ Maximum-measured-wear depths were generally less than the total amount of wear predicted by a wear analysis model developed from out-of-pile reciprocating wear tests. The predicted values included reciprocating wear, plus an allowance for vibratory wear and assembly and handling scratches.

- A high proportion, about $95 \%$, of the rod-grid contact points examined had low wear of less than one mil depth.

- $\quad$ High wear is sometimes found at contact points associated with off-nominal conditions such as high rod bowing or contacts between the rod and grid at other than the spring and dimples.

\section{C4.5 Fission Gas Release From $\mathrm{ThO}_{2}$ and $\mathrm{ThO}_{2}-\mathrm{UO}_{2}$ Fuels (Goldberg et al. 1982, WAPD-TM-1350)}

Fission gas release data are presented from 51 fuel rods irradiated as part of the LWBR irradiation test program (23 of these fuel rods are contained in the scrap canister). The fuel rods were Zircaloy-4 clad and contained $\mathrm{ThO}_{2}$ or $\mathrm{ThO}_{2}-\mathrm{UO}_{2}$ fuel pellets, with $\mathrm{UO}_{2}$ compositions ranging from 2.0-24.7 w/o and fuel densities ranging from $77.8-98.7 \%$ of theoretical. Rod diameters ranged from $0.25-0.71 \mathrm{in}$. and fuel active lengths ranged from 3-84 in. Peak linear power outputs ranged from $2-22 \mathrm{~kW} / \mathrm{ft}$ for peak fuel burnups up to 56,000 MWD/MTM. Measured fission gas release was quite low ranging from $0.1-5.2 \%$. Fission gas release was higher at higher temperature and burnup and was lower at higher initial fuel density. No sensitivity to $\mathrm{UO}_{2}$ composition was evidenced. A calculation model is described that includes terms to represent fission gas release as a function of temperature, using a diffusion model, and as a function of density to account for release due to knockout and recoil at free surfaces. The model is developed on both a best estimate and bounding basis.

The amount of fission gases released from oxide fuel pellets during irradiation in power reactors is important to reactor design primarily in two design areas. First, release of fission gases from the fuel to the internal rod compartment results in an increase in rod internal pressure with increasing burnup. The higher internal pressure increases proximity to material property limits for a postulated loss of coolant accident, during which fuel rod cladding can potentially experience high temperatures, resulting in loss of strength and more susceptibility to swelling and rupture. Second, because fission gases (primarily xenon and krypton) have much lower thermal conductivity than the initial fill gas (typically helium or argon) used in light water reactor fuel rods, more fission gas release can result in higher operating fuel temperatures due to the degraded heat transfer in the fuel-cladding gap.

The report contains (1) data on fission gas release from $\mathrm{ThO}_{2}$ or $\mathrm{ThO}_{2}-\mathrm{UO}_{2}$ fuels obtained from 51 fuel rods from the LWBR test program, and (2) comparisons of the measurements to a calculation model used in performance assessments. Dimensional, material characteristics, and environmental history 
of the test fuel rods are described. The fission gas release measurements are given along with a description of the measurement procedures and an assessment of measurement uncertainty. The calculation model is described, and the results of application of the model are compared to the measurements.

Measured fission gas release (measurement uncertainty of plus or minus $8 \%$ of nominal) was generally low, ranging from $<0.1-5.2 \%$ of the fission gases theoretically produced by fissioning. Gas release was predominantly below $2 \%$ for high-density $(95 \%$ theoretical or greater) fuels. Fission gas release was higher at higher temperatures, higher burnup, and lower density. No sensitivity to $\mathrm{UO}_{2}$ composition was observed.

A calculation model was presented that includes terms to represent fission gas release at both high temperatures (assuming a gas bubble diffusion model) and low temperatures (based on a recoil plus knockout mechanism). The high temperature term accounts for migrating gas bubbles that are released from the fuel due to intersection with a surface (e.g., cracks or open pores). Depending on specific fuel properties and burnup, critical temperatures for release of bubbles from dislocations and grain boundaries are calculated.

The low temperature term is adapted from a model that assumes that fission gas is released by recoil and knockout at free surfaces. Pellet density initially serves as a measure of free surface area, which increases with burnup (presumably due to fuel cracking). The model is developed on both a best estimate and bounding basis.

Gas release for long rods, which experience nonuniform power profiles, is calculated in several axial segments (using average power generation for each segment) and integrated along rod length. The best-estimate model fits through the middle of the scattered data. All data are conservatively bounded by the bounding model.

\section{C4.5.1 Rod Characteristics}

Test fuel rods from the LWBR development program were Zircaloy-4 clad, nonpressurized (one atmosphere of helium, initial fill) and contained $\mathrm{ThO}_{2}$ or $\mathrm{ThO}_{2}-\mathrm{UO}_{2}$ fuel pellets. Rod characteristics are summarized in the report for the 51 rods for which fission gas release data was obtained ( 23 of the fuel rods are contained in the scrap canister). The fuel rods are grouped by fuel type $\left(100 \% \mathrm{ThO}_{2}, \mathrm{ThO}_{2}+\right.$ ${ }^{233} \mathrm{UO}_{2}$ and $\mathrm{ThO}_{2}+{ }^{235} \mathrm{UO}_{2}$ ). The identification numbers of the 23 rods contained in the scrap canister are given in Table C-7. (In the scrap canister there are no $100 \% \mathrm{ThO}_{2}$, three $\mathrm{ThO}_{2}+{ }^{233} \mathrm{UO}_{2}$ [ the first three below], and the rest are $\mathrm{ThO}_{2}+{ }^{235} \mathrm{UO}_{2}$ fuel rods).

Table C-7. Rods used in testing.

\begin{tabular}{llllll}
$79-442$ & $79-509$ & $79-570$ & $79-576$ & $79-613$ & $79-632$ \\
$79-445$ & $79-513$ & $79-572$ & $79-605$ & $79-617$ & $79-656$ \\
$79-449$ & $79-514$ & $79-573$ & $79-608$ & $79-623$ & $79-671$ \\
$79-349$ & $79-522$ & $79-575$ & $79-610$ & $79-631$ & \\
\hline
\end{tabular}

Fuel characteristics given for each rod are composition, pellet density, pellet dimensions, and in-core fuel pellet stack length. Fuel compositions ranged from pure thoria to about $25 \mathrm{w} / \mathrm{o} \mathrm{UO}_{2}$. Fuel densities were generally $95-98 \%$ theoretical oxide density $\left(10.0 \mathrm{~g} / \mathrm{cc}-\mathrm{ThO}_{2}\right.$ and $10.24 \mathrm{~g} / \mathrm{cc}-\mathrm{ThO}_{2}+25 \mathrm{w} / \mathrm{o}$ $\mathrm{UO}_{2}$ ). Nominal fuel pellet dimensions are given, including end-face geometry (flat or dished, with 
4-22 mil dish depth). Fuel pellet diameters were 0.21-0.65 in., with length/diameter ratios of 1.0-3.0. In-core fuel pellet stack length ranged from about 3-7 in. in short rods and from 30-84 in. in long rods.

Cladding heat treatment (RXA-recrystallization anneal or SRA-stress relief anneal), outside diameter, and diameter to wall thickness ratio are given for each rod. Rod diameters ranged from about $0.25-0.71$ in., with cladding OD/t ratios of $12-25$. As-fabricated fuel-cladding diametric gaps were 2-10 mils. Fuel-cladding diametric gaps (no direct contact) are a source of thermal impedance and lead to higher fuel temperatures and greater gas release. Cladding OD/t and heat treatment affect the rate of creep down of the cladding diameter (under external pressure) and thereby the fuel-cladding diametric gap and gas release.

\section{C4.5.2 Rod Operating Parameters}

The test rods for the fission gas tests were irradiated in three different test reactors: (1) the ETR, (2) the ATR, and (3) the NRX. In-pile operating times ranged from $<1000$ to $\sim 20,000$ hours under nominal coolant conditions of $2000 \mathrm{psi}$ and $550^{\circ} \mathrm{F}$. Individual rod operating parameters are summarized in the report.

Peak and average axial linear power and fuel burnup are reported for each rod. Axial average values are equal to peak values for short rods, but are about 0.6-0.9 times the peak values for long rods. Peak linear power of most rods ranged from $2-15 \mathrm{~kW} / \mathrm{ft}$; 4 of the 51 rods were higher than $15 \mathrm{~kW} / \mathrm{ft}$ up to a maximum of $22 \mathrm{~kW} / \mathrm{ft}$. Peak burnup ranged from about 1,000-56,000 MWD/MTM.

Peak values (axial position and operating history) of fuel temperatures at the rod centerline and pellet surface were calculated using the CYGRO (Newman, Giovengo, and Comden 1977)/FIGRO (Goldberg 1969, WAPD-TM-757) computer programs. (Time averaged temperatures are about 80\% of peak temperatures.) Centerline fuel temperatures at the peak axial power locations ranged from $<2000$ to over $4000^{\circ} \mathrm{F}$ and fuel pellet surface temperatures ranged from about $800-1800^{\circ} \mathrm{F}$. These temperatures are low relative to the thoria-based oxide melting temperatures (about $5900^{\circ} \mathrm{F}$ ) so that no significant fuel redistributions due to pellet coring or melting were expected.

The $\mathrm{ThO}_{2}$ dislocation release temperature (for release of gas bubbles from dislocations) was also calculated for each rod, assuming peak conditions and using the model by Warner (1969) WAPD-TM-805. This temperature provides a measure of fractional fuel pellet volume for intermediatehigh-temperature fission gas release. The $\mathrm{ThO}_{2}$ dislocation release temperatures range from about $2630-2930^{\circ} \mathrm{F}$.

\section{C4.5.3 Findings} as follows:

The conclusions drawn from the testing within the range of parameters tested for 51 fuel rods are

- $\quad$ Fission gas release is greater at higher fuel temperatures and burnups. These effects can be satisfactorily predicted by a model that accounts for gas bubble-coalescence, release from grain boundaries, and dislocations.

- $\quad$ Higher initial fuel density results in significantly less fission gas release. This effect can be satisfactorily predicted by a model that accounts for release due to recoil and knockout of gas bubbles at free surfaces.

- $\quad$ No sensitivity to $\mathrm{UO}_{2}$ composition or rod diameter was observed. 
Additional testing (Goldberg et al. 1979, WAPD-TM-1350ADD) was conducted on three fuel rods (79-349, 79-375, and 79-405). All three rods are contained in the scrap canister; 79-349 was included in the first gas testing. These rods experienced relatively high-constant-peak power $(18-22 \mathrm{~kW} / \mathrm{ft})$. The data indicate that at these high powers (and thus high fuel temperatures), $\mathrm{ThO}_{2}-\mathrm{UO}_{2}, 92-95 \%$ of theoretical density, experiences equiaxed grain growth and relatively high fission gas release (up to 15\%). These data supplement the data on the 51 fuel rods from above, which indicated low fission gas release(from $0.1-5.2 \%$ ) for operation predominately below $14 \mathrm{~kW} / \mathrm{ft}$.

\section{C4.6 Irradiation Testing of Internally Pressurized and/or Graphite Coated Zircaloy-4 Clad Fuel Rods in the NRX Reactor (from Hoffman and Sherman 1978, WAPD-TM-1376)}

Alternate fuel rod design concepts were explored to improve performance capability for commercial scale light water prebreeder cores to efficiently produce ${ }^{233} U$ from thoria. The initial screening tests used three fuel rods and two previously tested rods. The three rods (79-584, 79-706, and 79-707) were assembled from spare components previously fabricated for an LWBR blanket irradiation test to provide a basis for comparison with two previously irradiated, noncoated, nonpressurized rods, one of which was intentionally defected (79-583D and 79-587). All five rods are contained in the scrap liner. The rod identification and basic feature of the rods follows:

- $\quad$ Prepressurized with helium to 500 psi at room temperature

- $\quad$ Graphite barrier coating on the cladding inside surface

- $\quad$ Combined prepressurization and graphite coating

- $\quad$ Previously irradiated, noncoated, nonpressurized rod, and intentionally defected (79-583D)

- $\quad$ Previously irradiated, noncoated, and nonpressurized rod.

The helium pressurization, which is standard commercial practice, prevents collapse into unsupported gaps, delays fuel-cladding interaction due to reduced cladding pressure differential and mitigates the reduction of the thermal conductivity of the gas mixture in the fuel-cladding gap with depletion. The graphite coating provides lubrication of the fuel-cladding interface, thereby reducing fuelcladding interaction, and may provide a barrier to fission product stress corrosion attack of the cladding. The tests of pressurized rods were directed at investigation of fuel rod performance, and were not focused on thermal-hydraulic considerations.

The fuel was $\mathrm{ThO}_{2}-3.06 \mathrm{w} / \mathrm{o} \mathrm{UO}_{2}$ at a density of $95-98 \%$ of theoretical density. The fuel stack contained $84 \mathrm{in}$. of $\mathrm{ThO}_{2}-\mathrm{UO}_{2}$ pellets with thoria pellets above and below the $\mathrm{ThO}_{2}-\mathrm{UO}_{2}$ fuel stack. A 10 -in. plenum incorporating a Fe-Ni-Cr alloy hold-down spring was present at the top of the stack.

The three test rods (79-584, 79-706, and 79-707) were irradiated, one rod at a time, in the NRX reactor. The coolant was 2000-psi water at an average temperature of $560^{\circ} \mathrm{F}$ with a $\mathrm{pH}$ of $10.1-10.3$ maintained by $\mathrm{NH}_{4} \mathrm{OH}$. Flow velocity was $19.6 \mathrm{ft} / \mathrm{s}$. Each rod was irradiated for about 100 full power days at peak linear power output of $13-14 \mathrm{~kW} / \mathrm{ft}$. Power was then increased by $30 \%$ to $17-18 \mathrm{~kW} / \mathrm{ft}$ to simulate the increased power in an up-power maneuver. The power was maintained at the $30 \%$ higher level for about 40 full power days, and the rods reached a peak depletion of $1.5 \times 10^{20} \mathrm{f} / \mathrm{cc}$ $(5800 \mathrm{MWD} / \mathrm{MT})$ and a peak, fast fluence $(>1 \mathrm{Mev})$ of $1.9 \times 10 \mathrm{n} / \mathrm{cm}^{2}$. Rods 79-583D and 79-587 experienced similar histories except that $79-583 \mathrm{D}$, the intentionally defected rod, did not experience the 
up-power maneuver. All rods were periodically removed from testing during reactor shutdowns and examined at Chalk River; these measurements included both rod length and diameter.

Based on comparisons between the nonpressurized, noncoated rod (79-587) and the prepressurized and graphite coated rod (79-707), initial prepressurization with helium plus graphite coating the inside cladding surface reduce both overall axial cladding strains and peak axial cladding strains. Diameter changes have also been significantly reduced. These reductions are attributed to reduced fuel-cladding interaction and possible enhanced fuel densification due to the relatively higher gas pressure on the fuel pellets. Either prepressurization or graphite coating by itself resulted in an intermediate level of improvement from the nonpressurized, noncoated rod, but these comparisons are not as direct due to differences in fuel-cladding gap size.

\section{C4.7 Early-In-Life Performance of Short Rod Duplex Pellet Screening (D-1) Test (Sphar and Sherman 1979, WAPD-TM-1378)}

To support the development of the duplex pellet fuel element, a screening irradiation test was designed, fabricated, and irradiated in the ATR at the Idaho National Engineering Laboratory. The test consisted of 21 rods irradiated in three holders of seven rods each in a single ATR test loop. The length of the rods was restricted to $11 \mathrm{in}$. to allow a greater number of rods and thus a greater number of variables to be tested. Duplex pellet annuli of three different compositions was included. The seven rods of the first holder contained $\mathrm{UO}_{2}$ annuli; the second holder contained $\mathrm{UO}_{2}-\mathrm{ZrO}_{2}$ annuli; and the third contained $\mathrm{UO}_{2}-\mathrm{ZrO}_{2}-\mathrm{CaO}$ annuli. Other test parameters were:

- $\quad$ Two levels of rod internal prepressurization (100 and 500 psig at room temperature)

- $\quad$ Two types of zircaloy cladding heat treatment and diameter to thickness ratio (stress relief annealed with $\mathrm{OD} / \mathrm{t}=16.0$ and recrystallized annealed with $\mathrm{OD} / \mathrm{t}=13.9$ )

- $\quad$ Thoria spacers of three different thicknesses for separating duplex pellets axially to maintain axial alignment of the annulus and central core (0.05 in., 0.1 in., and $0.5 \mathrm{in.})$

- Varying initial diametric clearance gap between the annulus and cladding (45-85 mils) and between the annulus and central pellet (21-102 mils).

The D-1 duplex pellet-screening test used 21 fuel elements (16 are in the scrap canister) 11 in. in length and $0.3 \mathrm{in}$. in diameter. The rods consisted of top and bottom Zircaloy- 4 end-closures welded into seamless Zircaloy-4 cladding. Contained within the cladding was an 8-in. stack of fuel pellets and a 0.785-in. long plenum region containing an Inconel-X hold-down spring. All 21-test rods were irradiated simultaneously for 32.6 days in the ATR at the INEEL. The rods operated at $13-15 \mathrm{~kW} / \mathrm{ft}$ reaching depletion of $1.2-1.3 \times 10^{20} \mathrm{f} / \mathrm{cc}$ averaged over the total duplex pellet volume and $2.4-2.6 \times 10^{20} \mathrm{f} / \mathrm{cc}$ in the annulus. The fast neutron fluence $(\mathrm{E}>1 \mathrm{Mev})$ exposure of the rods ranged from $2.8-3.9 \times 10^{20} \mathrm{n} / \mathrm{cm}^{2}$. The coolant was water pressurized to $2000 \mathrm{psi}$ at an average temperature of $520^{\circ} \mathrm{F}$. Coolant velocity past the rods was $18 \mathrm{ft} / \mathrm{s}$. Following irradiation, the 21 rods were subjected to nondestructive examination. In addition, one rod of each annulus composition type was subjected to destructive examination.

Nondestructive examinations consisted of:

- Visual inspections

- Dimensional measurements 


\section{- $\quad$ Neutron radiography}

- Gamma ray scanning.

Destructive examinations consisted of:

- Collection and analysis of the rod internal atmosphere to determine fission gas release

- Depletion analysis

- Cladding fluence determination

- Metallographic evaluation of fuel components and cladding.

Visual examinations of the rods as removed from the reactor revealed a thin gray layer of crud that was readily removed by wiping with alcohol soaked cloths. Removal of the crud layer revealed lustrous black oxide surfaces not noticeably different from the preirradiation condition. Rod average diameter changes were small, the greatest being a decrease of 0.52 mil. The changes correlated with cladding properties, fast fluence, and rod internal pressure as was expected in the absence of fuel-cladding interaction. Averaged diameter changes for rods in each cladding type-internal pressurization category agreed with calculations to within 0.24 mil.

Rod lengths increased by as much as $0.061 \%$ and, as in the case of diameter, correlated with cladding properties, fluence, and rod internal pressure. Predicted length increases by stress-free zircaloy growth, and elongation caused by the diameter change and anisotropy of the cladding material, were larger than the measured changes by factors of 1.5-2.9. However, the length changes were small, and the over-prediction represented only $0.02-0.05 \%$ strain.

Neutron radiography revealed no evidence of fuel redistribution and melting. Cracking of the annuli of all three compositions was observed with the maximum degree of cracking noted in the $\mathrm{UO}_{2}-\mathrm{ZrO}_{2}$ annuli. Fuel stack lengths in the $\mathrm{UO}_{2}$ annulus rods and in the $\mathrm{UO}_{2}-\mathrm{ZrO}_{2}-\mathrm{CaO}$ annulus rods decreased on the average by 0.22 and $0.40 \%$ respectively. The fuel stacks in the $\mathrm{UO}_{2}-\mathrm{ZrO}_{2}$ annulus rods showed an average length increase of $0.41 \%$. There is no basis for expecting expansion of the fuel stacks in the $\mathrm{UO}_{2}-\mathrm{ZrO}_{2}$ rods, and the length increase is believed to be associated with the significantly greater cracking observed for this fuel material and small separations of fuel pieces.

Gamma scans, performed primarily to determine the axial power shape in the rods, indicated that peak to minimum duplex pellet power in the rods was less than 1.25. This indicates that the differential neutron shrouding employed during irradiation to offset the basic neutron flux profile of the test reactor was effective.

Destructive analysis for depletion and fluence was completed for the $\mathrm{UO}_{2}$ annulus rod. The measured depletion was $1.27 \times 10^{20} \mathrm{f} / \mathrm{cc}$ of compartment (compartment is defined as: the volume inside the cladding per unit length of duplex pellet). The depletion implies a time-averaged rod power level of $14.4 \mathrm{~kW} / \mathrm{ft}$, in good agreement with the desired power level. The measured fast neutron fluence experienced by the cladding was $3.9 \times 10^{20} \mathrm{n} / \mathrm{cm}^{2}$, which corresponds to a time-averaged neutron flux of $1.4 \times 10^{14} \mathrm{n} / \mathrm{cm}^{2}$-s.

The percentage of fission gas released from the fuel was measured on one rod of each fuel type. Results are presented in Table C-8. 
Table C-8. Percent of fission gas released from rods.

\begin{tabular}{lcc}
\hline \multicolumn{1}{c}{ Rod Type } & Rod ID & Fission Gas Release \\
\hline $\mathrm{UO}_{2}$ & $97-23$ & $0.06 \%$ \\
$\mathrm{UO}_{2}-\mathrm{ZrO}_{2}$ & $97-22$ & $0.21 \%$ \\
$\mathrm{UO}_{2}-\mathrm{ZrO}_{2}-\mathrm{CaO}$ & $97-37$ & $0.39 \%$ \\
\hline
\end{tabular}

These low values indicate that the annulus temperatures were below the temperatures at which substantial migration of gas from dislocation and grain boundaries occurs.

Hydrogen concentration in the cladding of all three rods was about $25 \mathrm{ppm}$, which is consistent with the as-received content plus the expected hydrogen pickup in the preirradiation corrosion test and 32.6 days of in-pile operation. No change in cladding grain size was observed.

Oxide formation on the outside surface of the cladding for all three rods was observed to be 1 micron or less. About 0.5 micron was present in the preirradiation condition based on the rod weight gain during preirradiation corrosion testing. On the clad inside surfaces, oxide formation was irregular, varying from no discernible thickness over most of the surface to isolated patches with maximum thickness of 7 microns. The oxide formation was presumably caused by oxygen, produced during fission and released from the fuel, collecting at the cladding.

Metallographic evaluation of the microstructure of the $\mathrm{ThO}_{2}$ central pellets and spacers from all three rods indicated little change, if any, from the preirradiation condition. Porosity did not appear to have changed during irradiation. Grain size after irradiation varied in the range ASTM 6-10 (13-50 microns) compared to a preirradiation size range of ASTM 5-11 (9-70 microns) with no evidence of equiaxed or columnar grain growth.

Comparison of pre- and postirradiation annulus porosity was made by means of a Quantimet Television Microscope analysis of pore volume. For the $\mathrm{UO}_{2}$ rod, total porosity volume in the annulus decreased to about $70 \%$ of the preirradiation value near the outer surface and to $40-50 \%$ in the inner regions. The average diameter of the remaining pores was not appreciably different from the average preirradiation pore diameter. The postirradiation grain size (12 microns average) was uniform and there was no evidence of change in grain size with irradiation. The porosity in the irradiated fuel was observed to be located primarily at the grain boundaries whereas both intra-granular and inter-granular pores existed in the preirradiation condition.

In the $\mathrm{UO}_{2}-\mathrm{ZrO}_{2}-\mathrm{CaO}$ annulus rod, Quantimet analysis showed an overall porosity decrease to about one-third of the preirradiation value, essentially equal to the decrease observed in the $\mathrm{UO}_{2}$ annulus. The porosity change was not uniform across the annulus wall thickness; it varied from a decrease to onehalf at the outside surface to one-fifth near the inside surface. The grain in the $\mathrm{UO}_{2}-\mathrm{ZrO}_{2}-\mathrm{CaO}$ fuel in the postirradiation condition was $\sim 40$ microns (on the average), and there was no evidence of grain growth.

In the $\mathrm{UO}_{2}-\mathrm{ZrO}_{2}$ annulus rod, the preirradiation porosity was uniform across the annulus thickness but the pore size was significantly larger than the pore sizes in the $\mathrm{UO}_{2}$ and $\mathrm{UO}_{2}-\mathrm{ZrO}_{2}-\mathrm{CaO}$ fuels. After irradiation, porosity appears to have been essentially eliminated. In addition, the lateral surfaces of the $\mathrm{UO}_{2}-\mathrm{ZrO}_{2}$ annulus show an irregular shape distinctly different from the other annulus materials. This may be due to nonuniform shrinkage associated with the greater $\mathrm{UO}_{2}-\mathrm{ZrO}_{2}$ densification and lower in-pile creep strength as compared to the $\mathrm{UO}_{2}$ and $\mathrm{UO}_{2}-\mathrm{ZrO}_{2}-\mathrm{CaO}$ fuels. The average preirradiation grain size of the $\mathrm{UO}_{2}-\mathrm{ZrO}_{2}$ material was about 11 microns. After irradiation, etching of the 
fuel failed to reveal grain structure. The lack of $\mathrm{UO}_{2}-\mathrm{ZrO}_{2}$ post-irradiation grain structure is consistent with prior experience and may be associated with the phase transformation.

Based on the densification implied by the Quantimet analysis of metallographic samples, and the assumed isotropic volume change and fuel swelling component of 0.7 -percent $\Delta \mathrm{v} / \mathrm{v}$ per $10 \mathrm{f} / \mathrm{cc}$, expected fuel stack length changes were derived and compared to the measured length changes with results as given in Table C-9.

Table C-9. Expected and measured fuel stack length changes.

\begin{tabular}{lccc}
\hline \multicolumn{3}{c}{ Fuel Stack Length Change } \\
\hline \multicolumn{1}{c}{ Rod Type } & Rod ID & $\begin{array}{c}\text { Derived from Densification } \\
\text { Measurements }\end{array}$ & $\begin{array}{c}\text { Measured from Neutron } \\
\text { Radiographs }\end{array}$ \\
\hline $\mathrm{UO}_{2}$ & $97-23$ & -0.5 & -0.22 \\
$\mathrm{UO}_{2}-\mathrm{ZrO}_{2}$ & $97-22$ & -1.7 & +0.41 \\
$\mathrm{UO}_{2}-\mathrm{ZrO}_{2}-\mathrm{CaO}$ & $97-37$ & -0.7 & -0.40 \\
\hline
\end{tabular}

For the $\mathrm{UO}_{2}$ and $\mathrm{UO}_{2}-\mathrm{ZrO}_{2}-\mathrm{CaO}$ rods, the measured stack shrinkage is $0.3 \%$ less than that implied by the net effect of densification and swelling. For the $\mathrm{UO}_{2}-\mathrm{ZrO}_{2}$ rods, the discrepancy is $2.1 \%$. However, the measurements from the radiographs include the effects of annulus cracks and associated small separations. The large discrepancy for the $\mathrm{UO}_{2}-\mathrm{ZrO}_{2}$ fuel is probably because it was more extensively cracked than the other fuels.

In summary, examination of the 21 rods of the D- 1 test after irradiation at $13-15 \mathrm{~kW} / \mathrm{ft}$ for 32.6 days to peak depletions of $1.2-1.3 \times 10^{20} \mathrm{f} / \mathrm{cc}$ and fast neutron fluences of $2.8-3.9 \times 10^{20} \mathrm{n} / \mathrm{cm}^{2}$ revealed no deficiencies in the early-in-life performance of rods with duplex pellets. The $\mathrm{UO}_{2}-\mathrm{ZrO}_{2}$ annuli duplex pellets had greater densification than the other two fuel types; however, this did not result in detrimental performance such as excessive operating temperatures or enhanced fission gas release.

The rod identification numbers of the 16 rods of this test contained in the scrap canister are given in Table C-10.

Table C-10. Rod identification numbers of rods from this test that are in the scrap canister.

\begin{tabular}{llll}
\hline $97-1$ & $97-19$ & $97-23$ & $97-36 \mathrm{D}$ \\
$97-12$ & $97-20$ & $97-25$ & $97-37$ \\
$97-16$ & $97-21$ & $97-31$ & $97-40$ \\
$97-16$ & $97-22$ & $97-34$ & $97-42$ \\
\hline
\end{tabular}




\section{C4.8 Cladding Corrosion and Hydriding in Irradiated Defected Zircaloy Fuel Rods (Clayton 1985, WAPD-TM-1393)}

Twenty-one LWBR irradiation test rods containing $\mathrm{ThO}_{2}-\mathrm{UO}_{2}$ fuel and zircaloy cladding with holes or cracks operated successfully. Zircaloy cladding corrosion on the inside and outside diameter surfaces and hydrogen pickup in the cladding were measured. The observed outer surface zircaloy cladding corrosion oxide thickness of the test rods were similar to thickness measured for nondefected irradiation test rods. An analysis model, which was developed to calculate outer surface oxide thickness of nondefected rods, gave results that were in reasonable agreement with the outer surface oxide thickness of defected rods. When the analysis procedure was modified to account for additional corrosion proportional to fission rate and to time, the calculated values agreed well with measured inner-oxide corrosion film values. Hydrogen pickup in the defected rods was not directly proportional to local corrosion oxide weight gain as was the case for nondefected rods.

The rod identification numbers of the rods in the scrap canister are given in Table C-11.

Table C-11. Rod identification numbers.

\begin{tabular}{llll}
\hline $79-301 \mathrm{D}$ & $79-353$ & $79-504 \mathrm{D}$ & $79-609 \mathrm{D}$ \\
$79-307 \mathrm{D}$ & $79-441 \mathrm{D}$ & $79-583 \mathrm{D}$ & $79-614 \mathrm{D}$ \\
$79-322 \mathrm{D}$ & $79-433 \mathrm{D}$ & $79-587$ & \\
\hline
\end{tabular}

Note: Rods 79-353 and 79-587 defected in-service

Nuclear power reactors are designed, manufactured, and operated to avoid conditions known to cause in-pile fuel rod cladding defects. Stringent controls on manufacturing and inspection minimize the probability of cladding fabrication defects. However, defected fuel rods (i.e., where the cladding has a through-thickness hole or crack) have occasionally occurred in both test reactors and commercial power reactors. In the event of a cladding defect, coolant can enter the rod interior and hence the cladding internal surface is subject to oxide corrosion and hydrogen pickup. Most defected zircaloy fuel rods operated satisfactorily until removal during a normal refueling. However, under certain conditions zircaloy cladding may be degraded over time and pose a threat to continued operation. Therefore, the operational behavior of defected fuel rods is an important engineering consideration for a reactor core.

The report summarizes the cladding corrosion and hydriding results of the LWBR irradiation test program on defected $\mathrm{ThO}_{2}-\mathrm{UO}_{2}$ - fueled Zircaloy-4 clad rods. Two major consequences of defected rod operation, internal surface cladding corrosion and cladding hydrogen pickup, were examined to determine if defected fuel rod corrosion rates and hydrogen pickup behave similarly to those of nondefected Zircaloy-4 rods; the nondefected rods are exposed to coolant on their outer diameter surfaces only. Cladding corrosion film thickness and hydrogen content measurement on intentionally defected Zircaloy-clad fuel rods from the LWBR irradiation test program are compared with values calculated by a computerized corrosion analysis procedure designated as CHORT (Corrosion and Hydriding of Reactor Tubing). The CHORT procedure was based on corrosion and hydriding data from nondefected irradiation test rods with only the outer cladding surface exposed to coolant. Predictions of corrosion oxide thickness are in reasonable agreement with measured data. However, hydrogen pickup in defected fuel rods was observed to behave differently than in nondefected rods. Unexpectedly high hydrogen concentration in cladding at low power segments of certain defected Zircaloy-4 fuel rods was observed and is attributed to gaseous hydrogen transport along the fuel rod cladding gap. 


\section{C4.8.1 Defected Fuel Rod Corrosion and Hydriding}

A defect is defined as a breach of cladding integrity, i.e., a perforation, slit, or pinhole, that usually leaks fission products to the coolant and coolant to the rod internals. A defected zircaloy-clad fuel rod experiences greater cladding corrosion and hydriding than a normal nondefected rod because both inside and outside cladding surfaces are exposed to coolant. The amount of corrosion and hydriding on the outside surface of a defected fuel rod should be about the same as on a nondefected rod because the conditions are the same. If a defect occurs in the cladding, coolant may enter the fuel rod and reach high temperature when the core is taken to power. Corrosion and hydriding on the inside surface of the cladding will then occur at a faster rate than on the outside cladding surface; this is due to higher temperatures at the inner surface because of fissions on or very near the corroding surface.

The Shippingport LWBR core contained 12 hexagonal-shaped modules, which were arranged in a symmetric array, surrounded by 15 reflector modules. Each of the hexagonal modules contained a central movable fuel assembly (seed) surrounded by a stationary blanket assembly. The fuel was in the form of ceramic pellets that were sealed within Zircaloy-4 tubes. In the seed and blanket regions, the fuel pellets

were composed of the mixed oxides of ${ }^{233} \mathrm{U}$ and ${ }^{232} \mathrm{Th}$ in solid solution. In the reflector region and in short sections at the tops and bottoms of the seed and blanket fuel rods, the pellets were $\mathrm{ThO}_{2}$. The seed-blanket-reflector configuration of the LWBR core had 17,287 fuel rods. LWBR fuel rod cladding was used in two metallurgical conditions, recrystallization annealed (RXA) seed rod tubing and stress-relief annealed (SRA) blanket and reflector rod tubing. Fuel rods were maintained in close-packed hexagonal arrays by AM-350 stainless steel grids. The LWBR core operated for about 29,000 EFPH. The absence of high coolant activity indicated that there were no fuel rod cladding defects.

Hydrogen transport through the fuel-cladding gap can also occur in irradiated defected fuel rods by the following sequence of events. First coolant enters the rod through the defect and oxidizes the inner zircaloy cladding surface through the reaction: $\mathrm{Zr}+2 \mathrm{H}_{2} \mathrm{O} \rightarrow \mathrm{ZrO}_{2}+2 \mathrm{H}_{2}$. The hydrogen that is not absorbed by the zircaloy (about 75\%) is released to the fuel-cladding gap, thus enriching the atmosphere in hydrogen. In addition, some of the coolant entering the defect is decomposed to hydrogen and peroxide by radiolysis, $2 \mathrm{H}_{2} \mathrm{O} \rightarrow \mathrm{H}_{2} \mathrm{O}_{2}+\mathrm{H}_{2}$. Thus the oxidant partial pressure is reduced both by corrosion of the internal surface of the zircaloy cladding and by peroxide oxidation of the fuel. High levels of free hydrogen generated by the radiolysis of the coolant and fuel and cladding oxidation can migrate through the fuel-cladding gap to the end regions of the defected rod where the hydrogen is absorbed.

\section{C4.8.2 Experimental Details}

Irradiation testing of defected fuel rods played an important role in development of fuel elements for the LWBR core. The LWBR irradiation test program encompassed 30 individual tests of 271 fuel rods. The test rods were irradiated either in standard specimen holders or in bundles resembling portions of LWBR fuel rod modules. The coolant for these irradiation tests was pressurized water maintained at $\mathrm{pH} 10$ by $\mathrm{NH}_{4} \mathrm{OH}$ additions. Nineteen fuel rods (14 seed and 5 blanket) were intentionally defected with drilled holes prior to testing. A larger ( $\sim 35$ mil diameter) spotting hole was first drilled halfway through the cladding wall from the outside surface and then continued through the wall to the inside surface with a smaller ( $\sim 5$ mil diameter) defect hole. The fuel stacks of some of the defected rods were short (6-11 in. in length). However, five seed rods and four blanket rods were of LWBR length, i.e., up to 118 in. long. Holes were located about halfway up the fuel stack on short rods and within 24 in. of the bottom on long rods, except on seed rod 79-443D where the hole was located at the bottom end plug-pellet stack interface. In addition, two blanket rods, which were irradiated at higher heat ratings than LWBR core rods, developed small cladding defects during planned in-service transient testing. 
All 21 defected rods successfully operated with limited radioactivity release to the coolant. Startup activities, i.e., the values measured immediately after a defected test rod reached full power following a shutdown, were 5-10 times greater than the steady state activities due to release of fission products to the coolant. These high activities declined over a period of 1 to 3 days to the steady state level. The steady state coolant activity values of irradiation tests with defected rods were higher than similar tests containing only nondefected rods. For example, the ${ }^{138} \mathrm{Cs}$ activity in the GRIP IIIA test with defected rod 79-614D was $1 \times 10^{5} \mathrm{dpm} / \mathrm{mL}$ compared to an activity value of $5 \times 10^{4} \mathrm{dpm} / \mathrm{mL}$ for the GRIP IIIC test with no defected rods. Irradiation histories of the 21 LWBR defected rods, including the two which defected in-pile, are given in the report. The fuel rods with intentionally fabricated defects are identified by the letter "D" after the rod number. The seed-size irradiation test rods with RXA cladding were irradiated to peak depletions up to $12 \times 10^{20} \mathrm{f} / \mathrm{cc}$ and peak fast neutron $(>1 \mathrm{Mev})$ fluences up to $101 \times 10^{20} \mathrm{n} / \mathrm{cm}^{2}$. The peak depletion and fluence for the LWBR core seed rods were $11 \times 10^{20} \mathrm{f} / \mathrm{cc}$ and $97 \times 10^{21} \mathrm{n} / \mathrm{cm}^{2}$, respectively. The blanket-size test rods with SRA cladding were irradiated to peak depletions up to $4 \times 10^{20} \mathrm{f} / \mathrm{cc}$ and fluences up to $12 \times 10^{20} \mathrm{n} / \mathrm{cm}^{2}$. The peak depletion and fluence for the LWBR core blanket rods were $5 \times 10^{20} \mathrm{f} / \mathrm{cc}$ and $74 \times 10^{20} \mathrm{n} / \mathrm{cm}^{2}$.

The objectives of the LWBR irradiation test program were:

- $\quad$ To test fuel rods under heat fluxes, fast neutron fluxes, and fuel depletions expected in the LWBR core

- To confirm satisfactory performance for design lifetime

- $\quad$ To support development of performance analyses for LWBR fuel rods.

The program for measuring corrosion and hydriding in Zircaloy-4 cladding of defected fuel rods consisted of rods from the 14 tests given in Table C-12.

Table C-12. LWBR defected irradiation tests containing fuel rods examined for cladding corrosion and hydriding.

\begin{tabular}{lllcc}
\hline Designation & \multicolumn{1}{c}{ Test Name } & Rod Type & Heat Treat Cladding & Test Reactor \\
\hline M-13-S2 & Seed Rod Screening & Seed & RXA & ETR \\
M-13-S3 & Seed Rod Screening & Seed & RXA & ETR \\
M-13-S3A & Seed Rod Screening & Seed & RXA & ETR \\
M-13-S4 & Seed Rod Screening & Seed & RXA & ETR \\
GRIP II & Grid Rod In-Pile & Seed & RXA & ETR \\
GRIP IIIA & Grid Rod In-Pile & Seed & RXA & ETR \\
GRIP IIIB & Grid Rod In-Pile & Seed & RXA & ATR \\
LSR & Long Seed Rod & Seed & RXA & NRX \\
- & Production Thoria & Seed & RXA, SRA & ETR \\
C-7B3 & Blanket Screening Test & Blanket & SRA & ETR \\
C7-B3A & Blanket 6-Rod Assembly & Blanket & SRA & ETR \\
C7-BBT & Blanket Bundle Test & Blanket & SRA & ETR \\
SBR & Short Blanket Rod & Blanket & SRA & NRX \\
NLBR & New Long Blanket Rod & Blanket & SRA & NRX \\
\hline
\end{tabular}




\section{C4.8.3 Postirradiation Examination Results}

All of the defected rods were visually examined. The inside and outside corrosion cladding-surface oxide thickness was measured for 16 of the defected rods on at or near the fuel rod peak power position. The same 16 rods were analyzed for hydrogen content and distribution. Summaries of internal and external cladding-corrosion data for the $16 \mathrm{LWBR}$ irradiated defected test fuel rods that were destructively examined are presented for RXA and SRA Zircaloy-4 cladding. External corrosion-oxide thickness measured on the defected fuel rods was about the same as those of nondefected rods with similar irradiation histories.

Nine of the intentionally fabricated defected rods had a white or gray streak downstream from the defect hole (streamers). The defect hole streamer of GRIP IIIB Rod 79-609D was observed at the first interim examination (1330 EFPH). At 2360 hours, the streamer consisted of a bright white area and a darker phase extending downstream from the defect hole and increasing in width as the distance from the hole increased. With continued irradiation the white portion increased in area and covered the darker phase. Postirradiation examination confirmed the streamer to be $\mathrm{ZrO}_{2}$. The nine oxide streamers were local and had no noticeable effect on general cladding integrity. It is thought that either eroded $\mathrm{ThO}_{2}$ fuel or fission products emanating from the defect hole caused the accelerated corrosion of the zircaloy cladding.

Internal cladding surface oxide films in the defected rods were usually more variable in thickness and several times thicker than the external oxide films. The thicker inner-surface corrosion films are due to several factors: higher internal cladding surface temperatures (up to $780^{\circ} \mathrm{F}$ ), fission-induced corrosion acceleration at the internal surface and exposure to a steam environment. The internal film on Rod 79-587, however, was thinner than the external film because the rod was removed from test about 8.5 hours following the planned up-power transient test that produced the defect. Four of the intentionally fabricated defected rods experienced cladding swelling. Rod 79-504D swelled along the primary fuel stack. Three rods (79-433D, 79-307D, and 79-583D) had periods of normal dimensional changes during irradiation before any significant swelling, mainly in the plenum region, was detected. Blockage or partial blockage of the defect hole occurred in all four rods. The combination of hole blockage and swelling is indicative of water logging, i.e., excessive internal pressure built up by trapped coolant, which deforms the cladding.

\section{C4.8.4 Zircaloy-4 Cladding Hydriding}

Measured hydrogen pickups in irradiated LWBR nondefected test rods and autoclaved Zircaloy-4 tubing specimens were proportional to measured outside diameter corrosion thickness. The hydriding in defected Zircaloy fuel rods falls into three categories: expected due to corrosion, accelerated, and massive. Expected hydrogen pickup in defected rods results from the additional hydrogen which enters the cladding through the inside diameter $\mathrm{ZrO}_{2}$ film during corrosion. Twelve of the 16 destructively examined defected LWBR test rods exhibited normal behavior of this type $\left(\sim 100-1000 \mathrm{ppm} \mathrm{H}_{2}\right)$. Accelerated hydriding is defined as hydrogen absorption from the coolant far in excess of the nominal $25 \%$ pickup fraction of free $\mathrm{H}_{2}$ produced by the $\mathrm{Zr}-\mathrm{H}_{2} \mathrm{O}$ corrosion reaction for Zircaloy-4 ( several thousand ppm). Massive hydriding is the formation of regions of delta phase zirconium hydride in the cladding due to grossly accelerated hydrogen pickup (16,300 ppm).

The hydrogen contents of Zircaloy-4 cladding samples from the LWBR intentionally defected test rods are summarized in the report. Measurements were made with a vacuum extraction technique and by visual comparison with known metallographic standards. Because of the greater internal surface corrosion, the total hydrogen contents in the defected rod cladding were several times those in nondefected rod cladding with similar irradiation histories. For example, in the GRIP-IIIA test, defected 
rod 79-614D had $174 \mathrm{ppm}$ hydrogen in the peak power region, whereas companion nondefected rod 79-617 had only $40 \mathrm{ppm}$ hydrogen. Hydrogen pickup in nondefected fuel rods is proportional to corrosion oxide thickness and, therefore, is greater in peak power positions than in cooler, low power regions. In contrast, several defected test rods (79-433D, 79-443D, 79-609D, and 79-614D), that were examined at several power positions, had higher hydrogen contents in cooler, low power cladding regions where the corrosion was less. Also, due to the steep temperature and higher hydrogen concentration radial gradients in defected rods, hydrogen tends to diffuse from the hotter inside cladding surface to the cooler outside surface; this results in higher hydrogen concentrations at the outside cladding surface.

Several instances of localized accelerated and massive hydriding were observed. Two intentionally fabricated defected fuel rods (GRIP-II rod 79-443D and GRIP-IIIB rod 79-609D) had areas of accelerated hydriding with several thousand ppm of hydrogen. Localized areas of massive hydriding were found in C7-B3A rod 79-353, GRIP-II rod 79-441D, and GRIP-IIIB rod 79-609D. These localized areas were converted to solid zirconium delta hydride $\left(\sim 16,300 \mathrm{ppm}_{2}\right)$. Massive hydriding was also accompanied by dimensional changes in these three rods due to the lower density of zirconium delta hydride compared with Zircaloy-4. However, none of these incidents interfered with the operation of the irradiation tests. For example, C7-B3A rod 79-353, which defected in-pile due to iodine stress-corrosion cracking, operated successfully for about 12,000 EFPH even though during postirradiation examination the cladding was observed to be massively hydrided near the bottom end of the rod. None of these hydrided rods lost additional structural integrity during operation, which attests to their ability to function under localized accelerated and massive hydriding conditions.

\section{C4.8.5 Summary of Corrosion and Hydriding Behavior}

Oxide films on internal surfaces of defected Zircaloy-4 fuel rods were several times as thick as films on external surfaces. This can be explained both by higher temperatures at the internal surface and by the effect of surface fissile enhancement.

Total hydrogen contents in defected fuel rod cladding were several times those in nondefected rod cladding. Further, evidence of hydrogen migration to cooler regions of the rods remote from the defect hole was observed, indicating that hydrogen pickup is not proportional to corrosion oxide thickness.

Hydrogen levels in the cladding of the defected fuel rods were generally higher at the external surface than at the internal surface because, in a sufficiently high thermal gradient, hydrogen diffuses toward the cooler region.

Defected rods with areas of accelerated or massive hydride continued to operate satisfactorily.

\section{C4.8.6 Conclusions}

- $\quad$ The measured outer surface zircaloy cladding corrosion oxide thickness of both defected and nondefected LWBR irradiation test rods were similar and can be calculated using a model based on nondefected outer surface corrosion experience.

- There is a significant corrosion enhancement on the inside-cladding surface in defected zircaloy fuel rods that can be attributed to radiation damage caused by fission product recoil.

- When modified to account for the additional corrosion caused by fission activity on the inner zircaloy cladding surface, a model qualified to the corrosion of nondefected rods provided calculated values that agree well with measured inner oxide corrosion film values. 
- Hydrogen concentrations are higher than predicted in the lower power segments of defected zircaloy fuel rods and are not proportional to oxide thickness. This phenomenon is attributed to gaseous hydrogen transport through the fuel-cladding gap; this results in high hydrogen concentrations in the gap at the top and bottom ends of the defected rod.

- Hydrogen absorption models in which hydrogen pickup is calculated to be directly proportional to local corrosion oxide weight gain, while adequate for the prediction of external hydriding in nondefected rods, are unsuitable for prediction of axial hydrogen distribution in defected zircaloy rods.

\section{C4.9 lodine and Cesium in Oxide Fuel Pellets and Zircaloy-4 Cladding of Irradiated Fuel Rods (Ivak and Waldman 1979, WAPD-TM-1394)}

Measurements of fission product iodine and cesium are reported for thoria and binary $\left(\mathrm{ThO}_{2}-\mathrm{UO}_{2}\right)$ fuels with various irradiation histories. These volatile fission products were measured on the cladding surface or in the fuel by using specially developed radiochemical techniques. The radiochemical iodine measurements are in agreement with a theoretical iodine release model for irradiated fuel. Microprobe examinations of irradiated fuel rod cladding sections show fission product cesium to be located preferentially at the pellet to pellet interface region. Fission product iodine was detected in the interface microprobe-limit region of one sample but generally remained below the limit of detection.

Twenty-two fuel rods were analyzed for this report; ten of the 22 rods are contained in the scrap canister. The rod identification numbers of the 10 rods are listed in Table C-13.

Table C-13. Rod identification numbers.

\begin{tabular}{lllll}
\hline $79-353$ & $79-449$ & $79-576$ & $79-605$ & $79-617$ \\
$79-442$ & $79-572$ & $79-587$ & $79-610$ & $79-671$ \\
\hline
\end{tabular}

Rod 79-587 failed in-pile during up-power transient.

The iodine and cesium concentrations obtained from radiochemical analysis of the 22 test-rods are given along with a summary of the irradiation history of each test rod. Electron microprobe examination of cladding segments from four irradiation test rods was also conducted to determine iodine and cesium distribution on the inside diameter surface of cladding. A brief summary of the results for two of the rods that are contained in the scrap canister is presented below.

Rod 79-442 - One of the two locations, corresponding to a pellet interface location on the clad surface had only barely detectable amounts of cesium. The second interface location displayed only background levels. No iodine, cadmium, tellurium or mercury was detected above the background levels anywhere on the sample.

Rod 79-576- One of the two pellet-to-pellet interfaces on the cladding surface showed a relatively strong indication of cesium. No iodine, mercury, cadmium, or tellurium was detected above the sample background levels. 
The conclusions of the report were as follows:

- $\quad$ There is essential agreement of microprobe evaluation with the low-level of iodine found by radiochemical analysis. Results of both radiochemical and microprobe examinations suggested less iodine than calculated using the iodine release upper-bound calculation model. In one case, the radiochemical iodine measurement was greater than the upper bound model. Remeasurement of this rod, 79-617, showed a decrease in the iodine concentration to a level well below the upper-bound calculation. The upper-bound iodine calculation method presented in the report is therefore corroborated by the radiochemical data.

- The presence of other volatile fission products on the cladding, cesium, and tellurium were confirmed by electron microprobe evaluation. The cesium concentration obtained from radiochemical data was on the cladding in greater concentration than iodine, as might be expected due to its higher fission product yield. Similarly, the failure to detect cadmium on the cladding during microprobe examination was probably due to its extremely small fission product yield.

\section{C4.10 Corrosion and Hydriding of Irradiated Zircaloy Fuel Rod Cladding (Clayton 1982, WAPD-TM-1440)}

Metallography and other destructive examinations were performed on some of the test samples. After collection of internal atmosphere gases, LWBR irradiation test fuel rods were sectioned to provide samples for measuring depletion, fluence, and hydrogen content and for metallographic evaluation. Metallographic samples were mounted in Hysol epoxy resin, which locked the fuel pieces in place and preserved the corrosion oxide for examination. Each piece was pressure-mounted by immersion in the epoxy resin pressurized to $1000 \mathrm{psi}$. A silicone rubber sleeve was used to isolate the outside cladding surface from the Hysol while it was immersed in Hysol for 24 hours at room temperature. The Hysol was cured for 2 hours at $200^{\circ} \mathrm{F}$. The pressure-mounted pieces were sectioned with a diamond cutoff wheel to provide both transverse and longitudinal metallographic samples. More details about the sample preparation and the results are provided in Clayton 1982.

Nondestructive examinations of the rods consisted of visual examinations, dimensional measurements, gamma ray scanning, and neutron radiography; dimensional measurements consisted of measuring the overall length and diameter of the cladding; gamma ray scanning and neutron radiography were used to determine the condition of the internal rod components.

Irradiation histories of 47 LWBR test fuel rods 29 with RXA cladding and 18 with SRA cladding are given. The rod identification numbers of 25 of these rods, which are contained in the scrap canister, are given in Table C-14.

Table C-14. Rod identification numbers.

\begin{tabular}{lllll}
$79-349$ & $79-513$ & $79-575$ & $79-610$ & $79-623$ \\
$79-405$ & $79-514$ & $79-576$ & $79-613$ & $79-624$ \\
$79-442$ & $79-570$ & $79-579$ & $79-617$ & $79-631$ \\
$79-449$ & $79-572$ & $79-605$ & $79-619$ & $79-632$ \\
$79-509$ & $79-573$ & $79-608$ & $79-621$ & $79-656$ \\
\hline
\end{tabular}


The results of the study are summarized below.

- $\quad$ CHORT predictions compare well with measured corrosion data from out-of-pile autoclave tests on LWBR Zircaloy-4 tubing.

- $\quad$ Corrosion thickness and hydrogen uptakes in LWBR irradiation test program fuel rod Zircaloy-4 cladding are less accurately accounted for by the CHORT program due in part to measurement scatter and material variability.

- $\quad$ Both out-of-pile and in-pile test data indicate that SRA Zircaloy-4 corrodes faster than RXA Zircaloy-4 does.

- $\quad$ Measured corrosion thickness of Maine Yankee, Kernkraftwerk Obrigheim, Turkey Point, and MELBA fuel rods are in reasonable agreement with CHORT predictions.

\section{C4.11 Irradiation Performance of Duplex Fuel Pellet Test Rods Depleted to $9 \times 10^{20}$ Fissions $/ \mathrm{cm}^{3}$ of Compartment-D-1 Test (Sphar, Mertz, and Roesener 1982, WAPD-TM-1460)}

This report evaluated the irradiation performance of the D-1 test, which was a screening test of the duplex pellet prebreeder reactor fuel concept. The duplex pellet consisted of a cylindrical thoria pellet surrounded by an annulus containing urania enriched in U-235. The duplex pellet geometry offered the advantage of lower fuel temperatures than solid pellets for equal power output and provided a means of including the fertile material in the fuel rods with little or no loss of heat transfer surface while also providing a practical (chemical) means for separating the U-233 bred in the thoria central core without contamination by other uranium isotopes in the annulus. The test was conducted on duplex pellet annuli of four different compositions: $\mathrm{UO}_{2}, \mathrm{ZrO}_{2}-\mathrm{UO}_{2}, \mathrm{ZrO}_{2}-\mathrm{UO}_{2}-\mathrm{CaO}$ and $\mathrm{ThO}_{2}-\mathrm{UO}_{2}$. Rods were irradiated, and destructive and nondestructive examinations were conducted.

The rod identification numbers of the rods used in the D-1 test are listed in Table C-15.

Table C-15. Rod identification numbers.

\begin{tabular}{ccccc}
\hline $97-1$ & $97-16$ & $97-24$ & $97-32$ & $97-41$ \\
$97-5$ & $97-17$ & $97-25$ & $97-33$ & $97-42$ \\
$97-11$ & $97-19$ & $97-27$ & $97-34$ & $97-48 \mathrm{D}$ \\
$97-12$ & $97-20$ & $97-28$ & $97-36 \mathrm{D}$ & \\
$97-13 \mathrm{D}$ & $97-21$ & $97-29$ & $97-37$ & \\
$97-14$ & $97-22$ & $97-30$ & $97-39$ & \\
$97-15$ & $97-23$ & $97-31$ & $97-40$ & \\
\hline
\end{tabular}

The D-1 Test rods are 11 in. in length by $0.3 \mathrm{in}$. in diameter and consist of top and bottom Zircaloy-4 end- closures welded into seamless Zircaloy-4 cladding tubes. Cladding tube heat treatment is incorporated as a test variable. Rods were fabricated with recrystallization-annealed tubing or highly cold-worked stress-relief annealed tubes. Contained within the cladding tube are an 8-in. stack of fuel pellets and a 0.8 -in. long plenum region containing an Inconel-X spring. Five different fuel stack arrangements were used for each of the duplex-annulus material type. These arrangements are designed to 
test various sizes and configurations of solid thoria spacers that maintain alignment of the duplex pellet components in the fuel stack. Each rod contains a solid cylindrical pellet, with about half the fuel loading of the duplex pellets, at each end of the duplex pellet stack. These pellets reduce power peaking at the ends of the pellet stack. Thoria pellets are incorporated on the outboard side of the power peaking suppressor pellets, against the bottom end closure and against the plenum spring; this is done to limit operating temperatures of the bottom end closures and the plenum spring. The four-annulus compositions tested in the D-1 rods are listed in Table C-16.

Table C-16. Compositions in the D-1 rods.

\begin{tabular}{lccccc}
\hline \multicolumn{1}{c}{ Annulus } & $\mathrm{UO}_{2}$ w/o & $\mathrm{ZrO}_{2}$ w/o & $\mathrm{CaO}$ w/o & $\mathrm{ThO}_{2}$ w/o & $\begin{array}{c}{ }^{235} \mathrm{U} \text { Enrichment } \\
(\%)\end{array}$ \\
\hline $\mathrm{UO}_{2}$ & 22.3 & & & & 22.3 \\
$\mathrm{ZrO}_{2}-\mathrm{UO}_{2}$ & 34.0 & 66.0 & & & 97.7 \\
$\mathrm{ZrO}_{2}-\mathrm{UO}_{2}-\mathrm{CaO}$ & 36.9 & 58.1 & 5.0 & & 97.7 \\
$\mathrm{ThO}_{2}-\mathrm{UO}_{2}$ & 33.8 & & & 66.2 & 93.1 \\
\hline
\end{tabular}

The $\mathrm{UO}_{2}$ fuel was included because it is the fuel most commonly employed in commercial reactors. The $\mathrm{ZrO}_{2}$ based fuels were included because they contain essentially no ${ }^{238} \mathrm{U}$. Absence of ${ }^{238} \mathrm{U}$ results in a significant neutron economy advantage. Inclusion of the thoria based binary fuel extends the technology developed in the LWBR program for solid pellets with this fuel system to include the duplex pellet geometry.

Other D-1 test variables are: (1) magnitude of initial diametric clearance gap between the annuli and cladding and between the annuli and central pellets, (2) levels of rod internal prepressurization, and (3) defect operation.

Diametric clearance gaps between the annuli and cladding ranged from 45-84 mils, which is in the range of current commercial design practice. The gaps between annuli and the thoria central pellets were varied from 24-102 mils to investigate the effect of a wide range of this parameter on rod performance.

The principal advantages of prepressurization are: (1) increased margin to cladding collapse in the presence of an axial gap between fuel pellets and (2) decreased degradation of the thermal conductivity of the rod's internal atmosphere as fission gases are released from the fuel. Degradation in gap thermal conductivity is lessened by the increased concentration of higher conductivity helium as compared with released fission gases. In addition, there is reduced cladding "creep-down" due to the reduced pressure differential across the cladding which delays fuel-cladding interaction, reduces cladding strain, and reduces the potential for formation of fuel stack gaps. On the other hand, higher internal pressure reduces the loss-of-coolant accident performance capability with respect to an unpressurized rod. Therefore, it is desirable to optimize the initial pressure level within the rods. To study these effects, initial helium pressures of 100 and 500 psig at room temperature were selected.

Although not included in the original test, rods containing intentional defects in the cladding were introduced as replacement rods for the $\mathrm{UO}_{2}$ and $\mathrm{ThO}_{2}-\mathrm{UO}_{2}$ rods terminated for destructive examination at an early stage. The intentional defects, included to investigate the behavior of rods with breached cladding, were in the form of 5-mil diameter holes drilled through the cladding at the approximate axial midplane of the rods.

The prime characteristics and variables of the individual D-1 test rods are given in the report. 


\section{C4.11.1 Fuel Components}

Annuli-The outside chamfers at the pellet ends and the perpendicularity control were specified to minimize frictional forces between the fuel pellets and the cladding as the fuel stack lengthens and shortens with power changes. The chamfer eliminates sharp corners on the pellet while the limits on end face nonperpendicularity reduce pellet tilting tendencies and resulting radial forces of the pellet against the cladding. The chamfers also minimize the potential for creation of chips during rod loading. Chips, if present in the rod, may increase local strains in the cladding. The length-to-diameter ratio of the duplex-pellet annulus (2.1) is consistent with that of the LWBR seed pellets. The annulus wall thickness provides a nominal-annulus-to-central core cross sectional area ratio of unity that was considered acceptable with respect to manufacturing limitations and integrity during irradiation. With this 50/50 split, the volumetric heat generation rate and depletion of the annulus is about twice that of solid pellets producing equal power.

The annulus outside-diameters are sized to provide clearance gaps in the range of present commercial practice, which avoids premature fuel-cladding contact. Large radial gaps reduce heat transfer capability and increase fuel temperatures. Increases in fuel temperatures must be limited to avoid fuel structural changes or melting which can lead to cladding failure. The $\mathrm{UO}_{2}$ rods and the $\mathrm{ThO}_{2}-\mathrm{UO}_{2}$ rods contain fuel-to-cladding diametric gaps in the range 49-85 mils. Because of poorer heat conduction properties, the Zirconia-based fuels have fuel-to-cladding gaps in the $45-58$ mil range.

High density ( $>96 \%$ TD) was desired for all fuel materials to maximize thermal conductivity, thereby resulting in higher power production at the maximum allowable temperature of the fuel. In addition, high density minimizes fuel dimensional changes in service and consequent axial shrinkage of the fuel stack. Axial shrinkage in rods of commercial length might lead to collapse of unsupported cladding if axial gaps were to form between pellets.

The densities (derived from pellet dimensions and weights) of the annular fuel materials are as listed in Table C-17.

Table C-17. Density of annular fuel materials.

\begin{tabular}{lccc}
\hline & \multicolumn{3}{c}{$\begin{array}{c}\text { Density } \\
\text { (Percent TD) }\end{array}$} \\
\cline { 2 - 4 } Fuel Material & Average & Maximum & Minimum \\
\hline $\mathrm{UO}_{2}$ & 95.1 & 96.5 & 93.1 \\
$\mathrm{ZrO}_{2}-\mathrm{UO}_{2}$ & 92.4 & 93.1 & 91.6 \\
$\mathrm{ZrO}_{2}-\mathrm{UO}_{2}-\mathrm{CaO}$ & 94.0 & 95.0 & 93.3 \\
$\mathrm{ThO}_{2}-\mathrm{UO}_{2}$ & 96.7 & 96.0 & 97.2 \\
\hline
\end{tabular}

The fuel-to-cladding gap for the $\mathrm{ZrO}_{2}-\mathrm{UO}_{2}$ annular pellets was set about 1 mil below the gap sizes for the other fuel compositions to compensate for the lower density.

C4.11.1.1 Thoria Central Pellets. The thoria central pellets were prepared from available LWBR seed thoria pellets. The LWBR pellets, of about 98.8 -percent TD, were nominally 0.256 in. OD and 0.530 in. long. The end dish depth and corner chamfers were 9 and 15 mils, respectively. Outside diameters of the thoria central pellets were ground to different sizes to obtain a range of annulus-to-central pellet diametric gaps. This was done as a test variable to evaluate the effect of central pellet eccentricity in the annulus on pellet temperatures and the effect of total clearance gap on fuelcladding interaction. The length of the central cores was made less than that of the annuli to ensure that 
the annular pellets are longer than the central pellets at the highest predicted operating temperature and thus avoid axial gaps between the annuli.

C4.11.1.2 Thoria Spacers. Thoria spacers separating the duplex pellets may be necessary to maintain the axial alignment of the fuel stack. The effect of these spacers is investigated in the seven test rods of each fuel material by varying the length of the spacers $(0.050,0.100$, and $0.530 \mathrm{in}$.) and the number of duplex pellets between spacers. The rods range from no spacers in the duplex pellet stack to having a spacer at each duplex pellet interface. These were prepared by slicing long pellets transversely and breaking the corners by tumbling in silicon carbide grit. The outside diameter of these thin spacers is nominally the same as the duplex pellets of the particular rod in which the spacers are located. The design of the 0.530 -in. long spacer is the same as for the LWBR seed thoria pellets. The concave dish in each end of 0.530 -in. spacer reduces the convex shape that would exist at power in a flat and ended pellet. Reduction of the convex contour minimizes axial expansion fuel-cladding interaction. The outside diameter of the long thoria spacers matches the outside diameter of the duplex pellets of the rod in which they are located.

C4.11.1.3 Thoria End Pellets. One long spacer was used at the bottom of the fuel stack in each rod to reduce operating temperatures at the end closure insert. The thin thoria spacers were used as required at the top of the fuel stacks to reduce operating temperature of the plenum spring and to achieve the desired overall fuel stack and plenum lengths in the rods.

C4.11.1.4 End Peak Suppressor Pellets. Power peaking is significant at the ends of the fuel stack of these short rods, which are in the high flux region of ends of the ATR. To limit this end peaking to acceptable values, $\mathrm{ThO}_{2}-\mathrm{UO}_{2}$ pellets with fissile loading about $40 \%$ of the annular pellets were positioned at the top and bottom of the fuel stack of each rod. The design of these flux suppressor pellets is the same as the long thoria pellets except that they are $0.58 \mathrm{in.} \mathrm{long.}$

\section{C4.11.2 Nonfuel Components}

C4.11.2.1 End closures. The end closures, which were Tungsten Inert Gas welded into the cladding tube, were machined from Zircaloy-4 bar stock. The bottom end closure is designed to provide lateral, axial, and rotational restraint of the rod in the test holder while the top end closure provides lateral restraint but permits limited axial motion.

C4.11.2.2 Plenum Springs. The 0.785-in. long plenum region above the fuel stack contains an Inconel-X spring that provides a preirradiation axial load of $1.82 \mathrm{lb}$ on the fuel stack. This force is about 12 times the fuel pellet stack weight and restrains the pellet stack from shifting during handling and shipment of the rods.

C4.11.2.3 Cladding. The Zircaloy-4 cladding for the D-1 test rods was fabricated by the Wolverine Tube Division of Universal Oil Products. Both RXA and SRA conditions were used; the properties are given in Table C-18. The outside diameter of the RXA tubing was decreased by about 4 mils to produce an outside diameter-to-thickness ratio (OD/t) of 13.9, which is representative of the LWBR seed rod design. The SRA tubing diameter was decreased by about 11 mils to produce an OD/t of 16.0, which is typical of commercial reactor practice. The outside diameters reductions were achieved by pickling in a mixture of hydrofluoric and nitric acids following fuel rod assembly. 
Table C-18. Properties of tubing for D-1 test rods.

\begin{tabular}{lll} 
& \multicolumn{1}{c}{ RXA } & SRA \\
\cline { 2 - 3 } As Fabricated outside Diameter (mil) & $308 \pm 1$ & $308 \pm 1$ \\
Inside Diameter (mil) & $259 \pm 1$ & $259 \pm 1$ \\
Wall Thickness (mil) & 24.5 & 24.5 \\
Final Heat Treatment ( $\left.{ }^{\circ} \mathrm{F} / \mathrm{hr}\right)$ & $1225 / 4$ & $925 / 4$ \\
Cold-work, last of 3 Passes (\%) & 51 & 51 \\
ASTM Grain Size & 10 & $\mathrm{NA}$ \\
Longitudinal Tensile Properties at $700^{\circ} \mathrm{F}$ & & \\
0.2\% Yield Stress (psi) & 19,000 & 44,000 \\
$\quad$ Ultimate-to-Yield Ratio & 1.73 & 1.27 \\
Total Elongation (\%) & 34 & 13 \\
Contractile Strain Ratio & 1.44 & 1.35 \\
Chemistry (Billet Analysis) & & \\
Hafnium (ppm) & 23 & 23 \\
Hydrogen (ppm) & 4 & 4 \\
Nickel (ppm) & 30 & 30 \\
Nitrogen (ppm) & 30 & 30 \\
Oxygen (ppm) & 1300 & 1300 \\
\hline
\end{tabular}

\section{C4.11.3 Test Train Design}

The in-pile hardware design used for the AWBA D-1 test was available from short rod tests in the LWBR Irradiation Testing Program. The D-1 rods are supported in the in-pile hardware by means of the end stems. The bottom, spade-shaped end stems of the rods are inserted through the bottom base plate. Flats on the portion of the end stem engaged by the base plate prevent rotation of the rods. A locking plate goes over the spade ends and slides laterally engaging the spade ends to prevent axial movement of the rods. The round, cone-tipped end stems at the top of the rods are inserted through mating holes in the upper locator plate. The distance between the bottom base plate and the top locator plate is 0.2 in. larger than the shoulder to shoulder length of the rods. This allows for free elongation of the rods by thermal expansion and axial clad strain. In the holder internals, the rods have the cross-sectional array. The rods are arranged on a square pitch of $0.355 \mathrm{in}$. with rod spacing of $0.052 \mathrm{in}$. The internal surface of the holder half shells are sculpted to represent the shape of additional rods, thus giving a flow pattern representative of a larger rod array.

The results of the study are summarized below.

\section{C4.11.4 Nondestructive Examinations}

C4.11.4.1 Rods Without Intentional Cladding Defects. Visual examinations of rods without intentional cladding defects resulted in no observations of irradiation-induced effects that raise concern over rod performance. Early stage corrosion in the form of isolated small white spots was observed on some rods at an early state of irradiation but did not appreciably worsen with irradiation. 
Rod cladding dimensional measurements, overall length and diameters, in general indicate that fuel-cladding interaction has not yet become significant in the D-1 test rods.

At a fast neutron fluence of $25 \times 10^{20} \mathrm{n} / \mathrm{cm}^{2}$, the maximum reached by any of the rods, overall length strains were at most $0.24 \%$ for rods with SRA cladding and $0.12 \%$ for rods with RXA cladding; the strains are principally the result of stress-free zircaloy growth. The expected effects of rod internal prepressurization are evident in those rods with higher internal pressure that exhibit smaller length changes than rods with lower internal pressure.

Because of the lack of fuel-cladding interaction during the first half of test life, the diameter changes continued the trend of diameter shrinkage. Cladding heat treatment and thickness, level of rod internal BOL pressurization, and fast neutron fluence are the determining effects. The SRA clad rods with their thinner wall show greater diametric shrinkage than the RXA clad rods. Rods with higher fast neutron fluence show greater shrinkage. Furthermore, within the cladding material categories, the rods with lower BOL pressure show greater shrinkage due to the higher-pressure differential across the cladding.

Only one rod clearly shows onset of fuel-cladding interaction. Diameter traces for this rod reveal irregularities that correlate with the fuel stack components. Fuel-cladding contact was expected to occur first in this rod because of the unfavorable combination of characteristics, which included stress relief annealed cladding, low internal prepressurization, small-fuel-cladding clearance-gap, and high power rating.

Nondestructive examinations aimed at determining the condition of the internal rod components were gamma ray scanning and neutron radiography. The internal components of the rods did not have any abnormalities of intentional defects. Fuel stacks were shown to be in good condition with no evidence of pellet crushing or development of gaps between pellets. The various sizes and configurations of $\mathrm{ThO}_{2}$ spacers performed satisfactorily.

The lengths of the fuel stacks in the D-1 rods were measured from the neutron radiographs and compared with the preirradiation fuel stack length changes. Observed changes ranged from -1.3 to $+1.5 \%$. Although data at depletions beyond $\sim 1 \times 10^{20} \mathrm{f} / \mathrm{cc}$-compartment are limited, tentative trends in fuel stack behavior were observed which correlate with duplex-pellet annulus material. The $\mathrm{UO}_{2}$ annulus rods showed small increases or decreases in stack length $(-0.40$ to $+0.15 \%)$ at depletions $<1.5 \times 10^{20} \mathrm{f} / \mathrm{cc}$-compartment. However, the one rod, which was radiographed a second time, at depletion of $\sim 6 \times 10^{20} \mathrm{f} / \mathrm{cc}$-compartment had stack elongation of $0.39 \%$ following early-in-life shrinkage of $0.20 \%$. This implies that following some early-in-life densification, fuel swelling becomes dominant.

Early-in-life fuel stack shrinkage was observed in the rods with $\mathrm{ZrO}_{2}-\mathrm{UO}_{2}-\mathrm{CaO}$ duplex pellets (ranging from $0.29 \%-0.45 \%$ ) with no change during subsequent irradiation for the one rod radiographed again at depletion of $\sim 6 \times 10^{20} \mathrm{f} / \mathrm{cc}$-compartment. Thus, it may be that in the ternary fuel swelling is less than for $\mathrm{UO}_{2}$ and/or that densification is greater. The initial density, in terms of percent of theoretical, was lower for the ternary fuel $(93.2 \% \mathrm{TD})$ than for the $\mathrm{UO}_{2}$ fuel $(95.5 \% \mathrm{TD})$.

Three rods with $\mathrm{ThO}_{2}-\mathrm{UO}_{2}$ duplex pellet annuli were subjected to neutron $\mathrm{t}$ radiography. Fuel stacks in all three elongated with a nearly linear growth rate of about $0.14 \%$ per $10^{20} \mathrm{f} /$ cc-compartment.

The $\mathrm{ThO}_{2}-\mathrm{UO}_{2}$ rods had substantial shrinkage (up to $1.3 \%$ ) at depletions above $2 \times 10^{20} \mathrm{f} / \mathrm{cc}$-compartment after initial increases; the increases are attributed to accumulation of small separations associated with the more extensive early-in-life cracking of the $\mathrm{ZrO}_{2}-\mathrm{UO}_{2}$ annuli as compared to the others. The subsequent shrinkage may be associated with lower in-pile creep-strength of the 
$\mathrm{ZrO}_{2}-\mathrm{UO}_{2}$ material. Evidence of dimensional instability of the $\mathrm{ZrO}_{2}-\mathrm{UO}_{2}$ annuli was revealed by destructive examination of rod 97-22.

Based on these nondestructive examination results, it was concluded that performance of the duplex-pellet fuel system is quite good. Cladding and fuel pellet integrity was maintained, and dimensional changes were compared favorably with results of solid pellet tests previously conducted as part of the LWBR development program.

C4.11.4.2 Rods with Intentional Cladding Defects. Nondestructive examinations of rods with intentional cladding penetrations revealed several features of interest not observed on nondefected rods.

On the external cladding surfaces of rods with intentional cladding defects, flow patterns downstream from the intentional defect holes were observed. The most extensive flow pattern was observed on the rod that contained duplex pellets with $\mathrm{UO}_{2}$ annuli. The one other defected rod irradiated for a long time contained $\mathrm{ThO}_{2}-\mathrm{UO}_{2}$ annulus duplex pellets and evidenced a flow pattern that was much less extensive than for the $\mathrm{UO}_{2}$ rod. This indicates that the $\mathrm{ThO}_{2}$-based fuel may be less susceptible to erosion and corrosion than the $\mathrm{UO}_{2}$ fuel.

Circumferential white corrosion rings were observed on the cladding of the defected rod with $\mathrm{ThO}_{2}-\mathrm{UO}_{2}$ fuel at the locations of 50-mil thick thoria spacers separating duplex pellets in the fuel stack. Neutron radiography and preliminary metallographic examination of the cladding from this rod demonstrated that the white corrosion rings are associated with substantial nonuniform concentrations of hydrogen in the cladding; the regions affected by the corrosion rings coincided with the regions of heaviest hydrogen concentration. Preliminary destructive examination results also indicate that the primary source of the hydrogen was accelerated corrosion of the cladding inner surface during irradiation in the defected state. The fuel stack arrangement in this rod consists of pellets containing the fissile material (with high heat generation) interspersed with the $\mathrm{ThO}_{2}$ spacers (with lower heat output) and generates hydrogen "cold traps" in the cladding.

The circumferential white corrosion rings on the cladding external surface, coincident with the regions of high hydrogen concentrations, are thought to be a result of the hydriding. Diameter measurements revealed ridging of the cladding at the locations of the corrosion rings; the average diametric ridge height was 0.8 mils with a maximum of 1.2 mils. This ridging was probably caused by the cladding-material volume increases associated with the extensive hydriding from internal cladding corrosion. Subsequent development of the external accelerated corrosion rings resulted from disturbances in the protective corrosion film due to local straining and/or perhaps reduced corrosion resistance of zirconium hydride. In the intentionally defected rod with $\mathrm{UO}_{2}$ duplex pellets, irregularities in gamma ray intensity from a pellet near the defect hole were observed. Neutron radiography of this rod revealed the abnormality to be a fractured pellet with some rearrangement of the pellet fragments. The damage to the duplex pellet is believed to be the result of forces generated by the pressure buildup release through the defect hole during rod startup. The damage occurred during the first 30 days of irradiation and did not noticeably worsen during 118 days of additional irradiation.

These abnormalities are the result of defect operation and are not specifically related to the duplex pellet fuel design. The local high concentration of hydrogen in the cladding was caused by variations in cladding temperature associated with the alternating arrangement of fissile and fertile fuel pellets in the fuel stack. This problem can be solved by eliminating the thoria spacers and using other methods to maintain axial registry of the duplex pellet components. Fractured pellets near intentional defect holes have also been observed in previous LWBR tests with solid pellets. 


\section{C4.11.5 Destructive Examinations}

Destructive examinations were not completed for nondefected rods and only started on the $\mathrm{ThO}_{2}$ $\mathrm{UO}_{2}$ rod with intentionally defected cladding.

Over the depletion ranges covered, fission gas release percentages were for all four fuel systems being investigated in the D-1 test and appeared to depend on fuel depletion more than on fuel material. The highest release measured is $1.75 \%$ for a $\mathrm{ThO}_{2}-\mathrm{UO}_{2}$ rod with depletion in the annulus material of $18.9 \times 10^{20} \mathrm{f} / \mathrm{cc}$. $\mathrm{UO}_{2}$ and $\mathrm{ZrO}_{2}-\mathrm{UO}_{2}-\mathrm{CaO}$ rods with depletions of $\sim 12 \times 10^{20} \mathrm{f} / \mathrm{cc}$ had lower gas release, roughly in proportion to the annulus depletion.

Metallographic evaluations of the fuel components demonstrated that, macroscopically, all components appeared to be in good condition. Cracking of the duplex pellet components and the thoria spacers was observed, but geometrical integrity was maintained with no evidence of crushing or crumbling. No evidence was found for any of the fuel types of mass transport by evaporation of material from the high temperature (inside) surface of the duplex pellet annuli and condensation in colder regions of the rod.

The metallographic samples were analyzed using a Quantimet 720 Image Analyzing Computer to determine the total porosity and porosity-size distributions in the duplex pellet annuli. For all fuel material types, total porosity decreased during early irradiation. For the $\mathrm{UO}_{2}$ fuel, continued irradiation to $13.0 \times 10^{20} \mathrm{f} / \mathrm{cc}$ of annulus material resulted in continued reduction of porosity. For the $\mathrm{ZrO}_{2}-\mathrm{UO}_{2}-\mathrm{CaO}$ fuel, the existence of nonuniformly distributed large pores resulted in high variability of the Quantimet results and larger uncertainties in the porosity volume percents. However, disappearance of small-fabricated porosity early in life and emergence of very fine porosity believed to be fission gas bubbles with continued irradiation to $13.0 \times 10^{20} \mathrm{f} / \mathrm{cc}$ of annulus material is evident. The $\mathrm{ThO}_{2}-\mathrm{UO}_{2}$ fuel, irradiated to the highest depletion $\left(18.9 \times 10^{20} \mathrm{f} / \mathrm{cc}\right.$ of annulus material), also shows emergence of very small fission gas bubbles after initial disappearance of small pores; the translucency of the fuel and visibility of pores below the surface viewed complicates the pore volume analysis.

The dimensions of the duplex pellet components in the transverse metallographic samples were measured and, along with the fuel length changes derived from neutron radiography, were used to determine the effects of porosity changes and swelling effects on the fuel volume. For the $\mathrm{UO}_{2}$ and $\mathrm{ZrO}_{2}-\mathrm{UO}_{2}-\mathrm{CaO}$ fuels, both at compartment depletions of $\sim 6 \times 10^{20} \mathrm{f} / \mathrm{cc}$, decrease in the annulus volume is observed; whereas an increase in annulus volume is indicated for the $\mathrm{ThO}_{2}-\mathrm{UO}_{2}$ fuel at compartment depletion of $9.3 \times 10^{20} \mathrm{f} / \mathrm{cc}$. These volume changes correlate with the preirradiation densities of the pellets as shown in Table C-19.

Table C-19. Preirradiation density and volume change of fuel materials.

\begin{tabular}{lcc}
\hline Fuel Material & $\begin{array}{c}\text { Preirradiation Density } \\
(\% \mathrm{TD})\end{array}$ & $\begin{array}{c}\text { Volume Change } \\
(\%)\end{array}$ \\
\hline $\mathrm{UO}_{2}$ & 95.5 & -1.4 \\
$\mathrm{ZrO}_{2}-\mathrm{UO}_{2}-\mathrm{CaO}$ & 93.7 & -4.7 \\
$\mathrm{ThO}_{2}-\mathrm{UO}_{2}$ & 96.6 & +1.2 \\
\hline
\end{tabular}


For the $\mathrm{UO}_{2}$ and $\mathrm{ZrO}_{2}-\mathrm{UO}_{2}-\mathrm{CaO}$ materials, no appreciable change in grain size from that of the unirradiated fuel was noted. For the $\mathrm{ThO}_{2}-\mathrm{UO}_{2}$ material, considerable difficulty was experienced in developing grain structure by chemical etching. Indistinct grain boundaries were revealed near the pellet outside diameter with size unchanged from the unirradiated size. Throughout the inner regions of the annuli, a finer microstructure without the angular shape characteristic of grains was observed. At the high depletion of this material, $\left(18.9 \times 10^{20} \mathrm{f} / \mathrm{cc}\right.$ of fuel material $)$ it appears that subdivision of grains, perhaps associated with high concentration of fission products, may be occurring. This phenomenon does not appear to have had any deleterious effects on fuel performance.

The microstructure of the $\mathrm{ThO}_{2}$ components (central cores and spacer pellets) with maximum depletion of $\sim 0.5 \times 10^{20} \mathrm{f} / \mathrm{cc}$-compartment is little different from the unirradiated material. Although there appears to be a decrease in the population of very small pores, larger pores, which constitute the bulk of the porosity, are essentially unchanged in number or size. Grain size also is unchanged from the preirradiation condition.

Investigations of the rod cladding to develop data relative to stress-corrosion cracking included:

- Metallography to assess cladding internal corrosion and fuel-cladding mechanical and chemical interaction.

- Visual examination of the inside surface of cladding.

- $\quad$ Examination of the inside surface of the cladding on the Scanning Electron Microscope. The cladding surface morphology of the irradiated cladding and of unirradiated cladding was studied.

- $\quad$ Electron Microprobe analysis of the irradiated cladding inside surface to determine the elements present and the local distribution of each.

- $\quad$ Chemical analysis to determine the total amount of iodine and cesium present on the cladding inside surface and inside the cladding material.

- Macroscopically, the metallographic evaluation of the cladding revealed no evidence of cracking or other defects.

Corrosion of the external cladding surface resulted in an oxide layer typically $0.04-0.08$ mils (1-2 microns) thick. About $1 / 2$ of this corrosion was present following preirradiation corrosion testing. On the internal surface of the cladding from the higher depletion rods with $\mathrm{UO}_{2}$ and $\mathrm{ThO}_{2}-\mathrm{UO}_{2}$ fuel, localized patches (nodules) of corrosion, typically several microns thick and with maximum thickness of about 0.3 mil (10 microns), were observed. Visual examination of the cladding surfaces indicated these to be evenly distributed over the surface except at pellet interfaces where none were found. Electron microprobe analyses of the cladding from the $\mathrm{UO}_{2}$ and $\mathrm{ThO}_{2}-\mathrm{UO}_{2}$ fueled rods indicate the corrosion nodules to be sites of concentration of uranium, thorium (if present in the fuel) and fission products. The coincidence of cladding corrosion nodules and fuel material/fission products implies a fuel transfer and fission enhancement mechanism for the formation of the corrosion. Simple rubbing of the fuel material on the cladding could be the cause.

This explanation is reinforced by observed differences in patterns of corrosion nodules on the cladding which correlate with different methods of fuel pellet grinding. The $\mathrm{UO}_{2}$ fuel was centerless ground to diameter with the pellet simultaneously rotating and moving axially during the grinding. Corrosion nodules in the rod with $\mathrm{UO}_{2}$ fuel were randomly distributed. The $\mathrm{ThO}_{2}-\mathrm{UO}_{2}$ fuel was plunge ground to diameter. In plunge grinding, the pellets do not move axially resulting in a series of minute 
ridges and grooves on the pellet surface. In the rod with $\mathrm{ThO}_{2}-\mathrm{UO}_{2}$, the corrosion nodules tended to be aligned in circumferential rows. Thus, it appears that fuel material transfer to the cladding occurred at points of fuel-cladding contact.

The cladding inner surface for the rod with $\mathrm{ZrO}_{2}-\mathrm{UO}_{2}-\mathrm{CaO}$ fuel was observed metallographically to have a continuous corrosion film about 0.3 mil rather than the patchy corrosion noted in the rods with the other fuel types. Visual examination of the interior cladding surface confirmed that the corrosion film covered essentially the entire surface; in addition the examination showed a mosaic-like appearance with individual parts of the mosaic roughly equal to the size of the fragments of the cracked annulus. Electron microprobe analysis of the cladding surface indicated spatially uniform concentrations of uranium, calcium and fission products. The causes of the differing appearance of the cladding associated with the $\mathrm{ZrO}_{2}-\mathrm{UO}_{2}-\mathrm{CaO}$ fuel as compared to the cladding associated with the $\mathrm{UO}_{2}$ and $\mathrm{ThO}_{2}-\mathrm{UO}_{2}$ fuels is not well understood.

Corrosion nodules in the $\mathrm{UO}_{2}$ and $\mathrm{ThO}_{2}-\mathrm{UO}_{2}$ fueled rods using replicas of the cladding surfaces observed visually with a Scanning Electron Microscopy ranged from $<1$ mil to $\sim 3$ mils in diameter. In areas not affected by the corrosion nodules, the surface appeared very similar to the unirradiated tubing. For the $\mathrm{ZrO}_{2}-\mathrm{UO}_{2}-\mathrm{CaO}$ rod, Electron microscopy shows a structure of very closely spaced corrosion patches.

Measurements were made of the quantities of iodine and cesium on the inside surface of cladding samples from rods of the different fuel types. The $\mathrm{UO}_{2}$ and $\mathrm{ZrO}_{2}-\mathrm{UO}_{2}-\mathrm{CaO}$ fuel rods were at depletions of $\sim 6 \times 10^{20} \mathrm{f} /$ cc-compartment and the $\mathrm{ThO}_{2}-\mathrm{UO}_{2}$ rod was at depletion of $9.3 \times 10^{20} \mathrm{f} / \mathrm{cc}$-compartment. Iodine and cesium on the surface were collected by means of a rinse with dilute nitric acid. The cladding sample was then dissolved to obtain iodine and cesium that had penetrated below the surface. Concentrations of these fission products found on and in the cladding, assuming uniform distribution, are shown in Table C-20.

Table C-20. Fission product concentrations on and in the cladding.

\begin{tabular}{lcc}
\hline & \multicolumn{2}{c}{$\begin{array}{c}\text { Concentration } \\
\left(\mathrm{mg} / \mathrm{dm}^{2}\right)\end{array}$} \\
\cline { 2 - 3 } & Iodine & Cesium \\
\hline $\mathrm{UO}_{2}$ fueled rod 97-24 & 0.05 & 1.50 \\
$\mathrm{ZrO}_{2}-\mathrm{UO}_{2}-\mathrm{CaO}$ fueled rod $97-39$ & 0.05 & 0.85 \\
$\mathrm{ThO}_{2}-\mathrm{UO}_{2}$ fueled rod $97-17$ & 0.08 & 1.10 \\
\hline
\end{tabular}

Microprobing of the cladding surfaces indicated that in the $\mathrm{UO}_{2}$ and $\mathrm{ThO}_{2}-\mathrm{UO}_{2}$ rods, fission products were concentrated in corrosion nodules covering about $1 / 2$ of the surface. Thus, local concentrations of iodine and cesium for the $\mathrm{UO}_{2}$ and $\mathrm{ThO}_{2}-\mathrm{UO}_{2}$ rods might be about twice the values given in the above summary. In the $\mathrm{ZrO}_{2}-\mathrm{UO}_{2}-\mathrm{CaO}$ fueled rod, microprobing indicated uniform distribution of fission products.

The amounts of iodine found on or in the cladding of the three rods represent $0.26-0.31 \%$ of the amount of iodine calculated to have been generated in the fuel. These releases are a factor of 4-6 below the measured release of noble fission gases from the fuel. For cesium, the release percentages range from $0.16-0.34 \%$ and are a factor of $4-11$ less than the percentage release of noble fission gases. 
Based on the destructive examination results for nonintentionally defected D-1 test rods, it is concluded that performance capability of the duplex fuel system is excellent. For the range of depletion covered, fission gas release was low and fuel pellet integrity was maintained with minimal dimensional changes. No effects of irradiation beyond expectations were observed.

\section{C4.12 Irradiation Performance of Long Rod Duplex Fuel Pellet Bundle Test-LDR Test (Waldman, Sphar, and Alff 1982, WAPD-TM-1481)}

This test was conducted to investigate the performance characteristics of a long column of duplex fuel, interacting with the cladding, as distinguished from earlier tests of very short lengths of duplex fuel. The test was designated The Long Duplex Rod (LDR) Test. Six rods were used for the test (97-52, 97-53, 97-54, 97-55D, 97-57, and 97-58), all are contained in the scrap canister. The rods contained duplex-fuel stacks about $67 \mathrm{in}$. in length and were operated in a test reactor with a 48-in. fuel height; this resulted in an irradiated fuel length of about 63 in. The LDR Bundle Test was irradiated in the north and southeast test loops of the ATR; these loops provided separate pressure, flow, and heat removal systems, independent of those of the ATR facility; the ATR provided the neutron environment.

Individual fuel rod characteristics are listed in the report. All the fuel rods had fuel cladding diametric gaps in the range 4.4-8.8 mils; they were operated at relatively high power levels, characterized near BOL in the range $14-16.9 \mathrm{~kW} / \mathrm{ft}$, and to high depletions, the highest being $14.2 \times 10^{20} \mathrm{f} / \mathrm{cc}$ of compartment $\left(28.0 \times 10^{20} \mathrm{f} / \mathrm{cc}\right.$ of fuel annulus volume $)$ during normal testing. At the end of normal testing, five rods were irradiated at a power level higher than in the preceding cycle, for a period of about 27 days. Four rods experienced an increase in power in the range $40-49 \%$ and one rod $19 \%$. None of the rods failed. All dimensional data given in the report were obtained prior to the EOL high power cycle. Properties of the cladding are the same as those given for the D-1 tests given above.

Significant variables included in the test were the following:

- $\quad$ Three different fuel compositions were tested as the annular portion of the duplex fuel. These compositions were $\mathrm{UO}_{2}, \mathrm{ZrO}_{2}-\mathrm{UO}_{2}-\mathrm{CaO}$, and $\mathrm{ThO}_{2}-\mathrm{UO}_{2}$ respectively. In all cases, the central core pellet was $\mathrm{ThO}_{2}$.

- $\quad$ The duplex fuel was stacked with and without periodic full-diameter $\mathrm{ThO}_{2}$ spacer pellets. Spacer pellets were intended to maintain axial registry between the annulus and the core.

- $\quad$ Both SRA and RXA zircaloy cladding were used.

- $\quad$ Rod internal prepressurization levels of 100 and 500 psig at room temperature were established.

- In addition, one intentionally defected rod was tested.

Based on the resulting data, the following summary observations have been made:

Compared with fuel rods with RXA cladding, fuel rods with SRA cladding experienced greater elongation and more cladding diametric shrinkage in regions where pellet-cladding interaction (PCI) was absent.

Fuel rods prepressurized to 500 psig experienced less cladding elongation and less cladding shrinkage than fuel rods prepressurized to $100 \mathrm{psig}$, within each group of the two cladding types. 
No differences in performance characteristics could be assigned to any of the three fuel compositions. As evidenced by rod diameter change, the largest amount of PCI occurred with the rod having $\mathrm{ThO}_{2}-\mathrm{UO}_{2}$ fuel. This observation has no special significance, however, because this rod operated at the highest power and to the highest depletion.

No appreciable PCI occurred in rods with RXA cladding at intermediate peak depletions of $6.0 \times 10^{20}$ and $7.9 \times 10^{20} \mathrm{f} / \mathrm{cc}$ of compartment or at a high depletion of $11 \times 10^{20} \mathrm{f} / \mathrm{cc}$ of compartment. This determination was made from axial diameter profiles.

Measurable PCI occurred in fuel rods with SRA cladding at high-peak compartment depletions of $11.7 \times 10^{20}$ and $14.2 \times 10^{20} \mathrm{f} / \mathrm{cc}$ compartment.

Of the two fuel rods which experienced the largest length change (rods with SRA cladding), the rod with the most pellet-cladding interaction, as indicated by axial diameter traces, did not show the largest length increase. The reason for this behavior may be related to two possible mechanisms acting separately or in concert; namely, (1) radial expansion of cladding would be expected to be reflected in a corresponding axial shrinkage and (2) a decrease in axial ratcheting could occur due to local locking and compartmentalization of fuel within the cladding. The latter mechanism may be enhanced by the presence of spacer pellets.

Neutron radiography showed a fuel stack length increase of $0.18 \%$ at a low peak compartment depletion of $1.1 \times 10^{20} \mathrm{f} / \mathrm{cc}$, indicating little or no densification in the high density, high fission rate $\mathrm{UO}_{2}$ annular fuel.

Neutron radiographs of one fuel rod at a peak compartment depletion of $7.9 \times 10^{20} \mathrm{f} / \mathrm{cc}$, and a second rod at a peak compartment depletion of $11.7 \times 10^{20} \mathrm{f} / \mathrm{cc}$ indicate no loss in the mechanical integrity of the annular fuel column; i.e., no fragmentation of the annuli. Fuel stack growth of about $0.5 \%$ was observed for these rods.

The neutron radiograph of one fuel rod identified a 0.14-in. gap in the central-core thoria-pellet stack in the upper portion of the rod, and a gap of $0.52 \mathrm{in}$. between the top of the central-core thoria-pellet stack and the top of the annular fuel stack. Based on these observations, the annular fuel stack was 0.66 in. longer than an uninterrupted central core stack. This rod was fabricated with no thoria spacer pellets and a central thoria core length 0.2 in. less than the annular fuel length to form an intentional axial gap. Comparison with an X-ray of the as-built rod revealed that the annular fuel stack had grown 0.37 in., and the central-core thoria-stack had contracted 0.09 in.

A comparison was made of cladding elongation between two groups of rods, both had SRA cladding and one operated with solid $\mathrm{ThO}_{2}-\mathrm{UO}_{2}$ pellets; the other was the LDR test with $\mathrm{UO}_{2}$ and $\mathrm{ThO}_{2}-\mathrm{UO}_{2}$ duplex pellets. These rods all operated with similar power and fuel cladding gaps. Based on the data, less PCI-induced length change occurs with duplex fuel.

Based on fuel rod-to-fuel rod gap measurements, no significant fuel rod bowing occurred over the life of the test.

The intentionally defected rod was fabricated with a 5-mil diameter hole but experienced a water logging event that increased the diameter of the unirradiated portion of the rod; this reached a stress level near yield and caused an apparent flux-induced creep bulging in the power region.

The intentionally defected rod, which had $\mathrm{ThO}_{2}$ spacer pellets between adjacent duplex pellets, developed hydride rims and subsequent accelerated corrosion on the external surface of the cladding at 
the locations of the spacer pellets. These hydride rims were revealed in axial diameter traces and in neutron radiographs showing a typical hydride color contrast in cladding over thoria spacers. These hydride rims could result in cladding embrittlement and reduced load carrying capacity.

It is concluded that this program demonstrated satisfactory performance of the test bundle and of fuel rods containing duplex fuel pellets, which were irradiated to high fuel-annulus depletion and through a severe transient.

\section{C4.13 Experimental Results of the Irradiation of Long Rod Duplex Pellet Screening Tests in the NRX Reactor, New Long Duplex Rod (NLDR) Test (Hoffman, Yerman and Alff 1982, WAPD-TM-1492)}

One of the designs developed by the AWBA program for a commercial-scale, prebreeder reactor core was based upon the use of fuel rods containing duplex pellets. A duplex pellet consists of a cylindrical thoria central pellet within an oxide annulus that contains fissile material. During irradiation, ${ }^{232} \mathrm{Th}$ in the central pellet is converted to ${ }^{233} \mathrm{U}$ for subsequent use in a breeder reactor core. If $\mathrm{a} \mathrm{UO}_{2}$ annulus is used, it can be chemically separated from the thoria central pellet following irradiation so that the ${ }^{233} \mathrm{U}$ in the central pellet is kept free of contamination by other uranium isotopes. Freedom from contamination could also be achieved by use of separate fissile and fertile fuel rods. However, reactor core power densities comparable to those of commercial cores cannot be achieved when the thorium fraction in a separate fuel rod core is high enough for efficient production of ${ }^{233} \mathrm{U}$.

There are also a number of advantages of duplex pellets over solid pellets in both breeders and commercial reactor core applications. These advantages result mainly from the low operating fuel temperature. An irradiation test program was undertaken at Bettis to support development of duplex-pellet fuel rods. The New Long Duplex Rod (NLDR) test series (designated NLDR-1, NLDR-2, NLDR-3, and NLDR-4) was one part of this irradiation test program. The NLDR tests used six 110-in.-long, 0.3-in.-diameter Zircaloy-4 clad rods containing duplex pellets. The principal design variables are given in Table C-21. The NLDR test series was accomplished in the NRX reactor at the Chalk River Nuclear Laboratory in Chalk River, Ontario, Canada.

Table C-21. Principal design variables.

\begin{tabular}{lclclc}
\hline Rod ID & Test & \multicolumn{1}{c}{$\begin{array}{c}\text { Annular Pellet } \\
\text { Composition }\end{array}$} & $\begin{array}{c}\text { Fuel Cladding } \\
\text { Gap } \\
\text { (mils) }\end{array}$ & \multicolumn{1}{c}{ Special Features } & $\begin{array}{c}\text { Total } \\
\text { Trradiation }\end{array}$ \\
\hline $97-61$ & $\mathrm{NLBR}-1$ & $\mathrm{UO}_{2}-\mathrm{ZrO}_{2}-\mathrm{CaO}$ & 55 & None & 11,149 \\
$97-62$ & $\mathrm{NLBR}-1$ & $\mathrm{UO}_{2}$ & 55 & None & 11,149 \\
$97-64$ & $\mathrm{NLBR}-2$ & $\mathrm{ThO}_{2}-\mathrm{UO}_{2}$ & 55 & None & 10,281 \\
$97-65$ & $\mathrm{NLBR}-2$ & $\mathrm{UO}_{2}$ & 36 & None & 6,340 \\
$97-123$ & $\mathrm{NLBR}-3$ & $\mathrm{UO}_{2}$ & 36 & 2 plenum springs & 8,056 \\
$97-162$ & $\mathrm{NLBR}-4$ & $\mathrm{UO}_{2}$ & 43 & Longer central pellets & 4,115 \\
\hline
\end{tabular}


The test series was conducted to:

- $\quad$ Evaluate the behavior of duplex fuel pellets in long rods with pellet-cladding interaction axial loads similar to those that would be experienced by fuel rods in commercial service

- $\quad$ Compare the performance of $\mathrm{UO}_{2}$ and $\mathrm{UO}_{2}-\mathrm{ZrO}_{2}-\mathrm{CaO}$ duplex pellet fuel systems at power levels adjusted to reflect relative melting points

- $\quad$ Compare the performance $\mathrm{UO}_{2}$ duplex fuel with a smaller cladding gap

- $\quad$ Compare the performance of fuel rod containing two plenum springs with fuel that has one spring

- $\quad$ Assess the effect of longer central thoria pellets on rod behavior.

The conclusions drawn from the testing are as follows:

- All fuel rods experienced relatively small overall external dimensional changes with irradiation up to $17.8 \times 10^{20} \mathrm{f} / \mathrm{cc}$ compartment (about $35.6 \times 10^{20} \mathrm{f} / \mathrm{cc}$ annulus).

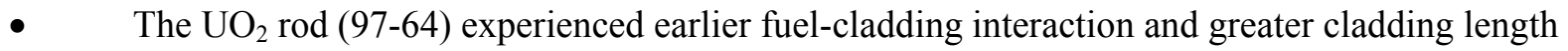
increases than the $\mathrm{UO}_{2}-\mathrm{ZrO}_{2}-\mathrm{CaO}$ rod (97-61) irradiated under the same conditions.

- $\quad$ Beyond about $12-13 \times 10^{20} \mathrm{f} / \mathrm{cc}$ peak depletion, both rods experienced cladding length decreases. This phenomenon had not been previously observed in Bettis long rod tests of solid $\mathrm{ThO}_{2}-\mathrm{UO}_{2}$ fuel pellets irradiated in the LWBR program.

- $\quad$ Large gap $\mathrm{ThO}_{2}-\mathrm{UO}_{2}$ rod (97-64) exhibited overall length increase less than those of the large gap $\mathrm{UO}_{2}$ rod (97-62) but greater than those noted for the large gap $\mathrm{UO}_{2}-\mathrm{ZrO}_{2}-\mathrm{CaO}$ rod (97-61).

- Small gap $\mathrm{UO}_{2}$ rod (97-65) experienced greater length increases and an earlier "turn around" in length change than large gap $\mathrm{UO}_{2}$ rod (97-62).

- $\quad$ At comparable depletions, small gap $\mathrm{UO}_{2}$ rod (97-123) with two plenum springs experienced less length increase than any other $\mathrm{UO}_{2}$ rod in the test; some of this difference is attributed to operation at only $75-80 \%$ of design power for about $1 / 3$ of the lifetime.

- $\quad \mathrm{UO}_{2}$ rod (97-162) with long central pellets experienced a greater initial length increase than any other NLDR test rod but its behavior at intermediate depletions was typical of the other $\mathrm{UO}_{2}$ rods in the test.

- $\quad$ Closure of both the fuel-to-cladding and annulus-to-central pellet gaps resulted in significant cladding diameter increases due to continued radial swelling of the fuel. This phenomenon was observed in all three fuel systems.

\section{C4.14 In-Pile and Out-of-Pile Corrosion Behavior of Thoria-Urania Pellets (Clayton 1987a, WAPD-TM-1548)}

A total of 19 LWBR irradiation test rods from 14 irradiation tests (summarized in the report) composed the database for the in-pile portion of the fuel stability study. Nine of the rods are contained in 
the scrap canister (79-301D, 79-307D, 79-322D, 79-433D, 79-441D, 79-504D, 79-583D, 79-609D, and 79-614D). The 19 fuel rods contained $\mathrm{ThO}_{2}, \mathrm{ThO}_{2}{ }^{235} \mathrm{UO}_{2}$, and $\mathrm{ThO}_{2}{ }^{233} \mathrm{UO} 2$ fuel pellets. The rods (14 seed and 5 blanket) were intentionally defected with drilled holes prior to testing. A larger ( $\sim 0.089$-cm diameter) spotting hole was first drilled halfway through the Zircaloy-4 cladding from the outside surface and then continued through the wall to the inside surface with a smaller 5-mil diameter $(\sim 0.013-\mathrm{cm}$ diameter) defect hole. Irradiation histories of the 19 defected rods are given; irradiation exposures were up to 19,970 EFPH with peak fluences ( $>1 \mathrm{Mev}$ ) of up to $98 \times 10^{20} \mathrm{n} / \mathrm{cm}^{2}$. The coolant for these irradiation tests was pressurized water maintained at $\mathrm{pH} 10$ by $\mathrm{NH}_{4} \mathrm{OH}$ addition. Coolant oxygen, hydrogen, and chlorine concentrations were $<0.14 \mathrm{ppm}, 40-70 \mathrm{cc} / \mathrm{kg}$, and $<0.1 \mathrm{ppm}$, respectively. The irradiation tests were performed in the ETR, the ATR and the NRX. A summary of the in-pile testing results follows.

- $\quad$ Satisfactory fuel performance was demonstrated in the $\mathrm{ThO}_{2}$ and $\mathrm{ThO}_{2}-\mathrm{UO}_{2}$ fueled defected LWBR test rods irradiated to peak depletions up to $12 \times 10^{20} \mathrm{f} / \mathrm{cc}$ and peak fast neutron $(>1 \mathrm{Mev})$ fluences up to $98 \times 10^{20}$ neutron $/ \mathrm{cm}^{2}$.

- $\quad$ Excellent fuel chemical, mechanical, and thermal behavior was shown for operating conditions up to peak linear power levels of $518 \mathrm{w} / \mathrm{cm}$, peak heat fluxes up to $189 \mathrm{w} / \mathrm{cm}^{2}$, and peak center temperatures up to $2366 \mathrm{~K}$.

- $\quad$ No evidence of significant corrosion or erosion of the fuel pellets was observed. Nine of the 19 intentionally defected rods displayed some minor indications of corrosion-erosion; white or gray streaks or spots manifested this just around or downstream from the defect hole openings. These effects were only observed in the area around the defect and were most likely the result of a limited amount of fuel, fission product, or contaminated zircaloy corrosion locally downstream of the hole.

- No other indications of fuel corrosion-erosion were detected. The $\mathrm{ThO}_{2}$ and $\mathrm{ThO}_{2}-\mathrm{UO}_{2}$ fuel pellets, when compared with previous in-pile tests on $\mathrm{UO}_{2}$ and $\mathrm{ZrO}_{2}-\mathrm{UO}_{2}$ fuels, had lower levels of released activity, slower fission product leaching, and minimal fuel solution and attrition by the coolant.

No fuel grain growth was detected but there was some migration of porosity to the grain boundaries. Fuel cracking occurred as would be expected for long-term operation of both defected and nondefected fuel rods. No evidence of fuel waterlogging was observed. (Waterlogging is deformation of the cladding caused by excessive internal fuel rod pressure of entrapped coolant as it flashes to steam during a power increase).

The conclusions drawn from the testing are as follows:

- Both $\mathrm{ThO}_{2}$ and homogeneous $\mathrm{ThO}_{2}-\mathrm{UO}_{2}\left(2-30 \mathrm{w} / \mathrm{o} \mathrm{UO}_{2}\right)$ fuel pellets have excellent corrosion resistance - even in oxygenated, high temperature, pressurized water.

- Thoria-urania is one of the most corrosion resistant of all $\mathrm{UO}_{2}$ solid solution oxide fuels. Even when oxidative attack does occur, the mode of oxidation, growth of a second cubic phase, permits the $\mathrm{ThO}_{2}-\mathrm{UO}_{2}$ samples to maintain their integrity.

- Maintenance of fuel integrity in defected irradiation test rods was consistent with the favorable stability of out-of-pile corrosion tests on thoria-base fuel pellets. 
- Under the defect condition of exposure to high temperature water containing an oxidant $\left(\mathrm{H}_{2} \mathrm{O}_{2}\right.$ or $\mathrm{O}_{2}$ from fission fragment radiolysis of the water coolant), thoria-base fuels exhibit: (1) slower fission product leaching, (2) lower levels of released activity, and (3) slower fuel solution and attrition by the coolant than is the case for $\mathrm{UO}_{2}$ and $\mathrm{ZrO}_{2}-\mathrm{UO}_{2}$ fuel systems.

- $\quad$ Both the in-pile and out-of-pile test results support the conclusion that LWBR-type fuel rods containing $\mathrm{ThO}_{2}$ and $\mathrm{ThO}_{2}-\mathrm{UO}_{2}$ pellets can successfully operate in the defect condition with limited radioactivity release to the coolant.

\section{C4.15 Internal Hydriding in Irradiated Defected Zircaloy Fuel Rods-A Review (Clayton 1987b, WAPD-TM-1604)}

The review summarizes the test data, causes, mechanism, and methods of minimizing internal hydriding failures in defected zircaloy-clad fuel rods. A defect is defined as a breach of cladding integrity, i.e., a perforation (slit. crock. or pinhole) that leaks fission products to the coolant and coolant to the rod internals. Many defected zircaloy-clad fuel rods operated satisfactorily without diminishing core performance. A fuel rod failure is defined as loss of cladding integrity, high coolant activity level, and contamination of the coolant by particulate fuel.

Two types of hydriding, external hydriding produced by hydrogen outside the fuel rod and internal hydriding due to reactions inside the fuel rod, were identified in zircaloy-clad fuel rods. Internal hydriding is further classified as primary or secondary hydriding. Primary hydriding is generated internally in an initially nondefected zircaloy fuel rod. Its sources are hydrogenous contaminants (moisture, oil, grease, etc.) introduced into the fuel rod during fabrication as well as any residual hydrogen in the oxide fuel resulting from the hydrogen sintering operation. In secondary hydriding the initial breach of the zircaloy cladding is caused either by primary hydriding itself or by a nonhydride-related incident that allows coolant to enter and hydride the rod. Examples of a nonhydriding incident include stress-corrosion cracking induced by pellet-cladding interaction, power ramp, aggressive fission product attack, rod-to-rod contact causing high cladding temperatures, cladding wear at support grid contact points, etc. The report reviewed the problem of secondary hydriding, mainly in pressurized water reactors where the coolant contains some dissolved hydrogen.

Hydrogen pickup in zircaloy fuel rods falls into three categories: expected due to corrosion, accelerated, and massive. Expected hydrogen pickup results from the additional hydrogen that enters the zircaloy cladding through the $\mathrm{ZrO}_{2}$ corrosion film (about 50-500 ppm). Accelerated hydriding is defined as hydrogen absorption from the coolant far in excess of the nominal $25 \%$ pickup fraction of free $\mathrm{H}_{2}$ produced by the $\mathrm{Zr}-\mathrm{H}_{2} \mathrm{O}$ corrosion reaction for Zircaloy-4 (several thousand ppm). Massive hydriding is the formation of regions of delta phase zirconium hydride in the cladding due to grossly accelerated hydrogen pickup (16,300 ppm). At operating temperatures for PWRs, zirconium is thermodynamically unstable with respect to hydrogen and should completely hydride. The protective corrosion oxide surface film prevents the gaseous hydrogen in the coolant from reacting with the bare zircaloy.

As part of the review intentionally defected rods from pre-LWBR tests, the LWBR (19 fuel rods - identification numbers of the rods in the scrap canister are given above), and the AWBA programs (3 fuel rods-97-36D is in the scrap canister) were analyzed. 


\section{C4.15.1 Pre-LWBR Tests}

The Bettis Laboratory was one of the first to study the behavior of defected zircaloy-clad $\mathrm{UO}_{2}$ fuel rods in-pile and the factors affecting the limit of their performance. The initial work was carried out in the 1950s in support of the Shippingport PWR Core I blanket rods. Excessive cladding hydriding was observed in both intentionally defected rods and in rods that operationally defected in-pile (unintentionally defected). Hydrogen contents of 100-200 ppm were found in cladding near defects and $1400 \mathrm{ppm}$ at the ends of the rods. Either the intentionally fabricated defect holes of some rods became plugged or the areas of the rod away from the defect hole became effectively isolated and behaved as though the rods were not defected. In any case, the cladding of these rods became stressed and ruptured during irradiation with resultant hydriding.

Since 1960, massive internal hydriding was found only in rods that operationally defected in-pile. Sixteen such in-pile defected rods were observed. Fuel compositions were mainly $\mathrm{UO}_{2}, \mathrm{ZrO}_{2}-\mathrm{UO}_{2}$ and $\mathrm{UO}_{2}-\mathrm{ZrO}_{2}-\mathrm{CaO}$. Irradiation periods in the defected state after cladding rupture varied from about five minutes to approximately 200 days. Cladding cracking, both ductile and brittle, was attributed to bad welds, burnout caused by molten fuel, cladding instability due to fuel swelling, and water logging. All 16 rods were destructively examined, and extensive areas of massive internal hydride were detected in 13 of them. Both accelerated and massive hydriding occurred at remote locations from the defect. Two of the remaining rods were found to have brittle cladding fractures. Hydride-was observed mainly in the cladding near the end caps. The cladding over the fuel stacks was relatively free of hydride. The last rod waterlogged and displayed only an overall high hydrogen content in the cladding (about $300 \mathrm{ppm}$ ) but did not exhibit massive hydriding.

Thirty intentionally fabricated defected rods were tested between 1960-1970. These rods were fabricated with various pellet geometries (annular, dished-end, solid), pellet densities (84-98\% theoretical), and fuel materials $\left(\mathrm{UO}_{2}, \mathrm{ZrO}_{2}-\mathrm{UO}_{2}, \mathrm{ThO}_{2}-\mathrm{UO}_{2}\right)$. The irradiation performance of these intentionally defected rods was satisfactory. Postirradiation fuel structures ranged from that of the preirradiation structures to almost total fuel melting.

Three cases of water logging occurred in these intentionally fabricated defected rods. Cladding diameter swelling was measured in a $\mathrm{UO}_{2}$-fuel and a $\mathrm{ZrO}_{2}-\mathrm{UO}_{2}$ fuel rod. Another $\mathrm{ZrO}_{2}-\mathrm{UO}_{2}$ fuel rod ruptured resulting in cladding hydrogen concentrations of about $500 \mathrm{ppm}$, but massive internal hydriding was not found. This failure was attributed to excessive plastic straining caused by repeated water logging incidents during irradiation. With the exception of the ruptured rod, there were no detectable fuel losses associated with the irradiation of these 30 intentionally defected fuel rods.

Six of these intentionally defected rods contained $\mathrm{ThO}_{2}-\mathrm{UO}_{2}$ fuel. There were no unusual incidents during the irradiation of these rods indicating satisfactory performance.

The pre-LWBR test data can be summarized as follows:

- $\quad$ Fuel rods with intentionally fabricated defects generally did not excessively hydride.

- $\quad$ Fuel rods that defected in-pile generally had areas of accelerated or massive hydriding.

\section{C4.15.2 LWBR Tests}

The Shippingport LWBR core contained 12 hexagonal-shaped modules that were arranged in a symmetric array surrounded by 15 reflector modules. Each of the hexagonal fuel modules contained a central movable seed assembly surrounded by a stationary blanket assembly. The fuel was $\mathrm{ThO}_{2}$ and 
$\mathrm{ThO}_{2}-\mathrm{UO}_{2}$ pellets that were sealed in Zircaloy-4 tubes. The absence of higher-than-expected coolant activity during operation indicated that there was no detectable breach of the cladding in any of the LWBR rods.

As part of the LWBR irradiation test program, 19 fuel rods (14 seed and 5 blanket) were intentionally defected with drilled holes (0.005-in. diameter) prior to testing. In addition, two blanket test rods developed small cladding defects during planned in-service transient testing. The transient testing was at higher heating rates than occurred during LWBR reactor operations.

All 21 defected test rods operated successfully with limited radioactivity release to the coolant. No significant $\mathrm{ThO}_{2}$ or $\mathrm{ThO}_{2}-\mathrm{UO}_{2}$ fuel erosion was detected. Because of the greater internal surface corrosion, the total hydrogen content in the defected rod cladding was several times those in nondefected rod cladding with similar irradiation histories $100-500 \mathrm{ppm}$ compared to 30-70 ppm hydrogen. A pronounced variation in hydride concentration was observed through the cladding wall thickness of the defected rods. Hydrogen levels in the cladding were higher at the external surface than at the internal surface because hydrogen diffuses toward the cooler region in a sufficiently high thermal gradient. The hydride concentrations for nondefected rod cladding were relatively uniform.

Hydrides in the vicinity of the defect hole were generally low in concentration with typical uniform levels of about $100 \mathrm{ppm}$. This might occur from hydrogen escaping through the defect hole resulting in a low $\mathrm{H}_{2} / \mathrm{H}_{2} \mathrm{O}$ ratio or hydrogen diffusion to adjacent cooler cladding areas. Evidence of hydrogen migration to cooler regions of the rods remote from the defect hole was observed, indicating that local hydrogen levels are not always proportional to corrosion oxide thickness in defected rods.

Instances of localized accelerated and massive hydriding were detected in three intentionally defected and one operationally defected fuel rod. None of these incidents interfered with the operation of the irradiation tests. For example, one rod that defected in service due to iodine stress corrosion cracking operated successfully for about 12,000 EFPH. This rod was operational even though during postirradiation examination the cladding was observed to be massively hydrided near the bottom end of the rod. None of these hydrided rods lost structural integrity during operation, which attests to their ability to function under localized and massive hydriding conditions.

\section{C4.15.3 AWBA Tests}

The AWBA program used a duplex pellet concept. The duplex pellet design consisted of a cylindrical thoria central core inside an oxide annulus that contained the initial fissile material.

Transmutation of the thorium in the duplex pellet to ${ }^{233} \mathrm{U}$ provides fuel for use in subsequent breeders. The irradiation test program supporting development of the duplex fuel pellet included three intentionally fabricated defected rods, two with $\mathrm{UO}_{2}$ and one with $\mathrm{ThO}_{2}-\mathrm{UO}_{2}$ annuli.

Some slight erosion was noted in the $\mathrm{UO}_{2}$ fueled defected rod. The irradiation performance of the $\mathrm{ThO}_{2}-\mathrm{UO}_{2}$ fueled defected rod compared favorably with that of the LWBR solid $\mathrm{ThO}_{2}-\mathrm{UO}_{2}$ pellet irradiation tests. Circumferential white corrosion rings were observed on the outside cladding surface of the defected rod with the $\mathrm{ThO}_{2}-\mathrm{UO}_{2}$ annulus at the locations of 50-mil-thick $\mathrm{ThO}_{2}$ spacers separating the duplex pellets in the fuel stack. Neutron radiography and metallographic examination of the cladding showed that the white corrosion rings were associated with substantial nonuniform concentrations of hydrogen in the cladding, with the regions affected by the corrosion rings coinciding with the regions of heaviest hydrogen concentration. In regions of cladding adjacent to the $\mathrm{ThO}_{2}-\mathrm{UO}_{2}$ annulus, hydrogen concentrations ranged from $<100 \mathrm{ppm}$ near the inner surface to several hundred ppm or more near the outer surface. In the cooler cladding adjacent to $\mathrm{ThO}_{2}$ spacer pellets, much higher concentrations of hydrogen were observed. These concentrations varied from about $500 \mathrm{ppm}$ near the inner surface to 
approximately $12,000 \mathrm{ppm}$ in a rim about 3 to 5 mils thick at the outer surface. The fuel stack arrangement in this rod, consisting of pellets containing the fissile material (with high power and heat generation) interspersed with the $\mathrm{ThO}_{2}$ spacers (with lower power and heat output), generated hydrogen cold traps in the cladding.

Diameter measurements revealed ridging of the cladding at the locations of the white corrosion rings. The average diametric ridge height was 0.8 mil with a maximum of 1.2 mils. This ridging could be caused by the volumetric increases associated with the extensive hydriding. Subsequent development of the accelerated white corrosion rings then resulted from disturbances in the protective corrosion film due to local straining and/or reduced corrosion resistance of zirconium hydride.

A summary of the review follows:

- Intentionally defected zircaloy test rods usually do not excessively hydride.

- Zircaloy fuel rods that defect in service generally acquire localized areas of accelerated or massive hydride.

- $\quad$ Both intentionally and operationally defected fuel rods with local areas of accelerated and massive zirconium hydride can operate without failure for extended periods of time under restricted power conditions.

- $\quad$ Out-of-pile zirconium hydriding test data in $\mathrm{H}_{2} / \mathrm{H}_{2} \mathrm{O}$ gas mixtures shows that specimen characteristics (geometry and surface conditions) as well as environmental factors (hydrogen pressure, test temperature. and test time) affect the amount of hydrogen pickup in zircaloy. In addition, the type of zircaloy ( 2 or 4 ), the heat treatment, and minor variations in the alloying conditions were also found to influence hydrogen absorption.

- The significant factors affecting internal hydriding in defected zircaloy rods are defect size, sources of hydrogen, zircaloy cladding inside surface properties, aggressive fission product attack on inner oxide film, nickel alloy contamination of zircaloy, and the effects of heat flux and fluence.

- $\quad$ Pertinent in-pile and out-of-pile test data and the significant factors affecting internal hydriding in defected zircaloy fuel rods are used as a data base in constructing a descriptive model which explains hydrogen distribution in zircaloy cladding of defected water-cooled reactor fuel rods.

- $\quad$ Methods for minimizing secondary hydride failures in defected zircaloy fuel rods include control of hydride orientation, protective coatings, hydrogen getters, and power operating restrictions.

\section{C5. REFERENCES}

Belle, J., and R. M. Berman, 1978, Properties of Thoria and Thoria-Urania: A Review, (LWBR Development Program), WAPD-TM-1340, June 1978.

Clayton, J. C., 1982, Corrosion and Hydriding of Irradiated Zircaloy Fuel Rod Cladding, (LWBR Development Program), WAPD-TM-1440, September 1982.

Clayton, J. C., 1985, Cladding Corrosion and Hydriding in Irradiated Defected Zircaloy Fuel Rods, (LWBR Development Program), WAPD-TM-1393, August 1985. 
Clayton, J. C., 1987a, In-Pile and Out-of-Pile Corrosion Behavior of Thoria-Urania Pellets, (LWBR Development Program), WAPD-TM-1548, January 1987.

Clayton, J. C., 1987b, Internal Hydriding in Irradiated Defected Zircaloy Fuel Rods-a Review, (LWBR Development Program), WAPD-TM-1604, October 1987.

Daniel, R. C., 1970, In-Pile Dimensional Changes of Zircaloy-4 Tubing Having Low Hoop Stresses, (LWBR Development Program), WAPD-TM-973, July 1970.

Duncombe, E. and I. Goldberg, 1970, Comparison of Dimensional Changes in Fuel Rods with Predictions under Cyclic conditions of Power and System Pressure, (LWBR Development Program), WAPD-TM-940, March 1970.

Giovengo, J. F., I. Goldberg, and C. D. Sphar, 1978, Fission Gas Release From High burnup ThO $\mathrm{T}_{2}$ and $\mathrm{ThO}_{2}-\mathrm{UO}_{2}$ Fuels Irradiated at Low Temperature, (LWBR Development Program), WAPD-TM-1350ADD2, August 1978.

Giovengo, J. F., 1970, In-Pile Dimensional Changes of $\mathrm{ThO}_{2}-\mathrm{UO}_{2}$ Fuel Rods with Non-Free-Standing Cladding, (LWBR Development Program), WAPD-TM-986, November 1970.

Goldberg, I., 1969, A Procedure for Calculation of Stead-State Temperature in Zircaloy-Clad Bulk Oxide Fuel Elements Using the FIGRO Computer Program, WAPD-TM-757, November 1969.

Goldberg, I., et al., 1979, Fission Gas Release and Grain Growth in $\mathrm{ThO}_{2}$ and $\mathrm{ThO}_{2}-\mathrm{UO}_{2}$ Fuel Irradiated at High Temperature, (LWBR Development Program), WAPD-TM-1350ADD, July 1979.

Goldberg, I., et al., 1982, Fission Gas Release From $\mathrm{ThO}_{2}$ and $\mathrm{ThO}_{2}-\mathrm{UO}_{2}$ Fuels, (LWBR Development Program), WAPD-TM-1350, May 1982.

Hoffman, R. C., and J. Sherman, 1978, Irradiation Testing of Internally Pressurized and/or Graphite Coated Zircaloy-4 clad Fuel Rods in the NRX Reactor, (AWBA Development Program), WAPD-TM-1376, November 1978.

Hoffman, R. C., J. F. Yerman, and T. H. Alff, 1982, Experimental Results of the Irradiation of Long Rod Duplex Pellet Screening Test in the NRX Reactor (NLDR-1 Test), (AWBA Development Program), WAPD-TM-1492, July 1982.

Ivak, D. M. and L. A. Waldman, 1979, Iodine and Cesium in Oxide Fuel Pellets and Zircaloy-4 Cladding of Irradiated Fuel Rods, (LWBR Development Program), WAPD-TM-1394, March 1979.

Newman, J. B., J. F. Giovengo, and L. P. Comden, 1977, The CYGRO-4 Fuel Rod Analysis Computer Program, WAPD-TM-1300, July 1977.

Pruss, C. A., 1987, ICPP Fuel Receipt Criteria for LWBR Core and Irradiation Test Fuel, WAPD-NRF(L)D-96, August 10, 1987 and W. J. Babyak, Revised Response to ICPP Fuel Receipt Criteria, Parts $A$ and B, for the LWBR Irradiation Test Fuel, WAPD-NRF(L)D-110, September 23, 1987.

Sphar, C. D., and J. Sherman, 1979, Early-in-life Performance of Short Rod Duplex Pellet Screening (D-1) Test, WAPD-TM-1378, November 1979. 
Sphar, C. D., D. A. Mertz, and W. S. Roesener, 1982, Irradiation Performance of Duplex Fuel Pellet Test Rods Depleted to $9 \times 10^{20}$ Fissions $/ \mathrm{cm}^{3}$ of Compartment-D-1 Test, (AWBA Development Program), WAPD-TM-1460, January 1982.

Stackhouse, R. M., ed., 1979, Fuel Rod-Grid Interaction Wear: In-Reactor Tests, (LWBR Development Program), WAPD-TM-1347, November 1979.

Waldman, L. A., C. D. Sphar, and T. H. Alff, 1982, Irradiation Performance of Long Rod Duplex Fuel Pellet Bundle Test-LDR Test, (AWBA Development Program), WAPD-TM-1481, April 1982.

Warner, H. R., 1969, Release of Fission Gases from Oxide Fuels, (LWBR Development Program), WAPD-TM-805, July 1969. 
Appendix D

Rods in the Type C Storage Liners 


\section{Appendix D}

\section{Rods in the Type C Storage Liners}

The rod serial numbers and end-of-life isotopic contents are presented below, sorted first by liner number then by liner cell. The liner cell numbers correspond to Figures 6-17 through 6-23. The first two digits of the rod serial numbers for the seed and blanket rods indicate the rod type.

The data in the tables are end-of-life isotopic data based on modeling done before the time of shipment. These data were extracted from tables attached to the Part B Fuel Receipt Criteria for the Type C (loose rod) storage liners. These data are presented here for convenience. Refer to the original documentation to confirm the accuracy of transcription. 


\begin{tabular}{|c|c|c|c|c|c|c|c|c|c|c|}
\hline $\begin{array}{c}\text { Liner } \\
\text { Cell } \\
\end{array}$ & $\begin{array}{c}\text { Rod } \\
\text { Number }\end{array}$ & $\begin{array}{c}\text { Liner } \\
\text { Number }\end{array}$ & $\begin{array}{c}\text { Assembly } \\
\text { Number }\end{array}$ & Liner no. & $\begin{array}{c}\text { POB } \\
\text { Category }\end{array}$ & $\begin{array}{c}\text { Th-232 } \\
(\mathrm{kg})\end{array}$ & $\begin{array}{c}\mathrm{U}-232 \\
(\mathrm{~g})\end{array}$ & $\begin{array}{c}\mathrm{U}-233 \\
(\mathrm{~g})\end{array}$ & $\begin{array}{c}\mathrm{U}-234 \\
(\mathrm{~g})\end{array}$ & $\begin{array}{c}\mathrm{U}-235 \\
(\mathrm{~g}) \\
\end{array}$ \\
\hline 101 & 3120818 & 15681 & L-RA01-10 & R 4-3 & 43 & 6.09 & 0.00 & 4.54 & 0.03 & 0.00 \\
\hline 102 & 3116829 & 15681 & L-RA01-10 & R 4-3 & 47 & 6.04 & 0.04 & 30.97 & 1.12 & 0.09 \\
\hline 103 & 3225352 & 15681 & L-RA01-10 & R 4-3 & 44 & 6.09 & 0.00 & 9.36 & 0.10 & 0.00 \\
\hline 104 & 3214013 & 15681 & L-RA01-10 & R 4-3 & 45 & 6.08 & 0.01 & 15.31 & 0.28 & 0.01 \\
\hline 105 & 3206266 & 15681 & L-RA01-10 & R 4-3 & 46 & 6.08 & 0.02 & 22.42 & 0.59 & 0.04 \\
\hline 144 & 3116443 & 15681 & L-RA01-09 & R 4-4 & 40 & 6.08 & 0.01 & 16.57 & 0.32 & 0.01 \\
\hline 145 & 3122403 & 15681 & L-RA01-09 & R 4-4 & 41 & 6.07 & 0.02 & 23.53 & 0.65 & 0.04 \\
\hline 146 & 3116508 & 15681 & L-RA01-09 & R 4-4 & 41 & 6.07 & 0.02 & 23.53 & 0.65 & 0.04 \\
\hline 147 & 3116755 & 15681 & L-RA01-09 & R 4-4 & 41 & 6.07 & 0.02 & 23.53 & 0.65 & 0.04 \\
\hline 148 & 3124547 & 15681 & L-RA01-09 & R 4-4 & 42 & 6.04 & 0.04 & 32.39 & 1.22 & 0.10 \\
\hline 149 & 3121009 & 15681 & L-RA01-09 & R 4-4 & 42 & 6.04 & 0.04 & 32.39 & 1.22 & 0.10 \\
\hline 150 & 3215104 & 15681 & L-RA01-09 & R 4-4 & 40 & 6.08 & 0.01 & 16.57 & 0.32 & 0.01 \\
\hline 151 & 3224665 & 15681 & L-RA01-09 & R 4-4 & 40 & 6.08 & 0.01 & 16.57 & 0.32 & 0.01 \\
\hline 152 & 3202216 & 15681 & L-RA01-09 & R 4-4 & 40 & 6.08 & 0.01 & 16.57 & 0.32 & 0.01 \\
\hline 153 & 3203233 & 15681 & L-RA01-09 & R 4-4 & 40 & 6.08 & 0.01 & 16.57 & 0.32 & 0.01 \\
\hline 154 & 3202243 & 15681 & L-RA01-09 & R 4-4 & 41 & 6.07 & 0.02 & 23.53 & 0.65 & 0.04 \\
\hline 155 & 3200346 & 15681 & L-RA01-09 & R 4-4 & 41 & 6.07 & 0.02 & 23.53 & 0.65 & 0.04 \\
\hline 156 & 3207568 & 15681 & L-RA01-09 & R 4-4 & 42 & 6.04 & 0.04 & 32.39 & 1.22 & 0.10 \\
\hline 157 & 3207357 & 15681 & L-RA01-09 & R 4-4 & 42 & 6.04 & 0.04 & 32.39 & 1.22 & 0.10 \\
\hline 158 & 3116553 & 15681 & L-RA01-09 & R 4-4 & 41 & 6.07 & 0.02 & 23.53 & 0.65 & 0.04 \\
\hline 159 & 3118000 & 15681 & L-RA01-09 & R 4-4 & 41 & 6.07 & 0.02 & 23.53 & 0.65 & 0.04 \\
\hline 160 & 3107486 & 15681 & L-RA01-09 & R 4-4 & 41 & 6.07 & 0.02 & 23.53 & 0.65 & 0.04 \\
\hline 161 & 3117377 & 15681 & L-RA01-09 & R 4-4 & 41 & 6.07 & 0.02 & 23.53 & 0.65 & 0.04 \\
\hline 162 & 3116865 & 15681 & L-RA01-09 & R 4-4 & 41 & 6.07 & 0.02 & 23.53 & 0.65 & 0.04 \\
\hline 163 & 3123401 & 15681 & L-RA01-09 & R 4-4 & 42 & 6.04 & 0.04 & 32.39 & 1.22 & 0.10 \\
\hline 164 & 3104572 & 15681 & L-RA01-09 & R 4-4 & 42 & 6.04 & 0.04 & 32.39 & 1.22 & 0.10 \\
\hline
\end{tabular}




\begin{tabular}{|c|c|c|c|c|c|c|c|c|c|c|}
\hline $\begin{array}{c}\text { Liner } \\
\text { Cell } \\
\end{array}$ & $\begin{array}{c}\text { Rod } \\
\text { Number }\end{array}$ & $\begin{array}{c}\text { Liner } \\
\text { Number }\end{array}$ & $\begin{array}{c}\text { Assembly } \\
\text { Number }\end{array}$ & Liner no. & $\begin{array}{c}\text { POB } \\
\text { Category }\end{array}$ & $\begin{array}{c}\text { Th-232 } \\
(\mathrm{kg})\end{array}$ & $\begin{array}{c}\mathrm{U}-232 \\
(\mathrm{~g})\end{array}$ & $\begin{array}{c}\mathrm{U}-233 \\
(\mathrm{~g})\end{array}$ & $\begin{array}{c}\mathrm{U}-234 \\
(\mathrm{~g})\end{array}$ & $\begin{array}{c}\mathrm{U}-235 \\
(\mathrm{~g}) \\
\end{array}$ \\
\hline 165 & 3207027 & 15681 & L-RA01-09 & R 4-4 & 40 & 6.08 & 0.01 & 16.57 & 0.32 & 0.01 \\
\hline 166 & 3204680 & 15681 & L-RA01-09 & R 4-4 & 41 & 6.07 & 0.02 & 23.53 & 0.65 & 0.04 \\
\hline 167 & 3204764 & 15681 & L-RA01-09 & R 4-4 & 41 & 6.07 & 0.02 & 23.53 & 0.65 & 0.04 \\
\hline 168 & 3205507 & 15681 & L-RA01-09 & R 4-4 & 41 & 6.07 & 0.02 & 23.53 & 0.65 & 0.04 \\
\hline 169 & 3220265 & 15681 & L-RA01-09 & R 4-4 & 41 & 6.07 & 0.02 & 23.53 & 0.65 & 0.04 \\
\hline 170 & 3206578 & 15681 & L-RA01-09 & R 4-4 & 41 & 6.07 & 0.02 & 23.53 & 0.65 & 0.04 \\
\hline 171 & 3206367 & 15681 & L-RA01-09 & R 4-4 & 42 & 6.04 & 0.04 & 32.39 & 1.22 & 0.10 \\
\hline 172 & 3214884 & 15681 & L-RA01-09 & R 4-4 & 42 & 6.04 & 0.04 & 32.39 & 1.22 & 0.10 \\
\hline 173 & 3216873 & 15681 & L-RA01-09 & R 4-4 & 42 & 6.04 & 0.04 & 32.39 & 1.22 & 0.10 \\
\hline 174 & 3108779 & 15681 & L-RA01-09 & R 4-4 & 42 & 6.04 & 0.04 & 32.39 & 1.22 & 0.10 \\
\hline 175 & 3107203 & 15681 & L-RA01-09 & R 4-4 & 42 & 6.04 & 0.04 & 32.39 & 1.22 & 0.10 \\
\hline 176 & 3102419 & 15681 & L-RA01-09 & R 4-4 & 42 & 6.04 & 0.04 & 32.39 & 1.22 & 0.10 \\
\hline 177 & 3122834 & 15681 & L-RA01-09 & R 4-4 & 42 & 6.04 & 0.04 & 32.39 & 1.22 & 0.10 \\
\hline 178 & 3118880 & 15681 & L-RA01-09 & R 4-4 & 42 & 6.04 & 0.04 & 32.39 & 1.22 & 0.10 \\
\hline 179 & 3122356 & 15681 & L-RA01-09 & R 4-4 & 42 & 6.04 & 0.04 & 32.39 & 1.22 & 0.10 \\
\hline 180 & 3217322 & 15681 & L-RA01-09 & R 4-4 & 42 & 6.04 & 0.04 & 32.39 & 1.22 & 0.10 \\
\hline 181 & 3101815 & 15681 & L-RA01-08 & R 5-4 & 50 & 6.07 & 0.01 & 19.14 & 0.42 & 0.02 \\
\hline 182 & 3102354 & 15681 & L-RA01-08 & R 5-4 & 49 & 6.09 & 0.00 & 10.46 & 0.12 & 0.00 \\
\hline 183 & 3210127 & 15681 & L-RA01-08 & R 5-4 & 48 & 6.09 & 0.00 & 4.80 & 0.03 & 0.00 \\
\hline 184 & 3125500 & 15681 & L-RA01-03 & R 4-9 & 39 & 6.09 & 0.00 & 10.34 & 0.13 & 0.00 \\
\hline 185 & 3121615 & 15681 & L-RA01-03 & R 4-9 & 38 & 6.09 & 0.00 & 4.99 & 0.03 & 0.00 \\
\hline 186 & 3222768 & 15681 & L-RA01-03 & R 4-9 & 38 & 6.09 & 0.00 & 4.99 & 0.03 & 0.00 \\
\hline 187 & 3220650 & 15681 & L-RA01-03 & R 4-9 & 40 & 6.08 & 0.01 & 16.57 & 0.32 & 0.01 \\
\hline 188 & 3202032 & 15681 & L-RA01-03 & R 4-9 & 39 & 6.09 & 0.00 & 10.34 & 0.13 & 0.00 \\
\hline 189 & 3126177 & 15681 & L-RA01-03 & R 4-9 & 42 & 6.04 & 0.04 & 32.39 & 1.22 & 0.10 \\
\hline 190 & 3122521 & 15681 & L-RA01-03 & R 4-9 & 41 & 6.07 & 0.02 & 23.53 & 0.65 & 0.04 \\
\hline
\end{tabular}




\begin{tabular}{|c|c|c|c|c|c|c|c|c|c|c|}
\hline $\begin{array}{c}\text { Liner } \\
\text { Cell } \\
\end{array}$ & $\begin{array}{c}\text { Rod } \\
\text { Number }\end{array}$ & $\begin{array}{c}\text { Liner } \\
\text { Number }\end{array}$ & $\begin{array}{c}\text { Assembly } \\
\text { Number }\end{array}$ & Liner no. & $\begin{array}{c}\text { POB } \\
\text { Category }\end{array}$ & $\begin{array}{c}\text { Th-232 } \\
(\mathrm{kg})\end{array}$ & $\begin{array}{c}\mathrm{U}-232 \\
(\mathrm{~g})\end{array}$ & $\begin{array}{c}\mathrm{U}-233 \\
(\mathrm{~g})\end{array}$ & $\begin{array}{c}\text { U-234 } \\
(\mathrm{g})\end{array}$ & $\begin{array}{c}\mathrm{U}-235 \\
(\mathrm{~g}) \\
\end{array}$ \\
\hline 191 & 3126186 & 15681 & L-RA01-03 & R 4-9 & 38 & 6.09 & 0.00 & 4.99 & 0.03 & 0.00 \\
\hline 601 & 3224023 & 15681 & L-RA01-10 & R 4-3 & 43 & 6.09 & 0.00 & 4.54 & 0.03 & 0.00 \\
\hline 602 & 3214250 & 15681 & L-RA01-10 & R 4-3 & 43 & 6.09 & 0.00 & 4.54 & 0.03 & 0.00 \\
\hline 603 & 3225085 & 15681 & L-RA01-10 & R 4-3 & 44 & 6.09 & 0.00 & 9.36 & 0.10 & 0.00 \\
\hline 604 & 3222566 & 15681 & L-RA01-10 & R 4-3 & 43 & 6.09 & 0.00 & 4.54 & 0.03 & 0.00 \\
\hline 605 & 3102015 & 15681 & L-RB01-08 & R 5-4 & 50 & 6.07 & 0.01 & 19.14 & 0.42 & 0.02 \\
\hline 606 & 3105315 & 15681 & L-RB01-08 & R 5-4 & 49 & 6.09 & 0.00 & 10.46 & 0.12 & 0.00 \\
\hline 607 & 3105167 & 15681 & L-RB01-08 & R 5-4 & 49 & 6.09 & 0.00 & 10.46 & 0.12 & 0.00 \\
\hline 609 & 3113336 & 15681 & L-RB01-08 & R 5-4 & 48 & 6.09 & 0.00 & 4.80 & 0.03 & 0.00 \\
\hline 610 & 3122879 & 15681 & L-RA01-10 & R 4-3 & 46 & 6.08 & 0.02 & 22.42 & 0.59 & 0.04 \\
\hline 611 & 3114326 & 15681 & L-RA01-10 & R 4-3 & 47 & 6.04 & 0.04 & 30.97 & 1.12 & 0.09 \\
\hline 612 & 3114804 & 15681 & L-RA01-10 & R 4-3 & 46 & 6.08 & 0.02 & 22.42 & 0.59 & 0.04 \\
\hline 613 & 3111504 & 15681 & L-RA01-10 & $\mathrm{R}$ 4-3 & 45 & 6.08 & 0.01 & 15.31 & 0.28 & 0.01 \\
\hline 614 & 3112815 & 15681 & L-RA01-10 & R 4-3 & 45 & 6.08 & 0.01 & 15.31 & 0.28 & 0.01 \\
\hline 615 & 3120156 & 15681 & L-RA01-10 & R 4-3 & 45 & 6.08 & 0.01 & 15.31 & 0.28 & 0.01 \\
\hline 616 & 3223188 & 15681 & L-RA01-10 & R 4-3 & 44 & 6.09 & 0.00 & 9.36 & 0.10 & 0.00 \\
\hline 617 & 3213858 & 15681 & L-RA01-10 & R 4-3 & 44 & 6.09 & 0.00 & 9.36 & 0.10 & 0.00 \\
\hline 618 & 3201776 & 15681 & L-RA01-10 & R 4-3 & 45 & 6.08 & 0.01 & 15.31 & 0.28 & 0.01 \\
\hline 619 & 3211429 & 15681 & L-RA01-10 & R 4-3 & 45 & 6.08 & 0.01 & 15.31 & 0.28 & 0.01 \\
\hline 620 & 3126022 & 15681 & L-RA01-10 & R 4-3 & 47 & 6.04 & 0.04 & 30.97 & 1.12 & 0.09 \\
\hline 621 & 3126159 & 15681 & L-RA01-10 & R 4-3 & 43 & 6.09 & 0.00 & 4.54 & 0.03 & 0.00 \\
\hline 622 & 3211034 & 15681 & L-RA01-10 & R 4-3 & 45 & 6.08 & 0.01 & 15.31 & 0.28 & 0.01 \\
\hline 623 & 3208834 & 15681 & L-RA01-10 & R 4-3 & 46 & 6.08 & 0.02 & 22.42 & 0.59 & 0.04 \\
\hline 624 & 3117709 & 15681 & L-RA01-10 & R 4-3 & 44 & 6.09 & 0.00 & 9.36 & 0.10 & 0.00 \\
\hline 625 & 3115580 & 15681 & L-RA01-10 & R 4-3 & 44 & 6.09 & 0.00 & 9.36 & 0.10 & 0.00 \\
\hline 626 & 3117560 & 15681 & L-RA01-10 & R 4-3 & 43 & 6.09 & 0.00 & 4.54 & 0.03 & 0.00 \\
\hline
\end{tabular}




\begin{tabular}{|c|c|c|c|c|c|c|c|c|c|c|}
\hline $\begin{array}{c}\text { Liner } \\
\text { Cell } \\
\end{array}$ & $\begin{array}{c}\text { Rod } \\
\text { Number }\end{array}$ & $\begin{array}{c}\text { Liner } \\
\text { Number }\end{array}$ & $\begin{array}{c}\text { Assembly } \\
\text { Number }\end{array}$ & Liner no. & $\begin{array}{c}\text { POB } \\
\text { Category }\end{array}$ & $\begin{array}{c}\text { Th-232 } \\
(\mathrm{kg})\end{array}$ & $\begin{array}{c}\mathrm{U}-232 \\
(\mathrm{~g})\end{array}$ & $\begin{array}{c}\mathrm{U}-233 \\
(\mathrm{~g})\end{array}$ & $\begin{array}{c}\text { U-234 } \\
(\mathrm{g})\end{array}$ & $\begin{array}{c}\text { U-235 } \\
(\mathrm{g}) \\
\end{array}$ \\
\hline 627 & 3102583 & 15681 & L-RA01-10 & R 4-3 & 43 & 6.09 & 0.00 & 4.54 & 0.03 & 0.00 \\
\hline 628 & 3122513 & 15681 & L-RA01-03 & R 4-9 & 40 & 6.08 & 0.01 & 16.57 & 0.32 & 0.01 \\
\hline 629 & 3120165 & 15681 & L-RA01-03 & R 4-9 & 41 & 6.07 & 0.02 & 23.53 & 0.65 & 0.04 \\
\hline 630 & 3104417 & 15681 & L-RA01-03 & R 4-9 & 38 & 6.09 & 0.00 & 4.99 & 0.03 & 0.00 \\
\hline 631 & 3121173 & 15681 & L-RA01-03 & R 4-9 & 38 & 6.09 & 0.00 & 4.99 & 0.03 & 0.00 \\
\hline 632 & 3121476 & 15681 & L-RA01-03 & R 4-9 & 38 & 6.09 & 0.00 & 4.99 & 0.03 & 0.00 \\
\hline 633 & 3124886 & 15681 & L-RA01-03 & R 4-9 & 38 & 6.09 & 0.00 & 4.99 & 0.03 & 0.00 \\
\hline 634 & 3224683 & 15681 & L-RA01-03 & R 4-9 & 38 & 6.09 & 0.00 & 4.99 & 0.03 & 0.00 \\
\hline 635 & 3226176 & 15681 & L-RA01-03 & R 4-9 & 38 & 6.09 & 0.00 & 4.99 & 0.03 & 0.00 \\
\hline 636 & 3218540 & 15681 & L-RA01-03 & R 4-9 & 38 & 6.09 & 0.00 & 4.99 & 0.03 & 0.00 \\
\hline 637 & 3224748 & 15681 & L-RA01-03 & R 4-9 & 39 & 6.09 & 0.00 & 10.34 & 0.13 & 0.00 \\
\hline 638 & 3222815 & 15681 & L-RA01-03 & R 4-9 & 38 & 6.09 & 0.00 & 4.99 & 0.03 & 0.00 \\
\hline 639 & 3211135 & 15681 & L-RA01-03 & R 4-9 & 39 & 6.09 & 0.00 & 10.34 & 0.13 & 0.00 \\
\hline 640 & 3202757 & 15681 & L-RA01-03 & R 4-9 & 39 & 6.09 & 0.00 & 10.34 & 0.13 & 0.00 \\
\hline 641 & 3218743 & 15681 & L-RA01-03 & R 4-9 & 39 & 6.09 & 0.00 & 10.34 & 0.13 & 0.00 \\
\hline 642 & 3222667 & 15681 & L-RA01-03 & R 4-9 & 38 & 6.09 & 0.00 & 4.99 & 0.03 & 0.00 \\
\hline 643 & 3221530 & 15681 & L-RA01-03 & R 4-9 & 38 & 6.09 & 0.00 & 4.99 & 0.03 & 0.00 \\
\hline 644 & 3223529 & 15681 & L-RA01-03 & R 4-9 & 38 & 6.09 & 0.00 & 4.99 & 0.03 & 0.00 \\
\hline 645 & 3120376 & 15681 & L-RA01-03 & R 4-9 & 42 & 6.04 & 0.04 & 32.39 & 1.22 & 0.10 \\
\hline 646 & 3123474 & 15681 & L-RA01-03 & R 4-9 & 40 & 6.08 & 0.01 & 16.57 & 0.32 & 0.01 \\
\hline 647 & 3123263 & 15681 & L-RA01-03 & R 4-9 & 41 & 6.07 & 0.02 & 23.53 & 0.65 & 0.04 \\
\hline 648 & 3125389 & 15681 & L-RA01-03 & R 4-9 & 39 & 6.09 & 0.00 & 10.34 & 0.13 & 0.00 \\
\hline 649 & 3125005 & 15681 & L-RA01-03 & R 4-9 & 38 & 6.09 & 0.00 & 4.99 & 0.03 & 0.00 \\
\hline 650 & 3111448 & 15681 & L-RA01-03 & R 4-9 & 40 & 6.08 & 0.01 & 16.57 & 0.32 & 0.01 \\
\hline 651 & 3124805 & 15681 & L-RA01-03 & R 4-9 & 38 & 6.09 & 0.00 & 4.99 & 0.03 & 0.00 \\
\hline 652 & 3100282 & 15681 & L-RA01-03 & R 4-9 & 42 & 6.04 & 0.04 & 32.39 & 1.22 & 0.10 \\
\hline
\end{tabular}




\begin{tabular}{|c|c|c|c|c|c|c|c|c|c|c|}
\hline $\begin{array}{c}\text { Liner } \\
\text { Cell } \\
\end{array}$ & $\begin{array}{c}\text { Rod } \\
\text { Number }\end{array}$ & $\begin{array}{c}\text { Liner } \\
\text { Number }\end{array}$ & $\begin{array}{c}\text { Assembly } \\
\text { Number }\end{array}$ & Liner no. & $\begin{array}{c}\text { POB } \\
\text { Category }\end{array}$ & $\begin{array}{c}\text { Th-232 } \\
(\mathrm{kg})\end{array}$ & $\begin{array}{c}\mathrm{U}-232 \\
(\mathrm{~g}) \\
\end{array}$ & $\begin{array}{c}\mathrm{U}-233 \\
(\mathrm{~g})\end{array}$ & $\begin{array}{c}\text { U-234 } \\
(\mathrm{g})\end{array}$ & $\begin{array}{c}\mathrm{U}-235 \\
(\mathrm{~g}) \\
\end{array}$ \\
\hline 653 & 3118836 & 15681 & L-RA01-03 & R 4-9 & 42 & 6.04 & 0.04 & 32.39 & 1.22 & 0.10 \\
\hline 654 & 3123135 & 15681 & L-RA01-03 & R 4-9 & 40 & 6.08 & 0.01 & 16.57 & 0.32 & 0.01 \\
\hline 655 & 3123236 & 15681 & L-RA01-03 & R 4-9 & 42 & 6.04 & 0.04 & 32.39 & 1.22 & 0.10 \\
\hline 656 & 3220404 & 15681 & L-RA01-03 & R 4-9 & 41 & 6.07 & 0.02 & 23.53 & 0.65 & 0.04 \\
\hline 657 & 3221659 & 15681 & L-RA01-03 & R 4-9 & 40 & 6.08 & 0.01 & 16.57 & 0.32 & 0.01 \\
\hline 658 & 3221448 & 15681 & L-RA01-03 & R 4-9 & 40 & 6.08 & 0.01 & 16.57 & 0.32 & 0.01 \\
\hline 659 & 3218844 & 15681 & L-RA01-03 & R 4-9 & 39 & 6.09 & 0.00 & 10.34 & 0.13 & 0.00 \\
\hline 660 & 3124556 & 15681 & L-RA01-03 & R 4-9 & 38 & 6.09 & 0.00 & 4.99 & 0.03 & 0.00 \\
\hline 661 & 3121586 & 15681 & L-RA01-03 & R 4-9 & 39 & 6.09 & 0.00 & 10.34 & 0.13 & 0.00 \\
\hline 662 & 3121265 & 15681 & L-RA01-03 & R 4-9 & 38 & 6.09 & 0.00 & 4.99 & 0.03 & 0.00 \\
\hline 663 & 3126140 & 15681 & L-RA01-03 & R 4-9 & 39 & 6.09 & 0.00 & 10.34 & 0.13 & 0.00 \\
\hline 664 & 3224739 & 15681 & L-RA01-03 & R 4-9 & 39 & 6.09 & 0.00 & 10.34 & 0.13 & 0.00 \\
\hline 665 & 3215048 & 15681 & L-RA01-03 & R 4-9 & 38 & 6.09 & 0.00 & 4.99 & 0.03 & 0.00 \\
\hline 666 & 3220229 & 15681 & L-RA01-03 & R 4-9 & 38 & 6.09 & 0.00 & 4.99 & 0.03 & 0.00 \\
\hline 667 & 3207256 & 15681 & L-RA01-03 & R 4-9 & 38 & 6.09 & 0.00 & 4.99 & 0.03 & 0.00 \\
\hline 668 & 3222135 & 15681 & L-RA01-03 & R 4-9 & 39 & 6.09 & 0.00 & 10.34 & 0.13 & 0.00 \\
\hline 669 & 3225783 & 15681 & L-RA01-03 & R 4-9 & 39 & 6.09 & 0.00 & 10.34 & 0.13 & 0.00 \\
\hline 670 & 3223152 & 15681 & L-RA01-03 & R 4-9 & 39 & 6.09 & 0.00 & 10.34 & 0.13 & 0.00 \\
\hline 671 & 3223050 & 15681 & L-RA01-03 & R 4-9 & 38 & 6.09 & 0.00 & 4.99 & 0.03 & 0.00 \\
\hline 672 & 3224564 & 15681 & L-RA01-03 & R 4-9 & 39 & 6.09 & 0.00 & 10.34 & 0.13 & 0.00 \\
\hline 673 & 3206542 & 15681 & L-RA01-03 & R 4-9 & 42 & 6.04 & 0.04 & 32.39 & 1.22 & 0.10 \\
\hline 674 & 3221062 & 15681 & L-RA01-03 & R 4-9 & 41 & 6.07 & 0.02 & 23.53 & 0.65 & 0.04 \\
\hline 675 & 3218577 & 15681 & L-RA01-03 & R 4-9 & 41 & 6.07 & 0.02 & 23.53 & 0.65 & 0.04 \\
\hline 101 & 1406785 & 15682 & L-GU51-01 & B $1-3$ & 16 & 2.92 & 0.09 & 40.74 & 3.63 & 0.61 \\
\hline 102 & 1607084 & 15682 & L-GU51-01 & В $1-3$ & 25 & 2.89 & 0.10 & 52.19 & 4.92 & 0.80 \\
\hline 103 & 1310849 & 15682 & L-GU51-01 & B $1-3$ & 19 & 2.87 & 0.10 & 47.20 & 4.42 & 0.74 \\
\hline
\end{tabular}




\begin{tabular}{|c|c|c|c|c|c|c|c|c|c|c|}
\hline $\begin{array}{c}\text { Liner } \\
\text { Cell } \\
\end{array}$ & $\begin{array}{c}\text { Rod } \\
\text { Number }\end{array}$ & $\begin{array}{c}\text { Liner } \\
\text { Number }\end{array}$ & $\begin{array}{c}\text { Assembly } \\
\text { Number }\end{array}$ & Liner no. & $\begin{array}{c}\text { POB } \\
\text { Category }\end{array}$ & $\begin{array}{c}\text { Th-232 } \\
(\mathrm{kg})\end{array}$ & $\begin{array}{c}\mathrm{U}-232 \\
(\mathrm{~g})\end{array}$ & $\begin{array}{c}\mathrm{U}-233 \\
(\mathrm{~g})\end{array}$ & $\begin{array}{c}\text { U-234 } \\
(\mathrm{g})\end{array}$ & $\begin{array}{c}\mathrm{U}-235 \\
(\mathrm{~g}) \\
\end{array}$ \\
\hline 104 & 1103407 & 15682 & L-GU51-01 & B $1-3$ & 13 & 2.90 & 0.10 & 35.40 & 3.25 & 0.54 \\
\hline 107 & 1200225 & 15682 & L-GU51-01 & B $1-3$ & 13 & 2.90 & 0.10 & 35.40 & 3.25 & 0.54 \\
\hline 108 & 1411084 & 15682 & L-GU51-01 & B $1-3$ & 16 & 2.92 & 0.09 & 40.74 & 3.63 & 0.61 \\
\hline 109 & 1607066 & 15682 & L-GU51-01 & B $1-3$ & 25 & 2.89 & 0.10 & 52.19 & 4.92 & 0.80 \\
\hline 110 & 2701476 & 15682 & L-GT22-03 & В $3-6$ & 37 & 2.42 & 0.07 & 41.78 & 4.04 & 0.62 \\
\hline 111 & 2301756 & 15682 & L-GT22-03 & В $3-6$ & 33 & 2.42 & 0.05 & 46.13 & 3.53 & 0.47 \\
\hline 112 & 2401746 & 15682 & L-GT22-03 & В 3-6 & 31 & 2.46 & 0.05 & 34.11 & 2.62 & 0.37 \\
\hline 113 & 2202655 & 15682 & L-GT22-03 & В 3-6 & 29 & 2.45 & 0.05 & 28.98 & 2.29 & 0.31 \\
\hline 122 & 1604179 & 15682 & L-GT22-03 & В 3-6 & 27 & 2.90 & 0.09 & 52.06 & 4.53 & 0.70 \\
\hline 123 & 1413275 & 15682 & L-GT22-03 & В 3-6 & 18 & 2.92 & 0.08 & 39.40 & 3.21 & 0.50 \\
\hline 124 & 1200766 & 15682 & L-GT22-03 & В $3-6$ & 15 & 2.91 & 0.08 & 33.30 & 2.73 & 0.41 \\
\hline 135 & 1512524 & 15682 & L-GT22-03 & В $3-6$ & 24 & 2.88 & 0.09 & 46.71 & 4.29 & 0.67 \\
\hline 136 & 1310813 & 15682 & L-GT22-03 & В $3-6$ & 21 & 2.87 & 0.08 & 46.59 & 4.02 & 0.63 \\
\hline 140 & 2701265 & 15682 & L-GS22-01 & B 2-2 & 36 & 2.42 & 0.07 & 41.72 & 4.14 & 0.64 \\
\hline 141 & 2302443 & 15682 & L-GS22-01 & B 2-2 & 32 & 2.42 & 0.06 & 45.57 & 3.95 & 0.57 \\
\hline 142 & 2100170 & 15682 & L-GS22-01 & B 2-2 & 28 & 2.45 & 0.06 & 30.09 & 2.67 & 0.40 \\
\hline 143 & 2304459 & 15682 & L-GS22-01 & B 2-2 & 32 & 2.42 & 0.06 & 45.57 & 3.95 & 0.57 \\
\hline 144 & 2512103 & 15682 & L-GS22-01 & B 2-2 & 34 & 2.43 & 0.05 & 53.87 & 3.78 & 0.47 \\
\hline 145 & 2406088 & 15682 & L-GS22-01 & B 2-2 & 30 & 2.46 & 0.06 & 34.68 & 2.98 & 0.45 \\
\hline 147 & 2401012 & 15682 & L-GS22-01 & B 2-2 & 30 & 2.46 & 0.06 & 34.68 & 2.98 & 0.45 \\
\hline 242 & 2517087 & 15682 & L-GW52-01 & B $3-2$ & 35 & 2.43 & 0.03 & 55.13 & 3.30 & 0.38 \\
\hline 243 & 2503467 & 15682 & L-GW52-01 & B $3-2$ & 35 & 2.43 & 0.03 & 55.13 & 3.30 & 0.38 \\
\hline 244 & 2520784 & 15682 & L-GW52-01 & В 3-2 & 35 & 2.43 & 0.03 & 55.13 & 3.30 & 0.38 \\
\hline 245 & 2511240 & 15682 & L-GW52-01 & B $3-2$ & 35 & 2.43 & 0.03 & 55.13 & 3.30 & 0.38 \\
\hline 246 & 2520766 & 15682 & L-GW52-01 & B 3-2 & 35 & 2.43 & 0.03 & 55.13 & 3.30 & 0.38 \\
\hline 247 & 2511039 & 15682 & L-GW52-01 & B 3-2 & 35 & 2.43 & 0.03 & 55.13 & 3.30 & 0.38 \\
\hline
\end{tabular}




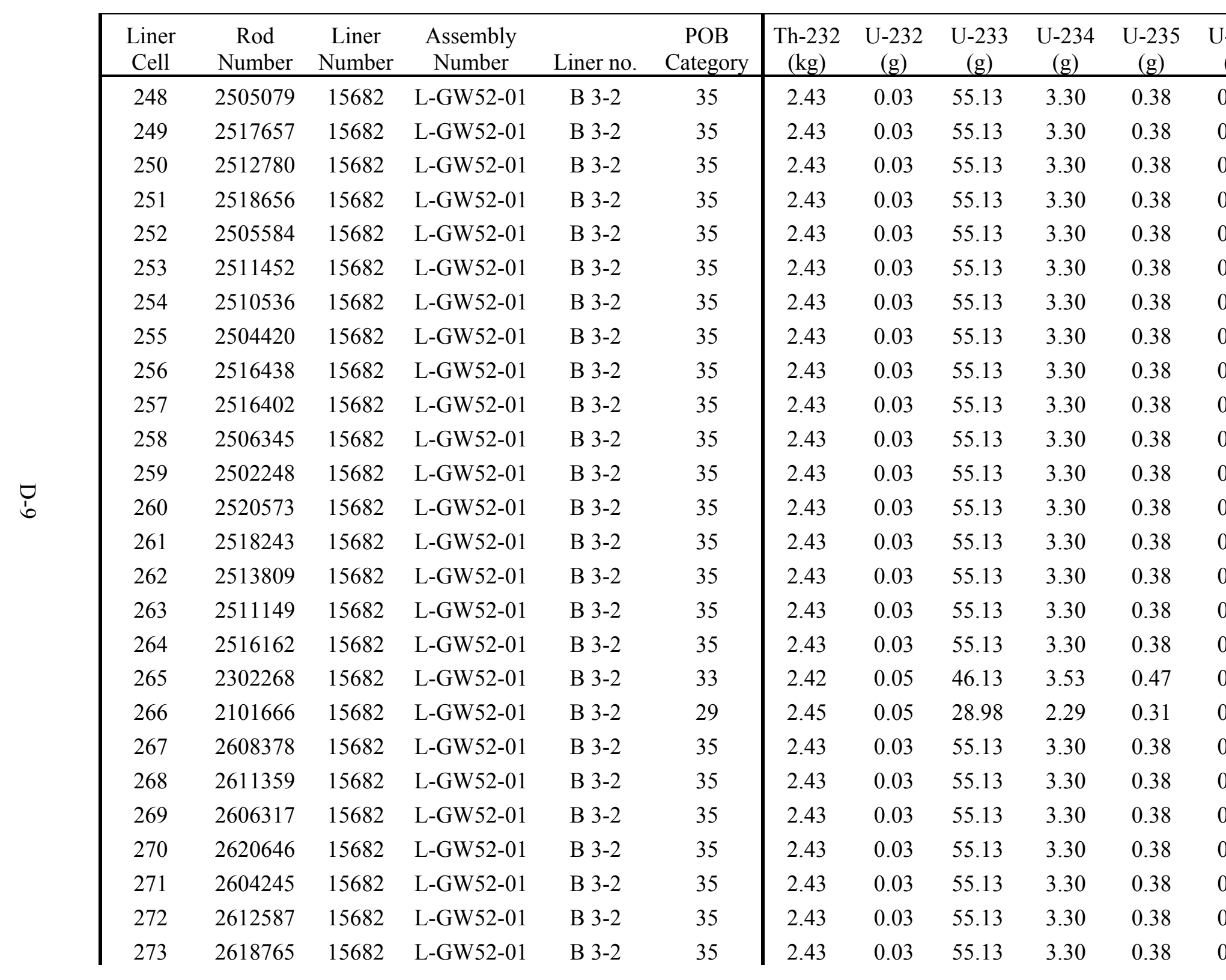




\begin{tabular}{|c|c|c|c|c|c|c|c|c|c|c|}
\hline $\begin{array}{c}\text { Liner } \\
\text { Cell }\end{array}$ & $\begin{array}{c}\text { Rod } \\
\text { Number }\end{array}$ & $\begin{array}{c}\text { Liner } \\
\text { Number }\end{array}$ & $\begin{array}{c}\text { Assembly } \\
\text { Number }\end{array}$ & Liner no. & $\begin{array}{c}\text { POB } \\
\text { Category }\end{array}$ & $\begin{array}{c}\text { Th-232 } \\
(\mathrm{kg})\end{array}$ & $\begin{array}{c}\mathrm{U}-232 \\
(\mathrm{~g})\end{array}$ & $\begin{array}{c}\mathrm{U}-233 \\
(\mathrm{~g})\end{array}$ & $\begin{array}{c}\text { U-234 } \\
(\mathrm{g})\end{array}$ & $\begin{array}{c}\text { U-235 } \\
(\mathrm{g})\end{array}$ \\
\hline 274 & 2612028 & 15682 & L-GW52-01 & B 3-2 & 35 & 2.43 & 0.03 & 55.13 & 3.30 & 0.38 \\
\hline 275 & 2600010 & 15682 & L-GW52-01 & B $3-2$ & 35 & 2.43 & 0.03 & 55.13 & 3.30 & 0.38 \\
\hline 276 & 2602202 & 15682 & L-GW52-01 & B $3-2$ & 35 & 2.43 & 0.03 & 55.13 & 3.30 & 0.38 \\
\hline 277 & 2616730 & 15682 & L-GW52-01 & B $3-2$ & 35 & 2.43 & 0.03 & 55.13 & 3.30 & 0.38 \\
\hline 278 & 2613485 & 15682 & L-GW52-01 & B $3-2$ & 35 & 2.43 & 0.03 & 55.13 & 3.30 & 0.38 \\
\hline 279 & 2603412 & 15682 & L-GW52-01 & B $3-2$ & 35 & 2.43 & 0.03 & 55.13 & 3.30 & 0.38 \\
\hline 280 & 2402175 & 15682 & L-GW52-01 & B $3-2$ & 31 & 2.46 & 0.05 & 34.11 & 2.62 & 0.37 \\
\hline 281 & 2616327 & 15682 & L-GW52-01 & B $3-2$ & 35 & 2.43 & 0.03 & 55.13 & 3.30 & 0.38 \\
\hline 282 & 2602036 & 15682 & L-GW52-01 & B $3-2$ & 35 & 2.43 & 0.03 & 55.13 & 3.30 & 0.38 \\
\hline 283 & 2402276 & 15682 & L-GW52-01 & B $3-2$ & 31 & 2.46 & 0.05 & 34.11 & 2.62 & 0.37 \\
\hline 284 & 2621829 & 15682 & L-GW52-01 & B $3-2$ & 35 & 2.43 & 0.03 & 55.13 & 3.30 & 0.38 \\
\hline 285 & 2620884 & 15682 & L-GW52-01 & B $3-2$ & 35 & 2.43 & 0.03 & 55.13 & 3.30 & 0.38 \\
\hline 286 & 2403073 & 15682 & L-GW52-01 & B $3-2$ & 31 & 2.46 & 0.05 & 34.11 & 2.62 & 0.37 \\
\hline 287 & 2200134 & 15682 & L-GW52-01 & B 3-2 & 29 & 2.45 & 0.05 & 28.98 & 2.29 & 0.31 \\
\hline 288 & 2205055 & 15682 & L-GW52-01 & B $3-2$ & 29 & 2.45 & 0.05 & 28.98 & 2.29 & 0.31 \\
\hline 289 & 2620049 & 15682 & L-GW52-01 & B $3-2$ & 35 & 2.43 & 0.03 & 55.13 & 3.30 & 0.38 \\
\hline 290 & 2608517 & 15682 & L-GW52-01 & B $3-2$ & 35 & 2.43 & 0.03 & 55.13 & 3.30 & 0.38 \\
\hline 291 & 2402340 & 15682 & L-GW52-01 & B $3-2$ & 31 & 2.46 & 0.05 & 34.11 & 2.62 & 0.37 \\
\hline 292 & 2204763 & 15682 & L-GW52-01 & B $3-2$ & 29 & 2.45 & 0.05 & 28.98 & 2.29 & 0.31 \\
\hline 293 & 2520867 & 15682 & L-GW52-01 & B $3-2$ & 35 & 2.43 & 0.03 & 55.13 & 3.30 & 0.38 \\
\hline 294 & 2503072 & 15682 & L-GW52-01 & B 3-2 & 35 & 2.43 & 0.03 & 55.13 & 3.30 & 0.38 \\
\hline 295 & 2510076 & 15682 & L-GW52-01 & B $3-2$ & 35 & 2.43 & 0.03 & 55.13 & 3.30 & 0.38 \\
\hline 296 & 2303112 & 15682 & L-GW52-01 & B 3-2 & 33 & 2.42 & 0.05 & 46.13 & 3.53 & 0.47 \\
\hline 297 & 2520463 & 15682 & L-GW52-01 & B $3-2$ & 35 & 2.43 & 0.03 & 55.13 & 3.30 & 0.38 \\
\hline 298 & 2304046 & 15682 & L-GW52-01 & B 3-2 & 33 & 2.42 & 0.05 & 46.13 & 3.53 & 0.47 \\
\hline 299 & 2103417 & 15682 & L-GW52-01 & B 3-2 & 29 & 2.45 & 0.05 & 28.98 & 2.29 & 0.31 \\
\hline
\end{tabular}




\begin{tabular}{|c|c|c|c|c|c|c|c|c|c|c|}
\hline $\begin{array}{c}\text { Liner } \\
\text { Cell }\end{array}$ & $\begin{array}{c}\text { Rod } \\
\text { Number }\end{array}$ & $\begin{array}{c}\text { Liner } \\
\text { Number }\end{array}$ & $\begin{array}{l}\text { Assembly } \\
\text { Number }\end{array}$ & Liner no. & $\begin{array}{c}\text { POB } \\
\text { Category }\end{array}$ & $\begin{array}{c}\text { Th-232 } \\
\text { (kg) }\end{array}$ & $\begin{array}{c}\mathrm{U}-232 \\
(\mathrm{~g})\end{array}$ & $\begin{array}{c}\mathrm{U}-233 \\
(\mathrm{~g})\end{array}$ & $\begin{array}{c}\mathrm{U}-234 \\
(\mathrm{~g})\end{array}$ & $\begin{array}{c}\mathrm{U}-235 \\
(\mathrm{~g})\end{array}$ \\
\hline 300 & 2501433 & 15682 & L-GW52-01 & B $3-2$ & 35 & 2.43 & 0.03 & 55.13 & 3.30 & 0.38 \\
\hline 301 & 2517161 & 15682 & L-GW52-01 & В $3-2$ & 35 & 2.43 & 0.03 & 55.13 & 3.30 & 0.38 \\
\hline 302 & 2512010 & 15682 & L-GW52-01 & В $3-2$ & 35 & 2.43 & 0.03 & 55.13 & 3.30 & 0.38 \\
\hline 303 & 2305808 & 15682 & L-GW52-01 & В $3-2$ & 33 & 2.42 & 0.05 & 46.13 & 3.53 & 0.47 \\
\hline 304 & 2517217 & 15682 & L-GW52-01 & B $3-2$ & 35 & 2.43 & 0.03 & 55.13 & 3.30 & 0.38 \\
\hline 305 & 2303305 & 15682 & L-GW52-01 & B $3-2$ & 33 & 2.42 & 0.05 & 46.13 & 3.53 & 0.47 \\
\hline 306 & 2101877 & 15682 & L-GW52-01 & B $3-2$ & 29 & 2.45 & 0.05 & 28.98 & 2.29 & 0.31 \\
\hline 307 & 2515329 & 15682 & L-GW52-01 & B $3-2$ & 35 & 2.43 & 0.03 & 55.13 & 3.30 & 0.38 \\
\hline 308 & 2517482 & 15682 & L-GW52-01 & В $3-2$ & 35 & 2.43 & 0.03 & 55.13 & 3.30 & 0.38 \\
\hline 309 & 2302874 & 15682 & L-GW52-01 & B 3-2 & 33 & 2.42 & 0.05 & 46.13 & 3.53 & 0.47 \\
\hline 310 & 2100337 & 15682 & L-GW52-01 & B 3-2 & 29 & 2.45 & 0.05 & 28.98 & 2.29 & 0.31 \\
\hline 311 & 2604135 & 15682 & L-GW52-01 & В $3-2$ & 35 & 2.43 & 0.03 & 55.13 & 3.30 & 0.38 \\
\hline 312 & 2404606 & 15682 & L-GW52-01 & B 3-2 & 31 & 2.46 & 0.05 & 34.11 & 2.62 & 0.37 \\
\hline 313 & 2200116 & 15682 & L-GW52-01 & B $3-2$ & 29 & 2.45 & 0.05 & 28.98 & 2.29 & 0.31 \\
\hline 314 & 2200704 & 15682 & L-GW52-01 & В $3-2$ & 29 & 2.45 & 0.05 & 28.98 & 2.29 & 0.31 \\
\hline 315 & 2620637 & 15682 & L-GW52-01 & B $3-2$ & 35 & 2.43 & 0.03 & 55.13 & 3.30 & 0.38 \\
\hline 316 & 2604254 & 15682 & L-GW52-01 & B 3-2 & 35 & 2.43 & 0.03 & 55.13 & 3.30 & 0.38 \\
\hline 317 & 2600819 & 15682 & L-GW52-01 & B 3-2 & 35 & 2.43 & 0.03 & 55.13 & 3.30 & 0.38 \\
\hline 318 & 2406373 & 15682 & L-GW52-01 & B $3-2$ & 31 & 2.46 & 0.05 & 34.11 & 2.62 & 0.37 \\
\hline 319 & 2202334 & 15682 & L-GW52-01 & В $3-2$ & 29 & 2.45 & 0.05 & 28.98 & 2.29 & 0.31 \\
\hline 320 & 2612634 & 15682 & L-GW52-01 & B $3-2$ & 35 & 2.43 & 0.03 & 55.13 & 3.30 & 0.38 \\
\hline 321 & 2614879 & 15682 & L-GW52-01 & B $3-2$ & 35 & 2.43 & 0.03 & 55.13 & 3.30 & 0.38 \\
\hline 322 & 2602650 & 15682 & L-GW52-01 & В 3-2 & 35 & 2.43 & 0.03 & 55.13 & 3.30 & 0.38 \\
\hline 323 & 2403046 & 15682 & L-GW52-01 & B $3-2$ & 31 & 2.46 & 0.05 & 34.11 & 2.62 & 0.37 \\
\hline 324 & 2200501 & 15682 & L-GW52-01 & B 3-2 & 29 & 2.45 & 0.05 & 28.98 & 2.29 & 0.31 \\
\hline 601 & 2200840 & 15682 & L-GT22-03 & В 3-6 & 29 & 2.45 & 0.05 & 28.98 & 2.29 & 0.31 \\
\hline
\end{tabular}




\begin{tabular}{|c|c|c|c|c|c|c|c|c|c|c|}
\hline $\begin{array}{c}\text { Liner } \\
\text { Cell } \\
\end{array}$ & $\begin{array}{c}\text { Rod } \\
\text { Number }\end{array}$ & $\begin{array}{c}\text { Liner } \\
\text { Number }\end{array}$ & $\begin{array}{c}\text { Assembly } \\
\text { Number }\end{array}$ & Liner no. & $\begin{array}{c}\text { POB } \\
\text { Category }\end{array}$ & $\begin{array}{c}\text { Th-232 } \\
(\mathrm{kg})\end{array}$ & $\begin{array}{c}\mathrm{U}-232 \\
(\mathrm{~g})\end{array}$ & $\begin{array}{c}\mathrm{U}-233 \\
(\mathrm{~g})\end{array}$ & $\begin{array}{c}\text { U-234 } \\
(\mathrm{g})\end{array}$ & $\begin{array}{c}\mathrm{U}-235 \\
(\mathrm{~g}) \\
\end{array}$ \\
\hline 607 & 2513880 & 15682 & L-GT22-03 & B 3-6 & 35 & 2.43 & 0.03 & 55.13 & 3.30 & 0.38 \\
\hline 608 & 2518169 & 15682 & L-GT22-03 & В $3-6$ & 35 & 2.43 & 0.03 & 55.13 & 3.30 & 0.38 \\
\hline 609 & 2507720 & 15682 & L-GT22-03 & В $3-6$ & 35 & 2.43 & 0.03 & 55.13 & 3.30 & 0.38 \\
\hline 610 & 2700643 & 15682 & L-GW52-01 & В $3-2$ & 37 & 2.42 & 0.07 & 41.78 & 4.04 & 0.62 \\
\hline 611 & 2300601 & 15682 & L-GW52-01 & B $3-2$ & 33 & 2.42 & 0.05 & 46.13 & 3.53 & 0.47 \\
\hline 612 & 2300279 & 15682 & L-GW52-01 & B $3-2$ & 33 & 2.42 & 0.05 & 46.13 & 3.53 & 0.47 \\
\hline 613 & 2304652 & 15682 & L-GW52-01 & B $3-2$ & 33 & 2.42 & 0.05 & 46.13 & 3.53 & 0.47 \\
\hline 614 & 1612357 & 15682 & L-GU51-01 & B $1-3$ & 25 & 2.89 & 0.10 & 52.19 & 4.92 & 0.80 \\
\hline 615 & 1606278 & 15682 & L-GU51-01 & B 1-3 & 25 & 2.89 & 0.10 & 52.19 & 4.92 & 0.80 \\
\hline 616 & 2517179 & 15682 & L-GW52-01 & B 3-2 & 35 & 2.43 & 0.03 & 55.13 & 3.30 & 0.38 \\
\hline 617 & 1604758 & 15682 & L-GU51-01 & B $1-3$ & 25 & 2.89 & 0.10 & 52.19 & 4.92 & 0.80 \\
\hline 618 & 1404356 & 15682 & L-GU51-01 & B $1-3$ & 16 & 2.92 & 0.09 & 40.74 & 3.63 & 0.61 \\
\hline 619 & 1411479 & 15682 & L-GU51-01 & B $1-3$ & 16 & 2.92 & 0.09 & 40.74 & 3.63 & 0.61 \\
\hline 620 & 2502082 & 15682 & L-GW52-01 & B $3-2$ & 35 & 2.43 & 0.03 & 55.13 & 3.30 & 0.38 \\
\hline 621 & 2521022 & 15682 & L-GW52-01 & B $3-2$ & 35 & 2.43 & 0.03 & 55.13 & 3.30 & 0.38 \\
\hline 622 & 1200500 & 15682 & L-GU51-01 & B $1-3$ & 13 & 2.90 & 0.10 & 35.40 & 3.25 & 0.54 \\
\hline 623 & 1208042 & 15682 & L-GU51-01 & B $1-3$ & 13 & 2.90 & 0.10 & 35.40 & 3.25 & 0.54 \\
\hline 624 & 1206347 & 15682 & L-GU51-01 & B $1-3$ & 13 & 2.90 & 0.10 & 35.40 & 3.25 & 0.54 \\
\hline 625 & 1510589 & 15682 & L-GU51-01 & B $1-3$ & 22 & 2.88 & 0.10 & 47.04 & 4.66 & 0.76 \\
\hline 626 & 1311811 & 15682 & L-GU51-01 & B $1-3$ & 19 & 2.87 & 0.10 & 47.20 & 4.42 & 0.74 \\
\hline 627 & 1307152 & 15682 & L-GU51-01 & B $1-3$ & 19 & 2.87 & 0.10 & 47.20 & 4.42 & 0.74 \\
\hline 628 & 1107750 & 15682 & L-GU51-01 & B $1-3$ & 13 & 2.90 & 0.10 & 35.40 & 3.25 & 0.54 \\
\hline 629 & 1105477 & 15682 & L-GU51-01 & B 1-3 & 13 & 2.90 & 0.10 & 35.40 & 3.25 & 0.54 \\
\hline 630 & 1507058 & 15682 & L-GU51-01 & B $1-3$ & 22 & 2.88 & 0.10 & 47.04 & 4.66 & 0.76 \\
\hline 631 & 1506683 & 15682 & L-GU51-01 & B $1-3$ & 22 & 2.88 & 0.10 & 47.04 & 4.66 & 0.76 \\
\hline 632 & 1500386 & 15682 & L-GU51-01 & B $1-3$ & 22 & 2.88 & 0.10 & 47.04 & 4.66 & 0.76 \\
\hline
\end{tabular}




\begin{tabular}{|c|c|c|c|c|c|c|c|c|c|c|}
\hline $\begin{array}{c}\text { Liner } \\
\text { Cell } \\
\end{array}$ & $\begin{array}{c}\text { Rod } \\
\text { Number }\end{array}$ & $\begin{array}{c}\text { Liner } \\
\text { Number }\end{array}$ & $\begin{array}{c}\text { Assembly } \\
\text { Number }\end{array}$ & Liner no. & $\begin{array}{c}\text { POB } \\
\text { Category }\end{array}$ & $\begin{array}{c}\text { Th-232 } \\
(\mathrm{kg})\end{array}$ & $\begin{array}{c}\mathrm{U}-232 \\
(\mathrm{~g})\end{array}$ & $\begin{array}{c}\mathrm{U}-233 \\
(\mathrm{~g})\end{array}$ & $\begin{array}{c}\text { U-234 } \\
(\mathrm{g})\end{array}$ & $\begin{array}{c}\mathrm{U}-235 \\
(\mathrm{~g}) \\
\end{array}$ \\
\hline 633 & 1500846 & 15682 & L-GU51-01 & B $1-3$ & 22 & 2.88 & 0.10 & 47.04 & 4.66 & 0.76 \\
\hline 634 & 1107623 & 15682 & L-GU51-01 & B $1-3$ & 13 & 2.90 & 0.10 & 35.40 & 3.25 & 0.54 \\
\hline 635 & 1103700 & 15682 & L-GU51-01 & B $1-3$ & 13 & 2.90 & 0.10 & 35.40 & 3.25 & 0.54 \\
\hline 636 & 1106844 & 15682 & L-GU51-01 & B $1-3$ & 13 & 2.90 & 0.10 & 35.40 & 3.25 & 0.54 \\
\hline 637 & 1610157 & 15682 & L-GU51-01 & B $1-3$ & 25 & 2.89 & 0.10 & 52.19 & 4.92 & 0.80 \\
\hline 638 & 1503742 & 15682 & L-GU51-01 & B $1-3$ & 22 & 2.88 & 0.10 & 47.04 & 4.66 & 0.76 \\
\hline 639 & 2518041 & 15682 & L-GW52-01 & B $3-2$ & 35 & 2.43 & 0.03 & 55.13 & 3.30 & 0.38 \\
\hline 640 & 1302873 & 15682 & L-GU51-01 & B $1-3$ & 19 & 2.87 & 0.10 & 47.20 & 4.42 & 0.74 \\
\hline 641 & 1500157 & 15682 & L-GU51-01 & B 1-3 & 22 & 2.88 & 0.10 & 47.04 & 4.66 & 0.76 \\
\hline 642 & 2610167 & 15682 & L-GT22-03 & В 3-6 & 35 & 2.43 & 0.03 & 55.13 & 3.30 & 0.38 \\
\hline 643 & 2615512 & 15682 & L-GT22-03 & В $3-6$ & 35 & 2.43 & 0.03 & 55.13 & 3.30 & 0.38 \\
\hline 644 & 2622617 & 15682 & L-GT22-03 & В 3-6 & 35 & 2.43 & 0.03 & 55.13 & 3.30 & 0.38 \\
\hline 645 & 2607509 & 15682 & L-GT22-03 & В 3-6 & 35 & 2.43 & 0.03 & 55.13 & 3.30 & 0.38 \\
\hline 646 & 2605502 & 15682 & L-GT22-03 & В 3-6 & 35 & 2.43 & 0.03 & 55.13 & 3.30 & 0.38 \\
\hline 647 & 2622507 & 15682 & L-GT22-03 & В 3-6 & 35 & 2.43 & 0.03 & 55.13 & 3.30 & 0.38 \\
\hline 648 & 2404018 & 15682 & L-GT22-03 & В $3-6$ & 31 & 2.46 & 0.05 & 34.11 & 2.62 & 0.37 \\
\hline 649 & 2204846 & 15682 & L-GT22-03 & В 3-6 & 29 & 2.45 & 0.05 & 28.98 & 2.29 & 0.31 \\
\hline 650 & 2616684 & 15682 & L-GT22-03 & В 3-6 & 35 & 2.43 & 0.03 & 55.13 & 3.30 & 0.38 \\
\hline 651 & 2600377 & 15682 & L-GT22-03 & В 3-6 & 35 & 2.43 & 0.03 & 55.13 & 3.30 & 0.38 \\
\hline 652 & 2606876 & 15682 & L-GT22-03 & В 3-6 & 35 & 2.43 & 0.03 & 55.13 & 3.30 & 0.38 \\
\hline 653 & 2601367 & 15682 & L-GT22-03 & B 3-6 & 35 & 2.43 & 0.03 & 55.13 & 3.30 & 0.38 \\
\hline 654 & 2101464 & 15682 & L-GT22-03 & B $3-6$ & 29 & 2.45 & 0.05 & 28.98 & 2.29 & 0.31 \\
\hline 655 & 2612735 & 15682 & L-GT22-03 & B 3-6 & 35 & 2.43 & 0.03 & 55.13 & 3.30 & 0.38 \\
\hline 656 & 2600314 & 15682 & L-GT22-03 & В $3-6$ & 35 & 2.43 & 0.03 & 55.13 & 3.30 & 0.38 \\
\hline 657 & 2501670 & 15682 & L-GT22-03 & В 3-6 & 35 & 2.43 & 0.03 & 55.13 & 3.30 & 0.38 \\
\hline 658 & 2513634 & 15682 & L-GT22-03 & В 3-6 & 35 & 2.43 & 0.03 & 55.13 & 3.30 & 0.38 \\
\hline
\end{tabular}




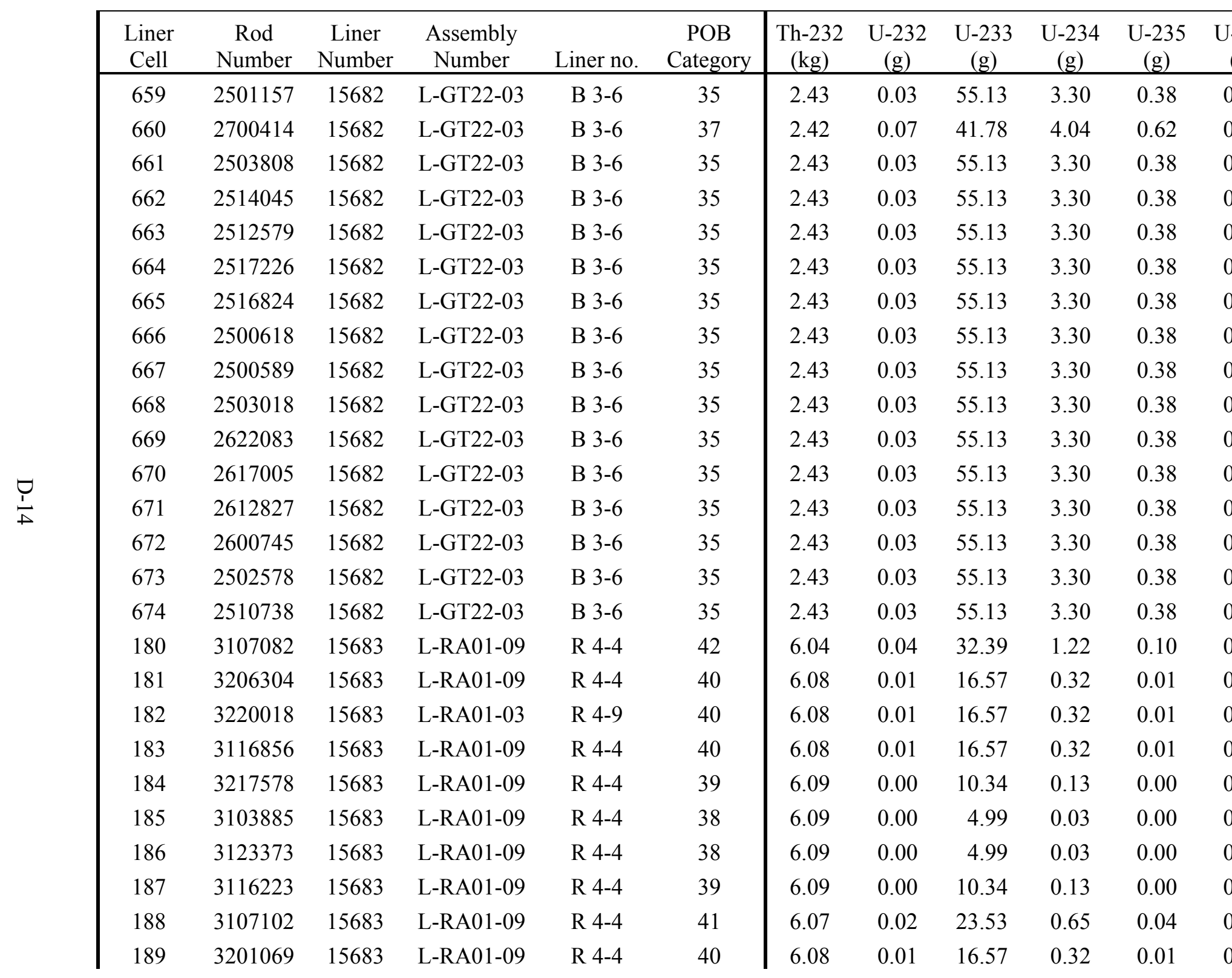




\begin{tabular}{|c|c|c|c|c|c|c|c|c|c|c|}
\hline $\begin{array}{c}\text { Liner } \\
\text { Cell } \\
\end{array}$ & $\begin{array}{c}\text { Rod } \\
\text { Number }\end{array}$ & $\begin{array}{c}\text { Liner } \\
\text { Number }\end{array}$ & $\begin{array}{c}\text { Assembly } \\
\text { Number }\end{array}$ & Liner no. & $\begin{array}{c}\text { POB } \\
\text { Category }\end{array}$ & $\begin{array}{c}\text { Th-232 } \\
(\mathrm{kg})\end{array}$ & $\begin{array}{c}\mathrm{U}-232 \\
(\mathrm{~g})\end{array}$ & $\begin{array}{c}\mathrm{U}-233 \\
(\mathrm{~g})\end{array}$ & $\begin{array}{c}\text { U-234 } \\
(\mathrm{g})\end{array}$ & $\begin{array}{c}\text { U-235 } \\
(\mathrm{g}) \\
\end{array}$ \\
\hline 190 & 3218505 & 15683 & L-RA01-09 & R 4-4 & 40 & 6.08 & 0.01 & 16.57 & 0.32 & 0.01 \\
\hline 191 & 3202674 & 15683 & L-RA01-09 & R 4-4 & 41 & 6.07 & 0.02 & 23.53 & 0.65 & 0.04 \\
\hline 601 & 3102143 & 15683 & Calibration & N/A & Unirrad & 6.04 & 0.00 & 0.00 & 0.00 & 0.00 \\
\hline 602 & 31124 & 15683 & Calibration & N/A & Unirrad & 5.98 & 0.00 & 69.40 & 0.82 & 0.06 \\
\hline 603 & 31063 & 15683 & Calibration & $\mathrm{N} / \mathrm{A}$ & Unirrad & 6.04 & 0.00 & 29.05 & 0.34 & 0.03 \\
\hline 604 & 31123 & 15683 & Calibration & N/A & Unirrad & 5.98 & 0.00 & 69.36 & 0.82 & 0.06 \\
\hline 605 & 3106718 & 15683 & Calibration & N/A & Unirrad & 6.09 & 0.00 & 0.00 & 0.00 & 0.00 \\
\hline 606 & 31062 & 15683 & Calibration & N/A & Unirrad & 6.03 & 0.00 & 29.05 & 0.34 & 0.03 \\
\hline 607 & 3108707 & 15683 & Calibration & N/A & Unirrad & 6.03 & 0.00 & 0.00 & 0.00 & 0.00 \\
\hline 609 & 3203545 & 15683 & L-RA01-09 & R 4-4 & 41 & 6.07 & 0.02 & 23.53 & 0.65 & 0.04 \\
\hline 610 & 3220751 & 15683 & L-RA01-09 & R 4-4 & 42 & 6.04 & 0.04 & 32.39 & 1.22 & 0.10 \\
\hline 611 & 3127075 & 15683 & L-RA01-09 & R 4-4 & 40 & 6.08 & 0.01 & 16.57 & 0.32 & 0.01 \\
\hline 612 & 3216258 & 15683 & L-RA01-09 & R 4-4 & 38 & 6.09 & 0.00 & 4.99 & 0.03 & 0.00 \\
\hline 613 & 3214875 & 15683 & L-RA01-09 & R 4-4 & 42 & 6.04 & 0.04 & 32.39 & 1.22 & 0.10 \\
\hline 614 & 3103555 & 15683 & L-RA01-09 & R 4-4 & 41 & 6.07 & 0.02 & 23.53 & 0.65 & 0.04 \\
\hline 615 & 3118708 & 15683 & L-RA01-09 & R 4-4 & 41 & 6.07 & 0.02 & 23.53 & 0.65 & 0.04 \\
\hline 617 & 3203379 & 15683 & L-RA01-09 & R 4-4 & 41 & 6.07 & 0.02 & 23.53 & 0.65 & 0.04 \\
\hline 619 & 3104664 & 15683 & L-RA01-09 & R 4-4 & 40 & 6.08 & 0.01 & 16.57 & 0.32 & 0.01 \\
\hline 620 & 3122163 & 15683 & L-RA01-09 & R 4-4 & 39 & 6.09 & 0.00 & 10.34 & 0.13 & 0.00 \\
\hline 621 & 3222833 & 15683 & L-RA01-09 & R 4-4 & 39 & 6.09 & 0.00 & 10.34 & 0.13 & 0.00 \\
\hline 622 & 3216139 & 15683 & L-RA01-09 & R 4-4 & 38 & 6.09 & 0.00 & 4.99 & 0.03 & 0.00 \\
\hline 623 & 3217506 & 15683 & L-RA01-09 & R 4-4 & 40 & 6.08 & 0.01 & 16.57 & 0.32 & 0.01 \\
\hline 624 & 3116167 & 15683 & L-RA01-09 & R 4-4 & 42 & 6.04 & 0.04 & 32.39 & 1.22 & 0.10 \\
\hline 625 & 3118019 & 15683 & L-RA01-09 & R 4-4 & 38 & 6.09 & 0.00 & 4.99 & 0.03 & 0.00 \\
\hline 626 & 3113006 & 15683 & L-RA01-09 & R 4-4 & 38 & 6.09 & 0.00 & 4.99 & 0.03 & 0.00 \\
\hline 627 & 3120744 & 15683 & L-RA01-09 & R 4-4 & 38 & 6.09 & 0.00 & 4.99 & 0.03 & 0.00 \\
\hline
\end{tabular}




\begin{tabular}{|c|c|c|c|c|c|c|c|c|c|c|}
\hline $\begin{array}{c}\text { Liner } \\
\text { Cell } \\
\end{array}$ & $\begin{array}{c}\text { Rod } \\
\text { Number }\end{array}$ & $\begin{array}{c}\text { Liner } \\
\text { Number }\end{array}$ & $\begin{array}{c}\text { Assembly } \\
\text { Number }\end{array}$ & Liner no. & $\begin{array}{c}\text { POB } \\
\text { Category }\end{array}$ & $\begin{array}{c}\text { Th-232 } \\
(\mathrm{kg})\end{array}$ & $\begin{array}{c}\mathrm{U}-232 \\
(\mathrm{~g})\end{array}$ & $\begin{array}{c}\mathrm{U}-233 \\
(\mathrm{~g})\end{array}$ & $\begin{array}{c}\mathrm{U}-234 \\
(\mathrm{~g})\end{array}$ & $\begin{array}{c}\mathrm{U}-235 \\
(\mathrm{~g}) \\
\end{array}$ \\
\hline 629 & 3208127 & 15683 & L-RA01-09 & R 4-4 & 41 & 6.07 & 0.02 & 23.53 & 0.65 & 0.04 \\
\hline 630 & 3211236 & 15683 & L-RA01-09 & R 4-4 & 42 & 6.04 & 0.04 & 32.39 & 1.22 & 0.10 \\
\hline 631 & 3217266 & 15683 & L-RA01-09 & R 4-4 & 42 & 6.04 & 0.04 & 32.39 & 1.22 & 0.10 \\
\hline 632 & 3218413 & 15683 & L-RA01-09 & R 4-4 & 39 & 6.09 & 0.00 & 10.34 & 0.13 & 0.00 \\
\hline 633 & 3218669 & 15683 & L-RA01-09 & R 4-4 & 39 & 6.09 & 0.00 & 10.34 & 0.13 & 0.00 \\
\hline 634 & 3222474 & 15683 & L-RA01-09 & R 4-4 & 38 & 6.09 & 0.00 & 4.99 & 0.03 & 0.00 \\
\hline 635 & 3203774 & 15683 & L-RA01-09 & R 4-4 & 38 & 6.09 & 0.00 & 4.99 & 0.03 & 0.00 \\
\hline 636 & 3207458 & 15683 & L-RB01-08 & R 5-4 & 50 & 6.07 & 0.01 & 19.14 & 0.42 & 0.02 \\
\hline 637 & 3204654 & 15683 & L-RB01-08 & R 5-4 & 50 & 6.07 & 0.01 & 19.14 & 0.42 & 0.02 \\
\hline 638 & 3206762 & 15683 & L-RB01-08 & R 5-4 & 50 & 6.07 & 0.01 & 19.14 & 0.42 & 0.02 \\
\hline 639 & 3201380 & 15683 & L-RB01-08 & R 5-4 & 50 & 6.07 & 0.01 & 19.14 & 0.42 & 0.02 \\
\hline 640 & 3226636 & 15683 & L-RB01-08 & R 5-4 & 50 & 6.07 & 0.01 & 19.14 & 0.42 & 0.02 \\
\hline 641 & 3213629 & 15683 & L-RB01-08 & R 5-4 & 50 & 6.07 & 0.01 & 19.14 & 0.42 & 0.02 \\
\hline 642 & 3122605 & 15683 & L-RA01-09 & R 4-4 & 39 & 6.09 & 0.00 & 10.34 & 0.13 & 0.00 \\
\hline 643 & 3126470 & 15683 & L-RA01-09 & R 4-4 & 40 & 6.08 & 0.01 & 16.57 & 0.32 & 0.01 \\
\hline 644 & 3105488 & 15683 & L-RA01-09 & R 4-4 & 40 & 6.08 & 0.01 & 16.57 & 0.32 & 0.01 \\
\hline 645 & 3123245 & 15683 & L-RA01-09 & R 4-4 & 39 & 6.09 & 0.00 & 10.34 & 0.13 & 0.00 \\
\hline 648 & 3111228 & 15683 & L-RB01-08 & R 5-4 & 50 & 6.07 & 0.01 & 19.14 & 0.42 & 0.02 \\
\hline 649 & 3106819 & 15683 & L-RB01-08 & R 5-4 & 50 & 6.07 & 0.01 & 19.14 & 0.42 & 0.02 \\
\hline 650 & 3100228 & 15683 & L-RB01-08 & R 5-4 & 50 & 6.07 & 0.01 & 19.14 & 0.42 & 0.02 \\
\hline 651 & 3102318 & 15683 & L-RB01-08 & R 5-4 & 50 & 6.07 & 0.01 & 19.14 & 0.42 & 0.02 \\
\hline 652 & 3111513 & 15683 & L-RB01-08 & R 5-4 & 48 & 6.09 & 0.00 & 4.80 & 0.03 & 0.00 \\
\hline 653 & 3102620 & 15683 & L-RB01-08 & R 5-4 & 48 & 6.09 & 0.00 & 4.80 & 0.03 & 0.00 \\
\hline 654 & 3106635 & 15683 & L-RB01-08 & R 5-4 & 48 & 6.09 & 0.00 & 4.80 & 0.03 & 0.00 \\
\hline 655 & 3106846 & 15683 & L-RB01-08 & R 5-4 & 48 & 6.09 & 0.00 & 4.80 & 0.03 & 0.00 \\
\hline 656 & 3204663 & 15683 & L-RB01-08 & R 5-4 & 49 & 6.09 & 0.00 & 10.46 & 0.12 & 0.00 \\
\hline
\end{tabular}




\begin{tabular}{|c|c|c|c|c|c|c|c|c|c|c|}
\hline $\begin{array}{c}\text { Liner } \\
\text { Cell } \\
\end{array}$ & $\begin{array}{c}\text { Rod } \\
\text { Number }\end{array}$ & $\begin{array}{c}\text { Liner } \\
\text { Number }\end{array}$ & $\begin{array}{c}\text { Assembly } \\
\text { Number }\end{array}$ & Liner no. & $\begin{array}{c}\text { POB } \\
\text { Category }\end{array}$ & $\begin{array}{c}\text { Th-232 } \\
(\mathrm{kg})\end{array}$ & $\begin{array}{c}\mathrm{U}-232 \\
(\mathrm{~g})\end{array}$ & $\begin{array}{c}\mathrm{U}-233 \\
(\mathrm{~g})\end{array}$ & $\begin{array}{c}\mathrm{U}-234 \\
(\mathrm{~g})\end{array}$ & $\begin{array}{c}\mathrm{U}-235 \\
(\mathrm{~g}) \\
\end{array}$ \\
\hline 657 & 3210136 & 15683 & L-RB01-08 & R 5-4 & 48 & 6.09 & 0.00 & 4.80 & 0.03 & 0.00 \\
\hline 658 & 3201160 & 15683 & L-RB01-08 & R 5-4 & 48 & 6.09 & 0.00 & 4.80 & 0.03 & 0.00 \\
\hline 659 & 3223675 & 15683 & L-RB01-08 & R 5-4 & 48 & 6.09 & 0.00 & 4.80 & 0.03 & 0.00 \\
\hline 660 & 3208852 & 15683 & L-RB01-08 & R 5-4 & 48 & 6.09 & 0.00 & 4.80 & 0.03 & 0.00 \\
\hline 661 & 3204810 & 15683 & L-RB01-08 & R 5-4 & 48 & 6.09 & 0.00 & 4.80 & 0.03 & 0.00 \\
\hline 662 & 3201464 & 15683 & L-RB01-08 & R 5-4 & 48 & 6.09 & 0.00 & 4.80 & 0.03 & 0.00 \\
\hline 663 & 3200815 & 15683 & L-RB01-08 & R 5-4 & 48 & 6.09 & 0.00 & 4.80 & 0.03 & 0.00 \\
\hline 664 & 3204609 & 15683 & L-RB01-08 & R 5-4 & 49 & 6.09 & 0.00 & 10.46 & 0.12 & 0.00 \\
\hline 665 & 3220182 & 15683 & L-RB01-08 & R 5-4 & 49 & 6.09 & 0.00 & 10.46 & 0.12 & 0.00 \\
\hline 666 & 3206423 & 15683 & L-RB01-08 & R 5-4 & 49 & 6.09 & 0.00 & 10.46 & 0.12 & 0.00 \\
\hline 667 & 3203030 & 15683 & L-RB01-08 & R 5-4 & 49 & 6.09 & 0.00 & 10.46 & 0.12 & 0.00 \\
\hline 668 & 3110624 & 15683 & L-RA01-10 & R 4-3 & 46 & 6.08 & 0.02 & 22.42 & 0.59 & 0.04 \\
\hline 670 & 3207716 & 15683 & L-RA01-10 & R 4-3 & 47 & 6.04 & 0.04 & 30.97 & 1.12 & 0.09 \\
\hline 671 & 3220357 & 15683 & L-RA01-10 & R 4-3 & 47 & 6.04 & 0.04 & 30.97 & 1.12 & 0.09 \\
\hline 672 & 3225453 & 15683 & L-RB01-08 & R 5-4 & 50 & 6.07 & 0.01 & 19.14 & 0.42 & 0.02 \\
\hline 673 & 3204636 & 15683 & L-RB01-08 & R 5-4 & 49 & 6.09 & 0.00 & 10.46 & 0.12 & 0.00 \\
\hline 674 & 3200705 & 15683 & L-RB01-08 & R 5-4 & 49 & 6.09 & 0.00 & 10.46 & 0.12 & 0.00 \\
\hline 675 & 3217275 & 15683 & L-RB01-08 & R 5-4 & 49 & 6.09 & 0.00 & 10.46 & 0.12 & 0.00 \\
\hline 101 & 1612210 & 15684 & L-GW52-01 & B $3-2$ & 27 & 2.90 & 0.09 & 52.06 & 4.53 & 0.70 \\
\hline 102 & 1614824 & 15684 & L-GW52-01 & В $3-2$ & 27 & 2.90 & 0.09 & 52.06 & 4.53 & 0.70 \\
\hline 103 & 1606884 & 15684 & L-GW52-01 & B $3-2$ & 27 & 2.90 & 0.09 & 52.06 & 4.53 & 0.70 \\
\hline 104 & 1600330 & 15684 & L-GW52-01 & B $3-2$ & 27 & 2.90 & 0.09 & 52.06 & 4.53 & 0.70 \\
\hline 105 & 1611275 & 15684 & L-GW52-01 & В 3-2 & 27 & 2.90 & 0.09 & 52.06 & 4.53 & 0.70 \\
\hline 106 & 1602071 & 15684 & L-GW52-01 & B $3-2$ & 27 & 2.90 & 0.09 & 52.06 & 4.53 & 0.70 \\
\hline 107 & 1607571 & 15684 & L-GW52-01 & B 3-2 & 27 & 2.90 & 0.09 & 52.06 & 4.53 & 0.70 \\
\hline 108 & 1514513 & 15684 & L-GW52-01 & В $3-2$ & 24 & 2.88 & 0.09 & 46.71 & 4.29 & 0.67 \\
\hline
\end{tabular}




\begin{tabular}{|c|c|c|c|c|c|c|c|c|c|c|}
\hline $\begin{array}{c}\text { Liner } \\
\text { Cell } \\
\end{array}$ & $\begin{array}{c}\text { Rod } \\
\text { Number }\end{array}$ & $\begin{array}{c}\text { Liner } \\
\text { Number }\end{array}$ & $\begin{array}{c}\text { Assembly } \\
\text { Number }\end{array}$ & Liner no. & $\begin{array}{c}\text { POB } \\
\text { Category }\end{array}$ & $\begin{array}{c}\text { Th-232 } \\
(\mathrm{kg})\end{array}$ & $\begin{array}{c}\mathrm{U}-232 \\
(\mathrm{~g}) \\
\end{array}$ & $\begin{array}{c}\mathrm{U}-233 \\
(\mathrm{~g})\end{array}$ & $\begin{array}{c}\text { U-234 } \\
(\mathrm{g})\end{array}$ & $\begin{array}{c}\mathrm{U}-235 \\
(\mathrm{~g}) \\
\end{array}$ \\
\hline 109 & 1510874 & 15684 & L-GW52-01 & B $3-2$ & 24 & 2.88 & 0.09 & 46.71 & 4.29 & 0.67 \\
\hline 110 & 1500184 & 15684 & L-GW52-01 & В $3-2$ & 24 & 2.88 & 0.09 & 46.71 & 4.29 & 0.67 \\
\hline 111 & 1504144 & 15684 & L-GW52-01 & В $3-2$ & 24 & 2.88 & 0.09 & 46.71 & 4.29 & 0.67 \\
\hline 112 & 1500727 & 15684 & L-GW52-01 & В $3-2$ & 24 & 2.88 & 0.09 & 46.71 & 4.29 & 0.67 \\
\hline 113 & 1514329 & 15684 & L-GW52-01 & B $3-2$ & 24 & 2.88 & 0.09 & 46.71 & 4.29 & 0.67 \\
\hline 114 & 1510883 & 15684 & L-GW52-01 & В $3-2$ & 24 & 2.88 & 0.09 & 46.71 & 4.29 & 0.67 \\
\hline 115 & 1508865 & 15684 & L-GW52-01 & B 3-2 & 24 & 2.88 & 0.09 & 46.71 & 4.29 & 0.67 \\
\hline 116 & 1405714 & 15684 & L-GW52-01 & B $3-2$ & 18 & 2.92 & 0.08 & 39.40 & 3.21 & 0.50 \\
\hline 117 & 1312764 & 15684 & L-GW52-01 & В $3-2$ & 21 & 2.87 & 0.08 & 46.59 & 4.02 & 0.63 \\
\hline 118 & 1303652 & 15684 & L-GW52-01 & B 3-2 & 21 & 2.87 & 0.08 & 46.59 & 4.02 & 0.63 \\
\hline 119 & 1301387 & 15684 & L-GW52-01 & В $3-2$ & 21 & 2.87 & 0.08 & 46.59 & 4.02 & 0.63 \\
\hline 120 & 1302670 & 15684 & L-GW52-01 & В $3-2$ & 21 & 2.87 & 0.08 & 46.59 & 4.02 & 0.63 \\
\hline 121 & 1101555 & 15684 & L-GW52-01 & B 3-2 & 15 & 2.91 & 0.08 & 33.30 & 2.73 & 0.41 \\
\hline 122 & 1110280 & 15684 & L-GW52-01 & B $3-2$ & 15 & 2.91 & 0.08 & 33.30 & 2.73 & 0.41 \\
\hline 123 & 1311215 & 15684 & L-GW52-01 & B 3-2 & 21 & 2.87 & 0.08 & 46.59 & 4.02 & 0.63 \\
\hline 124 & 1408518 & 15684 & L-GW52-01 & B $3-2$ & 18 & 2.92 & 0.08 & 39.40 & 3.21 & 0.50 \\
\hline 125 & 1408554 & 15684 & L-GW52-01 & B 3-2 & 18 & 2.92 & 0.08 & 39.40 & 3.21 & 0.50 \\
\hline 126 & 1206677 & 15684 & L-GW52-01 & B 3-2 & 15 & 2.91 & 0.08 & 33.30 & 2.73 & 0.41 \\
\hline 127 & 1205788 & 15684 & L-GW52-01 & B $3-2$ & 15 & 2.91 & 0.08 & 33.30 & 2.73 & 0.41 \\
\hline 128 & 1208161 & 15684 & L-GW52-01 & В $3-2$ & 15 & 2.91 & 0.08 & 33.30 & 2.73 & 0.41 \\
\hline 129 & 1207447 & 15684 & L-GW52-01 & B $3-2$ & 15 & 2.91 & 0.08 & 33.30 & 2.73 & 0.41 \\
\hline 130 & 1401608 & 15684 & L-GW52-01 & B $3-2$ & 18 & 2.92 & 0.08 & 39.40 & 3.21 & 0.50 \\
\hline 131 & 1607048 & 15684 & L-GW52-01 & В $3-2$ & 27 & 2.90 & 0.09 & 52.06 & 4.53 & 0.70 \\
\hline 132 & 1304889 & 15684 & L-GW52-01 & B $3-2$ & 21 & 2.87 & 0.08 & 46.59 & 4.02 & 0.63 \\
\hline 133 & 1506288 & 15684 & L-GW52-01 & B 3-2 & 24 & 2.88 & 0.09 & 46.71 & 4.29 & 0.67 \\
\hline 134 & 1502862 & 15684 & L-GW52-01 & В $3-2$ & 24 & 2.88 & 0.09 & 46.71 & 4.29 & 0.67 \\
\hline
\end{tabular}




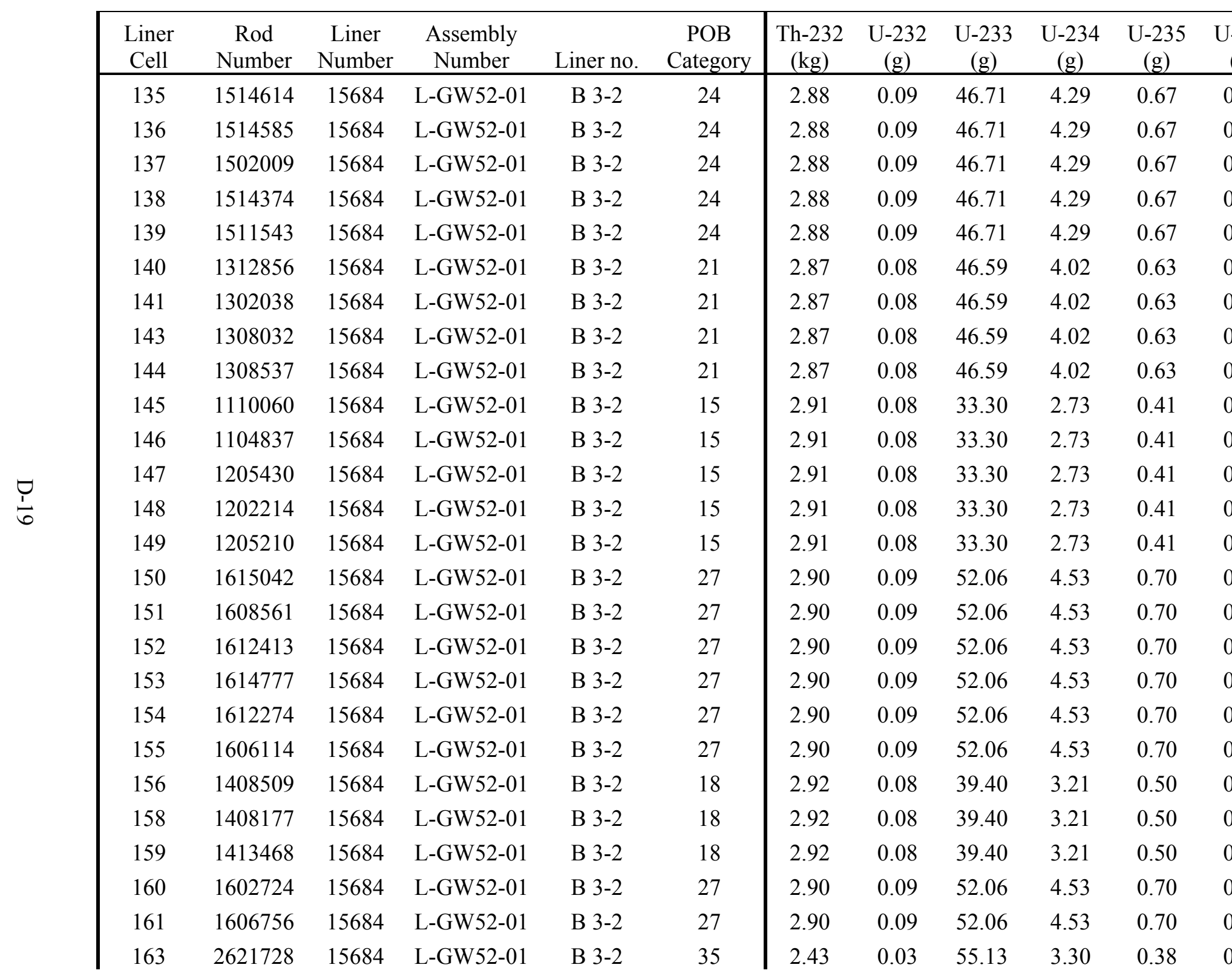




\begin{tabular}{|c|c|c|c|c|c|c|c|c|c|c|}
\hline $\begin{array}{c}\text { Liner } \\
\text { Cell }\end{array}$ & $\begin{array}{c}\text { Rod } \\
\text { Number }\end{array}$ & $\begin{array}{c}\text { Liner } \\
\text { Number }\end{array}$ & $\begin{array}{l}\text { Assembly } \\
\text { Number }\end{array}$ & Liner no. & $\begin{array}{c}\text { POB } \\
\text { Category }\end{array}$ & $\begin{array}{c}\text { Th-232 } \\
\text { (kg) }\end{array}$ & $\begin{array}{c}\mathrm{U}-232 \\
(\mathrm{~g})\end{array}$ & $\begin{array}{c}\mathrm{U}-233 \\
(\mathrm{~g})\end{array}$ & $\begin{array}{c}\mathrm{U}-234 \\
(\mathrm{~g})\end{array}$ & $\begin{array}{c}\text { U-235 } \\
(\mathrm{g})\end{array}$ \\
\hline 164 & 2404615 & 15684 & L-GW52-01 & B $3-2$ & 31 & 2.46 & 0.05 & 34.11 & 2.62 & 0.37 \\
\hline 165 & 2202352 & 15684 & L-GW52-01 & В $3-2$ & 29 & 2.45 & 0.05 & 28.98 & 2.29 & 0.31 \\
\hline 166 & 1401754 & 15684 & L-GW52-01 & В $3-2$ & 18 & 2.92 & 0.08 & 39.40 & 3.21 & 0.50 \\
\hline 167 & 1201307 & 15684 & L-GW52-01 & B $3-2$ & 15 & 2.91 & 0.08 & 33.30 & 2.73 & 0.41 \\
\hline 168 & 2515860 & 15684 & L-GW52-01 & B $3-2$ & 35 & 2.43 & 0.03 & 55.13 & 3.30 & 0.38 \\
\hline 169 & 2700660 & 15684 & L-GW52-01 & B $3-2$ & 37 & 2.42 & 0.07 & 41.78 & 4.04 & 0.62 \\
\hline 170 & 2302130 & 15684 & L-GW52-01 & B $3-2$ & 33 & 2.42 & 0.05 & 46.13 & 3.53 & 0.47 \\
\hline 171 & 2505272 & 15684 & L-GW52-01 & B $3-2$ & 35 & 2.43 & 0.03 & 55.13 & 3.30 & 0.38 \\
\hline 172 & 2501588 & 15684 & L-GW52-01 & В $3-2$ & 35 & 2.43 & 0.03 & 55.13 & 3.30 & 0.38 \\
\hline 173 & 2516878 & 15684 & L-GW52-01 & B 3-2 & 35 & 2.43 & 0.03 & 55.13 & 3.30 & 0.38 \\
\hline 174 & 2513827 & 15684 & L-GW52-01 & B 3-2 & 35 & 2.43 & 0.03 & 55.13 & 3.30 & 0.38 \\
\hline 324 & 1103167 & 15684 & L-GW52-01 & В $3-2$ & 15 & 2.91 & 0.08 & 33.30 & 2.73 & 0.41 \\
\hline 601 & 2517208 & 15684 & L-GT22-03 & В 3-6 & 35 & 2.43 & 0.03 & 55.13 & 3.30 & 0.38 \\
\hline 602 & 2505236 & 15684 & L-GT22-03 & В 3-6 & 35 & 2.43 & 0.03 & 55.13 & 3.30 & 0.38 \\
\hline 603 & 2701430 & 15684 & L-GT22-03 & В 3-6 & 37 & 2.42 & 0.07 & 41.78 & 4.04 & 0.62 \\
\hline 604 & 2305449 & 15684 & L-GT22-03 & В $3-6$ & 33 & 2.42 & 0.05 & 46.13 & 3.53 & 0.47 \\
\hline 605 & 2305312 & 15684 & L-GT22-03 & В 3-6 & 33 & 2.42 & 0.05 & 46.13 & 3.53 & 0.47 \\
\hline 606 & 2101363 & 15684 & L-GT22-03 & В 3-6 & 29 & 2.45 & 0.05 & 28.98 & 2.29 & 0.31 \\
\hline 607 & 2620747 & 15684 & L-GT22-03 & В 3-6 & 35 & 2.43 & 0.03 & 55.13 & 3.30 & 0.38 \\
\hline 608 & 2612625 & 15684 & L-GT22-03 & В 3-6 & 35 & 2.43 & 0.03 & 55.13 & 3.30 & 0.38 \\
\hline 609 & 2613413 & 15684 & L-GT22-03 & B 3-6 & 35 & 2.43 & 0.03 & 55.13 & 3.30 & 0.38 \\
\hline 610 & 2622175 & 15684 & L-GT22-03 & B 3-6 & 35 & 2.43 & 0.03 & 55.13 & 3.30 & 0.38 \\
\hline 611 & 2604887 & 15684 & L-GT22-03 & B 3-6 & 35 & 2.43 & 0.03 & 55.13 & 3.30 & 0.38 \\
\hline 612 & 2305853 & 15684 & L-GT22-03 & В $3-6$ & 33 & 2.42 & 0.05 & 46.13 & 3.53 & 0.47 \\
\hline 613 & 2406355 & 15684 & L-GT22-03 & В 3-6 & 31 & 2.46 & 0.05 & 34.11 & 2.62 & 0.37 \\
\hline 614 & 2204855 & 15684 & L-GT22-03 & В 3-6 & 29 & 2.45 & 0.05 & 28.98 & 2.29 & 0.31 \\
\hline
\end{tabular}




\begin{tabular}{|c|c|c|c|c|c|c|c|c|c|c|}
\hline $\begin{array}{c}\text { Liner } \\
\text { Cell } \\
\end{array}$ & $\begin{array}{c}\text { Rod } \\
\text { Number }\end{array}$ & $\begin{array}{c}\text { Liner } \\
\text { Number } \\
\end{array}$ & $\begin{array}{c}\text { Assembly } \\
\text { Number }\end{array}$ & Liner no. & $\begin{array}{c}\text { POB } \\
\text { Category }\end{array}$ & $\begin{array}{c}\text { Th-232 } \\
(\mathrm{kg})\end{array}$ & $\begin{array}{c}\mathrm{U}-232 \\
(\mathrm{~g})\end{array}$ & $\begin{array}{c}\mathrm{U}-233 \\
(\mathrm{~g})\end{array}$ & $\begin{array}{c}\mathrm{U}-234 \\
(\mathrm{~g})\end{array}$ & $\begin{array}{c}\text { U-235 } \\
(\mathrm{g}) \\
\end{array}$ \\
\hline 615 & 2610223 & 15684 & L-GS22-01 & B 2-2 & 34 & 2.43 & 0.05 & 53.87 & 3.78 & 0.47 \\
\hline 616 & 2613505 & 15684 & L-GS22-01 & B 2-2 & 34 & 2.43 & 0.05 & 53.87 & 3.78 & 0.47 \\
\hline 617 & 2610205 & 15684 & L-GS22-01 & B 2-2 & 34 & 2.43 & 0.05 & 53.87 & 3.78 & 0.47 \\
\hline 618 & 2620655 & 15684 & L-GS22-01 & B 2-2 & 34 & 2.43 & 0.05 & 53.87 & 3.78 & 0.47 \\
\hline 619 & 2606389 & 15684 & L-GS22-01 & B 2-2 & 34 & 2.43 & 0.05 & 53.87 & 3.78 & 0.47 \\
\hline 620 & 2614769 & 15684 & L-GS22-01 & B 2-2 & 34 & 2.43 & 0.05 & 53.87 & 3.78 & 0.47 \\
\hline 621 & 2610883 & 15684 & L-GS22-01 & B 2-2 & 34 & 2.43 & 0.05 & 53.87 & 3.78 & 0.47 \\
\hline 622 & 2618866 & 15684 & L-GS22-01 & B 2-2 & 34 & 2.43 & 0.05 & 53.87 & 3.78 & 0.47 \\
\hline 623 & 2617106 & 15684 & L-GS22-01 & B $2-2$ & 34 & 2.43 & 0.05 & 53.87 & 3.78 & 0.47 \\
\hline 624 & 2605583 & 15684 & L-GS22-01 & B 2-2 & 34 & 2.43 & 0.05 & 53.87 & 3.78 & 0.47 \\
\hline 625 & 2616776 & 15684 & L-GS22-01 & B 2-2 & 34 & 2.43 & 0.05 & 53.87 & 3.78 & 0.47 \\
\hline 626 & 2405522 & 15684 & L-GS22-01 & B 2-2 & 30 & 2.46 & 0.06 & 34.68 & 2.98 & 0.45 \\
\hline 627 & 2505025 & 15684 & L-GS22-01 & B 2-2 & 34 & 2.43 & 0.05 & 53.87 & 3.78 & 0.47 \\
\hline 628 & 2518371 & 15684 & L-GS22-01 & B 2-2 & 34 & 2.43 & 0.05 & 53.87 & 3.78 & 0.47 \\
\hline 629 & 2511663 & 15684 & L-GS22-01 & B 2-2 & 34 & 2.43 & 0.05 & 53.87 & 3.78 & 0.47 \\
\hline 630 & 2504585 & 15684 & L-GS22-01 & B 2-2 & 34 & 2.43 & 0.05 & 53.87 & 3.78 & 0.47 \\
\hline 631 & 2513717 & 15684 & L-GS22-01 & B 2-2 & 34 & 2.43 & 0.05 & 53.87 & 3.78 & 0.47 \\
\hline 632 & 2517823 & 15684 & L-GS22-01 & B 2-2 & 34 & 2.43 & 0.05 & 53.87 & 3.78 & 0.47 \\
\hline 633 & 2504706 & 15684 & L-GS22-01 & B 2-2 & 34 & 2.43 & 0.05 & 53.87 & 3.78 & 0.47 \\
\hline 634 & 2506814 & 15684 & L-GS22-01 & B 2-2 & 34 & 2.43 & 0.05 & 53.87 & 3.78 & 0.47 \\
\hline 635 & 2516759 & 15684 & L-GS22-01 & B 2-2 & 34 & 2.43 & 0.05 & 53.87 & 3.78 & 0.47 \\
\hline 636 & 2400287 & 15684 & L-GS22-01 & B 2-2 & 30 & 2.46 & 0.06 & 34.68 & 2.98 & 0.45 \\
\hline 637 & 2406153 & 15684 & L-GS22-01 & B 2-2 & 30 & 2.46 & 0.06 & 34.68 & 2.98 & 0.45 \\
\hline 638 & 2608003 & 15684 & L-GS22-01 & B 2-2 & 34 & 2.43 & 0.05 & 53.87 & 3.78 & 0.47 \\
\hline 640 & 2701357 & 15684 & L-GS22-01 & В 2-2 & 36 & 2.42 & 0.07 & 41.72 & 4.14 & 0.64 \\
\hline 641 & 2700055 & 15684 & L-GS22-01 & B 2-2 & 36 & 2.42 & 0.07 & 41.72 & 4.14 & 0.64 \\
\hline
\end{tabular}




\begin{tabular}{|c|c|c|c|c|c|c|c|c|c|c|}
\hline $\begin{array}{c}\text { Liner } \\
\text { Cell } \\
\end{array}$ & $\begin{array}{c}\text { Rod } \\
\text { Number }\end{array}$ & $\begin{array}{c}\text { Liner } \\
\text { Number }\end{array}$ & $\begin{array}{c}\text { Assembly } \\
\text { Number }\end{array}$ & Liner no. & $\begin{array}{c}\text { POB } \\
\text { Category }\end{array}$ & $\begin{array}{c}\text { Th-232 } \\
(\mathrm{kg})\end{array}$ & $\begin{array}{c}\mathrm{U}-232 \\
(\mathrm{~g})\end{array}$ & $\begin{array}{c}\mathrm{U}-233 \\
(\mathrm{~g})\end{array}$ & $\begin{array}{c}\text { U-234 } \\
(\mathrm{g})\end{array}$ & $\begin{array}{c}\mathrm{U}-235 \\
(\mathrm{~g}) \\
\end{array}$ \\
\hline 642 & 2304138 & 15684 & L-GS22-01 & B 2-2 & 32 & 2.42 & 0.06 & 45.57 & 3.95 & 0.57 \\
\hline 643 & 2303552 & 15684 & L-GS22-01 & В $2-2$ & 32 & 2.42 & 0.06 & 45.57 & 3.95 & 0.57 \\
\hline 644 & 2303560 & 15684 & L-GS22-01 & В $2-2$ & 32 & 2.42 & 0.06 & 45.57 & 3.95 & 0.57 \\
\hline 645 & 2103352 & 15684 & L-GS22-01 & В $2-2$ & 28 & 2.45 & 0.06 & 30.09 & 2.67 & 0.40 \\
\hline 646 & 2102225 & 15684 & L-GS22-01 & B $2-2$ & 28 & 2.45 & 0.06 & 30.09 & 2.67 & 0.40 \\
\hline 647 & 2102077 & 15684 & L-GS22-01 & B 2-2 & 29 & 2.45 & 0.05 & 28.98 & 2.29 & 0.31 \\
\hline 648 & 2504347 & 15684 & L-GS22-01 & B 2-2 & 34 & 2.43 & 0.05 & 53.87 & 3.78 & 0.47 \\
\hline 649 & 2516061 & 15684 & L-GS22-01 & B $2-2$ & 34 & 2.43 & 0.05 & 53.87 & 3.78 & 0.47 \\
\hline 650 & 2518142 & 15684 & L-GS22-01 & B 2-2 & 34 & 2.43 & 0.05 & 53.87 & 3.78 & 0.47 \\
\hline 651 & 2520288 & 15684 & L-GS22-01 & B 2-2 & 34 & 2.43 & 0.05 & 53.87 & 3.78 & 0.47 \\
\hline 652 & 2100245 & 15684 & L-GS22-01 & В $2-2$ & 28 & 2.45 & 0.06 & 30.09 & 2.67 & 0.40 \\
\hline 653 & 2504834 & 15684 & L-GS22-01 & B 2-2 & 34 & 2.43 & 0.05 & 53.87 & 3.78 & 0.47 \\
\hline 654 & 2517289 & 15684 & L-GS22-01 & B $2-2$ & 34 & 2.43 & 0.05 & 53.87 & 3.78 & 0.47 \\
\hline 656 & 2611002 & 15684 & L-GW52-01 & B $3-2$ & 35 & 2.43 & 0.03 & 55.13 & 3.30 & 0.38 \\
\hline 657 & 2615016 & 15684 & L-GW52-01 & В $3-2$ & 35 & 2.43 & 0.03 & 55.13 & 3.30 & 0.38 \\
\hline 658 & 2601147 & 15684 & L-GW52-01 & B $3-2$ & 35 & 2.43 & 0.03 & 55.13 & 3.30 & 0.38 \\
\hline 659 & 2607031 & 15684 & L-GW52-01 & B 3-2 & 35 & 2.43 & 0.03 & 55.13 & 3.30 & 0.38 \\
\hline 660 & 2607325 & 15684 & L-GW52-01 & B 3-2 & 35 & 2.43 & 0.03 & 55.13 & 3.30 & 0.38 \\
\hline 661 & 2511810 & 15684 & L-GW52-01 & B $3-2$ & 35 & 2.43 & 0.03 & 55.13 & 3.30 & 0.38 \\
\hline 662 & 2520656 & 15684 & L-GW52-01 & В $3-2$ & 35 & 2.43 & 0.03 & 55.13 & 3.30 & 0.38 \\
\hline 663 & 2516850 & 15684 & L-GW52-01 & B $3-2$ & 35 & 2.43 & 0.03 & 55.13 & 3.30 & 0.38 \\
\hline 664 & 2608434 & 15684 & L-GW52-01 & B $3-2$ & 35 & 2.43 & 0.03 & 55.13 & 3.30 & 0.38 \\
\hline 665 & 2621407 & 15684 & L-GW52-01 & B $3-2$ & 35 & 2.43 & 0.03 & 55.13 & 3.30 & 0.38 \\
\hline 666 & 2602375 & 15684 & L-GW52-01 & B $3-2$ & 35 & 2.43 & 0.03 & 55.13 & 3.30 & 0.38 \\
\hline 667 & 2201178 & 15684 & L-GW52-01 & B 3-2 & 29 & 2.45 & 0.05 & 28.98 & 2.29 & 0.31 \\
\hline 668 & 2401636 & 15684 & L-GW52-01 & B 3-2 & 31 & 2.46 & 0.05 & 34.11 & 2.62 & 0.37 \\
\hline
\end{tabular}




\begin{tabular}{|c|c|c|c|c|c|c|c|c|c|c|}
\hline $\begin{array}{c}\text { Liner } \\
\text { Cell } \\
\end{array}$ & $\begin{array}{c}\text { Rod } \\
\text { Number }\end{array}$ & $\begin{array}{c}\text { Liner } \\
\text { Number }\end{array}$ & $\begin{array}{c}\text { Assembly } \\
\text { Number }\end{array}$ & Liner no. & $\begin{array}{c}\text { POB } \\
\text { Category }\end{array}$ & $\begin{array}{c}\text { Th-232 } \\
(\mathrm{kg})\end{array}$ & $\begin{array}{c}\mathrm{U}-232 \\
(\mathrm{~g}) \\
\end{array}$ & $\begin{array}{c}\mathrm{U}-233 \\
(\mathrm{~g})\end{array}$ & $\begin{array}{c}\text { U-234 } \\
(\mathrm{g})\end{array}$ & $\begin{array}{c}\mathrm{U}-235 \\
(\mathrm{~g}) \\
\end{array}$ \\
\hline 669 & 2402314 & 15684 & L-GW52-01 & B $3-2$ & 31 & 2.46 & 0.05 & 34.11 & 2.62 & 0.37 \\
\hline 670 & 2605152 & 15684 & L-GW52-01 & В $3-2$ & 35 & 2.43 & 0.03 & 55.13 & 3.30 & 0.38 \\
\hline 671 & 2600653 & 15684 & L-GW52-01 & B 3-2 & 35 & 2.43 & 0.03 & 55.13 & 3.30 & 0.38 \\
\hline 672 & 2606775 & 15684 & L-GW52-01 & B $3-2$ & 35 & 2.43 & 0.03 & 55.13 & 3.30 & 0.38 \\
\hline 673 & 2603383 & 15684 & L-GW52-01 & B $3-2$ & 35 & 2.43 & 0.03 & 55.13 & 3.30 & 0.38 \\
\hline 674 & 2620509 & 15684 & L-GW52-01 & B $3-2$ & 35 & 2.43 & 0.03 & 55.13 & 3.30 & 0.38 \\
\hline 101 & 2502616 & 15685 & Calibration & N/A & Unirrad & 2.43 & 0.00 & 63.14 & 0.75 & 0.05 \\
\hline 102 & 25064 & 15685 & Calibration & N/A & Unirrad & 2.49 & 0.00 & 11.65 & 0.14 & 0.01 \\
\hline 103 & 25123 & 15685 & Calibration & N/A & Unirrad & 2.47 & 0.00 & 27.94 & 0.33 & 0.02 \\
\hline 104 & 25163 & 15685 & Calibration & N/A & Unirrad & 2.46 & 0.00 & 38.17 & 0.51 & 0.03 \\
\hline 154 & 1612146 & 15685 & L-GS22-01 & B 2-2 & 26 & 2.89 & 0.09 & 52.10 & 4.74 & 0.75 \\
\hline 155 & 1605629 & 15685 & L-GU51-01 & B $1-3$ & 25 & 2.89 & 0.10 & 52.19 & 4.92 & 0.80 \\
\hline 156 & 2620628 & 15685 & L-GW52-01 & В $3-2$ & 35 & 2.43 & 0.03 & 55.13 & 3.30 & 0.38 \\
\hline 157 & 1407712 & 15685 & L-GU51-01 & B $1-3$ & 16 & 2.92 & 0.09 & 40.74 & 3.63 & 0.61 \\
\hline 158 & 2104416 & 15685 & L-GS22-01 & B 2-2 & 28 & 2.45 & 0.06 & 30.09 & 2.67 & 0.40 \\
\hline 159 & 1104478 & 15685 & L-GU51-01 & B $1-3$ & 13 & 2.90 & 0.10 & 35.40 & 3.25 & 0.54 \\
\hline 160 & 1503329 & 15685 & L-GU51-01 & B $1-3$ & 22 & 2.88 & 0.10 & 47.04 & 4.66 & 0.76 \\
\hline 161 & 1105055 & 15685 & L-GS22-01 & В 2-2 & 14 & 2.90 & 0.09 & 34.30 & 2.98 & 0.47 \\
\hline 162 & 1203626 & 15685 & L-GW52-01 & B $3-2$ & 15 & 2.91 & 0.08 & 33.30 & 2.73 & 0.41 \\
\hline 163 & 1402762 & 15685 & L-GU51-01 & B $1-3$ & 16 & 2.92 & 0.09 & 40.74 & 3.63 & 0.61 \\
\hline 164 & 1601036 & 15685 & L-GU51-01 & B $1-3$ & 25 & 2.89 & 0.10 & 52.19 & 4.92 & 0.80 \\
\hline 165 & 1600616 & 15685 & L-GS22-01 & B 2-2 & 26 & 2.89 & 0.09 & 52.10 & 4.74 & 0.75 \\
\hline 166 & 2606243 & 15685 & L-GW52-01 & В $3-2$ & 35 & 2.43 & 0.03 & 55.13 & 3.30 & 0.38 \\
\hline 167 & 2620316 & 15685 & L-GW52-01 & B $3-2$ & 35 & 2.43 & 0.03 & 55.13 & 3.30 & 0.38 \\
\hline 168 & 2402249 & 15685 & L-GW52-01 & B $3-2$ & 31 & 2.46 & 0.05 & 34.11 & 2.62 & 0.37 \\
\hline 169 & 2204525 & 15685 & L-GW52-01 & В $3-2$ & 29 & 2.45 & 0.05 & 28.98 & 2.29 & 0.31 \\
\hline
\end{tabular}




\begin{tabular}{|c|c|c|c|c|c|c|c|c|c|c|}
\hline $\begin{array}{c}\text { Liner } \\
\text { Cell }\end{array}$ & $\begin{array}{c}\text { Rod } \\
\text { Number }\end{array}$ & $\begin{array}{c}\text { Liner } \\
\text { Number }\end{array}$ & $\begin{array}{l}\text { Assembly } \\
\text { Number }\end{array}$ & Liner no. & $\begin{array}{c}\text { POB } \\
\text { Category }\end{array}$ & $\begin{array}{c}\text { Th-232 } \\
\text { (kg) }\end{array}$ & $\begin{array}{c}\mathrm{U}-232 \\
(\mathrm{~g})\end{array}$ & $\begin{array}{c}\mathrm{U}-233 \\
(\mathrm{~g})\end{array}$ & $\begin{array}{c}\mathrm{U}-234 \\
(\mathrm{~g})\end{array}$ & $\begin{array}{c}\text { U-235 } \\
(\mathrm{g})\end{array}$ \\
\hline 170 & 2604034 & 15685 & L-GW52-01 & B $3-2$ & 35 & 2.43 & 0.03 & 55.13 & 3.30 & 0.38 \\
\hline 171 & 2616455 & 15685 & L-GW52-01 & В $3-2$ & 35 & 2.43 & 0.03 & 55.13 & 3.30 & 0.38 \\
\hline 172 & 2618408 & 15685 & L-GW52-01 & В $3-2$ & 35 & 2.43 & 0.03 & 55.13 & 3.30 & 0.38 \\
\hline 173 & 2401672 & 15685 & L-GW52-01 & B $3-2$ & 31 & 2.46 & 0.05 & 34.11 & 2.62 & 0.37 \\
\hline 174 & 2617555 & 15685 & L-GW52-01 & B $3-2$ & 35 & 2.43 & 0.03 & 55.13 & 3.30 & 0.38 \\
\hline 175 & 2611332 & 15685 & L-GW52-01 & B $3-2$ & 35 & 2.43 & 0.03 & 55.13 & 3.30 & 0.38 \\
\hline 176 & 2605134 & 15685 & L-GW52-01 & B $3-2$ & 35 & 2.43 & 0.03 & 55.13 & 3.30 & 0.38 \\
\hline 177 & 2615429 & 15685 & L-GW52-01 & B $3-2$ & 35 & 2.43 & 0.03 & 55.13 & 3.30 & 0.38 \\
\hline 178 & 2615236 & 15685 & L-GW52-01 & В $3-2$ & 35 & 2.43 & 0.03 & 55.13 & 3.30 & 0.38 \\
\hline 179 & 2613514 & 15685 & L-GW52-01 & B 3-2 & 35 & 2.43 & 0.03 & 55.13 & 3.30 & 0.38 \\
\hline 180 & 2202058 & 15685 & L-GW52-01 & В $3-2$ & 29 & 2.45 & 0.05 & 28.98 & 2.29 & 0.31 \\
\hline 181 & 2202132 & 15685 & L-GW52-01 & В $3-2$ & 29 & 2.45 & 0.05 & 28.98 & 2.29 & 0.31 \\
\hline 182 & 2305229 & 15685 & L-GW52-01 & B 3-2 & 33 & 2.42 & 0.05 & 46.13 & 3.53 & 0.47 \\
\hline 183 & 2520519 & 15685 & L-GW52-01 & B $3-2$ & 35 & 2.43 & 0.03 & 55.13 & 3.30 & 0.38 \\
\hline 184 & 2517419 & 15685 & L-GW52-01 & В $3-2$ & 35 & 2.43 & 0.03 & 55.13 & 3.30 & 0.38 \\
\hline 185 & 2511508 & 15685 & L-GW52-01 & B $3-2$ & 35 & 2.43 & 0.03 & 55.13 & 3.30 & 0.38 \\
\hline 186 & 2300885 & 15685 & L-GW52-01 & В $3-2$ & 33 & 2.42 & 0.05 & 46.13 & 3.53 & 0.47 \\
\hline 187 & 2102317 & 15685 & L-GW52-01 & B 3-2 & 29 & 2.45 & 0.05 & 28.98 & 2.29 & 0.31 \\
\hline 188 & 2518804 & 15685 & L-GW52-01 & B $3-2$ & 35 & 2.43 & 0.03 & 55.13 & 3.30 & 0.38 \\
\hline 189 & 2517354 & 15685 & L-GW52-01 & В $3-2$ & 35 & 2.43 & 0.03 & 55.13 & 3.30 & 0.38 \\
\hline 190 & 2303644 & 15685 & L-GW52-01 & B $3-2$ & 33 & 2.42 & 0.05 & 46.13 & 3.53 & 0.47 \\
\hline 191 & 2100667 & 15685 & L-GW52-01 & B $3-2$ & 29 & 2.45 & 0.05 & 28.98 & 2.29 & 0.31 \\
\hline 192 & 2102804 & 15685 & L-GW52-01 & В $3-2$ & 29 & 2.45 & 0.05 & 28.98 & 2.29 & 0.31 \\
\hline 193 & 2513753 & 15685 & L-GW52-01 & B $3-2$ & 35 & 2.43 & 0.03 & 55.13 & 3.30 & 0.38 \\
\hline 194 & 2301619 & 15685 & L-GW52-01 & B 3-2 & 33 & 2.42 & 0.05 & 46.13 & 3.53 & 0.47 \\
\hline 195 & 2102150 & 15685 & L-GW52-01 & В 3-2 & 29 & 2.45 & 0.05 & 28.98 & 2.29 & 0.31 \\
\hline
\end{tabular}




\begin{tabular}{|c|c|c|c|c|c|c|c|c|c|c|}
\hline $\begin{array}{c}\text { Liner } \\
\text { Cell } \\
\end{array}$ & $\begin{array}{c}\text { Rod } \\
\text { Number }\end{array}$ & $\begin{array}{c}\text { Liner } \\
\text { Number }\end{array}$ & $\begin{array}{c}\text { Assembly } \\
\text { Number }\end{array}$ & Liner no. & $\begin{array}{c}\text { POB } \\
\text { Category }\end{array}$ & $\begin{array}{c}\text { Th-232 } \\
(\mathrm{kg})\end{array}$ & $\begin{array}{c}\mathrm{U}-232 \\
(\mathrm{~g})\end{array}$ & $\begin{array}{c}\mathrm{U}-233 \\
(\mathrm{~g})\end{array}$ & $\begin{array}{c}\text { U-234 } \\
(\mathrm{g})\end{array}$ & $\begin{array}{c}\mathrm{U}-235 \\
(\mathrm{~g}) \\
\end{array}$ \\
\hline 196 & 2518720 & 15685 & L-GW52-01 & B $3-2$ & 35 & 2.43 & 0.03 & 55.13 & 3.30 & 0.38 \\
\hline 197 & 2502440 & 15685 & L-GW52-01 & В $3-2$ & 35 & 2.43 & 0.03 & 55.13 & 3.30 & 0.38 \\
\hline 198 & 2303166 & 15685 & L-GW52-01 & В $3-2$ & 33 & 2.42 & 0.05 & 46.13 & 3.53 & 0.47 \\
\hline 199 & 2200309 & 15685 & L-GW52-01 & B $3-2$ & 29 & 2.45 & 0.05 & 28.98 & 2.29 & 0.31 \\
\hline 200 & 2200648 & 15685 & L-GW52-01 & B $3-2$ & 29 & 2.45 & 0.05 & 28.98 & 2.29 & 0.31 \\
\hline 201 & 2200721 & 15685 & L-GW52-01 & B $3-2$ & 29 & 2.45 & 0.05 & 28.98 & 2.29 & 0.31 \\
\hline 202 & 2402305 & 15685 & L-GW52-01 & B $3-2$ & 31 & 2.46 & 0.05 & 34.11 & 2.62 & 0.37 \\
\hline 203 & 2600258 & 15685 & L-GW52-01 & B $3-2$ & 35 & 2.43 & 0.03 & 55.13 & 3.30 & 0.38 \\
\hline 204 & 2306356 & 15685 & L-GW52-01 & В $3-2$ & 33 & 2.42 & 0.05 & 46.13 & 3.53 & 0.47 \\
\hline 205 & 2602853 & 15685 & L-GW52-01 & B 3-2 & 35 & 2.43 & 0.03 & 55.13 & 3.30 & 0.38 \\
\hline 206 & 2617077 & 15685 & L-GW52-01 & B $3-2$ & 35 & 2.43 & 0.03 & 55.13 & 3.30 & 0.38 \\
\hline 207 & 2618004 & 15685 & L-GW52-01 & В $3-2$ & 35 & 2.43 & 0.03 & 55.13 & 3.30 & 0.38 \\
\hline 208 & 2621636 & 15685 & L-GW52-01 & B 3-2 & 35 & 2.43 & 0.03 & 55.13 & 3.30 & 0.38 \\
\hline 209 & 2605125 & 15685 & L-GW52-01 & B $3-2$ & 35 & 2.43 & 0.03 & 55.13 & 3.30 & 0.38 \\
\hline 210 & 2617537 & 15685 & L-GW52-01 & В $3-2$ & 35 & 2.43 & 0.03 & 55.13 & 3.30 & 0.38 \\
\hline 211 & 2601064 & 15685 & L-GW52-01 & B $3-2$ & 35 & 2.43 & 0.03 & 55.13 & 3.30 & 0.38 \\
\hline 212 & 2620269 & 15685 & L-GW52-01 & В $3-2$ & 35 & 2.43 & 0.03 & 55.13 & 3.30 & 0.38 \\
\hline 213 & 2622368 & 15685 & L-GW52-01 & B 3-2 & 35 & 2.43 & 0.03 & 55.13 & 3.30 & 0.38 \\
\hline 214 & 2406236 & 15685 & L-GW52-01 & B $3-2$ & 31 & 2.46 & 0.05 & 34.11 & 2.62 & 0.37 \\
\hline 215 & 2405605 & 15685 & L-GW52-01 & В $3-2$ & 31 & 2.46 & 0.05 & 34.11 & 2.62 & 0.37 \\
\hline 216 & 2400572 & 15685 & L-GW52-01 & B $3-2$ & 31 & 2.46 & 0.05 & 34.11 & 2.62 & 0.37 \\
\hline 217 & 2404155 & 15685 & L-GW52-01 & B $3-2$ & 31 & 2.46 & 0.05 & 34.11 & 2.62 & 0.37 \\
\hline 218 & 2404247 & 15685 & L-GW52-01 & В $3-2$ & 31 & 2.46 & 0.05 & 34.11 & 2.62 & 0.37 \\
\hline 219 & 2401158 & 15685 & L-GW52-01 & B $3-2$ & 31 & 2.46 & 0.05 & 34.11 & 2.62 & 0.37 \\
\hline 220 & 2201629 & 15685 & L-GW52-01 & B 3-2 & 29 & 2.45 & 0.05 & 28.98 & 2.29 & 0.31 \\
\hline 221 & 2104167 & 15685 & L-GW52-01 & В $3-2$ & 29 & 2.45 & 0.05 & 28.98 & 2.29 & 0.31 \\
\hline
\end{tabular}




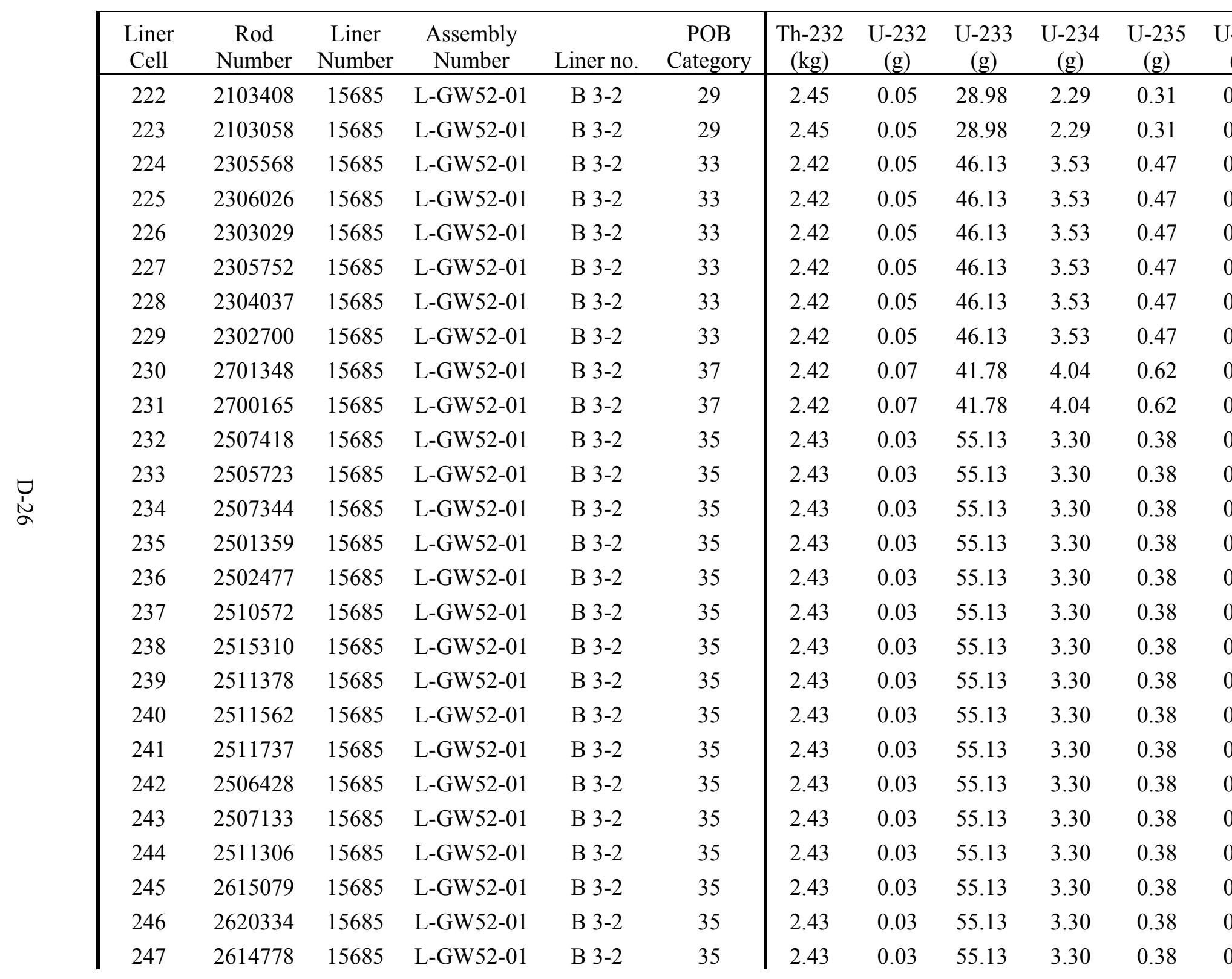




\begin{tabular}{|c|c|c|c|c|c|c|c|c|c|c|}
\hline $\begin{array}{c}\text { Liner } \\
\text { Cell } \\
\end{array}$ & $\begin{array}{c}\text { Rod } \\
\text { Number }\end{array}$ & $\begin{array}{c}\text { Liner } \\
\text { Number }\end{array}$ & $\begin{array}{l}\text { Assembly } \\
\text { Number }\end{array}$ & Liner no. & $\begin{array}{c}\text { POB } \\
\text { Category }\end{array}$ & $\begin{array}{c}\text { Th-232 } \\
\text { (kg) }\end{array}$ & $\begin{array}{c}\mathrm{U}-232 \\
(\mathrm{~g}) \\
\end{array}$ & $\begin{array}{c}\mathrm{U}-233 \\
(\mathrm{~g}) \\
\end{array}$ & $\begin{array}{c}\mathrm{U}-234 \\
(\mathrm{~g}) \\
\end{array}$ & $\begin{array}{c}\text { U-235 } \\
(\mathrm{g}) \\
\end{array}$ \\
\hline 248 & 2602348 & 15685 & L-GW52-01 & B 3-2 & 35 & 2.43 & 0.03 & 55.13 & 3.30 & 0.38 \\
\hline 249 & 2616832 & 15685 & L-GW52-01 & B $3-2$ & 35 & 2.43 & 0.03 & 55.13 & 3.30 & 0.38 \\
\hline 250 & 2618417 & 15685 & L-GW52-01 & B 3-2 & 35 & 2.43 & 0.03 & 55.13 & 3.30 & 0.38 \\
\hline 251 & 2616805 & 15685 & L-GW52-01 & B $3-2$ & 35 & 2.43 & 0.03 & 55.13 & 3.30 & 0.38 \\
\hline 252 & 2605620 & 15685 & L-GW52-01 & B 3-2 & 35 & 2.43 & 0.03 & 55.13 & 3.30 & 0.38 \\
\hline 253 & 2613467 & 15685 & L-GW52-01 & B $3-2$ & 35 & 2.43 & 0.03 & 55.13 & 3.30 & 0.38 \\
\hline 254 & 2600047 & 15685 & L-GW52-01 & B 3-2 & 35 & 2.43 & 0.03 & 55.13 & 3.30 & 0.38 \\
\hline 255 & 2622579 & 15685 & L-GW52-01 & B $3-2$ & 35 & 2.43 & 0.03 & 55.13 & 3.30 & 0.38 \\
\hline 256 & 2606546 & 15685 & L-GW52-01 & B 3-2 & 35 & 2.43 & 0.03 & 55.13 & 3.30 & 0.38 \\
\hline 257 & 2517473 & 15685 & L-GW52-01 & B $3-2$ & 35 & 2.43 & 0.03 & 55.13 & 3.30 & 0.38 \\
\hline 258 & 2512543 & 15685 & L-GW52-01 & B $3-2$ & 35 & 2.43 & 0.03 & 55.13 & 3.30 & 0.38 \\
\hline 259 & 2515255 & 15685 & L-GW52-01 & B 3-2 & 35 & 2.43 & 0.03 & 55.13 & 3.30 & 0.38 \\
\hline 260 & 2518068 & 15685 & L-GW52-01 & B $3-2$ & 35 & 2.43 & 0.03 & 55.13 & 3.30 & 0.38 \\
\hline 261 & 2500039 & 15685 & L-GW52-01 & B $3-2$ & 35 & 2.43 & 0.03 & 55.13 & 3.30 & 0.38 \\
\hline 262 & 2511746 & 15685 & L-GW52-01 & B $3-2$ & 35 & 2.43 & 0.03 & 55.13 & 3.30 & 0.38 \\
\hline 263 & 2513423 & 15685 & L-GW52-01 & B $3-2$ & 35 & 2.43 & 0.03 & 55.13 & 3.30 & 0.38 \\
\hline 264 & 1107127 & 15685 & L-GW52-01 & В $3-2$ & 15 & 2.91 & 0.08 & 33.30 & 2.73 & 0.41 \\
\hline 265 & 1608552 & 15685 & L-GW52-01 & B 3-2 & 27 & 2.90 & 0.09 & 52.06 & 4.53 & 0.70 \\
\hline 266 & 1402625 & 15685 & L-GW52-01 & B 3-2 & 18 & 2.92 & 0.08 & 39.40 & 3.21 & 0.50 \\
\hline 267 & 1208785 & 15685 & L-GW52-01 & B 3-2 & 15 & 2.91 & 0.08 & 33.30 & 2.73 & 0.41 \\
\hline 268 & 1203507 & 15685 & L-GW52-01 & B 3-2 & 15 & 2.91 & 0.08 & 33.30 & 2.73 & 0.41 \\
\hline 269 & 1200480 & 15685 & L-GW52-01 & B 3-2 & 15 & 2.91 & 0.08 & 33.30 & 2.73 & 0.41 \\
\hline 270 & 1203139 & 15685 & L-GW52-01 & B $3-2$ & 15 & 2.91 & 0.08 & 33.30 & 2.73 & 0.41 \\
\hline 271 & 1208179 & 15685 & L-GW52-01 & B $3-2$ & 15 & 2.91 & 0.08 & 33.30 & 2.73 & 0.41 \\
\hline 272 & 1401846 & 15685 & L-GW52-01 & B $3-2$ & 18 & 2.92 & 0.08 & 39.40 & 3.21 & 0.50 \\
\hline 273 & 1304202 & 15685 & L-GW52-01 & B $3-2$ & 21 & 2.87 & 0.08 & 46.59 & 4.02 & 0.63 \\
\hline
\end{tabular}




\begin{tabular}{|c|c|c|c|c|c|c|c|c|c|c|}
\hline $\begin{array}{c}\text { Liner } \\
\text { Cell } \\
\end{array}$ & $\begin{array}{c}\text { Rod } \\
\text { Number }\end{array}$ & $\begin{array}{c}\text { Liner } \\
\text { Number }\end{array}$ & $\begin{array}{c}\text { Assembly } \\
\text { Number }\end{array}$ & Liner no. & $\begin{array}{c}\text { POB } \\
\text { Category }\end{array}$ & $\begin{array}{c}\text { Th-232 } \\
(\mathrm{kg})\end{array}$ & $\begin{array}{c}\mathrm{U}-232 \\
(\mathrm{~g})\end{array}$ & $\begin{array}{c}\mathrm{U}-233 \\
(\mathrm{~g})\end{array}$ & $\begin{array}{c}\text { U-234 } \\
(\mathrm{g})\end{array}$ & $\begin{array}{c}\mathrm{U}-235 \\
(\mathrm{~g}) \\
\end{array}$ \\
\hline 274 & 1107118 & 15685 & L-GW52-01 & B $3-2$ & 15 & 2.91 & 0.08 & 33.30 & 2.73 & 0.41 \\
\hline 275 & 1101308 & 15685 & L-GW52-01 & В $3-2$ & 15 & 2.91 & 0.08 & 33.30 & 2.73 & 0.41 \\
\hline 276 & 1104709 & 15685 & L-GW52-01 & В $3-2$ & 15 & 2.91 & 0.08 & 33.30 & 2.73 & 0.41 \\
\hline 277 & 1101876 & 15685 & L-GW52-01 & B $3-2$ & 15 & 2.91 & 0.08 & 33.30 & 2.73 & 0.41 \\
\hline 278 & 1100529 & 15685 & L-GW52-01 & B $3-2$ & 15 & 2.91 & 0.08 & 33.30 & 2.73 & 0.41 \\
\hline 279 & 1306667 & 15685 & L-GW52-01 & B $3-2$ & 21 & 2.87 & 0.08 & 46.59 & 4.02 & 0.63 \\
\hline 280 & 1304835 & 15685 & L-GW52-01 & B $3-2$ & 21 & 2.87 & 0.08 & 46.59 & 4.02 & 0.63 \\
\hline 281 & 1304725 & 15685 & L-GW52-01 & B $3-2$ & 21 & 2.87 & 0.08 & 46.59 & 4.02 & 0.63 \\
\hline 282 & 1611376 & 15685 & L-GW52-01 & В $3-2$ & 27 & 2.90 & 0.09 & 52.06 & 4.53 & 0.70 \\
\hline 283 & 1607618 & 15685 & L-GW52-01 & B 3-2 & 27 & 2.90 & 0.09 & 52.06 & 4.53 & 0.70 \\
\hline 284 & 1412763 & 15685 & L-GW52-01 & В $3-2$ & 18 & 2.92 & 0.08 & 39.40 & 3.21 & 0.50 \\
\hline 285 & 1401056 & 15685 & L-GW52-01 & В $3-2$ & 18 & 2.92 & 0.08 & 39.40 & 3.21 & 0.50 \\
\hline 286 & 1402129 & 15685 & L-GW52-01 & B 3-2 & 18 & 2.92 & 0.08 & 39.40 & 3.21 & 0.50 \\
\hline 287 & 1205063 & 15685 & L-GW52-01 & B $3-2$ & 15 & 2.91 & 0.08 & 33.30 & 2.73 & 0.41 \\
\hline 288 & 1200683 & 15685 & L-GW52-01 & В $3-2$ & 15 & 2.91 & 0.08 & 33.30 & 2.73 & 0.41 \\
\hline 289 & 1200720 & 15685 & L-GW52-01 & B $3-2$ & 15 & 2.91 & 0.08 & 33.30 & 2.73 & 0.41 \\
\hline 290 & 1200436 & 15685 & L-GW52-01 & В $3-2$ & 15 & 2.91 & 0.08 & 33.30 & 2.73 & 0.41 \\
\hline 291 & 1201022 & 15685 & L-GW52-01 & B 3-2 & 15 & 2.91 & 0.08 & 33.30 & 2.73 & 0.41 \\
\hline 292 & 1105515 & 15685 & L-GW52-01 & B $3-2$ & 15 & 2.91 & 0.08 & 33.30 & 2.73 & 0.41 \\
\hline 293 & 1100235 & 15685 & L-GW52-01 & В $3-2$ & 15 & 2.91 & 0.08 & 33.30 & 2.73 & 0.41 \\
\hline 294 & 1103113 & 15685 & L-GW52-01 & B $3-2$ & 15 & 2.91 & 0.08 & 33.30 & 2.73 & 0.41 \\
\hline 295 & 1100684 & 15685 & L-GW52-01 & B $3-2$ & 15 & 2.91 & 0.08 & 33.30 & 2.73 & 0.41 \\
\hline 296 & 1101638 & 15685 & L-GW52-01 & В $3-2$ & 15 & 2.91 & 0.08 & 33.30 & 2.73 & 0.41 \\
\hline 297 & 1103755 & 15685 & L-GW52-01 & B $3-2$ & 15 & 2.91 & 0.08 & 33.30 & 2.73 & 0.41 \\
\hline 298 & 1107668 & 15685 & L-GW52-01 & B 3-2 & 15 & 2.91 & 0.08 & 33.30 & 2.73 & 0.41 \\
\hline 299 & 1204660 & 15685 & L-GW52-01 & В $3-2$ & 15 & 2.91 & 0.08 & 33.30 & 2.73 & 0.41 \\
\hline
\end{tabular}




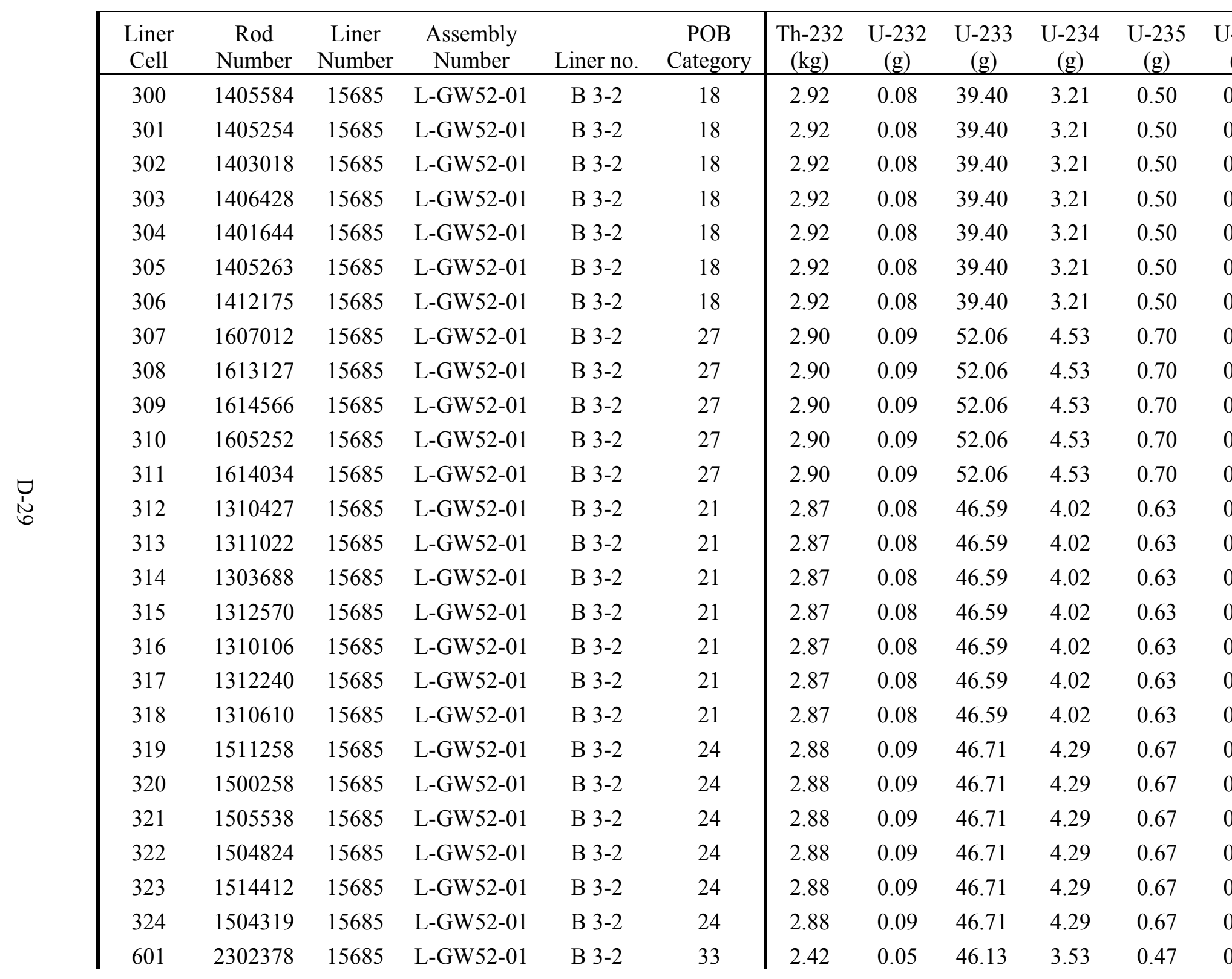




\begin{tabular}{|c|c|c|c|c|c|c|c|c|c|c|}
\hline $\begin{array}{c}\text { Liner } \\
\text { Cell } \\
\end{array}$ & $\begin{array}{c}\text { Rod } \\
\text { Number }\end{array}$ & $\begin{array}{c}\text { Liner } \\
\text { Number }\end{array}$ & $\begin{array}{c}\text { Assembly } \\
\text { Number }\end{array}$ & Liner no. & $\begin{array}{c}\text { POB } \\
\text { Category }\end{array}$ & $\begin{array}{c}\text { Th-232 } \\
(\mathrm{kg})\end{array}$ & $\begin{array}{c}\mathrm{U}-232 \\
(\mathrm{~g})\end{array}$ & $\begin{array}{c}\mathrm{U}-233 \\
(\mathrm{~g})\end{array}$ & $\begin{array}{c}\text { U-234 } \\
(\mathrm{g})\end{array}$ & $\begin{array}{c}\text { U-235 } \\
(\mathrm{g}) \\
\end{array}$ \\
\hline 602 & 2100759 & 15685 & L-GW52-01 & B 3-2 & 29 & 2.45 & 0.05 & 28.98 & 2.29 & 0.31 \\
\hline 603 & 2517363 & 15685 & L-GW52-01 & B 3-2 & 35 & 2.43 & 0.03 & 55.13 & 3.30 & 0.38 \\
\hline 604 & 2516777 & 15685 & L-GW52-01 & B $3-2$ & 35 & 2.43 & 0.03 & 55.13 & 3.30 & 0.38 \\
\hline 605 & 2517704 & 15685 & L-GW52-01 & В $3-2$ & 35 & 2.43 & 0.03 & 55.13 & 3.30 & 0.38 \\
\hline 606 & 2511350 & 15685 & L-GW52-01 & B $3-2$ & 35 & 2.43 & 0.03 & 55.13 & 3.30 & 0.38 \\
\hline 607 & 2512754 & 15685 & L-GW52-01 & B 3-2 & 35 & 2.43 & 0.03 & 55.13 & 3.30 & 0.38 \\
\hline 608 & 2517244 & 15685 & L-GW52-01 & B $3-2$ & 35 & 2.43 & 0.03 & 55.13 & 3.30 & 0.38 \\
\hline 609 & 2608755 & 15685 & L-GW52-01 & B $3-2$ & 35 & 2.43 & 0.03 & 55.13 & 3.30 & 0.38 \\
\hline 610 & 2605455 & 15685 & L-GW52-01 & В $3-2$ & 35 & 2.43 & 0.03 & 55.13 & 3.30 & 0.38 \\
\hline 611 & 2622433 & 15685 & L-GW52-01 & В $3-2$ & 35 & 2.43 & 0.03 & 55.13 & 3.30 & 0.38 \\
\hline 612 & 2622478 & 15685 & L-GW52-01 & B 3-2 & 35 & 2.43 & 0.03 & 55.13 & 3.30 & 0.38 \\
\hline 613 & 2607471 & 15685 & L-GW52-01 & B 3-2 & 35 & 2.43 & 0.03 & 55.13 & 3.30 & 0.38 \\
\hline 614 & 2611157 & 15685 & L-GW52-01 & B $3-2$ & 35 & 2.43 & 0.03 & 55.13 & 3.30 & 0.38 \\
\hline 615 & 2614640 & 15685 & L-GW52-01 & B $3-2$ & 35 & 2.43 & 0.03 & 55.13 & 3.30 & 0.38 \\
\hline 616 & 2610240 & 15685 & L-GW52-01 & В $3-2$ & 35 & 2.43 & 0.03 & 55.13 & 3.30 & 0.38 \\
\hline 617 & 2101758 & 15685 & L-GW52-01 & B $3-2$ & 29 & 2.45 & 0.05 & 28.98 & 2.29 & 0.31 \\
\hline 618 & 2515513 & 15685 & L-GW52-01 & B $3-2$ & 35 & 2.43 & 0.03 & 55.13 & 3.30 & 0.38 \\
\hline 619 & 2701274 & 15685 & L-GW52-01 & В $3-2$ & 37 & 2.42 & 0.07 & 41.78 & 4.04 & 0.62 \\
\hline 624 & 1104780 & 15685 & Calibration & N/A & Unirrad & 2.94 & 0.00 & 16.43 & 0.22 & 0.01 \\
\hline 625 & 1613834 & 15685 & Calibration & N/A & Unirrad & 2.92 & 0.00 & 54.38 & 0.72 & 0.04 \\
\hline 626 & 15124 & 15685 & Calibration & $\mathrm{N} / \mathrm{A}$ & Unirrad & 2.91 & 0.00 & 32.83 & 0.48 & 0.05 \\
\hline 627 & 1512019 & 15685 & Calibration & N/A & Unirrad & 2.91 & 0.00 & 45.53 & 0.61 & 0.04 \\
\hline 628 & 1613659 & 15685 & Calibration & N/A & Unirrad & 2.92 & 0.00 & 54.40 & 0.72 & 0.04 \\
\hline 629 & 15064 & 15685 & Calibration & N/A & Unirrad & 2.95 & 0.00 & 13.83 & 0.16 & 0.01 \\
\hline 630 & 1103425 & 15685 & Calibration & N/A & Unirrad & 2.93 & 0.00 & 16.45 & 0.22 & 0.01 \\
\hline 631 & 1412359 & 15685 & Calibration & N/A & Unirrad & 2.95 & 0.00 & 30.09 & 0.39 & 0.02 \\
\hline
\end{tabular}




\begin{tabular}{|c|c|c|c|c|c|c|c|c|c|c|}
\hline $\begin{array}{c}\text { Liner } \\
\text { Cell } \\
\end{array}$ & $\begin{array}{c}\text { Rod } \\
\text { Number }\end{array}$ & $\begin{array}{c}\text { Liner } \\
\text { Number }\end{array}$ & $\begin{array}{c}\text { Assembly } \\
\text { Number }\end{array}$ & Liner no. & $\begin{array}{c}\text { POB } \\
\text { Category }\end{array}$ & $\begin{array}{c}\text { Th-232 } \\
(\mathrm{kg})\end{array}$ & $\begin{array}{c}\mathrm{U}-232 \\
(\mathrm{~g})\end{array}$ & $\begin{array}{c}\mathrm{U}-233 \\
(\mathrm{~g})\end{array}$ & $\begin{array}{c}\mathrm{U}-234 \\
(\mathrm{~g})\end{array}$ & $\begin{array}{c}\mathrm{U}-235 \\
(\mathrm{~g})\end{array}$ \\
\hline 632 & 1300545 & 15685 & Calibration & N/A & Unirrad & 2.90 & 0.00 & 45.40 & 0.60 & 0.04 \\
\hline 633 & 1501827 & 15685 & Calibration & N/A & Unirrad & 2.92 & 0.00 & 45.58 & 0.61 & 0.04 \\
\hline 634 & 25161 & 15685 & Calibration & N/A & Unirrad & 2.46 & 0.00 & 37.81 & 0.50 & 0.03 \\
\hline 635 & 25122 & 15685 & Calibration & N/A & Unirrad & 2.47 & 0.00 & 27.93 & 0.33 & 0.02 \\
\hline 636 & 2303222 & 15685 & Calibration & N/A & Unirrad & 2.43 & 0.00 & 52.58 & 0.64 & 0.04 \\
\hline 637 & 2103140 & 15685 & Calibration & N/A & Unirrad & 2.47 & 0.00 & 18.97 & 0.26 & 0.02 \\
\hline 638 & 2500452 & 15685 & Calibration & N/A & Unirrad & 2.43 & 0.00 & 62.96 & 0.73 & 0.04 \\
\hline 639 & 25063 & 15685 & Calibration & N/A & Unirrad & 2.49 & 0.00 & 11.66 & 0.14 & 0.01 \\
\hline 640 & 2700468 & 15685 & Calibration & N/A & Unirrad & 2.45 & 0.00 & 46.31 & 0.64 & 0.05 \\
\hline 641 & 2701624 & 15685 & Calibration & N/A & Unirrad & 2.45 & 0.00 & 46.52 & 0.68 & 0.07 \\
\hline 642 & 2402626 & 15685 & Calibration & N/A & Unirrad & 2.47 & 0.00 & 30.60 & 0.42 & 0.03 \\
\hline 643 & 2100153 & 15685 & Calibration & N/A & Unirrad & 2.48 & 0.00 & 18.91 & 0.25 & 0.01 \\
\hline 644 & 25001 & 15685 & Calibration & N/A & Unirrad & 2.49 & 0.00 & 0.00 & 0.00 & 0.00 \\
\hline 645 & 25004 & 15685 & Calibration & N/A & Unirrad & 2.49 & 0.00 & 0.00 & 0.00 & 0.00 \\
\hline 646 & 15004 & 15685 & Calibration & N/A & Unirrad & 2.96 & 0.00 & 0.00 & 0.00 & 0.00 \\
\hline 647 & 15061 & 15685 & Calibration & N/A & Unirrad & 2.95 & 0.00 & 13.84 & 0.16 & 0.01 \\
\hline 648 & 15002 & 15685 & Calibration & N/A & Unirrad & 2.95 & 0.00 & 0.00 & 0.00 & 0.00 \\
\hline 649 & 15122 & 15685 & Calibration & $\mathrm{N} / \mathrm{A}$ & Unirrad & 2.91 & 0.00 & 32.81 & 0.48 & 0.05 \\
\hline 652 & 1102470 & 15685 & L-GS22-01 & В 2-2 & 14 & 2.90 & 0.09 & 34.30 & 2.98 & 0.47 \\
\hline 653 & 1104525 & 15685 & L-GS22-01 & В $2-2$ & 14 & 2.90 & 0.09 & 34.30 & 2.98 & 0.47 \\
\hline 654 & 1106586 & 15685 & L-GS22-01 & B $2-2$ & 14 & 2.90 & 0.09 & 34.30 & 2.98 & 0.47 \\
\hline 655 & 1106137 & 15685 & L-GS22-01 & B 2-2 & 14 & 2.90 & 0.09 & 34.30 & 2.98 & 0.47 \\
\hline 656 & 1103672 & 15685 & L-GS22-01 & B 2-2 & 14 & 2.90 & 0.09 & 34.30 & 2.98 & 0.47 \\
\hline 657 & 1305787 & 15685 & L-GS22-01 & B 2-2 & 20 & 2.87 & 0.09 & 46.87 & 4.22 & 0.68 \\
\hline 658 & 1311334 & 15685 & L-GS22-01 & B 2-2 & 20 & 2.87 & 0.09 & 46.87 & 4.22 & 0.68 \\
\hline 659 & 1302579 & 15685 & L-GS22-01 & В 2-2 & 20 & 2.87 & 0.09 & 46.87 & 4.22 & 0.68 \\
\hline
\end{tabular}




\begin{tabular}{|c|c|c|c|c|c|c|c|c|c|c|}
\hline $\begin{array}{c}\text { Liner } \\
\text { Cell } \\
\end{array}$ & $\begin{array}{c}\text { Rod } \\
\text { Number }\end{array}$ & $\begin{array}{c}\text { Liner } \\
\text { Number }\end{array}$ & $\begin{array}{c}\text { Assembly } \\
\text { Number }\end{array}$ & Liner no. & $\begin{array}{c}\text { POB } \\
\text { Category }\end{array}$ & $\begin{array}{c}\text { Th-232 } \\
(\mathrm{kg})\end{array}$ & $\begin{array}{c}\mathrm{U}-232 \\
(\mathrm{~g})\end{array}$ & $\begin{array}{c}\mathrm{U}-233 \\
(\mathrm{~g})\end{array}$ & $\begin{array}{c}\text { U-234 } \\
(\mathrm{g})\end{array}$ & $\begin{array}{c}\mathrm{U}-235 \\
(\mathrm{~g}) \\
\end{array}$ \\
\hline 660 & 1210125 & 15685 & L-GS22-01 & B 2-2 & 14 & 2.90 & 0.09 & 34.30 & 2.98 & 0.47 \\
\hline 661 & 1210226 & 15685 & L-GS22-01 & В $2-2$ & 14 & 2.90 & 0.09 & 34.30 & 2.98 & 0.47 \\
\hline 662 & 1208657 & 15685 & L-GS22-01 & В $2-2$ & 14 & 2.90 & 0.09 & 34.30 & 2.98 & 0.47 \\
\hline 663 & 1303248 & 15685 & L-GS22-01 & B 2-2 & 20 & 2.87 & 0.09 & 46.87 & 4.22 & 0.68 \\
\hline 664 & 1504667 & 15685 & L-GS22-01 & B $2-2$ & 23 & 2.88 & 0.10 & 46.88 & 4.50 & 0.72 \\
\hline 665 & 1507619 & 15685 & L-GS22-01 & B 2-2 & 23 & 2.88 & 0.10 & 46.88 & 4.50 & 0.72 \\
\hline 666 & 1504658 & 15685 & L-GS22-01 & B 2-2 & 23 & 2.88 & 0.10 & 46.88 & 4.50 & 0.72 \\
\hline 667 & 1200344 & 15685 & L-GT22-03 & В 3-6 & 15 & 2.91 & 0.08 & 33.30 & 2.73 & 0.41 \\
\hline 668 & 1204542 & 15685 & L-GT22-03 & В 3-6 & 15 & 2.91 & 0.08 & 33.30 & 2.73 & 0.41 \\
\hline 669 & 1410646 & 15685 & L-GT22-03 & В 3-6 & 18 & 2.92 & 0.08 & 39.40 & 3.21 & 0.50 \\
\hline 670 & 1404448 & 15685 & L-GT22-03 & B 3-6 & 18 & 2.92 & 0.08 & 39.40 & 3.21 & 0.50 \\
\hline 671 & 1602181 & 15685 & L-GS22-01 & B 2-2 & 26 & 2.89 & 0.09 & 52.10 & 4.74 & 0.75 \\
\hline 672 & 1607479 & 15685 & L-GS22-01 & B $2-2$ & 26 & 2.89 & 0.09 & 52.10 & 4.74 & 0.75 \\
\hline 673 & 1603676 & 15685 & L-GS22-01 & B 2-2 & 26 & 2.89 & 0.09 & 52.10 & 4.74 & 0.75 \\
\hline 674 & 1608083 & 15685 & L-GS22-01 & B 2-2 & 26 & 2.89 & 0.09 & 52.10 & 4.74 & 0.75 \\
\hline 101 & 0603381 & 15686 & L-BB01-04 & S 1-1 & 1 & 0.68 & 0.03 & 24.34 & 2.54 & 0.41 \\
\hline 103 & 0500809 & 15686 & L-BB01-04 & S 1-1 & 1 & 0.68 & 0.03 & 24.34 & 2.54 & 0.41 \\
\hline 104 & 0301450 & 15686 & L-BB01-04 & S 1-1 & 7 & 0.70 & 0.03 & 15.29 & 1.89 & 0.33 \\
\hline 105 & 0402072 & 15686 & L-BB01-04 & S 1-1 & 4 & 0.69 & 0.03 & 17.17 & 2.13 & 0.38 \\
\hline 106 & 0201460 & 15686 & L-BB01-04 & S 1-1 & 10 & 0.70 & 0.03 & 13.69 & 1.67 & 0.29 \\
\hline 108 & 0410185 & 15686 & L-BB01-08 & S 3-2 & 6 & 0.69 & 0.02 & 18.24 & 1.76 & 0.26 \\
\hline 109 & 0205677 & 15686 & L-BB01-08 & S 3-2 & 12 & 0.71 & 0.02 & 13.82 & 1.32 & 0.19 \\
\hline 110 & 0530132 & 15686 & L-BB01-08 & S 3-2 & 3 & 0.68 & 0.02 & 26.28 & 2.10 & 0.29 \\
\hline 111 & 0532213 & 15686 & L-BB01-08 & S 3-2 & 3 & 0.68 & 0.02 & 26.28 & 2.10 & 0.29 \\
\hline 112 & 0311003 & 15686 & L-BB01-08 & S $3-2$ & 9 & 0.70 & 0.02 & 15.88 & 1.53 & 0.23 \\
\hline 113 & 0505804 & 15686 & L-BB01-07 & S 3-1 & 3 & 0.68 & 0.02 & 26.28 & 2.10 & 0.29 \\
\hline
\end{tabular}




\begin{tabular}{|c|c|c|c|c|c|c|c|c|c|c|}
\hline $\begin{array}{c}\text { Liner } \\
\text { Cell } \\
\end{array}$ & $\begin{array}{c}\text { Rod } \\
\text { Number }\end{array}$ & $\begin{array}{c}\text { Liner } \\
\text { Number }\end{array}$ & $\begin{array}{c}\text { Assembly } \\
\text { Number }\end{array}$ & Liner no. & $\begin{array}{c}\text { POB } \\
\text { Category }\end{array}$ & $\begin{array}{c}\text { Th-232 } \\
(\mathrm{kg})\end{array}$ & $\begin{array}{c}\mathrm{U}-232 \\
(\mathrm{~g})\end{array}$ & $\begin{array}{c}\mathrm{U}-233 \\
(\mathrm{~g})\end{array}$ & $\begin{array}{c}\text { U-234 } \\
(\mathrm{g})\end{array}$ & $\begin{array}{c}\text { U-235 } \\
(\mathrm{g}) \\
\end{array}$ \\
\hline 114 & 0407067 & 15686 & L-BB01-07 & S 3-1 & 6 & 0.69 & 0.02 & 18.24 & 1.76 & 0.26 \\
\hline 115 & 0202478 & 15686 & L-BB01-07 & S 3-1 & 12 & 0.71 & 0.02 & 13.82 & 1.32 & 0.19 \\
\hline 116 & 0308168 & 15686 & L-BB01-07 & S 3-1 & 9 & 0.70 & 0.02 & 15.88 & 1.53 & 0.23 \\
\hline 118 & 0510002 & 15686 & L-BB01-07 & S 3-1 & 3 & 0.68 & 0.02 & 26.28 & 2.10 & 0.29 \\
\hline 401 & 0504107 & 15686 & L-BB01-04 & S 1-1 & 1 & 0.68 & 0.03 & 24.34 & 2.54 & 0.41 \\
\hline 402 & 0704628 & 15686 & L-BB01-13 & S 2-3 & 11 & 0.71 & 0.02 & 13.75 & 1.48 & 0.23 \\
\hline 403 & 0604555 & 15686 & L-BB01-04 & S 1-1 & 1 & 0.68 & 0.03 & 24.34 & 2.54 & 0.41 \\
\hline 404 & 0504502 & 15686 & L-BB01-04 & S 1-1 & 1 & 0.68 & 0.03 & 24.34 & 2.54 & 0.41 \\
\hline 405 & 0607258 & 15686 & L-BB01-07 & S 3-1 & 3 & 0.68 & 0.02 & 26.28 & 2.10 & 0.29 \\
\hline 406 & 0205154 & 15686 & L-BB01-04 & S 1-1 & 10 & 0.70 & 0.03 & 13.69 & 1.67 & 0.29 \\
\hline 407 & 0618561 & 15686 & L-BB01-08 & S 3-2 & 3 & 0.68 & 0.02 & 26.28 & 2.10 & 0.29 \\
\hline 408 & 0800117 & 15686 & L-BB01-04 & S 1-1 & 10 & 0.70 & 0.03 & 13.69 & 1.67 & 0.29 \\
\hline 409 & 0602209 & 15686 & L-BB01-04 & S 1-1 & 1 & 0.68 & 0.03 & 24.34 & 2.54 & 0.41 \\
\hline 410 & 0624153 & 15686 & L-BB01-13 & S 2-3 & 2 & 0.68 & 0.03 & 25.37 & 2.31 & 0.35 \\
\hline 411 & 0628324 & 15686 & L-BB01-13 & S $2-3$ & 2 & 0.68 & 0.03 & 25.37 & 2.31 & 0.35 \\
\hline 412 & 0625161 & 15686 & L-BB01-13 & S $2-3$ & 2 & 0.68 & 0.03 & 25.37 & 2.31 & 0.35 \\
\hline 413 & 0628544 & 15686 & L-BB01-13 & S 2-3 & 2 & 0.68 & 0.03 & 25.37 & 2.31 & 0.35 \\
\hline 414 & 0530224 & 15686 & L-BB01-13 & S 2-3 & 2 & 0.68 & 0.03 & 25.37 & 2.31 & 0.35 \\
\hline 415 & 0531048 & 15686 & L-BB01-13 & S $2-3$ & 2 & 0.68 & 0.03 & 25.37 & 2.31 & 0.35 \\
\hline 416 & 0531407 & 15686 & L-BB01-13 & S 2-3 & 2 & 0.68 & 0.03 & 25.37 & 2.31 & 0.35 \\
\hline 417 & 0530811 & 15686 & L-BB01-13 & S 2-3 & 2 & 0.68 & 0.03 & 25.37 & 2.31 & 0.35 \\
\hline 418 & 0515574 & 15686 & L-BB01-13 & S 2-3 & 2 & 0.68 & 0.03 & 25.37 & 2.31 & 0.35 \\
\hline 419 & 0525806 & 15686 & L-BB01-13 & S $2-3$ & 2 & 0.68 & 0.03 & 25.37 & 2.31 & 0.35 \\
\hline 420 & 0534808 & 15686 & L-BB01-13 & S 2-3 & 2 & 0.68 & 0.03 & 25.37 & 2.31 & 0.35 \\
\hline 421 & 0408084 & 15686 & L-BB01-13 & S 2-3 & 5 & 0.69 & 0.03 & 17.72 & 1.93 & 0.31 \\
\hline 422 & 0408645 & 15686 & L-BB01-13 & S $2-3$ & 5 & 0.69 & 0.03 & 17.72 & 1.93 & 0.31 \\
\hline
\end{tabular}




\begin{tabular}{|c|c|c|c|c|c|c|c|c|c|c|}
\hline $\begin{array}{c}\text { Liner } \\
\text { Cell }\end{array}$ & $\begin{array}{c}\text { Rod } \\
\text { Number }\end{array}$ & $\begin{array}{c}\text { Liner } \\
\text { Number }\end{array}$ & $\begin{array}{l}\text { Assembly } \\
\text { Number }\end{array}$ & Liner no. & $\begin{array}{c}\text { POB } \\
\text { Category }\end{array}$ & $\begin{array}{c}\text { Th-232 } \\
\text { (kg) }\end{array}$ & $\begin{array}{c}\mathrm{U}-232 \\
(\mathrm{~g})\end{array}$ & $\begin{array}{c}\mathrm{U}-233 \\
(\mathrm{~g})\end{array}$ & $\begin{array}{c}\mathrm{U}-234 \\
(\mathrm{~g})\end{array}$ & $\begin{array}{c}\text { U-235 } \\
(\mathrm{g})\end{array}$ \\
\hline 423 & 0412358 & 15686 & L-BB01-13 & S 2-3 & 5 & 0.69 & 0.03 & 17.72 & 1.93 & 0.31 \\
\hline 424 & 0412515 & 15686 & L-BB01-13 & S 2-3 & 5 & 0.69 & 0.03 & 17.72 & 1.93 & 0.31 \\
\hline 425 & 0411507 & 15686 & L-BB01-13 & S 2-3 & 5 & 0.69 & 0.03 & 17.72 & 1.93 & 0.31 \\
\hline 426 & 0310655 & 15686 & L-BB01-13 & S 2-3 & 8 & 0.70 & 0.03 & 15.60 & 1.70 & 0.28 \\
\hline 427 & 0314476 & 15686 & L-BB01-13 & S 2-3 & 8 & 0.70 & 0.03 & 15.60 & 1.70 & 0.28 \\
\hline 428 & 0316126 & 15686 & L-BB01-13 & S 2-3 & 8 & 0.70 & 0.03 & 15.60 & 1.70 & 0.28 \\
\hline 429 & 0315026 & 15686 & L-BB01-13 & S 2-3 & 8 & 0.70 & 0.03 & 15.60 & 1.70 & 0.28 \\
\hline 430 & 0313533 & 15686 & L-BB01-13 & S 2-3 & 8 & 0.70 & 0.03 & 15.60 & 1.70 & 0.28 \\
\hline 431 & 0210106 & 15686 & L-BB01-13 & S 2-3 & 11 & 0.71 & 0.02 & 13.75 & 1.48 & 0.23 \\
\hline 432 & 0211462 & 15686 & L-BB01-13 & S 2-3 & 11 & 0.71 & 0.02 & 13.75 & 1.48 & 0.23 \\
\hline 433 & 0204202 & 15686 & L-BB01-13 & S 2-3 & 11 & 0.71 & 0.02 & 13.75 & 1.48 & 0.23 \\
\hline 434 & 0212719 & 15686 & L-BB01-13 & S 2-3 & 11 & 0.71 & 0.02 & 13.75 & 1.48 & 0.23 \\
\hline 435 & 0214486 & 15686 & L-BB01-13 & S $2-3$ & 11 & 0.71 & 0.02 & 13.75 & 1.48 & 0.23 \\
\hline 436 & 0704664 & 15686 & L-BB01-13 & S 2-3 & 11 & 0.71 & 0.02 & 13.75 & 1.48 & 0.23 \\
\hline 437 & 0705048 & 15686 & L-BB01-13 & S 2-3 & 11 & 0.71 & 0.02 & 13.75 & 1.48 & 0.23 \\
\hline 438 & 0626068 & 15686 & L-BB01-13 & S 2-3 & 2 & 0.68 & 0.03 & 25.37 & 2.31 & 0.35 \\
\hline 439 & 0623659 & 15686 & L-BB01-13 & S 2-3 & 2 & 0.68 & 0.03 & 25.37 & 2.31 & 0.35 \\
\hline 440 & 0515823 & 15686 & L-BB01-13 & S 2-3 & 2 & 0.68 & 0.03 & 25.37 & 2.31 & 0.35 \\
\hline 441 & 0528058 & 15686 & L-BB01-13 & S 2-3 & 2 & 0.68 & 0.03 & 25.37 & 2.31 & 0.35 \\
\hline 442 & 0512072 & 15686 & L-BB01-13 & S 2-3 & 2 & 0.68 & 0.03 & 25.37 & 2.31 & 0.35 \\
\hline 443 & 0528004 & 15686 & L-BB01-13 & S 2-3 & 2 & 0.68 & 0.03 & 25.37 & 2.31 & 0.35 \\
\hline 444 & 0530563 & 15686 & L-BB01-13 & S 2-3 & 2 & 0.68 & 0.03 & 25.37 & 2.31 & 0.35 \\
\hline 445 & 0530114 & 15686 & L-BB01-13 & S 2-3 & 2 & 0.68 & 0.03 & 25.37 & 2.31 & 0.35 \\
\hline 446 & 0531342 & 15686 & L-BB01-13 & S 2-3 & 2 & 0.68 & 0.03 & 25.37 & 2.31 & 0.35 \\
\hline 447 & 0534256 & 15686 & L-BB01-13 & S 2-3 & 2 & 0.68 & 0.03 & 25.37 & 2.31 & 0.35 \\
\hline 448 & 0411010 & 15686 & L-BB01-13 & S 2-3 & 5 & 0.69 & 0.03 & 17.72 & 1.93 & 0.31 \\
\hline
\end{tabular}




\begin{tabular}{|c|c|c|c|c|c|c|c|c|c|c|}
\hline $\begin{array}{c}\text { Liner } \\
\text { Cell } \\
\end{array}$ & $\begin{array}{c}\text { Rod } \\
\text { Number }\end{array}$ & $\begin{array}{c}\text { Liner } \\
\text { Number }\end{array}$ & $\begin{array}{c}\text { Assembly } \\
\text { Number }\end{array}$ & Liner no. & $\begin{array}{c}\text { POB } \\
\text { Category }\end{array}$ & $\begin{array}{c}\text { Th-232 } \\
(\mathrm{kg})\end{array}$ & $\begin{array}{c}\mathrm{U}-232 \\
(\mathrm{~g})\end{array}$ & $\begin{array}{c}\mathrm{U}-233 \\
(\mathrm{~g})\end{array}$ & $\begin{array}{c}\text { U-234 } \\
(\mathrm{g})\end{array}$ & $\begin{array}{c}\mathrm{U}-235 \\
(\mathrm{~g}) \\
\end{array}$ \\
\hline 449 & 0410084 & 15686 & L-BB01-13 & S 2-3 & 5 & 0.69 & 0.03 & 17.72 & 1.93 & 0.31 \\
\hline 450 & 0413303 & 15686 & L-BB01-13 & S 2-3 & 5 & 0.69 & 0.03 & 17.72 & 1.93 & 0.31 \\
\hline 451 & 0411617 & 15686 & L-BB01-13 & S 2-3 & 5 & 0.69 & 0.03 & 17.72 & 1.93 & 0.31 \\
\hline 452 & 0413045 & 15686 & L-BB01-13 & S 2-3 & 5 & 0.69 & 0.03 & 17.72 & 1.93 & 0.31 \\
\hline 453 & 0412753 & 15686 & L-BB01-13 & S 2-3 & 5 & 0.69 & 0.03 & 17.72 & 1.93 & 0.31 \\
\hline 454 & 0411222 & 15686 & L-BB01-13 & S 2-3 & 5 & 0.69 & 0.03 & 17.72 & 1.93 & 0.31 \\
\hline 455 & 0410764 & 15686 & L-BB01-13 & S 2-3 & 5 & 0.69 & 0.03 & 17.72 & 1.93 & 0.31 \\
\hline 456 & 0412616 & 15686 & L-BB01-13 & S 2-3 & 5 & 0.69 & 0.03 & 17.72 & 1.93 & 0.31 \\
\hline 457 & 0410387 & 15686 & L-BB01-13 & S 2-3 & 5 & 0.69 & 0.03 & 17.72 & 1.93 & 0.31 \\
\hline 458 & 0315504 & 15686 & L-BB01-13 & S 2-3 & 8 & 0.70 & 0.03 & 15.60 & 1.70 & 0.28 \\
\hline 459 & 0315035 & 15686 & L-BB01-13 & S 2-3 & 8 & 0.70 & 0.03 & 15.60 & 1.70 & 0.28 \\
\hline 460 & 0314734 & 15686 & L-BB01-13 & S 2-3 & 8 & 0.70 & 0.03 & 15.60 & 1.70 & 0.28 \\
\hline 461 & 0313506 & 15686 & L-BB01-13 & S $2-3$ & 8 & 0.70 & 0.03 & 15.60 & 1.70 & 0.28 \\
\hline 462 & 0313275 & 15686 & L-BB01-13 & S 2-3 & 8 & 0.70 & 0.03 & 15.60 & 1.70 & 0.28 \\
\hline 463 & 0314303 & 15686 & L-BB01-13 & S 2-3 & 8 & 0.70 & 0.03 & 15.60 & 1.70 & 0.28 \\
\hline 464 & 0311700 & 15686 & L-BB01-13 & S 2-3 & 8 & 0.70 & 0.03 & 15.60 & 1.70 & 0.28 \\
\hline 465 & 0312487 & 15686 & L-BB01-13 & S 2-3 & 8 & 0.70 & 0.03 & 15.60 & 1.70 & 0.28 \\
\hline 466 & 0312516 & 15686 & L-BB01-13 & S 2-3 & 8 & 0.70 & 0.03 & 15.60 & 1.70 & 0.28 \\
\hline 467 & 0314788 & 15686 & L-BB01-13 & S 2-3 & 8 & 0.70 & 0.03 & 15.60 & 1.70 & 0.28 \\
\hline 468 & 0313423 & 15686 & L-BB01-13 & S 2-3 & 8 & 0.70 & 0.03 & 15.60 & 1.70 & 0.28 \\
\hline 469 & 0214660 & 15686 & L-BB01-13 & S 2-3 & 11 & 0.71 & 0.02 & 13.75 & 1.48 & 0.23 \\
\hline 470 & 0214726 & 15686 & L-BB01-13 & S 2-3 & 11 & 0.71 & 0.02 & 13.75 & 1.48 & 0.23 \\
\hline 471 & 0216513 & 15686 & L-BB01-13 & S 2-3 & 11 & 0.71 & 0.02 & 13.75 & 1.48 & 0.23 \\
\hline 472 & 0212277 & 15686 & L-BB01-13 & S 2-3 & 11 & 0.71 & 0.02 & 13.75 & 1.48 & 0.23 \\
\hline 473 & 0216448 & 15686 & L-BB01-13 & S 2-3 & 11 & 0.71 & 0.02 & 13.75 & 1.48 & 0.23 \\
\hline 474 & 0215559 & 15686 & L-BB01-13 & S 2-3 & 11 & 0.71 & 0.02 & 13.75 & 1.48 & 0.23 \\
\hline
\end{tabular}




\begin{tabular}{|c|c|c|c|c|c|c|c|c|c|c|}
\hline $\begin{array}{c}\text { Liner } \\
\text { Cell }\end{array}$ & $\begin{array}{c}\text { Rod } \\
\text { Number }\end{array}$ & $\begin{array}{l}\text { Liner } \\
\text { Number }\end{array}$ & $\begin{array}{l}\text { Assembly } \\
\text { Number }\end{array}$ & Liner no. & $\begin{array}{c}\text { POB } \\
\text { Category }\end{array}$ & $\begin{array}{c}\text { Th-232 } \\
(\mathrm{kg})\end{array}$ & $\begin{array}{c}\mathrm{U}-232 \\
(\mathrm{~g})\end{array}$ & $\begin{array}{c}\mathrm{U}-233 \\
(\mathrm{~g})\end{array}$ & $\begin{array}{l}\text { U-234 } \\
(\mathrm{g})\end{array}$ & $\begin{array}{c}\text { U-235 } \\
(\mathrm{g})\end{array}$ \\
\hline 475 & 0216686 & 15686 & L-BB01-13 & S 2-3 & 11 & 0.71 & 0.02 & 13.75 & 1.48 & 0.23 \\
\hline 476 & 0200408 & 15686 & L-BB01-13 & S 2-3 & 11 & 0.71 & 0.02 & 13.75 & 1.48 & 0.23 \\
\hline 477 & 0214578 & 15686 & L-BB01-13 & S 2-3 & 11 & 0.71 & 0.02 & 13.75 & 1.48 & 0.23 \\
\hline 478 & 0700530 & 15686 & L-BB01-13 & S 2-3 & 11 & 0.71 & 0.02 & 13.75 & 1.48 & 0.23 \\
\hline 479 & 0701209 & 15686 & L-BB01-13 & S 2-3 & 11 & 0.71 & 0.02 & 13.75 & 1.48 & 0.23 \\
\hline 480 & 0703454 & 15686 & L-BB01-13 & S 2-3 & 11 & 0.71 & 0.02 & 13.75 & 1.48 & 0.23 \\
\hline 481 & 0104046 & 15686 & L-BB01-13 & S 2-3 & 11 & 0.71 & 0.02 & 13.75 & 1.48 & 0.23 \\
\hline 482 & 0104708 & 15686 & L-BB01-13 & S 2-3 & 11 & 0.71 & 0.02 & 13.75 & 1.48 & 0.23 \\
\hline 483 & 0704325 & 15686 & L-BB01-13 & S 2-3 & 11 & 0.71 & 0.02 & 13.75 & 1.48 & 0.23 \\
\hline 484 & 0104468 & 15686 & L-BB01-13 & S 2-3 & 11 & 0.71 & 0.02 & 13.75 & 1.48 & 0.23 \\
\hline 485 & 0104414 & 15686 & L-BB01-13 & S 2-3 & 11 & 0.71 & 0.02 & 13.75 & 1.48 & 0.23 \\
\hline 486 & 0105210 & 15686 & L-BB01-13 & S 2-3 & 11 & 0.71 & 0.02 & 13.75 & 1.48 & 0.23 \\
\hline 487 & 0104477 & 15686 & L-BB01-13 & S 2-3 & 11 & 0.71 & 0.02 & 13.75 & 1.48 & 0.23 \\
\hline 488 & 0103846 & 15686 & L-BB01-13 & S 2-3 & 11 & 0.71 & 0.02 & 13.75 & 1.48 & 0.23 \\
\hline 489 & 0702805 & 15686 & L-BB01-13 & S 2-3 & 11 & 0.71 & 0.02 & 13.75 & 1.48 & 0.23 \\
\hline 490 & 0800227 & 15686 & L-BB01-07 & S 3-1 & 12 & 0.71 & 0.02 & 13.82 & 1.32 & 0.19 \\
\hline 491 & 0801482 & 15686 & L-BB01-03 & S 2-3 & 11 & 0.71 & 0.02 & 13.75 & 1.48 & 0.23 \\
\hline 492 & 0213736 & 15686 & L-BB01-13 & S 2-3 & 11 & 0.71 & 0.02 & 13.75 & 1.48 & 0.23 \\
\hline 493 & 0216338 & 15686 & L-BB01-13 & S 2-3 & 11 & 0.71 & 0.02 & 13.75 & 1.48 & 0.23 \\
\hline 494 & 0215678 & 15686 & L-BB01-13 & S $2-3$ & 11 & 0.71 & 0.02 & 13.75 & 1.48 & 0.23 \\
\hline 495 & 0215707 & 15686 & L-BB01-13 & S 2-3 & 11 & 0.71 & 0.02 & 13.75 & 1.48 & 0.23 \\
\hline 496 & 0215357 & 15686 & L-BB01-13 & S 2-3 & 11 & 0.71 & 0.02 & 13.75 & 1.48 & 0.23 \\
\hline 497 & 0408562 & 15686 & L-BB01-13 & S 2-3 & 5 & 0.69 & 0.03 & 17.72 & 1.93 & 0.31 \\
\hline 498 & 0215760 & 15686 & L-BB01-13 & S 2-3 & 11 & 0.71 & 0.02 & 13.75 & 1.48 & 0.23 \\
\hline 499 & 0630553 & 15686 & L-BB01-13 & S 2-3 & 2 & 0.68 & 0.03 & 25.37 & 2.31 & 0.35 \\
\hline 500 & 0625152 & 15686 & L-BB01-13 & S 2-3 & 2 & 0.68 & 0.03 & 25.37 & 2.31 & 0.35 \\
\hline
\end{tabular}




\begin{tabular}{|c|c|c|c|c|c|c|c|c|c|c|}
\hline $\begin{array}{c}\text { Liner } \\
\text { Cell } \\
\end{array}$ & $\begin{array}{c}\text { Rod } \\
\text { Number }\end{array}$ & $\begin{array}{c}\text { Liner } \\
\text { Number }\end{array}$ & $\begin{array}{c}\text { Assembly } \\
\text { Number }\end{array}$ & Liner no. & $\begin{array}{c}\text { POB } \\
\text { Category }\end{array}$ & $\begin{array}{c}\text { Th-232 } \\
(\mathrm{kg})\end{array}$ & $\begin{array}{c}\mathrm{U}-232 \\
(\mathrm{~g})\end{array}$ & $\begin{array}{c}\mathrm{U}-233 \\
(\mathrm{~g})\end{array}$ & $\begin{array}{c}\mathrm{U}-234 \\
(\mathrm{~g})\end{array}$ & $\begin{array}{c}\mathrm{U}-235 \\
(\mathrm{~g})\end{array}$ \\
\hline 501 & 0314054 & 15686 & L-BB01-13 & S 2-3 & 8 & 0.70 & 0.03 & 15.60 & 1.70 & 0.28 \\
\hline 502 & 0533423 & 15686 & L-BB01-13 & S 2-3 & 2 & 0.68 & 0.03 & 25.37 & 2.31 & 0.35 \\
\hline 503 & 0531654 & 15686 & L-BB01-13 & S 2-3 & 2 & 0.68 & 0.03 & 25.37 & 2.31 & 0.35 \\
\hline 504 & 0201746 & 15686 & L-BB01-04 & S 1-1 & 10 & 0.70 & 0.03 & 13.69 & 1.67 & 0.29 \\
\hline 505 & 0502347 & 15686 & L-BB01-07 & S 3-1 & 3 & 0.68 & 0.02 & 26.28 & 2.10 & 0.29 \\
\hline 506 & 0702069 & 15686 & L-BB01-04 & S 1-1 & 10 & 0.70 & 0.03 & 13.69 & 1.67 & 0.29 \\
\hline 507 & 0301340 & 15686 & L-BB01-04 & S 1-1 & 7 & 0.70 & 0.03 & 15.29 & 1.89 & 0.33 \\
\hline 508 & 0702161 & 15686 & L-BB01-07 & S 3-1 & 12 & 0.71 & 0.02 & 13.82 & 1.32 & 0.19 \\
\hline 601 & 0603464 & 15686 & L-BB01-04 & S 1-1 & 1 & 0.68 & 0.03 & 24.34 & 2.54 & 0.41 \\
\hline 602 & 0604519 & 15686 & L-BB01-04 & S 1-1 & 1 & 0.68 & 0.03 & 24.34 & 2.54 & 0.41 \\
\hline 603 & 0603289 & 15686 & L-BB01-04 & S 1-1 & 1 & 0.68 & 0.03 & 24.34 & 2.54 & 0.41 \\
\hline 604 & 0600577 & 15686 & L-BB01-04 & S 1-1 & 1 & 0.68 & 0.03 & 24.34 & 2.54 & 0.41 \\
\hline 608 & 0607184 & 15686 & L-BB01-04 & S 1-1 & 1 & 0.68 & 0.03 & 24.34 & 2.54 & 0.41 \\
\hline 609 & 0500082 & 15686 & L-BB01-04 & S 1-1 & 1 & 0.68 & 0.03 & 24.34 & 2.54 & 0.41 \\
\hline 610 & 0507333 & 15686 & L-BB01-04 & S 1-1 & 1 & 0.68 & 0.03 & 24.34 & 2.54 & 0.41 \\
\hline 611 & 0507782 & 15686 & L-BB01-04 & S 1-1 & 1 & 0.68 & 0.03 & 24.34 & 2.54 & 0.41 \\
\hline 613 & 0501128 & 15686 & L-BB01-04 & S 1-1 & 1 & 0.68 & 0.03 & 24.34 & 2.54 & 0.41 \\
\hline 614 & 0501779 & 15686 & L-BB01-04 & S 1-1 & 1 & 0.68 & 0.03 & 24.34 & 2.54 & 0.41 \\
\hline 615 & 0501265 & 15686 & L-BB01-04 & S 1-1 & 1 & 0.68 & 0.03 & 24.34 & 2.54 & 0.41 \\
\hline 616 & 0211224 & 15686 & L-BB01-04 & S 1-1 & 10 & 0.70 & 0.03 & 13.69 & 1.67 & 0.29 \\
\hline 617 & 0532120 & 15686 & L-BB01-08 & S 3-2 & 3 & 0.68 & 0.02 & 26.28 & 2.10 & 0.29 \\
\hline 618 & 0605269 & 15686 & L-BB01-04 & S 1-1 & 1 & 0.68 & 0.03 & 24.34 & 2.54 & 0.41 \\
\hline 619 & 0601504 & 15686 & L-BB01-04 & S 1-1 & 1 & 0.68 & 0.03 & 24.34 & 2.54 & 0.41 \\
\hline 620 & 0608165 & 15686 & L-BB01-04 & S 1-1 & 1 & 0.68 & 0.03 & 24.34 & 2.54 & 0.41 \\
\hline 621 & 0700219 & 15686 & L-BB01-04 & S 1-1 & 10 & 0.70 & 0.03 & 13.69 & 1.67 & 0.29 \\
\hline 622 & 0100821 & 15686 & L-BB01-04 & S 1-1 & 10 & 0.70 & 0.03 & 13.69 & 1.67 & 0.29 \\
\hline
\end{tabular}




\begin{tabular}{|c|c|c|c|c|c|c|c|c|c|c|}
\hline $\begin{array}{c}\text { Liner } \\
\text { Cell } \\
\end{array}$ & $\begin{array}{c}\text { Rod } \\
\text { Number }\end{array}$ & $\begin{array}{c}\text { Liner } \\
\text { Number }\end{array}$ & $\begin{array}{l}\text { Assembly } \\
\text { Number }\end{array}$ & Liner no. & $\begin{array}{c}\text { POB } \\
\text { Category }\end{array}$ & $\begin{array}{c}\text { Th-232 } \\
(\mathrm{kg})\end{array}$ & $\begin{array}{c}\mathrm{U}-232 \\
(\mathrm{~g})\end{array}$ & $\begin{array}{c}\text { U-233 } \\
(\mathrm{g}) \\
\end{array}$ & $\begin{array}{c}\text { U-234 } \\
(\mathrm{g})\end{array}$ & $\begin{array}{c}\text { U-235 } \\
(\mathrm{g})\end{array}$ \\
\hline 623 & 0608313 & 15686 & L-BB01-04 & S 1-1 & 1 & 0.68 & 0.03 & 24.34 & 2.54 & 0.41 \\
\hline 624 & 0606378 & 15686 & L-BB01-04 & S 1-1 & 1 & 0.68 & 0.03 & 24.34 & 2.54 & 0.41 \\
\hline 625 & 0606461 & 15686 & L-BB01-04 & S 1-1 & 1 & 0.68 & 0.03 & 24.34 & 2.54 & 0.41 \\
\hline 626 & 0605572 & 15686 & L-BB01-04 & S 1-1 & 1 & 0.68 & 0.03 & 24.34 & 2.54 & 0.41 \\
\hline 627 & 0537510 & 15686 & L-BB01-08 & S 3-2 & 3 & 0.68 & 0.02 & 26.28 & 2.10 & 0.29 \\
\hline 628 & 0537069 & 15686 & L-BB01-08 & S 3-2 & 3 & 0.68 & 0.02 & 26.28 & 2.10 & 0.29 \\
\hline 629 & 0518333 & 15686 & L-BB01-08 & S 3-2 & 3 & 0.68 & 0.02 & 26.28 & 2.10 & 0.29 \\
\hline 630 & 0516133 & 15686 & L-BB01-08 & S 3-2 & 3 & 0.68 & 0.02 & 26.28 & 2.10 & 0.29 \\
\hline 631 & 0536272 & 15686 & L-BB01-08 & S 3-2 & 3 & 0.68 & 0.02 & 26.28 & 2.10 & 0.29 \\
\hline 632 & 0511625 & 15686 & L-BB01-08 & S 3-2 & 3 & 0.68 & 0.02 & 26.28 & 2.10 & 0.29 \\
\hline 633 & 0517269 & 15686 & L-BB01-08 & S 3-2 & 3 & 0.68 & 0.02 & 26.28 & 2.10 & 0.29 \\
\hline 634 & 0608753 & 15686 & L-BB01-08 & S 3-2 & 3 & 0.68 & 0.02 & 26.28 & 2.10 & 0.29 \\
\hline 635 & 0613676 & 15686 & L-BB01-08 & S 3-2 & 3 & 0.68 & 0.02 & 26.28 & 2.10 & 0.29 \\
\hline 636 & 0630680 & 15686 & L-BB01-08 & S 3-2 & 3 & 0.68 & 0.02 & 26.28 & 2.10 & 0.29 \\
\hline 637 & 0606681 & 15686 & L-BB01-04 & S 1-1 & 1 & 0.68 & 0.03 & 24.34 & 2.54 & 0.41 \\
\hline 638 & 0624824 & 15686 & L-BB01-08 & S 3-2 & 3 & 0.68 & 0.02 & 26.28 & 2.10 & 0.29 \\
\hline 639 & 0412652 & 15686 & L-BB01-08 & S 3-2 & 6 & 0.69 & 0.02 & 18.24 & 1.76 & 0.26 \\
\hline 640 & 0408755 & 15686 & L-BB01-08 & S 3-2 & 6 & 0.69 & 0.02 & 18.24 & 1.76 & 0.26 \\
\hline 641 & 0202525 & 15686 & L-BB01-08 & S 3-2 & 12 & 0.71 & 0.02 & 13.82 & 1.32 & 0.19 \\
\hline 642 & 0314384 & 15686 & L-BB01-08 & S 3-2 & 9 & 0.70 & 0.02 & 15.88 & 1.53 & 0.23 \\
\hline 643 & 0315127 & 15686 & L-BB01-08 & S 3-2 & 9 & 0.70 & 0.02 & 15.88 & 1.53 & 0.23 \\
\hline 644 & 0105624 & 15686 & L-BB01-08 & S 3-2 & 12 & 0.71 & 0.02 & 13.82 & 1.32 & 0.19 \\
\hline 645 & 0106089 & 15686 & L-BB01-08 & S 3-2 & 12 & 0.71 & 0.02 & 13.82 & 1.32 & 0.19 \\
\hline 646 & 0615216 & 15686 & L-BB01-08 & S 3-2 & 3 & 0.68 & 0.02 & 26.28 & 2.10 & 0.29 \\
\hline 647 & 0622889 & 15686 & L-BB01-08 & S 3-2 & 3 & 0.68 & 0.02 & 26.28 & 2.10 & 0.29 \\
\hline 648 & 0618543 & 15686 & L-BB01-08 & S 3-2 & 3 & 0.68 & 0.02 & 26.28 & 2.10 & 0.29 \\
\hline
\end{tabular}




\begin{tabular}{|c|c|c|c|c|c|c|c|c|c|c|}
\hline $\begin{array}{c}\text { Liner } \\
\text { Cell } \\
\end{array}$ & $\begin{array}{c}\text { Rod } \\
\text { Number }\end{array}$ & $\begin{array}{c}\text { Liner } \\
\text { Number }\end{array}$ & $\begin{array}{c}\text { Assembly } \\
\text { Number }\end{array}$ & Liner no. & $\begin{array}{c}\text { POB } \\
\text { Category }\end{array}$ & $\begin{array}{c}\text { Th-232 } \\
(\mathrm{kg})\end{array}$ & $\begin{array}{c}\mathrm{U}-232 \\
(\mathrm{~g})\end{array}$ & $\begin{array}{c}\mathrm{U}-233 \\
(\mathrm{~g})\end{array}$ & $\begin{array}{c}\mathrm{U}-234 \\
(\mathrm{~g})\end{array}$ & $\begin{array}{c}\mathrm{U}-235 \\
(\mathrm{~g}) \\
\end{array}$ \\
\hline 649 & 0504648 & 15686 & L-BB01-04 & S 1-1 & 1 & 0.68 & 0.03 & 24.34 & 2.54 & 0.41 \\
\hline 650 & 0524302 & 15686 & L-BB01-08 & S 3-2 & 3 & 0.68 & 0.02 & 26.28 & 2.10 & 0.29 \\
\hline 651 & 0526336 & 15686 & L-BB01-08 & S 3-2 & 3 & 0.68 & 0.02 & 26.28 & 2.10 & 0.29 \\
\hline 652 & 0531728 & 15686 & L-BB01-08 & S 3-2 & 3 & 0.68 & 0.02 & 26.28 & 2.10 & 0.29 \\
\hline 653 & 0523779 & 15686 & L-BB01-08 & S 3-2 & 3 & 0.68 & 0.02 & 26.28 & 2.10 & 0.29 \\
\hline 654 & 0627076 & 15686 & L-BB01-08 & S 3-2 & 3 & 0.68 & 0.02 & 26.28 & 2.10 & 0.29 \\
\hline 655 & 0606874 & 15686 & L-BB01-08 & S 3-2 & 3 & 0.68 & 0.02 & 26.28 & 2.10 & 0.29 \\
\hline 656 & 0607561 & 15686 & L-BB01-08 & S 3-2 & 3 & 0.68 & 0.02 & 26.28 & 2.10 & 0.29 \\
\hline 657 & 0601558 & 15686 & L-BB01-08 & S 3-2 & 3 & 0.68 & 0.02 & 26.28 & 2.10 & 0.29 \\
\hline 658 & 0505362 & 15686 & L-BB01-07 & S 3-1 & 3 & 0.68 & 0.02 & 26.28 & 2.10 & 0.29 \\
\hline 659 & 0506388 & 15686 & L-BB01-07 & S 3-1 & 3 & 0.68 & 0.02 & 26.28 & 2.10 & 0.29 \\
\hline 660 & 0507039 & 15686 & L-BB01-07 & S 3-1 & 3 & 0.68 & 0.02 & 26.28 & 2.10 & 0.29 \\
\hline 661 & 0510139 & 15686 & L-BB01-07 & S 3-1 & 3 & 0.68 & 0.02 & 26.28 & 2.10 & 0.29 \\
\hline 662 & 0610275 & 15686 & L-BB01-08 & S 3-2 & 3 & 0.68 & 0.02 & 26.28 & 2.10 & 0.29 \\
\hline 663 & 0617865 & 15686 & L-BB01-08 & S 3-2 & 3 & 0.68 & 0.02 & 26.28 & 2.10 & 0.29 \\
\hline 664 & 0207428 & 15686 & L-BB01-08 & S 3-2 & 12 & 0.71 & 0.02 & 13.82 & 1.32 & 0.19 \\
\hline 665 & 0603327 & 15686 & L-BB01-04 & S 1-1 & 1 & 0.68 & 0.03 & 24.34 & 2.54 & 0.41 \\
\hline 666 & 0502200 & 15686 & L-BB01-07 & S 3-1 & 3 & 0.68 & 0.02 & 26.28 & 2.10 & 0.29 \\
\hline 667 & 0506206 & 15686 & L-BB01-07 & S 3-1 & 3 & 0.68 & 0.02 & 26.28 & 2.10 & 0.29 \\
\hline 668 & 0504363 & 15686 & L-BB01-07 & S 3-1 & 3 & 0.68 & 0.02 & 26.28 & 2.10 & 0.29 \\
\hline 669 & 0508617 & 15686 & L-BB01-07 & S 3-1 & 3 & 0.68 & 0.02 & 26.28 & 2.10 & 0.29 \\
\hline 670 & 0407702 & 15686 & L-BB01-07 & S 3-1 & 6 & 0.69 & 0.02 & 18.24 & 1.76 & 0.26 \\
\hline 671 & 0400083 & 15686 & L-BB01-07 & S 3-1 & 6 & 0.69 & 0.02 & 18.24 & 1.76 & 0.26 \\
\hline 672 & 0203652 & 15686 & L-BB01-07 & S 3-1 & 12 & 0.71 & 0.02 & 13.82 & 1.32 & 0.19 \\
\hline 673 & 0201342 & 15686 & L-BB01-07 & S 3-1 & 12 & 0.71 & 0.02 & 13.82 & 1.32 & 0.19 \\
\hline 674 & 0500385 & 15686 & L-BB01-07 & S 3-1 & 3 & 0.68 & 0.02 & 26.28 & 2.10 & 0.29 \\
\hline
\end{tabular}




\begin{tabular}{|c|c|c|c|c|c|c|c|c|c|c|}
\hline $\begin{array}{c}\text { Liner } \\
\text { Cell } \\
\end{array}$ & $\begin{array}{c}\text { Rod } \\
\text { Number }\end{array}$ & $\begin{array}{c}\text { Liner } \\
\text { Number }\end{array}$ & $\begin{array}{l}\text { Assembly } \\
\text { Number }\end{array}$ & Liner no. & $\begin{array}{c}\text { POB } \\
\text { Category }\end{array}$ & $\begin{array}{c}\text { Th-232 } \\
\text { (kg) }\end{array}$ & $\begin{array}{c}\mathrm{U}-232 \\
(\mathrm{~g})\end{array}$ & $\begin{array}{c}\mathrm{U}-233 \\
(\mathrm{~g})\end{array}$ & $\begin{array}{c}\mathrm{U}-234 \\
(\mathrm{~g})\end{array}$ & $\begin{array}{c}\text { U-235 } \\
(\mathrm{g}) \\
\end{array}$ \\
\hline 675 & 0501808 & 15686 & L-BB01-07 & S 3-1 & 3 & 0.68 & 0.02 & 26.28 & 2.10 & 0.29 \\
\hline 676 & 0506453 & 15686 & L-BB01-07 & S 3-1 & 3 & 0.68 & 0.02 & 26.28 & 2.10 & 0.29 \\
\hline 677 & 0502585 & 15686 & L-BB01-07 & S 3-1 & 3 & 0.68 & 0.02 & 26.28 & 2.10 & 0.29 \\
\hline 678 & 0503622 & 15686 & L-BB01-07 & S 3-1 & 3 & 0.68 & 0.02 & 26.28 & 2.10 & 0.29 \\
\hline 679 & 0504556 & 15686 & L-BB01-07 & S 3-1 & 3 & 0.68 & 0.02 & 26.28 & 2.10 & 0.29 \\
\hline 680 & 0508451 & 15686 & L-BB01-07 & S 3-1 & 3 & 0.68 & 0.02 & 26.28 & 2.10 & 0.29 \\
\hline 681 & 0508671 & 15686 & L-BB01-07 & S 3-1 & 3 & 0.68 & 0.02 & 26.28 & 2.10 & 0.29 \\
\hline 682 & 0508516 & 15686 & L-BB01-07 & S 3-1 & 3 & 0.68 & 0.02 & 26.28 & 2.10 & 0.29 \\
\hline 683 & 0302845 & 15686 & L-BB01-07 & S 3-1 & 9 & 0.70 & 0.02 & 15.88 & 1.53 & 0.23 \\
\hline 684 & 0302203 & 15686 & L-BB01-07 & S 3-1 & 9 & 0.70 & 0.02 & 15.88 & 1.53 & 0.23 \\
\hline 685 & 0701153 & 15686 & L-BB01-07 & S 3-1 & 12 & 0.71 & 0.02 & 13.82 & 1.32 & 0.19 \\
\hline 686 & 0603684 & 15686 & L-BB01-07 & S 3-1 & 3 & 0.68 & 0.02 & 26.28 & 2.10 & 0.29 \\
\hline 687 & 0604472 & 15686 & L-BB01-07 & S 3-1 & 3 & 0.68 & 0.02 & 26.28 & 2.10 & 0.29 \\
\hline 688 & 0600430 & 15686 & L-BB01-07 & S 3-1 & 3 & 0.68 & 0.02 & 26.28 & 2.10 & 0.29 \\
\hline 689 & 0602878 & 15686 & L-BB01-07 & S 3-1 & 3 & 0.68 & 0.02 & 26.28 & 2.10 & 0.29 \\
\hline 690 & 0100683 & 15686 & L-BB01-07 & S 3-1 & 12 & 0.71 & 0.02 & 13.82 & 1.32 & 0.19 \\
\hline 691 & 0102609 & 15686 & L-BB01-07 & S 3-1 & 12 & 0.71 & 0.02 & 13.82 & 1.32 & 0.19 \\
\hline 692 & 0600633 & 15686 & L-BB01-07 & S 3-1 & 3 & 0.68 & 0.02 & 26.28 & 2.10 & 0.29 \\
\hline 693 & 0608349 & 15686 & L-BB01-07 & S 3-1 & 3 & 0.68 & 0.02 & 26.28 & 2.10 & 0.29 \\
\hline 694 & 0602108 & 15686 & L-BB01-07 & S 3-1 & 3 & 0.68 & 0.02 & 26.28 & 2.10 & 0.29 \\
\hline 695 & 0604876 & 15686 & L-BB01-07 & S 3-1 & 3 & 0.68 & 0.02 & 26.28 & 2.10 & 0.29 \\
\hline 696 & 0414466 & 15686 & Calibration & $\mathrm{N} / \mathrm{A}$ & Unirrad & 0.70 & 0.00 & 24.08 & 0.32 & 0.02 \\
\hline 697 & 0100500 & 15686 & Calibration & N/A & Unirrad & 0.72 & 0.00 & 14.20 & 0.19 & 0.02 \\
\hline 698 & 0301754 & 15686 & Calibration & N/A & Unirrad & 0.71 & 0.00 & 19.11 & 0.23 & 0.00 \\
\hline 699 & 0511165 & 15686 & Calibration & N/A & Unirrad & 0.69 & 0.00 & 34.55 & 0.43 & 0.01 \\
\hline 700 & 05001 & 15686 & Calibration & N/A & Unirrad & 0.75 & 0.00 & 0.00 & 0.00 & 0.00 \\
\hline
\end{tabular}




\begin{tabular}{|c|c|c|c|c|c|c|c|c|c|c|}
\hline $\begin{array}{c}\text { Liner } \\
\text { Cell } \\
\end{array}$ & $\begin{array}{c}\text { Rod } \\
\text { Number }\end{array}$ & $\begin{array}{c}\text { Liner } \\
\text { Number }\end{array}$ & $\begin{array}{l}\text { Assembly } \\
\text { Number }\end{array}$ & Liner no. & $\begin{array}{c}\text { POB } \\
\text { Category }\end{array}$ & $\begin{array}{c}\text { Th-232 } \\
(\mathrm{kg})\end{array}$ & $\begin{array}{c}\mathrm{U}-232 \\
(\mathrm{~g})\end{array}$ & $\begin{array}{c}\mathrm{U}-233 \\
(\mathrm{~g})\end{array}$ & $\begin{array}{c}\mathrm{U}-234 \\
(\mathrm{~g})\end{array}$ & $\begin{array}{c}\text { U-235 } \\
(\mathrm{g})\end{array}$ \\
\hline 701 & 05061 & 15686 & Calibration & $\mathrm{N} / \mathrm{A}$ & Unirrad & 0.73 & 0.00 & 3.40 & 0.04 & 0.00 \\
\hline 702 & 05431 & 15686 & Calibration & N/A & Unirrad & 0.70 & 0.00 & 28.71 & 0.35 & 0.01 \\
\hline 703 & 05274 & 15686 & Calibration & N/A & Unirrad & 0.71 & 0.00 & 18.29 & 0.22 & 0.02 \\
\hline 704 & 0307748 & 15686 & Calibration & N/A & Unirrad & 0.71 & 0.00 & 19.15 & 0.26 & 0.03 \\
\hline 705 & 05062 & 15686 & Calibration & N/A & Unirrad & 0.73 & 0.00 & 3.40 & 0.04 & 0.00 \\
\hline 706 & 0101334 & 15686 & Calibration & $\mathrm{N} / \mathrm{A}$ & Unirrad & 0.72 & 0.00 & 14.28 & 0.19 & 0.02 \\
\hline 707 & 05004 & 15686 & Calibration & $\mathrm{N} / \mathrm{A}$ & Unirrad & 0.75 & 0.00 & 0.00 & 0.00 & 0.00 \\
\hline 708 & 05122 & 15686 & Calibration & $\mathrm{N} / \mathrm{A}$ & Unirrad & 0.72 & 0.00 & 8.13 & 0.10 & 0.01 \\
\hline 709 & 0401863 & 15686 & Calibration & N/A & Unirrad & 0.70 & 0.00 & 23.70 & 0.32 & 0.03 \\
\hline 710 & 05121 & 15686 & Calibration & N/A & Unirrad & 0.72 & 0.00 & 8.13 & 0.96 & 0.01 \\
\hline 711 & 0527674 & 15686 & Calibration & N/A & Unirrad & 0.69 & 0.00 & 34.80 & 0.46 & 0.03 \\
\hline 712 & 05273 & 15686 & Calibration & $\mathrm{N} / \mathrm{A}$ & Unirrad & 0.71 & 0.00 & 18.31 & 0.22 & 0.02 \\
\hline 713 & 05432 & 15686 & Calibration & N/A & Unirrad & 0.70 & 0.00 & 28.71 & 0.35 & 0.01 \\
\hline 741 & 0624465 & 15686 & L-BB01-13 & S 2-3 & 2 & 0.68 & 0.03 & 25.37 & 2.31 & 0.35 \\
\hline 742 & 0615739 & 15686 & L-BB01-13 & S 2-3 & 2 & 0.68 & 0.03 & 25.37 & 2.31 & 0.35 \\
\hline 743 & 0626528 & 15686 & L-BB01-13 & S 2-3 & 2 & 0.68 & 0.03 & 25.37 & 2.31 & 0.35 \\
\hline 744 & 0626573 & 15686 & L-BB01-13 & S 2-3 & 2 & 0.68 & 0.03 & 25.37 & 2.31 & 0.35 \\
\hline 745 & 0610239 & 15686 & L-BB01-13 & S 2-3 & 2 & 0.68 & 0.03 & 25.37 & 2.31 & 0.35 \\
\hline 746 & 0610818 & 15686 & L-BB01-13 & S 2-3 & 2 & 0.68 & 0.03 & 25.37 & 2.31 & 0.35 \\
\hline 747 & 0615409 & 15686 & L-BB01-13 & S 2-3 & 2 & 0.68 & 0.03 & 25.37 & 2.31 & 0.35 \\
\hline 748 & 0631800 & 15686 & L-BB01-13 & S 2-3 & 2 & 0.68 & 0.03 & 25.37 & 2.31 & 0.35 \\
\hline 749 & 0315310 & 15686 & L-BB01-13 & S 2-3 & 8 & 0.70 & 0.03 & 15.60 & 1.70 & 0.28 \\
\hline 750 & 0622532 & 15686 & L-BB01-13 & S 2-3 & 2 & 0.68 & 0.03 & 25.37 & 2.31 & 0.35 \\
\hline 751 & 0217061 & 15686 & L-BB01-13 & S 2-3 & 11 & 0.71 & 0.02 & 13.75 & 1.48 & 0.23 \\
\hline 752 & 0411534 & 15686 & L-BB01-13 & S 2-3 & 5 & 0.69 & 0.03 & 17.72 & 1.93 & 0.31 \\
\hline 753 & 0628315 & 15686 & L-BB01-13 & S 2-3 & 2 & 0.68 & 0.03 & 25.37 & 2.31 & 0.35 \\
\hline
\end{tabular}




\begin{tabular}{|c|c|c|c|c|c|c|c|c|c|c|}
\hline $\begin{array}{c}\text { Liner } \\
\text { Cell } \\
\end{array}$ & $\begin{array}{c}\text { Rod } \\
\text { Number }\end{array}$ & $\begin{array}{c}\text { Liner } \\
\text { Number }\end{array}$ & $\begin{array}{l}\text { Assembly } \\
\text { Number }\end{array}$ & Liner no. & $\begin{array}{c}\text { POB } \\
\text { Category }\end{array}$ & $\begin{array}{c}\text { Th-232 } \\
(\mathrm{kg})\end{array}$ & $\begin{array}{c}\mathrm{U}-232 \\
(\mathrm{~g})\end{array}$ & $\begin{array}{c}\mathrm{U}-233 \\
(\mathrm{~g})\end{array}$ & $\begin{array}{c}\mathrm{U}-234 \\
(\mathrm{~g})\end{array}$ & $\begin{array}{c}\text { U-235 } \\
(\mathrm{g})\end{array}$ \\
\hline 754 & 0610607 & 15686 & L-BB01-13 & S 2-3 & 2 & 0.68 & 0.03 & 25.37 & 2.31 & 0.35 \\
\hline 755 & 0524623 & 15686 & L-BB01-13 & S 2-3 & 2 & 0.68 & 0.03 & 25.37 & 2.31 & 0.35 \\
\hline 756 & 0312083 & 15686 & L-BB01-13 & S 2-3 & 8 & 0.70 & 0.03 & 15.60 & 1.70 & 0.28 \\
\hline 757 & 0531737 & 15686 & L-BB01-13 & S 2-3 & 2 & 0.68 & 0.03 & 25.37 & 2.31 & 0.35 \\
\hline 758 & 0535154 & 15686 & L-BB01-13 & S 2-3 & 2 & 0.68 & 0.03 & 25.37 & 2.31 & 0.35 \\
\hline 759 & 0614648 & 15686 & L-BB01-13 & S 2-3 & 2 & 0.68 & 0.03 & 25.37 & 2.31 & 0.35 \\
\hline 760 & 0624382 & 15686 & L-BB01-13 & S 2-3 & 2 & 0.68 & 0.03 & 25.37 & 2.31 & 0.35 \\
\hline 761 & 0618516 & 15686 & L-BB01-13 & S 2-3 & 2 & 0.68 & 0.03 & 25.37 & 2.31 & 0.35 \\
\hline 762 & 0411056 & 15686 & L-BB01-13 & S 2-3 & 5 & 0.69 & 0.03 & 17.72 & 1.93 & 0.31 \\
\hline 763 & 0528325 & 15686 & L-BB01-13 & S 2-3 & 2 & 0.68 & 0.03 & 25.37 & 2.31 & 0.35 \\
\hline 764 & 0216356 & 15686 & L-BB01-13 & S 2-3 & 11 & 0.71 & 0.02 & 13.75 & 1.48 & 0.23 \\
\hline 765 & 0623860 & 15686 & L-BB01-13 & S 2-3 & 2 & 0.68 & 0.03 & 25.37 & 2.31 & 0.35 \\
\hline 766 & 0623724 & 15686 & L-BB01-13 & S 2-3 & 2 & 0.68 & 0.03 & 25.37 & 2.31 & 0.35 \\
\hline 767 & 0404355 & 15686 & L-BB01-04 & S 1-1 & 4 & 0.69 & 0.03 & 17.17 & 2.13 & 0.38 \\
\hline 768 & 0302578 & 15686 & L-BB01-04 & S 1-1 & 7 & 0.70 & 0.03 & 15.29 & 1.89 & 0.33 \\
\hline 769 & 0502228 & 15686 & L-BB01-04 & S 1-1 & 1 & 0.68 & 0.03 & 24.34 & 2.54 & 0.41 \\
\hline 770 & 0200343 & 15686 & L-BB01-04 & S 1-1 & 10 & 0.70 & 0.03 & 13.69 & 1.67 & 0.29 \\
\hline 771 & 0535466 & 15686 & L-BB01-13 & S 2-3 & 2 & 0.68 & 0.03 & 25.37 & 2.31 & 0.35 \\
\hline 772 & 0705084 & 15686 & L-BB01-13 & S 2-3 & 11 & 0.71 & 0.02 & 13.75 & 1.48 & 0.23 \\
\hline 773 & 0527703 & 15686 & L-BB01-13 & S 2-3 & 2 & 0.68 & 0.03 & 25.37 & 2.31 & 0.35 \\
\hline 774 & 0106614 & 15686 & L-BB01-13 & S 2-3 & 11 & 0.71 & 0.02 & 13.75 & 1.48 & 0.23 \\
\hline 775 & 0202635 & 15686 & L-BB01-13 & S 2-3 & 11 & 0.71 & 0.02 & 13.75 & 1.48 & 0.23 \\
\hline 776 & 0532763 & 15686 & L-BB01-13 & S 2-3 & 2 & 0.68 & 0.03 & 25.37 & 2.31 & 0.35 \\
\hline 777 & 0536622 & 15686 & L-BB01-13 & S 2-3 & 2 & 0.68 & 0.03 & 25.37 & 2.31 & 0.35 \\
\hline 778 & 0518387 & 15686 & L-BB01-13 & S 2-3 & 2 & 0.68 & 0.03 & 25.37 & 2.31 & 0.35 \\
\hline 101 & 1604253 & 15687 & L-GS22-01 & B $2-2$ & 26 & 2.89 & 0.09 & 52.10 & 4.74 & 0.75 \\
\hline
\end{tabular}




\begin{tabular}{|c|c|c|c|c|c|c|c|c|c|c|}
\hline $\begin{array}{c}\text { Liner } \\
\text { Cell } \\
\end{array}$ & $\begin{array}{c}\text { Rod } \\
\text { Number }\end{array}$ & $\begin{array}{c}\text { Liner } \\
\text { Number }\end{array}$ & $\begin{array}{l}\text { Assembly } \\
\text { Number }\end{array}$ & Liner no. & $\begin{array}{c}\text { POB } \\
\text { Category }\end{array}$ & $\begin{array}{c}\text { Th-232 } \\
(\mathrm{kg})\end{array}$ & $\begin{array}{c}\mathrm{U}-232 \\
(\mathrm{~g})\end{array}$ & $\begin{array}{c}\mathrm{U}-233 \\
(\mathrm{~g})\end{array}$ & $\begin{array}{c}\mathrm{U}-234 \\
(\mathrm{~g})\end{array}$ & $\begin{array}{c}\text { U-235 } \\
(\mathrm{g})\end{array}$ \\
\hline 102 & 1408765 & 15687 & L-GS22-01 & B 2-2 & 17 & 2.92 & 0.09 & 40.74 & 3.63 & 0.61 \\
\hline 103 & 1203662 & 15687 & L-GS22-01 & B 2-2 & 14 & 2.90 & 0.09 & 34.30 & 2.98 & 0.47 \\
\hline 108 & 1512477 & 15687 & L-GS22-01 & B 2-2 & 23 & 2.88 & 0.10 & 46.88 & 4.50 & 0.72 \\
\hline 109 & 1305439 & 15687 & L-GS22-01 & B 2-2 & 20 & 2.87 & 0.09 & 46.87 & 4.22 & 0.68 \\
\hline 601 & 2202278 & 15687 & L-GW52-01 & B 3-2 & 29 & 2.45 & 0.05 & 28.98 & 2.29 & 0.31 \\
\hline 602 & 2200805 & 15687 & L-GW52-01 & B 3-2 & 29 & 2.45 & 0.05 & 28.98 & 2.29 & 0.31 \\
\hline 603 & 2401048 & 15687 & L-GW52-01 & B $3-2$ & 31 & 2.46 & 0.05 & 34.11 & 2.62 & 0.37 \\
\hline 604 & 2607563 & 15687 & L-GW52-01 & B $3-2$ & 35 & 2.43 & 0.03 & 55.13 & 3.30 & 0.38 \\
\hline 605 & 1607416 & 15687 & L-GW52-01 & B $3-2$ & 27 & 2.90 & 0.09 & 52.06 & 4.53 & 0.70 \\
\hline 606 & 1607075 & 15687 & L-GW52-01 & B $3-2$ & 27 & 2.90 & 0.09 & 52.06 & 4.53 & 0.70 \\
\hline 607 & 1615502 & 15687 & L-GW52-01 & B $3-2$ & 27 & 2.90 & 0.09 & 52.06 & 4.53 & 0.70 \\
\hline 608 & 1514365 & 15687 & L-GW52-01 & B $3-2$ & 24 & 2.88 & 0.09 & 46.71 & 4.29 & 0.67 \\
\hline 609 & 1513339 & 15687 & L-GW52-01 & B 3-2 & 24 & 2.88 & 0.09 & 46.71 & 4.29 & 0.67 \\
\hline 610 & 1310187 & 15687 & L-GW52-01 & B $3-2$ & 21 & 2.87 & 0.08 & 46.59 & 4.02 & 0.63 \\
\hline 611 & 1310472 & 15687 & L-GW52-01 & B $3-2$ & 21 & 2.87 & 0.08 & 46.59 & 4.02 & 0.63 \\
\hline 612 & 1303872 & 15687 & L-GW52-01 & B $3-2$ & 21 & 2.87 & 0.08 & 46.59 & 4.02 & 0.63 \\
\hline 613 & 1105102 & 15687 & L-GW52-01 & B $3-2$ & 15 & 2.91 & 0.08 & 33.30 & 2.73 & 0.41 \\
\hline 614 & 1103012 & 15687 & L-GW52-01 & B 3-2 & 15 & 2.91 & 0.08 & 33.30 & 2.73 & 0.41 \\
\hline 615 & 1103460 & 15687 & L-GW52-01 & B $3-2$ & 15 & 2.91 & 0.08 & 33.30 & 2.73 & 0.41 \\
\hline 616 & 1402542 & 15687 & L-GW52-01 & В 3-2 & 18 & 2.92 & 0.08 & 39.40 & 3.21 & 0.50 \\
\hline 617 & 1410316 & 15687 & L-GW52-01 & B 3-2 & 18 & 2.92 & 0.08 & 39.40 & 3.21 & 0.50 \\
\hline 618 & 1207520 & 15687 & L-GW52-01 & B $3-2$ & 15 & 2.91 & 0.08 & 33.30 & 2.73 & 0.41 \\
\hline 619 & 1203709 & 15687 & L-GW52-01 & B 3-2 & 15 & 2.91 & 0.08 & 33.30 & 2.73 & 0.41 \\
\hline 620 & 1511469 & 15687 & L-GW52-01 & B 3-2 & 24 & 2.88 & 0.09 & 46.71 & 4.29 & 0.67 \\
\hline 621 & 1401828 & 15687 & L-GW52-01 & B 3-2 & 18 & 2.92 & 0.08 & 39.40 & 3.21 & 0.50 \\
\hline 622 & 1100767 & 15687 & L-GW52-01 & B 3-2 & 15 & 2.91 & 0.08 & 33.30 & 2.73 & 0.41 \\
\hline
\end{tabular}




\begin{tabular}{|c|c|c|c|c|c|c|c|c|c|c|}
\hline $\begin{array}{c}\text { Liner } \\
\text { Cell } \\
\end{array}$ & $\begin{array}{c}\text { Rod } \\
\text { Number }\end{array}$ & $\begin{array}{c}\text { Liner } \\
\text { Number }\end{array}$ & $\begin{array}{c}\text { Assembly } \\
\text { Number }\end{array}$ & Liner no. & $\begin{array}{c}\text { POB } \\
\text { Category }\end{array}$ & $\begin{array}{c}\text { Th-232 } \\
(\mathrm{kg})\end{array}$ & $\begin{array}{c}\mathrm{U}-232 \\
(\mathrm{~g})\end{array}$ & $\begin{array}{c}\mathrm{U}-233 \\
(\mathrm{~g})\end{array}$ & $\begin{array}{c}\mathrm{U}-234 \\
(\mathrm{~g})\end{array}$ & $\begin{array}{c}\mathrm{U}-235 \\
(\mathrm{~g}) \\
\end{array}$ \\
\hline 623 & 2202518 & 15687 & L-GW52-01 & B $3-2$ & 29 & 2.45 & 0.05 & 28.98 & 2.29 & 0.31 \\
\hline 641 & 2516281 & 15687 & L-GW52-01 & В $3-2$ & 35 & 2.43 & 0.03 & 55.13 & 3.30 & 0.38 \\
\hline 642 & 2603044 & 15687 & L-GW52-01 & В $3-2$ & 35 & 2.43 & 0.03 & 55.13 & 3.30 & 0.38 \\
\hline 643 & 2514128 & 15687 & L-GW52-01 & B $3-2$ & 35 & 2.43 & 0.03 & 55.13 & 3.30 & 0.38 \\
\hline 644 & 2515585 & 15687 & L-GW52-01 & B $3-2$ & 35 & 2.43 & 0.03 & 55.13 & 3.30 & 0.38 \\
\hline 645 & 2621223 & 15687 & L-GS22-01 & B 2-2 & 34 & 2.43 & 0.05 & 53.87 & 3.78 & 0.47 \\
\hline 646 & 2516503 & 15687 & L-GW52-01 & B $3-2$ & 35 & 2.43 & 0.03 & 55.13 & 3.30 & 0.38 \\
\hline 647 & 2516319 & 15687 & L-GW52-01 & B $3-2$ & 35 & 2.43 & 0.03 & 55.13 & 3.30 & 0.38 \\
\hline 648 & 1402660 & 15687 & L-GS22-01 & B 2-2 & 17 & 2.92 & 0.09 & 40.74 & 3.63 & 0.61 \\
\hline 649 & 1505363 & 15687 & L-GS22-01 & B 2-2 & 23 & 2.88 & 0.10 & 46.88 & 4.50 & 0.72 \\
\hline 650 & 1407748 & 15687 & L-GS22-01 & B 2-2 & 17 & 2.92 & 0.09 & 40.74 & 3.63 & 0.61 \\
\hline 651 & 1412846 & 15687 & L-GS22-01 & B 2-2 & 17 & 2.92 & 0.09 & 40.74 & 3.63 & 0.61 \\
\hline 652 & 1404668 & 15687 & L-GS22-01 & B $2-2$ & 17 & 2.92 & 0.09 & 40.74 & 3.63 & 0.61 \\
\hline 653 & 1401882 & 15687 & L-GT22-03 & В $3-6$ & 18 & 2.92 & 0.08 & 39.40 & 3.21 & 0.50 \\
\hline 654 & 1601164 & 15687 & L-GT22-03 & В 3-6 & 27 & 2.90 & 0.09 & 52.06 & 4.53 & 0.70 \\
\hline 655 & 1613457 & 15687 & L-GT22-03 & В $3-6$ & 27 & 2.90 & 0.09 & 52.06 & 4.53 & 0.70 \\
\hline 656 & 1603483 & 15687 & L-GT22-03 & В 3-6 & 27 & 2.90 & 0.09 & 52.06 & 4.53 & 0.70 \\
\hline 657 & 1104800 & 15687 & L-GT22-03 & В 3-6 & 15 & 2.91 & 0.08 & 33.30 & 2.73 & 0.41 \\
\hline 658 & 1305724 & 15687 & L-GT22-03 & В 3-6 & 21 & 2.87 & 0.08 & 46.59 & 4.02 & 0.63 \\
\hline 659 & 1308564 & 15687 & L-GT22-03 & B 3-6 & 21 & 2.87 & 0.08 & 46.59 & 4.02 & 0.63 \\
\hline 660 & 1103315 & 15687 & L-GT22-03 & B 3-6 & 15 & 2.91 & 0.08 & 33.30 & 2.73 & 0.41 \\
\hline 661 & 1101059 & 15687 & L-GT22-03 & B 3-6 & 15 & 2.91 & 0.08 & 33.30 & 2.73 & 0.41 \\
\hline 662 & 1103443 & 15687 & L-GT22-03 & B 3-6 & 15 & 2.91 & 0.08 & 33.30 & 2.73 & 0.41 \\
\hline 663 & 1306117 & 15687 & L-GT22-03 & В $3-6$ & 21 & 2.87 & 0.08 & 46.59 & 4.02 & 0.63 \\
\hline 664 & 1512486 & 15687 & L-GT22-03 & В 3-6 & 24 & 2.88 & 0.09 & 46.71 & 4.29 & 0.67 \\
\hline 665 & 1513265 & 15687 & L-GT22-03 & В 3-6 & 24 & 2.88 & 0.09 & 46.71 & 4.29 & 0.67 \\
\hline
\end{tabular}




\begin{tabular}{|cccccc|cccccc}
\hline $\begin{array}{c}\text { Liner } \\
\text { Cell }\end{array}$ & $\begin{array}{c}\text { Rod } \\
\text { Number }\end{array}$ & $\begin{array}{c}\text { Liner } \\
\text { Number }\end{array}$ & $\begin{array}{c}\text { Assembly } \\
\text { Number }\end{array}$ & Liner no. & $\begin{array}{c}\text { POB } \\
\text { Category }\end{array}$ & $\begin{array}{c}\text { Th-232 } \\
(\mathrm{kg})\end{array}$ & $\begin{array}{c}\text { U-232 } \\
(\mathrm{g})\end{array}$ & $\begin{array}{c}\text { U-233 } \\
(\mathrm{g})\end{array}$ & $\begin{array}{c}\text { U-234 } \\
(\mathrm{g})\end{array}$ & $\begin{array}{c}\text { U-235 } \\
(\mathrm{g})\end{array}$ & $\begin{array}{c}\text { U. } \\
\text { ( }\end{array}$ \\
\hline 666 & 1507545 & 15687 & L-GT22-03 & B 3-6 & 24 & 2.88 & 0.09 & 46.71 & 4.29 & 0.67 & 0 \\
667 & 1208078 & 15687 & L-GU51-01 & B 1-3 & 13 & 2.90 & 0.10 & 35.40 & 3.25 & 0.54 & 0 \\
668 & 1401166 & 15687 & L-GU51-01 & B 1-3 & 16 & 2.92 & 0.09 & 40.74 & 3.63 & 0.61 & 0 \\
669 & 1604318 & 15687 & L-GU51-01 & B 1-3 & 25 & 2.89 & 0.10 & 52.19 & 4.92 & 0.80 & 0 \\
670 & 1200665 & 15687 & L-GU51-01 & B 1-3 & 13 & 2.90 & 0.10 & 35.40 & 3.25 & 0.54 & 0 \\
671 & 1407187 & 15687 & L-GU51-01 & B 1-3 & 16 & 2.92 & 0.09 & 40.74 & 3.63 & 0.61 & 0 \\
672 & 1605876 & 15687 & L-GU51-01 & B 1-3 & 25 & 2.89 & 0.10 & 52.19 & 4.92 & 0.80 & 0 \\
673 & 1311738 & 15687 & L-GU51-01 & B 1-3 & 19 & 2.87 & 0.10 & 47.20 & 4.42 & 0.74 & 0 \\
674 & 1306584 & 15687 & L-GU51-01 & B 1-3 & 19 & 2.87 & 0.10 & 47.20 & 4.42 & 0.74 & 0 \\
\hline
\end{tabular}


Letter numbers associated with the above data and liners are as follows:

\begin{tabular}{cll}
\hline Letter & \multicolumn{1}{c}{ Date } & \multicolumn{1}{c}{ Liner Numbers } \\
\hline WAPD-NRF(L) C-117 & June 26, 1987 & $15685,15686,15687$ \\
WAPD-NRF(L) C-123 & July 8, 1987 & 15687 \\
WAPD-NRF(L) C-149 & September 15, 1987 & $15683,15685,15686$ \\
WAPD-NRF(L) C-93 & March 26, 1987 & 15681,15682 \\
WAPD-NRF(L) C-104 & April 30, 1987 & 15683,15684 \\
\hline
\end{tabular}

